$$
\text { UNIVERSIDADE DE SÃO PAULO }
$$

FACULDADE DE FILOSOFIA, LETRAS E CIÊNCIAS HUMANAS DEPARTAMENTO DE LETRAS CLÁSSICAS E VERNÁCULAS PROGRAMA DE PÓS-GRADUAÇÃO EM FILOLOGIA E LÍNGUA PORTUGUESA

\title{
DEFINIÇÕES PRAGMÁTICO-FLEXIVAS E ORALIDADE
}

\author{
EUGÊNIO PAGOTTI
}

Tese apresentada ao Programa de PósGraduação em Filologia e Língua Portuguesa do Departamento de Letras Clássicas e Vernáculas da Faculdade de Filosofia, Letras e Ciências Humanas da Universidade de São Paulo, para obtenção do título de Doutor

ORIENTADORA: PROF ${ }^{\mathrm{a}}$ DR $^{\mathrm{a}}$ MARIA LÚCIA DA CUNHA VICTÓRIO DE OLIVEIRA ANDRADE

SÃO PAULO 
À CÉLIA, MEU MUNDO INTEIRO, PELO AMOR QUE TRANSCENDE O AMOR, DEDICO OS ESFORÇOS DESTA TESE "PULCHRUM SANE AURUM, SED FEMINA PULCHRIOR AVRO" 


\section{AGRADECIMENTOS}

*Às professoras doutoras BETH BRAIT e HELENA H. NAGAMINE BRANDÃO, agradeço mais uma vez pelas observações e sugestões, e pela generosíssima acolhida no exame de qualificação, fato que muito me auxiliou e motivou nesta nova empreitada. Em particular, destaco e agradeço a abacial paciência manifestada por essas professoras na leitura, não só de minha dissertação, mas também desta tese; suas indicações, incorporadas a este trabalho, justificam o que nele houver de melhor.

*Ao professor doutor ANTÔNIO PONCIANO BEZERRA — antes de tudo, um grande amigo -, agradeço a gentilíssima acolhida em terras sergipanas e os oportunos conselhos em momento crucial da elaboração desta tese: sua contribuição também está incorporada ao que nela houver de melhor.

*À minha amicíssima companheira de percurso e dedicada orientadora professora doutora MARIA LÚCIA DA CUNHA VICTÓRIO DE OLIVEIRA ANDRADE —, muito agradeço tudo e toda a ajuda que me tem oferecido há quase uma década. Grato por sua paciência, generosidade e boa vontade para comigo em mais este desafio. 
RESUMO

O propósito desta tese é estudar as definições nos contextos da oralidade e estabelecer a viabilidade e a conveniência de uma abordagem que considere sistemas de definições em operação - estruturas sistêmicas - em vez de definições como fenômenos discursivos isolados.

Após discutir as implicações de diversas abordagens para a teoria das definições, apresenta-se uma tipologia de definições que atenda àquele particular contexto.

Uma vez apresentado um esquema que distingue entre as operações de definição no plano empírico e as operações de definição no plano mental, desenvolvem-se os conceitos de estrutura stricto sensu de definição [ou seja, "estrutura (pró-)definidora"] e estrutura lato sensu de definição [ou seja, "contextura (pró-)definidora"].

Por fim, examina-se um tipo de definição que atende tanto aos aspectos pragmáticos da interação verbal quanto à flexibilidade ontológica de certos objetos de definição. 


\section{ABSTRACT}

The purpose of this thesis is to study definitions in the oral contexts and to establish the viability and convenience of an approach that considers systems of definitions at work (systemic structures), instead of definitions as isolated phenomena in discourse.

After discuss some implications of several approaches for definitions theory, we present a definitions typology, which fits with that particular context.

Once we have presented a scheme that distinguishes between definition operations in empirical level and definition operations in mental level, we develop the concepts of stricto sensu definition structure ["estrutura (pró-)definidora"] and lato sensu definition structure ["contextura (pró-)definidora"].

Finally, we examine a kind of definition, which responds at the same time to pragmatic aspects of verbal interactions and to the ontological flexibility of certain definition objects. 


\section{SUMÁRIO}

$\begin{array}{ll}\text { INTRODUÇÃO } & 10\end{array}$

1. Justificativa 12

2. Objetivos

3. Constituição do corpus 13

4. Procedimentos metodológicos e abordagem teórica

5. Organização do trabalho

CAPÍTULO I - CONSIDERAÇÕES SOBRE O CONCEITO DE DEFINIÇÃO

1.1 Definições e suas funções: por que definir?

1.2 Definição e suas condições: como definir?

1.3 Notas preliminares sobre o conceito de definição

CAPÍTULO II — DEFINIÇÕES DE DEFINIÇÃO

2.1 Conceitos implicados pelo ato definidor: explicitações em torno da abordagem essencialista e da abordagem terminista das definições 
CAPÍTULO III - TIPOS DE DEFINIÇÃO

3.1 Critérios para uma classificação das definições

3.2 Uma tipologia das definições

CAPÍTULO IV - ANÁLISE DAS DEFINIÇÕES SOB O PONTO DE VISTA DA ORALIDADE

4.1 As definições segundo o contexto da oralidade

4.2 Análise de definições presentes no corpus

CAPÍTULO V — UMA VISÃO SISTÊMICA DAS DEFINIÇÕES

5.1 Plano empírico e plano mental: discurso definidor e objeto referido; síntese definidora e conceito referente

5.2 Os conceitos de contextura (pró-) definidora e estrutura (pró-) definidora: o caráter pragmático-flexivo das definições - definições pragmático-flexivas 
a) "ENTRE AS VÁRIAS FORMAS DE PENSAMENTO CIENTÍFICO, DIFICILMENTE HÁ OUTRA SOBRE A QUAL AS OPINIÕES DIVIRJAM TÃO LARGAMENTE QUANTO AQUELAS QUE DIZEM RESPEITO À DEFINIÇÃO"1.

b) "É PRECISAMENTE O CONCEITO QUE CONSTITUI O INTERMEDIÁRIO ENTRE A IMAGEM E A FORMA, ENTRE O VIVIDO E O ABSTRATO [...] A FILOSOFIA NADA MAIS É DO QUE CONCEITO [...] ELA É PROPRIAMENTE REEXAME E REDEFINIÇÃO DO CONCEITO"2.

c) "PORÉM, SE O CONCEITO DE 〈JOGO〉 ESTÁ DE TAL MODO CARENTE DE DELIMITAÇÃO, ENTÃO NÃO SABES EM REALIDADE O QUE QUER DIZER 'JOGO' — SE DOU A DESCRIÇÃO: 'O SOLO ESTAVA TOTALMENTE COBERTO DE PLANTAS', QUERERÁS DIZER QUE NÃO SEI DO QUE FALO ENQUANTO NÃO PUDER DAR UMA DEFINIÇÃO DE PLANTA?"3.

e) CONTEXTO: 1) trabalho em andamento: pesquisa destinada a fixar o número de habitantes por quarto em certa área urbana; 2) falha detectada na pesquisa: ausência de uma definição de 'quarto'; 3) solicitação do coordenador: uma definição de 'quarto'; 4) efeito da solicitação: a) em geral, recusas, dada a obviedade da definição; b) um dos colaboradores propõe uma definição de 'quarto', nos seguintes termos: "Quarto é um espaço limitado por quatro paredes".

DIÁLOGO SUBSEQÜENTE ENTRE COORDENADOR E COLABORADOR:

- O quarto não pode ser triangular?

- Sim. Pode ter três ou quatro paredes.

- E não pode ser circular?

- Bem, pode ter uma ou mais paredes.

- Que dizer de uma caixa de madeira?

- Não. O quarto deve ser suficientemente grande para acomodar pessoas.

- Um armário embutido?

- Não. Deve ser usado para fins usuais.

- E que são "fins usuais"?

— Ora, não é preciso descer a tais minúcias; afinal, os resultados que recolhemos servem bem aos nossos objetivos.

- E quais são esses objetivos?

- Fixar um índice de condições de vida, determinando o número de pessoas que se alojam em cada quarto de uma habitação.

- O tamanho do quarto não entrou em cogitação nesse levantamento?

- Talvez se devesse determinar quantos metros quadrados teria o quarto...

- A altura do quarto não seria importante?

- Talvez...idealmente, o volume do quarto deveria ser levado em conta.

- Mas, em tal caso, um quarto de $20 \mathrm{~m}^{2}$ no chão e $3 \mathrm{~m}$ de altura seria considerado como equivalente a um quarto de $12 \mathrm{~m}^{2}$ de chão, mas de altura $5 \mathrm{~m}$ ?

- (impaciência do interlocutor) ORA, o índice que obtemos é perfeitamente satisfatório para o uso.

- E para que é usado?

- NÃO SEl... mas não temos recebido reclamações... ${ }^{4}$

e) "TODOS DIZEM COISAS DEFINITIVAS, MAS NINGUÉM DEFINE AS COISAS"5:

\footnotetext{
${ }^{1}$ Heinrich RICKERT. "The theory of Definition" In SAGER, Juan C. Essays on Definition. John Benjamins Publishing Co. Amsterdam / Philadelphia, 2000.

2 Frédéric COSSUTA. Elementos para leitura de textos filosóficos. São Paulo: Martins Fontes, 1994.

3 Ludwig WITTGENSTEIN, Investigaciones filosóficas. I, 70. 3ª ed. Barcelona: Editorial Crítica, 2004.

${ }^{4}$ Russel ACKOFF. Scientific method: optimizing applied research decisions. New York: John Wiley, 1962, pp. 147-148.

${ }^{5}$ Millôr FERNANDES. Millôr definitivo: a bíblia do caos. Porto Alegre: L \& PM, 1994. p. 121.
} 


\section{INTRODUÇÃO}

Dificilmente poderemos exagerar a importância do processo definidor, tanto no que diz respeito a seu papel nas linguagens científicas, quanto no que se refere às suas funções discursivas nas linguagens naturais. Porém, talvez devido à aparente obviedade desse processo- compreendido usualmente como a explicação dos significados dos termos empregados em discurso —, tendemos a assumi-lo como pressuposto, sem dar-lhe maiores cuidados e atenções.

De fato, é freqüente que se compreendam como adequados os discursos que, com maior ou menor sucesso, reproduzem mnemonicamente os textos definidores oferecidos em dicionários de prestígio: definir adequadamente, portanto, seria sinônimo de relembrar apropriadamente os significados das palavras - mais ainda, se for possível, aportar considerações de ordem etimológica. Conhecimento lingüístico, memória e erudição seriam, nessa perspectiva, os requisitos para bem definir.

Raramente se verificam questionamentos sobre o rigor técnico dos textos definidores citados em tais dicionários, sob o ponto de vista dos conceitos e dos referenciais; em verdade, tendemos a considerar que tais textos são adequados justamente porque produzidos e mencionados por eminentes lexicógrafos e lexicólogos.

Quanto às dificuldades discursivas atinentes às definições, originadas em situação concreta de interação, compreende-se normalmente que tais problemas dizem respeito: a) à ambigüidade no uso dos significados dos termos; b) ao puro desconhecimento de uma ou mais acepções registradas pelo léxico. Não parece usual a percepção de que questões sobre a natureza dos objetos de definição — por exemplo, os objetos sensíveis e os objetos conceituais - subjazam aos problemas puramente terminológicos. Nesse sentido, o processo de definição parece constituirse meramente no plano lingüístico e a ele restringir-se.

Também, não há uma consciência clara a respeito da distinção entre os conceitos de língua escrita e língua falada e suas implicações no âmbito das definições; de fato, tendemos a ignorar que diferentes condições de produção e 
diferentes propósitos discursivos devem produzir conseqüências sobre os respectivos processos definidores. Igualmente, não se costuma distinguir entre o saber de cunho científico (que mobiliza determinados tipos rigorosos de definição) e o saber de cunho paracientífico, próprio da linguagem natural empregada no quotidiano (que se contenta com definições de caráter diverso).

A partir do conceito já amplamente discutido de referenciação (que, em muitos autores, contrapõe-se ao conceito de referência), chega-se à discussão sobre o caráter sistêmico das definições: trata-se de entender que referência e referenciação — sob o ponto de vista das definições — talvez não sejam fenômenos opostos ou excludentes, mas sim complementares, uma vez que definir implica pressupor definições e, também, subentendê-las: nesse sentido, os objetos-de-discurso relacionam-se com os objetos-de-realidade — sendo a "realidade" aqui entendida não como categorias prontas para simples referência, mas sim como categorias simplesmente pressupostas e subentendidas (em outras palavras, pressupor já implica estabelecer como realidade).

Também, o processo de referenciação parece justificar a concepção de um tipo especial de definição - definição essa que atende aos fatores pragmáticos envolvidos no processo discursivo da oralidade e, ao mesmo tempo, atende à possibilidade de (re)elaboração ontológica dos objetos-de-discurso.

Por fatos como esses, investigar as relações entre o processo definidor e a oralidade, além de aprofundar os conhecimentos em relação à natureza dos objetos de definição, são propósitos que se mostram merecedores de estudo mais detalhado; a partir dessa constatação, propusemo-nos a desenvolver este tema particular, ou seja, postular a viabilidade do conceito de definição pragmático-flexiva (definição que atende, ao mesmo tempo, à natureza pragmática das interações verbais e à natureza especial dos objetos-de-discurso enquanto objetos flexivos).

Uma vez assinalado o tema principal deste trabalho, algumas questões podem ser propostas; dentre elas: a) de que maneira a oposição clássica entre "definições essencialistas" e "definições nominalistas" relaciona-se com os conceitos de oralidade e referenciação?; b) quais seriam as diretrizes para o processo definidor no contexto da oralidade, uma vez que haja necessidade de se definir (ou seja, 
como bem definir uma vez que é preciso definir)?; c) dentre os diversos tipos de definição, quais são os mais recorrentes no contexto da oralidade?; d) uma vez que, segundo nossa compreensão, não convém descartar nem o conceito de objeto-dediscurso nem o conceito de objeto-de-realidade, mas sim harmonizá-los sistemicamente, qual o conceito adequado e suficiente de definição, capaz de atendê-los segundo o contexto da oralidade? Algumas respostas a essas questões serão encaminhadas em capítulos específicos; outras procurarão ser respondidas pelo trabalho como um todo.

Quanto ao corpus, tomamos por referência o material registrado pelo Projeto NURC/SP; isso significa que observamos exemplos daquilo que se considera a linguagem falada culta na cidade de São Paulo. Parece-nos razoável assumir que o caráter diversificado do corpus - a) elocuções formais; b) diálogos entre dois informantes; c) entrevistas - , material esse distribuído por faixas etárias, garante a consistência das conclusões obtidas, segundo o espectro considerado. Isso, contudo, não elimina o interesse de estudos futuros que contemplem corpora diversos.

\section{Justificativa}

Parece-nos importante investigar, sob o ponto de vista da oralidade, a aplicabilidade do conceito de definição ou, mais precisamente, a pertinência dos diversos conceitos possíveis de definição na oralidade. Em especial, interessa-nos verificar em que medida é pertinente conceber um processo definidor de natureza sistêmica, para o qual seria possível conceber uma ação flexiva do definiendum em relação ao definiens.

\section{Objetivos}

\subsection{Gerais}


O objetivo geral da tese é examinar a consistência da visão sistêmica das definições e de um conceito de definição baseado na possibilidade de elaboração de definições que se fundamentem na flexividade ontológica dos objetos de definição definições pragmático-flexivas.

\subsection{Específicos}

a) examinar o conceito de definição e determinar suas funções sob o ponto de vista cognitivo-discursivo; b) apresentar os conceitos de contextura (pró-)definidora e estrutura (pró-)definidora; c) examinar o caráter flexivo das definições na oralidade.

\section{Constituição do corpus}

O corpus é formado pela documentação eletrônica organizada pelo Projeto NURC/SP - (Núcleo USP) - 2002: trata-se dos três volumes de $A$ linguagem falada culta na cidade de São Paulo — Elocuções formais (Volume I); Diálogos entre dois informantes (Volume II) e Entrevistas (Volume III). Os excertos mencionados ao longo do trabalho trazem o número do inquérito, o número da bobina, o número do(s) informante(s) e os números das linhas.

\section{Procedimentos metodológicos e abordagem teórica}

a) estabelecer algumas funções cognitivo-discursivas do ato definidor $e$ apresentar os conceitos de definição delas decorrentes; b) introduzir os conceitos de contextura (pró-)definidora e estrutura (pró-)definidora, mencionando a importância dos mecanismos inferenciais no processo definidor; c) apresentar o conceito de flexividade das definições; d) propor a conveniência teórica das definições pragmático-flexivas. Para tanto, esta tese mobilizará, direta e indiretamente, material teórico fornecido pelas teorias relativas a tópicos tais como definição, referência, inferência e referenciação. 


\section{Organização do trabalho}

\section{INTRODUÇÃO}

$\mathrm{Na}$ introdução, apresentaremos o tema a ser discutido e justificaremos a conveniência em fazê-lo.

\section{CAPÍTULO I — CONSIDERAÇÕES SOBRE O CONCEITO DE DEFINIÇÃO}

1.1 Definições e suas funções: por que definir?

1.2 Definições e suas condições: como definir?

1.3 Notas preliminares sobre o conceito de definição.

\section{CAPÍTULO II —- DEFINIÇÕES DE DEFINIÇÃO}

2.1 Conceitos implicados pelo ato definidor: explicitações em torno da abordagem essencialista e da abordagem terminista das definições.

2.2 Problemas teóricos atinentes ao conceito de definição.

\section{CAPÍTULO III - TIPOS DE DEFINIÇÃO}

3.1 Critérios para uma classificação das definições.

3.2 Uma tipologia das definições.

CAPÍTULO IV - ANÁLISE DAS DEFINIÇÕES SOB O PONTO DE VISTA DA ORALIDADE

4.1 As definições segundo o contexto da oralidade. 
4.2 Análise de definições presentes no corpus.

\section{CAPÍTULO V — UMA VISÃO SISTÊMICA DAS DEFINIÇÕES}

5.1 Plano empírico e plano mental: discurso definidor e objeto referido; síntese definidora e conceito referente.

5.2 Os conceitos de contextura (pró-)definidora e estrutura (pró-)definidora: o caráter flexivo das definições — definições pragmático-flexivas.

5.3 Análise de sistemas de definições presentes no corpus.

\section{CONSIDERAÇÕES FINAIS}

\section{REFERÊNCIA BIBLIOGRÁFICA}




\section{CAPÍTULO I - CONSIDERAÇÕES SOBRE O CONCEITO DE DEFINIÇÃO}

\subsection{DEFINIÇÕES E SUAS FUNÇÕES: POR QUE DEFINIR?}

Com HEGENBERG (1973, p. 15), verificamos que o ajuste do homem em relação a seu entorno é primordialmente de ordem intelectual, segundo as atividades e especificidades que caracterizam uma determinada cultura: como observa o autor, "o homem nasce em uma circunstância, o primariamente dado, e a transforma em 'mundo', um local em que pode viver"6. A evolução que parte de um caos aparente (expresso pelo circunstancial e pelo contingente) em direção a uma organização de fenômenos racionalmente apreensíveis (o "mundo" enquanto constructo da inteligência humana) implica a elaboração contínua de sistemas conceituais que atribuem racionalidade a esse caos apreendido e possibilitam a adaptação do homem à realidade assim concebida, tendo em vista sua compreensão e, se for possível, seu controle e dominação. A organização mental dos fenômenos apreensíveis - transformar xa/wj ("estado de completa desordem anterior à

${ }^{6}$ Em HEGENBERG (2001, p. 19), observa-se que "Ao nascer, somos 'atirados' em um mundo. Diante de nós, uma circunstância cheia de coisas, a que, aos poucos, nos ajustamos. Para que o ajuste não seja apenas 'físico', mas também intelectual, contamos com as interpretações que dela fizeram aqueles que nos antecederam. A função das interpretações é emprestar inteligibilidade às coisas, permitindo que, ao agir sobre elas, possamos usá-las em nosso benefício". Para nós, interessa destacar que o ajuste intelectual ao circunstancialmente dado baseia-se (em maior ou menor medida), em um conjunto de interpretações previamente efetuadas, à guisa de corpus intelectivo: assinala-se, portanto, o caráter perceptivo e fenomênico dos eventos aos quais se costuma denominar "realidade". Em HEGENBERG (2005, p. 21), lemos: "À medida que se ajusta (intelectualmente) ao meio em que vive, o ser humano dá nomes às coisas que o rodeiam ('mesa', 'livro' etc.), dá nome a vários atributos dessas coisas ('rugoso', 'perfumado', 'azedo' etc.) e a muitas relações que estabelece entre as coisas ('ao lado de', 'sob', 'maior do que' etc.). Ações e sentimentos geram palavras como 'fazer', 'esperar', 'sorrir', 'pôr', 'amar', 'dor', 'saudade' etc.". Modificações que percebe e processos que contempla geram, também, muitos outros termos, como, digamos, 'perecer', 'murchar', 'decompor' etc. Dessa maneira, nasce um vocabulário básico [...], um 'dicionário' cujos termos têm significados razoavelmente estáveis [...]. Aperfeiçoando seu ajuste intelectual com o meio, o ser humano sente necessidade de substituir um conceito inexato (pré-científico), de uso comum o explicandum - por um conceito exato - o explicatum -, cujo emprego seja governado por algumas regras fixas. [...] Como novos objetos, novos atributos, novas relações e novos processos (afinal, novos fatos) aparecem a cada instante, novos termos são indispensáveis para a comunicação. Vocábulos novos são introduzidos por meio de definições. As definições têm, justamente, o propósito de ampliar o vocabulário básico, criando novos termos e fixando, de algum modo, o significado desses termos". 
formação do mundo e a partir do qual se inicia tal formação [...]") em ko/smoj ("o mundo enquanto ordem [...]; [segundo Jaspers, que distingue entre 'mundo' e 'cosmo', este é uma] imagem do mundo que cada um forma, mas por isso mesmo não é o mundo como soma total de todas as coisas e os eus existentes, isto é, como totalidade omnicompreensiva [...]"7) — representa, portanto, uma das operações fundamentais que constituem o processo da racionalidade humana ${ }^{8}$.

Todas as fases desse processo de elaboração conceitual - percepção, observação, mensuração, discriminação, nominação, teorização, etc. — impõem uma correspondência entre a progressiva sofisticação da ciência produzida pelo homem e o gradual desenvolvimento da linguagem pela qual essa ciência é expressa. Os termos utilizados por tal linguagem, ao constituírem progressivamente o vocabulário da ciência em desenvolvimento, podem seguir um percurso semelhante: deixarem de ser termos que se prestam ao uso quotidiano imediato e concreto, e passarem a ser termos técnicos específicos, vinculados a conceitos mais abstratos e necessariamente mais elaborados, os quais possuem múltiplas relações empíricas com o mundo concebido e formam, enquanto grupo, uma linguagem científica peculiar e sistemática. Paralelamente a essa atribuição de estatuto científico aos termos da linguagem quotidiana, verifica-se também a legítima criação de termos científicos ad hoc, dotados de significados especiais e destinados a expressar conceitos especiais, sem relação imediata com o mundo empírico do quotidiano $^{9}$. Como podemos observar, ecoam aqui dois antigos problemas: a) as

\footnotetext{
${ }^{7}$ Nicola ABBAGNANO (2003, pp. 115; 215, verbetes: "caos" e "cosmo").

${ }^{8}$ Em HEGENBERG (2001, pp. 19-24), são expostos os principais "alicerces que sustentam as atividades científicas" (ou seja, o conjunto de premissas que fundamentam o pensamento científico); alguns são objetos de acordo imediato, enquanto outros são passíveis de discussão. São eles: a) existe um mundo exterior; b) o mundo é constituído de coisas; c) as coisas se associam para formar sistemas; d) qualquer sistema (com exceção do universo, globalmente considerado) tanto pode ser associado a outros quanto pode ser examinado, como se a nada estivesse vinculado; e) tudo se altera; f) a ciência estuda fatos; g) o comportamento dos objetos está sujeito a leis; h) o futuro assemelhar-se-á ao passado (postulado da permanência); i) indeterminado é apenas aquilo que ainda não chegou a ser colocado em alguma teoria apropriada; j) as leis são mutáveis (o que dá caráter provisório aos conhecimentos); I) sensações, percepções, expectativas, memória, delineiam o que se entende por 'observação'; m) há um discurso apropriado para discorrer a respeito de todos os itens agora mencionados". Conforme entenderemos ao longo deste trabalho, essas premissas científicas justificam nossas propostas teóricas em relação ao processo definidor na oralidade.

${ }^{9} \mathrm{O}$ autor assim exemplifica essa transição: "Assim, para exemplificar, passamos de algo como [1] 'este líquido é amarelo", uma expressão perfeitamente inteligível (recebida como relato
} 
relações entre no/moj e fu/sij — ou seja, as possíveis correspondências entre os nomes e as realidades sensíveis por eles designadas ${ }^{10}$-; b) as relações entre os nomes e os conceitos: i) identificados como tais; ii) apropriadamente definidos. Este último problema refere-se às situações nas quais é fácil identificar a vigência de um conceito, mas difícil defini-lo explicitamente ${ }^{11}$.

Em Metafísica, I, 1, Aristóteles afirma: Pa/ntej alnqrwpoi tou ei) de/nai o) re/gontai fu/sei, enunciado comumente traduzido por: "todos os homens desejam por natureza saber". RICKERT (1960, p. 19) ${ }^{12}$ destaca, acompanhando tal afirmação, que o pensamento do homem, dirigido pela vontade, quer primordialmente conhecer, nesse sentido, pretende ser lógico — denominandose "lógico" o pensamento deliberado e voluntário que se lança ao conhecimento racional daquilo que se compreende por "mundo" ou "realidade", buscando "encontrar, dentre as múltiplas opiniões possíveis sobre as coisas que o pensamento abarca, a opinião 'correta' ou 'verdadeira'"; em outras palavras, busca-se, a partir de

observacional), para algo como [2] 'o hidrogênio se combina com o oxigênio para formar a água', em que já aparecem termos como 'hidrogênio', que não são estritamente observacionais - já que não existe observação capaz de 'mostrar' que um dado gás é hidrogênio. Todavia, existem meios conhecidos que permitem a um cientista identificar em um laboratório, mediante testes adequados, a presença do hidrogênio, de modo que a asserção [2] está, ainda que de modo menos direto do que a primeira, ligada aos dados da observação. Generalizações do tipo [3] 'os átomos de hidrogênio possuem um elétron' já são mais amplas do que a anterior, no sentido de que sua relação com a experiência é apenas indireta. Enfim, pode-se chegar a generalizações muito abstratas (como as da mecânica quântica), em que se torna difícil até mesmo uma tentativa de tornar inteligível ao nãoespecialista o modo pelo qual elas se associam aos dados experimentais. Sem embargo, a conexão com a experiência deve existir, direta ou não, se as generalizações dizem respeito ao mundo em que vivemos" (op. cit., pp. 15-16). Assim, constatamos a necessária presença do empírico e do sensível nas teorizações a respeito da realidade - entendida por meio do conceito de mundo.

${ }^{10}$ Em NEVES (2005, pp. 30-34; 42-45; 48-58; 69-74; 96-99) discutem-se as relações entre no/moj e $\mathrm{fu} / \mathrm{sij}$ desde as primeiras reflexões gregas sobre a linguagem.

${ }^{11}$ Esta é uma situação freqüente, por exemplo, nos estudos gramaticais. Assim, em PERINI (2006, p. 54), afirma-se: "Vejamos finalmente um aspecto importante, mas muitas vezes negligenciado, de qualquer estudo gramatical: a necessidade de propor regras e definições explícitas. A situação das definições na gramática tradicional é tal que algumas pessoas chegam a negar a possibilidade de se definir uma série de noções fundamentais. Assim, dirão: 'O substantivo não se define; aprende-se a reconhecer'. Isso é certamente verdade no que diz respeito à aprendizagem prática da língua: o falante aprende a utilizar corretamente os substantivos (por exemplo, nunca tenta conjugá-los como se fossem verbos), sem nunca ter consciência de alguma definição explícita. Mas o gramático, ou o estudioso da gramática, não é um falante comum; seu objetivo não é aprender a usar a língua, mas pesquisar seu funcionamento interno. Para ele, é importante estabelecer definições, pois estas explicitam parte do conhecimento implícito que o falante adquire e que chamamos 'a estrutura da língua"'.

${ }^{12}$ Ver também RICKERT, Heinrich. "The theory of definitions". In SAGER, Juan. C. (Ed.). Essays on definition. Amsterdam/Philadelphia: John Benjamins Publishing Co., 2000. 
conhecimentos obscuros e confusos, atingir os conhecimentos considerados claros e distintos $^{13}$. Em suma, pretende-se conhecer de maneira lógica visando a uma verdade, mesmo que esta se refira a uma organização cosmológica fenomenicamente apreendida ${ }^{14}$.

Aqui é interessante lembrar que a verdade - a) lh/qeia - pode ser compreendida a partir de, pelo menos, cinco conceitos fundamentais: a) verdade como correspondência entre as coisas do mundo e os discursos que declaram como tais coisas são em sua essência; b) verdade como revelação ou manifestação: i) verdade como aquilo que se apresenta imediatamente ao homem, sob a forma de sensações, intuições ou fenômenos; ii) verdade como modo de conhecimento excepcional ou privilegiado (conhecimentos metafísicos ou teológicos), que tornam evidente a essência das coisas; c) verdade como conformidade das coisas frente a uma lei, regra ou conceito; d) verdade como coerência: se apenas o real é nãocontraditório, a verdade é a coerência perfeita segundo a ordem total e necessária das coisas; e) verdade como utilidade: a verdade teleologicamente entendida como aquilo que é apropriado à manutenção da existência ${ }^{15}$.

O desejo de conhecer, enquanto primeiro objetivo do pensamento humano, vincula-se a um segundo objetivo: "na maioria dos casos, o homem não pensa só para si; também se esforça para comunicar aos demais os resultados que encontrou, e para isso não tem outro meio senão a linguagem" (RICKERT, op. cit., p. 19). De fato, o pensamento, seja ele considerado verdadeiro ou falso — ou, sob outro ponto

\footnotetext{
${ }^{13}$ Em LEIBNIZ (2003, p. 358) afirma-se que: "para entender melhor a natureza das idéias, é preciso examinar em alguma medida a variedade dos conhecimentos. Quando posso reconhecer uma coisa entre outras sem poder dizer em que consistem suas diferenças ou propriedades, o conhecimento é confuso. Desse modo, conhecemos às vezes claramente sem ter qualquer dúvida sobre se um poema ou um quadro está bem ou mal feito, porque há um não sei quê que nos satisfaz ou que nos incomoda. Porém, quando posso explicar as características que possui, o conhecimento torna-se distinto".

${ }^{14}$ Contrapondo-nos à idéia episodicamente postulada de que a verdade em si mesma não existe, existindo apenas opiniões (oposição excludente entre "verdade" e "opinião"), lembramos que a noção de verdade permanece como um pressuposto, explícito ou implícito, em todos os estudos do Discurso; na Pragmática, por exemplo, basta recordar que a Máxima da Qualidade de Paul Grice, que o próprio Princípio da Cooperação e que o Princípio da Relevância de Sperber e Wilson pressupõem uma noção partilhada ou minimamente estável de verdade. Para uma discussão sobre as Teorias da Verdade, remetemos a KIRKHAM (2003).

${ }^{15}$ Ver ABBAGNANO (2003, pp. 994-998, verbete "verdade").
} 
de vista, seja ele considerado universal ou particular -, deve materializar-se compreensivelmente por meio de palavras ou textos, visando à comunicação.

Ambos os esforços - a busca de uma verdade e sua expressão textual voltada à comunicação — impõem grandes dificuldades práticas: primeiramente, porque "as opiniões sobre o fim último do conhecimento humano diferem extraordinariamente entre si, talvez não tanto acerca do fim desejado, mas sim quanto ao fim possível" (ibid., p. 34); em segundo lugar, porque a compreensão de uma verdade (ou a percepção de um fenômeno) não implica necessariamente sua correta delimitação conceitual, nem uma correta delimitação conceitual implica necessariamente sua correta formulação lingüística.

Nesse processo extremamente complexo, as definições possuem função primordial, tanto no estabelecimento do que se convenciona como "verdade", quanto na textualização da expressão lingüística dessa verdade, sob a forma de conceitos. De fato, os textos definidores — textos que estabelecem lingüisticamente a delimitação conceitual de uma verdade assim considerada — reúnem em si ambos os esforços mencionados, visando a um conhecimento sistemático e com características científicas:

\footnotetext{
"Seja que nos limitemos a conjecturar o curso do mundo [...], seja que vamos além e queiramos também compreendê-lo, em alguns pontos coincidirão todos os que não sejam 'pragmatistas' pré-teóricos, ou seja, todos os que tendam a conhecer sem limitar-se exclusivamente aos fins práticos. 'Ninguém trata de realizar uma ciência sem fundamentar-se em uma idéia — diz Kant - e, sob o domínio da razão, nosso conhecimento não pode consistir em uma rapsódia: tem de constituir um sistema' [...] O homem pré-científico, ateórico, contenta-se com um agregado de conhecimentos que necessita na vida quotidiana. $O$ homem científico tende a fazer surgir, a partir do agregado de conhecimentos que possui, um sistema; qualquer progresso efetivo da ciência é para ele um passo em direção a essa meta" (RICKERT, op. cit., p. 34).
}

Portanto, conhecer caracteriza-se por construir sistemas de juízos cujos sujeitos e predicados são formados por conceitos perfeitamente determinados; assim, cabe à definição formar tais conceitos de tal modo que, a partir deles, seja 
possível elaborar sistemas coerentes de juízos cujos alicerces sejam conceitualmente sólidos.

Ambos os objetivos já mencionados - conhecer e expressar lingüisticamente esse conhecimento - fazem parte da própria estrutura da racionalidade, embora constituam processos autônomos. Porém, quando se indaga pela necessidade de definir, a expressão lingüística do conhecimento comumente é priorizada frente ao próprio processo de conhecer; Rickert lembra que quase todos os lógicos principiam sua doutrina sobre a definição apresentando o seguinte argumento: na comunicação, as palavras empregadas não significam sempre o mesmo para o enunciador e para seu co-enunciador. Frente a isso, a principal tarefa das definições seria ajudar a deslindar os equívocos provocados pelo uso das palavras; impressão essa motivada pelas próprias condições de surgimento das reflexões filosóficas sobre as definições. Na verdade, devemos sempre ter em mente que o estabelecimento de conceitos e a formulação verbal visando à comunicação desses conceitos são processos diferentes e autônomos, embora, sob o ponto de vista prático, não sejam de fácil discriminação, tendo em conta o papel da linguagem frente ao processo de pensamento. Em realidade, a função definidora, ou seja, a formação de conceitos, precede em importância a função significativa e desambigüizadora da linguagem (em outras palavras, elaborar e definir um conceito é um processo anterior à vinculação de um nome à expressão lingüística que se refere a esse conceito agora definido).

IDE (1997, pp. IX-XIII; 1-22) menciona quatro "leis" que constituem o fundamento da arte de pensar $^{16}$; em particular, dedica-se a aprofundar a terceira dessas leis - que diz respeito diretamente ao problema das definições: o terceiro princípio mencionado afirma que a inteligência possui três atos ou operações específicas, denominadas "abstração/intuição", "juízo" e "raciocínio".

A abstração/intuição, segundo o autor, enquanto primeira operação mental, é o processo que extrai indutivamente das realidades sensíveis e materiais suas

\footnotetext{
${ }^{16}$ São elas: a) proceder do conhecido ao desconhecido; b) proceder do mais universal ao mais particular; c) proceder segundo os três atos da razão - abstração/intuição, juízo e raciocínio; d) proceder pela harmonia entre razão e objeto.
} 
essências inteligíveis e universais, visando ao conhecimento das substâncias últimas ("o abstrato não é um anexo cristalizado do concreto múltiplo e abundante; é o cerne desse concreto"); essas essências inteligíveis e universais são expressas mentalmente por meio de conceitos ou idéias e são expressas lingüisticamente por meio de definições - especificamente, pelos textos definidores. Portanto, o "conceito", freqüentemente compreendido como sinônimo de "idéia", representa o produto mental do ato de abstração; por sua vez, a definição representa o produto lingüístico desse ato ${ }^{17}$.

O juízo, enquanto segunda operação mental, é o processo da inteligência que une dois conceitos, vinculando-os mediante predicação e construindo uma proposição $^{18}$ que, quer sob o ponto de vista das essências/substâncias inteligíveis e universais, quer sob o ponto de vista das essências/substâncias inteligíveis e particulares, quer, enfim, sob o ponto de vista estrito dos significados nominais envolvidos, presta-se, dentre outras funções, a enunciar o verdadeiro ou a denunciar o falso, tendo sempre por base um determinado referencial (ou seja, uma vez estipulado um determinado referido — um objeto-de-realidade — ou determinado referenciado - um objeto-de-discurso ${ }^{19}$ —, podemos enunciar um juízo passível de ser compreendido como uma sentença verdadeira ou falsa, sempre sob a perspectiva desse referido ou desse referenciado, isto é, desses referenciais ${ }^{20}$ ).

${ }^{17}$ Convém considerar que o texto definidor é um discurso que expressa, sempre que possível clara e distintamente, um conceito previamente formado (assim, o processo seria: abstração $\rightarrow$ conceituação ou conformação do objeto mental $\rightarrow$ definição ou produção de um discurso definidor). Porém, veremos que é possível gerar um discurso definidor cujo fundamento é eminentemente discursivo, ou seja, é possível criar um texto definidor - produto do discurso definidor - que presuma um conceito obtido por abstração, sem, no entanto, partir dessa base indutiva.

${ }^{18}$ Para uma exposição sobre a teoria da proposição em Platão, indicamos SILVA (2002, pp. 101-126).

${ }_{19}$ Para uma ampla discussão sobre o conceito de referenciação e o conceito de objeto-dediscurso, ver os trabalhos e capítulos de: Cavalcante et alii (2003), Koch (2004), Koch et alii (2005) e Neves (2006). Neste trabalho, consideraremos a referenciação e o objeto-de-discurso, em suas versões apresentadas nessa bibliografia, como conceitos já estabelecidos.

20 Neste trabalho, entendemos por "referente" qualquer elemento que faça referência ou referenciação a algo ("referir" $\rightarrow$ agentivo "referente"): a) o processo é denominado "referência" e seu objeto é denominado "referido", caso se trate de um objeto-de-realidade ou objeto mental (conceito), ambos considerados objetos inflexivos; b) o processo é denominado "referenciação" e seu objeto é denominado "referenciado", caso se trate de um objeto-de-discurso e, portanto, considerado um objeto flexivo (o conceito de flexividade dos objetos de definição e dos objetos-de-discurso será apresentado posteriormente). Tanto o referido quanto o referenciado constituem "referenciais". Em suma: 
Por fim, o raciocínio, enquanto terceira operação mental, é o processo de elaboração de um discurso racional, cuja finalidade principal é tornar uma tese ou um postulado aceitos mediante argumentação ou demonstração, pela articulação coerente de juízos capazes de persuadir um auditório particular.

Conseqüentemente, sob o ponto de vista instrumental, a inteligência dispõe de três ferramentas: a) a definição (correspondente à abstração/intuição); b) a enunciação ou predicação (correspondente ao juízo); c) a demonstração e/ou a argumentação (correspondente ao raciocínio; assim, quando houver impossibilidade ou inconveniência em demonstrar, desenvolve-se, nesta terceira etapa, a argumentação).

Especialmente sob o ponto de vista da oralidade ${ }^{21}$, convém entender o conceito de discurso racional como relativo a qualquer discurso que:

a) esteja constituído por um sistema coerente de proposições (ou seja, um sistema de proposições que manifeste coerência interna);

b) assuma como pressuposto(s) outro(s) sistema(s) coerente(s) de proposições;

c) fundamente-se em um conjunto de referenciais racionalmente apreensíveis;

d) seja coerente em relação a esses sistemas de proposições e a esses referenciais;

e) seja capaz de justificar racionalmente ${ }^{22}$ um quadro de valores intrínsecos.

Assim, se, em dado contexto, a definição/hipogrifo $\leftarrow \pi$ «ser que possui as formas de águia, de leão e de cavalo $/ 23$, for aceita como designativa de um

\begin{tabular}{|c|c|c|c|}
\hline \multirow{2}{*}{ referência } & referente & referido & objeto-de-realidade \\
\cline { 2 - 4 } & referente & referido & objeto mental (conceito) \\
\hline referenciação & referente & referenciado & objeto-de-discurso \\
\hline
\end{tabular}

${ }^{21}$ Neste trabalho, não distinguiremos entre o conceito de língua falada e língua oral; assim, quando falarmos em "oralidade", estaremos nos referindo à modalidade não escrita da manifestação discursiva.

${ }^{22}$ Isto é, seja capaz de não atentar contra aquilo que denominamos genericamente "Princípios da Racionalidade", não só os atinentes ao campo da Lógica, mas também aqueles abarcados pelo conceito de coerência discursiva.

${ }^{23}$ Neste trabalho, apresentaremos as definições entre barras simples em itálico _ $/ 1 \ldots$ _; definiendum (conceito a ser definido) aparecerá em itálico; o definiens (conjunto de características que definem) aparecerá entre aspas angulares simples em itálico. Utilizaremos a notação $/ \boldsymbol{X} \leftarrow \boldsymbol{\pi}$ $\langle A B C\rangle /$ ou $/ D_{\text {dum }} \leftarrow \pi\left\langle D_{\text {iens }}\right\rangle /$, que devem ser lidos: "o conceito (definiendum) $X$ é adequadamente 
referencial (ou seja, esse referencial é considerado válido para o contexto em questão), podemos construir a partir dele o seguinte discurso racional: "Pégaso era filho de Netuno e da Medusa; ele, cavalo alado, vem-nos à mente quando falamos dos hipogrifos, seres igualmente alados: estes devem ser capazes de voar, assim como aquele o fazia. Ambos são criaturas semidivinas, pois não constituem exemplos de seres terrenos ordinários. Portanto, ambos são seres fabulosos e assemelhados". Segundo os referenciais em jogo, podemos considerar verdadeira a conclusão resultante: o fato de serem ou não referenciais empírica ou sensivelmente constatáveis não impede a elaboração de um discurso racional que os tome por tema.

Importa antecipar aqui que as definições de Pégaso e hipogrifo são definições essencialistas ou substancialistas, pois declaram, de modo claro e distinto, o ser (ou a substância) e a unicidade desses objetos (tais objetos são constituídos conceitualmente - e mesmo sensivelmente, como no caso da criação de suas imagens pictóricas - a partir de seus discursos definidores); não se trata, simplesmente, de exemplos das denominadas "definições nominalistas" ou terministas, isto é, definições que estritamente declaram os significados das palavras "Pégaso" e "hipogrifo" em dado contexto, estabelecendo uma relação parafrástica entre esses termos e determinadas expressões lingüísticas equivalentes.

Para nós, é útil distinguir entre três tipos de situação, no que tange às definições:

a) definições que declaram a essência ou a substância dos seres que são objetos de delimitação conceitual; nesse caso, os seres preexistem ao discurso definidor e sua essencialidade é apreendida mediante abstração, sendo o discurso definidor a formalização conceitual e lingüística dessa essencialidade. Podemos denominá-las "definições essencialistas não-constituintes": aquilo que se reconhece como "objeto-de-realidade" atende a esse conceito; assim se verifica em /homem $\leftarrow$

predicado pelo conjunto de traços $A B C$ ou definido pelos conceitos (definiens) $A B C$ ". As assim denominadas "definições nominalistas" — que, para nós, são mais bem denominadas "definições semióticas" ou "signações" - constituem casos de equivalências nominais e, ao mesmo tempo, casos de definições de significados; serão apresentadas neste trabalho pela estrutura parafrástica $/ " X " \approx " A B C " /$. 
$\pi$ ranimal racionalı/. Como vemos, o conceito de homem já preexiste a esse discurso definidor (embora tenha sido inaugurado alguma vez): temos aqui, pois, um tipo de definição analítica - definição cujo trabalho científico começa com a análise de um conceito dado;

b) definições que declaram a essência ou a substância dos seres que são objetos de delimitação conceitual, constituindo-os por meio desse ato; nesse caso, os seres não preexistem ao discurso definidor enquanto tais, mas passam a existir através de um discurso fundador que representa a formalização conceitual e lingüística dessa essencialidade. Podemos denominá-las "definições essencialistas constituintes": aquilo que se reconhece como "objeto-de-discurso" atende a esse conceito (embora os objetos-de-discurso possam também ser constituídos por definições subjetivistas e/ou convencionalistas, apresentadas adiante); suponhamos que alguém enuncie o neologismo: "Construí um 'hipoduto' em minha fazenda", sendo /hipoduto $\leftarrow \pi$ «conjunto de corredores que levam os cavalos de um pasto a outro em uma fazenda ou harası/. Como vemos, o conceito de hipoduto não preexistia ao discurso definidor (foi aqui inaugurado): temos aqui, pois, um tipo de definição sintética — definição cujo trabalho científico começa com a síntese de um conceito até então inexistente (ou, pelo menos, inexistente segundo aquela configuração particular);

c) definições que declaram os significados dos termos empregados discursivamente; nesse caso, o que está em jogo é o entendimento lingüístico dos termos em uso e o acordo coletivo sobre tal uso. Trata-se, portanto, das assim denominadas "definições terministas", as quais não cogitam dos seres que preexistem ou não preexistem ao discurso definidor, nem buscam definir (ou discutir) seus conceitos: procuram, simplesmente, especificar um significado dentre os muitos significados possíveis de um termo ou signo. Assim se verifica em /"laranja" $\approx$ "pessoa que empresta seu nome para a realização de fraudes; testa-de-ferro" /, no enunciado: "Os estelionatários conseguiram livrar-se por meio de uma 'laranja"'. Aqui, o objeto de definição (em um sentido lato) é o próprio signo "laranja"; trata-se de uma equivalência entre expressões lingüísticas — entre o 'definiendum' ou termo 
definido e o 'definiens' ou texto definidor ${ }^{24}$. Para que tal predicação seja possível, uma definição essencialista anterior foi necessária para que esta definição nominal seja possível agora; trata-se da definição/laranja $\leftarrow \pi$ «pessoa que empresta seu nome para a realização de fraudes /, na qual o termo escolhido — "laranja" — nada tem a ver com seu significado básico, referente à fruta (trata-se de uma simples homonímia). O fato de termos utilizado aqui o significante "laranja" é irrelevante sob o ponto de vista conceitual; importa verdadeiramente que o conceito expresso pelo definiens esteja estabelecido e fixado.

Devemos observar também que há definições universalmente válidas e aceitas em qualquer contexto; há, por outro lado, definições válidas e aceitas exclusivamente em contextos particulares; também, há objetos de definição constatáveis sensorialmente e há objetos de definição que se furtam às experiências sensoriais, sendo puramente racionais. Assim, a definição de homem como ranimal racionalı pode ser considerada uma definição universalmente válida para um objeto sensorialmente constatável; a definição de a priori kantiano puro como «conhecimento independente da experiência, mas não precedente à própria experiência e desprovido de qualquer elemento empíricos pode ser considerada como uma definição contextualmente válida para um objeto sensorialmente não constatável.

De acordo com COPI \& COHEN (2002, pp. 71-74), há três funções discursivas básicas a serem consideradas, sob o ponto de vista das definições:

a) a "função informativa" refere-se ao uso da linguagem com o intuito de comunicar informações, usualmente por meio de proposições afirmativas ou

${ }^{24}$ Em SANT'ANNA (2005, pp. 2-3), observa-se que: "[...] podem ser identificadas pelo menos duas partes em uma definição. Há aquilo que se deseja definir [...] e a expressão que será efetivamente empregada para definir [...]. O que se deseja definir chama-se de definiendum, e a expressão usada para definir o definiendum chama-se 'definiens'. Normalmente, em uma dada definição, definiendum e definiens ficam conectados pela expressão 'se e somente se' ou por um símbolo como ' $=_{\text {def }}$ ' ou ' $\equiv$ ', entre outros exemplos possíveis; o definiendum fica à esquerda e o definiens fica à direita. [...] No entanto, as relações entre definiendum e definiens não são tão obviamente perceptíveis [...]. Resumidamente, definições (pelo menos as chamadas 'definições explícitas') podem ter a seguinte estrutura: definiendum $=_{\text {def }}$ definiens. Essa visão pode ser enganosa pois conduziria o leitor a pensar que toda definição é explícita, no sentido de que sempre é possível substituir o definiendum pelo definiens em qualquer fórmula ou sentença da linguagem, independentemente do contexto. Mas isso não é verdade para certos tipos de definição". 
negativas, cujo conteúdo referencial pode ser convencionalmente considerado verdadeiro ou falso. Nesse sentido, um discurso informativo se presta para discorrer sobre aquilo que se convenciona denominar "realidade" ou "referente" (que, para nós, corresponde ao referido ou ao referenciado), conceitos esses que longe estão de serem pacíficos;

b) a "função expressiva" refere-se ao uso da linguagem: i) com o intuito de comunicar emoções, sentimentos e/ou crenças do enunciador; ii) com o intuito de (co)mover e condicionar determinadas atitudes em seu auditório. Nesse sentido, o discurso expressivo presta-se para exprimir os pontos de vista do enunciador e, de modo abrangente, presta-se para expressar sua própria individualidade. Tal discurso não admite qualquer juízo de valor (não é verdadeiro nem falso), mas deve ser avaliado por seu conteúdo expressivo e por seus efeitos pragmáticos nas interações;

c) a "função diretiva" refere-se ao uso da linguagem com o intuito de provocar ou evitar ações ou comportamentos, em outras palavras, tal função tem por objetivo condicionar determinados atos por parte dos interlocutores e provocar determinados resultados (efeitos perlocutórios).

Portanto, podemos conceber 0 uso de definições para informar referencialmente, para expressar posições pessoais e para condicionar atitudes e comportamentos. Para nós, importa considerar que, para cada uma dessas funções (informativa, expressiva e diretiva), é possível haver conflitos ou desacordos durante o processo de comunicação, de modo a reduzir ou anular a eficiência desse processo. Para esses casos, é possível que o processo definidor seja capaz de sanar tais conflitos e desacordos, auxiliando a aumentar a eficiência comunicativa (ou, simplesmente, viabilizando-a).

Segundo COPI \& COHEN (op. cit., pp. 88-91; 99-135), desacordos entre partes litigantes podem ser determinados por dois tipos de conflito: a) conflitos de crenças, quando os indivíduos discordam sobre a ocorrência ou a não-ocorrência de um evento; b) conflitos de atitudes, quando, embora concordando sobre a ocorrência de um evento (concordância de crença), mantêm atitudes e comportamentos conflitantes em relação a essa certeza (podem, por exemplo, expressar valores 
positivos, neutros ou negativos sobre o evento, ou seja, expressar aprovação, indiferença ou desaprovação perante uma dada crença comum).

Em suma, litígios de crenças implicam: i) conflitos de afirmação ou negação do estatuto ontológico de um fenômeno ou manifestação; ii) conflitos de afirmação ou negação do valor de verdade de uma proposição sobre a realidade desse fenômeno ou manifestação. Já os litígios de atitudes implicam conflitos de atribuição de outros valores que não os valores de verdade ou falsidade, mediante predicação, a determinados fenômenos ou manifestações (positividade, negatividade, neutralidade etc.).

A partir disso, podemos construir o seguinte quadro de relações:

R1: acordo de crença \& acordo de atitude (acordo total)

R3: desacordo de crença \& acordo de atitude (desacordo parcial de crença)
2: acordo de crença \& desacordo de atitude (desacordo parcial de atitude)

R4: desacordo de crença \& desacordo de atitude (desacordo total)

Como exemplo, podemos considerar a proposição "Deus existe". Em caso de "R1", assumamos que as partes envolvidas não só acreditam que a proposição é verdadeira (ou falsa), como também avaliam-na positivamente (ou negativamente), ou seja, consideram positivo (ou negativo) que essa proposição seja verdadeira (ou falsa) e que o objeto de referência mencionado - Deus - exista (ou não exista). Temos, portanto, um caso de acordo total.

Em caso de "R2", ambas as partes acreditam que a proposição é verdadeira (ou falsa), isto é, crêem que o objeto de referência Deus existe (ou não existe), mas avaliam diferentemente as implicações dessa crença: para uma das partes, essa existência (ou inexistência) é considerada positiva (ou negativa); para outra, trata-se de uma negatividade (ou positividade). Temos, assim, um caso de desacordo parcial de atitude.

Em "R3" há um desacordo de crença: uma das partes crê que a proposição é verdadeira (ou falsa) e que o objeto de referência Deus de fato existe (ou não existe); outra parte crê que a proposição é falsa (ou verdadeira) e que o objeto de referência Deus não existe (ou existe). Porém, ambas as partes demonstram um 
acordo de atitudes: avaliam tal crença por meio dos mesmos valores, quer positiva, quer negativamente. Assim, uma das partes pode considerar verdadeira a proposição e positivo (ou negativo) o fato; outra parte pode considerar falsa a proposição e positivo (ou negativo) o fato. Trata-se, em suma, de um caso de desacordo parcial de crença.

Por fim, em "R4" há um desacordo de crença e um desacordo de atitude: uma das partes crê que a proposição é verdadeira (ou falsa), enquanto outra parte crê que a proposição é falsa (ou verdadeira). Ao mesmo tempo, uma das partes avalia positivamente (ou negativamente) esse fato, enquanto outra parte avalia-no negativamente (ou positivamente). Temos, então, um caso de desacordo total.

Como podemos concluir, a solução dos conflitos apresentados pelo quadro ("R2", "R3" e "R4") exige considerar não só os desacordos de crença, mas também os desacordos de atitudes, gerando com isso diferentes métodos de conciliação. Conflitos de crença podem ser dissolvidos pela atenção aplicada à verdadeira natureza dos fatos; já para os conflitos de atitudes, a produção do acordo é muito mais complexa, por envolver aspectos outros que não os atinentes ao senso comum, à razão, à Lógica ou à busca de verdades consideradas universais.

Para melhor compreender a natureza de tais conflitos, é útil ter em conta os conceitos de ambigüidade ${ }^{25}$ e vaguidão ${ }^{26}$ apresentados por Copi \& Cohen:

"Um termo é ambíguo em determinado contexto quando ele tem mais de um significado distinto, e o contexto não esclarece qual deles é intentado [Ambigüidade: incerteza de

${ }^{25} \mathrm{Em}$ CHIERCHIA (2003, pp. 61-68) discutem-se conceitos de ambigüidade. a) ambigüidade lexical (Exemplo: "Tocou o cão [animal ou peça de revólver] com o dedo"); b) ambigüidade estrutural ou sintática (Exemplo: "Referiram-se aos homens ou mulheres em forma"); c) ambigüidade semântica (Exemplo: "Pedro, não se esqueça que o assassino quis matar seu pai").

${ }^{26}$ CHIERCHIA (op. cit., pp. 65; 224), trata-se da "vagueza": "a vagueza concerne [...] a expressões que denotam classes ou quantidades definidas de maneira apenas aproximada. Tome-se como exemplo o adjetivo 'alto'. Que altura alguma coisa precisa ter para ser alta? Não se pode responder a essa pergunta de uma vez por todas. Uma casa com vinte andares seria geralmente considerada alta; uma casa térrea certamente não é. Um homem adulto com $1 \mathrm{~m} 30 \mathrm{~cm}$ não é alto. Uma criança de cinco anos com a mesma altura seria, ao contrário, preocupantemente alta. [...] a vagueza é muito útil do ponto de vista comunicativo. Ela permite que nos expressemos de maneira econômica e, paradoxalmente, exata, sem precisar decidir muitas coisas que seriam difíceis de decidir"; "uma das nossas suposições tácitas é que os enunciados (uma vez satisfeitas suas pressuposições, quando existirem) ou são verdadeiros ou são falsos. Porém, não é tão evidente que essa suposição seja realista [...] na verdade, todas as expressões da nossa língua comportam virtualmente uma área de vagueza; mesmo expressões aparentemente bem definidas [...]". 
significado, freqüentemente conduzindo a disputas e enganos, quando a mesma palavra ou frase tem dois ou mais significados distintos, e o contexto não torna claro qual significado é o pretendido]. Um termo é vago quando há casos limítrofes, de modo que não se pode determinar se um termo deve ser aplicado a eles ou não [Vaguidão: atributo de um termo que comporta 'casos limítrofes', graças aos quais não se pode determinar se o termo deve ou não ser aplicado a tais casos]. Evidentemente, qualquer termo simples - por exemplo, uma frase como 'direito à vida' ou 'direito de escolha' — pode ser ao mesmo tempo ambíguo e vago" (COPI \& COHEN. op. cit., pp. 106-107).

Portanto, dissolver a ambigüidade de um termo implica indagar sobre seus significados possíveis e sobre qual deles está sendo focalizado; em outras palavras, indagar sobre as definições nominais que se vinculam a esse termo e sobre qual delas vem ao caso. Assim, para dissolver a ambigüidade do enunciado "A manga está completamente passada", é preciso perguntar a qual definição do termo "manga" refere-se o enunciador, bem como é preciso especificar o significado de "passada".

Por sua vez, dissolver a vaguidão de um termo implica indagar sobre o conjunto de objetos aos quais se aplica cada uma das definições a que esse termo se vincula, estabelecendo fronteiras que excluam inequivocamente objetos limítrofes. Assim, para o enunciado "Os homens são animais racionais", se o conceito de animal racional for definido como user vivo organizado, dotado de sensibilidade e movimento, e capaz de usar a razão para pensar logicamentes, coloca-se a questão da possibilidade ou não da inclusão dos loucos nessa classe de objetos, sem mencionar o problema da própria definição do conceito de louco.

Em FRAWLEY, (1992, pp. 58-59), verificamos que uma mesma palavra pode ser ambígua e vaga ao mesmo tempo, segundo as possíveis interpretações:

a) a expressão é ambígua se houver pelo menos duas distintas especificações semânticas vinculadas a uma única forma de expressão, ou seja, há uma só forma lingüística vinculada a dois ou mais significados a ela atribuíveis;

b) a expressão é vaga se uma única expressão lingüística for inespecífica para dois ou mais significados, ou seja, se não os discriminar exatamente, sendo 
necessário então o recurso ao contexto para a inclusão ou exclusão dos objetos no dado campo semântico.

No exemplo "Muitos racionais são malucos", vemos que, pragmaticamente, procurar-se-á atribuir um sentido a essa expressão aparentemente contraditória; uma possível interpretação atribui:

a) ambigüidade ao termo "maluco" (1. "Muitos racionais são irracionais" [!?] ou 2. "Muitos racionais são excêntricos"). Neste caso, é possível afirmar e negar a sentença ao mesmo tempo, sem contradição: "Muitos racionais são malucos (ou seja, excêntricos), mas esses mesmos racionais não são malucos (ou seja, irracionais)";

b) vaguidão ao termo "racionais" (indagação: "Sendo racional aquele que raciocina [/raciocinar $\leftarrow \pi$ 〈pensar, discorrer, fazer cálculos, fazer raciocínios`/], os loucos propriamente ditos devem ou não ser incluídos no conjunto dos seres racionais?"). Neste caso, não é possível afirmar e negar a sentença ao mesmo tempo sem contradição: "Muitos loucos são irracionais, mas esses mesmos loucos são racionais" [!?] — sentença contraditória.

A partir desses conceitos de ambigüidade e vaguidão, podemos identificar três situações de conflito, acionando os conceitos de intensão e extensão ${ }^{27}$ :

a) conflitos por "imprecisão intensional" (expressão que pode ser interpretada como sinônima de "ambigüidade"). Entendendo que o termo "intensão" (ou "conotação") refere-se ao conjunto de atributos compartilhado por todos os objetos, e exclusivamente por eles, que pertencem à classe designada por esse termo (sendo a intensão estabelecida por definição), vemos que, quando um termo é ambíguo: i) sua intensão não está claramente estabelecida, ou seja, o conjunto de atributos necessários que caracteriza os objetos legitimamente designados por esse termo não está bem definido; ii) há mais de uma intensão, ou seja, mais de um

${ }^{27}$ SALMON (2002, p. 75 ) registra: "na maioria dos casos, o significado de uma palavra tem dois aspectos. [...] A extensão de uma palavra consiste na classe de todos os objetos a que a palavra pode ser corretamente aplicada. A extensão é um dos aspectos do significado da palavra. [...] A intensão de uma palavra refere-se às propriedades que um ser deve possuir a fim de estar na extensão dessa palavra. A extensão de uma palavra é a classe de coisas a que a palavra se aplica; a intensão de uma palavra é a coleção de propriedades que determinam as coisas a que a palavra se aplica". Para ulteriores considerações sobre extensionalidade e intensionalidade, ver KIRKHAM (2003, pp. 17-32) e AUROUX (1998, pp. 226-229). 
significado ou texto definidor acionado pelo termo, e é impossível especificar qual dessas intensões está sendo mencionada por ele. Assim, duas substâncias distintas podem ser designadas pelo mesmo termo, gerando com isso confusões e conflitos terminológicos. Em suma, nesse tipo de conflito, o termo possui mais de uma intensão e seu uso discursivo não permite identificar qual delas corresponde ao significado pretendido pelo usuário. Como se vê, sob o ponto de vista da imprecisão intensional, podemos entender "intensão", "significado" e "texto definidor" como termos equivalentes, cada qual em seu âmbito;

b) conflitos por "imprecisão extensional" (expressão que pode ser interpretada como sinônima de "vaguidão"). Antecipando que o termo "extensão" (ou "denotação") refere-se ao conjunto de objetos aos quais um termo pode ser corretamente aplicado, vemos que quando um termo é vago, sua extensão não está claramente delimitada, ou seja, o conjunto de objetos designados pelo termo pode ou não aceitar certos objetos em situação-limite, para os quais não há certeza de inclusão ou exclusão, considerando os significados, intensões ou definições desse termo;

c) conflitos por "imprecisão intensional e extensional", casos em que ocorrem ambas as dificuldades anteriores. Trata-se de casos simultâneos de ambigüidade e vaguidão: por problemas intensionais, são produzidas dificuldades extensionais.

Com isso, podemos distinguir três situações que implicam desacordos em diferentes graus, envolvendo o discurso e, especificamente, as definições ${ }^{28}$ :

\footnotetext{
${ }^{28}$ Resumidamente, temos dois tipos de conflitos: a) conflitos reais e genuínos, isto é, conflitos cujo caráter é, em sua essência, verdadeiramente opositivo e cuja existência é um fato patente para todos os envolvidos. Assim, temos os conflitos reais de crença, nos quais há um genuíno desacordo em relação à ocorrência de um determinado evento ou a existência de um determinado objeto. Temos, também, os conflitos reais de atitudes, nos quais há desacordo manifesto em relação à avaliação de eventos e objetos. Para os conflitos reais e genuínos, temos desacordos de motivação substancialista (o que está em questão é a própria substancialidade do objeto de definição, ao qual um termo se refere; o problema diz respeito aos objetos extralingüísticos, sejam eles objetos sensíveis, objetos mentais ou objetos-de-discurso); b) conflitos aparentes e não-genuínos, isto é, conflitos cujo caráter é, em sua essência, não-opositivo, embora sua existência seja um fato indiscutível para todos os envolvidos. Aqui, temos conflitos aparentes de crença e conflitos aparentes de atitudes, ambos provocados por desentendimentos em relação aos nomes ou termos empregados em um discurso particular que estabelece juízos de natureza ontológica e valorativa. Para os conflitos aparentes e não-genuínos, temos desacordos de motivação nominalista ou terminista (o que está em questão são os significados aos quais um determinado termo remete; o problema diz respeito exclusivamente aos
} 
a) nos desacordos estritamente reais, as partes litigantes clara e explicitamente estão em desacordo, quer por diferenças de crenças em relação à realidade dos fatos, quer por diferenças de atitudes em relação aos valores acionados por essas crenças. Tais tipos de pendências sempre envolvem algum tipo e grau de genuíno desacordo: não se trata, portanto, apenas de uma questão meramente lingüísticodiscursiva. Assim, o fato de que os termos empregados possam apresentar imprecisão intensional e/ou extensional não alterará a posição das partes litigantes. Aqui, o papel conciliador da definição pode ser diminuto ou mesmo nulo, isto é; a função decisória das definições aqui pode não ser preponderante.

Como exemplo de desacordo estritamente real por diferença de crença, independente das definições, temos uma discussão sobre o papel das preces na concessão da graça divina, em que não haverá, por princípio, acordo entre um religioso e um agnóstico, sejam quais forem as definições do conceito de graça divina: isso porque a crença em relação à existência desse objeto é o cerne da questão.

Um exemplo de desacordo estritamente real por diferença de atitude ocorre na avaliação da expressão "vitória da equipe de futebol X", por parte de sua torcida fanática e, ao contrário, por parte da torcida adversária (os valores atribuídos a essa realidade serão diversos);

b) nos desacordos estritamente verbais, não há desacordo genuíno entre as partes (nem por diferenças de crença, nem por diferenças de atitudes), mas sim uma aparência de conflito, motivada por desentendimentos no emprego de certos termos ou expressões; nesse caso, é usual tratar-se apenas de mal-entendidos ou de usos incorretos da linguagem e, especificamente, das definições. Aqui, o papel conciliador das definições é decisivo, pois o conflito aparente é criado por imprecisões intensionais e extensionais no uso de um termo-chave que se vincula a determinadas conviç̧ões e atitudes das partes envolvidas. O conflito deixa de existir uma vez que tais imprecisões, já reconhecidas, sejam sanadas e esclarecidas mediante definições apropriadas.

signos - objetos lingüísticos — e seus significados convencionais, que podem não corresponder aos significados essenciais ou substanciais). 
Como exemplo de desacordos puramente verbais que dependem de ajustes no âmbito das definições, temos - considerando-se dois observadores em cujo entremeio está um poste - a discussão sobre quem tem em vista a posição frontal do poste e quem o contempla pela retaguarda, pendência essa criada pela expressão — "Vejo o poste pela frente" —, empregada por ambos os observadores: obviamente, a pendência não será resolvida enquanto não houver uma definição clara sobre o que significa a expressão "parte frontal do poste";

c) nos desacordos aparentemente verbais, mas, de fato, reais, há um desacordo real, quer por convicções, quer por atitudes, que se oculta por detrás de um desacordo supostamente verbal. Aqui, desfazer o desacordo verbal, por meio de definições, não dissolverá de fato o desacordo real que, para todos os efeitos, independe de uma anuência meramente lingüístico-discursiva. Neste caso, não se trata de um tipo de imprecisão intensional ou extensional de um dado termo, mas sim da existência de diferentes critérios valorativos para a aplicação de um termo a um objeto, isto é, há interpretações diversas sobre a natureza real do objeto ao qual se deve aplicar tal termo. $O$ fato de se tornar patente a todos que os termos estão sendo empregados com imprecisões intensionais e extensionais não modificará a posição dos litigantes: o antagonismo surge da manutenção, por cada parte, de diferentes critérios de julgamento em relação aos objetos (sensíveis, mentais ou discursivos), quer em termos de existência, quer em termos de valor.

Como exemplo de desacordo aparentemente verbal, mas, de fato, real, temos o caso da aplicação do termo "pornográfico" a um determinado filme que exibe cenas de nudez: de acordo com o ponto de vista adotado, tais cenas podem receber uma avaliação positiva ou negativa e tais atitudes estarão na base do desacordo real que emergirá, aparentemente, como uma questão de especificação do termo "pornográfico" aplicado ao filme. Neste caso, mesmo que não exista qualquer ambigüidade na aplicação do termo "pornografia" (ambos os contendores definem do mesmo modo o conceito de pornografia, ou seja, há acordo sobre a definição do objeto de definição pornografia: /pornografia $\leftarrow \pi$ rexpressão artística que se caracteriza pela exposição de cenas de nudez e sexo»/), o conflito permanecerá, pois ocorre no âmbito dos valores morais considerados. 
Copi \& Cohen propõem o seguinte método para reconhecer e distinguir esses três tipos de desacordos:

\begin{abstract}
"Para auxiliar o reconhecimento e a compreensão desses diferentes tipos de conflitos, um 'diagrama' é útil. Uma vez que determinamos que existe uma disputa de algum tipo, perguntamos: 'Há algum tipo de ambigüidade presente?'. Se a resposta a essa questão for 'Não', temos uma disputa do tipo um (obviamente genuíno). Se a resposta for 'Sim', formulamos uma segunda questão: 'O esclarecimento da ambigüidade elimina o desacordo?'. Se a resposta a essa questão for 'Sim', então temos uma disputa do tipo dois (meramente verbal). Se a resposta à segunda questão for 'Não', então temos uma disputa de tipo três (aparentemente verbal, mas, de fato, genuína)" (COPI \& COHEN. op. cit., p. 102).
\end{abstract}

O seguinte quadro resume os tipos de desacordos apresentados:

\begin{tabular}{|c|c|c|}
\hline $\begin{array}{l}\text { 1. des } \\
\text { reais }\end{array}$ & $\begin{array}{l}\text { 2. } d \epsilon \\
\text { verb }\end{array}$ & $\begin{array}{l}\text { temente } \\
\text { reais }\end{array}$ \\
\hline $\begin{array}{l}\text { a) não há ambigüidade nos } \\
\text { termos empregados; } \\
\text { b) há desacordo de crença } \\
\text { e/ou de atitude. }\end{array}$ & $\begin{array}{l}\text { a) há ambigüidade nos termos } \\
\text { empregados; } \\
\text { b) não há desacordo de crença } \\
\text { e/ou de atitude. }\end{array}$ & $\begin{array}{l}\text { a) há ambigüidade nos termos } \\
\text { empregados; } \\
\text { b) há desacordo de crença e/ou } \\
\text { de atitude. }\end{array}$ \\
\hline $\begin{array}{l}\text { apel das definições: } \\
\text { elevante ou pouco rel }\end{array}$ & $\begin{array}{l}\text { papel das definições: } \\
\text { extremamente relevante }\end{array}$ & $\begin{array}{l}\text { papel das definições: } \\
\text { moderadamente rele। }\end{array}$ \\
\hline
\end{tabular}

Observando as situações básicas de desacordo, vemos que o papel das definições é de grande relevância na segunda situação, quando se manifestam desacordos cuja natureza é estritamente verbal; na terceira situação, o papel das definições é um recurso auxiliar para a dissolução do desacordo, mas não é o fator decisivo; enfim, na primeira situação, temos um desacordo que pouco depende de qualquer contribuição fornecida pelo processo definidor.

Para o segundo caso, ocorre um verdadeiro problema discursivo de definibilidade e será, portanto, necessário (re)definir os termos empregados: (re)definir-se-á, então, com os seguintes objetivos: a) eliminar a imprecisão intensional de um termo (eliminar sua ambigüidade); b) reduzir a imprecisão extensional desse termo (eliminar sua vaguidão).

Ao apresentar as razões pelas quais se justificam as definições, SALMON (1993, pp. 75-80) igualmente menciona a freqüente necessidade de se definir mais 
adequadamente a intensão de um termo frente à realidade dos objetos que compõem sua extensão. De modo mais específico, trata-se de propor uma delimitação conceitual que não seja ampla em excesso, nem restrita em demasia: se muito ampla, a intensão de um termo passa a acomodar em sua extensão objetos que não deveriam estar incluídos nela; se muito restrita, a intensão desse termo excluirá objetos que legitimamente pertencem à sua extensão - ou que, pelos menos, compartilham de traços específicos dessa intensão. É possível, inclusive, que uma definição seja, ao mesmo tempo, muito ampla e muito restrita ${ }^{29}$.

Porém, mesmo que se produza uma proposta definidora que harmonize adequadamente a intensão e a extensão de um termo, resta a solução do problema dos objetos fronteiriços. A questão que se coloca é a seguinte: como estabelecer, de modo claro e inequívoco, em que condições determinados objetos podem ou não ser incluídos na extensão correspondente à intensão proposta? Em muitos casos, os critérios decisórios devem ser estabelecidos por outras áreas de conhecimento que, freqüentemente, não oferecem respostas conclusivas ${ }^{30}$.

Como problema ulterior, constata-se que, mesmo obtendo uma delimitação intensional que acomode adequadamente os casos limítrofes conhecidos, nada garante que tal intensão prestar-se-á para acomodar outros casos limítrofes, atualmente apenas concebíveis ${ }^{31}$.

\footnotetext{
${ }^{29}$ Assim justifica-se o autor: "Por exemplo, propôs-se [...] a definição 'ser humano' significa 'animal racional'. Existem boas razões para supor que essa definição seja, simultaneamente, ampla demais em alguns aspectos e estreita demais em outros. Consideramos normalmente seres humanos os bebês, os indivíduos muito retardados e os loucos. Contudo, é duvidoso que sejam racionais, pelo que a definição proposta os excluiria da extensão de 'ser humano'. Assim, a definição é demasiado estreita. Ao mesmo tempo, certos símios parecem muito inteligentes e capazes de um raciocínio elementar. Tais criaturas, claramente excluídas da extensão de 'ser humano', tal como entendemos, ficariam incluídas na definição proposta. Sob esse aspecto, a definição intensional é demasiado ampla" (op. cit., p. 78).

${ }^{30}$ Continuando com o exemplo da expressão "ser humano", surge uma controvérsia sobre o momento em que um organismo torna-se um ser humano: é possível estabelecer diversos momentos para isso e muitas teorias postulam possuir a resposta correta. O caso dos fetos é uma ilustração apropriada; se devem ou não devem ser considerados seres humanos é uma questão controversa que envolve disputas em diversos campos do conhecimento humano.

${ }^{31} \mathrm{O}$ autor observa aqui: "Por exemplo, vamos supor que uma nave espacial chegue à Terra trazendo seres de outro planeta, obviamente inteligentes e semelhantes a pessoas terráqueas sob muitos outros aspectos. Imaginemos ainda que alguém mate um desses seres sem qualquer provocação. Seria isso um homicídio? A resposta depende da definição dada a 'ser humano"'.
} 
Observemos, ainda, que as formulações definidoras, em realidade, pressupõem conceitos: se considerarmos a presença de uma definição adequada, capaz de ajustar apropriadamente a intensão e a extensão do termo, deveremos garantir que os pressupostos dessa definição atendam igualmente a esse ajuste. Assim, se aceitarmos que ser humano é igual, por definição, a ‘animal racional, devemos ter em conta que definição de racional estamos acionando: a) racional é igual, por definição, a rem que há coerência, lógica; inteligente); b) racional é igual, por definição, a ‘que tem a possibilidade do uso da razão); c) racional é igual, por definição, a ‘que demonstra bom senso e juízo ponderado; sensatos? Dependendo da escolha feita, teremos uma definição cujo texto definidor inicia-se com a expressão "animal racional" (assassino serial é igual, por definição, a ranimal racional etc.), mas para a qual a afirmação "essa definição é falsa" pode representar um juízo verdadeiro ou falso, de acordo com as escolhas conceituais assumidas como pressupostas.

O autor (op. cit., pp. 78-80) retoma algumas razões discursivas já mencionadas para que se verifique o processo definidor e, além disso, apresenta outras:

a) a primeira delas refere-se à necessidade de se precisar, dentre os usos correntes de um termo, um particular conceito e seu(s) contexto(s) de uso ou, então, precisar os particulares conceitos que estão vinculados ao nome do termo. É o que se encontra nas diversas acepções que os termos dicionarizados oferecem à consulta.

O autor destaca que não convém interpretar as diversas definições, encontradas em dicionários de renome, sob o prisma do critério da verdade versus falsidade (ou seja, não faz sentido considerar que uma definição lexical é, em si mesma, a verdadeira definição do referido objeto de definição). Melhor considerá-las segundo aquilo que de fato são: um mostruário de usos, contextos e convenções no âmbito das definições. São, em suma, propostas de delimitações conceituais a serem empregadas em contextos lingüísticos específicos e, portanto, por princípio, nem verdadeiras nem falsas.

É importante discernir entre as definições, ou seja, os textos definidores ou definiens, e os juízos de valor aplicados às definições, isto é, os enunciados que 
declaram o valor de verdade ou falsidade das definições: i) as definições, entendidas como propostas de delimitação conceitual e como diretrizes para o uso dos termos, não podem ser consideradas nem verdadeiras nem falsas em si mesmas: são, simplesmente, postulações; ii) os juízos de valor aplicados a um texto definidor, sustentando a procedência ou improcedência dessa regra ou afirmando sua aceitabilidade em uma situação específica, são, de acordo com as situações, verdadeiros ou falsos.

Por exemplo, a definição que propõe uma equivalência entre o objeto certeza e os textos definidores: i) (segurança subjetiva da verdade de um conhecimento); ii) 'garantia que um conhecimento oferece de sua verdade) (ABBAGNANO, 2003, p. 131, verbete "certeza"), não pode ser considerada nem verdadeira, nem falsa em si mesma; porém o enunciado valorativo "a primeira das acepções é a única que deve ser considerada verdadeira" pode ser verdadeiro ou falso e, no caso desse enunciado, considerado em si mesmo, deve ser ajuizado como falso, uma vez que a primeira acepção, enfatizando o aspecto subjetivo da certeza, não justifica sua precedência em relação à segunda acepção, que enfatiza o aspecto objetivo desse conceito;

b) outra razão discursiva para o emprego de definições dá-se pela percepção de existência de um conceito relevante ainda não convenientemente denominado, ou seja, pela inexistência de um termo específico que articule convenientemente um conceito e um nome a ele adequado ${ }^{32}$. Trata-se, portanto, dos casos em que há um objeto mental ${ }^{33}$ (ou, mesmo, um objeto sensível) propriamente caracterizado (há a percepção clara desse objeto mental ou desse conceito), mas não há ainda a aposição de um nome que, junto dele, constitua um novo signo. Nesses casos, a definição tem por função discursiva introduzir oficialmente esse termo. $O$ exemplo do

\footnotetext{
${ }^{32}$ Para uma exposição sobre as teorias no nome - relações entre os nomes e os objetos designados pelos nomes, especificamente em Platão e Aristóteles - remetemos a SILVA (2002, pp. 27- 97). Nessas páginas, a autora discute a exatidão da significação dos nomes para Platão; a distinção entre a teoria essencialista e a teoria relativista dos nomes; os critérios para a formação e utilização dos nomes; por fim, o nome e seu papel predicativo em Aristóteles.

${ }^{33}$ Entendemos por "objeto mental" qualquer entidade ontologicamente individualizada e previamente constituída como uma unidade que existe mentalmente, quer em âmbito individual, quer em âmbito coletivo ou social. Racionalmente, tal objeto pode assim ser entendido como um conceito ou uma idéia.
} 
autor é o termo "mesete", assim definido: mesete é igual, por definição, a "mês que tem menos de trinta e um dias";

c) uma terceira razão discursiva para o emprego de definições surge a partir da indefinição extensional intrínseca a determinados termos, conforme já apontamos. Assim define o autor o termo "vago": "vago" é igual, por definição, a "termo cujos objetos não estão claramente incluídos em sua extensão, nem estão claramente excluídos dela". Nesses casos, as definições têm por função especificar com mais precisão a intensão e a extensão de tais termos; usualmente, novas definições são propostas de modo a diminuir a subjetividade do conceito, agregando-se informações quantitativas e critérios observáveis que melhor o caracterizem. $O$ exemplo do autor é o termo "rico"; torna-se muito difícil precisar o que seria um indivíduo rico, sem o apelo a algum dado empírico ou numérico. Uma proposta de definição mais tangível poderia ser: rico é igual, por definição, a sindivíduo que possui um patrimônio avaliado em, pelo menos, quinhentos mil dólares);

d) a quarta razão discursiva para o emprego de definições tem lugar quando há termos cuja extensão é conhecida, mas cuja intensão não está definida de modo adequado, por não se ajustar ao campo extensional conhecido (caso igualmente já mencionado). Ou seja, aqui, diversos objetos são intuitivamente incluídos na classe extensional de um dado termo, segundo os contextos apropriados, mas não se tem uma definição adequada que, intensionalmente, justifique essa inclusão. Este é o exemplo mencionado por Salmon:

"Raras vezes teremos dificuldade em empregar a expressão 'ser humano'; diante de um
determinado objeto, estamos em geral aptos a afirmar peremptoriamente se se trata ou não de
um ser humano. Não obstante, podemos enfrentar consideráveis dificuldades para dizer que
propriedades distinguem os seres humanos dos não-humanos. O problema é encontrar uma
definição intensional que forneça a extensão já aceita para o termo. [...] Encontrar uma
adequada definição intensional de 'ser humano' requer que apuremos um conjunto de
propriedades compartilhadas por todos os objetos definitivamente situados na extensão, mas
não compartilhadas por qualquer dos objetos definitivamente ausentes da extensão" (op. cit., p. 78). 
Em resumo, trata-se do seguinte fenômeno: discursivamente, são usados termos cujas definições não estão estipuladas com segurança, fato que, contudo, parece não impedir os usuários de enunciarem convictamente tais termos; temos, assim, três situações verificáveis: i) vários objetos incluem-se indiscutivelmente na extensão de um termo; ii) outros objetos não se incluem, obviamente, nessa extensão; iii) alguns objetos permanecem em posição vaga nessa extensão: nem totalmente incluídos, nem totalmente excluídos dela (objetos fronteiriços);

e) a quinta razão discursiva para o emprego das definições verifica-se por motivações eminentemente teóricas, enfatizando não tanto a função de dissipar ambigüidades, mas sim a função de enunciar generalizações fundamentais em dada ciência, sob a forma de conceitos universais. Como exemplo, temos, em filosofia, a definição de substância para a metafísica tradicional: sua definição deve ser rigorosa o suficiente para que seu emprego, nessa doutrina específica, não produza qualquer incompreensão. O mesmo se dá para os conceitos de trabalho e energia em Física;

f) o autor menciona também a função emotiva das definições; nesse caso, temos definições que expressam não tanto um conteúdo teórico rigorosamente sintetizado por uma doutrina, mas sim um texto definidor que tem por objetivo acionar determinados valores e produzir determinadas atitudes: são as chamadas "definições persuasivas ou argumentativas" — discursos definidores cuja função principal é produzir determinados efeitos retóricos frente a um auditório. Por exemplo, o texto definidor robjeto que desce aos mínimos detalhes de determinado assunto, enumerando-os exaustivamente e comentando-os com grande riqueza de detalhes` poderá, segundo usuários diversos, ser vinculado ao conceito de profundo ou ao conceito de enfadonho.

Assim o autor explana o papel emotivo das definições:

\footnotetext{
"Em primeiro lugar, podemos escolher uma palavra dotada de considerável força emotiva e defini-la de modo que se aplique a algo que desejamos aplaudir ou condenar. Por exemplo, podemos definir 'socialista' como 'que tende a distribuir uniformemente a riqueza por meio de ação governamental' [...] Definições desse tipo transferem a força emotiva do definiendum para o definiens. [...] Em segundo lugar, o processo pode ser revertido. [...] Suponha-se que uma certa obra teatral é reconhecidamente naturalista. Alguém poderia definir 'naturalista' como
} 
'glorificação da mesquinhez da natureza humana e da indignidade da existência humana'. Essa definição transfere a força emotiva negativa do definiens para a palavra 'naturalista' — o definiendum — e daí para a própria obra teatral" (op. cit., p. 80).

As diversas razões discursivas até aqui apresentadas justificam a existência de um processo definidor e constituem autênticas categorias tipológicas sob o ponto de vista da teoria das definições; porém, usual é que os diversos autores que tratam do tema construam suas tipologias normalmente baseadas na clássica divisão (e, digamos até, no antagonismo) entre definições essencialistas (definições cujos conceitos dizem respeito à essência dos objetos de definição) e definições nominalistas (definições cujos conceitos são, em verdade, explicitações dos possíveis significados dos termos vinculados aos objetos de definição).

\subsection{DEFINIÇÕES E SUAS CONDIÇÕES: COMO DEFINIR?}

Os autores que estudam o mecanismo definidor procuram apresentar critérios para descrever o que seria uma definição ideal ou, em outras palavras, procuram encontrar a melhor definição de definição. Encontramos parâmetros para as definições ideais quer na doutrina essencialista/substancialista quer na doutrina nominalista/terminista das definições: em tais doutrinas, procura-se prescrever normas para a criação de definições qualitativamente aceitáveis (ou seja, estipulamse regras que constituem parâmetros de qualidade para as definições), de acordo com os propósitos das respectivas ciências ${ }^{34}$.

\footnotetext{
${ }^{34}$ Os objetivos de cada campo de estudo determinam os princípios que governam suas definições; assim, em PERINI (2006, pp. 55-56), lemos: Para que serve uma definição? A formulação de uma definição só se justifica se ela possibilita a identificação de uma entidade gramatical. É inútil uma definição que só possa ser aplicada corretamente por quem já saiba o resultado de antemão. Assim, uma boa definição de 'sujeito' deve possibilitar a identificação do sujeito de uma oração por alguém que não saiba qual é o sujeito — ou mesmo o que é um sujeito - simplesmente aplicando a definição. Para que uma definição atinja tais objetivos, é necessário que ela tenha (pelo menos) as qualidades seguintes: a) ser explícita: isto é, fornecer todos os elementos necessários à sua aplicação; b) ser adequada ao usuário em perspectiva: isto é, utilizar noções e termos que o usuário já conheça; c) ser adequada à realidade lingüística: isto é, descrever fatos reais da língua, e não fantasias ou opiniões pessoais a respeito dela". Destacamos a inclusão de aspectos pragmáticos no conjunto de características apresentadas pelo autor; destacamos igualmente os comentários feitos pelo autor em relação a algumas definições gramaticais tradicionalmente postuladas.
} 
Como exemplo dessas normas, em IDE (op. cit., pp. 196-198) encontramos dois critérios fundamentais:

a) a expressão que define deve visar a essência universal, ou seja, a real natureza do objeto definido, e não suas características acidentais e superficiais (declarar o que nele é substancial e desconsiderar o que nele é contingente);

b) a definição ideal declara o gênero ${ }^{35}$ próximo e a espécie ou diferença específica do objeto definido.

Como critérios complementares, temos:

c) a expressão que define (o definiens) deve ser mais clara e de mais fácil entendimento do que o termo definido (o definiendum);

d) a expressão que define deve ser a mais econômica possível (isto é, o texto definidor deve ser preciso, utilizando o menor número possível de palavras);

e) a expressão que define não deve retomar ou incluir o termo definido (ou seja, deve evitar a circularidade);

f) a expressão que define não deve ser negativa, isto é, deve-se dizer aquilo que o termo definido é, e não aquilo que não é.

Como podemos perceber, esses critérios têm em vista, como ideal, as definições que declaram a substancialidade dos objetos de definição por gênero e diferença específica ${ }^{36}$.

${ }^{35}$ Em ABBAGNANO (2003, pp. 478-479, verbete "gênero"), lemos: "Aristóteles distinguiu três significações desse termo: a) geração, particularmente a 'geração contínua de seres que têm a mesma espécie'; b) estirpe ou raça como 'primeiro motor' ou 'aquilo que deu ser às coisas de uma mesma espécie' [...]; c) o sujeito ao qual se atribuem as oposições ou as diferenças específicas, e nesse sentido o gênero é o primeiro constituinte da definição. [...] Para Aristóteles, essa significação também é a mais importante e, em vista disso, pode-se dizer que o gênero, juntamente com a espécie, é substância segunda [...] porque entram na composição da substância primeira, ou seja, da essência necessária. [...] O gênero não é substância, mas componente necessário da essência necessária, que é a substância [raquilo que subsiste, que permanece)]. Dessa formulação de Aristóteles nasceu a contenda medieval dos universais. Os universais são de fato o gênero e a espécie. A outra alternativa fundamental para a solução da discussão foi proposta pelas estóicos, que definiram o gênero, de modo nominalista, como 'a conjunção de noções diferentes e permanentes, como por exemplo, animal, que abrange como suas espécies todos os animais [...]. Na filosofia moderna e contemporânea, a palavra 'gênero', assim como a palavra 'espécie', ainda é empregada esporadicamente, mas sem as implicações ontológicas que possuía em Platão e Aristóteles".

${ }^{36}$ Como exemplo de definição bem construída, o autor menciona: /glória $\leftarrow \pi$ igrande renome difundido num público muito vasto, e que se deve a méritos, ações ou obras julgadas notáveis`/. Temos uma definição por gênero e diferença específica: gênero distante = "grande renome"; gênero próximo = "difundido num público muito vasto"; diferença específica = "e que se deve a méritos, ações ou obras julgadas notáveis". Outro exemplo ocorre em: /tecido $\leftarrow \pi$ «conjunto de estruturas celulares 
Para PALACIOS \& PALACIOS (2002, pp. 8-9), estas são as "regras de definição":

a) a definição não deve ser muito ampla nem muito estreita, pois se trata de delimitar claramente o objeto e distingui-lo de todos os demais. Ser muito ampla significa incluir outros conceitos que não se pretende definir. Ser muito estreita significa que, além do gênero e da diferença específica, a definição inclui características que destroem a identidade entre definiendum e definiens ${ }^{37}$;

b) a definição deve ser mais clara que o definido, já que se trata de produzir o conhecimento do objeto, e não de obscurecê-lo;

c) o nome do definido não deve fazer parte da definição, evitando-se definições circulares;

d) o texto definidor deve ser positivo na medida do possível — a não ser nos casos de definição de termos ou conceitos essencialmente negativos; como exemplo, temos: /cegueira $\leftarrow \pi$ 〈privação do sentido da visão /;

e) o texto definidor não deve incorporar termos metafóricos.

Em HEGENBERG (op. cit., p. 27), são mencionados princípios gerais para a elaboração de definições adequadas: "1. uma definição deve aludir à essência daquilo que se procura definir; 2. uma definição não deve ser circular; 3. uma definição deve ser colocada, sempre que possível, em forma afirmativa; 4. uma definição não deve ser formulada em linguagem obscura ou metafórica". Temos, portanto, uma recomendação relativa ao conteúdo das definições e três recomendações relativas à forma do texto definidor; como vemos, tais diretrizes são reiteradas por diversos autores.

Hegenberg comenta que tais princípios possuem, como um conjunto, razoável utilidade prática, porque permitem a exclusão de algumas formulações pseudodefinidoras que não resistem ao crivo de uma análise minimamente rigorosa; o autor menciona algumas dessas pseudodefinições: "A beleza é a eternidade

e extracelulares especializadas em vista de uma mesma funçãos /. O gênero é "conjunto de estruturas celulares e extracelulares"; a diferença específica é "especializadas em vista de uma mesma função" (IDE, op. cit., pp. 204-205).

37 "No ato de definir, pretende-se estabelecer uma identidade entre o definido e a definição. Para isso, há de se explicitar tudo o que está implícito no definido e somente isso" (op. cit., p. 9). 
contemplando-se no espelho"; "Medo é a sensação de estar à beira do nada"; "Razão é substância, assim como poder infinito, cujo material se coloca na base de toda a vida espiritual e material"; "Razão é a substância de que tudo deriva seu ser". Como vemos, tais formulações dificilmente podem ser tomadas seriamente como definições válidas — pois, simplesmente, não realizam a operação teórica fundamental que anunciam pretensamente realizar: não definem os conceitos em questão.

Assim, tanto podemos considerar a proposta /"Medo" $\approx$ "Sensação de estar à beira do nada" / quanto podemos aceitar como definiens: a) "Sensação de estar próximo ao nada"; b) "Sensação de estar-se aproximando do nada". Que é, realmente, "estar à beira" do nada? Que é, de fato, esse "nada"? Também, se aceitarmos que o conceito de beleza é definido pelo texto "é a eternidade contemplando-se no espelho", então deveremos aceitar a validade da expressão: "Sua eternidade contemplando-se no espelho deslumbrou a comissão julgadora".

Tomados como um conjunto, esses princípios, embora racionais, resistem à utilização prática (ou seja, não são de fácil aplicação); em especial, é possível endereçar objeções ao primeiro princípio, por ser de difícil determinação a noção de essência - ou, pelo menos, de difícil operacionalização. Na prática do processo definidor, torna-se necessário, freqüentemente, lançar mão de conceitos de definição que incluam outros parâmetros mais flexíveis, muitos de cunho pragmático.

FOLSCHEID \& WUNENBURGER (1997, p. 361), ao tratarem das características dos textos filosóficos, declaram inicialmente que "definir consiste em explicitar o sentido das palavras de uma língua" (doutrina terminista-nominalista da definição). Conforme observam os autores, para a Filosofia, o ato de definir é de primordial importância, uma vez que opera com termos de uma língua natural, usualmente polissêmicos, aos quais atribui significados ad hoc (exemplo: o conceito filosófico de natureza): embora a Filosofia não construa seus discursos em línguas artificiais (cujos termos são monossêmicos desde o momento de sua criação), opera com termos técnicos especiais que, apesar de serem definidos de modo particular por um dado sistema filosófico e freqüentemente variarem de autor para autor, permanecem usualmente constantes e necessariamente explícitos em dado autor 
(exemplo: o conceito de transcendência para Kant). Ou seja, os termos filosóficos representam um emprego específico e rigoroso dos termos das línguas naturais, pouco se assemelhando, portanto, aos termos das línguas artificiais (assim, não devemos cometer o corriqueiro engano de confundir Filosofia e Lógica, tomando-as por equivalentes).

Porém, como podemos notar, essa mesma observação dos autores traz em si a informação de que a Filosofia não lida apenas com definições nominalistasterministas, uma vez que ela procura estabilizar o significado de seus termos e, portanto, dos conceitos por eles mencionados: ela opera, de fato, com definições essencialistas-substancialistas. Trata-se de um processo de fixação semântica dos termos e uma etapa preliminar imprescindível para que sistemas conceituais específicos demonstrem precisão e validade, características que dependem decisivamente da definição adequada dos conceitos que se prestam à construção do edifício textual. Para tanto, é preciso que os significados dos termos naturais e dos termos técnicos criados ad hoc sejam evidentes e constantes - ou seja, é preciso que as palavras empregadas aproximem-se do ideal de univocidade, uma vez que, filosoficamente, o implícito e a polissemia são descartados como marcas de um texto antifilosófico $^{38}$.

Os autores apontam que as definições menos rigorosas e menos operacionais são aquelas que se apresentam como simples descrições do objeto definido; isso porque as caracterizações descritivas fornecem usualmente apenas traços acidentais dos objetos, ou seja, atributos contingentes que não constituem caracteres essenciais e necessários para que um dado objeto seja aquele objeto específico e nenhum outro. Todavia, há certa utilidade nas descrições dos objetos definidos: podemos apreender, por meio delas, diversas manifestações fenomênicas

\footnotetext{
${ }^{38}$ Os autores classificam os termos filosóficos em três grupos: "- o primeiro compreende termos que não são propriamente filosóficos, mas podem adquirir um sentido filosófico. Por exemplo: 'bom senso', 'senso comum', 'intuição', 'liberdade', 'mundo', 'natureza'; — o segundo compreende termos filosóficos universalmente usados (por exemplo: 'essência', 'substância', 'idéia', 'razão'), mas que adquirem significações diferentes conforme a época, o contexto doutrinal ou o autor; - o terceiro compreende termos absolutamente específicos, que é impossível retirar de seu contexto sem o risco de interpretação errônea (por exemplo: o 'transcendental' em Kant)" (op.cit., p. 26).
} 
contingentes dos objetos; inegavelmente, trata-se de uma possibilidade inicial de acesso à essência objetal.

Assim concebem os autores uma boa definição:

"A boa definição é a que expõe, que desdobra, as características necessárias (aquilo sem o que a coisa não pode ser, nem ser concebida) da coisa definida, ela 'explica a natureza de uma coisa pelos atributos essenciais, dos quais os que são comuns chamam-se gênero e os que são próprios, diferença [...]. Essa definição adequada deve apresentar três características: ser universal (deve compreender todo o definido), ser própria (deve convir apenas ao definido) e ser clara (deve explicar a razão das principais propriedades do definido). O ideal é poder chegar progressivamente a uma definição genérica, que expõe a essência (o objeto da definição) e o movimento (que deve ser reproduzido na redação [do filósofo]) pelo qual o pensamento concebe a definição. Por exemplo, a 'esfera' é o 'volume descrito pelo movimento de um semicírculo sobre si mesmo em torno de seu diâmetro', ou 'pelo movimento do círculo em torno de si mesmo'. [...] Para apreciar seu poder de instrução, comparem-se essas definições genéticas a esta outra definição, igualmente exata, porém mais pobre, porque mais estática: o 'círculo' é a 'figura na qual as retas traçadas do centro até a circunferências são iguais'" (op.cit., p. 362).

Em COPI \& COHEN (2002, pp. 125-129) também são mencionadas "regras" para a elaboração de definições por gênero e diferença específica; os autores destacam que tais regras visam primordialmente às definições lexicais — ou seja, definições que reportam o significado (ou um dos significados) que um definiendum já possui, com o intuito de selecionar ou mencionar um dos usos já consagrados do termo e desfazer possíveis ambigüidades. São elas: a) a definição deve declarar os atributos essenciais da espécie; b) a definição não deve ser circular ou tautológica; c) a definição não deve ser nem muito abrangente nem muito restrita; d) a definição não deve ser expressa em linguagem ambígua, obscura ou figurativa; e) a definição não deve ser negativa se puder ser afirmativa.

Em SANT'ANNA (2005, pp. 3-7), apresentam-se os principais pontos de uma crítica aos preceitos comumente mencionados, relativos a como se deve bem definir:

a) quanto à diretriz sobre a necessidade de se fornecer a essência daquilo que se define, pode-se destacar a indefinição e/ou a vaguidão da própria expressão 
"essência de algo"; em particular, conforme destaca o autor, tal expressão pressupõe uma "postura essencialista", isto é, uma convicção de que faz sentido falar em "essência" das coisas - certeza que não implica, de modo algum, uma unanimidade teórica, pois é razoável colocar em questão a realidade de tal essência;

b) quanto à diretriz sobre a necessidade de se formular um texto definidor nãoobscuro, pode-se argumentar contra a própria obscuridade da expressão "linguagem obscura": qual o conceito de obscuridade válido universalmente para as definições?;

c) o seguinte preceito - "o definiens deve ser mais claro do que o definiendum" — é passível da mesma crítica: qual o conceito de clareza acionado por tal formulação? Há um conceito universal de clareza?;

d) o preceito — "uma definição não deve ser circular"39 —, isto é, o definiens não deve incluir o definiendum, constrói-se a partir de uma circularidade, pois, uma vez que a regra serve para definir o conceito de definição, há uma circularidade implícita: também, o próprio preceito inclui o termo "definição", conceito esse que é o objeto da diretriz apresentada ("definição boa" $\approx$ "definição não circular" $\rightarrow$ "definição circular" $\approx$ "definição cujo definiens repete um conceito do definiendum");

e) por fim, o preceito — "o definiens não deve ser negativo" - censura a formulação do preceito anterior.

Como vemos, os preceitos sobre como se deve definir mencionam em geral a necessidade de declarar atributos essenciais do definiendum; outras recomendações são diretrizes formais do texto definidor, muitas de difícil operacionalização. Verificase que, praticamente, tais preceitos representam apenas um modelo ideal de definição, realizado em circunstâncias discursivas extremamente favoráveis, mesmo nas linguagens não-naturais.

\footnotetext{
${ }^{39}$ Como ocorre nos exemplos: "Um jogador compulsivo é aquele que joga desenfreadamente" ou "Idoso é aquele que tem muita idade".
} 


\subsection{NOTAS PRELIMINARES SOBRE O CONCEITO DE DEFINIÇÃO}

$\mathrm{Na}$ já mencionada obra clássica de Rickert sobre a teoria das definições, destaca-se a diversidade de opiniões sobre o conceito de definição ${ }^{40}$. De fato, segundo o autor, "por mais correntes que sejam para nós as palavras 'definição' e 'definir', resultaria muito difícil indicar, seguindo os textos modernos de Lógica, o que propriamente significam em sentido lógico" (op. cit., p. 13). Tal situação surpreende, pois as exposições teóricas sobre as definições apresentam-se em geral de forma breve, direta e precisa, fato que nos induz a considerar ser essa uma questão pacífica: sempre que se discorre sobre a teoria das definições, apresentam-se algumas fórmulas consagradas e alguns preceitos absolutamente racionais, os quais parecem atribuir ao processo definidor uma facilidade que, contudo, demonstra ser enganosa ${ }^{41}$.

Rickert destaca a gênese do problema teórico das definições: "[...] a razão para isso pode-se facilmente assinalar: as fórmulas lógicas constantemente mencionadas [relativas às definições] procedem de Aristóteles e têm uma estreita conexão com sua metafísica, de tal modo que carecem de significado sem ela". Assim, o problema tem origem na seguinte distorção: a teoria moderna, quase sem exceções, não opera no terreno da metafísica aristotélica, mas conserva, não obstante, suas

\footnotetext{
${ }^{40}$ Sobre as dificuldades em conceituar a definição, lemos em SANT'ANNA (2005, p. 1): "Como definir uma definição? Isso é como perguntar o significado da palavra 'significado' ou o conceito de conceito. [...] Parece haver uma circularidade inerente em qualquer tentativa de definir uma definição. [...] Uma maneira de definir uma definição é por meio da distinção entre linguagem e metalinguagem. A metalinguagem pode ser usada para conceituar definições que se inserem no contexto de alguma linguagem-objeto. Mas nem sempre isso ocorre, pois muitas vezes não há distinção entre linguagemobjeto e metalinguagem. [...] Definições interessam a filósofos, cientistas, jornalistas, etimólogos, lexicólogos, engenheiros, entre outros. Do ponto de vista etimológico, por exemplo, a palavra 'definição' significa 'uma ação para estabelecer limites'. Já para um jornalista, definições podem desempenhar um papel ligado a sentimentos e ideologias; por exemplo, 'comunismo', que alguns definem como a 'democratização do capital'. Apesar dessa afirmação não definir precisamente o que é comunismo, pode provocar um sentimento de bem-estar ao associar o termo 'comunismo' com a palavra 'democratização', a qual normalmente está ligada a uma ideologia agradável e politicamente correta".

41 "Contudo, se virmos as coisas com maior cuidado e tratarmos de formar com essas fórmulas uma opinião determinada sobre o conceito de definição, especialmente sobre sua posição no sistema da lógica, observaremos que essas fórmulas só adquirem um sentido compreensível com as interpretações subseqüentes, e essas interpretações mostram divergências tão fortes que não resta quase nada de sua aparente concordância" (RICKERT, op. cit., p. 13).
} 
formulações teóricas no que diz respeito ao conceito de definição e lhes dá um novo significado. Esse novo significado precisa depender novamente de novos pressupostos metafísicos ou epistemológicos, para não se revelar carente de sentido. Instaura-se, portanto, uma tensão entre aquilo que se constituiu como a teoria formal das definições e aquilo que é, de fato, a respectiva teoria aristotélica.

Em suma, no que diz respeito ao processo definidor, não se pode isolar a teoria aristotélica das definições de seu contexto teórico mais amplo - o pensamento aristotélico como um todo, em particular sua metafísica ou ontologia, além de sua filosofia da ciência —; se assim for feito, projetar-se-ão seus postulados em um vácuo teórico ou, mais grave, revestir-se-ão eles de uma moldura teórica imprópria que gera interpretações incompatíveis com o pensamento teórico original ${ }^{42}$.

Em Tópicos, VII, 5, Aristóteles afirma: (Orismo/j e)sti lo/goj o( tol ti/ ei \}nai shmai/nwn, enunciado que se costuma traduzir por "a definição é o discurso que nos indica a essência" ${ }^{43}$. Segundo essa visão, a função da definição é declarar o conhecimento sobre a essência de um ser — isto é, "[...] determinar o conceito geral atemporalmente válido, cuja expressão particular constitui a coisa individual do mundo sensível" (RICKERT, op. cit., p. 14). Como realizar essa tarefa, o próprio Aristóteles encarrega-se de declarar; em Tópicos, I, 8, afirma: (Orismo/j e)k ge/nouj kai\ diaforw n e)stin, ou seja, "a definição é gênero e diferença". O gênero indica a essência e, pelo enquadramento de um objeto em um dado gênero, conhecemos sua natureza ou substância; acrescentando a diferença específica, designamos um modo particular pelo qual se manifesta fenomenicamente tal essência. Assim, ao propor a definição /homem $\leftarrow \pi$ 〈animal racionalı/, indicamos desse objeto seu gênero próximo (animal) e sua diferença específica (racional); com isso, construímos o conceito de homem.

\footnotetext{
${ }^{42}$ Para o exame das relações entre a metafísica e a linguagem em Aristóteles — além da questão da significação das palavras segundo o pensamento do estagirita — remetemos o leitor para SANTOS (2002, pp. 79-150)

${ }^{43}$ Interessa destacar que Aristóteles não desconhece o papel dos nomes ou dos signos dentro do processo definidor, ao lado das definições substancialistas; assim, em Segundos Analíticos, II, 10, assinala: "Desde que a definição é dita ser uma proposição sobre a natureza de uma coisa, obviamente um tipo de definição será uma proposição sobre o significado do nome [da coisa] ou uma proposição sobre um tipo de fórmula nominal equivalente. [...] Esse, então, é um modo de definir definição. Outro tipo de definição é uma fórmula exibindo a causa da existência de uma coisa [...]".
} 
Portanto, conforme assinala Rickert:

"Enquanto as outras formas lógicas constituem membros do processo de investigação e exposição científica - enquanto o silogismo, por exemplo, significa um instrumento com o qual progredimos de um pensamento a outro, a tarefa da definição, para Aristóteles, é concluir a investigação sobre a natureza de um ser, fixando de modo cabal a essência de um particular objeto de investigação" (op. cit., p. 14).

Assim, essa função transcende o mero aspecto terminológico, pois a essência de um ser é infinitamente mais permanente do que os nomes que possam eventualmente designá-lo. Também, sendo o texto definidor a correta expressão lingüística da essência de um ser, tende tal texto à unicidade, aceitando-se apenas variações parafrásticas do definiens ideal.

Como vemos, os conceitos de gênero e essência são fundamentais para a teoria aristotélica das definições; a possibilidade de determiná-los claramente vincula-se à investigação sobre a natureza dos seres: à medida que tal natureza é estabelecida e conhecida, igualmente se estabelece a definição essencial correspondente, declarando e fixando permanentemente o conceito assim especificado.

Instaura-se aqui um problema crucial:

"Na filosofia moderna não se costuma identificar essência e gênero, e, portanto, os modernos lógicos da definição não podem partilhar, sem maiores pressupostos, a tarefa de indicar a essência de uma coisa mediante gênero e diferença. Quanto mais clara e compreensível resulta essa tarefa no sistema aristotélico, com determinados pressupostos objetivos de tipo metafísico, tanto mais incompreensível torna-se ela na lógica moderna, que já não supõe uma metafísica" (RICKERT, op. cit., p. 15).

Mesmo assim, repete-se à exaustão em muitos tratados sobre lógica e definições que definir significa declarar genus proximum e differentia specifica. Em realidade, isso implica indagar sobre o sentido de se postular a possibilidade de estabelecer a substância de um ser sem a garantia da possibilidade de enunciar seu gênero e diferença específica. Em outros termos, trata-se de indagar sobre a 
pertinência de se sustentar uma teoria das definições de caráter essencialista ou substancialista sem a certeza de se pressupor uma ontologia que the dê fundamento (ou seja, sem que haja a possibilidade concreta de se estabelecer a essência dos objetos de definição).

Esse é, na teoria das definições, um problema fundamental, pois, na impossibilidade de um sólido fundamento ontológico, as definições restringir-se-iam à especificação dos significados dos nomes em uso: nesse sentido, abandonar-se-ia um conceito de definição semelhante a /definir $\leftarrow \pi$ rexpressar a substância do objeto de conceito, indicando todos os elementos essenciais nele contidos e que o constituems/(próprio das definições substancialistas) em favor de um conceito semelhante a /definir $\leftarrow \pi$ rexpressar um juízo que distingue o significado de uma palavra que designa um conceitos / (próprio das definições terministas).

Por um lado, aceitar a possibilidade de uma ontologia como pressuposto do processo definidor implica a capacidade de abstrair os traços essenciais dos objetos de definição, sendo eles: a) os traços que contêm o fundamento comum e permanente dentro de uma multiplicidade de manifestações; b) os traços dos quais depende a consistência do objeto e de seu valor — assim como a significação que Ihe corresponde - em uma série ordenada de objetos. A definição é "a expressão da essência (essentia) do objeto de conceito", uma vez que indica "todas as características essenciais contidas no objeto de conceito, ou todos os seus elementos essenciais" (ÜBERWEG apud RICKERT, op. cit., p. 16).

Lotze afirma que a teoria da definição independe de considerações epistemológicas; para ele, a definição implica uma descrição metódica, na qual o postulado de gênero e diferença constitui simplesmente uma regra que atribui maior brevidade e precisão à definição, sem ser rigorosamente necessária. Para esse autor, contudo, a definição não se confunde com a explicação do significado dos termos: "os nomes podem ser enunciados ou traduzidos; porém, só podemos definir seu conteúdo - nossa idéia ou representação daquilo que devem denotar" (LOTZE apud RICKERT, op. cit., pp. 16-17).

Já para o conceito de definição como «juízo que indica a significação dos termos que designam conceitos», a determinação do gênero e da diferença 
específica presta-se para localizar e posicionar o conceito dentro de um sistema ordenado de conceitos; trata-se, portanto, de um recurso para relacionar organizadamente o pensamento e a linguagem: "a definição é um juízo pelo qual se indica a significação de uma palavra que designa um conceito"; "se chamamos 'definição' a indicação das características de um conceito ou do genus proximum e da differentia specifica, é claro que não se trata de uma explicação do conceito, mas sim — se algo é explicado - trata-se unicamente de uma explicação de palavras" (SIGWART apud RICKERT, op. cit., pp. 16-17).

Como se vê, os conceitos de definição diferem basicamente: a) pela aceitação ou não aceitação da viabilidade de um pressuposto ontológico/epistemológico; tratase, então, de aceitar ou não a possibilidade de se conhecer a essência do objeto de definição (por exemplo, mediante indução) e de expressá-la mediante discurso definidor; b) pelo foco sobre o ser cujo conceito é objeto de definição ou sobre o significado de um nome que designa o conceito do ser. Assim, a definição/cobaia $\leftarrow \Pi$ 〈roedor sul-americano da família dos caviídeos» / representa uma definição por gênero e diferença que pressupõe a possibilidade ontológica de conhecer a essência do ser conceituado como cobaia; já a definição /"cobaia" "pessoa manipulada experimentalmente; boi de piranha"/ representa uma definição do significado vinculado ao significante "cobaia" — trata-se, portanto, de uma 'definição' puramente lingüística que destaca, dentre múltiplos significados, um significado intentado, esclarecendo assim qual a leitura que tal termo deve receber (não se pretende, como se vê, discutir nosso conhecimento sobre o roedor caviídeo e seu conceito).

Rickert indaga sobre qual tendência e preocupação do pensamento humano originou-se a definição. Segundo o autor, a filosofia grega passa a interessar-nos quando começa a se dedicar ao estudo dos processos de pensamento; em outras palavras, a racionalidade humana toma a si mesma como objeto de reflexão à medida que as contradições entre os produtos do pensamento e a realidade dos 
fatos põem em dúvida a capacidade do pensamento humano para encontrar a verdade. Para esse movimento reflexivo, foi decisivo o papel dos sofistas ${ }^{44}$.

Até então, a base do pensamento fundava-se no pressuposto da nãocontradição ${ }^{45}$, tomado em caráter hipostático; é justamente esse pressuposto que será questionado pelo pensamento sofístico:

\begin{abstract}
"Os eleatas não podiam pensar o devir por ser contraditório; para Heráclito, ao contrário, não havia nada permanente senão apenas o devir. [...] Pretendendo-se sustentar uma ou outra doutrina, de todas as maneiras parecia resultar uma conseqüência: o mundo dos sentidos, tal como se apresenta ao homem - como mescla de coisas permanentes e mutáveis - é aparência. O homem não conhece as coisas como são, mas sim como para ele aparecem assim como se apresentam a ele enquanto indivíduo. Um saber objetivo é, portanto, impossível; só existe a opinião subjetiva. Protágoras, a partir da metafísica heraclitiana, e Górgias, a partir da eleática, combateram a possibilidade de um conhecimento seguro" (RICKERT, op. cit., p. 21).
\end{abstract}

Importa considerar que, para Aristóteles, o Princípio da Contradição presta-se para refutar essa posição sofista: se alguém afirma algo de determinado, necessariamente nega a negação desse algo, reafirmando a validade desse Princípio. Portanto, tudo o que é determinado, ou seja, tudo que é afirmado como determinado, atribui validade a tal axioma. Segundo o exemplo aristotélico, dizer "homem" implica não dizer "não-homem", pois é impossível ser e não ser ao mesmo tempo; simultaneamente, dizer "homem" implica dizer "animal racional" e não dizer "não-animal não racional".

\footnotetext{
${ }^{44}$ Para observações sobre a contribuição dos sofistas para os estudos da linguagem e do discurso, ver NEVES (2005, pp. 35-45); para a oposição $\mathrm{fu} / \mathrm{sij}$ e no/moj no pensamento sofista, interessa consultar GUTHRIE (1995, pp. 57-126).

${ }^{45}$ Em ABBAGNANO (2003, pp. 203-205, verbete "contradição"), afirma-se que "tendo nascido como princípio ontológico, o Princípio da Contradição só passou para o campo da Lógica no século XVIII, para tornar-se, nesse mesmo século, uma das 'leis fundamentais do pensamento'. Como princípio ontológico, foi admitido explicitamente, pela primeira vez, por Aristóteles, que o tomou como fundamento da 'filosofia primeira' ou metafísica. [...] Aristóteles, [...], constantemente formula esse princípio de duas maneiras. Uma é estritamente ontológica e se expressa assim: 'nada pode ser e não ser simultaneamente' [...]; a outra poderia ser chamada de lógica e se expressa assim: 'é impossível que a mesma coisa, ao mesmo tempo, seja inerente e não seja inerente a uma mesma coisa sob o mesmo aspecto' [...], ou então: 'é necessário que toda asserção seja afirmativa ou negativa'".
} 
Como conseqüência, o Princípio da Contradição, tratando de seres determinados e afirmando sua existência, permite que deles se abstraia, em uma condição única, o que neles há de necessário - sua substância ou essência substancial -: a afirmação "O homem é um animal racional", antes de tudo, determina e assevera a existência desse ser (seja ele apreensível ou não pelos sentidos humanos); em segundo lugar, tal afirmação declara sua essência substancial. Declara, enfim, a definição de homem. O Princípio da Contradição, incorporado como um dos fundamentos da Metafísica (ou ciência do ser enquanto ser), implica assim as noções de substância e causa.

Colocando em questão o Princípio da Não-Contradição, o pensamento sofista induz a uma sobrevalorização da do/ca (opinião) ${ }^{46}$ : havendo apenas opiniões sobre a realidade, ou seja, sendo impossível chegar a um acordo sobre uma verdade universal, não faz sentido distinguir entre verdade e erro, justificando-se plenamente as afirmações contraditórias. Porém, a importância da posição sofista é maior: questionando a certeza da distinção entre realidade e aparência, coloca-se em questão o Princípio da Não-Contradição, que se mantivera hipostasiado em caráter de axioma:

\begin{abstract}
"Esses pensadores [os sofistas] negavam, assim, a validade do mesmo princípio pelo qual haviam desenvolvido sua argumentação; isso tinha a maior significação. As leis lógicas, que haviam sido seguidas até então sem serem conhecidas expressamente, nunca teriam podido ser descobertas se não tivessem sido questionadas pelo menos uma vez. Assim, os sofistas ajudaram o pensamento humano a tornar-se consciente em relação à lógica. A consciência dos primeiros metafísicos havia sido em certo modo alógica; a dos sofistas era antilógica e, nesse instante, a lógica foi sacudida de seu torpor; com Sócrates surgiu a consciência lógica" (RICKERT, op. cit., pp. 21-22).
\end{abstract}

Tal consciência lógica socrática atribui um papel fundamental às definições. Segundo seu pensamento, os sofistas tinham razão ao afirmarem que o

\footnotetext{
${ }^{46}$ ABBAGNANO (2003, pp. 729-730, verbete "opinião") registra: "esse termo tem dois significados: o primeiro, mais comum e restrito, designa qualquer conhecimento (ou crença) que não inclua garantia alguma da própria validade; no segundo, designa genericamente qualquer asserção ou declaração, conhecimento ou crença, que inclua ou não uma garantia da própria validade [...]".
} 
conhecimento absoluto, de fato, não existe — ou, em outras palavras, não está ao alcance da razão humana -; porém, entendia que, acima das opiniões dispersas e conflitantes, havia algo de comum a todas elas. Precisamente a existência de um conflito de opiniões era um indício desse fato. A verdade não repousa naquilo que um indivíduo descobre isoladamente; a verdade é aquilo que tais descobertas individuais têm em comum, e o caminho para estabelecer tal verdade é determinar o que há de concordante entre as diferentes opiniões - ou seja, o que há de comum na diversidade. Essa é a base socrática para a necessidade de definições: estabelecer esse ponto de convergência conceitual a partir do conflito discursivo.

Sócrates compreendeu, confrontando-se com o método sofista, que os exemplos que davam os sofistas da relatividade de qualquer conhecimento (e, portanto, da vigência exclusiva de opiniões) baseavam-se no estratagema de designar vários conceitos distintos por meio de um mesmo termo; trata-se, portanto, do estratagema da homonímia. Para desarticular tal discurso, Sócrates exigia de seu interlocutor que determinasse com precisão os conceitos que eram vinculados aos nomes, reconhecendo que apenas seria possível afirmar a certeza de algo se os conceitos utilizados na investigação fossem conceitos determinados e concordes: "a definição era, para Sócrates, o meio de criar conceitos determinados e designados de maneira inequívoca" (RICKERT, op. cit., p. 23).

Platão avança a teoria das definições; com Sócrates, definir implicava formar conceitos a partir do geral, ou seja, daquilo que tem estatuto de conhecimento por ser o comum. Platão aceita a visão heraclitiana, segundo a qual as coisas singulares e sensíveis não são em si mesmas, mas apenas devêm; assim, considera que o conhecimento de um singular não pode ser considerado conhecimento autêntico. Porém, é impossível negar que os singulares, formando conjuntos, possuem traços comuns e que, com isso, revela-se aquilo que têm de permanente: esse comum significa não aquilo que apenas devém, mas sim aquilo que, de fato, é. A esse comum que verdadeiramente é deve dirigir-se 0 conhecimento para ser conhecimento de um ser em si.

Rickert destaca que essa concepção platônica não perde validade teórica quando, reinterpretada, atribui ao universal — sob o conceito de idéia - uma 
existência autônoma em relação às coisas singulares, desempenhando em relação a estas a função de causa: "a definição, que para Sócrates era um meio de conhecimento verdadeiro porque construía o conceito comum, fornece agora um conhecimento na medida que determina a idéia universal cuja forma de aparecer é a coisa singular a ser conhecida" (RICKERT, op. cit., p, 24).

Outra contribuição platônica avança a teoria das definições em direção daquilo que encontramos a esse respeito em Aristóteles: Platão não apenas procurou identificar cada uma das diversas idéias universais, mas também fez a primeira tentativa de organizar tais idéias em um sistema. Assim como idéias universais compreendem grupos de coisas singulares, também grupos de idéias universais podem ser compreendidos por idéias de ordem superior (ou seja, em graus maiores de universalidade), caracterizando com isso uma pirâmide de idéias. Nesse sentido, a definição segundo a visão platônica diz respeito ao processo de conhecer um objeto assinalando seu lugar nessa pirâmide: subordina-se tal objeto a uma idéia universal e acrescenta-se aquilo que permite distingui-lo frente aos demais objetos vinculados à mesma idéia, construindo-se, assim, seu conhecimento completo. Como podemos concluir, esta visão representa a origem daquilo que se denominará definição por gênero próximo e diferença específica: definir, para Platão, implica conhecer a essência de um objeto pela indicação da idéia que o abarca e da qual ele é a manifestação sensível (ou, em outros termos, da qual ele participa).

Porém, Platão nunca formalizou expressamente uma teoria das definições, ou seja, jamais deu uma definição de definição, tarefa essa realizada por Aristóteles, para quem bastou analisar a construção teórica platônica a esse respeito e extrair suas conseqüências:

"Platão havia perguntado qual era o objeto de conhecimento verdadeiro e tinha respondido: a idéia. Aristóteles perguntou, por sua vez — 'como conhecemos?' — e respondeu: determinando o conceito ao indicar gênero e a diferença. Metodologicamente não há entre Aristóteles e Platão, em relação à definição, nenhuma diferença fundamental, pois tanto a idéia quanto o conceito têm por tarefa indicar a essência de uma coisa e, portanto, devem ser empregados para dar dela uma definição. A diferença metafísica entre idéia e conceito não vem ao caso aqui" (RICKERT, op. cit., p. 25). 
Com isso, percebemos claramente como a teoria das definições em Aristóteles vincula-se estreitamente com sua doutrina metafísica e dela não pode abrir mão: pois, sem esse substrato ontológico, resta apenas uma forma definidora arbitrária e não significativa. Tanto em Sócrates quanto em Platão quanto em Aristóteles, definir pressupõe sempre um processo mental cuja tarefa é determinar um conceito e fixálo permanentemente, evitando empregá-lo em discursos de maneira inconsistente, flutuante ou ambígua (como faziam os sofistas). Sendo o conceito de um objeto de definição a própria essência desse objeto, entende-se que definir implica indicar a essência de um ser ou estabelecer o conceito desse ser, indiferentemente.

Observamos anteriormente que conhecer mediante definição (ou seja, estabelecer conceitos e sistemas de conceitos) e comunicar conhecimentos são dois processos distintos; o primeiro objetivo precede em importância o segundo, mas, usualmente, verifica-se a compreensão oposta. Isso se deve à relação estreita e nem sempre consciente entre pensamento e linguagem. Segundo Rickert,

\footnotetext{
"Que todos aprendemos a pensar por meio da linguagem e continuamos a pensar com seu auxílio é indubitavelmente certo. [...] sem a linguagem apenas poderíamos pensar de modo incompleto ou, talvez, não poderíamos pensar logicamente de modo algum; portanto, não é possível à lógica ignorar a linguagem. Porém, a razão para isso não está em que haja coincidência entre pensamento e linguagem. [...] Por um lado, há palavras e orações que compreendemos; por outro lado, há aquelas que nos são incompreensíveis: ouvi-las não nos faz e não nos pode fazer pensar. A distinção reside em que muitas palavras e orações possuem significados e sentidos, enquanto para outras não é o caso. Assim, pois, por mais ligadas que estejam as palavras e seus significados, tais elementos podem ser separados conceitualmente. [...] O puro falar carece de significado ou sentido e, portanto, de pensamento. O pensamento, por sua própria essência, não se encontra no campo das palavras e das orações, mas sim no campo dos significados e da formação dos sentidos" (op. cit., pp. 27-28).
}

Em suma, o ato locutório, em si mesmo, não garante o processo de pensamento e a produção de sentido: a linguagem depende, como contrapartida, de um processo prévio - a determinação e a fixação dos conceitos - para que sirva como ferramenta do pensamento; eis porque "a linguagem não constitui um 
elemento conceitualmente inseparável do pensamento": trata-se de duas operações intelectivas diversas e que não devem ser confundidas, podendo ser conceitualmente separadas ${ }^{47}$.

Isso mostra que é plausível considerar o pensamento em relação aos conceitos envolvidos e à produção dos sentidos, embora não se considere simultaneamente a formulação verbal que visa à comunicação desse pensamento a outrem. Em outros termos, é possível isolar mentalmente $\mathrm{o}$ ato de pensar e $\mathrm{o}$ ato de expressar e explicar esse pensamento - embora para ambos empreguemos a mesma linguagem.

Isso nos leva a considerar a conveniência de distinguir entre: a) o processo de determinar o conteúdo e a estrutura de um conceito; b) o processo de indicar ou designar o significado do termo que se vincula a tal conceito. No segundo caso, importa o próprio termo; a construção dos conceitos que são acionados por tal termo é pressuposta de antemão (trata-se, portanto, de indicar ou designar, dentre os muitos conceitos já estabelecidos, aquele conceito particular visado pela comunicação). No primeiro caso, importa a elaboração do conceito a ser vinculado ao termo mencionado (trata-se, portanto, de estabelecer a essência ou conceito de um objeto de definição). Obviamente, este caso sempre antecederá o outro caso.

Cabe aqui uma observação sobre as "definições nominais". Quem enuncia presumivelmente pretende ser compreendido; isso significa que o enunciador pretende, com sua enunciação, que seu co-enunciador acione mentalmente, através das palavras empregadas, os mesmos conceitos e/ou os mesmos referenciais que o enunciador tem em mente. Em geral, uma vez que os interlocutores têm em mente um grande número de conceitos compartilhados, bastará, para designar o significado de um termo,

\footnotetext{
${ }^{47}$ Assim continua o autor: "Que o homem, com exercícios, possa ou não chegar a pensar sem palavras não importa aqui. [...] uma vez que linguagem e pensamento, palavra e significado, enunciado e sentido não são idênticos, o que importa naquela linguagem usada para pensar, independentemente da comunicação do pensamento para outrem, deve desempenhar um papel diferente do que o esforço especificamente direcionado para expressar os resultados do pensamento em uma forma que os outros compreendam. Se no primeiro caso a linguagem é secundária e externa ao processo - embora de fato indispensável - no segundo caso ela é o verdadeiro objeto a que nosso pensamento se dirige" (RICKERT, op. cit., p. 28).
} 
"[...] nomear outro que evoque na consciência do ouvinte o maior número de características do conceito a transmitir, acrescentando os termos que evoquem o restante das significações intentadas pelo falante. [...] este ou aquele nome designa um conceito cujos elementos constituem significações designadas por este ou aquele outro nome" (RICKERT, op. cit., p. 30).

O autor lembra que esse procedimento é, em Lógica, usualmente denominado "definição", compreendendo-se, desse modo, que a definição caracteriza-se por uma explicação de termos (e não de conceitos): "só a palavra, que é extrínseca e contingente frente ao conceito, precisa de uma explicação, de uma rememoração constante de seu significado (SIGWART apud RICKERT, op. cit., p. 30). Aceitando esse conceito de definição, estaríamos entendendo a teoria das definições como uma teoria de otimização da expressão formal do pensamento (ou seja, dados os conceitos, a teoria das definições trataria exclusivamente da utilização precisa dos termos que correspondem a esses conceitos).

Assim, os conceitos não deveriam necessitar de definições, pois devem ser utilizados já prontos como pressupostos - matérias-primas - para que se desenvolva a explicação nominal. Em resumo, estaríamos denominando "definição nominal" a explicação dos termos, ou seja, a especificação dos significados intentados dentro de um conjunto de significados possíveis dos termos: a finalidade das definições, ao nomear uma palavra, seria evocar a lembrança de certos conceitos em detrimento de outros.

Com esse conceito de definição, descarta-se a necessidade de definir por meio do gênero próximo e a diferença específica; mesmo a declaração das características essenciais do objeto de definição carece de sentido em um processo definidor que se limite a especificar os significados dos termos em uso. "Definir" significa aqui suscitar no co-enunciador um determinado significado de um termo enunciado e, nesse sentido, seriam válidas todas as explicações puramente verbais que, suficientemente, apresentem todos os traços do conceito selecionado, frente a determinada intenção de comunicação. Porém, conforme observa Rickert,

"Sigwart diz: 'Ninguém denomina 'definições' as explicações meramente verbais como — 'lógica' quer dizer 'teoria do pensamento'; 'democracia' significa 'governo do povo' —; nem as 
explicações de abreviações verbais como - 'reta' significa uma 'linha de formato retilíneo'-'. Isso é certo, mas na doutrina de Sigwart não se pode ver por que essas explicações de palavras não são definições. Pois, segundo ele, não se definem conceitos, mas sim palavras, e que outra coisa pode ser a definição das palavras senão uma 'mera explicação verbal'? Qual é a diferença fundamental entre esta e a definição sigwartiana? Não há nenhuma e não pode havê-la se a definição é somente explicação da palavra e não a determinação do conceito" (RICKERT, op. cit., pp. 31-32).

O fato é que, antes de explicarmos o significado de uma palavra que designa um conceito, precisamos ter desenvolvido um processo de pensamento lógico na elaboração desse conceito, para só então encontrar sua expressão verbal ${ }^{48}$. Tratase de saber se faz sentido denominar "definição" a essa expressão verbal, isto é, importa indagar pela consistência da expressão "definição nominal": temos aqui uma verdadeira definição? Vale lembra que, em Aristóteles, o termo o(rismo/j, traduzido como "definição", sempre significou primordialmente o processo de definição conceitual, para só secundariamente significar a especificação do significado do nome empregado para designar tal conceito.

Convém, portanto, distinguir como definição propriamente dita a definição de conceitos - esta é a definição lógica por excelência. Doravante, neste trabalho, estabeleceremos distinção entre a definição intensional essencialista/substancialista — que denominamos "definições reais" ou "definições objetivas" - e a definição intensional subjetivista ou convencionalista - definição esta que se presta para especificar o significado intentado de um termo por meio de estruturas parafrásticas nas quais ocorre uma proposta de equivalência nominal —, que passaremos a denominar "definição semiótica" ou "signação". Como já assinalamos, as definições intensionais objetivas são simbolizadas pela estrutura $/ D_{\text {dum }} \leftarrow \pi\left\langle D_{\text {iens }}\right.$ / $/$ ou $/ X \leftarrow \pi$ $\langle A B C\rangle /$, enquanto as definições semióticas ou signações são representadas pelo estrutura /"X" $\approx$ "ABC"/.

\footnotetext{
48 "O ato lógico do pensamento, enquanto definição própria de um conceito, tem de estar já concluído antes de ser formulado verbalmente, pois, apenas tendo encerrado completamente um conceito, podemos enunciar uma proposição na qual determinado nome deve ser usado na linguagem como signo desse conceito previamente definido. Qualquer definição que queiramos expor, [...], segundo a fórmula ' $S=f(a, b, c, \ldots)$ ' [...] pode desdobra-se em dois juízos, se for formulado verbalmente: 1. $f(a$, $b, c, \ldots)$ é um conceito; 2. esse conceito deve ter o nome 'S"' (RICKERT, op. cit., p. 32).
} 
Como se vê, aquilo que a tradição denomina "definição nominal" é para nós a definição semiótica ou signação; isso porque consideramos que definir um nome é tarefa própria das definições autonímicas, as quais declaram a intensão convencional de um conceito lingüístico - mais especificamente, de um nome ou significante; assim, a definição /"que" ₹ "pronome relativo que introduz oração subordinada, reproduzindo o sentido de um termo ou da totalidade da oração anterior" / é uma definição intensional autonímica, pois declara o conceito lingüístico ou o significado vinculado ao nome "que".

Tal distinção é útil porque, devido à função desempenhada pela linguagem no processo de definição, nem sempre se diferencia precisamente a palavra empregada para elaboração de um conceito da palavra empregada para comunicar um pensamento baseado nesse mesmo conceito. Para nós, portanto, interessa enfatizar a separação conceitual entre: a) o ato lógico da razão cuja função é a determinação de conceitos e que desde a origem foi chamado de "definição"; b) o ato lingüístico de designar um significado nominal com vistas à produção de uma comunicação eficiente, isto é, sem ambigüidades. Em suma, quando empregarmos a expressão "definição objetiva", assumiremos como pressuposta a referência ao processo de (re)construção de um conceito essencialista/substancialista (e seu produto); neste trabalho, entenderemos a expressão "definição nominal" como simplesmente designadora de um processo autonímico de definição.

Com isso não pretendemos afirmar que a linguagem não exerce função relevante no conceito de definição que estamos adotando; de fato, o processo do pensamento eficiente pressupõe a linguagem como ferramenta necessária e realiza a crítica dessa linguagem justamente para que haja tal eficiência. A própria origem das reflexões sobre as definições sinaliza isso:

"A definição conserva ainda algo de sua origem que a põe em estreita relação com a linguagem - gerou-se na luta pela verdade através do diálogo. Porém, sua origem não é decisiva para sua essência lógica. A definição é um meio para um fim que não consiste somente em indicar a significação de um nome. [...] consiste, em termos gerais, na determinação dos conceitos [...] a natureza lógica das definições" (RICKERT, op. cit., pp. 3334). 
Uma vez estabelecida essa diferença conceitual, importa observar que o próprio termo "definição" permite uma ambigüidade clara que, porém, nem sempre é notada: trata-se de discernir entre "definição" como "ato de definir (definitio)" e "definição" como "o produto do ato de definir (definitum)", entendido este como o conceito em si mesmo. Assim, temos o seguinte quadro:

\begin{tabular}{|c|c|}
\hline OBJETOS DE DEFINIÇÃO & CONCEITOS \\
\hline$D E F I N I T I O$ & Ato de definir ou processo de definição de um conceito \\
\hline$D E F I N I E N D U M$ & Conceito em processo de definição \\
\hline$D E F I N I E N S$ & Conjunto de características que definem o conceito \\
\hline$D E F I N I T U M \sim$ CONCEPTUS & produto do ato de definir ou conceito definido \\
\hline
\end{tabular}

Como vemos, o termo "definitio" — a definição — designa primariamente o processo de definição de um conceito, enquanto o termo "definitum" — o definido — designa o próprio conceito já definido, o produto do ato de definir. Junto a essa distinção, é importante sempre distinguir, como já assinalamos, entre o ato mental de definir (definitio) e a expressão verbal do produto desse ato (expressão verbal do definitum ou conceito): estes são processos vinculados, mas conceitualmente independentes.

Temos com isso um conceito geral de definição: /definir $\leftarrow \pi$ «processo de elaborar uma definição, ou seja, determinar e delimitar um conceito que declara a essência de um objeto /, sendo, portanto, /definição $\leftarrow \pi$ «conceito que declara a essência de um objetos/. Agora, é interessante considerar que tipo de material forma os conceitos, isto é, interessa-nos examinar a constituição dos conceitos.

Para tanto, verifiquemos primeiramente a própria definição de conceito em algumas fontes:

Em SEVERINO (2002, p. 188), lê-se que "o conceito é a imagem mental por meio da qual se representa um objeto, sinal imediato do objeto representado. $O$ conceito garante uma referência direta ao objeto real. [...] Este objeto passa então a existir para a inteligência, passa a ser pensado. Portanto, o conceito representa e 'substitui' a coisa no nível da inteligência. O conceito [...] é simbolizado pelo termo ou palavra, no nível da expressão lingüística". 
Define-se conceito como "[...] conteúdo de um ato mental (pensar, perceber, acreditar, esperar, pretender). [...] Assim, o pensamento de que algo é azul, o pensamento de que há um cavalo no jardim, ou de que vai chover amanhã, são conceitos" (HEGENBERG, op. cit., p. 59).

IDE (op.cit., p. IX) destaca que o conceito é o produto da atividade de abstração, cuja função é extrair das realidades sensíveis e materiais as essências inteligíveis e universais; assim, enunciar um conceito implica declarar a substancialidade dos objetos. Nesse sentido, o conceito é entendido como equivalente à idéia.

Verificamos em ABBAGNANO (2003, pp. 164-169), quanto às definições de conceito, que se trata, de modo generalíssimo, de "[...] todo processo que torne possível a descrição, a classificação e a previsão dos objetos cognoscíveis" (op. cit., p. 164). Portanto, é por meio de conceitos que conhecemos qualquer objeto: estabelecer seu conceito é conhecê-lo (observemos: dissemos "estabelecer seu conceito", e não "estabelecer seu nome" ou "apreendê-lo sensorialmente").

A partir dessa afirmação, cabem as seguintes observações:

i) o conceito, embora normalmente indicado por meio de um nome, não se confunde com esse nome, uma vez que um mesmo conceito pode receber diversos nomes, ou diferentes conceitos podem ser indicados, homonimicamente, pelo mesmo nome;

ii) o conceito não é um elemento simples ou indecomponível, mas pode ser constituído por um conjunto de conceitos correlatos (ou seja, um conceito pode ser decomposto ou analisado em outros conceitos primitivos; ao contrário, um conjunto de conceitos pode ser sintetizado em um conceito derivado);

iii) o conceito não se refere necessariamente a fatos ou coisas reais, ou seja, não está necessariamente vinculado a qualquer experiência empírica sensível ["[...] pode haver conceito de coisas inexistentes ou passadas, cuja existência não é verificável nem tem um sentido específico" (Ibidem)].

Dois problemas fundamentais em relação aos conceitos são apontados, o problema da natureza do conceito e o problema da função do conceito: 
i) quanto ao problema da natureza do conceito, há duas soluções históricas fundamentais: 1) o conceito compreendido como a ressência das coisas, ou seja, como a essência substancial necessária, segundo a qual a coisa não pode ser diferente daquilo que é̀; 2) o conceito compreendido como (signo das coisas»:

1) a doutrina do conceito compreendido como essência substancial necessária pertence à filosofia grega em seu período clássico; o conceito é aquilo que se subtrai à contingência, à temporalidade, à mudança e à opinião (do/ca); o conceito referese às características constitutivas do próprio objeto, as quais não podem ser alteradas em sua perspectiva por qualquer discurso opinativo, sob pena de se alterar o próprio objeto ${ }^{49}$. Essa operação, para o pensamento grego, caracteriza o homem enquanto animal racional, ou seja, identifica a presença de um ser dotado de razão; não por coincidência, para o grego, o conceito e a razão eram identificados pelo mesmo termo - 10/goj ${ }^{50}$;

2) a doutrina do conceito compreendido como signo das coisas ou dos objetos implica que o conceito está em relação de significação com seu objeto: trata-se do lekto/n grego ${ }^{51}$, o significado ou significação das palavras. Tal doutrina,

\footnotetext{
49 "Nos primórdios da filosofia grega, o conceito aparece como o termo conclusivo de uma indagação, prescindindo, na medida do possível, da mutabilidade das aparências e visando àquilo que o objeto é 'realmente', isto é, à sua 'substância' ou 'essência'".

${ }_{50}$ Podemos acompanhar o princípio da formalização desse conceito de conceito: "[...] Aristóteles atribuiu a Sócrates o mérito de haver descoberto 'o raciocínio indutivo e a definição do universal, duas coisas que se referem ao princípio da ciência [...]: Sócrates mostrou como o raciocínio indutivo leva à definição do conceito, e o conceito exprime a essência ou a natureza de uma coisa, o que a coisa verdadeiramente é. Platão faz do universal socrático a própria realidade. $\mathrm{O}$ belo, o bem, o justo são substâncias, isto é, realidades no sentido forte do termo, realidades absolutas. [...] Aristóteles, nesse ponto, só faz reproduzir e articular em uma doutrina bem mais complexa o ponto de vista de Platão. $\mathrm{O}$ conceito $(1 \circ / g \circ j)$ é o que circunscreve ou define a substância ou a essência necessária de uma coisa [...]; por isso, ele é independente do gerar-se e corromper-se das coisas e não pode ser produzido e destruído por tais processos. [...] Em outros termos, para Aristóteles, o conceito é idêntico à substância, que é a estrutura necessária do ser, aquilo pelo qual todo o ser não pode ser diferente do que é [...]. Essas determinações são típicas da concepção do conceito como essência. Com relação a elas, o caráter da universalidade aparece como secundário e derivado: 'por universal', diz Aristóteles, 'entendo o que é inerente ao sujeito em qualquer caso e por si, na medida em que um sujeito é o que é' [...]. Ora, 'o que é inerente ao sujeito em qualquer caso e por si [...]' nada mais é do que a essência necessária do próprio sujeito, aquilo que ele não pode não ser; de sorte que, para Aristóteles, a universalidade é a substancialidade ou necessidade do conceito. Por isso, Aristóteles diz que pode haver também conceito de indivíduo (conceito de su/nolon [synolon - stodo o conjunto; o inteiro; o completo; o composto por matéria e forma)] ), mas não do indivíduo considerado em sua matéria, que é indeterminada, logo, indefinível [...]" (ABBAGNANO, op. cit., pp. 164-165).

${ }^{51} \mathrm{le} / \mathrm{ktoj}, \mathrm{h} /, \circ / \mathrm{n}$ - "reunido; escolhido; que se pode dizer; as coisas que não existem senão em discurso ou no pensamento, isto é, não visíveis ou não tangíveis (como o espaço e o tempo); as
} 
inicialmente proposta pelos estóicos ${ }^{52}$, aborda a teoria dos conceitos como se fosse uma teoria dos signos e permaneceu como modelo para a segunda alternativa fundamental da teoria dos conceitos (ou seja, trata-se do conceito de conceito como correspondente ao conceito de significado, pela intermediação do conceito de signo). Nesse caso, não se trata de focalizar o conceito pelo prisma da essencialidade e substancialidade, mas sim estudá-lo como o fazem a Semântica e a Semiótica, pelo vínculo entre um significante e um significado convencionado, sem que se cogite necessariamente da natureza ou da essência do ser designado pelo termo em questão (ou seja, sem que haja a necessidade imperiosa de se estabelecer a verdadeira natureza do conteúdo referencial correspondente ao signo empregado);

ii) quanto ao problema da função do conceito, pode-se concebê-la como finalista ou como instrumentalista:

1) a função finalista do conceito vincula-o à interpretação das essências; assim, sua função seria expressar e revelar a substância das coisas. Nesse caso, função e natureza do conceito formam uma identidade;

2) a doutrina do conceito como signo das coisas implica concebê-lo através de suas funções instrumentais (funções essas que são patentes nos modelos e sistemas de conceitos científicos): 2.1) primeira função instrumental: descrever objetos de experiência permitindo assim seu reconhecimento; 2.2) segunda função instrumental: classificar fatos e experiências; 2.3) terceira função instrumental: organizar os dados da experiência, estabelecendo entre eles conexões lógicas; 2.4 ) quarta função instrumental: permitir previsões de resultados e experimentos, por antecipação.

Já em COSSUTA (1994, p. 41), vemos que;

"O conceito não é apenas uma entidade assinalável graças à presença de um vocábulo; é também uma função mediadora que organiza a ordem interna do discurso. Na medida em que essa função é apta para designar a si mesma e, portanto, para emergir em uma palavra ou numa configuração de palavras ('o ser enquanto ser' de Aristóteles; 'a extensão' em Descartes;

coisas abstratas" (BAILLY, Anatole. Le Grand Bailly. Dictionnaire Grec-Français. Paris: Hachette, 2000).

${ }_{52}$ Para observações sobre a contribuição estóica às reflexões sobre a linguagem e o discurso, ver NEVES (2005, pp. 85-107). 
'a intuição' em Bergson etc.), é certamente possível, por comodidade, fazermos referência ao significante que permite nomeá-la".

O autor destaca o conceito como uma autêntica "função conceitual" — ou seja, o conceito entendido como uma função mediadora entre o discurso e sua intelecção -; isso porque a leitura de um texto implica dificuldades terminológicas: a) deve-se tornar possível estabelecer o sentido preciso dos termos utilizados, através da seleção de seus significados (que, por sua vez, foram fixados anteriormente pelas definições dos conceitos respectivos); b) deve ser possível estabelecer as relações propostas entre os significados dos termos mobilizados pelo juízo.

Segundo essa visão funcional dos conceitos, a unidade básica lingüísticodiscursiva é o juízo, no qual os conceitos adentram em relação de predicação; aqui, o conceito participa de um duplo sistema de relações:

a) relações conceituais intrajudicativas, ou seja, relações conceituais internas a um juízo, estabelecidas pela estrutura definidora (conexão entre os conceitos de uma oração ou enunciado). Exemplo: em "Todo homem é efêmero", correlacionamse os conceitos de homem e efemeridade;

b) relações extrajudicativas, ou seja, relações conceituais externas aos juízos, estabelecidas entre os diversos conceitos que compõem a demonstração ou argumentação (conexão entre os conceitos de um conjunto de orações ou enunciados). Exemplo: em "Todo homem é efêmero"; "Todo filósofo é homem" e "Todo filósofo é efêmero", os conceitos de homem, efemeridade e filósofo constituem relações extrajudicativas.

Por meio dessas relações conceituais (internas e externas), constrói-se a coerência discursiva: nesse sentido, o conceito é um autêntico operador textual, capaz de vincular o discurso, entendido em sua dimensão puramente lingüística, com o discurso, entendido em sua máxima dimensão discursiva - cuja função é, retomando a expressão de Francis Wolff ${ }^{53}$, "dizer o mundo":

\footnotetext{
${ }^{53}$ Francis WOLFF, Dizer o mundo, São Paulo: Discurso Editorial, 1999.
} 
"O conceito filosófico apresenta-se como um operador textual que, graças a propriedades da língua, permite categorizar o real ou o ser, integrando-os no domínio do dizível. Para isso ele deve articular um termo significante [...] a um sentido (conjunto de propriedades que o especificam) e uma referência (designação de entidades extralingüísticas. [...] o conceito não é nem a palavra, nem a coisa, nem sua relação, como também não é a imagem mental que lhe está associada. Ele é um objeto do pensamento construído dentro da ordem da representação, pela qual tentamos reatribuir, de forma unívoca e explícita, a significação que queremos dar às palavras, às coisas e à sua relação" (COSSUTA, op. cit., pp. 50-51).

Para nós, importa conservar essa visão do conceito como um operador lingüístico-discursivo de categorização do real ou do ser, visando a expressão mental desse real ou desse ser sob a forma de representações determinadas. Notemos que não se trata simplesmente de representações gerais.

De fato, Rickert (op. cit.) afirma que os elementos constituintes do conceito não se confundem nem com os significados verbais indeterminados e variáveis, nem com as representações gerais. Em primeiro lugar, não se trata de entender $\underline{a}$ matéria-prima do conceito como oriunda das representações ${ }^{54}$ gerais:

"A lógica costuma subordinar o conceito à representação. 'O conceito (notio; conceptus) é a representação que apresenta a totalidade das características essenciais ou a essência (essentia) dos objetos relevantes', diz Überweg. Uma vez que se considera fundamental para o conceito ser geral, ele deverá, segundo esse ponto de vista, estar subordinado à representação

${ }^{54}$ Em ABBAGNANO (2003, pp. 853-854, verbete "representação"), lemos que tal termo, de origem medieval, relaciona-se aos conceitos de imagem (fa/ntasma - "semelhança ou sinal das coisas, que pode conservar-se independentemente das coisas. Aristóteles dizia que as imagens são como as coisas sensíveis, só que não têm matéria [...]. Nesse sentido, a imagem é: 1) produto da imaginação; 2) sensação ou percepção, vista por quem a recebe") e/ou idéia (i) de/a — "este termo foi empregado com dois significados fundamentais diferentes: 1) como a espécie única intuível numa multiplicidade de objetos; 2) como um objeto qualquer do pensamento humano, ou seja, como representação em geral"). Seu uso foi sugerido aos escolásticos pelo conceito de conhecimento como "semelhança" do objeto: "Representar algo' - dizia São Tomás de Aquino - 'significa conter a semelhança da coisa". O verbete informa que foi principalmente no fim da escolástica que esse termo passou a ser mais usado, freqüentemente para indicar o significado das palavras: "Ockham distinguia três significados fundamentais [do termo "representação"]: 'Representar tem vários sentidos. Em primeiro lugar, designa-se com esse termo aquilo por meio do qual se conhece algo; nesse sentido, o conhecimento é representativo e representar significa ser aquilo com que se conhece alguma coisa. Em segundo lugar, por 'representar' entende-se conhecer alguma coisa, após cujo conhecimento conhece-se outra coisa; nesse sentido, a imagem representa aquilo de que é imagem, no ato de lembrar. Em terceiro lugar, por 'representar' entende-se causar o conhecimento do mesmo modo como o objeto causa o conhecimento". 
geral. Segundo isso, a tarefa que teria a definição seria, antes de tudo, construir conceitos a partir de representações gerais" (RICKERT, op. cit., p. 36).

De acordo com essa visão, o pensamento pré-científico limita-se às representações gerais, enquanto o pensamento científico parte dessas representações para construir conceitos: sua matéria-prima seria, portanto, as representações gerais, consideradas como ponto de partida para o processo de síntese conceitual.

A questão está em que podemos argumentar pela inexistência de representações gerais em termos práticos: haveria apenas representações para o indivíduo, ou seja, representações dadas por percepções individuais (o indivíduo não conhece empiricamente a representação geral de uma flor, mas apenas suas representações determinadas ou manifestações fenomênicas). Teríamos, portanto, o problema da operacionalidade do princípio que afirma serem as representações gerais a matéria-prima para os conceitos, desde que consideremos as representações apenas como fenômenos individuais: "considerada com um critério psicológico, minha representação poderia ser sempre uma representação determinada individualmente. Porém a questão está justamente em saber se nos significados das palavras que compreendemos sem definir-lhes os conceitos há algo que se possa denominar 'representação' no sentido psicológico" [lbidem]).

Também, há o fato de que podemos compreender termos cujas definições conceituais nos são desconhecidas e para os quais, contudo, conseguimos estabelecer os vínculos significativos gerais (o indivíduo não necessita conhecer a definição do conceito de cão para poder enunciar: "Meu cão fugiu" ou "Este é um cão"; também, é comum que se enuncie: "O imposto no Brasil é injusto", sem que se indague pela definição do conceito de justiça que está em jogo). De fato,

"[...] mesmo o homem cientificamente desinformado, que não dispõe de nenhum conceito definido, vincula coisas que ainda não viu a significados verbais gerais. Isso é evidente a partir do fato de que ele designa tais objetos não familiares por meio dos mesmos nomes que emprega para designar objetos que the são familiares. Isso não nos permite afirmar que ele tornou-se explicitamente cônscio em relação às características essenciais e acessórias do 
objeto em questão e, portanto, constitutivas do significado geral do termo que emprega" (RICKERT, op. cit., p. 36).

Em segundo lugar, é um fato inconteste que as palavras, em geral, possuem vários significados genéricos, acionando vários conceitos alternativos; nesse sentido, são, por si mesmas, indeterminadas e variáveis (ou seja, sujeitas a mudanças constantes de significados). A partir disso, basear-se em representações gerais vinculadas a termos indeterminados e variáveis com o intuito de produzir conceitos rigorosamente determinados apresenta-se como um objetivo contraditório. O esforço está em minimizar o grau de generalidade das representações e o grau de indeterminação e variabilidade dos termos vinculados aos conceitos; em suma, aumentar o grau de determinação e constância das características que comporão o conceito.

Os conceitos são formados por partes constitutivas expressamente especificadas, identificadas, determinadas e constantes, isto é, a matéria-prima dos conceitos é formada por uma seleção de características precisamente delimitadas, presentes nos objetos compreendidos sob o conceito em definição e dotadas das seguintes qualidades:

a) posse de valor lógico frente ao intuito de estabelecer a verdade conceitual (as partes constitutivas devem contribuir efetivamente para o verdadeiro conhecimento de seu objeto de definição e seu conceito);

b) capacidade de fazer ver com certeza e necessidade a quais objetos de definição o conceito resultante se aplica (o campo de vigência do conceito deve estar precisamente delimitado);

c) implicação mútua entre as características reunidas sob a mesma rubrica conceitual, de modo a constituírem um sistema, ou seja, um conjunto coerente de partes articuladas e interdependentes.

Importa, em suma, que o conceito seja determinado com precisão e esteja rigorosamente delimitado frente aos demais conceitos, de modo a poder ser logicamente empregado pelo discurso racional por não se confundir com outros conceitos correlatos. 
Passemos agora a verificar como são formados os conceitos. Para isso, interessa distinguir entre dois movimentos lógicos possíveis para a produção do conhecimento: o processo de síntese e o processo de análise ${ }^{55}$.

O processo de análise implica a formação de conceitos determinados ou específicos a partir de significações verbais genéricas e representações gerais indeterminadas - como é o caso das ciências naturais para as quais existem, como objetos de análise, objetos sensíveis reais.

Tal procedimento pode ser denominado "abstração", porque ocorre a abstração de características gerais a partir de objetos singulares. As características comuns a todos os objetos são compostas ou são combinadas para formar o conceito em processo de definição, como elementos do conteúdo significativo que está em processo de determinação. Os elementos individuais são denominados "características contingentes ou não-essenciais"; os elementos formadores do conceito - presentes no texto do definitum - são denominados "características essenciais".

Para a pergunta sobre como se devem formar os conceitos a partir de representações gerais ou significações verbais indeterminadas, responde-se logicamente: a definição de um conceito deve determinar as características essenciais (características comuns a todos os objetos incluídos na extensão do conceito) de seu objeto de definição e com elas formar o conceito.

Podemos indagar agora sobre os critérios empregados para incluir ou excluir certos objetos na extensão de um conceito - ou seja, perguntar a quais objetos um

${ }^{55}$ RICKERT (op. cit., p. 39), registra: "a lógica distingue entre ciências analíticas e ciências sintéticas. As primeiras [...] derivam seu nome da circunstância de que nelas o trabalho científico começa com uma análise. Seu material [ponto de partida] são as representações gerais que já existem antes de se formalizar o pensamento científico e que incluem uma vasta variedade de objetos. Em caso de admitirem análise, tais representações são compostas por complexos de significações verbais elementares, isto é, contêm já algumas sínteses espontaneamente geradas de elementos que são característicos dos objetos incluídos em sua extensão. As ciências analíticas submetem essas sínteses à critica porque não pretendem aceitar esses complexos como dados pressupostos, mas sim pretendem entender a composição das partes constitutivas, analisando-as para então voltar a recompô-las enquanto partes essenciais, agora com a consciência das relações recíprocas que formam uma unidade. O procedimento da ciência sintética é outro. Não encontra seu material do modo indicado anteriormente, mas sim o produz. Seu trabalho começa, portanto, com uma síntese de elementos e a base para o próximo passo investigativo são os conceitos, que ela mesma cria, de objetos nos quais os elementos desses novos conceitos são encontrados como características de tais objetos. O exemplo perfeito de tal ciência sintética é a Matemática. 
dado conceito deve ser aplicado e, ao contrário, a quais objetos a aplicação de tal conceito é inconsistente.

A resposta mais imediata apontaria para a linguagem como critério discriminador: forma-se um conceito comum a dois ou mais objetos aos quais a linguagem designa por meio de um mesmo nome; porém, tal resposta é cientificamente insatisfatória, pois a atribuição de nomes muitas vezes nada tem a ver com a seleção de características essenciais e necessárias dos respectivos conceitos $^{56}$. Permanece a questão: qual o critério que assinala a presença de uma característica essencial ou não-essencial?

Rickert observa que a lógica tradicional não dá uma resposta concludente a essa questão: em geral, afirma-se apenas que são essenciais as características que um objeto compartilha com o conceito que o representa; tal conceito, porém, é formado pela distinção entre características essenciais e características acessórias: temos, assim, uma circularidade nas respostas. Necessitamos, pois, estabelecer um critério científico para especificar as características essenciais de um conceito sem que se pressuponha ter sido ele já formado e sem que se considere essencial aquilo que a convenção lingüística estabelece como tal.

Devemos observar que uma ciência, enquanto parcialização do conhecimento total, deve necessariamente distinguir entre fatores essenciais e fatores acessórios; o autor afirma que: "para compreender o que sejam características essenciais e acessórias, devemos considerar cada ciência particular por si mesma. Para um método universal, tudo seria, sem dúvida, igualmente essencial no mundo" (p. 42). Portanto, aparentemente, os objetivos de cada ciência estipulam metas operacionais que implicam princípios, máximas ou regras que, em conjunto, servem como critério

\footnotetext{
${ }^{56}$ A atribuição de nomes aos objetos, mesma sendo aleatória, constituiu importante passo: "[...] se o pensamento pré-científico não houvesse começado já certa classificação, para a qual utilizou significações verbais gerais, o trabalho científico de formação de conceitos, nas ciências analíticas, não teria nenhum ponto pelo qual poder-se-ia implantar. Certas características das coisas chamaram a atenção do homem pré-científico; graças a isso, reuniram-se em classes os objetos que compartilhavam tais características; tais classes foram nomeadas por um mesmo nome e, portanto, foram subordinados à mesma significação verbal geral. Contudo, o pensamento científico é necessariamente crítico: deve pôr à prova a razão pela qual o pensamento dirige-se com particular interesse a certas características em detrimento de outras; assim, freqüentemente se vê diante da necessidade de considerar como essenciais características distintas daqueles selecionadas pelo pensamento pré-científico, vendo-se obrigado a compreender sob um conceito comum outros objetos que não os selecionados por este modo" (RICKERT, op. cit., pp. 40-41).
} 
para julgar a essencialidade das características dos objetos em processo de conceituação.

O autor ilustra com o exemplo da jurisprudência ("ciência famosa desde a Antigüidade pela claridade lógica de suas proposições e a precisão de seus conceitos"): trata-se de uma ciência analítica cujo material prévio (corpus jurídico) é formado pela soma de proposições jurídicas constituída por significações verbais determinadas (termos jurídicos) e juízos estabelecidos (enunciados jurídicos). Tal material é reunido pela rubrica "Direito". A validade desses juízos baseia-se naquilo que se denomina "vontade do legislador" — uma vontade consciente que representa uma sociedade (ou seja, é socialmente representativa) e que estabelece objetivos jurídicos validos durante certo espaço de tempo para essa organização social particular. Tais proposições jurídicas contêm juízos hipotéticos prospectivos sob a forma: "se o indivíduo ' $X$ ' realiza a ação ' $Y$ ', sofrerá a ação 'Z'" ou "é proibida a ação ' $Y$ ' sob pena de sofrer a ação ' $Z$ '". Trata-se de uma suposição e de uma conseqüência que a vontade do legislador quer que esteja vinculada àquela:

"[...] os conceitos utilizados nas proposições jurídicas devem ser compostos de características tais que qualquer fenômeno, ao qual queira o legislador vincular uma conseqüência determinada, pode ser claramente submetido ao conceito que participa da proposição jurídica correspondente. Enquanto os pressupostos do juízo jurídico hipotético forem significações verbais gerais e indeterminadas, sempre se poderá discutir se tal juízo compreende ou não um fenômeno da realidade e se, portanto, deve ser vinculado às conseqüências desejadas pelo legislador. Porém, se as características desse juízo estiverem determinadas com precisão em um conceito, bastará ligar a conseqüência correspondente a qualquer circunstância que revele as mesmas características que o conceito empregado pela proposição jurídica; assim, estaremos seguros de cumprir a vontade do legislador" (op. cit., p. 44).

Isso nos leva a estabelecer o seguinte critério para a seleção de características essenciais para os conceitos jurídicos: serão características essenciais aquelas que contribuem para a concretização da vontade do legislador e que permitem que o direito se realize: "proposições jurídicas que contêm a vontade do legislador devem constar, portanto, de conceitos que possam ser referidos de modo inequívoco ao processo da realidade"; "a finalidade do Direito, que consiste em realizar-se, constitui 
o critério último para decidir se uma característica é essencial ou não para a formação de um conceito jurídico" (pp. 44; 46).

O autor observa que esse critério não se confunde com os seguintes princípios propostos usualmente pelas teorias lógicas para a determinação das características essenciais de um conceito: a) características que o conceito compartilha com um conceito de ordem superior; b) características comuns de diferentes objetos, os quais a linguagem designa pelo mesmo nome. Evita-se, com esse procedimento jurídico, a circularidade em que incorrem muitas definições que buscam justificar internamente a escolha de características essenciais.

Para distinguir entre características essenciais e características acessórias torna-se necessário especificar determinados fins, desdobrados em objetivos e $\underline{\text { metas, }}$, ou seja, tal distinção não pode realizar-se por meio de reflexões puramente lógicas e internas, prescindindo de um ponto de vista material e externo: "[...] também nas demais ciências chamadas 'analíticas', é impossível formar conceitos sem um ponto de vista semelhante, [...], de fato, ninguém pode tratar de 'realizar uma ciência sem basear-se um uma idéia fundamental'" (p. 47).

Em suma, Rickert aponta que o princípio científico para a seleção entre características conceituais essenciais e acessórias é sempre o mesmo: estabelecer um ponto de vista diretor - um princípio ou uma finalidade externa à lógica interna da ciência particular - e verificar como, nos conceitos produzidos, inclui-se no objeto em conceituação aquilo que é essencial sob o ponto de vista desse princípio diretor: "sem um princípio de seleção, a separação entre o essencial e o acessório perde o sentido, e sem essa separação não há ciência" (p. 50).

Segundo essa concepção teórica sobre a formação de conceitos, verificamos que unicamente um princípio diretor, específico para cada ciência e não rígido, isto é, mutável e passível de constante aperfeiçoamento e/ou adaptação, pode ser o critério decisivo para determinar as características do objeto de definição que devem ser incluídas em um conceito e quais devem ser consideradas acessórias. Dispensamos com isso a necessidade de uma ontologia possível (problema já mencionado para a teoria aristotélica das definições), uma vez que operamos com o pressuposto de que "[...] até agora não se descobriu um método universal para a 
compreensão científica do mundo em sua totalidade" (p. 51), embora devamos aceitar uma certa relatividade na formação dos conceitos resultantes, não só porque novas observações empíricas podem redirecionar o conceito anteriormente formado, mas também porque os princípios diretores podem mudar significativamente, pois os fins científicos trazem inevitavelmente a marca do perspectivismo.

Interessa ter em conta que, para as ciências sintéticas, a formação de conceitos se dá de modo diverso: para estas, ao contrário das ciências analíticas, não existe material prévio do qual se extraem as características essenciais e se formam os conceitos; seu material é criado por síntese e, portanto, criado unicamente com características essenciais. Não existe aqui a criação de conceitos por abstração: os conceitos independem de representações gerais e significados verbais indefinidos; tampouco dependem da análise de objetos sensíveis reais, dos quais derivam as representações gerais / individuais e os significados verbais que se ligam aos nomes atribuídos a tais objetos.

Podemos conceber, a partir da discussão anterior, a existência de dois tipos de definição: definições analíticas e definições sintéticas:

a) estas se fundamentam no princípio de que definir implica iniciar o pensamento científico pela criação de conceitos por meio da composição ou síntese de várias características - todas essenciais. Em suma, nas definições sintéticas, o procedimento científico exige um trabalho preparatório à formação de conceitos pela reunião de elementos essenciais que ainda não estavam coligidos em representações gerais e individuais. Assim, as definições sintéticas podem ser entendidas como um ato do pensamento que reúne os elementos que constituirão um conceito;

b) aquelas se fundamentam no princípio de que definir implica analisar representações gerais e individuais de objetos (em geral, objetos sensíveis reais), e das quais existem conceitos já formados antes que se inicie o procedimento científico de elaboração conceitual da definição. Em suma, nas definições analíticas, o procedimento científico exige um trabalho preparatório (isto é, anterior à formação do conceito) que obtém seu material pela análise de elementos essenciais e acessórios, presentes em representações gerais e individuais já existentes. Uma vez 
concluído tal trabalho, pode-se construir o conceito mediante sua definição; assim, as definições analíticas podem ser entendidas como um ato de pensamento que separa e distingue os elementos que constituirão um conceito.

Importa destacar que, em ambos os tipos de definição, o processo lógico de pensamento pelo qual se forma o conceito precede imediatamente sua expressão verbal sob a forma de discursos definidores (ou definiens): em suma, definir um conceito e expressar verbalmente sua definição são processos vinculados e sucessivos. Isso implica que a definição por excelência é a própria síntese conceitual de características essenciais de objetos manifestados por meio de representações gerais ou individuais e não, como freqüentemente se compreende, a produção de um discurso definidor.

Como acontece na ciência jurídica, após o estabelecimento das definições há a possibilidade da construção de juízos científicos e sistemáticos - baseados em princípios diretores externos - que constituem o corpo de proposições legais (conjunto de leis cuja aplicação e cumprimento levariam à realização do direito).

Rickert destaca que as expressões "definição sintética" e "definição analítica" serão entendidas de modo diverso daquele adotado tradicionalmente, que distingue entre as ciências analíticas (como ocorre com as ciências naturais e humanas) e as ciências sintéticas (como é o caso da Matemática):

"Não se trata da distinção entre duas espécies de ciências [definições], uma das quais iniciaria suas investigações com uma análise de objetos dados, e a outra com construções livres mediante a síntese de elementos; [...]. Trata-se [...] de dois atos de formação e divisão do conceito, que se efetuam igualmente em ambas as ciências, e que operam na matemática exatamente da mesma forma que em qualquer ciência empírica. Há de se separar com precisão entre si esses dois atos do pensamento; [...] uma síntese conceitual das características essenciais do objeto, [...] uma análise do conceito em suas características essenciais. [...] é óbvio que uma definição analítica só pode ser efetuada se for precedida por uma definição sintética; [...] a definição analítica pressupõe uma definição sintética; [...] o ato de pensamento em seu conjunto, [...] compreende tanto a síntese quanto a análise" (op. cit., p. $57)$. 
Podemos concluir que, segundo essa visão, a definição enquanto definitum produto da definitio ou processo definidor - equivale ao conceito; ou seja, produzir uma definição significa elaborar um conceito. Isso é importante na medida em que não permite entender a definição como simples "explicação verbal" de um termo. Portanto, não cabe rigorosamente compreender que as "definições" que estabelecem simplesmente a equivalência discursiva entre um termo e uma expressão lingüística sejam legitimamente entendidas como definições: há, de fato, grande diferença entre a definição / xaveco $\leftarrow \pi$ «navio mourisco, de formas finas, proa e popa lançadas, com dois ou três mastros que envergam velas redondas ou latinas, / e a estrutura /"xaveco" $\approx$ "pessoa muito feia" /57.

Verificamos qual a matéria-prima dos conceitos e como se formam os conceitos; devemos indagar agora sobre a forma de um conceito (para a pergunta que é um conceito? - , ou seja, sobre a indagação sobre o conceito de conceito, já apresentamos anteriormente, neste mesmo capítulo, as respostas de alguns autores). Rickert afirma que a análise de um conceito quanto à sua forma nos revela a estrutura de um juízo. - este entendido como uma operação intelectual de síntese que se expressa por meio de proposições. Assim, "[...] por juízo devemos entender a estrutura total de pensamento expressa por uma proposição declarativa ou a ela correspondente, e distinta do significado ligado a um termo simples, o qual representa apenas uma parte do conteúdo lógico" (p. 58).

De fato, sendo a especificação de uma característica geralmente expressa por um juízo, a formação de conceitos implica a composição de várias características e, portanto, um complexo de juízos: nas definições analíticas, temos um complexo de juízos analíticos que afirmam tudo o que está compreendido pelo conceito. Podemos concluir que uma definição analítica transforma conceitos em complexos de juízos, enquanto a definição sintética transforma complexos de juízos em conceitos: ambas as definições implicam um complexo de juízos e implicam-se simultaneamente ${ }^{58}$.

\footnotetext{
${ }^{57}$ AURÉLIO SÉCULO XXI. Dicionário eletrônico. Versão 3.0. Rio de Janeiro: Editora Nova Fronteira.

58 "Não nos apercebemos disso claramente [que a definição sintética deve constar de uma série de juízos], porque nunca temos ocasião de levar a cabo verbalmente esse ato de formação de conceitos, [...], mas é claro que a síntese de elementos não pode ser efetuada de nenhuma outra maneira a não ser por meio de juízos. Assim, as definições sintéticas que compõem as características conceituais
} 
No juízo, o "sujeito" é constituído pelo conceito em análise (definiendum) e o "predicado" (definiens) é constituído pelas características que a respectiva definição sintética incluiu previamente no conceito com o estatuto de características essenciais; conforme o autor: "[...] o ideal lógico de nosso conhecimento consiste em um sistema completo de juízos cujos sujeitos e predicados são conceitos constantes, isto é, conceitos plenamente definidos" (p. 59). Em suma, o conceito é, em seu conteúdo lógico, o conjunto de juízos que o formam; já para a lógica, o conceito é a representação geral que se distingue, por sua constância e estabilidade, das demais representações gerais.

Rickert observa que essa doutrina, que considera equivalentes o conteúdo lógico do conceito e o conteúdo lógico dos juízos que o formam, está em contraposição com as teorias tradicionais: o conceito é visto, usualmente, como uma etapa anterior do pensamento, sendo então o juízo uma etapa posterior por implicar a relação entre, pelo menos, dois conceitos. Aparenta ser paradoxal a afirmação de que um conceito definido é, em seu conteúdo lógico, a apresentação determinada de um juízo. Também, a tradição dos estudos sobre as definições afirma que o conceito é um tipo de representação geral determinada, distinto, por sua constância e estabilidade, das demais representações gerais indefinidas; a relação entre os conceitos produzidos e as representações gerais que constituem sua matéria-prima é dada por abstração, como demonstram exemplos tirados das ciências naturais e humanas.

Vimos, em nota, que o conceito de representação relaciona-se com o conceito de imagem e/ou idéia. O autor alerta sobre a necessidade de cuidado com os exemplos apresentados:

"Se utilizamos para ilustrar essas relações os conceitos de um animal ou de uma planta, facilmente se introduz uma imagem sensível determinada no conteúdo desses conceitos; as proposições acerca do conceito aparecem então como se o conceito fosse não uma

aparecem como atos do pensamento que a definição analítica apenas retoma para invertê-los e para dividir o conceito em seus juízos; conseqüentemente, podemos designar a definição sintética como 'a passagem do juízo ao conceito' e, inversamente, a definição analítica - que separa novamente as características - como 'a passagem do conceito ao juízo'"' (p. 59). 
significação verbal, mas sim uma imagem intuitiva geral, embora determinada com precisão" (p. $61)$.

Portanto, não devermos confundir entre o conceito de um objeto e a imagem intuitiva e/ou imagem sensível desse objeto, embora o conceito utilizado de representação não distinga entre imagem e idéia ${ }^{59}$ : "toda a teoria das características e a teoria ligada a ela que concebe o conceito como uma representação geral determinada com precisão é esquemática e superficial" (p. 62). Importa, pois, não confundir entre o conceito de um objeto e a imagem intuitiva sensível desse objeto; ao contrário, apenas é possível estabelecer o conceito de um objeto de definição se conseguimos prescindir de qualquer intuição sensível desse objeto, uma vez que tal intuição ou imagem não é necessariamente construída a partir de um conjunto estrito de características essenciais. Citando o exemplo do autor, em nada nos auxilia a compreensão do conceito a imagem de um homem como um "bípede implume".

O conteúdo essencial de um conceito não consiste em imagens mentais que produzimos ao compreender os significados verbais, mas se encontra na relação sistêmica entre juízos essenciais - um ponto de convergência de juízos —, assim considerados segundo princípios diretores externos ao próprio processo lógico de elaboração conceitual (por exemplo, para a Botânica, os fins analíticos pelos quais se dirigem seus conceitos [ou seja, a construção lógica desses conceitos] aplicáveis ao objeto árvore divergem dos fins analíticos relativos ao mesmo objeto, no que diz respeito às Artes Plásticas).

Rickert também enfatiza que não devemos entender que se faz aqui uma distinção entre "conceitos de coisas ou objetos sensíveis" e "conceitos de relações de juízos sobre essas mesmas coisas ou objetos sensíveis". Verdadeiramente, esses hipotéticos "conceitos de coisas" nada são senão complexos de juízos: não apenas os conceitos de relações são compostos de relações de juízos em seus

\footnotetext{
59 "Por exemplo, se, por um lado, falo da representação geral de uma árvore e, por outro lado, do conceito de árvore, e trato de esclarecer adequadamente um dos dois, o conceito ou a representação, talvez o consiga melhor se represento a imagem intuitiva de uma árvore e, ao mesmo tempo, tenha o pensamento de que não importam as distintas propriedades individuais dessa imagem. $\mathrm{Na}$ representação, não se determinam as propriedades relevantes: hoje penso em outras distintas das pensadas amanhã; no conceito, por sua vez, as características estão fixas de uma vez por todas, como elementos essenciais do objeto" (pp. 61-62).
} 
conteúdos lógicos; também das coisas e de qualquer outro objeto sensível pode-se formar um conceito constituído por relações ou conexões de juízos. Assim, "não apenas o conceito de gravitação - como conceito de uma relação entre massas consta de juízos; também o próprio conceito científico de massa [portanto, uma coisa ou objeto sensível], em seu conteúdo essencial, é um complexo de juízos, na medida em que se trata de um conceito definido de massa e não de uma representação geral indeterminada" (p. 65).

Em suma, importa distinguir entre representações gerais e indeterminadas de objetos (estrutura dos objetos que são compreendidos pelo conceito, para os quais podemos expressar juízos que são, contudo, indefinidos e inconstantes) e suas representações determinadas (estrutura do conteúdo do conceito que é formado por relações de juízos definidos e constantes). Sempre consideraremos nesse processo conceitos definidos - princípio que atende a uma possível objeção de uma regressão ao infinito na vinculação entre conceitos e juízos ou, então, no inevitável encontro de conceitos intraduzíveis em juízos. O princípio geral é, pois, o seguinte: "o conceito, na medida em que é definido, consta de juízos. [...] o conteúdo lógico de um conceito definido e cientificamente válido consiste no conteúdo lógico de juízos" (pp. 66-68).

Para uma teoria dos conceitos, cabe perguntar se o juízo pode ser entendido como uma simples relação entre representações. Segundo Rickert:

"É possível provar que, para cada sentido 'verdadeiro' ou 'falso' de uma asserção — isto é, para cada conteúdo de um juízo - há um 'sim' ou 'não' que se acrescenta à relação de representações como um novo elemento. Isso é decisivamente importante para a relação entre conceito e juízo, pois é precisamente esse 'sim' ou 'não' que parece faltar nos conceitos. Nesse aspecto, então, o conceito definido não poderia ser considerado como um complexo de juízos" (RICKERT, op. cit., p. 67).

De fato, não parece plausível entender que um conceito definido possa atender a uma tábua de valores ("verdadeiro versus falso"), assim como podemos fazer com os juízos; para nossos propósitos, porém, basta aceitar que um conceito definido já 
contém uma relação de representações fundamentais para o conteúdo lógico do juízo e é por isso que se equiparam conceito e juízo, logicamente considerados.

Como exemplo, podemos considerar a definição: /homem $\leftarrow \pi$ sanimal discursivo /. Há três conceitos principais aqui acionados (homem, animal e discurso [discursivo]). Não parece razoável pretender atribuir um valor de verdade ou falsidade a esses três conceitos, pois não cabe considerá-los nem verdadeiros nem falsos em si mesmos. Porém, há juízos presentes nessa definição — "homem é animal" e "homem é um ser discursivo" —; podemos, então, considerar verdadeiros ou falsos esses juízos, ou seja, considerar o valor de verdade do enunciado que afirma ser o homem um animal e ser o homem um ente discursivo.

É necessário agora incluir um elemento fundamental para a viabilidade do pensamento conceitual, ou seja, para que se possa pensar conceitualmente. Temos os conceitos, formados por juízos fixos e determinados, e temos a linguagem — ou, mais especificamente, a palavra. Nesse processo, a palavra possui uma função primordial no processo conceitual de pensamento, função essa que vai além da simples comunicação desse pensamento. Se entendermos o conceito definido cientificamente como sendo o conjunto das relações entre os juízos que o formam, a unidade desses juízos — ou seja, a unidade do pensamento - é obtida pela unidade da palavra:

\footnotetext{
"De fato, nunca poderíamos chegar a um pensamento conceitual tão complicado, se não estivesse à nossa disposição a linguagem para designar com uma só palavra os complexos de juízos que nunca poderíamos apreender como uma unidade; essa palavra toma o lugar do conceito, associa-se indissoluvelmente com os juízos pensados como fixos e pode ser utilizada então como um elemento primário (um 'tijolo') no processo de pensamento" (RICKERT, op. cit., p. 69).
}

Assim, por meio da palavra, podemos reutilizar os juízos reunidos em um conceito, formando novos juízos mediante a síntese das significações por ele implicadas; podemos construir um sistema de juízos ou proposições cujos elementos (sujeito e predicado) também constituam complexos de juízos. 
O autor destaca que essa teoria não se confunde com o "nominalismo" ${ }^{60}$, embora uma análise da verdadeira natureza lógica do conceito pode induzir a essa confusão: "se perguntarmos o que realmente corresponde ao conceito geral, não se encontra nada de geral nele porque tudo o que é real é individual" (p. 69). Assim, procurou-se encontrar a essência do objeto representado e designado pela palavra na própria palavra, pensando que o conceito geral seria um complexo sonoro, seus significados vinculados e suas representações gerais e indeterminadas. Para Rickert, a palavra é apenas um recurso a ser empregado pelo processo de pensamento, um complexo de juízos sintetizados unitariamente, um elemento lingüístico de maior permanência e estabilidade; o conceito geral deve, portanto, ser encontrado no próprio conteúdo dos juízos que o compõem.

Tratamos anteriormente das definições sintéticas e definições analíticas. Estas correspondem ao juízo que extrai novamente do conceito os produtos do pensamento nele previamente incluídos por aquelas; no enunciado que expressa esse juízo, teremos um sujeito gramatical constituído por uma palavra que designa uma unidade que substitui os juízos concebidos como fixos (uma espécie de síntese lingüística desses juízos). Assim, podemos entender que em uma definição procurase "definir uma palavra", mas apenas nesse sentido: a palavra é um recurso externo de nomeação de um conceito; o fundamento lógico reside não na explicação verbal, mas sim na análise da determinação do conceito sinalizado por tal palavra - ou seja, na análise de sua composição em juízos.

\footnotetext{
60 "Nominalismo (Terminismo) - Doutrina dos filósofos nominalistas, que constituíram uma das grandes correntes da Escolástica. Os termos 'nominalista' ou 'terminista' foram usados somente no princípio do século XV [...] No princípio do século XII, o Nominalismo era defendido por Abelardo, [...], mas seu triunfo na Escolástica foi devido à obra de Guilherme de Ockham [...]. Assim exprimia Ockham sua convicção sobre o assunto: 'Nada fora da alma, nem por si nem por algo de real ou de racional que the seja acrescentado, de qualquer modo que seja considerado ou entendido, é universal, pois é tão impossível que algo fora da alma seja de qualquer modo universal (a menos que isso se dê por convenção, como quando se considera universal a palavra 'homem', que é particular), quanto é impossível que o homem, segundo qualquer consideração ou qualquer ser, seja um asno' [...]. Do ponto de vista positivo, o Nominalismo admite que o universal ou conceito é um signo dotado de capacidade de ser o predicado de várias coisas. [...] Leibniz dizia que 'são nominalistas todos os que acreditam que, além das substâncias singulares, só existem os nomes puros e, portanto, eliminam a realidade das coisas abstratas e universais'" (ABBAGNANO, op. cit., p. 715, verbete "Nominalismo").
} 
É possível também entender a definição analítica como um juízo de identidade — ou seja, uma identidade entre juízos —, "[...], pois indica, explicitamente, para uma série de juízos, o mesmo conteúdo lógico do que é indicado implicitamente por meio de uma palavra" (p. 70). Mais uma vez, porém, isso não significa que a definição visa à explicação da palavra que designa lingüisticamente um conceito (e que, portanto, não visaria à explicação de um conceito): ao contrário, não se trata de compreender que em um dos termos da estrutura definidora $/ X \leftarrow \pi\langle Y\rangle /$ encontrase apenas uma palavra e, no outro termo, a explicação de seu significado lingüístico; em verdade, em um dos termos está uma palavra como uma marca lingüística de um conceito e, no outro termo, um enunciado assinalando o complexo de juízos que articula uma série de conceitos primitivos e que analisa as partes constituintes do conceito derivado.

Apenas em uma condição, portanto, podemos entender a possibilidade de uma equivalência absoluta entre os sujeitos e seus predicados - quando temos uma equivalência entre juízos: a) os primeiros, considerados fixos e determinados sob a forma de um conceito que implicitamente os contém (o definiendum); b) os segundos, explicitamente enunciados (o definiens).

Uma vez examinada a definição sob o ponto de vista de seu conteúdo lógico, podemos investigá-la em sua forma, no que diz respeito ao gênero próximo e a diferença específica. Definir um conceito não implica indicar a totalidade dos juízos nele formulados e reunidos, mas sim, com a ajuda de uma palavra, nomear um outro conceito e, em seguida, acrescentar a ele juízos: ao definir, devemos "[...] proceder de modo o mais eficaz possível — com vistas a um fim —, escolhendo primeiramente um conceito que contenha o maior número possível de juízos sobre o conceito a definir, para que seja necessário o menor número possível de juízos suplementares" (p. 73). Assim, para definir o conceito de homem, uma escolha eficaz para constituir o definiens é o conceito de animal - que possui um grande número de características do conceito a definir ou definiendum -; basta um suplemento para estabelecer satisfatoriamente o conceito em definição: dotado de linguagem. 
Há casos em que, de fato, definir por gênero e diferença convém por razões externas à lógica do processo definidor. Assim, verificamos em IDE (1997, p. 205), que o seguinte texto: "chama-se 'tecido' um conjunto de estruturas celulares e extracelulares especializadas em vista de uma mesma função", é uma definição por gênero ("conjunto de estruturas celulares e extracelulares") e diferença ("especializadas em vista de uma mesma função"), sendo que a diferença indica também a finalidade do objeto tecido. Tal definição atende satisfatoriamente à finalidade do campo de estudo respectivo (Histofisiologia), que provavelmente organiza seus conteúdos segundo uma distribuição que se assemelha à pirâmide platônica de conceitos. O sistema de Lineu desenvolve suas classificações basicamente por gênero e diferença, pois este é o sistema mais eficiente de classificação para seu objeto de estudo.

Porém, pela herança aristotélica das definições que, como vimos, só pode ser compreendida no contexto de sua metafísica, a lógica moderna ainda declara formalmente que a definição ideal se caracteriza pela declaração de um gênero próximo e uma diferença específica. Trata-se de uma exigência puramente formal, pois o sentido do princípio aristotélico - o(rismo/j e)k ge/nouj kai $\backslash$ diaforo n e) stin — radica em que indicar o ge/noj significa, primeiramente, indicar a essência de um ser metafísico; em segundo lugar, indicar a essência de qualquer objeto sensível, de modo a ser possível concebê-lo clara e distintamente, sem confundi-lo com qualquer outro objeto sensível. A pergunta, portanto, é a seguinte: "se prescindirmos de razões externas de conveniência, a indicação do gênero [ou seja, a essência] tem ainda um valor teórico autônomo para quem haja abandonado a metafísica aristotélica e já não possa pretender da definição uma indicação metafísica da essência no sentido antigo?" (p. 74).

O problema está na multiplicidade de significados atribuíveis ao termo "essência": uma coisa é entendê-lo como o fundamento último das coisas ou o ser absoluto; outra coisa é compreendê-lo como o máximo conhecimento possível ao alcance do investigador, ou seja, como a compreensão das leis naturais que determinam um objeto. O problema está em saber se o custo teórico de se manter o princípio do gênero próximo e da diferença específica é justificado, frente às 
finalidades e necessidades das ciências modernas. Em certos casos, de fato, há uma correspondência entre a visão aristotélica e a visão científica contemporânea:

"A definição que indica o gênero, no último caso que consideramos [trata-se da Física estudando o conceito de gravitação], obtém formalmente o mesmo que a o(rismo/j aristotélica. Para Aristóteles, o ge/noj era a expressão da forma pura, que sempre é e sempre aparece fenomenicamente nas coisas individuais e transitórias; para nós, o gênero é a expressão da lei válida atemporalmente, que sempre encontramos novamente nos fenômenos mutáveis. Se o conceito consta de juízos que contêm uma lei, de fato procura o maior conhecimento sobre a essência das coisas ao que podemos aspirar dentro das ciências empíricas. Baseada nesse suposto, a metodologia requer uma definição que indique o gênero. Definir significa, pois - de novo com Aristóteles —, conceber a essência de uma coisa" (RICKERT, op. cit., p. 76).

A teoria das definições costuma distinguir freqüentemente entre "definições reais" (definições essencialistas-substancialistas) e "definições nominais" (definições nominalistas-terministas): à primeira caberia declarar a natureza essencial do definiendum, entendido como um conceito; à segunda caberia declarar o significado acionado pelo uso de uma palavra. Segundo Rickert, a expressão "definição nominal", entendida como um juízo que indica a significação de uma palavra, distorceria completamente o conceito do o ( rismo/j aristotélico: seria possível, sem dúvida, entender por "definição" a explicação e/ou a especificação dos significados das palavras; porém, com isso estaríamos transformando a teoria das definições em uma teoria da expressão nominal mais adequada, em vez de mantê-la como uma teoria da lógica conceitual (ou seja, teoria da síntese e da análise de conceitos).

Também não é pertinente entender que a definição real faz corresponder diretamente um "objeto real" — o tradicional referente — ao conceito definido, enquanto a definição nominal faz corresponder diretamente um nome a esse referente. Isso porque a palavra é um constituinte necessário para qualquer definição, sendo que à palavra corresponde apenas a tarefa de expressar lingüisticamente conceitos e juízos: quando está definido um conceito, o significado lingüístico da palavra que o sintetiza é formado pelo conteúdo (também lingüístico) dos juízos considerados fixos pela definição do conceito. Em suma, em ambas as 
modalidades de definição, o que está primariamente em jogo são os conceitos - e não os objetos do mundo real nem os objetos do mundo lingüístico. Como se vê, definem-se unicamente conceitos; portanto, verdadeiramente não faz sentido distinguir entre definição real e definição nominal, segundo tais definições são interpretadas usualmente: como estabeleceremos, uma definição real / ideal / substancial diz respeito a conceitos e juízos que constituem uma intensão considerada objetiva (ou seja, acima da subjetividade ou convencionalismo); uma definição nominalista / terminista diz respeito a conceitos e juízos que constituem uma intensão subjetiva e/ou convencional (ou seja, baseada em percepções individuais ou coletivas, mas que não têm em vista precipuamente a essência da substância cujo conceito está em definição). 


\title{
CAPÍTULO II — DEFINIÇÕES DE DEFINIÇÃO
}

\author{
2.1 CONCEITOS IMPLICADOS PELO ATO DEFINIDOR: EXPLICITAÇÕES EM \\ TORNO DA ABORDAGEM ESSENCIALISTA E DA ABORDAGEM TERMINISTA \\ DAS DEFINIÇÕES
}

Com Rickert, vimos que, de acordo com o sentido original da expressão "o(rismo/j" — «ação de limitar ou de definir —, compreende-se a definição (definitio) como um modo de pensar cuja tarefa é determinar o conceito (definitum), indicando a essência de um objeto de definição (sensível ou puramente mental). Vimos também que o conceito pode ser entendido como um juízo formado por um definiendum - que se apresenta como um termo que designa um determinado complexo de juízos - e por um definiens, constituído por um sistema de juízos capaz de reunir características essenciais que uma definição sintética prévia considerou como constituintes do conceito e/ou da essência do objeto de definição. O critério para julgar a essencialidade do sistema de características é próprio da cada ciência e é estabelecido externamente (ou seja, é extrínseco à lógica estrita do sistema de juízos), de acordo com a finalidade, objetivos e metas dessa ciência; trata-se, portanto, de um critério teleológico para a seleção de características essenciais.

Para que possamos melhor compreender os diversos tipos de definição a serem discutidos, é útil apresentar alguns conceitos auxiliares que, de alguma forma, são acionados pelo conceito principal de definição. As definições de tais conceitos deixam transparecer, em especial, a histórica polarização entre o conceito essencialista de definição versus o conceito nominalista de definição (ou seja, a clássica divisão entre "definições essenciais" e "definições nominais").

Duas observações são de interesse: em primeiro lugar, examinando estes conceitos auxiliares, verificaremos que há uma constante permeabilidade entre eles, de modo que convém considerá-los em conjunto; em segundo lugar, a partir da exposição desses conceitos, assim como são apresentados em algumas fontes, 
teremos condição de fixar nossa compreensão sobre cada um deles, tal como serão acionados sistemicamente neste trabalho.

a) HEGENBERG (op. cit., p. 59) assim define /termo $\leftarrow \pi$ «em um sentido, o vocábulo é empregado para referir-se a uma classe de palavras (sons ou marcas) que se destinam a fixar certas características de objetos - sejam propriedades, sejam relações. Essas palavras serão aqui chamadas 'termos'. Assim, 'branco', 'blanco', 'white', 'weiss' são palavras distintas, mas um só termo. [...] Os termos podem ser empregados ou para fazer referência a conceitos (os pensamentos de alguém) ou para fazer referência a coisas e suas característicası/.

Importa observar que nas próprias definições do conceito de termo, existem importantes implicações para a teoria das definições. Segundo ABBAGNANO (2003, pp. 956-957), por "termo" — o\#roj / terminus — podemos entender basicamente: i) o signo lingüístico ou o conjunto de signos; ii) qualquer objeto ou coisa a que um discurso se refira; iii) o limite de uma extensão.

Assim, a expressão "o termo 'definição'" pode referir-se ao signo "definição", ao objeto definição (referencial identificado pelo nome "definição") ou ao processo de delimitação do conceito de definição. Notamos, pois, a polissemia da palavra "termo": o que devemos, portanto, entender pela expressão — "defina o termo 'X'" —: a) 'definir' o signo "X"?; b) declarar as propriedades do objeto $X$ ?; c) delimitar precisamente o conceito $X$ ?

Segundo LALANDE (1999, pp. 1132-1133), entende-se que "termo" é: i) a fronteira, o limite (muitas vezes dado pela natureza das coisas); ii) uma expressão verbal que representa uma idéia definida. Neste sentido, "torna-se muitas vezes sinônimo de 'palavra' e até é aplicado (contrariamente à etimologia) a palavras cujo sentido é mal definido [...]"; iii) "um dos elementos simples (ou considerados como tais) entre os quais se estabelece uma relação lógica [...]".

Na crítica do verbete, lemos que:

"Os sentidos atuais desta palavra ["termo"] são díspares porque são derivados segundo direções muito diversas do sentido primitivo. \#Oroj significa primeiramente 'limite material', 'marco' (cf. horizonte); depois, por metáfora, 'aquilo que delimita ou define uma espécie de ser, aquilo que constitui sua característica essencial', do mesmo modo que em latim finis, definitio; 
daí passa a designar 'a própria operação de determinação ou definição' (este sentido desapareceu na palavra "termo"); finalmente, designa 'as palavras que estão definidas' e até, como vimos mais acima, aquelas que não o estão". (Ibidem).

Como vemos novamente, a expressão "o termo 'definição'" pode ser interpretada polissemicamente: a) como uma delimitação conceitual orientada pela "natureza das coisas" — situação das definições de caráter essencial-substancialista (que tratam dos objetos enquanto essências, no caso, o objeto essencial definição); b) como um discurso sobre um conceito ou objeto mental; c) como a especificação de um componente de um sistema lógico.

A crítica do verbete indica o percurso que: i) parte do vocábulo o3roj / terminus, com sua acepção concreta; ii) passa a designar um ser ou sua essencialidade e, então, vincula-se à forma latina finis / definitio; iii) passa, igualmente, a designar o próprio processo de determinação ou definição, acepção essa que não se vincula ao vocábulo terminus, mas que permanece ligada ao vocábulo definitio; iv) passa a designar as próprias palavras que identificam os processos de definição bem realizados; v) termina por designar palavras cujas definições não estão bem estipuladas, quer por razões técnicas, quer por razões discursivas (ou seja, um termo pode ser ou permanecer mal definido pela ausência de um processo adequado de definição, ou pode ser deliberadamente mal definido por conveniência discursiva); 
b) para a correta compreensão do conceito de $\operatorname{ser}^{61}$ — to \ oln — (isto é, da substância ser; verificar os próximos conceitos: substância ou ou) si/a e essência ou ti/ estin), é importante estabelecer uma distinção fundamental entre o uso predicativo e o uso existencial do verbo "ser". No uso predicativo, temos "ser" empregado, digamos, em seu sentido fraco — "ser" enquanto simples nexo de predicação —; assim, na oração "A pedra é dura", a função do "ser" é praticamente estabelecer o adjetivo "dura" como um atributo (no caso, essencial) do objeto pedra. Já no segundo uso, temos o "ser" empregado em seu sentido forte — "ser" enquanto processo existencial -; assim, na oração "A pedra é", temos a afirmação de que "A pedra existe enquanto tal".

${ }^{61}$ Em CAYGILL (2000, pp.290-292, verbete "ser"), observa-se que: "o ponto de partida tradicional para a questão do 'ser' na filosofia ocidental são os fragmentos da Parmênides (século VI a. C.). Neles, o 'ser' é diferenciado do 'não-ser' em termos da distinção entre o caminho da verdade e o caminho das opiniões. Não pode haver transição do 'não-ser' para o 'ser', nenhuma mudança ou movimento; 'ser' é tudo o que pode ser conhecido e é uno [...]. Paradoxalmente, Platão atenuou e intensificou a distinção de Parmênides entre 'ser' e 'não-ser'. Este último não é mais o oposto absoluto de 'ser', mas participa no 'ser' em graus variáveis; 'ser' informa imediatamente as idéias, assim como forma uma idéia superior em si. Aristóteles, entretanto, na 'Metafísica', enfatiza a participação de seres distintos no Ser em geral, estabelecendo um repertório de caminhos em que Ser pode ser falado de entes [...]. Ele faz uma distinção crucial entre 'energeia' e 'dynamis', que mais tarde evoluiu, primeiro, para a distinção entre 'esse' e 'essentia', e depois entre existência e efetividade. Em sua recepção da extremamente diversa herança do pensamento grego de Ser, os comentaristas medievais, islâmicos e cristãos sistematizaram algumas de suas características mais salientes. Persistiu a problemática básica de descrever os vários modos em que o Ser pode ser falado de seres [...]. E, como em Platão e Aristóteles, 'ser' continua a ser entendido como um termo transcendental que não pode ser afirmado categoricamente como predicado. Para a tradição tomista, 'ser' só pode ser predicado analogicamente - o 'ser' de Deus e o 'ser' do mundo só analogicamente são o mesmo. Para a tradição scotista, 'ser' pode ser predicado univocamente, tendo em mente o mesmo sentido de 'ser' quando é predicado do mundo ou de Deus. Os escolásticos concordaram em distinguir entre 'ser' como existência, 'ser' como efetividade e 'ser' como tal: 'ser' como efetividade, ou 'esse', designava a existência de uma essência, como em o 'ser' da humanidade; 'ser' como 'essentia' designava a efetividade aqui e agora individual de, digamos, esta mulher ou este homem; enquanto 'ser' como tal, aquele 'ser' cuja essência é existência e efetividade, só pode ser dito de Deus. Os termos e distinções das discussões escolásticas do 'ser' continuaram a informar a inauguração cartesiana da modernidade filosófica. Embora para Descartes e Leibniz (mas não Espinosa) o foco para a questão do 'ser' de Deus, o mundo e a alma se tivesse transferido de Deus para a alma e a certeza que esta tem sua própria existência, persistia a estrutura básica do problema. Para os modernos, Ser permanece extracategorial e não é algo que possa ser simplesmente predicado em um juízo como qualquer outro predicado. Para eles, 'esse' designa agora possibilidade, ou aquilo que é sem contradição, ao passo que 'essentia' são aqueles fenômenos percebidos como existentes, e 'ser' como tal é agora interpretado como referente ao 'ser' privilegiado em si, quer isto seja descrito em termos de Deus ou causa sui, o sujeito, ou o ser-em-si da nova ciência pós-cartesiana da ontologia. A discussão do 'ser' por Kant segue precedentes ao afirmar que 'ser' pode mencionar-se de muitas maneiras mas, para ele, o que é comum a todas elas é a noção de síntese. [consultar a continuação do verbete para a discussão sobre o conceito de ser em Kant]. 
Em ABBAGNANO (2003, pp. 878-882), afirmam-se três doutrinas possíveis para a interpretação do uso predicativo do verbo "ser": i) a doutrina da inerência; ii) a doutrina da identidade ou suposição; iii) a doutrina da relação.

i) de acordo com a doutrina da inerência, o "ser" predicativo implica que o atributo predicado é, de algum modo, inerente ao objeto que recebe a predicação. Esta visão baseia-se na teoria aristotélica da substância, para a qual as relações de inerência à substância, expressas pelo "ser", podem ser divididas em dois grandes grupos: 1) substância e essência necessária (determinações categóricas essenciais); 2) substância e essência contingente ou acidental (determinações categóricas contingentes ou acidentais):

"Uma vez que há uma diferença segundo algo é inerente, é necessariamente inerente, ou pode ser eventualmente inerente à outra coisa (pois muitas coisas são, de fato, inerentes, mas não necessariamente; outras não são nem necessariamente nem de fato inerentes, mas podem possivelmente sê-lo), é claro que haverá diferentes silogismos para provar cada uma dessas relações" (ARISTÓTELES, Primeiros analíticos, I, 8, 29b, 28).

$\mathrm{i}_{1}$ ) a inerência essencial necessária diz respeito à essência de um objeto para ser aquilo que é (categorias essenciais necessárias): um ser essencial necessário ou ser-em-si. Este é, por excelência, o objeto das definições essenciais ideais, as quais visam precipuamente à substância dos seres.

Como exemplo, em relação à oração "A pedra é dura", essa doutrina considera que o atributo dura - ou a essência dureza - é necessariamente inerente (ou seja, é característica inalienável) à essência substancial pedra, sem a qual tal substância deixaria de ser essa substância particular. Conseqüentemente, segundo essa visão substancialista, a dureza é uma categoria universal necessária que pode ser abstraída por indução a partir de um conjunto de objetos pedra (ou, por outro ponto de vista, um conjunto de objetos que podem ser identificados pelo termo "pedra"). Conseqüentemente, podemos dizer que a essência dureza é não só uma categoria universal, mas também uma essência inerente à essência pedra.

$\dot{\mathrm{i}}_{2}$ ) inerência acidental diz respeito a qualquer essência acidental ou contingente, dada por uma determinação categórica (como, por exemplo, qualidade, 
quantidade, etc.) que não é exigida obrigatoriamente pela definição essencial ideal do objeto. Portanto, a inerência contingente ou acidental diz respeito às determinações categoriais que não fazem parte da essência necessária a um objeto para ser aquilo que é: trata-se de categorias puramente acidentais. Assim, segundo Aristóteles:

\footnotetext{
"Em sentido acidental, dizemos, por exemplo, que o justo é músico, que o homem é músico e que o músico é homem, ou dizemos que o músico constrói quando acontece de o construtor ser músico ou de o músico ser construtor: em todos esses casos, dizer 'isto é aquilo' significa 'a isto acontece aquilo' [mas poderia não acontecer]" (Metafísica, V, 7, 1017a, 7).
}

Como exemplo, na oração "A pedra é granito", a essência granito é acidentalmente inerente à essência pedra. Em resumo, o "ser" predicativo inerencial essencial indica que uma essência é inerentemente necessária a um determinado sujeito, enquanto o "ser" predicativo inerencial acidental expressa a inerência ao sujeito de determinações categoriais essenciais contingentes, embora aplicáveis racionalmente a essa substância. Esse conceito de "ser" predicativo baseia-se em um tipo único de relação - a relação de inerência - e dá destaque à necessidade de tal relação.

Importa observar que o processo predicativo não se restringe à inerência essencial. Como um exemplo, na oração "A pedra é bonita", temos uma predicação que não é inerentemente substancialista: a essência beleza não está na essência pedra, mas esta é aplicada àquela por conta daquele que elabora a proposição; desse modo, há um juízo subjetivo, expresso lingüística e discursivamente, que, de alguma forma, (re)elabora o objeto pedra de modo a dispô-lo a receber o predicado bonita. É o que ocorre com as "pseudodefinições predicativas subjetivas", estruturas predicativas de caráter puramente subjetivo que propõem uma equivalência lingüística entre um termo e um texto os quais, em dada situação de uso, podem ser considerados intercambiáveis, sem que se cogite em declarar a essência necessária nem a essência contingente da substância nomeada pelo termo em questão. 
ii) de acordo com a doutrina da identidade ou suposição ${ }^{62}$, o "ser" nas estruturas oracionais indica a identidade do objeto existente a que tanto o sujeito quanto o predicado da proposição se referem. Aqui, é importante a referência feita pelas proposições em relação a um mesmo objeto ou situação imediatamente presente. Ou seja, para essa doutrina: 1) é necessário existir uma referência a uma realidade imediatamente dada ou intuída enquanto tal; 2) é necessário que haja identidade de referência objetiva dos termos da proposição (ou seja, os termos da proposição devem ser vicários em relação a um mesmo objeto). Assim, na oração "A pedra é dura", teríamos o verbo "ser" indicando que a essência pedra e o atributo dura referem-se a um mesmo objeto existente, que aceita, portanto, ser predicado por ambos os termos da proposição e, igualmente, aceita ser representado por eles.

Como afirmamos, é fundamental para essa doutrina a referência feita por um enunciado a uma realidade imediatamente dada ou intuída; tal postulado impõe dificuldades à abstração de universais por indução e à predicação por meio de atributos essenciais dos objetos. Como um exemplo da ênfase aplicada à referência a uma realidade por parte dessa doutrina, eis como se expressa Ockham (colocando-se em oposição à doutrina da inerência):

"Proposições como 'Sócrates é um homem' ou 'Sócrates é um animal' não significam que Sócrates tem humanidade ou animalidade. Tampouco significam que a humanidade ou a animalidade está em Sócrates, nem que o homem ou o animal é uma parte da substância ou da essência de Sócrates, ou uma parte do conceito ou da substância de Sócrates. Significam

\footnotetext{
${ }^{62}$ Em ABBAGNANO (2003, p. 934), encontramos o verbete "suposição": "grego u9po/qesij / latim suppositio - [...] Na lógica terminista medieval, é o significado denotativo dos termos presentes na proposição, enquanto o significado em sentido estrito é o conotativo [...]. Nesse sentido, a suposição é definida como uma positio pro alio, um estar em lugar de alguma coisa: por exemplo, quando dizemos 'o homem corre', o termo 'homem' está em lugar de Sócrates, Platão ou algum outro [...]. Com exceção de alguns casos isolados, a teoria da suppositio é mais ou menos uniforme em todos os lógicos do século XIV. Eles distinguiam três espécies fundamentais de suposição: pessoal, simples e material. Tem-se a suposição pessoal quando o termo está no lugar do objeto significado, qualquer que seja ele: coisa externa, palavra, conceito, sinal escrito ou outra coisa. Assim, nas frases 'o homem é um animal', 'o nome é parte da proposição', 'a espécie é um universal', os termos 'homem', 'nome' e 'espécie' têm suposição pessoal porque estão no lugar dos respectivos objetos. Tem-se suposição simples quando o termo não está no lugar do objeto significado, mas de seu conceito. Assim, quando se diz 'o homem é uma espécie', o termo 'homem' não está no lugar de 'o homem' [um indivíduo], mas do conceito 'homem' [a idéia ou o conceito]. Finalmente, tem-se a suposição material quando um termo está no lugar da palavra ou do sinal escrito, como nas frases 'homem é substantivo' ou 'está escrito homem', onde 'homem' está no lugar de uma palavra ou sinal escrito".
} 
que Sócrates é na realidade um homem e é na realidade um animal: não no sentido de Sócrates ser esse predicado 'homem' ou esse predicado 'animal', mas no sentido de que existe alguma coisa em lugar da qual esses dois predicados estão; como quando acontece que esses predicados estão no lugar de Sócrates" (Summa logicae, II, 2).

iii) de acordo com a doutrina da relação, a cópula promovida pelo "ser" pode ser entendida como uma relação predicativa: 1) subjetiva (interpretação do "ser" predicativo como uma relação que constitui um ato e uma operação do sujeito pensante); 2) objetiva.

Para a relação predicativa subjetiva, o objeto imediato do conhecimento humano é a idéia, e a proposição apresenta-se como um juízo (uma operação de espírito pela qual se acrescenta alguma coisa à idéia de um objeto [conforme formulação cartesiana], caracterizando um ato de síntese). Assim, na proposição "A pedra é dura", temos três elementos: "pedra" como sujeito ou objeto de predicação; "dura" como predicado ou atributo da predicação, e "é" como índice da ação do espírito que, mediante um juízo, acrescenta a idéia de dureza (ser dura) como um atributo conveniente à idéia de pedra.

Para essa doutrina, o "ser" expressa as relações percebidas pelo espírito, ou seja, relações que, em realidade, estão fundamentalmente no sujeito de conhecimento (embora não unicamente nele).

A principal dificuldade dessa doutrina está em que, para ela, uma asserção não tem por objetivo estabelecer relações entre idéias, representações ou conceitos, mas sim entre os objetos passíveis de referência: a proposição "A pedra é dura" não implica que a idéia, representação ou conceito pedra possui o atributo dureza, mas sim que um dado objeto real pedra, ao qual a proposição se refere, tem a propriedade de ser dura. Há, portanto, uma dificuldade em se transitar da realidade individual indicada por referência concreta para a essencialidade conceitual que seja universal e necessária para todo e qualquer objeto-membro de uma classe; 
c) quanto à definição de substância ${ }^{63}$ — ou ) si/a —, interessa-nos destacar, em ABBAGNANO (2003, pp. 925-927), dois significados fundamentais para esse objeto: substancia enquanto estrutura necessária, e substância enquanto conexão constante.

$\mathrm{C}_{1}$ ) para a substância entendida como estrutura necessária, há duas determinações: i) substância como (aquilo que é necessariamente aquilo que és; ii) substância como raquilo que existe necessariamentè.

i) a primeira determinação refere-se àquilo que pode ser entendido por essência necessária a partir da expressão, dada por Aristóteles em sua Metafísica, to $t i / h\} n$ ei\}nai, ou seja, "aquilo que o ser era [sempre foi e sempre será]". A essência necessária de uma substância é expressa por sua definição, ou seja, é função das definições expressar as essências necessárias das substâncias — ou seu conceito objetivo.

ii) a segunda determinação diz respeito à substância compreendida como uma existência necessária; isso é fundamental para que haja o conhecimento das coisas particulares:

${ }^{63}$ Em CAYGILL (op. cit., pp. 7-10; 299-300, verbetes "substância"; "acidente"; "sujeito"), lemos que: "acidente é classicamente definido em oposição à substância [...]. Desde Aristóteles [...] é aquilo que pode ser predicado de um sujeito e o que não pode existir sem um sujeito. É o inverso da substância ou o que 'não é predicável de um sujeito nem está presente em um sujeito' [...] Seguindo Aristóteles, Santo Tomás de Aquino define um acidente como o que tem seu 'ser em outro' (esse in alio) [...], acrescentando que 'uma substância não depende de um acidente, embora um acidente dependa de uma substância' [...]. Acidentes podem acontecer a uma substância, embora não sejam necessários para sua definição ou existência. [...] Leibniz [...] esclareceu o caráter temporal de substância e acidente: 'uma entidade ou é em si mesma (per se) ou acidental (per accidens) ou um termo é necessário ou mutável. [...] Substância é assim redefinida como o que pode perdurar ao longo do tempo, ao passo que acidentes são aquelas qualidades que podem mudar com o tempo sem aniquilar a substância. a tendência de Hobbes, Locke e Hume foi para minimizar a distinção de substância e acidente. Observa Locke: 'Aqueles que pela primeira vez se deparam com a noção de acidentes como uma espécie de seres reais que necessitavam de algo que lhes fosse inerente, viram-se forçados a descobrir a palavra 'substância' para lhes servir de sustentáculo' [...]. Hume é ainda menos benévolo: 'o mesmo hábito que nos faz inferir uma conexão entre causa e efeito leva-nos, neste caso, a inferir a dependência de todas as qualidades da substância desconhecida' [...]". Ver verbete para a exposição da noção kantiana de acidente. Sobre o verbete "sujeito", temos: "Em Aristóteles, o sujeito [...] designa 'aquilo que está sob' e é usado em muitas acepções. [...] é usado como um modo de designar a matéria e como um modo de designar a substância como um 'sujeito primeiro' ou aqueles seres que 'são denominados 'substância' porque não são predicados de um sujeito, mas tudo o mais é predicado deles' [...]. Ver verbete para a exposição da noção kantiana de sujeito. 


\begin{abstract}
"Há conhecimento das coisas individuais apenas quando conhecemos sua essência; e o caso é o mesmo para outras coisas assim como para o bem. Pois, se a essência do bem não é o bem, então nem a essência da realidade é o real, nem a essência da unidade é o uno. E todas as essências semelhantes existem, ou nenhuma delas existe; assim, se a essência da realidade não é real, nenhuma das outras o é. [...] àquilo que a essência do bem não pertence não é o bem. O bem, portanto, deve ser uno com a essência do bem, e o belo com a essência do belo, e assim com todas as coisas que não dependem de outra coisas, mas são auto-subsistentes e primárias" (ARISTÓTELES, Metafísica, VII, 6, 1031b, 5-15).
\end{abstract}

Segundo essa afirmação, tudo que é, é tal coisa em virtude de sua essência necessária, considerada causa intrínseca ou extrínseca desse ser. Tudo que há de real e cognoscível nos seres é inerente à essência necessária desses seres: sendo assim, eles existem necessariamente e desse modo podem ser conhecidos e definidos.

Segundo a visão aristotélica, a substância é a estrutura necessária do ser segundo um encadeamento causal: todas as espécies de causas podem ser determinações da substância. Enquanto estrutura necessária do ser, a substância é o fundamento do saber verdadeiramente científico (que se opõe à mera do/ca ou opinião): a essência necessária dos seres é conhecida por demonstração científica de sua necessidade ontológica.

$\mathrm{c}_{2}$ ) o segundo enfoque entende a substância como conexão constante entre determinações simultaneamente dadas pela experiência sensível. Tal doutrina empirista destaca que a substância em si mesma é incognoscível porque não é objeto de experiências: apenas as individualidades são fenomenicamente apreensíveis. Dessa forma, coloca-se em questão a substância concebida como essência necessária, uma vez que tal necessidade não é resultado de qualquer experiência sensível: assim, sendo, tal conceito seria meramente conjectural.

A incognoscibilidade da substância-em-si deve-se ao fato de que tal substância - sua constituição essencial - dá-se para a experiência apenas como a manifestação de um conjunto de atributos ou qualidades concretamente determinadas, as quais constituem, em última análise, uma coleção de idéias 
sensíveis (sempre poderemos objetar, contra a abstração, que a observação de uma amostra jamais representará o universo de seres considerados por tal amostra).

Para esse enfoque, em suma, a substância - entendida como a constituição interna do ser, cujas qualidades devem ser dedutíveis dessa constituição e devem ser explicadas por ela — é, em si mesma, incognoscível. Assim sendo, essa abordagem empirista vê a substância como uma simples coleção de idéias ou conceitos que, em lugar de serem determinadas pelo princípio da necessidade, são determinações percebidas por nossos sentidos como coexistências de fato - são, em última análise, fenômenos. Como um exemplo dessa doutrina, assim se pronuncia Locke ${ }^{64}$ :

\begin{abstract}
"No conhecimento e na distinção das substâncias, nossas faculdades não vão além de uma coleção de idéias sensíveis que observamos nelas; esta, mesmo que criada com a maior diligência e exatidão de que sejamos capazes, estará sempre distante da verdadeira constituição interna de que tais qualidades derivam. [...] Quando nos ocorre examinar as pedras sobre as quais caminhamos ou o ferro que manejamos todos os dias, logo descobrimos que não sabemos como são feitos nem sabemos explicar as diversas qualidades que descobrimos neles. É evidente que a constituição interna de que dependem suas propriedades nos é desconhecida" (An essay concerning human understanding, III, 6, 9).
\end{abstract}

Como vemos, a constituição da substância deixa de ser uma necessidade ditada pela razão e passa a ser uma facticidade sem causa demonstrável: deixamos de considerar que as determinações de uma substância estão todas racionalmente interligadas e são deriváveis da determinação fundamental que caracteriza a essência do ser, e passamos a considerá-las como uma conexão de contigüidade e causação ou, em outras palavras, como uma interconexão persistente entre determinados atributos sensíveis e determinados resultados previsíveis (ou seja, a substância seria uma constância e uma consistência na percepção sobre a uniformidade e reprodutibilidade de determinadas relações entre objetos);

\footnotetext{
${ }^{64}$ Sobre a natureza do signo lingüístico e o convencionalismo lockiano - que trata da arbitrariedade da linguagem —, ver AUROUX (1998, pp. 114-118).
} 
d) quanto à definição de essência ${ }^{65}$ — ti/ estin —, com Aristóteles distingue-se entre dois tipos de resposta à pergunta — "O que é $X$ ?" — e dois tipos de essência conseqüentes: i) respostas que apresentam atributos contingentes dos seres; ii) respostas que apresentam atributos essenciais e necessários dos seres.

No primeiro caso, enunciam-se atributos (qualidades ou caracteres) que o objeto possui, mas poderia não possuir sem deixar de ser aquele objeto particular; trata-se de sua essência contingente. No segundo caso, enunciam-se atributos que o objeto necessariamente possui, sem os quais deixaria de ser aquele objeto particular; trata-se de sua essência necessária, que constitui a substância de um determinado ser, implica o porquê dessa substância e é a referência para sua definição.

Devemos distinguir, nesta teoria da essência, entre a essência de um ser, dada por qualquer resposta adequada, objetiva e racional à pergunta — "Que é esse ser?" _ - e a essência de um ser, dada pela resposta à pergunta — "Que é esse ser, sem o quê deixaria de ser o que ele é?".

Como exemplo, na proposição "A pedra é granito", a substância granito é atributo contingente à substância pedra, porém é um atributo que, racional e pertinentemente, pode ser aplicado a esta; trata-se, assim, da declaração de uma das manifestações da essência do objeto pedra. O mesmo ocorre na proposição " $A$

${ }^{65}$ CAYGILL (op. cit., pp. 127-128, verbete "essência") registra: "essência é, classicamente, o que constitui a natureza específica de uma coisa e o que é dado em sua definição. A noção de essência foi desenvolvida por Aristóteles na Metafísica como parte de uma resposta à pergunta 'O que é uma coisa?'. Na definição de uma coisa, a essência é distinta de acidentes e substâncias: os acidentes são sempre predicados de um sujeito e servem somente para qualificar uma essência [...], enquanto a substância indica 'que uma coisa é' e não 'o que é'. Assim, a essência define a espécie de um gênero ou o seu caráter específico [...]. Santo Tomás de Aquino aclara esses pontos quando discute a essência como função da composição de matéria e forma. A definição de essência não é formal, não separada da matéria, nem é material e derivada da matéria individualizante. Usando o exemplo da essência de humanidade, Santo Tomás de Aquino diz que não é a forma de humanidade nem a carne, os ossos e acidentes que designam a matéria, mas, antes, o constituinte formal em relação à matéria individualizante [...]. Um dos efeitos da definição aristotélica de essência foi o surgimento de uma relação equívoca entre essência e existência. Como função da relação de forma e matéria, a essência não era puramente formal, distinta da existência, nem puramente material, identificada com existência. Com Descartes e, em seguida, Espinosa, essa ambigüidade foi transformada em uma oposição entre o que pode ser concebido e o que existe. [...] A transformação da essência em possibilidade foi sistematizada por Wolff e sua escola, para quem a essência passou a ser definida como simples possibilidade [...]. É dessa tradição que Kant recebe a sua noção de essência. 
pedra é pesada": o atributo pesada é contingente; porém, é adequado ao objeto que se propõe predicar.

Já na proposição "A pedra é mineral duro e sólido", temos a presença de atributos não só essenciais, mas também necessários para que o objeto pedra seja o que é; trata-se da declaração da essência necessária do referido objeto, isto é, a declaração da substância pedra. Neste caso, vemos que a substância pedra não pode deixar de ser mineral, dura e sólida e continuar a ser pedra; além disso, declara-se o porquê da pedra ser uma pedra (a proposição apresentada equivale à outra proposição: "A pedra é pedra porque é mineral, dura e sólida").

No exemplo seguinte: "A pedra é feliz", vemos o resultado daquilo que, em ABBAGNANO (op. cit., pp. 358-359), afirma-se como válido para a constatação da essência de um objeto: "[...] deve-se distinguir: 1) a essência de uma coisa, que é qualquer resposta que se possa dar à pergunta 'O quê?'; 2) a essência necessária ou substância, que é a resposta (à mesma pergunta) que enuncia aquilo que a coisa não pode deixar de ser e que é o porquê da coisa [...]". Parece-nos importante a ressalva feita anteriormente, no que diz respeito à essência contingente: pois, se a resposta não for adequada, objetiva e racional frente à essencialidade do objeto interrogado, interpretaremos livremente o trecho anteriormente citado e sublinhado, produzindo qualquer resposta cuja pretensão seria declarar a essência de um objeto. No exemplo, o atributo feliz não constitui nem a essência necessária nem a essência contingente do objeto predicado; trata-se apenas de uma pseudodefinição.

Essa observação é importante para nossos propósitos, pois o autor aduz os seguintes comentários ao verbete "essência" — essência entendida como resposta à pergunta "Que é?":

"O significado geral e fundamental desse termo ["essência"] pode ser admitido também por filósofos que não compartilham a teoria da substância. Mas os estóicos, que não admitiam a teoria da substância, evitaram (ao que saibamos) o termo 'essência'. Para eles, a definição não manifesta a essência de uma coisa, mas foi definida (por Crisipo) como 'resposta' ( a opo/dosij ). Com isso, deram a entender que qualquer resposta à pergunta 'Que é?' pode ser considerada definição da coisa sobre a qual se faz uma pergunta. Com efeito, diziam que a descrição 'é um discurso que conduz à coisa através de suas pegadas' [...], vendo assim nos 
enunciados lingüísticos um modo de orientar-se em relação às coisas, e não a expressão da substância das coisas. [...] Uma proposição ou um enunciado qualquer nada exprime que possa referir-se à substância e, portanto, declarar-se essencial ou acidental em relação a ela, dedutível ou não dedutível dela, mas exprime simplesmente um estado de fato que, se é como se diz, verifica a proposição ou, se não é, torna-a falsa." (ABBAGNANO, op. cit., pp. 359-360).

Como se vê, essa visão estóica da essência e da definição não vincula a teoria da essência à teoria da substância; a relação predicativa " $X$ é $Y$ " deve ser entendida como uma relação factual que implica uma identidade constatável empiricamente entre o objeto $X$ (o sujeito da proposição) e o objeto $Y$ (predicado atribuído à $X$ ). Não existe aqui relação de inerência, nem uma relação de substancialidade e necessidade. Assim, o juízo: "A pedra é feliz", segundo essa visão, seria simplesmente considerado verdadeiro, falso ou indeterminado, sem qualquer outra consideração de ordem substancialista.

$\mathrm{Na}$ evolução histórica desta orientação, teremos, citando alguns nomes tais como Ockham, Hobbes, Locke, Stuart Mill, Carnap e Quine, considerações que levaram à cristalização de uma teoria da essência nominal.

Segundo o conceito de essência nominal, a essência de um objeto é: i) o caráter acidental graças ao qual se dá um nome a esse objeto; ii) a idéia abstrata à qual se associa um nome de uma espécie, de modo que tudo o que esteja contido nessa idéia é essencial à espécie designada pelo nome; iii) uma proposição puramente verbal que afirma, em relação a uma coisa designada por um nome particular, apenas aquilo que é afirmado sobre ela pelo próprio fato de essa coisa ser chamada por esse nome, dando-se informações apenas em relação ao nome, e não em relação à coisa em si por ele designada.

Como exemplo dessa posição, assim Quine se expressa em relação à doutrina aristotélica da essência:

"Para Aristóteles, era essencial no homem ser racional e acidental possuir duas pernas. Mas há uma importante diferença entre essa atitude e a doutrina do significado. Deste ponto de vista, pode, de fato, ser concedido (ainda que para efeito de argumentação) que racionalidade está envolvida no significado da palavra 'homem', enquanto possuir duas pernas não esteja; mas possuir duas pernas pode, ao mesmo tempo, ser visto como envolvido no significado de 
'bípede', enquanto racionalidade não. Então, sob o ponto de vista da doutrina do significado, não faz sentido dizer de um indivíduo real, que é, ao mesmo tempo, um homem e um bípede, que sua racionalidade é essencial e sua condição de bípede acidental, ou vice-versa. As coisas têm essência para Aristóteles, mas apenas formas lingüísticas possuem significados. Significado é aquilo que a essência se torna quando é separada do objeto de referência e unida à palavra" (From a logical point of view, II, 1, p. 22).

O conceito de essência nominal termina por vincular-se, portanto, à teoria do significado, ou seja, a essência de uma substância passa a ser interpretada como uma simples regra para o emprego correto de um termo: um exemplo disso encontra-se em Carnap, para quem a essência de um objeto é expressa pelo critério de verdade de proposições nas quais comparece o signo desse objeto;

e) quanto às definições do conceito de significado ou significação lekto $/ \mathrm{n}^{66}$-, ABBAGNANO (op. cit., pp. 890-893) assim se expressa: "entende-se por este termo a dimensão semântica do procedimento semiológico, ou seja, a possibilidade de um signo referir-se a seu objeto". Portanto, de acordo com essa definição, o significado de um signo, nome ou termo é sua capacidade de fazer referência a um objeto - seja qual for a natureza desse objeto (objeto-de-realidade, objeto mental, objeto-de-discurso ou objeto lingüístico) -; assim, postular a existência de um significado para um signo implica reiterar a vigência de um ato de referência: não existe signo que não realize tal ato. As questões disso derivadas podem assim ser formuladas: uma vez que o ato de referência a um objeto é intrínseco ao próprio conceito de significado, pergunta-se quais seriam: i) as definições desse ato de referência?; ii) as definições do objeto desse ato de referência?

Segundo Abbagnano, há duas condições básicas para a existência de um significado ou uma significação: i) um nome, um conceito ou uma essência, cuja função é delimitar a referência; ii) um objeto de referência ao qual esse nome, conceito ou essência se referem. Assim se compreendem as relações entre esses dois elementos, segundo o autor:

\footnotetext{
${ }^{66}$ Para uma exposição do conceito de lekto/n, ver SILVA (2002, pp. 159-212) — "Os estóicos e o conceito de lekton". Também, ver NEF (1995, pp. 28-35) sobre a semântica estóica.
} 
"Os dois aspectos são inseparáveis; o segundo é função do primeiro porque é o nome ou conceito que determina a que objeto se faz ou não referência. Mas os dois aspectos não se identificam porque o objeto pode ser o mesmo, ao passo que o nome ou conceito usado para a referência é diferente, como no caso de 'Alessandro Manzoni' [nome] e 'autor de Os noivos' [nome], que se referem ao mesmo objeto [o próprio Alessandro Manzoni], mas são nomes diferentes. Tampouco as determinações que têm o mesmo objeto podem ser consideradas equivalentes, porque não podem ser substituídas umas pelas outras; por exemplo, perguntar se 'Alessandro Manzoni [objeto de referência] é o autor de Os noivos [objeto de referência]' não é o mesmo que perguntar se 'Alessandro Manzoni é Alessandro Manzoni'. A diferença entre os dois aspectos do significado (ou a relação entre eles) constitui a base dos problemas aos quais esse termo deu origem e das diferentes definições que ele recebeu" (op. cit., p. 890).

Portanto, o nome de um dado objeto de referência e esse mesmo objeto de referência são elementos, ao mesmo tempo, inseparáveis e distintos: não podem ser confundidos nem intercambiados. Nome e objeto de referência (referencial) são elementos constitutivos do significado de um termo e quanto a isso não há dúvida; a questão que se coloca diz respeito à natureza desse referencial: podemos considerá-lo um objeto-de-realidade, um objeto mental, um objeto-de-discurso ou um objeto puramente lingüístico. Neste trabalho, parece-nos razoável conceber uma natureza flexível para esse referencial: em determinadas circunstâncias, manifestase como objeto-de-realidade e, nesse caso, como um objeto ontologicamente já constituído (um objeto acabado e pronto para simples menção); em outras condições, constrói-se como objeto-de-discurso e, nesse caso, como um objeto ontologicamente em construção (um objeto que, ao ser mencionado, é, ao mesmo tempo, (re)construído pelo discurso definidor).

Os estóicos, que avançaram a doutrina da significação, distinguiam entre: i) "aquilo que significa", ou seja, a palavra (o nome); ii) "o significado", isto é, "a coisa indicada pela palavra, que nós apreendemos ao pensar na coisa correspondente" (a idéia ou conceito); iii) "aquilo que é" (a coisa propriamente dita), ou seja, o ser ou o objeto exterior ao processo mental: 
"São três os elementos que se inter-relacionam: o significado, aquilo que significa e aquilo que é. O que significa é a palavra como, por exemplo, 'Díon'. O significado é a coisa indicada pela palavra, que nós apreendemos ao pensar na coisa correspondente [o conceito de Díon]. Aquilo que é, é o sujeito exterior como, por exemplo, o próprio Díon" (Sexto Empírico. Adversus mathematicos, VIII, 12 apud ABBAGNANO, op. cit., p. 890).

Em suma, o significado é, especificamente, uma "[...] representação racional, graças à qual é possível expor, por meio de um discurso, aquilo que é representado" (Sexto Empírico, Adversus mathematicos, VIII, 70; Diógenes Laércio, Vitae et placita philosophorum, VII, 63 apud ABBAGNANO). Como afirmamos, é possível identificar aqui três elementos: i) a "palavra" (objeto lingüístico vinculado a um significado); ii) a "coisa indicada pela palavra" (conceito ou objeto mental que é fruto do ato de apreensão); iii) o "sujeito exterior" (o referencial). Os dois primeiros grupos dizem respeito ao significado enquanto nome, conceito ou essência; o último grupo diz respeito ao significado enquanto objeto referencial extradiscursivo. Os estóicos vinculavam mais especificamente aos dois primeiros grupos o conceito de significado.

Considerando as observações anteriores, podemos perceber que na definição de conceito, assim como ocorre na definição de termo, delineia-se uma tendência à polarização entre uma visão substancialista, que tem em mira a essência dos seresem-si e a visão nominalista-terminista, que tem em conta primordialmente os significados dos signos lingüísticos. Conseqüentemente, é possível conceber uma distinção entre definições substancialistas (objeto de definição visto como essência substancial - objetos-de-realidade, objetos mentais ou objetos-de-discurso), e definições nominalistas-terministas (objeto de definição visto como nome ou termo - objetos lingüísticos ou signos). Neste trabalho, entendemos que as tradicionais "definições nominais" são mais bem compreendidas como definições intensionais subjetivo-convencionais autonímicas, conforme veremos.

Segundo FRAWLEY (1991, pp. 55-59), duas questões são fundamentais no que diz respeito às definições: a) o que significa definir uma forma lingüística?; b) como devem as definições ser consideradas no que diz respeito à especificação do significado gramatical? 
Para o autor, definir uma expressão de acordo com propriedades semânticas não corresponde a fornecer uma única e exaustiva lista de todos os caracteres essenciais de um referente, de modo que tal lista possa ser confiavelmente utilizada em qualquer contexto. Propriedades semânticas gramaticalmente relevantes não incluem obrigatoriamente definições necessárias e suficientes, ou seja, não são forçosamente formadas por conceitos que unicamente admitem características necessárias e suficientes:

O autor também observa que uma definição não implica a limitação do significado de um conceito, mas sim um enunciado sobre a interpretação de um item em um dado contexto, objetivo esse que pode ser atingido sem o apelo ao conceito de condições necessárias e suficientes: "nenhum lexicógrafo, por exemplo, tem em mente alguma ilusão de que as definições definam absolutamente um verbete, ou que um verbete e sua definição possam ser lidos simetricamente. Uma definição lexicográfica é também uma regra de preferência: ela fixa a referência probabilisticamente como um enunciado sobre como interpretar um verbete em cada contexto" (p. 57).

Essa posição aproxima-se da doutrina de Wittgenstein ${ }^{67}$ em "Investigações filosóficas", em que se apresenta uma teoria do significado: este, entendido como de usos de expressões em contextos bem definidos e controlados, permite observar que alguns fenômenos agrupam-se não por compartilharem propriedades categoriais necessárias e suficientes que os diferencie rigorosamente de outros fenômenos, mas sim por possuírem entre si um aspecto familiar ou determinadas analogias:

\footnotetext{
"Seu famoso exemplo é o conceito de um jogo. O que faz 'Basebol', 'Checkers' e 'Scrabble' serem jogos? Eles não compartilham qualquer característica [necessária e suficiente]: nem

${ }^{67}$ Wittgenstein, no Tratactus Logico-Philosophicus [WITTGENSTEIN (1994)], afirma: "o nome não pode ser desmembrado por meio de uma definição: é um sinal primitivo (3.26)"; "o que não vem expresso nos sinais, seu emprego mostra. $\mathrm{O}$ que os sinais escamoteiam, seu emprego denuncia (3.262)"; "definições são regras de tradução de uma linguagem para outra. Cada notação correta deve poder traduzir-se em cada uma das demais segundo tais regras: é isso que todas elas têm em comum (3.343)"; "se uso dois sinais com um único e mesmo significado, exprimo isso colocando entre os dois o sinal '="'. Portanto, 'a = b' quer dizer: o sinal 'a' é substituível pelo sinal 'b'. (Se introduzo, por meio de uma equação, um novo sinal ' $b$ ', determinando que the cumpre substituir um sinal 'a' já conhecido, escrevo a equação — definição — na forma 'a = b' Def. [como Russell]. A definição é uma regra notacional)".
} 
mesmo a característica de serem constituídos por regras, pois a sociedade, por exemplo, também é constituída por regras e não é um jogo. O que faz de um jogo um jogo é uma ordenação preferencial de propriedades de cada jogo. Wittgenstein, portanto, propôs que as definições são organizadas por esses aspectos familiares - constelações de propriedades não necessárias, porém dotadas de critério" (FRAWLEY, op. cit., pp. 57-58) ${ }^{68}$.

De acordo com Frawley, entender as definições por meio de conceitos tais como regras de preferência, aspectos familiares e protótipos não implica falta de rigor e inexata caracterização dos significados: mesmo os critérios de ambigüidade e vaguidão podem ser atendidos sem que se aplique o princípio das condições necessárias e suficientes.

Como se percebe, temos um critério substancialista para o processo definidor; as definições ideais declaram direta e claramente a essência de um objeto - sem isso, esse objeto não pode ser concebido nem pode, tampouco, simplesmente existir. Definições não tão rigorosas abandonam esse ideal de essencialidade e limitam-se a apresentar os traços contingentes de um objeto, ou seja, contentam-se em enumerar e descrever os acidentes que se vinculam a uma manifestação particular deste. Por fim, a mera indicação do significado de um signo, ou a especificação do uso que tal signo deve obedecer em dado contexto, caracterizam 'definições' nominais — as quais se afastam decididamente da intenção de determinar a substância de objetos de definição.

Com base na discussão anterior, procuremos fixar nossa compreensão sobre alguns conceitos fundamentais a serem utilizados doravante; assim, neste trabalho,

${ }^{68}$ WITTGENSTEIN, em Investigações Filosóficas, afirma: "Se levarmos ainda mais distante essa comparação, está claro que o grau em que a figura nítida pode assemelhar-se com a figura indefinida depende do grau de indefinição desta última. Pois imagina que deves desenhar uma figura nítida 'correspondente' à figura indefinida. Nesta há um retângulo vermelho difuso; pões em seu lugar um nítido. Certamente se podem traçar muitos desses retângulos nítidos que correspondem aos difusos. Porém, se no original as cores se misturam sem indício de limite, não se converterá em uma tarefa desesperada traçar uma figura nítida que corresponda à difusa? Não terás então de dizer: 'Aqui eu poderia igualmente bem traçar um círculo como um retângulo, ou uma forma de coração; pois todas as cores se entremesclam. Vale tudo e nada'? Nesta posição se encontra, por exemplo, quem, em estética ou ética, busca definições que correspondam a nossos conceitos. Pergunta-te sempre nesta dificuldade: 'Como aprendemos o significado desta palavra ('bom', por exemplo)? A partir de que exemplos; em quais jogos de linguagem? Verás facilmente, então, que a palavra há de ter uma família de significados" (§ 77). Para a compreensão do conceitos de definir e definição em Wittgenstein, ver, nesta obra do filósofo, os parágrafos $6,28,29,30,33,34,38,49,70,75,79,182$, $197,205,354$ e 665. 
teremos em vista o seguinte quadro de definições, cujos conceitos introduzem considerações de ordem pragmática e têm em vista as condições de produção da oralidade:

\begin{tabular}{|c|c|}
\hline /substância $\leftarrow \pi$ & $\begin{array}{l}\text { ¿entenderemos por "substância" aquilo que subsiste dos seres, ou seja, } \\
\text { aquilo que há neles de permanente, segundo a percepção subjetiva e/ou } \\
\text { convencional, produzida em dado contexto social, ou segundo a percepção } \\
\text { objetiva, produzida nesse mesmo contexto /69 }\end{array}$ \\
\hline $\begin{array}{l}\text { lessência } \leftarrow \pi \\
\text { /qüididade } \leftarrow \pi\end{array}$ & $\begin{array}{l}\text { rentenderemos por "essência" — ou "qüididade" _ o conjunto de atributos } \\
\text { necessários e suficientes com os quais uma substância aparece como } \\
\text { aquela substância particular e distinta, segundo a percepção subjetiva e/ou } \\
\text { convencional, produzida em dado contexto social, ou segundo a percepção } \\
\text { objetiva, produzida nesse mesmo contexto, não se confundindo, assim, } \\
\text { com nenhuma outra substância) / }\end{array}$ \\
\hline $\begin{array}{l}\text { /definição substancial } \\
\leftarrow \pi\end{array}$ & $\begin{array}{l}\text { ¿determinação ou delimitação conceitual de uma essência ou qüididade, } \\
\text { estável e perene o suficiente para constituir uma intensão considerada } \\
\text { objetiva, segundo a percepção subjetiva e/ou convencional, produzida em } \\
\text { dado contexto socialı / }\end{array}$ \\
\hline $\begin{array}{l}\text { /definição subjetiva } \leftarrow \\
\pi \\
\text { /definição } \quad \text { semiótica } \\
\leftarrow \pi\end{array}$ & $\begin{array}{l}\text { ¿determinação ou delimitação conceitual de uma essência ou qüididade, } \\
\text { segundo a percepção subjetiva, produzida em dado contexto socialı / }\end{array}$ \\
\hline $\begin{array}{l}\text { /definição } \\
\text { convencional } \leftarrow \pi \\
\text { /definição semiótica } \\
\leftarrow \pi\end{array}$ & $\begin{array}{l}\text { ¿determinação ou delimitação conceitual de uma essência ou qüididade, } \\
\text { segundo a percepção convencional, produzida em dado contexto socialı / }\end{array}$ \\
\hline
\end{tabular}

\subsection{PROBLEMAS TEÓRICOS ATINENTES AO CONCEITO DE DEFINIÇÃO}

HEGENBERG (op.cit., pp. 25-34) comenta que, sob o ponto de vista rigoroso da Lógica tradicional, definir significa delimitar um objeto por meio da alusão ao seu gênero e às diferenças que o especificam: a espécie é uma subclasse mais restrita da classe mais ampla denominada "gênero".

${ }^{69}$ Ver Capítulo III, no qual se conceituam os três tipos de intensão (objetiva, subjetiva e convencional). 
Porém, observa que nem sempre é possível formular com precisão e clareza as definições de certos objetos, utilizando-se este critério - quer porque se torna difícil, em certos casos, estabelecer o gênero e a diferença específica, quer porque existe a necessidade de outras informações relevantes que não se incluem sob essas rubricas ${ }^{70}$.

O autor argumenta que, mesmo nos casos em que é viável definir-se por gênero e diferença específica, essa formulação não é estritamente necessária (pois é possível definir o mesmo conceito por meio de outro tipo de informação) nem estritamente suficiente (pois é freqüente a necessidade de outras informações que não se enquadram nessas categorias). Assim sendo, alguns dos princípios propostos para a definição ideal, sob o ponto de vista da teoria tradicional, freqüentemente não podem ser atendidos ou não há conveniência em atendê-los.

Também, sob o ponto de vista da Lógica, é comum entender-se a definição como um mecanismo que, estabelecendo relações claras entre definiens e definiendum, funciona como uma regra de permutabilidade entre esses elementos. Dessa forma, o definiendum passa a operar como uma abreviação conceitual, útil por simplificar a remissão ao conceito expresso no definiens e plenamente intercambiável em relação aos termos primitivos presentes neste.

Hegenberg observa, porém, que essa visão de permutabilidade não possui validade incondicional - ou seja, definir um conceito não implica necessariamente que definiendum e definiens sejam intercambiáveis em qualquer contexto. Não é

\footnotetext{
${ }^{70}$ Em SANT'ANNA (2005, p. 2) vemos um exemplo dessa dificuldade: "Na ciência, o termo 'definição' tem diversas acepções. Costuma-se definir, por exemplo, a unidade fundamental de comprimento no sistema métrico como $1.650 .763,73$ vezes o comprimento de onda da radiação do isótopo criptônio 86 no vácuo. Isso significa que a definição de metro depende simplesmente de uma observação experimental, ou seja, de uma medição, um processo físico. Em contrapartida, quando se define a hipotenusa de um triângulo retângulo, como o maior lado desse triângulo, essa é uma definição que nada tem a ver com qualquer fato experimental. Pode-se demonstrar matematicamente por raciocínio lógico que, no contexto da geometria euclidiana, cada triângulo retângulo admite um lado maior que os outros. A esse lado dá-se o nome 'hipotenusa' Essas duas definições - metro e hipotenusa têm essencialmente naturezas distintas, pois os contextos são radicalmente diferentes. No caso da definição de metro, um novo termo é criado na linguagem a partir de uma observação experimental. Já no caso da definição de hipotenusa, um novo termo é introduzido em uma dada linguagem a partir de uma fórmula que pode ser expressa nessa mesma linguagem, sem compromisso algum com qualquer fato experimental. Mas o que pode confundir é o fato de que o mesmo termo 'definição' é utilizado nesses dois contextos. Além disso, há muitos outros contextos possíveis, mesmo quando o discurso se limita somente ao domínio da matemática".
} 
possível, para as definições comuns do quotidiano, solucionar certas dificuldades semânticas que determinados termos - como, por exemplo, o vocabulário formado por pronomes, preposições e conjunções — introduzem em um sistema lingüístico ${ }^{71}$.

Tal fato se dá porque cada termo é, em si mesmo, único, sob o ponto de vista das definições, ou seja, assim como não existem sinônimos perfeitos, também não existem dois recortes conceituais cuja correspondência absoluta os faça serem precisamente representados pelo mesmo discurso definidor, vinculado a dois termos diversos, ou dois discursos definidores vinculados a um único objeto-de-discurso, objeto mental ou objeto sensível. Ocorrem, assim como se dá na sinonímia, concessões e acomodações semânticas, de modo que, para o uso prático das línguas naturais (isto é, fora do campo das linguagens científicas), os falantes como que tacitamente concordam que dois discursos definidores dizem respeito ao mesmo objeto de definição ou, então, que dois discursos definidores podem ser identificados por meio de um mesmo nome ou termo.

O autor (op, cit., p. 42) destaca que, comparando várias definições de um mesmo conceito em diferentes dicionários, constata-se a presença e/ou a ausência de características mais ou menos relevantes: ocorrem diferentes caracterizações dos conceitos em processo de definição, segundo diferentes pontos de vista adotados pelos textos definidores. Em suma, há geralmente várias alternativas de definições para um mesmo objeto, de acordo com: a) os pontos de vista adotados pelos textos definidores; b) as necessidades técnicas externas que motivam a criação dessas definições.

O princípio que inspira comumente o procedimento definidor baseia-se na convicção de que, a partir de um conjunto diverso de definições aplicadas a um

${ }^{71}$ O autor observa: "Alguns vocábulos são ambíguos, no sentido de que permitem consideração de dois ou mais significados. Veja-se, por exemplo, o que os dicionários registram acerca de 'mas': 'mas - conj. designativa de oposição ou restrição'. O vocábulo admite, contudo, dois significados alternativos: 'com exceção de', de um lado e, de outro, 'ao contrário, porém, apesar de'. Não se pode formular uma regra (de substituição) que leve em conta essa indefinição intensional residual. De fato, a regra não pode incluir os dois significados (que diferem) e não pode deixar de lado qualquer deles. $\mathrm{O}$ que se poderia tentar, talvez, seria a formulação de um par de regras, selecionando, em cada ocasião, a mais apropriada, em função do contexto. Assim, em 'Todos se foram, mas ele não', o 'mas' indicaria 'exceção'; já em 'O primeiro problema foi corretamente resolvido, mas o segundo não', o 'mas' desempenha função de 'porém' ou de 'ao contrário'. A escolha da regra dependeria, por seu turno, da compreensão do texto e da capacidade de fazer discriminações, às vezes bem sutis" (op.cit., p. 56). 
mesmo conceito (ou objeto de definição), é possível estabelecer um substrato conceitual comum, formado por um feixe de traços definidores que invariavelmente comparecem em todas as definições desse objeto. A detecção desse substrato conceitual permite abstrair princípios que governam a organização do discurso definidor: o texto definidor desse objeto particular deverá conter esse substrato de traços definidores, mais outros traços secundários que definam convenientemente esse objeto, segundo as necessidades técnicas e os contextos de uso ${ }^{72}$.

Para identificar esse substrato comum, poder-se-ia considerar dois tipos de propriedades cuja presença e/ou ausência são fundamentais para a validação de uma determinada definição: a) propriedades necessárias; b) propriedades suficientes. Ambas caracterizam o "critério da necessidade e da suficiência":

"Diremos que uma propriedade $[P]$ é necessária para que algo seja um [item] $X$ se um item não pode ser classificado como sendo um [item] $X$ se lhe falta essa propriedade $[P]$. A ausência da propriedade $[P]$ encerra a questão: o item não é um [item] $X$. De outra parte, diremos que uma propriedade $\mathrm{P}$ é suficiente para que algo seja um [item] $X$ se um item pode ser classificado como sendo um [item] $X$ quando possui essa propriedade $P$ - não importando que outras propriedades tal item possa ter. A presença de [propriedade] $\mathrm{P}$ encerra a questão: $\mathrm{o}$ item é um [item] X" (HEGENBERG, op. cit., p. 42).

O critério proposto determina que a ausência de uma propriedade necessária em um discurso definidor implica a desautorização da definição postulada, por ser insuficiente ou imprópria; por sua vez, a presença de uma propriedade suficiente implica seu credenciamento imediato. Portanto, se um determinado objeto de definição puder ser caracterizado conceitualmente por meio de uma definição que articule o conjunto total de conceitos que representam propriedades necessárias e suficientes, teremos então uma definição ideal — concebida agora por meio do critério da necessidade e da suficiência.

\footnotetext{
72 "A diferença de caracterização (de um para outro dicionário) e a presença (ou ausência) de informes 'paralelos' (mais ou menos supérfluos) não impede que se procure identificar algumas categorias semânticas que permitam estabelecer alguma conexão entre o objeto $X$ e seu nome ' $X$ ' ou [...] entre as propriedades de $\mathrm{X}$ e o termo ' $\mathrm{X}$ ' - entendendo-se por 'propriedade' [...] qualquer fato singular acerca de um item'" (HEGENBERG, op. cit., p. 42).
} 
Assim, teríamos a seguinte definição de definição ideal: /definição ideal $\leftarrow \pi$ «discurso definidor que articula, como um conjunto total de conceitos, as propriedades necessárias e suficientes para caracterizar um determinado objeto como esse objeto particular e apenas esse objeto distintor /.

Contudo, mesmo esse critério é, na prática, de difícil atendimento: na maioria dos casos de definição, surgem discursos definidores que incluem conceitos não apenas não-necessários, mas também não-suficientes. Tal fato que se acentua à medida que nos afastamos das definições próprias das linguagens científicas. Como exemplo, Hegenberg observa que, freqüentemente, as assim denominadas "definições lexicais" apresentam os seguintes problemas técnicos:

a) propõem discursos definidores cuja articulação conceitual não inclui propriedades necessárias e suficientes;

b) declaram conceitos ou propriedades que não se aplicam a todos os itens que pertencem à extensão do termo, isto é, não é possível, para muitas das definições lexicais propostas, generalizar os conceitos mencionados para todos os itens aos quais se aplicam legitimamente tais definições;

c) declaram conceitos ou propriedades que se aplicam a itens que não pertencem à extensão do termo, ou seja, é possível, em muitas definições, aplicar os conceitos mencionados a itens aos quais não pertencem legitimamente tais definições ${ }^{73}$.

Tendo em conta a dificuldade de se formular definições ideais, baseadas unicamente em conceitos necessários e suficientes, torna-se conveniente e operacional introduzir, segundo o autor, o conceito de relevância:

\footnotetext{
"Dentre as propriedades arroladas, algumas podem ser relevantes, no sentido de que a presença (ou ausência) dessas propriedades contribui, muitas vezes de modo decisivo, para caracterizar um item como sendo (ou não sendo) um [item] X. [...] Imagine-se que $P_{1}, \ldots, P_{n}$ são

${ }^{73} \mathrm{O}$ exemplo do autor sobre o critério da necessidade é a definição de metal, cujo discurso definidor geralmente inclui os conceitos considerados necessários restado sólido à temperatura ambiente) e relevado ponto de fusãos. No entanto, o mercúrio é metal e é líquido à temperatura ambiente; o sódio é um metal e possui baixo ponto de fusão. Como exemplo sobre o critério da suficiência, o autor aponta a definição de cobre, para o qual se menciona como conceito suficiente sponto de fusão em 1083 graus Celsius), conceito este também válido para certas ligas de cobre, fósforo e arsênico.
} 
propriedades relevantes de $\mathrm{X}$. Se elas tendem a contar em favor da classificação de um dado item como sendo um $X$, essas propriedades se dizem 'semanticamente relevantes'. Outras propriedades, Q1, ...Qp, que tendem a contar em favor da classificação de um dado item como sendo um $X$ - mas somente porque delas se infere que $O$ item possui propriedades semanticamente relevantes - podem ser chamadas 'não semanticamente relevantes'; [...] as propriedades relevantes [...] de um objeto são aquelas que se tornam individualmente necessárias e, em conjunto, suficientes para a colocação do objeto em uma classe [...]" (HEGENBERG, op. cit., pp. 43-44; 113).

Tal princípio baseia-se no fato de que existem propriedades que incluem um item sob uma dada rubrica conceitual, embora essas propriedades não sejam nem necessárias e nem suficientes para o referido item ${ }^{74}$. É o que se passa na definição de metal, para a qual se mostra usualmente relevante mencionar, no definiens, o conceito de condutibilidade, embora este não seja necessário nem suficiente para o item (para ser metal, não é necessário que um corpo conduza eletricidade, pois outros corpos metálicos não o fazem; por outro lado, não basta que um corpo conduza eletricidade, pois outros corpos não-metálicos também o fazem).

Conclui-se que, em muitos casos, é possível substituir os critérios de necessidade e suficiência pelo critério de relevância, sob o ponto de vista prático; o quadro seguinte compara os três critérios:

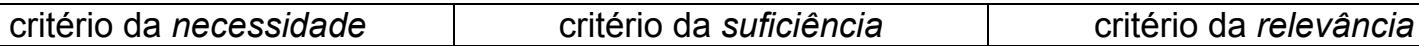

\footnotetext{
${ }^{74}$ Hegenberg distingue, portanto, entre "propriedades semanticamente relevantes" e "propriedades não semanticamente relevantes" (um conjunto de propriedades relevantes de um item $X$ pode ser tomado diretamente como um parâmetro de aferição para que outros itens possam ser ou não considerados $X$; sendo assim, tal conjunto denomina-se "semanticamente relevante"; um conjunto de propriedades de um item $X$, sem relevância semântica, do qual, porém, infere-se a existência de um conjunto de propriedades semanticamente relevantes que funcionam como parâmetro de aferição para que outros itens possam ser ou não considerados $X$, denomina-se "não semanticamente relevante"). Contudo, tal distinção não é de fácil apreensão porque a relevância de um fator modificase ao longo do tempo, de acordo com a evolução do conhecimento científico: "os metais eram caracterizados, até meados de século XVII, pelas propriedades como cor, sabor, odor, consistência, solubilidade e alguns processos de fabricação. [que eram, assim, as propriedades semanticamente relevantes dos metais] [...] Depois das teorias de Lavoisier, porém, em meados do século XVIII, a composição química passou a ser semanticamente relevante e as propriedades antigamente levadas em conta (cor, sabor, dureza, passaram a ser encaradas apenas como indícios de composição química - propriedades que permitiam apenas inferir a existência (provável) de propriedades semanticamente relevantes [ou seja, passaram a ser propriedades não semanticamente relevantes]" (op. cit., p. 44).
} 
Uma propriedade necessária é Uma propriedade suficiente é Uma propriedade relevante é uma condição sine qua non para uma condição que, uma vez uma condição que, direta ou que um item seja incluído na constatada, por si só basta para indiretamente, contribui para que extensão de um conceito, ou que um item seja incluído na a inclusão de um item na para que, em caso de sua extensão de um conceito. extensão de um conceito possa ausência, tal item seja excluído dessa extensão. ser considerada como válida, razoável e aceitável.

Se considerarmos a existência de definições que, embora não correspondam ao perfil de uma definição ideal sob o critério da necessidade e da suficiência, são mesmo assim operacionais sob o critério da relevância, poderemos conceber a presença de um continuum de definições por relevância que, tomando por ponto de partida o parâmetro ideal (isto é, coloque em um extremo da escala a identidade entre definição por relevância e definição ideal), constitua um gradiente de variações progressivamente mais afastadas desse ideal extremo.

Isto implica conceber não só uma distinção entre propriedades semanticamente relevantes e propriedades semanticamente irrelevantes, mas também a distinção entre diversos graus de relevância: há, portanto, graus maiores e menores de relevância, segundo a posição ocupada por uma propriedade no mencionado continuum.

Considerando esse gradiente, o autor introduz o conceito de centralidade: há, segundo essa visão, propriedades cujo grau de relevância é mais ou menos central, sendo mais central o maior grau de relevância. Trata-se do critério da centralidade, apontado pelo autor ${ }^{75}$ :

"De modo genérico, [a propriedade ] P é mais central [ou seja, mais relevante] do que [a propriedade] $\mathrm{R}$ se a presença de $\mathrm{P}$ tende a contar mais, em favor da colocação de um item como [um item] $X$, do que a presença de R. (Ou a ausência de $P$ tende a contar mais, em favor da colocação do item como não-X, do que a ausência de R)" (HEGENBERG, op. cit., p. 45).

O autor destaca que o critério da relevância basicamente depende, para sua aplicação, do uso consagrado por parte de autoridades em determinados campos

\footnotetext{
${ }^{75} \mathrm{O}$ exemplo citado é: "No caso da prata, por exemplo, pode-se dizer que a propriedade de ter um número atômico 107,87 é mais central do que a propriedade de ter o ponto de fusão de 960,5 graus" (op. cit., p. 45).
} 
científicos. Isso faz com que se estabeleça um conceito de definição por relevância cuja formulação discursiva pode ser assim expressa:

\footnotetext{
"Tal como o termo ' $X$ ' é usualmente empregado, itens são corretamente classificados com $X$ se e somente se possuem muitas das (ou quase todas as) propriedades $P_{1}, \ldots, P_{n}$ [propriedades semanticamente relevantes e, além disso, centrais, isto é, com alto grau de relevância] — a par de outras" (op. cit., p. 45).
}

No que diz respeito às denominadas "definições nominais", Hegenberg, citando ZIFF (1960, cap. 5) ${ }^{76}$, menciona a sugestão de distinguir entre "possuir [um] significado" - ser dotado de significado, bastando para tanto ser um signo - e "possuir o significado" — possuir conceito formado por características necessárias e suficientes:

"'Tigre', por exemplo, é termo que [no corrente das definições] possui significado, embora não
possua o significado. As palavras que possuem o significado estão associadas a conjuntos de
condições - cada uma das quais é necessária, sendo suficiente a reunião delas. Por isso, não
se pode falar em o significado para 'tigre' [no corrente das definições], pois as propriedades
usualmente lembradas (carnívoro, quadrúpede, de proporções avantajadas, etc.) não são
propriedades necessárias e suficientes. Em geral, para os vocábulos de nossa lista de termos
comuns — termos que designam objetos físicos do quotidiano — não há condições
necessárias que possam ser expressas em palavras isoladas ou em frases curtas (embora
possa haver, talvez, condições necessárias expressas de modo muito mais rebuscado, com
longas descrições)" (HEGENBERG, op. cit., p. 46).

Em resumo, "possuir [um] significado" implica uma condição geral a qual todos os termos atendem, uma vez instituídos como signos (para cada signo - sendo ele um signo - sempre haverá algum significado vinculado a um significante); por sua vez, "possuir o significado" implica uma condição estrita: possui o significado o termo cujo conceito ou objeto mental está definido por um conjunto suficiente de propriedades necessárias e suficientes.

${ }^{76}$ Paul ZIFF. Semantic analysis. New York: Cornell Univ. Press, 1960, cap. 5. 
O que Ziff propõe pode ser interpretado como a criação de dois grupos de significados ou, então, de definições: a) definições (significados) cujos conceitos envolvem propriedades necessárias e suficientes (condição que faria com que os termos tivessem $\underline{o}$ significado); b) definições (significados) cujos conceitos envolvem propriedades relevantes em diversos graus de centralidade (condição que faria que os termos tivessem significado, simplesmente) $)^{77}$.

Se empregarmos a distinção apresentada por Ziff, verificaremos que a tentativa de definir termos de uso quotidiano (particularmente de objetos cuja natureza se presta melhor à ostensão), de modo a delimitar $\underline{o}$ significado é extremamente trabalhosa, quando não impossível. Apenas em casos particulares torna-se possível desenvolver definições baseadas exclusivamente nos critérios da necessidade e suficiência; fato que nos leva a considerar que, na maior parte dos casos, os termos em uso discursivo possuem, simplesmente, significado, porém não $\underline{o}$ significado; isso, de modo aparentemente paradoxal, justifica por que, em geral, podemos explicar um conceito, mas não podemos defini-lo precisamente; também, explica por que podemos utilizar as palavras sem nos determos em considerações de ordem conceitual.

Frente a isso, torna-se operacional voltar os olhos para o conceito de uso de um termo; variando o contexto de uso, torna-se mais ou menos relevante discernir entre possuir significado e possuir $\underline{o}$ significado. Citando ACHINSTEIN (1968, pp. 31 ss. $)^{78}$, Hegenberg menciona três tipos de uso para um termo; diremos aqui, mais especificamente, três contextos de uso: a) contexto de uso gramatical; b) contexto de uso em ato; c) contexto de uso semântico:

77 O exemplo citado pelo autor é a definição de tigre: ‘carnívoro, quadrúpede, de proporções avantajadas, de pêlo amarelo e ventre esbranquiçado, com estrias negras, originário da Ásia. Matam cerca de 32.000 cabeças de gado, por ano, em países como a Índià (op. cit., p. 42). O AURÉLIO ELETRÔNICO XXI registra, para o mesmo verbete: «mamífero carnívoro, felídeo [...], da Sibéria e sudeste asiático, de coloração amarelo-tostada, com barras negras sobre o corpos. Por sua vez, HOUAISS (2001) registra: ‘grande felino asiático [...], encontrado em uma grande variedade de ambientes, como florestas tropicais, mangues ou savanas, com o corpo, cabeça, cauda e membros listrados de negro, dorso e flanco variando do laranja avermelhado ao ocre avermelhado e região ventral de cor creme ou branca (espécie ameaçada de extinção; algumas subespécies já foram extintas)>. A partir dessas definições, vemos que o termo "tigre" possui significado, mas não possui um significado, pois as propriedades mencionadas em sua definição não são propriedades rigorosamente necessárias, embora sejam relevantes para caracterizar esse objeto.

${ }^{78}$ P. ACHINSTEIN. Concepts of science. Baltimore (USA): Johns Hopkins Press, 1968. 
a) o contexto de uso gramatical de um termo é determinado pela organização sintática de um enunciado, ou seja, depende do co-texto no qual se insere um termo, de modo a produzir-se um enunciado gramaticalmente legítimo. A proficiência lingüística dos usuários permite-lhes julgar a gramaticalidade e a agramaticalidade de uma dada construção sintática e, portanto, a aceitabilidade do emprego de um termo. Trata-se, assim, de um critério lingüístico;

b) o contexto de uso em ato de um termo é determinado pelo alcance pragmático de um enunciado no qual se insere um termo, não só sob o ponto de vista dos diversos tipos de frases (frase declarativa, interrogativa, exclamativa etc.), mas também sob a ótica dos diversos atos de fala implícitos na enunciação de enunciado (promessa, ameaça, pedido etc.). Trata-se, portanto, de um critério discursivo;

c) já o contexto de uso semântico de um termo é determinado:

i) pela possibilidade de identificar - 1) a intensão da definição desse termo (isto é, pela possibilidade de identificar as propriedades relevantes quando for impossível reconhecer as propriedades necessárias e suficientes de um objeto ao qual o termo em questão se aplica); 2) a extensão da definição desse termo (isto é, pela possibilidade de identificar os objetos que, em conjunto, formam uma classe à qual o termo em questão se aplica);

ii) pela possibilidade de realizar a ostensão de objetos aos quais tal termo se aplica (isto é, pela possibilidade de aplicar o termo em questão a itens que apropriadamente atendam aos critérios de intensionalidade e de extensionalidade da classe a qual pertencem $)^{79}$.

O correto uso semântico de um termo implica, portanto, a capacidade de: i) especificar um certo quadro intensional, formado por características ou propriedades necessárias e suficientes (ou, na impossibilidade disso, por características relevantes e centrais); em outras palavras, definir precisamente um conceito $X$; ii) reconhecer tal quadro ou conceito em um dado objeto e apenas nele; iii) vincular claramente tal quadro intensional a um nome "X"; iv) aplicar corretamente o termo

\footnotetext{
${ }^{79}$ Segundo a formulação do autor: "uma pessoa conhece o aspecto semântico do uso de um termo ' $X$ ' se sabe: 1) distinguir $X$ de outros objetos; 2) reconhecer casos paradigmáticos de $X ; 3$ ) aplicar o termo ' $X$ ' aos itens apropriados, notados em (1) e (2)" (op. cit., p. 47).
} 
"X", segundo usos gramaticais e atos discursivos apropriados. Como vemos, trata-se de um critério lógico.

Em suma, dependendo da vigência de um critério lingüístico, discursivo ou lógico, buscar a determinação de $\underline{o}$ significado pode ser operacionalmente inadequado ou, simplesmente, desnecessário.

Importa lembrar que, sob o ponto de vista da linguagem quotidiana (digamos, os gêneros textuais relativos às comunicações interpessoais em língua falada culta, localizados no extremo do continuum apresentado em MARCUSCHI [2001, p. 41]), os termos comuns são polissêmicos e ambíguos em situação de uso - ao contrário dos termos comuns transportados para a linguagem científica, os quais, por princípio, eliminam a polissemia em favor de uma definição considerada a mais adequada e uniformemente aceita, capaz de eliminar a indefinição intensional nas situações de uso. Nos casos de ambigüidade, então, pareceria conveniente (re)definir os conceitos.

Devemos notar, contudo, que a polissemia natural de um termo pode ou não determinar ambigüidades, pois isso depende não só do termo em si, mas também dos demais termos com os quais ele interage em dada estrutura discursiva, isto é, depende de seu co-texto; além disso, há a questão do contexto em que os termos são empregados (ou seja, a situação comunicativa como um todo).

Há um grau de relatividade ou flexibilidade semântica própria dos termos em uso, de acordo com a composição de definições resultante. Hegenberg lembra o caso dos adjetivos (modificados ou não por advérbios), os quais, dependendo dos substantivos por eles qualificados, têm seu caráter referencial modificado consideravelmente ${ }^{80}$. Contudo, um certo grau de indefinição intensional, considerado como uma característica dos termos usados quotidianamente, não só é inevitável

\footnotetext{
${ }^{80} \mathrm{O}$ autor observa: "há, por exemplo, um bom número de termos corriqueiros que envolvem, de algum modo, a noção de comprimento. Entre eles, 'comprido', 'muito comprido', 'mais comprido do que', 'pequeno', 'grande' etc., Esses termos são ambíguos, no sentido de que o substantivo que os acompanha pode, em muitas situações, modificar o sentido do próprio termo. Exemplificando, um 'gato grande' é consideravelmente menor do que um 'pequeno elefante'. Essa indefinição intensional é que os torna tão úteis para a comunicação usual, pois muitos adjetivos diversos seriam necessários para distinguir, digamos, um grande inseto de um grande homem (recordando que 'grande homem' pode ter, ainda, um sentido diverso de 'homem grande'). A essa indefinição intensional se alia uma segunda, mais séria, pois mesmo conservando o contexto, é possível que 'gato grande' tenha significados muito diversos para pessoas diversas" (op. cit., p. 50).
} 
como também é desejável, para que haja uma economia vocabular mediante a distribuição da tarefa de significação entre os diversos planos da linguagem (nível lexical, nível textual, nível discursivo, nível pragmático).

Importa distinguir, igualmente, entre o conceito de indefinição intensional e o conceito de incerteza: em uma definição, a indefinição intensional pode ser razoavelmente limitada pelo concurso dos diversos níveis da linguagem; porém, a certeza sobre aquilo que constitui a definição de um conceito, entendida como a validade referencial daquilo que é afirmado conceitualmente - não apenas sob o ponto de vista ontológico, mas também sob o aspecto de seu valor de verdade ${ }^{81}$ não depende, naturalmente, da própria linguagem, mas sim de instrumentos de aferição cujos parâmetros apóiam-se, direta ou indiretamente, em fatos constatáveis de modo quantitativo ou, em outra perspectiva, em fatos demonstráveis.

Tradicionalmente, as definições são suficientemente classificadas pela reunião ou combinação dos seguintes pares conceituais: a) intensão vs. extensão (definições intensionais vs. definições extensionais); b) nome ou termo vs. substância ou essência (definições nominais vs. definições substanciais ou essenciais). Ou seja, os tipos de definição são distribuídos destacando-se: $a_{1}$ ) no primeiro caso, as características necessárias, suficientes e/ou relevantes que um objeto deve possuir para poder integrar uma determinada classe de objetos; $\mathrm{a}_{2}$ ) no segundo caso, a série de objetos que são reconhecidos como pertencentes a uma determinada classe de objetos; $b_{1}$ ) no terceiro caso, textos definidores que estipulam

\footnotetext{
${ }^{81}$ ABBAGNANO (op. cit., p. 131, verbete "certeza", registra: "Gr. bebaiwth\&j [...]. Essa palavra tem dois significados fundamentais: $1^{\circ}$ segurança subjetiva da verdade de um conhecimento; $2^{\circ}$ garantia que um conhecimento oferece da sua verdade. [...] Os dois significados nem sempre constituem alternativas excludentes, mas freqüentemente são complementares. Todavia, no pensamento clássico prevalece o segundo significado, o objetivo, e a garantia a que se faz alusão é a solidez ou a estabilidade do conhecimento verdadeiro. Segundo esse conceito, que Platão expressou do modo mais claro, a estabilidade do conhecimento depende da estabilidade de seu objeto, de sorte que só podem ser estavelmente conhecidas (isto é, com certeza) as coisas estáveis, ao passo que as coisas instáveis, isto é, mutáveis, só podem ser objeto de conhecimento provável [...]. Nesse sentido, a certeza é apenas um atributo da verdade: é o caráter estável, ou seja, não sujeito a desmentidos, da própria verdade [...]. A noção subjetiva da certeza e os problemas a ela inerentes nasceram com a importância atribuída pelo Cristianismo à fé, quando foi reconhecida a possibilidade da segurança subjetiva do saber, não garantida por um critério objetivo de verdade. Mas, obviamente, o reconhecimento dessa possibilidade não levava a negar, mas a reconhecer a outra possibilidade, de garantia objetiva".
} 
lingüisticamente o significado de um termo; $b_{2}$ ) no quarto caso, textos definidores que declaram a natureza essencial de um objeto.

Além desses critérios, também é possível incluir, para a classificação das definições, um critério formalista ou normativo e um critério funcionalista ou pragmático:

a) o primeiro deles contempla a definição a partir de uma perspectiva teórica, para a qual é possível desconsiderar as indefinições intensionais práticas e considerar que as relações entre definiendum e definiens são aceitavelmente inequívocas e estáveis (ou seja, o horizonte definidor assume um alto grau de estabilidade, uma vez que desconsidera o contexto como fator de interferência ou distorção). Aqui, a definição possui caráter normativo, ou seja, concebe-se a existência de "definições corretas" que funcionam como referências para o conhecimento em relação aos seus objetos de definição (um mesmo texto definidor para um mesmo conceito, independentemente das situações específicas);

b) o segundo deles concebe a definição a partir de uma perspectiva prática (em situações concretas de uso), para a qual a indefinição intensional é uma contingência natural, gerada pela inevitável equivocidade da relação entre definiendum e definiens (ou seja, o horizonte definidor opera com graus de estabilidade considerados razoáveis, uma vez que considera o contexto como fator de interferência ou distorção). Aqui, a definição possui caráter descritivo, ou seja, concebe-se a existência de "definições concretas" que expressam as diversas manifestações práticas do ato definidor de um mesmo conceito (diversos textos definidores para um mesmo conceito, segundo as situações específicas).

Interessa retomar as considerações apresentadas em COSSUTA (1994, pp. 39-72); tratando da constituição dos conceitos filosóficos, concebe-se a existência de uma "função conceitual" vinculada a um processo que o autor denomina "semântica conceitual". Já mencionamos brevemente essa função conceitual; como lembra Cossuta, não há filosofia sem conceito e tal conceito pode ser compreendido como uma função que articula termo, sentido (extensão do conceito ou seus traços definicionais; relação entre conceitos) e referência (qualquer elemento extralingüístico ao qual se aplique esse conceito). 
Importa analisar como os conceitos se articulam no texto e quais são os papéis a eles atribuídos na construção do discurso: trata-se do processo de instauração do sentido. $\mathrm{O}$ autor destaca que, em princípio, pensamos em cumprir essa tarefa pelo trabalho (mais ou menos extenso) de fixação da terminologia (fixar e delimitar o significado dos termos empregados); porém:

"[...] não basta fixar o sentido das expressões num vocabulário para que seja instituído um universo autônomo de sentido, pois é preciso ainda integrá-las em contextos que concorrem para a construção de sua significação. Não se pode dissociar um conceito de os usos que são feitos dele. Além do mais, estes não permanecem isolados; um sistema de remissões e de relações tece a meada muito densa que desenha o campo conceitual de uma doutrina" (op. cit., p. 42).

Por meio desse processo, partimos dos contextos imediatos de cada conceito particular, constituintes de seu sentido, em direção a um horizonte semântico amplo que configura uma "[...] doutrina, tomada em sua mais ampla extensão"; isso porque "o sistema filosófico delimita um contexto global que, em última instância, define o sentido dos elementos que ele contém" (Ibidem).

Isso nos leva a enxergar o conceito em sua justa dimensão: não podemos entender a construção conceitual como um procedimento lingüístico isolado (isto é, como um processo técnico de definição de um conceito, visto como o significado de um termo), mas sim como um procedimento discursivo que visa, em seu horizonte, a um sistema ou a uma doutrina integralmente considerada - a qual, em movimento reverso, determina a correta leitura de cada um dos conceitos que a constituem. A correta estipulação do conceito — ou sua correta definição, dentro desse quadro sistêmico-doutrinal amplo — caracteriza a semântica conceitual.

O conceito, sendo uma articulação funcional de elementos, não se reduz a um deles em particular; trata-se de um "complexo funcional" que surge a partir da interação entre os elementos mencionados. Assim, tal processo poderia ser expresso por uma fórmula básica, semelhante a $D=f(T, S, R)$, ou seja, a definição seria uma função cujos componentes são: a) um dado termo "T" ou nome; b) um dado significado "S" a ele vinculado; c) um dado referencial "R" ou objeto visado 
(que pode ser um objeto-de-realidade, um objeto mental ou um objeto-de-discurso). A definição seria então o produto da interação desses três elementos, sem que se descarte qualquer um deles.

Em capítulo especial, o autor explica o conceito de referência, e como entende essas entidades extralingüísticas, que não se resumem aos objetos-de-realidade ${ }^{82}$; basta-nos ter em mente a estreita correlação entre definiens e referencial, ponto esse constantemente enfatizado.

Segundo essa estrutura funcional da definição, podemos verificar a presença de dois níveis de definição:

a) uma definição lato sensu - a produção de algum significado ( lekto/n ) que, vinculado a um significante qualquer, forma o signo aprioristicamente considerado;

b) uma definição stricto sensu, isto é, a definição que surge por meio da construção de um conceito e de uma designação referencial. Portanto, interessa-nos distinguir rigorosamente entre o conceito entendido como um sinônimo de "significado de um termo" (o conceito lato sensu) e o conceito stricto sensu, entendido como produto de um processo definidor triádico, implicando dois outros fatores imprescindíveis: a intensão do termo e o referente por ele e a ele vinculado (entendido como objeto mental, objeto-de-realidade ou objeto-de-discurso). Assim, temos:

"Definição - definir um conceito consiste, portanto, em fixar sentido, referência, produzir relações e fornecer as regras que permitem sua reutilização. Ela deve: a) identificar o conceito de dar-Ihe um 'nome' que o torne reconhecível e manipulável [...]; b) permitir o reconhecimento, seja por explicitação semântica das propriedades do termo, seja explicitando as propriedades comuns e específicas do conjunto de 'objetos' designados [intensão]; c) descrever ou, pelo menos, indicar a possibilidade de uma exposição dos elementos denotados [referenciais]. Identificar um termo significante, construir o sentido e descrever a referência: essas são as

\footnotetext{
82 "A referência, unindo o termo significante e o sentido à coisa, propriedade, acontecimento, permite ao universo filosófico focalizar o mundo exterior, e até mesmo obriga o filósofo a especificar o estatuto ontológico dele ('ser', 'aparência', 'fenômeno'). As entidades assim distinguidas pela função referencial constituem o denotado. $\mathrm{O}$ objeto concreto, que pode ser atestado pela experiência, é apenas uma forma particular dele, uma vez que uma das tarefas da filosofia consiste em visar idealidades" (COSSUTA, op. cit., p. 73).
} 
tarefas da definição conceitual. [...] constituintes da definição — a definição é marcada como tal graças a uma cláusula definicional, como 'por', 'entendo' [...] A cláusula definicional que dá forma ao enunciado coloca um termo em situação de tema ou referência; é o definido, que constitui o termo significante. [...] O definido é colocado em relação de equivalência com o definidor, que constitui o conteúdo da definição" (COSSUTA, op. cit., pp. 52-55).

O autor destaca a observação de Leibniz: "para conhecer uma coisa, é preciso considerar todos os requisitos dessa coisa, ou seja, o que é suficiente para distinguila de qualquer outra coisa. É o que chamamos 'definição'"'83. É possível interpretar esse critério — declarar os requisitos que distinguem um objeto de qualquer outro quer sob o ponto de vista nominal, quer sob a perspectiva real. Trata-se da distinção clássica entre "definição de um nome" e "definição de uma coisa": a) na primeira, o definidor diz respeito ao relacionamento entre o significante e aquilo que se supõe que ele designa; b) na segunda, o definidor afirma, por princípio, a verdade daquilo que se enuncia. Cossuta observa que essa distinção é bastante relativa, uma vez que ambas podem ser colocadas como dependentes do ponto de vista daquele que

${ }^{83}$ Em LEIBNIZ (2003, passim), destacam-se diversas observações relativas ao conceito de definição, segundo as abordagens terminista ("definições nominais") e substancialista ("definições reais"); assim, lemos: a) "A explicação de uma palavra é sua 'definição' [Hobbes apud Leibniz]. A explicação de uma proposição é igual a sua 'demonstração' — 'A definição é uma idéia significada. A demonstração é um raciocínio significado. Um raciocínio é um encadeamento de idéias. A demonstração é um encadeamento de definições" [104]; b) "A definição da verdade é real. É verdadeiro o que se pode demonstrar por meio de definições a partir do idêntico. O que se demonstra a partir de definições reais é absolutamente verdadeiro. Só é possível aduzir definições reais de aquelas noções que nós percebemos imediatamente, por exemplo, a extensão, a temperatura, quando digo que é verdadeiro que existem. [...] As definições reais se podem provar a posteriori, isto é, por experiência. Que todo existente é possível deve-se demonstrar a partir da definição de existência" [176]; c) "A definição nominal consiste na enumeração das características ou requisitos que são suficientes para distinguir uma coisa de todas as demais" [227]; d) "E assim teremos também uma diferença entre as definições nominais, que só contêm notas de aquela coisa que é preciso distinguir de outras, e as definições reais, pelas quais consta que a coisa é possível" [318]; e) "[...] chamo 'definição nominal' quando ainda se pode duvidar se a noção definida é possível, como, por exemplo, se digo que uma rosca sem fim é uma linha sólida cujas partes são congruentes ou podem coincidir umas com as outras; aquele que não conhece uma rosca sem fim poderá duvidar se tal linha é possível, embora esta seja, de fato, uma propriedade das roscas sem fim, pois as outras linhas cujas partes são congruentes (que são apenas a circunferência do círculo e a linha reta) são planas, isto é, podem-se descrever in plano. Isso permite ver que toda propriedade recíproca pode servir para uma definição nominal, mas, quando a propriedade dá a conhecer a possibilidade da coisa, forma a definição real. Enquanto só se tem uma definição nominal, não se pode ter segurança sobre as conseqüências que se extraem dela, pois se ocultasse alguma contradição ou impossibilidade, poderse-ia extrair dela conclusões opostas" [358-359]; f) "O que se menciona como explicação das palavras serve no sentido de que estas levam consigo a apresentação de sua causa, quando se trata daquelas definições que denomino 'reais' [...] [423]. 
formula o conceito ("com efeito, a "definição' nominal' constitui menos uma convenção do que um posicionamento do autor, enquanto a definição de coisas nos situa no ponto de vista das próprias 'idéias', que se desenvolvem segundo um vínculo de necessidade interno à doutrina" [op. cit., pp. 55-56]).

Como podemos constatar por aquilo que até aqui foi apresentado, a complexidade do processo definidor dá a dimensão das dificuldades desse mecanismo aparentemente elementar: afinal, responder a uma pergunta como "Que é tigre?" — parece representar uma tarefa que não impõe maiores dificuldades. A questão já se torna mais complexa quando percebemos as possibilidades de interpretação dessa pergunta: a pergunta diz respeito à palavra "tigre", ao conceito tigre ou ao animal tigre?

Se adotarmos a primeira interpretação, de inspiração nominalista-terminista, estaremos às voltas com as definições pressupostas do objeto palavra. Conforme observa SALMON (op. cit., p. 75), tratando das definições sob o ponto de vista estritamente lingüístico, aquilo que se denomina informalmente "palavra" é formado por um complexo de elementos cuja manifestação se dá em diversos níveis simultâneos, sendo o plano sensível (o plano do significante) apenas um deles. Essa manifestação sensível concretiza-se, diacronicamente, em sucessivas ocorrências ou situações de uso, as quais implicam não só uma evolução na materialidade da palavra, mas também, uma evolução histórica das matrizes significativas que se vinculam a esse fenômeno sensível. Tais matrizes significativas não surgem como um atributo natural desse objeto sensível; são, antes, estipulações usuais de cunho social, para as quais não cabe cogitar um critério de verdade (ou seja, a relação entre um fenômeno sensível e um fenômeno significante particular, desse objeto denominado "palavra", não se molda a partir da fixação de uma tabela de verdade ou falsidade).

Nesse sentido, as definições seriam operações metalingüísticas que expressam essas estipulações naturais. Seja através de uma estipulação genuína mediante definições oficiais, seja através de um vínculo usual entre o fenômeno sensível e o fenômeno de significação, importa que se caracterize uma proposta de 
uso semântico ao qual se aponha um nome convencionado. Trata-se, então, de uma regra de conversão e permuta, partilhada pelos usuários de um código.

Importa distinguir (nessa visão da definição como uma convenção metalingüística) entre a impossibilidade valorativa da proposta definidora em si mesma e a possibilidade valorativa das declarações feitas em relação a essa proposta definidora, quando se toma como parâmetro a realidade extralingüística.

Assim, no nosso exemplo — "Que é tigre?"_, interpretado como equivalente a "Qual o significado da palavra 'tigre'?", uma resposta, cuja estrutura definidora fosse "Tigre" $\approx$ "felino sem agressividade", não é verdadeira nem falsa em si mesma (tratase apenas de uma proposta de definição); porém, a afirmação "Esse texto definidor é verdadeiro", aplicada a essa signação da palavra "tigre", pode ser verdadeira ou falsa, uma vez que consideremos um objeto referido tigre em particular.

Se assumirmos as duas outras interpretações da pergunta — "Que é tigre?" —, ou seja, como equivalente a "Defina o conceito tigre" e "Defina o objeto sensível tigre", ambas de inspiração substancialista, estaremos às voltas com as complexidades naturais para a estipulação de conceitos: destaca-se, desde o início, a necessidade de distinção entre o conceito geral tigre e o objeto sensível (um determinado) tigre.

Para a constituição do conceito ou objeto mental, podemo-nos valer de uma composição de conceitos sem que haja apelo à experiência sensível; assim, é possível definir o conceito tigre sem qualquer experiência material em relação a um animal denominado "tigre". Mesmo no caso de experiências sensíveis, nada garante que a amostragem esteja formada por um grupo de indivíduos que representam adequadamente a espécie em questão (observar alguns tigres em zoológicos não é uma experiência suficiente para que se abstraiam todas os atributos essenciais e necessários para que a substância tigre esteja perfeitamente caracterizada). Em suma, a abordagem substancialista para as definições é complexa, assim como a abordagem empirista: para aquela, há quem sustente a impossibilidade de um genuíno conhecimento substancial; para esta, surgem questões técnicas sobre a consistência e a validade das informações obtidas mediante observação de determinadas amostras. 
De acordo com o que verificamos em relação à abordagem essencialista das definições, podemos partir do seguinte conceito universal de definição (definição stricto sensu): /definição $\leftarrow \pi$ roperação mental que diz distintamente o que uma coisa é, declarando sua essência ou substância /: Assim,

"A primeira questão que a inteligência se coloca é: 'O que é?'. Ela procura responder exprimindo o que é a realidade, dizendo-a. Ora, esse é o ofício da definição: exprimir com precisão o que é uma coisa, sua natureza ou sua essência, como se diz em filosofia. [...] $\underline{A}$ definição é, portanto, um discurso [...] que diz, o mais perfeita e distintamente possível, o que é a coisa" (IDE, 1997, p. 186).

Detrás dessa formulação aparentemente simples e óbvia escondem-se inúmeros problemas com amplas implicações; como vimos, verifica-se nesse conceito de definição a questão da multiplicidade de significados admissíveis ao afirmar-se que uma coisa é, a partir da própria diversidade de significados assumidos pelo verbo "ser" — problema filosófico fundador. Além disso, temos o problema da própria definição do conceito de coisa: como devemos definir o termo "coisa" ${ }^{14}$ ? Por fim, cabe indagar igualmente sobre as dificuldades práticas impostas à ação de "dizer distintamente", em especial sob o ponto de vista pragmático.

Examinemos rapidamente algumas dificuldades atinentes a esse conceito de definição stricto sensu:

a) se, por um lado, definir é uma operação do espírito que representa um pressuposto para a enunciação de juízos, para a demonstração de teses e para a argumentação persuasiva, por outro lado essa operação pode, ela mesma, ser compreendida e conceituada de muitos modos, segundo a multiplicidade de propósitos discursivos e a diversidade de contextos segundo os quais um dado conceito é abstraído.

\footnotetext{
${ }^{84}$ ABBAGNANO (2003, p. 149) registra para o verbete "coisa": "Tanto no discurso comum quanto no filosófico, esse termo tem dois significados fundamentais: $1^{\circ}$ genérico, designando qualquer objeto ou termo, real ou irreal, mental ou físico, etc., de que, de um modo qualquer, se possa tratar; $2^{\circ}$ específico, denotando os objetos naturais enquanto tais". Portanto, os objetos mentais, objetos-derealidade e objetos-de-discurso podem ser denominados "coisas", indistintamente.
} 
Assim, IDE (op.cit., pp. 183-184) destaca que, embora não se discuta a necessidade de esclarecer o que significam os termos de um discurso (ênfase aplicada pela visão nominalista-terminista do discurso, a qual considera ser esta a função primordial das definições), é freqüente que se questione não só a possibilidade de se definir precisamente determinados conceitos utilizados correntemente, mas até mesmo a conveniência de os definir: ocorre como que uma resistência contra 0 tratamento de alguns objetos ${ }^{85}$ de modo essencialistasubstancialista, sustentando-se que o método doxológico é o único praticável discursivamente. Segundo essa visão, a abordagem substancialista dos objetos de definição deveria cingir-se aos usos e propósitos do discurso filosófico e do discurso científico das ciências exatas ${ }^{86}$.

Contudo, importa ter em mente que a própria discussão sobre a possibilidade ou impossibilidade de se produzir, por meio de abstrações, definições que não se restrinjam ao campo da opinião (do/ca) localiza-se no nascedouro do exercício

${ }^{85}$ É interessante comparar as seguintes definições do termo "objeto" ou do conceito objeto, e verificar sua relação com o conceito de coisa: (1) NOVO AURÉLIO SÉCULO XXI; verbete "objeto" - "Tudo que é apreendido pelo conhecimento, que não é o sujeito de conhecimento"; "Tudo que é perceptível por qualquer dos sentidos"; "Filos.: Na relação de conhecimento, o correlato do sujeito, isto é, o que é conhecido, em oposição ao que conhece"; (2) HOUAISS (2001, p. 2041, verbete "objeto") — "Filos.: Qualquer realidade investigada em um ato cognitivo, apreendida pela percepção e/ou pelo pensamento, que está situada em uma dimensão exterior à subjetividade cognoscitiva"; (3) LALANDE (1999, pp, 753-754, verbete "objeto") — "Sentido geral: o que está perante nós, o que nós consideramos, o que temos em vista. a) O que é pensado ou representado enquanto se distingue do ato pelo qual é pensado"; b) "Aquilo que nos é apresentado na percepção como um caráter fixo e estável, independente do ponto de vista, dos desejos ou das opiniões do sujeito"; c) "Aquilo que possui uma existência em si, independente do conhecimento ou da idéia que os seres pensantes disso possam ter"; (4) ABBAGNANO (2003, pp. 149-151; 723-724, verbetes "coisa" / "objeto") "Tanto no discurso comum quanto no filosófico, esse termo tem dois significados fundamentais: a) genérico, designando qualquer objeto ou termo, real ou irreal, mental ou físico, etc., de que, de um modo qualquer, se pode tratar; b) específico, denotando os objetos naturais enquanto tais"; "Termo de qualquer operação, ativa, passiva, prática, cognoscitiva ou lingüística. O significado dessa palavra é generalíssimo e corresponde ao significado de coisa. Objeto é o fim a que se tende, a coisa que se deseja, a qualidade ou a realidade percebida, a imagem da fantasia, o significado expresso ou o conceito pensado"; "[...] pode-se considerar objeto do conhecimento uma idéia [...], uma representação [...], uma coisa material [...] ou um fenômeno [...], mas como objeto é sempre o termo ou limite da operação cognoscitiva".

${ }^{86}$ Como justificativas para essa posição concorrem: i) a própria natureza do objeto de investigação filosófica, de apreensão muito mais direta, dado seu caráter, do que os demais objetos científicos; ii) a incidência e o impacto dos temas filosóficos sobre o quotidiano, maiores e mais imediatos do que muitos temas científicos, apesar de a percepção contrária ser freqüente; iii) a dificuldade natural para se perceber a presença de postulados filosóficos, permeando muitas opiniões e expressões correntes do quotidiano, em particular aquelas tomadas como pressupostos nas interações verbais. 
metódico da racionalidade, fato que situa a questão para além dos limites da contemporaneidade;

b) dada a natureza polissêmica do signo lingüístico, os termos utilizados pelo discurso nele adentram, usualmente, com uma multiplicidade de possíveis significados e geram, segundo os contextos, uma diversidade de interpretações; ao mesmo tempo, essa multiplicidade semântica pode ser representada lingüisticamente por um só termo (ou seja, temos a possibilidade de uma só forma corresponder a mais de um conteúdo e, vice-versa, mais de uma forma corresponder a um só conteúdo). Conseqüentemente, importa distinguir claramente nas definições os casos de sinonímia e os casos de homonímia - em suma, importa estabelecer a justa relação pretendida entre significantes, significados e conceitos envolvidos no processo definidor, caso se pretenda cumprir o programa das definições stricto sensu: como se pode compreender, o esforço em "dizer distintamente o que uma coisa é" implica, por princípio, uma relação unívoca entre definiens e definiendum;

c) não só é necessário apreender corretamente o que significa definição (ou, então, o termo "definição"), mas também é preciso entender absolutamente aquilo que tal conceito, de fato, não é, evitando distorcer o ato definidor sob a aparência de pseudodefinições. De modo especial, é necessário não confundir as falsas definições com as definições legítimas que, contudo, não podem obedecer ao modelo da definição por gênero e diferença específica (processo definidor por excelência porque declara legitimamente a substancialidade do objeto definido, discriminando-o claramente perante o universo de conceitos) - tipo ideal de definição por que declara distintamente o que é o definiendum.

IDE (op.cit., pp. 187-188) destaca dois casos típicos e freqüentes de pseudodefinições: i) a enumeração de casos singulares sem qualquer abstração de essências inteligíveis e universais; ii) a simples apresentação da etimologia de um termo, sem que se proceda, novamente, à abstração de uma essência inteligível e universal ${ }^{87}$;

${ }^{87}$ Conforme observa IDE (op.cit., pp. 199-201), a etimologia de um termo pode interessar enquanto constituir um registro da evolução do pensamento de uma dada comunidade, materializado nas transformações semânticas sucessivas que os usos do termo revelam. Também, pode interessar saber quão concreta é a origem dos termos, cujos significados foram posteriormente transformados 
d) assim como devem ser evitadas as pseudodefinições, também deve ser evitada a pretensão de rigorosamente tudo definir; é preciso ter em mente a dificuldade de definir o absolutamente universal e o absolutamente singular, aquele por representar um conceito primitivo (de caráter axiomático) e este por constituir uma realidade única ou um dado empírico sui generis. Em ambos os casos, torna-se impossível abstrair conceitos universais ulteriores, mesmo que tais realidades absolutas sejam plenamente inteligíveis (como exemplos clássicos, temos as tentativas de apresentar definições claras e universais do conceito de $\operatorname{ser}^{88}$ e do indivíduo Sócrates).

A definição stricto sensu pressupõe a possibilidade de se extrair uma essência ou uma natureza universal a partir de fenômenos singulares e, ao mesmo tempo: a) ultrapassar a simples enumeração ou indicação de realidades particulares; b) superar a multiplicidade de fenômenos contingentes e aparentes, em direção a uma síntese definidora. Portanto, coloca-se em posição intermediária ao longo de um continuum formado por dois extremos: em um pólo, as substâncias absolutamente universais; em outro pólo, as substâncias absolutamente individuais. Assim, teremos uma escala de diferentes graus de complexidade definidora entre esses dois pólos:

por metáfora. Porém, há duas ressalvas ou obstáculos freqüentes: a) é necessário ter certeza sobre a consistência da etimologia pretendida, para que não se cometa o duplo pecado de se propor uma pseudodefinição apoiada sobre uma pseudo-etimologia; b) uma vez que as palavras, enquanto entidades vivas, evoluem semanticamente de acordo com a sucessão de contextos históricos e sociais, é impossível exagerar a importância da etimologia para além de limites consideravelmente estreitos, tendo-se em conta o ponto de vista contemporâneo.

${ }^{88}$ LALANDE (1999, pp. 1008-1009) registra para o verbete "ser": a) "No sentido absoluto [...], termo simples, impossível de definir. [...] Podem-se apenas distinguir diferentes ordens de idéias relativas às quais se diz que qualquer coisa é: $1^{\circ}$ no sentido substancial: 'Penso, logo sou'; $2^{\circ}$ no sentido fenomenal: uma coisa é quando está atualmente presente na experiência; $3^{\circ}$ no sentido objetivo: uma coisa é quando é afirmada como válida para a experiência de todos os indivíduos (ainda que não seja atualmente apresentada na experiência de cada um deles, ou mesmo ainda que não seja atualmente apresentada na experiência de nenhum deles)". Importa-nos reter esse sentido absoluto e intransitivo do verbo "ser", desconsiderando sua função de cópula. Cabe assinalar que, em ABBAGNANO (2003, pp. 878-888), tratando-se do uso existencial do verbo "ser", distinguem-se dois significados subordinados: a) "ser" como "existência em geral"; b) "ser" como "existência privilegiada". Para o primeiro significado, temos o ser como generalidade e indeterminação, embora "especificável e definível de acordo com um critério qualquer". Nesse sentido, "ser" corresponde à noção de existência como modo de ser determinado, determinável ou definível de algum modo (verbete "existência", id., pp. 398-402) ; para o segundo significado, temos o ser como existência primária, em sua modalidade primeira, fundamental e universal, da qual derivam todas as suas manifestações definíveis e determináveis, as quais a trazem mais ou menos oculta em uma multiplicidade de aspectos aparentes e contingentes. 
definir o conceito de ser é muito mais difícil do que definir o objeto homem; porém, definir o objeto homem é muito mais fácil do que definir o indivíduo Sócrates.

Embora encontremos dificuldades para consumar a definição de certos objetos segundo esse conceito de definição stricto sensu, não podemos deixar de reconhecer a importância do papel discursivo desempenhado por tal processo. A possibilidade de se declarar distintamente o que uma coisa é deve permanecer como um pressuposto basilar para o emprego de conceitos em um discurso, mesmo que tal possibilidade não passe de uma idealidade. Assim, uma argumentação alicerçada sobre uma proposição como "O homem é mau por natureza" implica, como pressuposto específico, a possibilidade de definir claramente o que se compreende pelo conceito de mau e, como pressuposto geral, a capacidade de declarar claramente o que é o Mal (versus o Bem). De fato, paradoxal resultaria se alguém nos instasse a aceitar a afirmação anterior e se mostrasse incapaz de responder às perguntas: "O que é o Mal?" e "O que é ser 'mau por natureza'?"89.

Conforme observa Hegenberg na obra citada, os termos de emprego comum pressupõem conceitos cuja formulação definidora assume equivalências e reciprocidades que apenas aproximadamente podem ser consideradas verdadeiras, sendo modelos típicos os dicionários de uso: as sinonímias são sabidamente concessões semânticas que operam em contextos elásticos e cujas funções freqüentemente buscam, antes de tudo, fixar pontos de vista e sustentar argumentos de modo persuasivo; as homonímias são, por sua vez, freqüentes. Destacamos que a dificuldade (ou impossibilidade) de definições conceituais precisas não impede que, pragmaticamente, estabeleçam-se pseudodefinições que nominalmente

\footnotetext{
${ }^{89}$ Parece-nos conveniente destacar que o Princípio da Cooperação de Grice (e suas decorrentes Máximas Conversacionais) implicam problemas sob o ponto de vista das definições; como exemplo, a Máxima da Qualidade ("Não diga algo que creia ser falso" / "Não diga algo sobre o qual não tenha provas suficientes") traz em sua formulação dois conceitos problemáticos: o conceito de falsidade e o conceito de prova. Assim, a afirmação "A influência de Júpiter é responsável pelo caráter impulsivo de Pedro" assume como pressuposto: a) que se defina claramente o que seria a "influência de Júpiter" sobre o caráter dos indivíduos; b) que exista de fato tal influência (para que não haja falsidade na afirmação); c) que se prove cabalmente tal influência (para que se afirme apenas o que se pode provar). Também, o Princípio da Cooperação permite propor, digamos, uma "Máxima das Definições", que poderia ser assim formulada: "Sob o ponto de vista das definições, faça com que sua contribuição à conversação: a) seja construída sobre conceitos cujas definições postas e pressupostas sejam contextualmente pertinentes; b) seja não contraditória em termos de definições postas e pressupostas; c) seja não contraditória em termos de referenciais mencionados por elas".
} 
solucionem essa dificuldade. Assim, temos a seguinte pseudodefinição: "'entusiasmo' provém do verbo grego e) nqousia/zw e significa 'ser inspirado pela divindade, ser tomado por um transporte divino'"; tal "definição" etimológica — que não passa de uma tradução e uma proposta de equivalência semântica entre duas expressões nominais - não possui qualquer caráter definidor substancial; isso, porém, não impede que seja utilizada em "raciocínios" do tipo: "Uma vez que o termo 'entusiasmo' provém do verbo grego e) nqousia/zw e significa 'ser inspirado pela divindade, ser tomado por um transporte divino', então aquele que doa à Igreja com entusiasmo realiza um ato inspirado por Deus".

Hegenberg destaca também que "[...] é preciso recordar que os dicionários encerram, muitas vezes, informes que, estritamente falando, não fazem parte do significado dos termos" (op. cit., p. 40). Ocorre que, de acordo com os termos e os propósitos do dicionário, justamente essas informações não-pertinentes são o verdadeiro foco de interesse, em detrimento de informações que, sob o ponto de vista da substancialidade do objeto em questão, poderiam ser obliteradas.

Além disso, o próprio termo "definição" ou, em outra perspectiva, o objeto conceitual definição representa por si mesmo a primeira dificuldade a ser considerada; segundo o autor, "é preciso, de início, decidir se vale a pena acolher a definição que desse vocábulo dão os dicionários" (op. cit. p. 57). É comum que neles se encontrem definições de definição com características que representam inadequações teóricas de diversos tipos, sob o ponto de vista estrito (como exemplos, presença de tautologias na formulação do texto definidor e propostas de relações entre conceito e objetos de referência que são ou excessivamente genéricas, ou excessivamente específicas) ${ }^{90}$.

${ }^{90}$ Os exemplos do autor são: "No Pequeno Dicionário, por exemplo, acha-se isto: 'Definição - ato de definir', o que nos leva a procurar 'definir'. Em outra obra acha-se isto: 'Definir - explicar o significado de uma palavra'. Esta caracterização parece estreita, pois muitos são os exemplos que fogem a ela [...] Caracterizações muito amplas, por outra parte, também não são muito desejáveis. Assim, Robinson (P. Robinson. Definition. Oxford: The Clarendon Press, 1950, p. 27) diz: '[...] qualquer processo, verbal ou não, pelo qual qualquer indivíduo, seja Deus, anjo, homem ou animal, conduz qualquer indivíduo, ele mesmo ou outro, a saber o significado de qualquer símbolo individual, seja este palavra ou não [...]'. Essa caracterização permitiria incluir, entre os processo, uma comunicação telepática, digamos — o que é exagero evidente" (op. cit., p. 57). 
Contudo, para que se tenha uma visão mais precisa do que convém esperar de uma definição, é interessante considerar a diferença entre o conceito de objeto definível e o conceito de objeto significante: nem todo objeto definível é significante e vice-versa. Assim:

a) o conceito de objeto definível pode ser definido como: robjeto para o qual se pode formular um discurso que declara explicitamente sua substancialidade ou essencialidade>. Portanto, trata-se de um objeto cujo conceito é passível de abstração, ou seja, trata-se de um processo racional que extrai de um objeto práxico (objeto sensível ou objeto fenomênico) sua essência inteligível e universal (declarando, preferencialmente, seu gênero e diferença específica);

b) o conceito de objeto significante pode ser definido como robjeto para o qual se pode formular um discurso que declara inteligivelmente qual é o significado lingüístico vinculado a seu nomè. Portanto, trata-se simplesmente de um objeto dotado de alguma significação lingüística.

Aqui, vale recordar a distinção entre "possuir $\underline{o}$ significado" e possuir [um] significado"; podemos entender que agora se trata da distinção entre definir uma substância mediante caracterização de sua essência e enunciar o significado de um termo vinculado a um conceito. Assim, distinguimos entre /aranha $\leftarrow \pi$ respécime dos artrópodes arácnidos, da ordem dos araneidos)/ (definição por gênero e diferença) e /"aranha" ₹ "(substantivo masculino): indivíduo tolo; palerma; ladrão que, no assalto a caminhões, participa abordando o veículo, inutilizando seu sistema de freios e imobilizando o motorista" /.

Essa distinção é importante porque é possível encontrar casos em que se torna difícil ou impossível definir uma determinada substância, mas é possível explicar o significado vinculado ao nome pelo qual se faz referência a esse conceito. Em outras palavras, é possível que muitos objetos significantes não sejam claramente definíveis e que a declaração do significado lingüístico vinculado a seu nome seja a única alternativa disponível.

Em suma, a definição de um conceito por abstração — assumindo-se um ponto de vista estritamente lógico - constitui uma operação técnica que, por princípio, declara as propriedades necessárias e suficientes do objeto e realiza o ideal 
operacional das denominadas "definições reais". Como exemplo, o definiendum homem e o definiens ranimal racional que apenas se realiza completamente na po/Iij e que é dotado de $10 / g \circ j$ ' constituem uma definição real que declara o gênero e a diferença específica de seu objeto de definição.

Já a explicação do significado do nome vinculado a um conceito pretende simplesmente que tal conceito torne-se, em certa medida ou de alguma forma, conhecido em algumas de suas características (essenciais ou acessórias). Nesse caso, o que se tem por horizonte é definição menos rígida de definição, assim formulada: "[...] a definição de um termo, pode-se dizer, é a definição que se presta corretamente para apresentá-lo ao usuário da linguagem que ainda não o conhecia" (HEGENBERG, op. cit., p. 58); entenda-se: ainda não o conhecia segundo um dado significado. Assim, para explicar um termo, é possível o recurso a uma série de elementos discursivos que não são, de modo algum, previstos pelo processo definidor stricto sensu (como, por exemplo, recursos de caráter pragmático).

A distinção entre definir uma substância por meio de definições essencialistas e explicar um termo tomado por meio de signações nominalistas e, mais importante, a imposição de fazê-lo leva àquilo que autor denomina "definições funcionais", definições que têm por objetivo não a definibilidade de uma substância a qual se refere um termo, mas sim a simples inteligibilidade desse mesmo termo em determinados contextos de uso. Ou seja, a definição de definição funcional é: /definição funcional $\leftarrow \pi$ sproduto de uma operação mental que diz distintamente o que um termo significa em dado contexto de uso /.

Operacionalmente, trabalhar com definições funcionais que enfatizam objetos significantes em detrimento dos objetos definíveis (alvo das definições reais ou essenciais/substanciais) não implica uma opção por uma simplificação excessiva do objeto de definição, pois o entendimento do(s) significado(s) de um termo representa por si só um processo de muita complexidade e grande importância discursiva. Em outras palavras, estabelecer claramente o(s) significado(s) de um termo sob o ponto de vista discursivo pode implicar, em certos casos, uma operação tão intrincada quanto declarar a essencialidade ou substancialidade do ser nomeado por esse nome. 
Frente a isso, torna-se operacionalmente razoável, conforme observa Hegenberg, adotar o conceito já citado de definição funcional: é usual que, em muitos casos, as definições limitem-se a fornecer informações genéricas sobre o significado e o uso dos termos, mencionando, por exemplo, suas funções gramaticais e discursivas, embora tal recurso não garanta absolutamente a eliminação de possíveis indefinições intensionais e extensionais (ambigüidade e vaguidão) do respectivo conceito:

"Não é muito difícil encontrar exemplos de definições em que são feitas alusões à função que as palavras são chamadas a desempenhar. [...] a simples apresentação das várias alternativas pode permitir ao usuário a escolha de uma delas - a que lhe parecer 'correta' no contexto em causa. Todavia, oferecer várias definições não equivale a oferecer a definição. Sem embargo, e esse é o ponto a realçar, são muitos os casos em que não se dispõe de meios para dar definições, a não ser arrolando funções que o vocábulo pode desempenhar. Sabendo, a partir do contexto, qual é a função gramatical do termo, é possível encontrar uma definição para ele. Nem sempre, porém, a ambigüidade fica eliminada, ainda quando se conheça a função gramatical. [...] Em vista disso, é natural que se dê atenção a certos pormenores - como o tipo de situação em que o termo é empregado - quando se procura identificar seu significado relevante" (op. cit., pp. 64-65).

Tais pormenores na definição de um objeto, possivelmente irrelevantes sob o ponto de vista das definições essencialistas/substancialistas, são extraídos dos contextos de uso dos respectivos termos - ou, mais precisamente, constituem tentativas de recuperar ou construir projetivamente os contextos em questão, informando os usuários sobre os possíveis vínculos referenciais e sobre os prováveis significados tencionados, sob a ótica pragmática.

O que se observa nesse conceito de definição funcional é uma conexão constante entre o plano lingüístico e o plano extralingüístico discursivo, de modo a tornar possível a construção de um texto definidor cuja elaboração seja regida por critérios pragmáticos, postulando-se apenas as propriedades suficientes para tornar o conceito inteligível, sem a pretensão de se estabelecer uma definição que caracterize substancialmente um determinado objeto a que se refere esse conceito. 
Retoma-se, portanto, a distinção entre objeto definível $\rightarrow$ possuir o significado e objeto significante $\rightarrow$ possuir [um] significado, apresentada anteriormente.

Porém, importa destacar que mesmo tal abordagem teórica (voltada aos objetos significantes) não garante absolutamente a definibilidade de todos os termos existentes em uma língua ${ }^{91}$ : para muitos casos, obtêm-se razoavelmente definições lato sensu, cuja formulação textual não pode avançar para além de um nível relativamente superficial de caracterização, sob o ponto de vista da substancialidade de seu objeto, ou da significação do(s) termo(s) que o designam. Para tais casos, torna-se muito mais simples apresentar exemplos de uso dos termos e seus respectivos contextos, deixando à margem o problema de apresentar uma definição stricto sensu ou uma definição funcionalmente completa. Exemplos claros desse procedimento verificam-se no caso dos termos puramente gramaticais, tais como preposições, conjunções e pronomes: quaisquer tentativas de definição desses termos incluirão considerações de ordem lingüística - mais precisamente, incluirão funções lingüístico-discursiva de tais termos - mas pouco ou nada dirão sobre a substancialidade desses objetos de definição e dificilmente constituirão uma definição funcional completa.

Em muitos casos de definição, temos proposições que, apesar de serem consideradas definições, sob o ponto de vista pragmático, não o são segundo a doutrina substancialista das definições e, freqüentemente, nem o são segundo os princípios da estrita referencialidade: são simplesmente convenções de tradução entre termos, condicionada por restrições contextuais específicas — são, em suma, simples signações ou definições semióticas.

Conforme observa o autor, mesmo no processo de investigação científica, há situações em que se torna necessário assumir provisoriamente definições com

91 Comentando o papel dos mencionados pormenores nas definições, o autor observa: "Os dicionários indicam esse pormenores, algumas vezes, acrescentando indicações como 'gíria', 'em geometria', 'obsoleto', 'inglês antigo' etc. [...] Se esses artifícios nos faltam (como é freqüente acontecer), é preciso buscar apoio em significado parcial que se possa perceber no contexto original, escolhendo, assim, a alternativa mais 'apropriada'. A conclusão é esta: as definições não nos dão coleções de possíveis traduções, mas apenas regras incompletas de seleção. Ao que se poderia acrescentar: distinção de significados (e, por conseguinte, definição) é muitas vezes facilitada e às vezes requer alusão às funções lingüísticas" (op. cit., p. 65). 
reconhecidos problemas intensionais e extensionais, no que tange à identificação de seu objeto e à determinação de seu conceito, para que, com o desenvolvimento das investigações, seja possível aperfeiçoar tais definições. Em realidade, a definição de um conceito pressupõe e implica outros conceitos, ou seja, raríssimos são os casos de definições construídas ab ovo, a partir de um vácuo conceitual, fato que assinala a conveniência de uma visão sistêmica sobre o processo definidor. De fato, as definições verificam-se predominantemente a partir de um determinado status quo teórico e dentro de um sistema de definições que as contextualiza:

"Definir não é sempre uma atividade simplesmente lingüística, mas, ao contrário, uma atividade que se executa sobre teorias e informações empíricas. [...] a definição não deve ser apenas formalmente correta, mas deve ainda, muitas vezes, ser materialmente adequada - tanto no sentido epistemológico (é correto o conhecimento que fica implicitamente recortado) como no sentido pragmático (a definição está de acordo, em linhas gerais, com o uso que ao termo vem sendo dado pelos especialistas)" (HEGENBERG, op. cit., pp. 68-69).

Como se pode perceber, embora o processo definidor constitua um mecanismo complexo, sob o ponto de vista dos elementos envolvidos, aparentemente sempre representa um caso elementar de equivalência lingüística entre signos: a abordagem terminalista-nominalista das definições parece englobar todos os casos de definição, inclusive aqueles de caráter substancialista. Sendo assim, poder-se-ia sugerir como válida uma definição de definição sinonímico-parafrástica semelhante à seguinte: /definição $\leftarrow \pi$ sprocedimento lingüístico que propõe uma relação de caráter sinonímico-parafrástico entre um dado termo e um dado enunciados/, formulação que implicaria uma operação conceitual relativamente óbvia: bastaria encontrar, em cada caso, um conjunto de signos (definiens) cujos significados, organizados de modo a formar um enunciado válido, reproduzissem, de modo convencional, o mesmo significado que possui um dado signo (definiendum).

Segundo esse conceito de definição, nosso entendimento sobre função das definições pode ser assim formulado: 
"Construções de paráfrases definicionais e didáticas - certas paráfrases realizadas por expressões nominais podem ter por função elaborar definições, como se pode verificar em 'argonautas' $\rightarrow$ estes tripulantes da nau mitológica Argos', em (14): (14) 'Vocês já ouviram falar dos argonautas? Pois conta-nos a lenda grega que estes tripulantes da nau mitológica Argos saíram em busca do Velocino de Ouro'. Exemplos como esse ilustram os efeitos que os autores chamam de 'definicionais' e 'didáticos', que propiciam, inclusive, a introjeção na memória de um léxico novo. Nas anáforas definicionais, o definiendum ou o termo técnico é o elemento previamente introduzido, e o definiens é aportado pela forma anafórica, que pode vir acompanhada de expressões características da definição, como 'um tipo de ', 'uma espécie de', como se pode ver no exemplo (11) (nematóide = tipo de verme cilíndrico) [...] A anáfora didática apresenta direção inversa: o definiens situa-se na expressão introdutora, ao passo que o definiendum, muitas vezes entre aspas, aparece na expressão referencial: (16) 'Para orientar as manobras dos aviões, os aeródromos são dotados de aparelhos que indicam a direção dos ventos de superfície. As birutas, que têm forma de sacola cônica, são instaladas perpendicularmente à extremidade de um mastro"' (KOCH, 2004, pp. 75-76).

Porém, se aceitarmos incondicionalmente essa doutrina, deveremos estar cientes de uma certa implicação: definir poderia redundar em um procedimento de contínua remissão entre termos, por meio de sinônimos e paráfrases mais ou menos precisas, fato que traria a possibilidade de uma produção discursiva caracterizada pela circulação do pensamento em um universo autônomo de signos - em verdade, um prodigioso jogo de palavras que elabora seu próprio sentido e seu próprio universo de essências e substâncias, vicário em relação ao universo extralingüístico. Retomaríamos, portanto, a antiga discussão entre a visão terminista-nominalista das definições e a visão rigorosamente substancialista desse processo.

É possível que haja polêmicas em relação à abordagem terminista-nominalista do processo definidor, que nele reconhece, quase que exclusivamente, um importante recurso discursivo e retórico — uma espécie de artifício mnemônico empregado para a correta utilização contextual dos termos de um dado código lingüístico:

"As definições são, de hábito, artifícios mnemônicos, aproximações mais ou menos grosseiras, que se prestam bem para uma primeira análise dos termos, sob o prisma dos significados, mas que exigem, nos casos dignos de nota, suplementação praticamente interminável — que 
resulta, freqüentes vezes, do exame de casos paradigmáticos de emprego dos termos em questão" (HEGENBERG, op. cit., p. 68).

Portanto, é comum que se compreendam as definições como um processo de especificação de significados e contextos de uso dos termos; o problema é que a prática discursiva (e o exame dos dados do corpus) aporta exemplos de definições que visam a objetos de definição, tratando-os como essências ontologicamente estabelecidas ou a estabelecer, quer enquanto objetos-de-realidade, que enquanto objetos-de-discurso. Nesse sentido, não nos parece aceitável limitar o processo definidor exclusivamente a um simples mecanismo parafrástico.

Um estudo sobre os tipos de definições deve preferivelmente iniciar apresentando uma definição clara do objeto definição ou, até mesmo, definições teoricamente válidas para esse objeto - empresa que envolve extremas dificuldades técnicas. Com o auxílio de conceitos já apresentados, podemo-nos voltar para a construção de uma tipologia das definições - tendo em vista nossos objetivos neste trabalho. Antes, porém, de concluir este capítulo, examinemos algumas considerações suplementares sobre $o$ ato de definir.

Em GREIMAS \& COURTÉS (1979, pp. 85-86, verbete "definição"), apresentam-se os seguintes comentários sobre o conceito de definição: a) identificado ao conceito de paráfrase, corresponde a um processo e/ou produto metalingüístico que correlaciona um termo e sua definição ou um sintagma (ou mesmo unidade textual) a sua denominação; b) a definição, em sentido estrito, assume os limites de uma frase ou de um sintagma (nominal ou verbal); em sentido lato, identifica-se, no limite, com a descrição; c) segundo Hjelmslev, a definição é uma divisão do conteúdo ou da expressão de um signo; d) finalmente, observa-se que: "toda teoria comporta um certo número de conceitos não definidos ou não definíveis, dos quais ela tem necessidade para sua articulação e coerência. [...] Os conceitos postos inicialmente como postulados devem ser pelo menos integrados em um rede de interdefinições, que garante a coerência interna do sistema".

Afirma-se em SEVERINO (2002, p.189) que, simplesmente, a definição é um "termo complexo e, como tal, destina-se a desdobrar todas as notas que compõem a 
compreensão [isto é, a intensão] do conceito", ou seja, destina-se a declarar o "conjunto de propriedades características do objeto pensado".

Em PALACIOS \& PALACIOS (2002, pp. 5-7), lê-se que o termo "definir" significa "fixar limites, pôr termos, determinar ou delimitar algo". Ao lado dessa definição etimológica, temos uma definição conceitual: "A definição, diz Aristóteles, é a enunciação desenvolvida pela qual expressamos a essência da coisa". Assim, enquanto o conceito constitui-se em uma representação mental da natureza da coisa, de modo a englobar nosso saber a seu respeito segundo uma visão mental unitária, a sua definição torna explicitamente discursivo esse saber.

Os autores destacam a necessidade de se distinguir entre conhecimento essencial e conhecimento da essência: aquele implica afirmar que nosso intelecto, por meio de conceitos, pode expressar certos aspectos essenciais de uma realidade, distinguindo-a de todas as outras; este implica afirmar que "[...] a limitada capacidade do intelecto humano [embora limitada] pode compreender integralmente a riqueza inesgotável do real" (op. cit., p. 5). Assim, podemos alcançar um conhecimento essencial de um ser (um ser-para-nós), sem que consigamos alcançar, contudo o conhecimento absoluto desse mesmo ser (agora, um ser-em-si). Além dessa distinção, apresentam a distinção entre definições essenciais e definições descritivas: aquelas ambicionam expressar aquilo que um objeto é; estas ambicionam expressar o modo como tal objeto se manifesta - sua expressão fenomênica.

Em REY (2000, pp. 1-3), destacam-se as múltiplas possibilidades de se definir o termo "definição" ou, então, o conceito de definição. É possível, segundo uma visão ontológica, compreendê-los como a "essência de uma certa operação lógicolingüística que é necessária frente à restrita disponibilidade de signos lingüísticos". Assim em Aristóteles desenvolve-se um "discurso de limitações", um o (ristiko/j 1o/goj (abreviado para o (rismo/j), que foi traduzido por "definição".

Também é possível conceituar a definição como o "significado de uma série de palavras em uma língua natural, consideradas como equivalentes". Tal conceito é amplo o suficiente para atender a todos os usos das palavras envolvidas em um 
contexto particular, permitindo distingui-las de outras palavras e de outros conteúdos semânticos relacionados.

Por "definição" pode-se, por fim, compreender a seguinte situação interativa:

"Às vezes, quando diante de uma noção ou conceito satisfatoriamente preciso, e quando há discordâncias em relação aos usos prévios do termo, é também possível apresentar uma descrição análoga de maneira autorizada e prescritiva, uma formulação que é precedida geralmente por uma expressão como: 'por definição, eu aqui (ou com isso) quero dizer...etc.' [ou seja, o que está sendo dito deve assim ser compreendido]" (op. cit., p. 1)

Conforme observa o autor, os resultados práticos dessas definições de definição são muito diferentes. O primeiro conceito de definição implica uma abordagem filosófica que nos conduz a um discurso metafísico o qual, ao mesmo tempo, pretende dar conta do significado dos termos empregados pelo discurso definidor, da natureza das idéias (conceitos) gerais correspondentes a esses termos e, finalmente, da natureza dos objetos, fenômenos ou essências referidas.

O segundo conceito de definição, que, segundo o autor, é lingüístico e filológico no verdadeiro sentido da palavra, respeita as variações na forma lingüística dos itens lexicais em uso e corresponde àquilo que se encontra em dicionários de uso - uma combinação de definições nominais e significados respaldados por exemplos.

O terceiro conceito de definição tende, assim como o primeiro, a enfatizar uma única expressão definidora, motivada pelo objetivo de restringir ou limitar o uso da noção em questão, vetando outros usos possíveis.

Nas palavras do autor, "essas diferenciações básicas já mostram a grande variedade de métodos de definir e, portanto, o grau de ambigüidade da palavra 'definição'" (op. cit., p. 2).

Tal afirmação estende-se aos próprios objetivos das definições, ou seja, os próprios objetivos do ato de definir não são nem óbvios nem absolutamente claros. Os objetivos variam consideravelmente de acordo com as áreas de conhecimento e, em cada área, com as diferentes teorias e metodologias.

Também, como destaca Rey, a própria oposição entre definições nominais ("definições de palavras") e definições essenciais ("definições de coisas") tampouco 
é clara e satisfatória: a própria relação entre as "palavras" (signos lingüísticos estabilizados) e as "coisas" é complexa, devido às relações semânticas que se estabelecem entre os signos e à própria compreensão do que seriam as "coisas" a que tais signos se referem: seriam objetos-em-si; objetos-de-realidade; objetos-dediscurso; fenômenos; conceitos?

Em HEGENBERG (1974, passim), lemos algumas definições de definição:

a) "Uma 'definição' é, segundo o consenso geral, 'especificação de sentido' de um dado símbolo, com auxílio de outros símbolos" (p. 23). Esta é a compreensão do conceito de definição adotada pela Lógica Formal: definir um termo/símbolo significa especificar qual seria sua relação semântica frente aos demais termos/símbolos que compõem o mesmo sistema de signos — isto é, como tal termo/símbolo pode ser "traduzido" ou convertido por outros termos/símbolos desse sistema;

b) "Na lógica tradicional, a definição é entendida como delimitação de uma espécie mediante alusão ao gênero e à diferença específica. A espécie é uma classe, relativamente estreita, incluída em classe mais ampla, que se denomina 'gênero'" (p. 25). Esta é a visão essencialista das definições; por "lógica tradicional" compreende-se, portanto, a lógica de base aristotélica;

c) "Nos tempos antigos e na Idade Média, a palavra 'definição' era usada, com freqüência, de modo a tornar possível falar em definição de uma coisa (ou idéia) e não de um termo. De acordo com esse uso original, quem define está relatando resultados de uma investigação - que conduz a propósito de um objeto, não de um vocábulo. O vocábulo que nomeia o objeto seria apenas um indicador do objeto" ( $p$. 30). Esta afirmação contrapõe a teoria nominalista em relação à teoria essencialista: pelo modo como o autor se expressa, inferimos que a visão substancialista foi uma teoria restrita à Antigüidade e à Idade Média;

d) "A definição é uma correspondência signo-signo e, pois, nessa medida, uma operação conceitual. Essa operação destina-se, em suma, a: i) introduzir formalmente um termo novo em algum sistema de signos (como a linguagem de uma teoria, por exemplo); ii) especificar, de algum modo, o significado do termo introduzido na medida em que são precisos os significados dos termos 'definientes'" (p. 35). Trata-se, portanto, de uma visão formal das definições, cujo papel é 
estabelecer o vínculo entre dois signos de um mesmo sistema; nesse sentido, retoma o conceito apresentado na nota "a" anterior.

Em LALANDE (1999, pp. 230-234) e ABBAGNANO (op. cit., pp. 235-237), constata-se que o verbete "definição" é introduzido por meio dos termos gregos o3roj; o9rismo/j e os termos latinos correspondentes finis; definitio ${ }^{92}$. Vemos, portanto, que as observações anteriormente feitas em relação ao conceito de termo são válidas para o próprio conceito de definição - ambos os conceitos confundemse mutuamente. Eis como os autores mencionados conceituam a definição:

a) Lalande define definição como: i) uma roperação do espírito que consiste em determinar a compreensão ou intensão de um conceito〉; ii) ro conjunto dos termos conhecidos cuja combinação determina o conceito definido e é representado por um termo único»; iii) ‘a expressão que enuncia a equivalência entre um termo a ser definido [definiendum] e seu termo definidor [definiens], ou seja, uma identidade em que o primeiro membro é o termo a definir e o segundo se compõe unicamente de termos e signos conhecidos que o definirão〉; iv) rem sentido amplo, qualquer proposição recíproca, universal ou singulan. Como vemos, ocorre uma progressão no conceito de definição, partindo de uma visão constitutiva da essência de um objeto, chegando a qualquer estrutura lingüística cuja fórmula é " $X$ é $Y$ ".

$\mathrm{Na}$ crítica do termo, o verbete registra que a origem histórica do sentido e das distinções estabelecidas em relação ao conceito de definição está em Aristóteles, para quem a definição é uma fórmula que exprime a essência de um objeto; tal essência é reconhecida por um gênero e por uma diferença específica que, em conjunto, identificam inequivocamente esse objeto enquanto tal; a mesma estrutura,

\footnotetext{
${ }^{92}$ Em PALACIOS \& PALÁCIOS (2002, p. 6), lemos: "Sem dúvida, foi Sócrates o primeiro que se esforçou por elaborar definições sistematicamente. Platão, por exemplo, em Laques, assinala que para a definição de um conceito é insuficiente mencionar simplesmente coisas que caem sob tal noção. Aristóteles, nos livros VI e VII dos Tópicos, aduz uma doutrina extensa da definição com grande número de regras. Cornifisius é o primeiro a usar o termo 'definitio', ao lado do qual empregase até a Alta Idade Média igualmente 'deffinitio'. Boécio dedica ao tema sua pequena monografia Líber de Deffinitione, em que enumera quinze tipos de definições. Guilherme de Ockham, em sua Summa Totius Logicae, introduz a distinção entre 'definição real' e 'definição nominal', que desde então pertence ao conteúdo fixo da Lógica tradicional. A definição real submete-se em seguida a diversas subdivisões posteriores. Enquanto muitos autores afirmam que apenas a definição real é a autêntica definição, (ou que toda definição autêntica tende a uma definição real), segundo Pascal a 'definição nominal' é a base de todo definir: uma definição é uma regra para abreviação de signos".
} 
portanto, é válida para a fórmula definidora desse objeto. Em suma, sob o ponto de vista aristotélico, a definição propriamente dita realiza-se no âmbito ontológicometafísico.

É possível, também, que se pretenda definir não um objeto essencial, mas sim o simples significado de um termo: esta possibilidade já é indicada pelo próprio Aristóteles (vide Segundos Analíticos, II, 7; 10). Nesse caso, haverá uma definição que focalizará a relação entre esse termo e o objeto que ele designa, ou seja, a ênfase definidora recairá sobre a relação entre o termo e sua referência, relação essa que é entendida como o significado do termo.

Assim, o ato de definir pode ter em vista, grosso modo, um nome ou uma coisa; tal doutrina fundamentará a posterior distinção escolástica entre definitiones quid rei (definições de coisas ou reais), e definitiones quid nominis (definições de palavras ou nominais); tal distinção produzirá ao longo do tempo muitos desdobramentos, polêmicas e implicações para a teoria das definições;

b) Abbagnano define definição como ‘declaração da essência), distinguindo-se diversos conceitos de definição, de acordo com os diversos conceitos de essência: i) definição como declaração da essência substancial; ii) definição como declaração da essência nominal; iii) definição como declaração da essência-significado. As duas primeiras modalidades de definição foram expostas em seus fundamentos por Aristóteles; a última modalidade expressa a visão estóica do conceito de definição:

i) a doutrina aristotélica da definição a aborda primordialmente pela perspectiva do conceito de substância, ou seja, da definição como declaração da essência substancial necessária. Esta doutrina da definição está de acordo com uma definição aristotélica do conceito de sabedoria - "claramente, então, sabedoria é conhecimento de certos princípios e causas" (Metafísica, I, 2, 982a) — , ou seja, saber é conhecer as causas primeiras das coisas e fatos (e não há conhecimento verdadeiro sem o conhecimento das causas primeiras). A partir disso, nos Segundos Analíticos, II, 1, 89b, 20-25, afirma-se que: "os tipos de perguntas que formulamos são tantas quantos são os tipos de coisas que conhecemos. Elas são, de fato, quatro: 1) se a conexão de um atributo com uma coisa é um fato; 2) qual é a razão da conexão; 3) se uma coisa existe; 4) qual é a natureza da coisa". 
Portanto, a essência substancial pertence às coisas para as quais é possível propor uma definição: para isso, não basta que se atribuam predicados aleatórios e acidentais aos termos; é preciso que o termo signifique algo de primário, ou seja, é preciso que se trate de coisas que não podem ser predicados de outras coisas. Tal é a definição de um objeto constituída pela identificação de um gênero próximo e uma diferença específica: i) entende-se por gênero próximo o predicado essencial comum a coisas que diferem em espécie; ii) entende-se por diferença específica aquilo que distingue uma espécie da outra. Esse conceito aristotélico de definição tornou-se um paradigma de procedimento definidor e o processo-padrão para a determinação da essência substancial e do ser como substância necessária;

ii) o segundo conceito, que se refere à definição como declaração da essência nominal (definição do nome que representa um objeto, isto é, definição do significado dos signos, e não a definição do objeto em si, isto é, definição das essências substanciais) foi reconhecido e mesmo admitido por Aristóteles ("uma vez que dizemos que a definição é a proposição sobre a natureza de uma coisa, obviamente um tipo de definição será a proposição sobre o significado do nome [da coisa] ou da fórmula nominal equivalente" [Segundos analíticos, II, 10, 93b, 25-30]); porém, foi aceito como um caminho preparatório para a produção das definições essenciais.

Já para o pensamento estóico, não havia interesse em distinguir entre definições essenciais e definições nominais: assim, não cabia à definição a tarefa de declarar as essências substanciais dos objetos. Conseqüentemente, não se encontra a adoção da doutrina das definições essenciais nos escritores de inspiração predominantemente estóica, como Cícero e Boécio; também, os lógicos terministas medievais aceitavam a "'definição' nominal" como adequada à visão da Lógica, entendida como a ciência dos signos. Uma teoria da "'definição' nominal" propriamente dita é elaborada cabalmente quando a essência nominal passa a ser considerada como a única possível e, portanto, a "'definição' nominal" passa a ser a única postulada.

Como exemplos típicos do pensamento nominalista-terminista, temos as seguintes conceituações: 
1) Hobbes: "a definição não pode ser outra coisa senão a explicação de um nome mediante um discurso" (De corpore, 6, § 14); "considerando [...] que a verdade consiste na correta ordenação de nomes nas nossas afirmações, um homem que procura a verdade rigorosa deve-se lembrar o que significa cada palavra de que se serve, e então empregá-la de acordo [...]. E, portanto, [...] os homens começam por estabelecer as significações de suas palavras, e a esse estabelecimento de significações chamam 'definições' [...]. [...] na correta definição de nomes reside o primeiro uso da linguagem, o qual consiste na aquisição da ciência; e na incorreta definição, ou na ausência de definições, reside o primeiro abuso, do qual resultam todas as doutrinas falsas e destituídas de sentido" (Leviatã, I, 4);

2) Locke: "a definição outra coisa não é senão dar a conhecer o significado de uma palavra mediante vários outros termos não sinônimos" (An essay concerning human understanding, III, 4, 6);

3) Stuart Mill: "definição é uma proposição declaratória do significado de uma palavra" (Logic, I, 8, 1).

Essa tradição se estende até filósofos e lógicos contemporâneos que não admitem a doutrina da substância e adotam a perspectiva nominalista-terminista.

Porém, a teoria pura da "'definição' nominal" apóia-se no pressuposto de que um nome não tem nem pode ter mais do que uma definição; tal postulado distingue a teoria da definição de uma outra visão teórica definidora - a teoria da definição enquanto essência-significado;

iii) esta última teoria já se encontra nos estóicos: Crisipo afirmava que a definição é, simplesmente, uma resposta — a) po//dosij —, entendendo com isso que qualquer resposta dada à pergunta "Que é $X$ ?" pode ser considerada uma definição do objeto $X$ - para aquele que respondeu. Com base nessa noção extremamente elástica de definição, propuseram-se extensas tipologias de definições, pela aceitação de definições cuja única característica definidora, de fato, é apresentar-se formalmente segundo uma sentença " $A$ é $B$ ".

O desenvolvimento dessa teoria estóica da definição chegou ao conceito moderno que afirma ser a definição a ‘declaração do significado de um termo, ou seja, do uso que o termo pode ter em dado contexto e em dado campo de 
investigaçãos. Nessa linha de pensamento, não existe qualquer essência privilegiada de um objeto; existem apenas múltiplas possibilidades de defini-lo, segundo propósitos discursivos diferentes: todas essas possibilidades de definição podem, em diversos graus, ser declaradas como essenciais aos seus propósitos.

Um conceito de definição conseqüente com essa teoria da essência significado seria: definição é ‘qualquer restrição ou limitação do uso de um termo em determinado contextos, sendo o contexto pressuposto em todos os casos, ou seja, considerado como um conjunto de pressupostos que constituem um condicionante à definição, de sorte que sua fórmula é: ‘toda vez que as condições $X, Y, \ldots, Z$ forem atendidas, o termo $T$ será usado segundo as instruções $A, B, \ldots, C$. Teremos, portanto, uma definição estipulativa se os pressupostos forem atinentes às linguagens artificiais; nesse caso, a definição será uma convenção sobre o uso do termo em tal linguagem. Teremos, por outro lado, uma definição lexical se os pressupostos forem atinentes às linguagens naturais ou parcialmente artificiais; agora, a definição será uma declaração sobre o uso corrente do termo em questão, ou uma proposta de modificação desse uso (uma redefinição).

O quadro seguinte reúne os principais conceitos de definição apresentados até aqui:

\begin{tabular}{|l|l|}
\hline $\begin{array}{l}\text { definição stricto sensu } \\
\text { ou definição real }\end{array}$ & $\begin{array}{l}\text { /definição stricto sensu ou definição real } \leftarrow \pi \text { roperação mental que diz } \\
\text { distintamente o que uma coisa é, declarando sua essência ou substância } /\end{array}$ \\
\hline definição ideal & $\begin{array}{l}\text { /definição ideal } \leftarrow \pi \text { «texto definidor que articula, como um conjunto total } \\
\text { de conceitos, as propriedades necessárias e suficientes para caracterizar } \\
\text { um determinado objeto como esse objeto particular e apenas esse objeto / }\end{array}$ \\
\hline $\begin{array}{l}\text { definição sinonímico- } \\
\text { parafrástica }\end{array}$ & $\begin{array}{l}\text { /definição } \leftarrow \pi \text { uprocedimento lingüístico que propõe uma relação de } \\
\text { caráter sinonímico-parafrástico entre um dado termo e um dado } \\
\text { enunciados / }\end{array}$ \\
\hline
\end{tabular}




\begin{tabular}{|l|l|l|}
\hline definição funcional & $\begin{array}{l}\text { /definição funcional } \leftarrow \pi \text { «produto de uma operação mental que diz } \\
\text { distintamente o que um termo significa em dado contexto de uso / }\end{array}$ \\
\hline $\begin{array}{l}\text { definição estipulativa } \\
\text { definição lexical }\end{array}$ & $/ \begin{array}{l}\text { /definição estipulativa ou definição lexical } \leftarrow \pi \text { rqualquer restrição ou } \\
\text { limitação do uso de um termo em determinado contexto, sendo o contexto } \\
\text { válido em todos os casos, ou seja, considerado como um conjunto de } \\
\text { pressupostos que constituem um condicionante à definição, de sorte que } \\
\text { sua fórmula é: "toda vez que as condições } X, Y, \ldots, Z \text { forem atendidas, o } \\
\text { termo } T \text { será usado segundo as instruções } A, B, \ldots, C \text { ") } / \text { / }\end{array}$ \\
\hline
\end{tabular}

Abaixo, relembramos o conceito de signação ou definição semiótica:

\begin{tabular}{|l|l|l|}
\hline signação ou definição & $\begin{array}{l}\text { Signação; definição semiótica } \leftarrow \pi \text { idefinição de caráter intensional } \\
\text { semiótica } \\
\text { subjetivista e/ou convencionalista; estrutura definidora que constrói uma } \\
\text { equivalência entre um definiendum e um definiens que, em dada situação } \\
\text { de uso, pode caracterizá-lo, embora sem declarar sua essência necessária } \\
\text { nem sua essência contingente, por visar a intensão subjetiva e/ou } \\
\text { convencional do conceito/ / }\end{array}$ \\
\hline
\end{tabular}

\section{CAPÍTULO III— TIPOS DE DEFINIÇÃO}

\subsection{CRITÉRIOS PARA UMA CLASSIFICAÇÃO DAS DEFINIÇÕES}

Procuraremos doravante estabelecer uma tipologia de definições; para isso, interessa-nos examinar as tipologias apresentadas por alguns autores, destacando sua multiplicidade de critérios.

Em SANT'ANNA (2005, pp. 3-14), apresentam-se dois grupos de definições: a) uma tipologia de corte tradicional; b) uma tipologia, digamos, moderna, a qual pretende sanar certas deficiências das definições tradicionais. Apresentaremos aqui um sumário das considerações do autor, citando-o textualmente; iniciamos com a tipologia tradicional:

Quanto à tipologia tradicional, temos: 
a) definição real: "trata-se de definir o significado de uma expressão em uma dada linguagem, de modo a retratar a essência de um dado objeto que aquela expressão designa";

b) definição nominal: "trata-se de definir um novo símbolo a partir de outros já conhecidos em uma dada linguagem";

c) definição por postulados: "quando se define uma teoria por meio de axiomas ou postulados";

d) definição ostensiva: "trata-se do caso em que se define um conceito simplesmente 'apontando' para um dado objeto, ou seja, via observação do mundo real";

e) definição contextual: "é aquela em que o conceito definido depende de um contexto";

f) definição explícita: "é aquela na qual é possível substituir diretamente o definiendum pelo definiens"93.

Criticando essa tipologia tradicional, o autor registra:

"Em [10 $]^{94}$ há uma lista de cinco propósitos de uma definição. Segundo o autor, definições servem para aumentar o vocabulário, eliminar a ambigüidade, esclarecer o significado, explicar teoricamente e influenciar atitudes. Tudo isso é bastante informal e vago, apesar de alguns autores antigos serem pensadores de renomada reputação como Girolamo Saccheri, Gottfried Wilhelm Leibniz, William of Ockham e Immanuel Kant [...]. Na verdade, a literatura específica sobre definições é relativamente extensa, mas comumente nebulosa. [...] Também vale observar que há discordâncias na literatura a respeito desses tipos de definições. [...] tais distinções não são claras. Por exemplo, não foi dada de forma objetiva a distinção entre definições reais e nominais" (op. cit., pp. 5-7).

Voltando-se para uma tipologia mais moderna, Sant'anna destaca que, tanto para as linguagens formais quanto para as linguagens naturais, as definições têm por função primordial introduzir novas notações, de modo a serem possíveis

${ }^{93}$ O autor observa: "Existem também outros tipos de definições, como as operacionais, nãooperacionais, genéticas, empíricas, quantitativas, geométricas, materiais, formais, sintéticas, por abstração, por recursão finita, por recursão transfinita, por composição, por simples sinônimo, entre outras".

${ }^{94}$ Trata-se de COPI \& COHEN (2002, pp. 102-111). 
substituições, eliminações e simplificações: "[...] é razoável considerar que toda definição [...] estabeleça algum tipo de relação de equivalência entre um definiendum [...] e um definiens [...]", de modo que seja possível a "eliminabilidade" ${ }^{95}$. Apresentaremos aqui um sumário das considerações do autor em relação à tipologia moderna, citando-o textualmente:

a) definições informais: "aquelas que introduzem novas notações em uma linguagem natural [...] ou mesmo em uma linguagem natural enriquecida ou fortalecida com termos técnicos e/ou científicos" $" 96$;

b) definições formais: "definições que introduzem novas notações que estão diretamente associadas a uma dada linguagem formal da seguinte maneira: i) por uma simples extensão de uma linguagem formal via introdução de novos símbolos; ii) por meio de abreviações metalingüísticas para seqüências de símbolos de uma linguagem formal; iii) por meio da introdução de novos símbolos a uma dada interpretação de uma linguagem formal":

b1) definições abreviativas: "visam abreviar ou substituir uma seqüência de símbolos de uma dada linguagem formal por uma expressão metalingüística. [...] definições abreviativas jamais introduzem novos símbolos em uma linguagemobjeto. [...] definições abreviativas têm a função de atribuir um significado a alguma seqüência de símbolos de uma linguagem formal";

b2) definições ampliativas: "essas definições ampliam uma linguagem formal, acrescentando novos símbolos a elas";

b2.1) definições semânticas: "introduzem novos símbolos a uma dada linguagem formal por uso de um símbolo metalingüístico usualmente denotado por ' = $_{\text {def ' }}$ [igual por definição a] ou ' $\equiv$ ', entre outras possíveis notações";

b2.2) definições sintáticas: "introduzem novos símbolos a uma teoria formal, portanto, a uma correspondente linguagem formal, por meio de acréscimo de axiomas à teoria".

\footnotetext{
${ }^{95}$ Isto é, o definiendum pode ser eliminado ou substituído pelo definiens em qualquer contexto e a qualquer momento.

${ }^{96} \mathrm{O}$ autor observa que as definições informais podem ser subdivididas em diversas categorias, mas "não são enumerados todos os possíveis casos de definições informais, pois se desconhece qualquer tratado geral sobre o assunto": assim, temos as definições ostensivas, as definições operacionais, as definições por gênero e espécie etc.
} 
As definições formais podem se subdivididas em outras categorias mencionadas pelo autor, como as definições tarskianas, definições por abstração, definições por meio de recursão, definições por meio de composição e definições operacionais, dentre outras ${ }^{97}$.

Em VANOYE (2003. pp. 152-153), afirma-se que, para a lexicografia, o problema das definições não é dos mais simples; para a questão sobre como definir uma palavra, propõem-se dois tipos tradicionais de definição:

" - os dicionários enciclopédicos [...] escolhem definições que fornecem o máximo de informações possíveis sobre os objetos aos quais as palavras remetes; - os dicionários de 'língua' [...] se prendem mais às palavras, à sua forma, sua origem, seus empregos - do que aos objetos. No primeiro caso, encontraremos definições descritivas, precisas, que procuram reunir os traços característicos dos objetos, e que vão do geral ao específico. [...] No segundo caso, a definição descritiva poderá estar substituída por uma definição nominal ou vir acompanhada dela, utilizando os sinônimos [...] ou antônimos [...], e ser completada por exemplos ou citações que precisam tal ou tal emprego da palavra. Certos dicionários alargam o domínio estrito da definição, agrupando em torno de um termo de base os termos derivados e compostos ou os termos de sentido análogo".

Portanto, o primeiro modelo de definição toma por referência os objetos práxicos ou sensíveis (incluindo características intensionais típicas); o segundo modelo de definição toma por referência os significados dos termos aplicados aos objetos práxicos. Em suma, trata-se da distinção entre definições substancialistas e definições terministas.

Para MARCONI \& LAKATOS (2005, pp. 162-163), o objetivo principal das definições é tornar "claros, compreensivos, objetivos e adequados" os termos empregados, evitando interpretações errôneas e contribuindo para a compreensão adequada da realidade observada. Assim, podemos identificar dois tipos de definição: a) definições simples - que "traduzem o significado do termo ou expressão menos conhecida" —; b) definições operacionais — que além de

\footnotetext{
${ }^{97}$ Para maiores detalhes, remetemos o leitor à própria obra de Sant'anna, na qual, em diversas passagens, são feitas referências a tipos de definições formais ; discuti-las aqui fugiria aos propósitos deste trabalho.
} 
esclarecerem os significados, auxiliam na "compreensão do conceito, tornando clara a experiência no mundo extensional".

Em GREIMAS \& COURTÉS (1979, pp. 85-86), lemos que é possível distinguir pelo menos três classes de definições nas línguas naturais: a) as definições taxionômicas, constituídas por um conjunto de qualificações; b) as definições funcionais que "[...] precisando [...] aquilo a que serve uma coisa, remete a seu valor de uso [...]"; c) as definições por geração, que "[...] explicam os objetos por seus modos de produção".

Verificamos que, em PALACIOS \& PALACIOS (2002, pp. 7-8), apresenta-se uma classificação das definições de acordo com o objetivo pretendido. Segundo os autores, três grupos de definições são possíveis: a) definição como determinação da essência de um objeto; b) definição como determinação do conceito de um objeto; c) definição do nome de um objeto, de acordo com seu uso.

a) no primeiro grupo, incluem-se as definições cuja doutrina foi defendida por Aristóteles e pela escolástica. Trata-se de distinguir entre propriedades essenciais e propriedades acidentais de uma dada substância - que, por princípio, é considerada universal - : é necessário discernir entre propriedades inerentes à essência desse objeto de definição e propriedades que podem ou não estar presentes em tal objeto, ou seja, propriedades contingentes. O discurso definidor é a expressão discursiva dessa essência;

b) no segundo grupo, incluem-se as definições cuja doutrina é sustentada por aqueles que negam a possibilidade do conhecimento das essências substanciais (ou consideram-no irrelevante, mesmo que possível): em lugar de se determinar a essência substancial do objeto de definição, trata-se de estipular um conceito vinculado a esse objeto. Assim:

"Para Kant, o que pretende a definição é a determinação do conceito: um conceito desconhecido é analisado a partir de conceitos já conhecidos (definição analítica) ou é construído novamente (definição sintética). Kant sustenta que nem todo conceito pode ser objeto de definição. Quando não é possível defini-lo, estabelece-se a exposição [diz Kant; 'Em lugar do termo 'definir', preferiria usar o termo 'exposição', que é mais cuidadoso e permite ao crítico dar validade à definição até certo ponto, mantendo reserva em relação à sua 
exaustividade' (...) 'Uma definição é um conceito suficientemente claro e delimitado' (...) 'Todas as definições são ou analíticas ou sintéticas. As primeiras são definições de um conceito dado; as segundas são definições de um conceito construído' (...) 'A exposição de um conceito consiste na representação sucessiva de suas características, na proporção em que estas tenham sido encontradas mediante análise'. A descrição é a exposição de um conceito na proporção em que este não seja preciso] (op. cit., pp. 7-8).

Como vemos, esta doutrina aproxima-se da visão desenvolvida por Rickert anteriormente ${ }^{98}$;

c) no terceiro grupo incluem-se as definições puramente nominais ou lexicais, as quais declaram a significação dos termos e seus exemplos de utilização. É possível que incluam considerações etimológicas e os significados denotativos e conotativos de tais termos.

Em REY (2000, pp. 3-5), apresentam-se dois extremos de um possível continuum de tipos de definição, de acordo com os objetivos definicionais:

a) "o objetivo pode ser revelar, por meio de um discurso racional (1०/goj) o ser, a essência ou a qüididade (essência ou natureza essencial de algo; virtude essencial) de um objeto de pensamento, isto é, de um estado (mais do que um ser) externo ao sujeito que conhece" (doutrina aristotélica);

b) "o objetivo pode ser estabelecer um corpo de sinônimos por meio de perífrases que podem esclarecer quer os significados quer os usos das unidades lexicais para usos mais ou menos específicos" (doutrina wittgensteiniana ${ }^{99}$ ). Muitas combinações intermediárias desses dois pólos podem ser obtidas.

${ }^{98}$ Em CAYGILL (1995, pp. 93-94, verbete "definição"), lemos que "Kant descreve 'definição' em CRP [Crítica da Razão Pura] como a apresentação do 'conceito original e pormenorizado de uma coisa dentro dos limites estabelecidos para o conceito', sendo 'pormenorização' usada com o significado de 'clareza e suficiência de características'; 'limites' refere-se ao número preciso de características no conceito pormenorizado [segundo Kant, "precisão, de tal maneira que não haja mais caracteres do que os que pertencem ao conceito pormenorizado"]; e 'original' quer dizer que a determinação dos limites não foi derivada de qualquer coisa [segundo Kant, "esta determinação de limites não foi derivada de qualquer outra coisa e, portanto, não tem necessidade ainda de uma demonstração, o que tornaria a pretensa definição incapaz de se colocar à cabeça de todos os juízos sobre o seu objeto"] (CRP: A 728 / B 756)". Para maiores explanações sobre o conceito kantiano de definição, ver KANT (2001, pp. 589-592).

${ }^{99}$ Em WITTGENSTEIN (2003, p. 43), verificamos que "Uma explicação do significado pode remover todo desacordo quanto a um significado. Pode esclarecer mal-entendidos. O entendimento de que se fala aqui é um correlato da explicação. Com 'explicação do significado de um signo' queremos nos referir a regras para o uso mas, acima de tudo, a definições". Para uma melhor compreensão da 
Outro continuum de possibilidades existe na polarização entre:

a) "a definição descritiva de um estado factual que respeita o emprego usual (por parte da maioria dos falantes de uma língua, assim como é sancionado pela norma social) dos signos a serem definidos";

b) a definição criadora do conceito (no sentido kantiano), sendo um de seus objetivos construir uma 'bem formada linguagem' de acordo com princípios científicos, a qual serve como metalinguagem para a linguagem natural".

Em PERELMAN \& OLBRECHTS-TYTECA (1996, pp. 238-243), afirma-se que a identificação de elementos que são objetos do discurso representa uma das técnicas essenciais da argumentação; a identificação completa tem nas definições seu procedimento mais característico ${ }^{100}$. Estas são argumentos quase-lógicos, pois, mesmo que não integrem um sistema formalizado (ou uma linguagem não-natural), pretendem identificar definiendum e definiens (assim, segundo REBOUL [1998, pp. 172-173], retomando Perelman \& Olbrechts-Tyteca, a definição é a proposição de uma identidade entre texto definidor e termo definido, visando à permuta sem descaracterização semântica, embora tal objetivo seja apenas alcançável nas línguas técnicas e artificiais).

Os autores distinguem então quatro espécies de definições:

a) definições normativas, cuja função é indicar como se deseja que um termo seja utilizado. Trata-se, portanto, da estipulação de uma norma a ser seguida doravante. Segundo Reboul, estas definições são denominações que propõem como convenção o uso de um termo, sem o envolvimento qualquer valor de verdade ou falsidade: importa aqui, simplesmente, a manutenção do uso do termo tal qual recém-convencionado;

abordagem wittgensteiniana em relação ao papel das definições, ver a primeira parte da Gramática Filosófica ("A proposição e seu sentido").

${ }^{100}$ Em CAMARGO (2004, p. 133) enfatiza-se o caráter argumentativo das definições: "A definição é um recurso argumentativo por meio do qual se propõe um determinado sentido para um termo que será empregado no decorrer do texto. A definição pode ser normativa (aquela que propõe uma definição como convenção a ser seguida, em construções do tipo 'o termo "x" vai ser aqui empregado como...'), descritiva (aquela que pretende enunciar o sentido corrente do termo definido, buscando, em geral, o sentido dado pelo dicionário), condensada (aquela que se limita a enunciar características essenciais, omitindo muitos aspectos do conceito) e oratória (uma espécie de definição imperfeita, na qual o que define e o que é definido não são, de fato, permutáveis, como em 'ser mãe é padecer num paraíso', tipo de construção própria para impressionar e persuadir)". 
b) definições descritivas, cuja função é indicar qual o sentido de um termo empregado em determinado contexto de uso. Para Reboul, tais definições buscam especificar um uso já corrente, ou uma determinada acepção do termo. Aqui já é possível conceber um valor de verdade: "a definição descritiva pode então ser verdadeira ou falsa — falsa se não descrever realmente o uso" (REBOUL, op.cit., p. 172);

c) definições de condensação, modalidades de definições descritivas baseadas na seleção e apresentação de características essenciais destas. Reboul afirma que as definições descritivas condensadas restringem-se às características essenciais, deixando de lado traços cuja ausência não compromete a definição, mesmo que sejam relevantes;

d) definições complexas, que combinam os três tipos anteriores de definição. Reboul acrescenta, em seus comentários sobre a obra de Perelman \& OlbrechtsTyteca, no que diz respeito às definições, as definições oratórias, que são "[...] definições imperfeitas, pois o que define e o que é definido não são realmente permutáveis: 'guerra é toda a nação em um esforço de vitória'" (op. cit., p. 172). De acordo com essa observação de Reboul, retóricas seriam todas as definições dotadas dessa característica; em verdade, a função argumentativa estará sempre presente, de uma forma ou de outra, no processo definidor; porém, necessários são alguns cuidados, no que diz respeito a esse ponto:

"Na realidade, toda definição é um argumento, pois impõe determinado sentido, geralmente em detrimento dos outros. Torna-se perigosa e abusiva quando, sendo apenas normativa, pretende-se descritiva; quando, sendo condensada ou oratória, pretende-se completa" (REBOUL, op. cit., p. 173).

Em outros termos, o autor destaca então a transição perniciosa de "entendo por ' $x$ '..." para "' $x$ ' é ..." e, enfim, para "' $x$ ' é unicamente...", processo que transforma uma definição normativa ou estipulativa em uma definição que pretende declarar a qüididade do objeto "x".

Perelman \& Olbrechts-Tyteca assim comentam a relação entre essas definições e a dicotomia clássica baseada na polarização entre definições reais 
(essencialistas ou substancialistas) e definições nominais (nominalistas ou terminalistas):

\begin{abstract}
"Todas essas definições e as possibilidades argumentativas que fornecem ainda são ignoradas pela maioria dos lógicos, cujo pensamento continua a mover-se no âmbito da dicotomia clássica das definições reais e nominais, sendo as primeiras tratadas como proposições suscetíveis de serem verdadeiras ou falsas, as segundas como sendo puramente arbitrárias" (op. cit., p. 239).
\end{abstract}

Destacamos a relação apontada entre as definições substancialistas e a atribuição de um valor de verdade ou falsidade à proposição, e as definições nominalistas e a arbitrariedade da relação definiendum - definiens. Vemos que os autores enfatizam a necessidade de interpretar corretamente o caráter arbitrário e convencional das definições nominalistas; como exemplo, Stuart Mill afirma:

\begin{abstract}
"As asserções relativas à significação das palavras, dentre as quais as mais importantes são as definições, ocupam um lugar, e um lugar indispensável, na filosofia. Mas, como a significação das palavras é essencialmente arbitrária, as asserções dessa classe não são suscetíveis nem de verdade, nem de falsidade e, em conseqüência, nem de prova, nem de refutação" ${ }^{101}$.
\end{abstract}

Esse texto de Mill destaca o caráter convencional e arbitrário das definições nominalistas; importa, contudo, compreender exatamente o alcance dessa condição: para os autores, afirmar que tais definições são arbitrárias ou convencionais não implica entender que haja indiferença na escolha de uma ou outra definição nominal, mas sim entender que, sendo arbitrárias ou convencionais, não se impõem necessariamente, assim como se impõem as definições essencialistas ou substancialistas (para as quais não se trata de normalizar uma convenção de uso, mas sim declarar, clara e indiscutivelmente, a qüididade do objeto de definição).

Assim justificam os autores a possível confusão entre essas duas situações:

${ }^{101}$ John Stuart MILL. Sistema de lógica dedutiva e indutiva. Vol. I, Livro II, Capítulo I, § 1. 
"O que faz crer no caráter convencional das definições é a possibilidade de introduzir em todas as linguagens, mesmo usuais, símbolos novos. Mas, embora esses signos novos sejam chamados a cumprir inteira ou parcialmente a função de termos antigos, o caráter arbitrário de sua definição é ilusório - mesmo que se trate de símbolos criados ad hoc. O é mais ainda se definiens e definiendum são ambos extraídos da linguagem usual" (op. cit., p. 240).

Compreende-se essa afirmação se recordarmos que, mesmo uma teoria que se pretenda puramente arbitrária - e, baseada nessa pretensão convencionalista, anuncie definir seus signos ad libidum - deve, se em algum momento buscar a "confrontação com o real" ou, se for aplicada a "situações anteriormente conhecidas", enfrentar o problema da compatibilidade entre as noções por ela definidas e as noções já empregadas pela linguagem natural ${ }^{102}$.

A literatura que trata de tipologias de definições tradicionalmente as classifica tomando por base a articulação das seguintes categorias: a) intensão vs. extensão; b) essências vs. nomes. Vimos o que se compreende pela oposição entre essencialismo vs. nominalismo; importa agora determinar claramente o que se compreende por definição extensional e definição intensional.

Em LYONS (1989, pp. 152-153), indaga-se sobre o modo de definir ou estabelecer a pertinência de um membro em relação a uma classe. Um dos procedimentos, em caso de um conjunto limitado de membros, consiste em, simplesmente, enumerá-los: teremos, então, uma definição extensional. Por sua vez, a definição intensional define um objeto a partir das propriedades que todos os membros da classe a que esse objeto pertence apresentam.

COPI \& COHEN (2002, pp. 114-117; 118-120), observam que, segundo o entendimento da lógica formal, uma definição deve declarar o significado de um

\footnotetext{
102 "Uma teoria pode pretender-se puramente convencional e querer fundamentar nessa pretensão o direito de definir seus signos como bem lhe parecer, mas, assim que visa a uma confrontação com o real, assim que seu criador se propõe aplicá-la a situações anteriormente conhecidas, o problema da identificação das noções que ela define com aquelas da linguagem natural não pode ser eludido. A dificuldade que se procurou evitar só pôde ser transposta para outro plano. Está aí todo o problema do formalismo: ou este fornecerá um sistema isolado, não só de suas aplicações, mas também de um pensamento vivo que deve compreendê-lo e manejá-lo, ou seja, integrá-lo a estruturas mentais preexistentes, ou então terá de ser interpretado e operará identificações que se reportarão à argumentação quase-lógica" (op. cit., pp. 240-241).
} 
termo ou símbolo, podendo, com isso, estabelecer possibilidades de permutas mais ou menos condicionadas ${ }^{103}$; porém, há vários significados para o termo 'significado'. Dois significados desse termo são de particular importância:

a) significado como extensão: "o significado do termo geral 'planeta' [...] consiste dos objetos aos quais o termo pode ser corretamente aplicado. Esse sentido de 'significado' é chamado 'significado extensional do termo'. [...] A coleção de objetos aos quais um termo geral aplica-se corretamente constitui a extensão daquele termo". Conseqüentemente, temos as definições extensionais: "Definições extensionais identificam a coleção de objetos aos quais o termo geral que está sendo definido se aplica";

b) significado como intensão - ou seja, "todos os objetos dentro da extensão de um dado termo possuem alguns atributos comuns ou características que nos levam a usar o mesmo termo para denotá-los. Portanto, podemos conhecer o significado de um termo sem conhecer sua extensão. [...] Este significado de 'significado' é chamado 'significado intensional' do termo. A série de atributos compartilhados por todos aqueles objetos aos quais um termo geral se refere é chamada a 'intensão' daquele termo".

Há termos perfeitamente significativos (ou seja, possuidores de intensão; um exemplo conhecidíssimo é "unicórnio"104) que não possuem, contudo, extensão (ou seja, não denotam nenhum objeto concreto); disso se conclui, segundo os autores, que a intensão é o núcleo central de construção do significado, sendo a extensão um fator secundário (assim sendo, privilegia-se o conceito de definição como determinação de um conceito).

\footnotetext{
103 Lemos em HAACK (2002, p. 318), que "uma 'definição explícita' define uma expressão (o definiendum) por meio de outra (o definiens) que pode substituir a primeira onde quer que ela ocorra. Uma 'definição contextual' fornece uma substituição para certas expressões mais longas nas quais o definiendum ocorre, mas não um equivalente para aquela própria expressão".

104 "Tais termos fazem mais do que mostrar uma limitação da definição extensional; eles mostram que 'significado' realmente pertence mais à intensão do que à extensão. Pois embora o termo 'unicórnio' tem uma extensão vazia, certamente não se deve dizer que ele é destituído de significado. De fato, ele não denota qualquer coisa, uma vez que não há unicórnios, mas se o termo 'unicórnio' não fosse significativo, não seria também significativo dizer 'não há unicórnios'. Esta sentença, contudo, está muito longe de não ser significativa; nós compreendemos totalmente seu significado, e ele é verdadeiro. Claramente, a intensão é a chave real para a definição".
} 
Porém, de acordo com os autores, é necessário distinguir três diferentes sentidos possíveis para essa definição do conceito de intensão: a) intensão subjetiva; b) intensão objetiva; c) intensão convencional:

a) a intensão subjetiva de um termo, para um falante, é o "conjunto de todos os atributos que o falante crê serem possuídos pelos objetos denotados por aquela palavra". Assim sendo, esse conjunto de atributos varia de acordo com o indivíduo e de acordo com o tempo; embora de inegável existência, a intensão subjetiva não se presta para os propósitos definidores que pretendam ser válidos coletivamente. Mas não se deve ignorar essa percepção individual das intensões, pois desempenham papel importante nas definições persuasivas;

b) a intensão objetiva de um termo é o "conjunto total de características compartilhadas por todos os objetos na extensão do termo". Esta intensão independe da crença individual e, até mesmo, do conhecimento pessoal: como salientam os autores, muitas propriedades da intensão objetiva do termo "círculo" (por exemplo, o fato de que um círculo limita uma área maior do que qualquer outra figura plana fechada de igual perímetro) podem ser absolutamente desconhecidas dos usuários do termo. Em verdade, para a maioria dos termos, não existe consciência dos usuários sobre todas as possíveis propriedades pertinentes às intensões; por isso, a intensão objetiva dos termos não corresponde à intensão que os usuários têm em vista quando utilizam os termos, especialmente em linguagem quotidiana;

c) a intensão convencional baseia-se no fato de que a ocorrência de uma comunicação satisfatória e entendimento mútuo mediante a utilização dos termos comuns da linguagem é prova de que há um tipo de intensão aceita e compartilhada pelos usuários, que não é exclusivamente subjetiva, nem absolutamente objetiva. Tal tipo de intensão surge pela existência de alguma forma de acordo sobre critérios de uso de termos e referenciais. Ou seja:

"Termos possuem significados estáveis porque concordamos em usar o mesmo critério (ou critérios) ao decidir, sobre um objeto, se ele é parte da extensão do termo. Desse modo, o que faz uma coisa ser um círculo, segundo esse termo é comumente usado, é ela ser curva plana fechada, cujos pontos são eqüidistantes de um ponto interno denominado 'centro'. Esse critério 
é estabelecido por convenção. Por meio de acordos informais estabelecemos a intensão convencional dos termos gerais. Este é o mais importante sentido de intensão, para os propósitos da definição, uma vez que ele é público e não requer onisciência para o uso. De fato, o termo 'intensão' é geralmente usado para significar 'intensão convencional'"' (op. cit., p. 121).

Segundo essa visão - a compreensão de que os conceitos de intensão e definição intensional implicam precisamente o conceito de intensão convencional-, a intensão de um termo não necessita declarar as características intrínsecas dos objetos denotados por ele (digamos, não precisa conter exclusivamente os atributos absolutamente essenciais, exigência que restringe extraordinariamente a possibilidade de definir); pode, satisfatoriamente, declarar os atributos que sejam suficientes para que não haja imprecisão intensional nem imprecisão extensional (ou, então, para que haja uma imprecisão aceitável sob o ponto de vista operacional).

Uma vez estabelecidos esses conceitos, interessa-nos examinar as definições (e as pseudodefinições) distribuindo-as em quatro grupos, de acordo com o foco de incidência do ato definidor, na seguinte ordem:

a) pseudodefinições de caráter extensional, cujo definiens é uma ação pragmática (eventualmente, até mesmo um discurso) sobre um objeto práxico (GRUPO I);

b) definições cujo definiens é um discurso sobre um conceito (ou objeto mental, isto é, qualquer entidade ontologicamente individualizada e previamente constituída como uma unidade que existe mentalmente, quer em âmbito individual, quer em âmbito coletivo ou social), segundo a perspectiva da intensão objetiva (GRUPO II);

c) definições cujo definiens é um discurso sobre um conceito (ou objeto mental), segundo a perspectiva da intensão subjetiva e/ou da intensão convencional (GRUPO III);

d) estruturas pseudodefinidores diversas: i) pseudodefinições metafóricas; ii) pseudodefinições etimológicas; iii) pseudodefinições predicativas subjetivas (GRUPO IV). 
Aqui, cabe ter em mente a seguinte observação sobre a relação entre definição e os objetos práxicos:

"Não definimos coisas. Definimos palavras. Muita gente discute a questão das definições por um ângulo extravagante, pedindo que definamos coisas. Pedem que apresentemos a 'definição de sapato, elefante, grade...'. Isso não é viável. Objetos desse gênero são exibidos e batizados — nada mais. Podemos, entretanto, no seio de uma particular língua, definir a palavra 'sapato', dizendo, por exemplo, que deliberamos usá-la para indicar 'qualquer tipo de calçado'. Mais tarde, se preciso, definiremos outras palavras, abrindo um leque destinado a distinguir, por exemplo, 'sandália', 'tamanco', 'chinelo', mocassim', etc. Também podemos, no seio de um particular discurso, definir a palavra 'elefante', decidindo empregá-la para indicar 'qualquer pessoa de peso superior a cem quilos'. Como podemos decidir que, para fins específicos, 'grade', em um particular contexto, significará 'locutório de um convento" (HEGENBERG, 2002, p. 76).

Partindo dessa observação de Hegenberg, quando dissemos na tipologia apresentada que um dos grupos trata de definições cujo foco é o objeto práxico ou sensível; com isso, não pretendemos dizer que há um grupo de definições que definem o objeto sensível em si mesmo, conforme nos alerta Hegenberg. Entendemos, contudo, que os objetos sensíveis, objetos fenomênicos ou objetos práxicos, em sua dimensão individual e sua dimensão social, são manifestações empíricas que inegavelmente influenciam o processo definidor e podem, até mesmo, participar parcialmente desse processo; não podem, porém, ser definidos enquanto objetos-em-si. Em outras palavras, podemos declarar a qüididade de um objeto enquanto conceito (declarar seus traços intensionais); podemos, se necessário, declarar a qüididade de um nome; porém, não podemos declarar a qüididade de um objeto empírico em si mesmo (não podemos, por exemplo, declarar a qüididade desta particular folha de papel).

Como exemplo, podemos definir:

a) o significante "Sócrates" (declarando suas características necessárias e suficientes em uma metalinguagem autonímica);

b) o conceito de Sócrates em dois planos - sob o ponto de vista individual (isto é, considerando tal conceito para um indivíduo particular) e sob a ótica social 
(ou seja, considerando tal conceito segundo a percepção de um grupo de indivíduos ou de uma dada organização sócio-cultural).

Podemos, até mesmo, utilizar o objeto sensível Sócrates para desenvolver certos tipos de 'definição' (como a 'definição' ostensiva que, para a pergunta "Que é Sócrates?", responde "Sócrates é ISTO", apontando para o indivíduo Sócrates): não podemos, contudo, pretender definir Sócrates-em-si; quanto a isso, não há polêmica.

Como se observa, colocamos o termo "definição" entre aspas simples no parágrafo anterior; isso porque entendemos que as assim denominadas "definições ostensivas" não são definições legítimas - pois não se trata de definir qualquer tipo de conceito - ; temos aqui, simplesmente, puras ostensões.

Primeiramente, organizaremos os diversos tipos de definições e pseudodefinições; em seguida, trataremos de cada tipo em particular.

\subsection{UMA TIPOLOGIA DE DEFINIÇÕES}

Consideremos o seguinte quadro:

\begin{tabular}{|c|c|c|c|}
\hline $\begin{array}{l}\text { GRUPO I: } \\
\text { pseudodefinições de } \\
\text { caráter extensional } \\
\rightarrow \text { pseudodefinições } \\
\text { práxicas }\end{array}$ & $\begin{array}{l}\text { GRUPO II: } \\
\text { definições de caráter } \\
\text { intensional objetivista: } \\
\text { intensão objetiva } \\
\rightarrow \text { definições } \\
\text { substanciais ou ideais }\end{array}$ & $\begin{array}{l}\text { GRUPO III: } \\
\text { definições de caráter } \\
\text { intensional subjetivista } \\
\text { e/ou convencionalista: } \\
\text { intensão subjetiva e/ou } \\
\text { convencional } \rightarrow \\
\text { definições semióticas } \\
\text { ou signações }\end{array}$ & $\begin{array}{l}\text { GRUPO IV: } \\
\text { estruturas } \\
\text { pseudodefinidoras } \\
\text { diversas }\end{array}$ \\
\hline $\begin{array}{l}\text { conceito: } \\
\text { pseudodefinições cujo } \\
\text { 'definiens' é um } \\
\text { discurso sobre objetos } \\
\text { práxicos, apontando-os, } \\
\text { nomeando-os ou } \\
\text { descrevendo-os. } \\
\text { Ex.: o filósofo Sócrates }\end{array}$ & $\begin{array}{l}\text { conceito: } \\
\text { definições cujo } \\
\text { definiens é um discurso } \\
\text { sobre conceitos } \\
\text { objetivos, individuais e } \\
\text { coletivos, focalizando a } \\
\text { qüididade, } \\
\text { essencialidade ou } \\
\text { substancialidade de um } \\
\text { ser ou ente. } \\
\text { Ex.: conceito objetivo } \\
\text { de filósofo enquanto ser } \\
\rightarrow \text { o ser filósofo }\end{array}$ & $\begin{array}{l}\text { conceito: } \\
\text { definições cujo } \\
\text { definiens é um discurso } \\
\text { sobre conceitos } \\
\text { subjetivos ou } \\
\text { convencionais, } \\
\text { individuais ou coletivos, } \\
\text { e que dizem respeito } \\
\text { aos significados dos } \\
\text { termos lingüísticos. } \\
\text { Ex.: conceito subjetivo } \\
\text { ou convencional de } \\
\text { filósofo } \rightarrow \text { o signo } \\
\text { "filósofo" }\end{array}$ & $\begin{array}{l}\text { conceito: } \\
\text { pseudodefinições cujo } \\
\text { 'definiens' é um } \\
\text { discurso livre sobre: } \\
\text { i) temas que guardem } \\
\text { alguma relação com o } \\
\text { nome do } \\
\text { (pseudo)definiendum; } \\
\text { ii) a etimologia do } \\
\text { (pseudo)definiendum; } \\
\text { iii) qualquer relação } \\
\text { lingüístico-pragmática } \\
\text { entre o } \\
\text { (pseudo)definiendum e } \\
\text { o (pseudo)definiens. }\end{array}$ \\
\hline
\end{tabular}




\begin{tabular}{|c|c|c|c|}
\hline $\begin{array}{l}1.1 \text { pseudodefinição } \\
\text { extensional por } \\
\text { nomeação }\end{array}$ & $\begin{array}{l}2.1 \text { definição intensional } \\
\text { objetiva por gênero } \\
\text { próximo e diferença } \\
\text { específica (gênero e } \\
\text { espécie) }\end{array}$ & $\begin{array}{l}3.1 \text { definição intensional } \\
\text { subjetivo-convencional } \\
\text { sinonímica/parafrástica }\end{array}$ & $\begin{array}{l}4.1 \text { pseudodefinição } \\
\text { metafórica }\end{array}$ \\
\hline $\begin{array}{l}1.2 \text { pseudodefinição } \\
\text { extensional por } \\
\text { ostensão }\end{array}$ & $\begin{array}{l}2.2 \text { definição intensional } \\
\text { objetiva pelas quatro } \\
\text { causas }\end{array}$ & $\begin{array}{l}3.2 \text { definição intensional } \\
\text { subjetivo-convencional } \\
\text { estipuladora } \rightarrow \text { objetos- } \\
\text { de-discurso }\end{array}$ & $\begin{array}{l}4.2 \text { pseudodefinição } \\
\text { etimológica }\end{array}$ \\
\hline $\begin{array}{l}1.3 \text { pseudodefinição } \\
\text { extensional semi- } \\
\text { ostensiva nominal }\end{array}$ & $\begin{array}{l}2.3 \text { definição intensional } \\
\text { objetiva teorética }\end{array}$ & $\begin{array}{l}\text { 3.3 definição intensional } \\
\text { subjetivo-convencional } \\
\text { lexical }\end{array}$ & $\begin{array}{l}4.3 \text { pseudodefinição } \\
\text { predicativa subjetiva } \\
X \Leftrightarrow Y\end{array}$ \\
\hline \multirow[t]{5}{*}{$\begin{array}{l}1.4 \text { pseudodefinição } \\
\text { extensional semi- } \\
\text { ostensiva descritiva }\end{array}$} & $\begin{array}{l}\text { 2.4 definição intensional } \\
\text { objetiva operacional }\end{array}$ & $\begin{array}{l}\text { 3.4 definição intensional } \\
\text { subjetivo-convencional } \\
\text { precisadora }\end{array}$ & \\
\hline & $\begin{array}{l}2.5 \text { definição intensional } \\
\text { objetiva condicional }\end{array}$ & $\begin{array}{l}3.5 \text { definição intensional } \\
\text { subjetivo-convencional } \\
\text { contextual }\end{array}$ & \\
\hline & $\begin{array}{l}2.6 \text { definição intensional } \\
\text { objetiva por atributos } \\
\text { secundários }\end{array}$ & $\begin{array}{l}\text { 3.6 definição intensional } \\
\text { subjetivo-convencional } \\
\text { funcional }\end{array}$ & \\
\hline & $\begin{array}{l}2.7 \text { definição intensional } \\
\text { objetiva estipuladora } \rightarrow \\
\text { objetos-de-discurso }\end{array}$ & $\begin{array}{l}3.7 \text { definição intensional } \\
\text { subjetivo-convencional } \\
\text { implícita }\end{array}$ & \\
\hline & & $\begin{array}{l}3.8 \text { definição intensional } \\
\text { subjetivo-convencional } \\
\text { autonímica } \rightarrow \\
\text { "definições nominais" }\end{array}$ & \\
\hline
\end{tabular}

A) GRUPO I - PSEUDODEFINIÇÕES CUJO DEFINIENS É UM DISCURSO SOBRE OBJETOS PRÁXICOS (PSEUDODEFINIÇÕES DE CARÁTER EXTENSIONAL)

Neste primeiro grupo, temos as pseudodefinições que primordialmente focalizam os objetos práxicos, ou seja, objetos sensíveis ou fenômenos. Freqüentemente esses objetos práxicos são denominados "referentes"; para nós, parecem ser mais bem entendidos como "referenciais" ou "objetos referidos" por meio de "conceitos referentes" (referente $\rightarrow$ aquele ou aquilo que faz referência a algo; referido $\rightarrow$ aquele ou aquilo que é passível de referência por algo).

Importa enfatizar que, ao afirmar a focalização dos objetos práxicos, não entendemos com isso que esses objetos-em-si serão definidos ou terão suas reais características enunciadas: nem definimos tais objetos nem declaramos suas 
características essenciais; simplesmente: a) apontamos tais objetos (dêixis ou ostensão); b) enunciamos o nome e/ou descrevemos certas características externas desse objeto (nomeação e/ou descrição).

Portanto, aqui não definimos verdadeiramente: não se trata de delimitar e determinar o conceito vinculado a um objeto sensível, mas sim indicar, dentre o conjunto de objetos que constituem a extensão do conceito vinculado a esse objeto, aquele(s) objeto(s) que correspondem à intensão (objetiva, subjetiva ou convencional) à qual se liga um determinado nome.

Vimos anteriormente o conceito de extensão e definições extensionais. Cabe agora esclarecer o conceito de ostensão. SALMON (2002, pp. 75-76) registra que a extensão de uma palavra consiste na classe de todos os objetos a que a palavra pode ser corretamente aplicada. Portanto, indica-se de dois modos a extensão de um termo - ou, mais precisamente, os elementos que estão incluídos na extensão de um conceito:

a) podemos simplesmente apontar para objetos abarcados por essa extensão. Assim, para indicar o significado da palavra "sapato", podemos apontar para uma grande variedade de sapatos. Esse procedimento de indicar a extensão da palavra recebe tradicionalmente o nome de "'definição' ostensiva". Portanto, uma 'definição' ostensiva é uma definição extensional não-verbal, pois o significado da palavra é dado não por um discurso definidor, mas pelo ato de apontar objetos sensíveis (dêixis). Como vemos, não se trata de uma verdadeira definição, embora se pressuponha o conhecimento da intensão ou conceito acionado pelo nome respectivo;

b) podemos nomear e/ou descrever os membros (ou alguns membros) de uma extensão, procedimento que constitui uma definição extensional verbal: o conceito seria, então, "ilustrado" por meio de um discurso pseudodefinidor que declara os nomes dos membros da extensão e, eventualmente, forneceria traços caracterizadores externos.

Cabe observar que, nesse tipo de procedimento, o uso dos dêiticos — junto à mobilização de recursos contextuais - é generalizado. 


\section{1 pseudodefinição extensional por nomeação}

Este é o modo mais imediato e óbvio de tornar patente a extensão de um termo: nomear exemplos de objetos denotados por ele, ou seja, exemplos de objetos que se incluem na classe de objetos aos quais tal termo aplica-se corretamente. Conforme Hegenberg (op. cit., p. 21), "pode-se [...] indicar a extensão de uma palavra nomeando objetos dessa extensão, caso eles possuam nomes. Pode-se, por exemplo, mencionar exemplos da extensão de 'elemento químico' nomeando vários elementos: prata, ferro, iodo, cobalto, oxigênio, mercúrio e assim por diante".

Esse tipo de pseudodefinição possui uma série de deficiências que desautorizam a considerá-lo como um autêntico processo definidor. Em COPI \& COHEN (op. cit., pp. 118-119) comentam-se tais deficiências:

a) é possível que dois termos ou duas expressões com diferentes significados (diferentes intensões) possam ter exatamente as mesmas extensões. Assim, temos que a intensão do termo "triângulo eqüilátero" é "o atributo de ser uma figura plana fechada e limitada por três linhas retas de igual comprimento". A extensão da expressão "triângulo eqüilátero" é a classe daqueles objetos (e unicamente desses objetos) que possuem esse atributo. A expressão "triângulo eqüiangular" tem outra intensão — "o atributo de ser uma figura plana limitada e fechada por três linhas retas que se interceptam mutuamente para formar ângulos iguais". Como se vê, a extensão da expressão "triângulo eqüiangular" é exatamente a mesma da expressão "triângulo eqüilátero", embora suas intensões sejam diferentes.

Para esses casos, se pudéssemos nomear completamente os objetos denotados por uma dessas expressões, essa pseudodefinição por nomeação deixaria de distingui-los da outra expressão que denota os mesmos objetos. Embora as expressões não sejam sinônimas, possuem a mesma extensão e nomear o grupo de objetos denotados por ambas não garante a clara distinção entre elas;

b) outra dificuldade reside na própria necessidade de declarar um número suficientemente grande de objetos para que as características comuns que os permitem incluí-los sob a mesma rubrica sejam explicitadas claramente. Nomear um número muito restrito de objetos — ou, em caso extremo, um só objeto — pode levar 
a uma indução defeituosa, transmitindo uma falsa caracterização da intensão; de fato, nomear um só objeto como exemplo para uma pseudodefinição extensional por nomeação não garante que esse objeto não seja incluído na extensão de outras rubricas. Por exemplo, o objeto denominado "Aristóteles" presta-se como membro da classe dos "filósofos", "discípulos de Platão", "estagiritas": o termo "Aristóteles" em nada contribui para discriminar tais expressões, nem tampouco para caracterizar adequadamente qualquer uma delas em particular. Em suma, a pseudodefinição extensional por nomeação dos membros da classe não garante nem a unicidade da relação entre definiendum e definiens, nem a delimitação clara das características necessárias e suficientes da intensão dos termos;

c) ocorre a freqüente impossibilidade de identificação de todos os objetos do campo extensional; ou seja, há um número restrito de termos cuja extensão pode ser completamente identificada. Assim, torna-se necessário contentar-se com uma enumeração parcial desses termos. Isso implica uma dificuldade considerável, pois é possível que haja a presença de um mesmo objeto em diversos campos extensionais de diversos termos, uma vez que os objetos possuem inúmeras propriedades e atributos, cada uma delas suficiente para incluí-lo em um campo extensional específico. Sendo assim, a simples menção do objeto não serve para discriminar e/ou excluir qualquer um desses campos.

É possível reunir objetos em determinadas classes ou grupamentos, recurso que se presta para esgotar, em muitos casos, a extensão dos termos que representam esses objetos; contudo, esse recurso, embora útil em certos casos, não é suficiente para eliminar a deficiência essencial deste tipo de pseudodefinição.

Como exemplos de pseudodefinição por nomeação, temos:

1. "filósofo" ₹ "Sócrates, Platão, Aristóteles";

2. "jogos de tabuleiro" $\approx$ "xadrez, damas, gamão".

1.2 pseudodefinição extensional por ostensão

Neste caso, temos um procedimento extensional diverso: não se trata de declarar o nome ou identificar nominalmente os objetos que pertencem à extensão 
do definiendum, mas sim de apontar ou tornar identificável, dentro de um universo de diferentes objetos, um objeto particular. Assim, temos uma pseudodefinição extensional ostensiva se, ao procurar definir a palavra "mesa", dizemos "a palavra 'mesa' significa isto" (apontando o objeto).

Obviamente, este tipo de definição possui limitações situacionais. De fato, em COPI \& COHEN (op. cit., pp. 119-120) enfatiza-se que este tipo de pseudodefinição possui as mesmas limitações da pseudodefinição extensional por nomeação, além de limitações peculiares.

Uma dessas limitações é de natureza física: exige-se a presença do objeto para que haja dêixis. Outra limitação é de natureza sensorial: é necessário que o objeto possa ser apontado e possa ser percebido. Ainda, há o problema da indefinição intensional dêitica dos gestos. Em suma, há a necessidade de uma situação contextual muito favorável - e um processo ativo de inferência por parte dos interlocutores - para que a pseudodefinição por ostensão ocorra com sucesso.

HEGENBERG (op. cit., pp. 21-23) comenta a questão das pseudodefinições ostensivas: elas podem ser entendidas como pseudodefinições extensionais nãoverbais, pois não se trata de produzir um discurso definidor, mas sim exibir objetos concretos. Contudo, apesar da aparente rusticidade desse processo, Hegenberg lembra que "muitas sentenças são apreendidas na situação que elas descrevem ou na presença daquilo que se descreve". Ou seja, muitas sentenças são compreensíveis porque estão condicionadas por observações concretas partilhadas pelos interlocutores e porque o movimento dêitico permite que a relação entre um nome e um referencial seja estabelecida:

\footnotetext{
"Apontando para objetos, podemos fazer com que alguém compreenda que têm nomes. Com efeito, a linguagem possui, entre outras, uma função nomeadora. Nomeando objetos que são exibidos, é viável ganhar uma noção de sua posição na circunstância e, indiretamente, uma noção do que 'significam', de sua importância, de sua utilidade, de suas relações conosco e com outros objetos" (op. cit., p. 22).
}

Porém, há muitos casos em que não se pode claramente partir de um movimento ostensivo e chegar à intensão do termo, ou seja, a ostensão de objetos 
concretos não constitui, por si só, recurso suficiente para determinar intensões por processo indutivo: o próprio movimento ostensivo pode ser contextualmente ambíguo $^{105}$. Contudo, se a pseudodefinição extensional ostensiva, por si só, em geral não é suficiente, representa procedimento complementar importante quando combinada com processos verbais de definição, como ocorre freqüentemente na oralidade.

Como exemplos de pseudodefinição por ostensão temos:

1. "cadeira" "'cadeira' é ISTO" (apontando o objeto);

2. "fazer justiça" ₹ "ISTO é 'fazer justiça"" (mostrando, por exemplo, uma escritura de posse de um lote em um assentamento).

\section{3 pseudodefinição extensional semi-ostensiva nominal}

A pseudodefinição extensional por semi-ostensão nominal é um tipo de pseudodefinição que utiliza, além do movimento dêitico de ostensão, um suporte verbal complementar de caráter nominal (nome ou sintagma nominal), com o intuito de reduzir a indefinição intensional produzida por aquele único movimento. Reduz-se a indefinição intensional pela adição de algum suporte verbal lexical, cuja função é direcionar a inferência a ser realizada pelo interlocutor. Em outras palavras, trata-se de compreender a presença de um processo de ostensão-inferência enriquecido por meio de um nome atinente ao definiendum. Como exemplo, temos uma pseudodefinição extensional semi-ostensiva nominal se, ao procurar definir a palavra "mesa", dizemos "a palavra 'mesa' significa esta peça de mobiliário" (realizando um

\footnotetext{
105 "Conta-se - para realçar as dificuldades que surgem na definição ostensiva - que um missionário, procurando ensinar a um silvícola o significado de 'azul', apontava sucessivamente para vários objetos azuis, repetindo sempre a palavra. Mais tarde, quando o silvícola chegou a dominar um pouco melhor o idioma que Ihe era ensinado, a palavra 'azul' ganhou o significado de 'dedo do missionário' - fator constante em todos os 'atos' em que a palavra havia comparecido. No anedotário pertinente poderia ser também incluída uma experiência feita com um grupo de estudantes, aos quais o professor, batendo com os dedos na mesa, perguntava: 'Que é isto?' Os jovens alunos, para não parecerem limitados, foram respondendo, em sucessão: — Uma batida de dedos; — Uma toalha; Um pedaço de fazenda; - Um som cavo; - Madeira...e assim por diante, até que, por falta de melhor resposta, alguém, por fim, afirmou - Mesa! Os dois exemplos servem para ilustrar que há boa margem de flexibilidade na caracterização de objetos ou propriedades por meio da ostensão" Hegenberg (op. cit., pp. 22-23).
} 
movimento dêitico). Em termos práticos, no exemplo ocorre como que a presença de uma estrutura definidora que tem por definiendum o termo "mesa" e por definiens o sintagma "peça de mobiliário" ( /mesa $\leftarrow \pi$ 〈peça de mobiliário〉/). Observemos que se trata de dois nomes ou sintagmas nominais que operam como termos gerais que especificam uma classe.

Há, porém, uma exigência: torna-se pressuposta a compreensão da expressão nominal de suporte: no exemplo dado, caso não se conheça o significado da expressão "peça de mobiliário", o pronome dêitico perde sua referência auxiliar.

Como exemplo de pseudodefinição semi-ostensiva nominal, temos:

1. "régua" "por 'régua' entendo ESTE instrumento de medição" (apontando o objeto);

2. "sarja" "por 'sarja' identifico ESTE tecido" (apontando o tecido).

1.4 pseudodefinição extensional semi-ostensiva descritiva

A pseudodefinição extensional semi-ostensiva descritiva assemelha-se à pseudodefinição extensional semi-ostensiva nominal; dela diferencia-se, porém, por acrescentar ao movimento ostensivo não simplesmente um nome ou sintagma nominal (que opera como um termo geral que especifica uma classe), mas sim acrescentar uma descrição de características essenciais e/ou contingentes do definiendum proposto. Como exemplo, ao procurar definir a palavra "mesa", podemos dizer "a palavra 'mesa' significa este móvel com três pernas de metal e um tampo de vidro" (realizando um movimento dêitico).

Observemos que se trata da declaração de traços caracterizadores do objeto, e não simplesmente da apresentação de um termo geral designador de uma classe de objetos. Com este tipo de pseudodefinição extensional, progredimos em direção às definições intensionais, que focalizam particularmente os conceitos ou objetos mentais.

Importa enfatizar que, para as pseudodefinições extensionais ostensivas, não é possível indicar ou nomear todos os membros da extensão do termo; praticamente, haverá a ostensão ou a nomeação de alguns poucos exemplares da classe, 
assumindo-se o pressuposto que, por indução, todos os demais membros poderão ser reconhecidos, tomando-se por referência uma pequena amostra representativa. Obviamente, esse método não impede a existência de uma certa margem de imprecisão definidora.

As pseudodefinições extensionais, contudo, não são empregadas por mera preferência; conforme observa SALMON (op. cit., p. 76), não só é possível definir certos termos de um discurso por meio de recursos não-verbais, como também, em alguns momentos da atividade de comunicação, será impossível defini-los de outro modo:

\footnotetext{
"Um momento de reflexão deve ser suficiente para se perceber que algumas palavras devem ser definidas não verbalmente. Se o significado de uma palavra só pudesse ser dado mediante o uso de outras palavras, ficaria impossível transmitir o significado de qualquer palavra. A menos que algumas palavras tivessem adquirido seus significados não verbalmente, não haveria palavras significativas que pudessem ser empregadas para explicar o significado de outras palavras. Imagine-se que se encontrou um dicionário de sânscrito e que cada vocábulo dessa língua viesse definido em termos de outros vocábulos do sânscrito. Um leitor poderia memorizar todas as definições apresentadas no dicionário, mas não saberia o que cada palavra significa, por ignorar a que coisas aquelas palavras se referem. Algo como a definição ostensiva é necessária para relacionar algumas das palavras com objetos; não é suficiente apenas relacionar todas as palavras entre si".
}

Como se vê, o autor destaca a importância dos referenciais sensíveis no processo semiótico: em algum momento do processo de significação, há a necessidade de se recorrer a referenciais extralingüísticos para a apreensão de características essenciais e/ou acessórias das intensões. O exemplo do autor pode ser facilmente constatado no caso dos dicionários monolíngües estrangeiros: o leitor desse tipo de dicionário não compreenderá qualquer termo definido por ele, a não ser que haja algum recurso auxiliar — como, por exemplo, sinônimos em outra língua ou figuras ilustrativas - que remeta o leitor a um universo exterior àquele exclusivo código lingüístico (nessas situações, patenteia-se a importância da concretude do referente). 
Enfatizemos que essa observação do autor é decisiva, pois revela a função do referencial dentro do processo definidor ${ }^{106}$. Podemos afirmar que é impossível descartar absolutamente o referencial ao longo do processo de significação - e, em particular, no processo de definição —, e quanto a isso não há dúvidas: sempre haverá uma referência e um referencial; para tanto, basta considerar o tipo de relação estabelecida entre definiendum e definiens: entre eles, há mútua referência e cada um, em particular, é o referencial lingüístico-conceitual do elemento correspondente; também, definiendum e definiens são constituídos de conceitos, e tais conceitos possuem, em algum momento, referenciais praxiológicos.

A questão que se coloca é a seguinte: não há dúvidas sobre a importância dos referenciais e seus papéis no processo de significação; resta saber quais seriam as definições de referencial a serem consideradas como as mais apropriadas, tanto para esse processo geral de significação, quanto para o processo particular de definição (ou seja, trata-se de estabelecer a essência necessária do objeto denominado "referencial", uma vez que se torna impossível dele prescindir, particularmente no que concerne à teoria das definições).

Como exemplos de pseudodefinições semi-ostensivas descritivas, temos:

1. "banquinho" $\approx$ "por 'banquinho' entendo ESSE móvel com tampo arredondado, sem encosto e com três pequenas pernas de madeira (apontando o móvel);

2. "varal" ₹ "'varal'" é AQUELE conjunto de cordas plásticas estendidas naquela armação de metal" (apontando o objeto).

106 Em ABBAGNANO (2003, p. 837), encontramos as seguintes observações para o verbete "referência": "[...] 1. Em geral, o ato de pôr um objeto qualquer em qualquer relação com outro objeto. Nesse sentido, esse termo tem um significado bastante amplo: um mesmo objeto (por exemplo, um comportamento) pode referir-se ao seu autor, aos seus efeitos, aos seus fins, às suas intenções, às suas condições, etc. O sentido específico da referência, ou seja, a relação que ela estabelece, é esclarecido ou sugerido em cada caso pelo contexto. 2. Mais particularmente, chama-se de 'referência' o ato que estabelece uma relação entre o símbolo e seu objeto, ou seja o ato de interpretação [e (rmhnei/a]. Foram sobretudo Ogden e Richards que difundiram o uso do termo nesse sentido. Identificaram a referência com o pensamento, e ambos com aquilo que chamaram de 'significado cognitivo' [...]. No âmbito deste significado, os mesmos autores chamaram de 'referendo' (referend) o veículo ou o instrumento de um ato de referência, e de 'referente' (referent) o objeto a que o ato de referência visa". 
B) GRUPO II - DEFINIÇÕES CUJO DEFINIENS É UM DISCURSO SOBRE CONCEITOS (OU OBJETOS MENTAIS) OBJETIVOS, INDIVIDUAIS E COLETIVOS, FOCALIZANDO A QÜIDIDADE, ESSENCIALIDADE OU SUBSTANCIALIDADE DE UM SER OU ENTE (DEFINIÇÕES DE CARÁTER INTENSIONAL ESSENCIALISTA — "DEFINIÇÕES SUBSTANCIAIS")

Neste segundo grupo, temos as definições que focalizam os objetos mentais (conceitos) e/ou os objetos-de-discurso (objetos produzidos pelo processo de referenciação). Trata-se das definições intensionais conceituais, pois são definições que têm por objetivo a produção de um discurso definidor que delimite ou circunscreva, de modo mais exato possível, o campo intensional que caracteriza um objeto mental.

Aqui, importa distinguir, conforme mencionamos no primeiro capítulo deste trabalho, entre:

a) definições que declaram a essência ou a substância dos seres conceitualizados, sendo que tais seres preexistem ao discurso definidor e sua essencialidade é apreendida mediante abstração ("definições intensionais essencialistas não-constituintes"). Tal conceito relaciona-se ao conceito de definição analítica;

b) definições que declaram a essência ou a substância dos seres conceitualizados, sendo que tais seres não preexistem ao discurso definidor enquanto tais, mas passam a existir através de um discurso definidor inaugural ou fundador que formaliza conceitual e lingüisticamente essa essencialidade ("definições intensionais essencialistas constituintes"). Tal conceito relaciona-se ao conceito de definição sintética. Os objetos-de-discurso recém-inaugurados incluemse nesse grupo.

Podemos, portanto, utilizar essa distinção para discernir entre aquilo que se denomina "objetos-de-realidade" e aquilo que se conhece por "objetos-de-discurso": os primeiros são, primariamente, objetos práxicos cujos conceitos já estão constituídos segundo uma configuração particular, a qual serve de fonte para seu discurso definidor; os segundos são conceitos constituídos por um discurso fundador 
que atribui a eles uma dada configuração conceitual e, a partir dos quais, elabora um tipo de versão pública de um objeto-de-realidade.

Devemos, em resumo, cuidar para que não se confundam os seguintes elementos: conceitos, objetos-de-realidade e objetos-de-discurso:

a) o conceito compreende-se como o produto da atividade de abstração e um conjunto de juízos que declara a qüididade de um ser. Assim, temos o seguinte conceito: /canal $\leftarrow \pi$ «leito para curso de água especialmente construído para estabelecer comunicação entre rios, lagos, mares etc., e utilizado para navegação, irrigação etc.; sulco ou vala corrida, natural ou artificial, por onde corre águas /;

b) o objeto-de-realidade compreende-se como o objeto práxico, ou seja, como o objeto sensível ou fenômeno apreensível a partir daquilo que se percebe como realidade ou, grosso modo, como "mundo" ou "cosmo"; assim, temos o canal em si, entendido como leito para curso [...] por onde corre água;

c) o objeto-de-discurso compreende-se como uma recategorização de constructos culturais ou um tipo de versão pública de um objeto-de-realidade e/ou de um objeto mental ou conceito, construído pelos interagentes por meio de práticas discursivas e cognitivas, social e culturalmente situadas ${ }^{107}$. É o que ocorre em: "O canal que divide a cidade, aquele sujo e pífio filete de água salobra" $\Rightarrow$ /canal $\leftarrow$ «sujo e pífio filete de água salobra» /. A partir deste discurso fundador - que constrói a representação de um objeto-de-discurso particular —, o termo "canal" passa a ser vinculado a esse juízo especial ("sujo e pífio filete de água salobra") que, em princípio, caracteriza um objeto práxico mencionado pelo termo "canal" e, em seguida, incorpora-se conotativamente à intensão do conceito.

Pensamos que o conceito de fundação é o mais adequado para distinguir entre ambos os objetos; de fato, o que distinguiria entre o conceito correspondente a um objeto-de-realidade e o conceito correspondente a um objeto-de-discurso? Se o conceito deste último já está configurado previamente, o que o distinguiria de um objeto-de-realidade? Certamente não o fato de este "existir concretamente" e aquele "existir apenas no discurso", pois, se assim fosse, seríamos forçados a considerar os

\footnotetext{
${ }^{107}$ Ver nota que indica bibliografia atinente aos conceitos de referenciação e objetos-de-discurso.
} 
referenciais de conceitos tais como Deus, justiça e saudade como simples objetosde-discurso (que se oporiam aos referenciais de conceitos tais como mesa, sapato e pedra - objetos-de-realidade). Em suma, tais objetos - por exemplo, Deus seriam apenas criações discursivas, sem qualquer substancialidade para além do discurso, fato que, para o caso de Deus, representaria a solução final para um problema ontológico milenar com o qual a racionalidade humana se debate.

Poderíamos argumentar que um objeto-de-discurso, sendo uma recategorização de constructos culturais ou um tipo de versão pública de um objetode-realidade e/ou de um objeto mental ou conceito, construído pelos interagentes por meio de práticas discursivas e cognitivas, social e culturalmente situadas, não deve ser considerado o produto de um ato de fundação, pois é uma reconstrução ou uma versão de um objeto já existente. Porém, interessa destacar que a fundação se dá precisamente pelo ineditismo discursivo: esse conceito e esse objeto-derealidade necessariamente não existiam previamente nessa versão, pois, se assim fosse, seriam um conceito e um objeto aos quais caberia simplesmente mencionar ou, em último caso, redefinir.

Sumariando, as definições intensionais essencialistas não-constituintes (ao contrário das definições intensionais essencialistas constituintes) estabelecem, delimitam e circunscrevem de modo claro e preciso as características de $\underline{u m}$ conceito (objeto mental) dado previamente sob aquela forma específica — um ente que é percebido primariamente como conceito e, possivelmente por extensão, como um objeto-de-realidade. Aqui, não há a necessidade de uma elaboração lingüística (texto definidor) que produza ontologicamente essa substância; de fato, ela foi estabelecida por um discurso definidor prévio, cuja função fora declarar sua qüididade, descrevendo ou enumerando de modo claro e inequívoco suas características essenciais (são entidades que precedem o discurso definidor, no sentido de constituírem unidades ontologicamente dadas).

As definições intensionais essencialistas têm a função de eliminar a vaguidão de um termo, de modo a dissolver, por meio de um maior rigor na formulação do texto definidor, pendências de inclusão ou exclusão de objetos-limite na classe de objetos que constituem a extensão do termo. Como exemplo dessa necessidade 
definidora, temos, na culinária, a formulação de receitas e seus termos específicos: pode-se tornar necessário definir com mais precisão o que se compreende pela expressão "uma colher de fermento", de modo a incluir ou excluir os infinitos objetos conhecidos em conjunto como quantidades de fermento. Assim, cinqüenta gramas de fermento devem ou não ser excluídos da extensão do objeto colher de fermento? E dez gramas?

Como exemplos de definições do grupo dois, temos:

1. /cão $\leftarrow \pi$ «mamífero carnívoro canídeo /;

2. /sapo $\rightarrow \pi$ «membro da classe dos anfíbios anuros; anfíbio terrestre do gênero 'Bufo', da família dos bufonídeos, de pele rugosa e secas /

2.1 definição intensional objetiva por gênero próximo e espécie ou diferença específica

Conforme afirma IDE (1997, pp. 188-190), trata-se de um tipo clássico de definição, acompanhando o movimento natural da inteligência humana, que procede do geral ao particular. Assim, "o gênero é o que diz comumente ou de maneira geral o que é uma coisa, enquanto a espécie diz precisamente, distintamente, o que ela é". Analogicamente, a inteligência vai do gênero próximo (mais universal) à espécie ou diferença específica (mais particular). Como exemplo, o autor apresenta: /satélite $\leftarrow \pi$ «corpo [gênero] que gravita ao redor de um planeta [diferença específica]) /. Assim, "a definição por gênero e espécie reproduz em seu arcabouço lógico a dinâmica da inteligência em busca de conhecimentos claros e distintos — uma vez que entendemos almejar o homem, por natureza, o saber.

Importa distinguir entre "gênero próximo" e "gênero distante": "o gênero próximo é imediatamente mais universal do que a diferença e o termo definido; o gênero distante é mais universal em um grau" (IDE, op. cit., p. 190). Como exemplo, se considerarmos o termo "homem", o definiens "animal" é dele um gênero próximo, enquanto o definiens "ser vivo" é dele um gênero distante (mais universal em um grau do que o gênero "animal"). 
A definição intensional objetiva por gênero e diferença específica também é conhecida por "definição real", "definição ideal", "definição por divisão", "definição analítica" e "definição intensional stricto sensu". Há a tendência de considerá-la como a única forma correta de definição, posição que merece crítica por parte de muitos teóricos; assim, "a definição real não é convenção para introduzir novos símbolos, mas proposição que estabelece equivalência entre duas entidades (o definiens e o definiendum), sempre que o definiens 'capture a natureza essencial' do definiendum" (HEGENBERG, op. cit., p. 30) ${ }^{108}$.

Continuando com Hegenberg, vemos que, na Lógica tradicional, definir implica delimitar uma espécie por meio da declaração de seu gênero e de sua diferença específica: tal espécie é uma classe mais restrita, incluída em uma classe mais ampla que constitui o gênero. Assim, a espécie é uma subdivisão do gênero, que inclui vários indivíduos nisso semelhantes, mas diferentes entre si por traços peculiares, as diferenças específicas. O homem branco e o homem negro pertencem ao gênero "homem"; o fato de serem "branco" e "negro" representa os traços que os diferenciam.

Seguiremos aqui COPI \& COHEN (op. cit., pp. 122-124). Esta modalidade definidora baseia-se no pressuposto de que existem propriedades ou atributos do objeto de definição que são complexos, ou seja, decomponíveis em outras propriedades ou atributos, de modo a organizar-se uma hierarquia de características essenciais; em suma, deve existir a possibilidade de se discriminar classes e subclasses de objetos, segundo atributos específicos (entendo-se "classe" como "uma coleção de entidades ou objetos que possuem alguma característica ou propriedade comum, deles abstraída").

O termo "gênero" refere-se à classe cujos componentes podem ser agrupados em subclasses; o termo "espécie" refere-se a tais subclasses. A característica

\footnotetext{
108 "Nos tempos antigos e na Idade Média, a palavra 'definição' era usada, com freqüência, de modo a tornar possível falar em definição de uma coisa (ou idéia) e não de um termo. De acordo com esse uso original, quem define está relatando resultados de uma investigação - que conduz a propósito de um objeto, não de um vocábulo. $O$ vocábulo que nomeia o objeto seria apenas um indicador do objeto. Assim, ao falar-se na definição da cidade de Santos, por exemplo, tratar-se-ia de falar de um esforço conduzido no sentido de delimitar as fronteiras de um objeto físico-político, algo real - e não de esforço voltado para identificar o significado da palavra 'Santos'" (op. cit., p. 30).
} 
desses termos é a relatividade: a espécie é subgrupo de um gênero que, por sua vez, pode ser subgrupo, ou seja, espécie, de um gênero mais abrangente. Assim, importa observar que, sob o ponto de vista da Lógica, o uso dos termos "gênero" e "espécie" sempre implicará essa relatividade; estarão implicadas, igualmente, uma hierarquia e uma abrangência de classes.

Todos os membros de uma classe possuem alguma característica comum, um certo "traço analógico" que os qualificará para serem incluídos nessa classe particular; ao mesmo tempo, cada membro de uma dada classe possui alguma característica não-comum, um certo "traço específico" que os qualificará para serem incluídos em subclasses diversas, formando-se assim as diversas espécies de um mesmo gênero. Assim se descreve o procedimento definidor por gênero e diferença:

"[...] define-se um termo por gênero e diferença em dois passos: primeiro, um gênero deve ser nomeado, a classe mais ampla na qual a espécie que está sendo definida é incluída; estão, a diferença específica deve ser nomeada, o atributo que distingue os membros da espécie que está sendo definida dos membros de todas as outras espécies daquele gênero" (op. cit., p. 123).

Os autores destacam que esse método definidor também possui limitações; a primeira delas advém de sua aplicabilidade exclusiva para termos cuja intensão é dada por atributos complexos, isto é, decomponíveis em classes e subclasses de atributos analisáveis: se o termo em definição possuir uma intensão não-complexa, ou seja, não decomponível em atributos analisáveis, o termo não poderá ser definido por gênero e diferença específica.

Outra limitação desse tipo de definição diz respeito aos termos que se referem a atributos universais, como, por exemplo, o termo "ser", ou categorias metafísicas originárias, tais como a representada pelo termo "substância": suas extensões representam uma classe universal última (summum genus), que não se constitui em espécie de uma classe maior; desse modo, torna-se impossível defini-los por meio de gênero e diferença específica.

A literatura especializada focaliza com detalhe a definição por gênero e diferença por ser ela, tradicionalmente, considerada a definição por excelência: é 
comum ser concebida como a única maneira correta de definir um termo, deixandose de considerar, ao assim proceder, a quantidade de termos para os quais tal modalidade definidora é, simplesmente, inaplicável. Em suma: tradicionalmente, esse tipo é considerado um modelo ideal de definição, embora, em termos práticos, possua aplicação restrita a casos muito favoráveis. Assim se pronunciam os autores sobre este tipo de definição:

\footnotetext{
"Certas regras foram estabelecidas para a definição por gênero e diferença. Elas, por si mesmas, não nos permitem construir boas definições intensionais, porque tais definições requerem a racional seleção do gênero apropriado e a identificação das diferenças específicas as mais valiosas. Mas essas regras, pensadas para serem aplicadas principalmente às definições lexicais, são úteis como critérios para avaliar definições, uma vez tenham sido elas propostas" (op. cit., p. 125).
}

Estas são as regras comumente apontadas como parâmetros para a criação de definições por gênero e diferença (regras que, já afirmamos, são usualmente tomadas como parâmetros para quaisquer definições):

a) a definição deve afirmar os atributos essenciais das espécies - essa formulação, conforme muitos autores, é, de certa forma, obscura porque, em si mesma, uma espécie de um gênero tem exatamente aqueles seus atributos e nenhum deles é mais essencial do que o outro.

Também, há o conhecido problema de se caracterizar com precisão o que se deve entender por "essência", aliado ao problema de como formulá-la claramente. Como exemplo desse problema, lê-se em IDE (1997, p.196) que um critério capital para a formulação de uma definição é este: "a definição deve visar o essencial. É preciso que a definição se refira, se possível, à essência e não a propriedades ou características mais superficiais. [...] a função de uma definição não é designar a existência, mas dizer a essência. Ela responde à questão 'O que é?"'. Como se vê, são dois os pontos a serem esclarecidos: i) qual o conceito de intensão acionado pela pergunta "O que é?"; ii) como ter certeza sobre a essencialidade dos atributos mencionados? Seria sua permanência? 
Copi \& Cohen (op. cit., pp. 125-128) lembram a distinção entre intensão subjetiva, intensão objetiva e intensão convencional; de acordo com isso, entendem que definir segundo a essência deve significar, propriamente, a menção à intensão convencional de um termo, uma vez que nem sempre a intensão objetiva é reconhecida convencionalmente como a verdadeira essência de uma substância. Portanto, a primeira regra deve ser interpretada: uma definição deve declarar, antes de tudo, a intensão convencional do conceito que está sendo definido;

b) a definição não deve ser circular — dá-se a circularidade em uma definição quando o definiendum inclui-se no definiens. Desse modo, o entendimento não é facilitado, uma vez que essa definição pressupõe o conhecimento daquilo que é, precisamente, o objeto de dúvida: nesse sentido, a função básica da definição tornar conhecida a intensão de um conceito - não é cumprida. Também, tal regra implica a não existência de sinônimos e antônimos do definiendum na composição do enunciado do definiens.

Porém, conforme observa HEGENBERG (op. cit., p. 36), essa regra não pode ser aplicada rigorosamente a não ser em sistemas científicos fechados e com alto grau de perfeição, cujos conceitos são, precisa e claramente, definidos tendo em vista o ideal de definição:

"No sistema de conhecimentos comuns, é viável apresentar definições (ou algo que muito se parece com definições) de todos os termos utilizados - e os dicionários aí estão para comprovar a veracidade da afirmação. O que se constata, porém, é que os dicionários (fugindo de um regresso infinito, que seria inevitável, quando se procura dar definições de todos os termos) apresentam definições 'circulares'. A circularidade se verifica sem dificuldades, bastando considerar, por exemplo, que os dicionários fixariam, em sucessão: "Omitir", v.t., [...], postergar. "Postergar", v.t., [...], preterir. "Preterir", v.t., [...], omitir [...]. A circularidade não precisa ser (como em geral não é) viciosa - no âmbito dos conhecimentos comuns. Com efeito, no processo de 'caminhada em círculos', é possível que os significados dos termos iniciais sejam enriquecidos, ganhando-se, dessa maneira, visão mais acurada do significado de cada termo que compõe o 'círculo', delimitando-se, com propriedade maior, os contextos 'apropriados' para uso de cada um deles". (op. cit., p. 36). 
Como vemos, o ideal de não-circularidade nas definições só pode ser atendido, em geral, por termos que compõem sistemas conceituais em linguagens nãonaturais; para o uso das linguagens naturais, algum grau de circularidade nas definições é inevitável. Em especial, a restrição quanto ao uso de sinônimos e antônimos é praticamente impossível de ser atendida em situações de uso. Deve-se ter em conta que, dentro de uma relação sinonímica, há termos mais conhecidos e utilizados do que alguns de seus sinônimos; assim, pode ser produtivo, em uma interação verbal, esclarecer que "léxico" é sinônimo de "dicionário", termo este muito mais divulgado;

c) a definição não deve ser nem muito abrangente nem muito restrita — aqui, afirma-se que deve haver uma correspondência entre definiendum e definiens, sob o ponto de vista da quantidade de objetos denotados, ou seja, a extensão mencionada por ambos os termos deve ser correspondente, não incluindo nem excluindo de modo impróprio os designata.

Conforme observam Copi \& Cohen, essa é uma regra de fácil entendimento, mas de difícil aplicação: "encontrar ou construir o definiens que tem precisamente a abrangência correta para explicar o definiendum pode mostrar-se muito desafiador"; em especial, há o perigo de se infringir esta regra quando há facilidade de se definir por meio das quatro causas (ver "definição pelas quatro causas");

d) a definição não deve ser expressa em uma linguagem ambígua, obscura ou metafórica - se, por sua vez, a imprecisão intensional dificulta o ato definidor para qualquer indivíduo, a questão da obscuridade é mais complicada, pois se trata de um conceito relativo: o que é considerado obscuro por um indivíduo pode ser absolutamente claro para outro, de acordo com seus conhecimentos. Assim, parece razoável conceber a necessidade de um ajuste de linguagens, na formulação das definições, entre o agente definidor e o público para o qual a definição é proposta.

Outra restrição aplica-se ao emprego de linguagem metafórica nas definições cujo objetivo é servir para, de fato, promover o conhecimento do conceito em definição. Fora desse propósito intelectivo, a metáfora definidora se presta para uma função discursiva de interesse, criando efeitos diversos sob o ponto de vista interativo: de fato, utilizar uma metáfora em uma pseudodefinição pode não constituir 
um processo definidor tecnicamente irrepreensível, mas tal procedimento é quotidianamente empregado nas interações verbais que privilegiam os efeitos pragmáticos em detrimento do rigor conceitual;

e) a definição não deve ser negativa se puder ser afirmativa - esta regra baseia-se na idéia de que uma definição existe para explicar o que um conceito é, e não o que ele não é, a não ser que a natureza do objeto seja em essência negativa, exigindo assim, naturalmente, uma definição negativa. Fora estes casos, a definição deve optar, sempre que possível, por textos definidores afirmativos.

Para que tais regras façam sentido, convém ter em mente a prática comum que distingue entre as já mencionadas definições semióticas, que implicam uma proposta de aceitação de um significado, novo ou renovado, e as definições reais (em especial, as definições por gênero e diferença específica), que implicam um procedimento de caracterização rigorosa da natureza ou essência de um ente. Neste caso, não se trata de determinar quais são os usos e significados correspondentes aos termos empregados por uma língua natural ou científica, mas sim de determinar o que são e como são os objetos aos quais os termos estão vinculados (em suma, nos primeiro caso existe uma preocupação lingüístico-discursiva [conhecer o termo que se refere a um certo objeto]; no segundo caso, existe uma preocupação ontológica [conhecer um objeto ao qual um certo termo se refere]).

Tratando-se, então, não mais de um processo puramente semiótico, mas sim de um processo que inclui preocupações com o objeto mental - o conceito - e/ou com o objeto sensível - o referencial —, temos que o próprio conceito de definição real sinaliza, em seu horizonte, a presença de um referencial extralingüístico subjetivo, através da citada ação de "captura" da essencialidade do objeto: isso porque há nesse aspecto, implícita, a ação perceptiva de um agente, fato que implica a presença de um ponto de vista pelo qual a apreensão da "natureza essencial" realiza-se.

HEGENBERG (op. cit., pp. 30-33) observa que, para alguns autores, há uma outra relação entre a definição semiótica e a definição real, assim constituída: a definição semiótica seria a definição apresentada com o intuito de indicar por qual sentido um dado termo deve ser interpretado (a fórmula, neste caso, seria, "quando 
eu digo ' $x$ ', pretendo dizer ' $y$ '"); por outro lado, a definição real seria apresentada com o intuito de indicar o sentido que um dado termo possui para outros autores, ou os significados desse termo, segundo um elenco de possíveis acepções, assim como aparecem nos verbetes de dicionário. Em suma, sob essa perspectiva, as definições semióticas prestam-se para definir, perante um interlocutor, o sentido que um dado termo possui para ele, o locutor; já as definições reais prestam-se para definir o sentido que um dado termo possui para terceiros ou para uma coletividade. Como podemos perceber, muito pouco resta neste caso do conceito clássico de definição real.

COPI \& COHEN (op. cit., p. 106) observam, em relação a esse ponto:

\begin{abstract}
"Aquilo que estamos denominando 'definição lexical' tem sido, às vezes, considerado como uma 'definição real' - o definiendum realmente tem aquele significado independente identificado. Mas se uma definição é estipuladora ou lexical, nada tem a ver com a questão de se o definiendum nomeia algum coisa real ou existente. A definição 'A palavra 'unicórnio' significa um animal semelhante a um cavalo, mas tendo um único chifre reto projetando-se de sua testa' certamente é uma definição real ou lexical, e correta, porque o definiendum é uma palavra com um uso longamente estabelecido e significa exatamente aquilo que é significado pelo definiens. Contudo, o definiendum neste caso não nomeia ou denota qualquer coisa existente, uma vez que não há unicórnios".
\end{abstract}

Para outros autores, a oposição entre definições semióticas e definições reais constrói-se por meio do conceito de verdade: aquelas são simples convenções estipuladas e, portanto, nem verdadeiras, nem falsas; estas, segundo aquilo que se declara no texto definidor, são passíveis de serem qualificadas como verdadeiras ou falsas. Também, há autores que constroem essa oposição assumindo que as definições reais asseguram a existência do definiendum, ou a possibilidade existencial daquilo que é objeto de definição, ao contrário das signações.

Segundo Hegenberg, o ponto comum a essas interpretações da definição real reside no fato de constituírem análises de significados que visam a explicações empíricas dos fenômenos em questão. Assim, há duas características fundamentais inerentes às definições reais: a analiticidade e o empirismo, processos que implicam a necessidade de transcender o plano meramente lingüístico e adentrar em algum 
tipo de contato com a realidade empírica, seja ela definida como for. ${ }^{109}$ Nessa perspectiva, as definições reais abandonam o formato sinonímico-parafrástico das definições semióticas e são formuladas à guisa de leis científicas válidas universalmente.

Pretendendo a universalidade conceitual, as definições reais deveriam acionar necessariamente, no definiendum, conceitos idealmente inequívocos, expressos por meio de termos idealmente unívocos - condições que, usualmente, fogem do horizonte interativo da oralidade. Para este horizonte, cabe esperar que, pelo menos, as condições de uso e os contextos válidos possuam uma estabilidade adequada e uma difusão a mais ampla possível entre os membros de uma comunidade lingüístico-cultural.

A idéia de uma universalidade conceitual (motivo primeiro das definições reais) aparentemente limita-se a textos de cunho lógico-científico; no entanto, verificamos que tal perspectiva comparece até mesmo em estudos sobre técnicas de produção textual. Assim, em GARCIA (2000, pp. 332-336), vemos a estrutura formal das definições denotativas — "na que se faz referência à coisa denotada pelo signo" -

"No que diz respeito à sua [definição denotativa] formulação lógica e à sua estrutura verbal, a definição traduz-se numa proposição, dita 'predicativa', constituída por quatro elementos: a) termo (definiendum) - a coisa a ser definida; b) cópula: verbo ser (ou seu equivalente [...]); c) gênero (genus) - a classe (ou ordem) das coisas a que pertence o termo; d) diferenças (differentiæ) - tudo aquilo que distingue a coisa representada pelo termo de outras coisas incluídas na mesma classe. A 'fórmula' da definição que daí se pode tirar $-T=G+d_{1}+d_{2}+\ldots$ $+d_{n}-$ corresponde à própria estrutura da proposição predicativa, em que $T=$ sujeito, $G=$ predicativo, e $\mathrm{d}=$ adjunto(s) do núcleo do predicativo. Exemplo: 'Retângulo é um quadrilátero de ângulos retos e lados iguais dois a dois'. Sujeito = termo $(\mathrm{T})$ : retângulo; verbo de ligação = cópula: é; predicativo = gênero $(\mathrm{G})$ : um quadrilátero; adjuntos = diferenças: de ângulos retos $\left(\mathrm{d}_{1}\right)$, lados iguais $\left(\mathrm{d}_{2}\right)$, dois a dois $\left(\mathrm{d}_{3}\right)^{\prime \prime}$.

${ }^{109}$ Em ABBAGNANO (2003, pp. 831-834, verbete "realidade"), encontramos pelo menos três linhas de definição para (realidade): "1. Em seu significado próprio e específico, esse termo indica o modo de ser das coisas existentes fora da mente humana ou independentemente dela [...] 2. Em oposição à aparência, ilusão e outros semelhantes, realidade significa às vezes o ser em qualquer dos seus significados existenciais [...] 3. Em oposição à possibilidade, potencialidade e às vezes também à necessidade, essa palavra significa atualidade, efetividade ou aquilo que se atualizou ou efetivou e possui existência de fato". 
Em seguida, o autor passa a mencionar os requisitos para a exatidão e a validade das definições denotativas; apresentaremos algumas: a) o objeto de definição deve pertencer realmente ao gênero ou classe em que aparece incluído ${ }^{110}$; b) "o gênero deve ser suficientemente amplo para compreender a espécie definida, e suficientemente restrito para que as características individualizantes possam ser percebidas sem dificuldades nem confusão com outras espécies"111; c) "deve ter uma estrutura gramatical rígida tal, que o termo (sujeito) e o gênero (predicativo) pertençam à mesma classe de palavras" ${ }^{112}$; d) "deve ser recíproca para não ser incompleta ou insatisfatória: 'todo homem é um ser vivo' não constitui definição suficiente porque a recíproca — 'todo ser vivo é um homem' — não é verdadeira $[\ldots]^{1113}$.

O autor destaca a importância das definições no processo de expressão e explanação de idéias; as normas apresentadas representam instruções indispensáveis "à clareza, à precisão e à objetividade da comunicação". No entanto, tais regras dificilmente são observadas no processo definidor da comunicação quotidiana, em especial na modalidade oral; isso faz supor a utilização de outros recursos discursivos que preencham a função de produzir uma expressão textual clara, precisa e objetiva.

Para todos os efeitos, contudo, a definição intensional objetiva por gênero e diferença representa o modelo por excelência da definição essencialistasubstancialista.

${ }^{110}$ Conforme o autor, "mesa é um 'móvel', e não uma 'ferramenta' ou uma 'instalação"'.

111 "[...] não é admissível dizer que 'a mesa é um objeto de uso doméstico' (gênero demasiadamente amplo, pois inclui um grande número de outros 'objetos que nada têm a ver com a mesa), ou que 'é um móvel de sala de jantar' (gênero demasiadamente restrito, pois exclui outras espécies de mesa $[\ldots])$.

112 "Em virtude desse requisito - que é tanto uma imposição gramatical quanto da lógica - é inaceitável uma definição do seguinte tipo [...]: 'madrugar é quando a gente acorda muito cedo', em que o gênero está expresso numa oração que não pode ser predicativa ('quando a gente acorda'), pois não equivale a um nome e, portanto, não pode pertencer à mesma classe do termo sujeito 'madrugar', forma nominal do verbo, equivalente a um nome".

${ }^{113}$ Outras exigências mencionadas pelo autor são: "deve obrigatoriamente ser afirmativa"; "deve ser breve"; "deve ser expressa em linguagem simples"; "não se pode usar no gênero o termo que se está definindo". 
Como exemplo de definição intensional objetiva por gênero e diferença específica, temos:

1. /mosquito $\leftarrow \pi$ 〈culex pipiens〉 /;

2. Iglória $\leftarrow \pi$ rgrande renome difundido em um público muito vasto, e que se deve a méritos, ações ou obras julgadas notáveis`/.

\section{2 definição intensional objetiva pelas quatro causas}

Trata-se de um tipo de definição intensional objetiva que define seu objeto por meio de quatro causas universais, sob o ponto de vista físico (ver Aristóteles. Física, livro II, capítulo IV ss.) São elas: a) a causa material (matéria); b) a causa formal (forma); c) a causa eficiente (autor); d) a causa final (finalidade). O conceito de causa que está em jogo é o seguinte: raquilo de que uma coisa depende tanto em seu ser quanto em seu devir», ou seja, a causa de um objeto é aquilo que determina e condiciona o ser e o vir-a-ser desse objeto. Nesse sentido, esse tipo de definição declara as principais causas que determinam a existência do objeto definido, sendo, portanto, completa.

Como exemplo, em IDE (op. cit., pp. 190-191), temos a definição de veículo: a) causa material $\rightarrow$ metal, vidro, plástico etc.; b) causa formal $\rightarrow$ sua forma ou seu conceito em design; c) a causa eficiente $\rightarrow$ o construtor ou a montadora; d) causa final $\rightarrow$ seu uso para transporte de passageiros ou carga.

É possível que se apresente uma formulação reduzida da definição pelas quatro causas, focalizando apenas algumas delas. Isto ocorre quando as demais causas estão subentendidas, são desnecessárias em dado contexto ou, simplesmente, não são pertinentes. Verifiquemos as definições apresentadas pelo autor: a) "'-_ O que é isso (perguntam, mostrando uma pedra)?' — 'É bauxita' (causa material); b) 'O que é isso (perguntam, mostrando uma figura matemática)?' — 'É um pentágono regular' (causa formal); c) '- O que é isso (perguntam, mostrando um quadro)?' - 'É um Rembrandt.' (causa eficiente); d) '- O que é isso (pergunta uma criança, mostrando um compasso)?' — 'Isso serve para traçar círculos' (causa final)". 
Pode-se verificar que a declaração das quatro causas poderia ser considerada imprópria ou inadequada nesses contextos; basta imaginar a criança do último exemplo, recebendo como resposta a seguinte definição: "-É um instrumento de metal [causa material], fabricado pela empresa Silberschmidt [causa eficiente], empregado para tomar ou referir medidas ou para traçar círculos [causa final] e que consta de dois braços unidos por uma charneira na parte superior, dos quais um termina em ponta-seca, podendo o outro ter ponta semelhante, ou um porta-lápis ou um tira-linhas [causa formal]". Assim, compreende-se que a composição de uma definição pelas quatro causas atende às conveniências e necessidades do contexto de comunicação; eis porque uma definição que indique apenas uma das quatro causas não deve necessariamente ser considerada incompleta ou inexata.

IDE (op. cit., p. 191), assim compara os dois tipos de definição intensionais objetivas apresentados:

"O primeiro modo de definir [definição por gênero e diferença específica] é mais pedagógico; ele é indispensável a uma primeira abordagem. Mas o segundo [definição pelas quatro causas], se não parte de um mais universal [...], tem a vantagem de ser mais completo e de dar uma noção mais exaustiva do ser a conhecer. Como vemos, esses dois modos se completam mais do que se opõem".

Portanto, trata-se de dois modos de definição complementares e interrelacionados.

Como exemplo de definição pelas quatro causas, temos:

1. /rumor $\leftarrow \pi$ semergência e a circulação no corpo social de informações ainda não confirmadas publicamente por fontes oficiais ou por elas desmentidas` /;

2. /instinto $\leftarrow \pi$ <mecanismo nervoso organizado hierarquicamente, sensível a certos influxos iniciadores, disparadores ou condutores de origem tanto interna quanto externa, e que respondem a esses influxos por movimentos coordenados que contribuem para a conservação do indivíduo e da espécie /.

2.3 definição intensional objetiva teorética 
COPI \& COHEN (op. cit., pp. 109-110) utilizam o nome "definição teorética" para identificar o seguinte texto definidor: "uma definição teorética de um termo é uma definição que tenta formular uma descrição teoricamente adequada ou cientificamente útil do objeto ao qual o termo se aplica". Portanto, concebe-se o definiens como um texto que apresenta as propriedades do definiendum que constituem, sob um determinado ponto de vista teórico e científico, uma adequada descrição desse objeto particular, sob o ponto de vista de sua essencialidade ou substancialidade. Difere da definição intensional objetiva por gênero e diferença e da definição pelas quatro causas pela explícita incorporação de uma discussão teórica no bojo do texto definidor; assim, tais definições pretendem, antes de tudo, validar uma determinada perspectiva teórica em relação a um dado objeto científico (ou, então, impugnar outras perspectivas teóricas concorrentes).

Segundo os autores, muitas disputas teóricas em relação às definições ocorrem por motivos mais profundos do que as simples questões da ambigüidade ou vaguidão. Como ocorre freqüentemente em ciência, a discussão de uma definição implica a aceitação ou refutação de teorias que estão pressupostas por tais termos: buscar definições mais precisas de um objeto de definição pode significar a consolidação ou a demolição de partes de uma teoria ou de toda ela, teoria essa que, até então, poderia ter sido a interpretação oficial dos fatos científicos.

Em suma, propor um texto definidor teorético implica, ao mesmo tempo, propor a aceitação de uma teoria subjacente como um pressuposto válido. À medida que as teorias evoluem, novas definições dos mesmos objetos são propostas, aceitas ou refutadas; em certos casos, definições teoréticas que exprimam a "verdade" dos fatos ainda aguardam consenso.

Assim, define-se calor como sforma de energia que se transfere de um sistema para outro graças à diferença de temperatura entre eles〉 (definição físico-química) ou caumento anormal, de causas fisiológicas, da temperatura do corpo, ou outro processo orgânico, como aceleração da circulação sangüínea ou alguma perturbação do equilíbrio homeostático, que causa sensação de calor, de aquecimento> (definição fisiológica). Importa observar que tais definições não implicam simplesmente uma formulação mais exata do texto definidor ao longo da 
evolução dessas ciências: ao contrário, sucessivas definições do conceito de calor trazem como substrato a história da ascensão e queda de teorias conflitantes sobre tal conceito.

As definições intensionais teoréticas, predominantemente de caráter científico, vinculam-se à questão da instabilidade categorial entre objetos-de-realidade e objetos-de-discurso. Vista por outro ângulo, trata-se da questão teórica sobre qual o estatuto ontológico dos objetos práxicos acionados pelo discurso: devem estes ser considerados categorias acabadas que se oferecem ao discurso como objetos de mapeamento (compondo a denominada "realidade"), ou devem ser considerados entidades que nascem e vivem no discurso, constituindo uma realidade discursiva povoada por "objetos-de-discurso" em contínua (re)construção? Com essa discussão, simplesmente retomamos aquilo que, em filosofia, coloca-se historicamente como a "questão sofística"; neste trabalho, apresentamos nossa visão sobre a relação entre tais objetos.

Como exemplos de definição intensional objetiva teorética, temos:

1. /democracia $\leftarrow \pi$ regime sócio-político baseado na soberania popular e na distribuição eqüitativa do poder de decisão política e econômica mediante pluripartidarismo /;

2. /democracia $\leftarrow \pi$ regime sócio-político monopartidário baseado na igualdade de participação decisória através do aparelho partidário hegemônico /.

\section{4 definição intensional objetiva operacional}

No item anterior, apresentamos as definições intensionais objetivas teoréticas. Agora, partiremos da seguinte observação de HEGENBERG (op. cit., p. 105): "a fim de que uma teoria possa referir-se à experiência, é indispensável que seus termos se associem, de algum modo, aos dados experimentais". Para uma visão "operacionista" das definições, os conceitos a serem definidos apenas adquirem significado quando passíveis que algum tipo de interpretação ou verificação empírica. Tal princípio fundamenta-se na idéia de que uma teoria destituída de alguma interpretação ou base empírica não é passível de testes e não se confirma 
enquanto teoria sobre fenômenos experimentais observados. Portanto, enquanto na definição intensional objetiva teorética a ênfase reside no sistema teórico que jaz como substrato ao conceito em definição, na definição intensional objetiva operacional a ênfase se dá pela demanda de possibilidades interpretativas concretas que justifiquem a formulação do conceito.

Assim, um conceito não poderá ser conhecido a não ser que sejam especificadas as operações realizadas para aplicar esse conceito a uma situação concreta e verificável. Em termos práticos, ocorre uma correspondência entre o conceito teórico e o conjunto equivalente de operações concretas visando sua manifestação empírica: dessa forma, o conceito pode ser entendido como um equivalente ao conjunto dessas operações:

"Os significados são operacionais. Para conhecer o significado de um termo é preciso conhecer os critérios operativos de seu uso e cada termo científico deve admitir uma definição operativa. Essa definição pode referir-se a certas operações mentais e deve, em última estância, fazer alusão a alguma operação instrumental" (op. cit., p. 107).

Citando ACKOFF ${ }^{114}$, Hegenberg destaca que as definições intensionais operacionais e as definições intensionais puramente conceituais (gênero e diferença; quatro causas, etc.) diferem porque estas inter-relacionam conceitos, enquanto aquelas relacionam um conceito em processo de definição com aquilo que seria observado caso as operações necessárias para aplicar concretamente tal conceito fossem desenvolvidas.

Para que se estabeleçam as definições intensionais operativas, uma série de passos deve ser respeitada. Trata-se de indicar precisamente: a) o objeto (ou a classe de objetos) a ser observado e definido; b) as condições em que tal observação deve ser realizada (contexto de observação); c) as operações que serão realizadas em tal contexto de observação; d) os instrumentos específicos e os padrões de aferição que serão empregados para a execução das operações; e) as

\footnotetext{
${ }^{114}$ ACKOFF, Russell. Scientific method: optimizing applied research decisions. New York: John Wiley,
} 1962. 
observações a serem realizadas; f) o tratamento a ser dado aos resultados do processo.

As definições intensionais operacionais são muito úteis quando o que está em definição é um definiendum constituído por um enunciado ou proposição e não apenas por um nome ou sintagma nominal. Como exemplo, temos:

"[...] imagine-se desejar saber o que significa 'este rato está com fome'. Seguindo as várias fases: 1) identifica-se o rato; 2) coloca-se o rato em um labirinto já conhecido pelo animal; o rato acha-se em uma extremidade do labirinto; colocando-se alimento na outra extremidade; 4) usa-se um cronômetro (padrão de medida: segundos); 5) se o rato chegar ao alimento em menos de 'x' segundos, dir-se-á que 'está com fome'" (HEGENBERG, op. cit., pp. 117-118).

Como vemos, não se trata de definir os conceitos de rato e fome, mas sim de definir o juízo "este rato está com fome"; em casos como esse, pode ser muito complicado buscar definições puramente conceituais; as definições que incorporam as operações implícitas no complexo conceitual podem, então, atender à caracterização dos conceitos implícitos nos juízos.

Importa observar que se torna possível com isso projetar um texto definidor para o próprio conceito de fome; assim, poderíamos ter: definição de /fome $\leftarrow$ «ser um rato; estar em um labirinto cujo percurso correto possui três metros de extensão; ser colocado em uma de suas extremidades; haver alimento na outra extremidade; alcançar o alimento no prazo de " $x$ " segundos`/.

Como se vê, a definição intensional objetiva operacional implica a vinculação do definiendum com algum conjunto descritível de operações técnicas aplicadas a qualquer situação concreta: "uma definição operacional de um termo afirma que o termo é corretamente aplicado a um dado caso se e apenas se o desempenho de operações específicas naquele caso fornece um resultado especificado" (COPI \& COHEN, op. cit., p. 122).

Por sua vez, SALMON (op. cit., pp. 76-77) afirma:

"Definições de um outro tipo são freqüentemente usadas para introduzir novos termos, ou novos significados para velhos termos, em contextos científicos. As ciências [...] 
empenham-se em fornecer enunciados precisos que contêm informação objetiva sobre o mundo. Para que esse objetivo seja alcançado, os termos científicos devem possuir significados exatos em relação a objetos e eventos encontrados no mundo. [...] $\underline{\text { A idéia }}$ básica subjacente numa definição operacional é que um termo é definido pela especificação de alguma operação física que fornece um critério para determinar se 0 termo se aplica ou não a um objeto".

Assim, trata-se de obter uma definição entendida como a correspondência entre um conceito e um objeto, baseada em critérios fornecidos por operações físicas específicas, aplicadas sobre esse objeto ${ }^{115}$. Parte-se de um conceito (físico ou não-físico, como por exemplo: temperatura, dureza, umidade, inteligência, percepção, criatividade etc.), não definido ou definido com pouca precisão, e buscase torná-lo mais bem definido através da especificação de procedimentos operacionais igualmente bem definidos, os quais transferirão para o definiendum esse grau satisfatório de definibilidade. Sempre haverá, neste procedimento, algum tipo de operação física envolvendo objetos reais.

Assim comenta Hegenberg a questão das definições operacionais:

\begin{abstract}
"A fim de que uma teoria possa referir-se à experiência, é indispensável que seus termos se associem, de algum modo, aos dados experimentais. Dogma fundamental do operacionismo é, precisamente, o de que todos os termos científicos só adquirem significado quando passíveis de alguma interpretação empírica. Esse dogma foi formulado por Bridgeman, nos artigos que escreveu em 1951: 'A idéia fundamental que norteia o operacionismo é simples; a saber, a de que não conhecemos os significados de um conceito a menos que possamos especificar as operações que foram realizadas, por nós ou por outrem, ao aplicar o conceito a qualquer situação concreta'” (op. cit., p. 105).
\end{abstract}

Apesar de certas dificuldades, tais como certo grau necessário de subjetividade na interpretação dos resultados operacionais, quando de sua vinculação ao conceito, em especial nos casos de conceitos não-físicos (a definição operacional de

115 O exemplo é: "Dizer que os diamantes são mais duros que o vidro significa: se o gume afiado de um diamante descrever um traço firme numa superfície de vidro, deixará nela um arranhão; se a aresta afiada de uma peça de vidro descrever um traço firme na superfície de um diamante, não deixará nela o menor arranhão" - esta é a definição operacional de «dureza do diamante`. (op. cit., p. 77). 
inteligência, por meio de operações concretas, é um bom exemplo), o método definidor operacionista é extremamente útil para destacar, dentre outros fatores, a necessidade da clara formulação de objetivos e de critérios para se alcançá-los ${ }^{116}$.

No que diz respeito aos cuidados necessários na aplicação das definições intensionais objetivas operacionais, SALMON (op. cit., p. 79) lembra que é importante ter em conta que os juízos objetivos, obtidos pelo método operacionista, podem entrar em conflito com os juízos subjetivos nas mesmas circunstâncias ${ }^{117}$.

Também, é necessário que os procedimentos operacionais adotados como método definidor estejam de acordo com aquilo que é de mais consistente sob o ponto de vista das teorias envolvidas. Em especial, é necessário que esteja claramente estabelecido o âmbito de aplicabilidade do método operacional que se presta como referência definidora: não pode haver inconsistência metodológica de qualquer tipo, nem dentro e nem fora dos parâmetros operacionais estipulados.

Enfim, é importante, nas definições operacionais, ter sempre certeza absoluta sobre a justa correspondência entre o conceito definido e a operação que se presta como método definidor.

Como exemplos de definições intensionais operacionais, temos:

1. /agressiva $\leftarrow \pi$ <considerando uma determinada pessoa ' $P$ ', colocada em uma sala junto a pessoas encarregadas de realizar uma tarefa, estando a sala em condições específicas ' $C$ ', permite-se que a pessoa ' $P$ ' aja livremente, sem qualquer atribuição oficial, sob a observação de câmaras ocultas. Se a ação de ' $P$ ' for no

\footnotetext{
${ }^{116}$ Como um resumo dos princípios operacionistas, temos: "1. Os significados são operacionais. Para conhecer o significado de um termo é preciso conhecer os critérios operativos de seu uso e cada termo científico deve admitir uma definição operativa. Essa definição pode referir-se a certas operações mentais e deve, em última instância, fazer alusão a alguma operação instrumental. 2. Para evitar indefinições intensionais, cada termo científico deve ser definido por meio de um só critério operativo. 3. A insistência em que os termos científicos tenham significados não ambíguos destina-se a assegurar a realização de testes objetivos para as hipóteses que venham a ser formuladas com tais termos" (HEGENBERG, op. cit., p. 107).

${ }^{117}$ É o que ocorre em situações nas quais nossos sentidos podem ser iludidos: "A temperatura de uma fumegante xícara de café deve resultar superior à de um copo de água gelada; a temperatura num típico dia de verão no Saara deve ser superior à de um típico dia de inverno no Círculo Polar Ártico. Uma definição em função das leituras em termômetros de mercúrio produzirá tais resultados. Contudo, alguns dos nossos juízos subjetivos de temperatura serão rejeitados. Nossa sensação de frio num ventoso dia de inverno será diferente da de um dia calmo, embora o termômetro forneça a mesma leitura. Compreendemos, entretanto, que nossos juízos subjetivos não são, por vezes, confiáveis, e estamos dispostos a aceitar o termômetro como um padrão objetivo". (op. cit., p. 79).
} 
sentido de inibir ou reduzir a ação livre e eficiente das demais pessoas da sala, então ' $P$ ' será considerada 'agressiva's /;

2. /inteligente $\leftarrow \pi$ «considerando uma determinada pessoa ' $P$ ', colocada um uma sala em condições específicas ' $C$ ', estipula-se um período de tempo ' $T$ ' (5 [cinco] minutos) para que ' $P$ ' desenvolva o maior número possível de definições por gênero e diferença específica relativas a 5 (cinco) conceitos metafísicos. Se ' $P$ ' produzir no tempo ' $T$ ' pelo menos uma definição válida para cada um dos cinco conceitos metafísicos, então ' $P$ ' será considerada 'inteligente's /.

\section{5 definição intensional objetiva condicional}

Tratamos anteriormente das denominadas "definições intensionais objetivas teoréticas", afirmando que tais definições implicam simultaneamente a definição de um conceito e a proposição, consolidação ou refutação de teoria(s): a própria definição é um esforço de formular uma descrição científica adequada de seu definiendum. Ou seja, o texto definidor representa, ao mesmo tempo, a definição do definiendum e a formulação de uma teoria cientificamente consistente vinculada à qüididade desse conceito.

Agora, podemos mencionar um tipo de definição aparentado: trata-se das definições intensionais objetivas condicionais, as quais se baseiam no seguinte fato: as teorias comportam uma série de sentenças ou proposições; cada uma destas estipula como pressupostos os contextos nos quais se devem interpretar os termos teóricos dessa teoria particular. Assim, conforme Hegenberg, para a definição de comportamento racional segundo a Economia, temos que:

\footnotetext{
"Para um economista, digamos, a sentença ' $X$ se comporta racionalmente' significa, por definição, 'Se várias alternativas se abrem para $X$, então $X$ hierarquiza as suas preferências de algum modo coerente'. Definições que toma essa forma são, muitas vezes, chamadas 'definições condicionais'. O antecedente especifica de que maneira e em que circunstâncias as observacões serão realizadas. O conseqüente especifica os comportamentos que, nas circunstâncias em causa, serão admitidas como 'casos' do termo definido". [...] (op. cit., pp. 77-
} 78). 
Ou seja, a estrutura definidora neste caso seria: /comportamento racional $\leftarrow \pi$ ¿X se comporta racionalmente se, ao se oferecerem várias alternativas, $X$ hierarquiza suas preferências de modo coerentes/. Como se vê, "o antecedente especifica de que maneira e em que circunstâncias as observações serão realizadas" ["se, ao se oferecerem várias alternativas"] e "o conseqüente especifica os comportamentos que, nas circunstâncias em causa, serão admitidas como 'casos' do termo definido" ["X hierarquiza suas preferências de modo racional, então X se comporta racionalmente"].

Como exemplos de definição intensional condicional, temos:

1. /agressiva $\leftarrow \pi$ ra pessoa ' $P$ ' será considerada 'agressiva' se, ao se oferecerem várias alternativas de comportamento em relação a pessoas concorrentes, ' $P$ ' reiteradamente escolher a alternativa que causa maior dano psicológico e, se possível, físico, a esses concorrentesı/;

2. /inteligente $\leftarrow \pi$ ra pessoa ' $P$ ' será considerada 'inteligente' se, ao se oferecerem várias alternativas de ação, ' $P$ ' invariavelmente escolher a alternativa que melhor assegurar sua integridade física, psicológica e socialı/.

\section{6 definição intensional objetiva por atributos secundários}

Como vimos nos dois tipos anteriores de definição, os conceitos de gênero, diferença específica e quatro causas implicavam a declaração de características essenciais e necessárias para que o objeto definido pudesse ser rigorosamente destacado como aquele objeto particular em sua qüididade. Trata-se do conceito de intensão objetiva - conjunto total de características compartilhadas por todos os objetos na extensão do termo. Temos, além dessa: a) a intensão subjetiva: conjunto de todos os atributos que o falante crê serem possuídos pelos referenciais denotados por um dado termo, características essas que comporão, segundo esse ponto de vista, a intensão do conceito; b) a intensão convencional: intensão compartilhada pelos usuários de um conceito, nem exclusivamente subjetiva, nem absolutamente objetiva, que surge pela existência de algum tipo de "acordo coletivo" 
sobre os critérios de uso do conceito e de suas referências. Vimos que, às vezes, convém adotar como essencial uma intensão convencional e não sua correspondente intensão objetiva.

Tal tipologia de intensões aponta para uma série de questões teóricas e práticas; dentre elas:

a) quanto à intensão objetiva, é possível que se torne impossível, muito difícil ou inadequado buscar características essenciais e necessárias, capazes de configurar indiscutivelmente a qüididade de um ser: HEGENBERG (op. cit., pp. 2526) mostra casos em que há dificuldades ou inconveniências em se consumar concretamente definições por gênero e diferença: por exemplo, talvez interesse mais definir: /cobre $\leftarrow \pi$ «metal de número atômico 29〉/, sem cogitar de gênero e diferença. Ou então, talvez convenha assim definir: / prata $\leftarrow \pi$ «símbolo 'Ag'; peso atômico 107,87; número atômico 47; metal branco e relativamente dúctil; gravidade específica 10,5; ponto de fusão 960,5 graus Celsius; o melhor condutor de eletricidade conhecido pelo homem /;

b) a tipologia de intensões apresentada destaca uma questão epistemológica: trata-se de saber em que medida temos acesso consciente à qüididade dos seres ou, então em que medida nos interessa praticamente essa essencialidade real (em outras palavras, indaga-se pela real preocupação prática com a determinação da verdadeira natureza dos seres cujos conceitos mobilizamos por meio dos termos empregados nas comunicações verbais do quotidiano);

c) cabe verificar a pertinência da noção de intuição intensional: se considerarmos que/intuição $\leftarrow \pi$ sfaculdade de perceber, discernir ou pressentir coisas, independentemente de raciocínio ou análise; forma de conhecimento direta, clara e imediata, capaz de investigar objetos pertencentes ao âmbito intelectual, a uma dimensão metafísica ou à realidade concreta; fenômeno que se apresenta com a clareza de uma evidências/, podemos indagar sobre o quanto de nosso conhecimento intensional é objetivo, subjetivo, convencional ou, ao contrário, puramente intuitivo — no sentido de se produzir conhecimento por apreensão de fenômenos que constituem uma realidade sem que intervenha um processo racional e crítico consciente por parte do agente cognoscitivo. Trata-se, digamos, de um 
conhecimento produzido e/ou conservado por 'insights' (compreensão de uma idéia ou de um conceito pela súbita captação mental dos elementos e relações implicadas nessa idéia ou conceito; ato de apreender a natureza e essência de um objeto; visão intuitiva) que não exigem qualquer discurso definidor constitutivo.

Assim, podemos conceber que, no homem, uma massa de conhecimentos seja constituída pela apreensão intensional de conceitos vinculados a nomes e referenciais, sem o contínuo processamento intelectual de tais conceitos (ou seja, sem que se questione continuamente a composição intensional dos conceitos utilizados): tal apreensão dar-se-ia por intuição e os resultados de tal processo integrariam como pressupostos a construção, mediante juízos, de novos conceitos.

Isso justificaria o fato de que freqüentemente os indivíduos produzem discursos a respeito de fatos e realidades sem, contudo, conhecer essencialmente os seres cujos conceitos são incluídos como pressupostos argumentativos. Assim, é possível encontrar discursos que afirmem que determinado homem cometeu um crime por estar "privado de sua razão"; tal afirmação é, em si mesma contraditória, pois, por definição intensional objetiva, o conceito de homem constrói-se a partir dos conceitos de animalidade (ıser vivo organizado, dotado de sensibilidade e movimento») e racionalidade («capacidade de exercer a própria razão ou exercer a faculdade de raciocinar, apreender, compreender, ponderar e julgar os fatos e a realidades); portanto, um homem não pode estar privado de razão e, ao mesmo tempo, continuar a ser homem. No entanto, nossa intuição intensional, por automatismo, não questiona o paradoxo e aceita a existência de "homens irracionais" - e mais, adota tal paradoxo como um pressuposto para novos juízos aparentemente irrepreensíveis (tais como: "Meu cliente cometeu o crime por estar dominado por fortíssima emoção e estar, por isso, privado de sua razão; nessas condições, não pode ser responsabilizado pelo homicídio e deve ser absolvido". No entanto, o mesmo advogado relutaria em validar a inferência: "Assim sendo, estamos julgando um ser que, durante a realização do ato criminoso, não era um homem naquele preciso momento e, portanto, abdicou então de todos os direitos de humanidade. Ele não deve, assim, ter as mesmas prerrogativas dos homens no julgamento desse ato criminoso"). 
A partir do conceito de intensão intuitiva ou intuição intensional, parece razoável considerar que parte de nosso conhecimento - e mais, parte dos discursos sobre nosso conhecimento - é construída por meio de intensões intuitivas, as quais explicam por que podemos discorrer tranqüilamente sobre objetos cujas qüididades nos são desconhecidas, sem que saibamos defini-los: temos deles uma apreensão conceitual global e intuitiva (mais ou menos grosseira), mesmo que não possamos definir exatamente sua intensão objetiva (grosso modo, sem que saibamos exatamente sobre o quê falamos; lembremos, a propósito, as epígrafes deste trabalho: podemos desenvolver um imenso trabalho científico a partir do conceito de quarto [ ‘cômodo onde se dorme $)^{118}$ ], sem que consigamos dar uma definição precisa das características essenciais e necessárias [ou a qüididade] de um quarto).

Um teste parece suficiente: diante de um juízo tal como "O analfabetismo no Brasil tem diminuído muito no atual governo", basta indagar - "Como se define aqui o conceito de analfabetismo? -; caso a resposta seja: Mas isso é óbvio" ou "Não sei exatamente", provavelmente estaremos diante de um uso intensional intuitivo do conceito (ou seja, somos incapazes de defini-lo precisamente, mas não nos furtamos de utilizá-lo corriqueiramente; é provável que consideremos ser o analfabetismo a incapacidade de ler e escrever - afirmação que nos leva a indagar se aqueles que apenas sabem escrever seu nome e reconhecer os grafemas do português são alfabetizados);

d) importa distinguir entre a intensão intuitiva (ou intensão por 'insight') e a intensão subjetiva:

i) esta implica, simplesmente, a capacidade de assinalar um conjunto de traços que o usuário crê serem pertinentes a um conceito: como vemos, menciona-se verbalmente o conjunto de traços constitutivos do conceito. Trata-se, portanto, de uma apreensão epistemológica individual, que pode ser determinada por uma crença pessoal ou, também, por um determinado tipo de conhecimento científico, embora não possua estatuto necessário para gerar uma intensão objetiva.

\footnotetext{
${ }^{118}$ Se a definição/quarto $\leftarrow \pi$ «cômodo onde se dormes / for válida, um quarto continua a ser um quarto se nele jamais dormimos? Mudaríamos a planta da casa (planta sob o ponto de vista da Arquitetura...) caso, porventura, cochilássemos na cozinha?
} 
Assim, entender a intensão do conceito de televisão como raparelho eletrônico que produz imagens sob a influência do Demônio e que é capaz de fazer pecar o homem, lançando-o ao Infernos representa uma apreensão subjetiva dessa intensão; firmada coletivamente, passa a caracterizar uma intensão convencional que identifica uma determinada doutrina religiosa;

ii) por sua vez, a intensão intuitiva implica uma apreensão global, instantânea e não-verbal de um objeto de definição — em suma, um 'insight' conceitual que não demanda, para existir, a formulação explícita dos conceitos formadores de uma intensão ou dos traços constituintes desses conceitos. Isto é, a intensão intuitiva se manifesta como uma convicção ou uma certeza sobre a pertinência de um objeto de conceito, considerado como uma unidade ou totalidade, sem que se exija uma formulação verbal dos juízos que compõem tal conceito.

Outra diferença básica entre a intensão subjetiva e a intensão intuitiva reside em que esta pode aproximar-se ou coincidir com a intensão objetiva, enquanto aquela sempre é uma crença de âmbito pessoal que não possui caráter universal ou certeza científica: a intensão intuitiva possui a clareza de uma evidência (como, por exemplo, a certeza de que, ao pensar, manifestamos nossa capacidade de pensar) — nesse aspecto, é indiscutível —; a intensão subjetiva traz em si, conforme o nome indica, a marca da relatividade, do perspectivismo, da opinião — nesse aspecto, é passível de contestação.

Como exemplo, o seguinte conceito - /crianção $\leftarrow \pi$ «criança grande; pessoa adulta que possui alma infantil, agindo como criançà / — possui uma formulação definidora que pode ser acusada de ambigüidade e vaguidão: dizer que crianção equivale à criança grande levanta dúvidas, pois nos referimos a maiores de $1 \mathrm{~m} 70 \mathrm{~cm}$ ou a maiores de dezesseis anos? Também, pessoa adulta que possui alma infantil significa pessoa que atingiu a maioridade, mas conserva a pureza de espírito? E agir como criança significa agir com franqueza e expressar abertamente seus sentimentos?

Vemos a imprecisão conceitual desse definiens; contudo, não parece haver dúvida que o juízo - "Garotinho parece um crianção" — seria considerado inteligível e plenamente compreendido pela maioria dos falantes do português brasileiro, que a 
ele atribuiriam pertinência. O mistério está em que, naturalmente, usamos de maneira definitiva conceitos que somos incapazes de definir ou deles temos simplesmente 'insights' conceituais, de modo a dizermos: "Não sei explicar o conceito, mas sei do que se trata".

Tendo isso em vista, pensamos ser conveniente e cabível distinguir entre duas categorias ou níveis de traços essenciais: a) traços essenciais de inerência primária; b) traços essenciais de inerência secundária ${ }^{119}$.

Os primeiros representam as características essenciais que devem ser incluídas obrigatoriamente em um conceito para que este declare - clara e distintamente - a qüididade de um ser; são, portanto, traços necessários e suficientes que não apenas não podem ser contrariados, mas também não podem se ausentar.

Os segundos representam as características essenciais não necessárias e não suficientes que convêm ser incluídas em um conceito para determinar a qüididade do ser, mas que podem se ausentar sem comprometer a consistência do conceito; contudo, mesmo ausentes, eles são pressupostos, pois não podem ser contrariados, sob pena de descaracterizar aquele conceito particular.

Assim, a definição - /água $\leftarrow \pi$ «substância líquida cuja composição molecular é constituída por um átomo de oxigênio e dois átomos de hidrogênio e cuja fórmula química é $\mathrm{H}_{2} \mathrm{O}$, / _ é formada por traços essenciais de inerência primária: água deve necessariamente ser líquida; sua constituição molecular é a declarada pelo definiens e essa composição é uma inerência primária para sua qüididade.

Por outro lado, /água $\leftarrow \pi$ 〈substância insípida, incolor e inodora) / caracteriza traços essenciais de inerência secundária, pois são, de fato, inerentes ao conceito de água (uma água sápida, colorida e odorante não mais seria a água propriamente dita), mas não são indispensáveis para caracterizá-lo enquanto tal. Como vemos, mesmo ausentes, tais traços não podem ser contrariados.

${ }^{119}$ Para o conceito de inerência, rever Capítulo II. 
Um critério de identificação possível: os traços inerentes secundários não são fatores sine quibus non para declarar a qüididade de um ser; contudo, sua ausência descaracteriza ou distorce o conceito, de modo a inviabilizá-lo em sua capacidade de definição, sob o ponto de vista do rigor conceitual. Assim, uma água colorida inegavelmente é uma manifestação particular do objeto geral denominado "água", mas não podemos confundir o conceito de água com o conceito de água colorida: aqui, o atributo faz a diferença.

Esses dois modos de expressão da essência inerencial não se confundem com os traços contingentes de um conceito ou de uma dada manifestação empírica. Essas são traços absolutamente dispensáveis, cuja ausência ou presença em nada afeta a qüididade do ser e seu conceito. Assim, o juízo — "A água é fria" — declara uma característica absolutamente eventual desse objeto, fator esse que em nada contribui para o conhecimento da substancialidade da água, mas que, sem dúvida, é um de seus modos de manifestação sensível.

Por fim, devemos distinguir as predicações subjetivas (pseudodefinições predicativas subjetivas), estruturas que declaram atributos impertinentes ao conceito de um ser. Em suma, são aquelas predicações que declaram atributos que não pertencem ao objeto em si, mas que assim são considerados pelo sujeito que emite o juízo. Assim, o juízo "A água é santa", temos uma predicação que não declara nem um traço essencial de inerência primária, nem um traço essencial de inerência secundária, nem, enfim, um traço acessório ou contingente: trata-se de um traço predicativo de pura subjetividade - um traço inerente à percepção do sujeito enunciador e não inerente a seu objeto de enunciação.

Resumindo: no exemplo fornecido, a essência santidade não está na essência água (ou seja, não the é inerente, nem essencial, nem contingencialmente), mas aquela é aplicada a esta por conta daquele que elabora a proposição; assim, há um juízo subjetivo, expresso lingüística e discursivamente, que, de alguma forma, (re)elabora o objeto água de modo a dispô-lo a receber o predicado santa.

Mais alguns exemplos; nas características contingentes de uma manifestação empírica, temos sempre traços intrínsecos ao objeto de definição, ou seja, traços que não são dados pela subjetividade do sujeito definidor. Assim, o enunciado " $A$ 
água está quente" apresenta uma característica contingente do conceito de água; porém, tal característica lhe é possivelmente inerente. Já o enunciado "A água é suave" propõe uma caracterização subjetiva desse conceito, uma vez que tal traço é produto de um juízo doxológico do sujeito definidor (de fato, a suavidade não faz parte da intensão contingente do objeto água - embora tal característica possa ser crível, pois, subjetivamente, o tato assim a poderia identificar -; já o calor pode contingencialmente ser inscrito na intensão do conceito).

A tabela seguinte resume essa discussão:

\begin{tabular}{|l|l|}
\hline $\begin{array}{l}\text { definição por traços essenciais } \\
\text { de inerência primária }\end{array}$ & $\begin{array}{l}\text { "O som é vibração que se propaga em meio elástico } \underline{\text { com }} \\
\text { freqüência entre vinte e vinte mil herz" }\end{array}$ \\
\hline $\begin{array}{l}\text { definição por traços essenciais } \\
\text { de inerência secundária }\end{array}$ & "O som é vibração capaz de ser percebida pelo ouvido humano" \\
\hline $\begin{array}{l}\text { definição por traços } \\
\text { contingentes }\end{array}$ & "O som é estridente" \\
\hline $\begin{array}{l}\text { pseudodefinição predicativa } \\
\text { subjetiva }\end{array}$ & "O som é agradável" \\
\hline
\end{tabular}

Como exemplos de definições intensionais por traços contingentes, temos:

1. lagressiva $\leftarrow \pi$ <uma pessoa ' $P$ ' será 'agressiva' se for competitiva e violenta na utilização de meios para atingir os fins pretendidosı /;

2. /inteligente $\leftarrow \pi$ <uma pessoa ' $P$ ' será 'inteligente' se manifestar-se sempre de forma comedida e ponderada/s.

Como vemos, competitividade e violência na utilização de meios visando a fins são traços que contingencialmente podem estar vinculados ao conceito de agressividade. Também, ponderação e comedimento são traços que se vinculam contingencialmente ao conceito de inteligência.

2.7 definição intensional objetiva estipuladora

Até este ponto, ao tratarmos das definições intensionais objetivas, pressupúnhamos um processo de análise conceitual: havia a decomposição do 
conceito complexo em conceitos singulares (que, por sua vez, podiam igualmente ser complexos) que o constituíam. Agora cabe assinalar a presença de definições intensionais objetivas resultantes de um processo de síntese.

Antes de concluir o estudo das definições deste grupo, cabe destacar que consideramos pertinente a ele uma das modalidades das denominadas "definições estipuladoras", por poderem estas ser compreendidas em um sentido objetivo e em um sentido subjetivo-convencional. Quando forem entendidas no sentido objetivo, serão denominadas "definições intensionais objetivas estipuladoras"; quando forem entendidas em um sentido subjetivo-convencional, serão denominadas "definições intensionais subjetivo-convencionais estipuladoras".

Consideremos aqui as definições intensionais objetivas estipuladoras; enquanto operação conceitual, essas definições propõem — ou seja, estipulam uma relação entre um novo conceito (re)elaborado (conceito derivado) e um conjunto de conceitos já existentes (conceitos primitivos); esse novo conceito passa a ser vinculado a um termo específico (um nome e seu significado). Trata-se de uma definição de caráter objetivo, pois a qüididade da substância está presente como fruto dessa (re)elaboração: em outras palavras, ocorre uma síntese de juízos (ou síntese de conceitos) que gera como resultado um conceito derivado que pode ou não possuir um referencial práxico.

A razão pela qual temos aqui uma definição objetiva repousa no seguinte princípio: a síntese de conceitos derivados que estabelecem a qüididade de uma substância pressupõe a escolha de conceitos primitivos essenciais à constituição desse conceito; conceitos acessórios ou conceitos impertinentes não seriam logicamente incorporados como característicos do conceito derivado (ou seja, seria irracional mencionar quaisquer traços conceituais que fossem menos do que essenciais). Portanto, o produto sintetizado só pode ser considerado um conceito intensional objetivo: fora disso, teríamos conceitos intensionais subjetivoconvencionais estipuladores ou, então, puras pseudodefinições.

Parece-nos importante considerar este tipo de processo, dada sua freqüência e razoabilidade: com efeito, se a racionalidade humana aplica-se a conhecer aquilo que entende por realidade, não só a conhece por análise (ou seja, pela operação de 
decompor os conceitos complexos e derivados em seus conceitos singulares e primitivos), mas também a conhece por síntese - isto é, pela operação de (re)compor conceitos complexos e derivados a partir de seus conceitos singulares e primitivos —:o fato de realizar essa síntese conceitual não implica ausência de realidade ou não-plausibilidade ontológica.

Assim, esse processo equivale a uma estipulação conceitual, daí o nome deste tipo de definição: se considerarmos os conceitos de filósofo, humanidade, animalidade, racionalidade, dedicar-se, estudar, visar, compreender, realidade absoluta, causas primeiras, fundamentos, valores, sentido, existir, podemos sintetizar o seguinte conceito: /filósofo $\leftarrow \pi$ ranimal racional que se dedica a estudos que visam a compreender a realidade absoluta, as causas primeiras, o fundamento dos valores humanos e o sentido da existência/. Se, por outro lado, considerarmos os conceitos de humanidade, animalidade, racionalidade, pensar, criticar, investigar essências, verdade absoluta, podemos sintetizar: /filósofo $\leftarrow \pi$ ranimal racional que pensa criticamente e investiga as essências e as verdades absolutası/.

Verificamos que ambas as definições declaram a qüididade do ser filósofo; nenhuma delas pode ser impugnada sob tal ponto de vista. Assim, parece-nos razoável considerar uma leitura específica do princípio da essencialidade necessária ou substancialidade, quando aplicado às definições: as sínteses apresentadas anteriormente parecem apontar para a possibilidade de mais do que uma manifestação discursiva da essência necessária.

É indiscutível que podemos conceber o conceito de manifestação discursiva ideal da essencialidade necessária: seria o discurso definidor que declara todos os traços essenciais (necessários e suficientes) para que a qüididade de um ser fosse estabelecida universalmente. Tal ser seria expresso conceitualmente por essa definição e apenas por ela.

Mas cabe indagar: dois discursos que declaram, cada um deles, uma parte desses traços essenciais - de modo que, ambos em conjunto declaram a universalidade conceitual — podem ser considerados ainda definições essenciais ou 
assim não devem mais ser considerados? Podemos trabalhar com o conceito de discurso essencialista parcial?

Vejamos exemplos: a) /filosofia $\leftarrow \pi$ ssaber entendido como amor ao conhecimento sobre o mundo e os homens /; b) /filosofia $\leftarrow \pi$ (sabedoria entendida como disposição humana para uma vida virtuosa e feliz $/{ }^{120}$. Ambas podem ser consideradas definições intensionais essenciais ou substanciais legítimas: ambas declaram a qüididade da essência filosofia - fato que não aconteceria na pseudodefinição puramente etimológica "filosofia" $\approx$ "palavra derivada de fili/a (amizade) e sofi/a (saber; ciência)" —, pois a filosofia é, ao mesmo tempo, desejo de conhecer a realidade e disposição para a virtude e a felicidade. Não poderíamos considerar que apenas uma dessas definições esgota em si mesma a essência conceitual do definiendum; ao mesmo tempo, não podemos legitimamente impugnar qualquer uma delas.

Concluímos, portanto, que convém considerar a possibilidade de existir mais do que uma definição intensional objetiva de um mesmo conceito - ou seja, que um objeto de definição possua mais do que uma possibilidade de reunir em um conceito características essenciais que constituam sua qüididade. Isso se dá segundo duas interpretações:

a) duas ou mais definições intensionais objetivas declaram parte do universo de características essenciais de uma substância, de modo que, em conjunto, tais definições definem completa e absolutamente tal ser. Teremos, então, definições intensionais objetivas complementares;

b) duas ou mais definições intensionais objetivas declaram dois ou mais fenômenos (no sentido husserliano ${ }^{121}$ ) de uma mesma substância. É o caso do

\footnotetext{
${ }^{120}$ Marilena CHAUÍ Introdução à filosofia: dos pré-socráticos a Aristóteles, volume um. $2^{\mathrm{a}}$ ed. São Paulo: Companhia das Letras, 2002, p. 15.

${ }^{121}$ ABBAGNANO (2003, pp. 436-437, verbete "fenômeno") registra: 1) O mesmo que aparência. Nesse sentido, o fenômeno é a aparência sensível que se contrapõe à realidade, podendo ser considerada manifestação desta, ou que se contrapõe ao fato, do qual pode ser considerado idêntico. [...]; 2) A partir do século XVIII, em virtude da reabilitação da aparência como manifestação da realidade aos sentidos e ao intelecto do homem, a palavra 'fenômeno' começa a designar o objeto específico do conhecimento humano que aparece sob condições particulares, características da estrutura cognitiva do homem. [...] Nesse sentido, o fenômeno não é o objeto que se manifesta, mas o objeto que se manifesta ao homem nas condições limitativas específicas que essa relação implica; 3)
} 
conceito de filosofia anteriormente apresentado: filosofia enquanto saber e filosofia enquanto sabedoria: seria legítimo descartar uma dessas versões? Se assim for, qual o critério? Devemos considerar que a filosofia diz respeito ao saber adquirido ou convém entender que a filosofia diz respeito ao estado alcançado pela posse desse saber? Não seria mais adequado entender que se trata aqui de duas manifestações fenomênicas de um mesmo ser — a filosofia — de modo que, cada qual, contribui para aumentar nosso conhecimento sobre esse conceito? Teremos, então, definicões intensionais objetivas suplementares.

Para nossos propósitos, convém considerar ambas as possibilidades anteriores; entendendo que podem ocorrer sínteses conceituais complementares e/ou suplementares estipuladoras: todas elas compreendidas, como afirmamos, em caráter objetivo.

A partir dessas observações, convém entender que os objetos-de-discurso podem atender aos requisitos propostos: enquanto discursos fundadores (ou seja, como discursos que inauguram uma nova realidade ontológica), os discursos que propõem objetos-de-discurso representam um tipo de definições intensionais objetivas estipuladoras. Se propusermos, por exemplo, o seguinte enunciado: "Ele colocou à venda sua 'mansão' - aquela tapera de $100 m^{2}$, construída em um barranco enlameado" - , estaremos inaugurando a seguinte estrutura definidora: /'mansão' $\leftarrow \pi$ < tapera de 100m², construída em um barranco enlameado /. Sem essas características declaradas no definiens, essa 'mansão' assim especificada deixaria de sê-lo.

Como exemplos gerais dessas definições, temos:

1. legoísmo $\leftarrow \pi$ «submissão do dever ao interesse particular, em detrimento da obediência à lei moralı /;

2. /mol $\leftarrow \pi$ «massa molecular de uma substância expressa em graması/;

Todavia, na filosofia contemporânea, a partir das Investigações lógicas (1900-1901) de Husserl, 'fenômeno' passou a indicar não só o que aparece ou se manifesta ao homem em condições particulares, mas aquilo que aparece ou se manifesta em si mesmo, como é em si, na sua essência. [...] Obviamente, neste sentido a noção de fenômeno não se opõe mais à de coisa em si: o fenômeno é o em si da coisa em sua manifestação, não constituindo, pois, uma aparência da coisa, mas identificando-se com o seu ser". 
3. /ânion $\leftarrow \pi$ 〈íon com carga elétrica negativa /.

C) GRUPO III - DEFINIÇÕES CUJO DEFINIENS É UM DISCURSO SOBRE CONCEITOS (OU OBJETOS MENTAIS) SUBJETIVOS OU CONVENCIONAIS, INDIVIDUAIS OU COLETIVOS, E QUE DIZEM RESPEITO AOS SIGNIFICADOS DOS TERMOS LINGÜÍSTICOS (DEFINIÇÕES INTENSIONAIS SUBJETIVAS OU CONVENCIONAIS — "DEFINIÇÕES SEMIÓTICAS" OU "SIGNAÇÕES")

Neste grupo, temos as definições intensionais subjetivas e/ou convencionais; no grupo anterior, focalizamos as definições intensionais objetivas: estas tomam por objeto os traços essenciais de uma substância (mencionando o conjunto total ou parcial de características compartilhadas por todos os objetos na extensão do termo); aquelas - enquanto: a) um conjunto de atributos que se crê serem pertinentes a um conceito; b) um tipo de intensão aceita e compartilhada pelos usuários, que surge por uma espécie de acordo social sobre os critérios de uso do conceito - tomam por objeto os significados do termo vinculado a tal conceito. Assim, passamos da relação essência de uma substância $\longleftrightarrow$ conceito para a relação conceito $\longleftrightarrow$ significado de um signo.

Esclareçamos perfeitamente esse ponto:

a) as definições intensionais objetivas, por enfeixarem em seus conceitos o conjunto de características necessárias e suficientes para declarar a qüididade de um ser extralingüístico ou extradiscursivo, transcendem o plano estritamente semiótico: o conceito definido corresponde à substância representada pelo conceito; por sua vez, tal conceito é representado lingüisticamente por um signo;

b) as definições intensionais subjetivas e convencionais não implicam o conjunto de características necessárias e suficientes - possuídas por todos os membros da extensão de um conceito - para que um ser seja aquele ser em particular; implicam, isto sim, uma percepção e/ou crença individual sobre tal 
conjunto de características e uma convenção social de uso desse conceito. Assim sendo, já não faz sentido compreender a equivalência entre o conceito definido e o ser extralingüístico representado por esse conceito (uma vez que tal conceito já não é substancial, ontologicamente falando); devemos, portanto, rebaixar o nível de exigência ontológica e aceitar que não teremos $\underline{o}$ conceito (assim como já falamos em $\underline{o}$ significado), mas definiremos um conceito (um significado) e trataremos em âmbito lingüístico-discursivo aquilo que idealmente pretendíamos tratar em âmbito metafísico ou ontológico. Em suma, definições intensionais objetivas definem conceitos que refletem qüididades ontológicas; definições intensionais subjetivas e convencionais definem conceitos que refletem significados lingüísticos vinculados a nomes: lá procuramos conhecer substâncias; cá procuramos conhecer signos.

Portanto, explica-se a denominação "definições semióticas", pois tratamos de definições que focalizam a constituição e o estabelecimento de signos (seus significados) - degrau imediatamente inferior à constituição e o estabelecimento de essências representativas de substâncias. Tais definições podem também ser denominadas "signações".

Para nós, interessa descartar o uso tradicional das denominadas "definições nominais", substituindo-as pelas definições semióticas; isso porque entendemos que falar em definição nominal ( $\approx$ "definição relativa a um nome") leva a erro de interpretação: não se trata, verdadeiramente, de definir nomes: para nós, as definições nominais são as definições intensionais subjetivo-convencionais autonímicas que, de fato, definem os nomes - isto é, os significantes dos termos em uso.

Preliminarmente, interessa considerar os conceitos tradicionais de definição nominal (conceito que, como afirmado, será aqui designado pelas expressões "definição semiótica" ou "signação"). Por "definição nominal" (também conhecidas por "definições explícitas") entende-se:

a) "[...] espécie de convenção que sugere alternativa para uma expressão lingüística previamente dada. A notação alternativa, usualmente breve, substitui, em tais casos, uma expressão mais longa, à maneira de uma estipulação" (HEGENBERG, op. cit., p. 28); 
b) "uma definição que permite a simples substituição do definiendum pelo definiens, em qualquer sentença, sem necessidade de alteração do restante da sentença" (HEGENBERG, Ibidem., p. 128). Como exemplo, /"antibiótico" $\approx$ "agente químico bactericida produzido por organismos vivos"/; tal definição permite que, em qualquer contexto, o definiendum e o definiens sejam empregados como sinônimos lingüisticamente intercambiáveis ${ }^{122}$.

Como se vê, a definição nominal equivale à sentença lingüística "seja o enunciado ' $B$ ' sinônimo do termo ' $A$ '"; nessa sentença, ocorrem expressões lingüísticas, ou seja, nomes ou termos lingüísticos colocados entre aspas simples: em outra formulação, obtemos "o termo 'A' é equivalente, por definição, ao enunciado ' $B$ '".

É comum compreender-se que a definição nominal não se limita a definir um nome, mas também define o conceito vinculado a esse nome; isso porque "a definição nominal seleciona um conceito (ou seja, uma entidade não-lingüística, $e$. g., uma propriedade, uma classe, uma relação ou algo semelhante) e the atribui um nome particular" (HEGENBERG, Ibidem, p. 29). Em verdade, não há aqui a elaboração de um conceito: simplesmente, as relações que se estabelecem entre os significados dos termos mencionados não podem estar desvinculadas dos conceitos que correspondem a esses significados, segundo a progressão: substâncias $\longleftrightarrow$ essências $\longleftrightarrow$ conceitos $\longleftrightarrow$ significados $\leftarrow$ nomes.

Podemos considerar, portanto, a seguinte distinção entre definições nominais e definições reais ou ideais:

a) as definições reais ou ideais declaram em seu texto definidor a qüididade de uma substância e seu correspondente conceito. Nesse sentido, o definiens busca idealmente "capturar a natureza essencial" do definiendum, considerado não como um nome, mas sim como um conceito (identificado por aquele nome particular);

b) as assim consideradas definições nominais propõem, por meio de seu texto definidor, uma sinonímia entre definiendum e definiens, estipulando a identidade "a

${ }^{122}$ É possível, portanto, construir os enunciados lingüisticamente equivalentes: a) "O antibiótico produziu o efeito esperado"; b) "O agente químico bactericida produzido por organismos vivos produziu o efeito esperado". Resta indagar se, semântica e pragmaticamente, tais enunciados serão percebidos como equivalentes por parte dos interagentes. 
expressão 'definiens' é igual, nesta definição, ao nome 'definiendum' (sentença que pode ser simbolizada por "definiendum $=_{d}$ definiens"). Como se vê, uma definição nominal pretende fornecer uma alternativa lingüística (o definiendum) para uma expressão já dada (o definiens). Idealmente, haverá a possibilidade de permuta sinonímica incondicional entre ambos.

Como exemplo de definições do grupo três, temos: "o termo 'definiendum' é, por definição, igual ao enunciado 'definiens'" $\rightarrow$ "O termo 'cão' é igual, por definição, ao enunciado 'peça da espingarda que percute a cápsula'". Nesse caso, definiendum e definiens permutam-se naturalmente (em qualquer ocorrência, dentro de um determinado contexto), sem que haja a necessidade de adaptações co-textuais. Assim, podemos escolher entre utilizar o termo "cão" ou a expressão "peça da espingarda que percute a cápsula", dentro do enunciado "o cão não funcionou no momento do tiro".

3.1 definição intensional subjetivo-convencional sinonímica/parafrástica

O tipo mais imediato e comum de definição semiótica ou signação - embora muito limitado - é constituído pelas "definições semióticas sinonímicas" e pelas "definições semióticas parafrásticas". Conforme COPI \& COHEN (op. cit., p. 121), pode-se definir um termo "fornecendo outra palavra, cujo significado já é conhecido e que tem o mesmo significado da palavra que está sendo definida". Assim, trata-se não exatamente de declarar o significado de um termo, mas sim colocar em relação de equivalência semântica dois termos, sugerindo com isso que: a) ambos compartilham o mesmo campo intensional; b) os objetos referidos pelos campos extensionais desses termos são os mesmos. Como exemplo, temos: /"justo" $\approx$ "legítimo" /.

Segundo os autores, trata-se de um método definidor que, embora prático, possui muitas restrições; para que seja operacional, tal método exige que se encontrem: a) termos sinônimos adequadamente equivalentes, sob pena de se propor uma aproximação sinonímica inaceitavelmente grosseira; b) termos sinônimos minimamente conhecidos, ou seja, termos que não sejam absolutamente 
novos, uma vez que o definiens é formado por um só termo. Assim, a definição nominal sinonímica /"tiltdôzer" $\approx$ "buldôzer" / nenhum serviço presta àquele que não conhece tais termos técnicos.

Como exemplo de definições intensionais subjetivo-convencionais sinonímicas/parafrásticas, temos:

1. /"lépido" $\approx$ "ligeiro" /;

2. /"agressiva" $\approx$ "hostil" /;.

3. /"lépido" $\approx$ "que se movimenta e/ou age com rapidez" /;

4. /"agressiva" $\approx$ "que agride, denota ou envolve agressão" /.

\section{2 definição intensional subjetivo-convencional estipuladora}

No tópico "2.7", examinamos as definições intensionais objetivas estipuladoras; com elas, tínhamos um processo de síntese conceitual objetiva a partir de conceitos primitivos. Lá, a seleção de traços que determina a estipulação conceitual garantia a existência de uma definição de caráter objetivo (que declara, portanto, a qüididade da substância cujo conceito é objeto de um processo definidor): considera-se que, tendo sido selecionados para esse processo de síntese, tais traços são elementos fundadores da essencialidade do objeto de definição. Como exemplo, se definirmos /irregularidade em um concurso $\leftarrow \pi$ 〈engano na confecção da lista de aprovados`/, atribuiremos à essência do conceito derivado (irregularidades o conceito primitivo 〈engano〉. Com isso, imporemos uma interpretação particular desse objeto: na intensão do conceito derivado, estipulamos que não se inclui, dentre outros, o conceito primitivo «má-fés, dado o caráter não voluntário sinalizado pelo conceito renganos.

Agora nos cabe examinar outra modalidade de definição estipuladora, aquela de caráter subjetivo-convencional: os conceitos primitivos selecionados para a composição do conceito derivado não são objetivos - pois não são de caráter universal (ou supradoxológico) para todos os objetos que compõem a extensão do conceito —; são, portanto, subjetivos (são julgados essenciais por um indivíduo, que assim o crê) e/ou convencionais (são incorporados por uma espécie de acordo ou 
anuência coletiva dos usuários desse conceito). Assim sendo, não visam à qüididade universal de uma substância, mas visam, em diferente patamar, aos significados lingüísticos implicados por essa intensão subjetiva e/ou convencional (transitamos ao longo do continuum substância $\leftarrow$ essência $\leftarrow$ conceito $\longleftrightarrow$ significado $\longleftrightarrow \rightarrow$ nome).

Enquanto injunção discursiva, a definição atende às necessidades interativas que demandam a constante introdução de novos termos e suas definições. A definição, vista como uma operação conceitual atinente às relações semióticas, presta-se à introdução de um novo termo necessário em um conjunto de termos sistemicamente vinculados, desse modo especificando-se o significado desse termo dentro de um conjunto de significados contrastantes. Dessa maneira, cria-se uma correspondência entre os termos e seus significados primitivos (o definiens), e um termo e seu significado derivado (o definiendum).

Assim surgem as denominadas "definições intensionais subjetivoconvencionais estipuladoras", cuja função é introduzir em uma linguagem (científica ou natural) um novo símbolo vinculado a um novo significado, ampliando, assim, o vocabulário dessa área de conhecimento; esse é um caso freqüente nas linguagens científicas. Um exemplo de definição intensional estipuladora citado por Copi \& Cohen refere-se à criação do termo "quark" pelo físico norte-americano Murray GellMann para designar um tipo especial de partícula subatômica constituinte da matéria; houve aqui, portanto, a introdução de um novo signo pela estipulação de um novo conceito mediante síntese.

Em resumo, as definições intensionais subjetivo-convencionais estipuladoras prestam-se a uma função primordial:

a) enquanto operação estritamente lingüística, essas definições instauram uma equivalência entre um termo e um significado. Ou seja, essa definição funciona como uma regra segundo a qual, em dado universo discursivo, o definiendum pode ser tomado como uma abreviatura da expressão do definiens;

b) enquanto operação estritamente conceitual, essas definições estipulam equivalência entre um novo conceito derivado por síntese e os conceitos primitivos 
constituintes, cujas intensões são subjetivo-convencionais. Ou seja, essa definição funciona como uma chave de acesso à síntese conceitual recém-inaugurada.

Segundo COPI \& COHEN (op. cit., pp. 103-105), as definições intensionais subjetivo-convencionais estipuladoras possuem a função de reduzir a imprecisão intensional não objetiva e/ou aumentar o vocabulário em determinada área do conhecimento: em outras palavras, verifica-se a introdução um novo signo em um sistema de signos ou uma delimitação conceitual (aumento da precisão conceitual) quando se tornar necessária.

$\mathrm{Na}$ maior parte dos casos (com exceção dos neologismos), trata-se da recolocação, em um novo sistema, de um signo já existente em um sistema simbólico anterior, agora redefinido segundo um novo contexto conceitual.

Os autores apontam algumas razões pelas quais convém utilizar as definições intensionais subjetivo-convencionais estipuladoras: a) um só termo pode servir como abreviatura de uma longa estrutura de termos em uma mensagem; b) um só termo pode servir como um código privativo, restrito ao emissor e receptor; c) novos termos são introduzidos para significar aquilo que, sem eles, requereria uma grande quantidade de termos já usuais; d) há a estipulação de novos termos por razões psicológicas; esse fato assim é justificado pelos autores:

"Novos símbolos são, às vezes, introduzidos pelos cientistas, tendo certos objetivos psicológicos. Pelo lado negativo, algumas palavras familiares possuem matizes emocionais que podem-se mostrar perturbadoras; símbolos definidos de modo estipulador, como tendo os mesmos significados literais que os termos familiares liberam o investigador do desvio dessas associações emotivas. [...] Pelo lado positivo, um nome cativante pode acrescentar entusiasmo e interesse a uma investigação que poderia parecer aborrecida se utilizasse uma terminologia descritiva estabelecida. [...] Termos novos que persuadem ou cativam podem ter um papel na aceitação de novas teorias" (op. cit., p. 104).

Os autores destacam que tais definições estipuladoras não são: a) nem verdadeiras nem falsas (pois são estipulações); b) nem precisas nem imprecisas (pois são subjetivo-convencionais). Em suma, assim são porque se trata de estipulações sintéticas baseadas em características não objetivas (características que não pretendem declarar a universalidade do conceito). 
Distinguem-se de uma definição puramente lexical, apresentada em verbete de dicionário, pois um conceito definido por uma definição intensional subjetivoconvencional estipuladora até então não tinha aquele significado específico, antes de ter sido ele proposto pelo ato definidor. Uma vez instaurado e vinculado a um nome, tal conceito constituirá um significado lingüístico a ser reiterado e explicado por sinonímia ou paráfrase.

Como vimos, para as definições intensionais subjetivo-convencionais estipuladoras, o ato definidor implica, de fato, uma espécie de acordo pelo qual se convenciona que o significado (delimitação conceitual) do definiendum e o significado (delimitação conceitual) do definiens passam a ser, doravante, considerados como equivalentes. Isso, porém, é válido - e este é o ponto a ser destacado - , para todos que aceitam a definição proposta, e essa decisão é própria aos indivíduos, mas não um fato intrínseco à definição em si mesma. Trata-se, em suma, de um tipo de proposta para se usar doravante o definiendum para significar o que é significado pelo definiens, como se houvesse então uma regra ou instrução lingüística a ser cumprida, dentro de um determinado código.

Casos muito freqüentes de definições intensionais subjetivo-convencionais estipuladoras verificam-se na caracterização dos denominados "objetos-dediscurso". Vejamos um exemplo:

\footnotetext{
"Isso que nesta região convencionamos chamar de 'estradas', que desaforadamente indicamos como tais nos mapas por uma linha dupla, usada em outros lugares para indicar grandes vias de comunicação, não passa de atalhos de um pé de largura, cavados numa profundidade de oito ou dez polegadas" (Haussez, Voyage d'um exile de Londres à Naples et Sicile, Lausanne, 1835 , v. 2 , p. 347$)^{123}$.
}

Como vemos, o enunciador estipula - segundo sua percepção - um novo conceito a ser vinculado ao conceito de estrada: trata-se de um ratalho de reduzidas dimensões».

\footnotetext{
${ }^{123}$ Exemplo extraído de MONDADA, Lorenza \& DUBOIS, Danièle. "Construção dos objetos de discurso e categorização: uma abordagem dos processos de referenciação" In CAVALCANTE, Mônica Magalhães et alii (Org.). Referenciação. São Paulo: Contexto, 2003.
} 
Observemos o quadro seguinte:

estrada $\leftarrow \pi$ <via mais larga que um caminho, que atravessa certa extensão territorial, ligando dois ou mais pontos, e através da qual as pessoas, animais e/ou veículos transitam

estrada $\leftarrow \pi$ ratalho de um pé de largura, cavado numa profundidade de oito ou dez polegadass

Observa-se que a definição da esquerda é formada pela declaração da causa formal (via mais larga que um caminho, que atravessa certa extensão territorial, ligando dois ou mais pontos) e da causa final (através da qual as pessoas, animais e/ou veículos transitam). A definição da direita constrói-se por um processo de redução semântica da causa formal: a "estrada" deve ser entendida como um "atalho" (termo hierarquicamente inferior) estreito e de pouca profundidade. Esse ajustamento semântico, contudo, passa a caracterizar apropriadamente - para aquele auditório particular - aquilo que poderíamos denominar "'estrada"' (estrada entre aspas simples): uma "picada" (‘atalho estreito aberto a golpes de facão)) de, aproximadamente, trinta centímetros de largura por, aproximadamente, vinte e cinco centímetros de profundidade.

Definir /estrada $\leftarrow \pi$ <atalho minúsculo / representa uma intensão conceitual subjetivo-convencional, estipulada pelo enunciador segundo sua crença em relação àquele referencial (não entra em julgamento a coerência em se denominar "estrada" um atalho de trinta centímetros, ou se, de fato, tal estrada apresenta as características mencionadas). Trata-se, podemos entender, do discurso fundador de um novo objeto-de-discurso que, doravante, passará a assim ser mencionado.

Como podemos constatar, os denominados "objetos-de-discurso" são exemplos deste tipo de definições estipuladoras: são discursos que recategorizam ou reconstroem os dados da realidade (ou "versões públicas do mundo") mediante referenciação, considerando-os segundo uma nova perspectiva ontológica (ou sob perspectivas ontológicas alternativas):

"[...] quer se trate de objetos sociais ou de objetos 'naturais', observa-se que o que é habitualmente considerado como um ponto estável de referência para as categorias pode ser 'decategorizado', tornado instável, evoluir sob o efeito de uma mudança de contexto ou de 
ponto de vista. Nosso argumento consiste em dizer que a 'estabilidade' resulta, de fato, de um ponto de vista realista que relaciona as categorias às propriedades do mundo - como se a objetividade do mundo produzisse a estabilidade das categorias - no lugar de relacioná-las aos discursos sócio-históricos e aos procedimentos culturalmente ancorados. Se, ao contrário, adotarmos este segundo ponto de vista, não será surpresa ler que a cenoura é transformada de 'raiz' ou de 'legume' em 'fruta' por decisão da Comunidade Européia em janeiro de 1991. [...] Assim, a administração pode impor uma transformação categorial, mesmo que o conhecimento científico continue a considerar a cenoura como uma raiz e as práticas alimentares, como um legume" (Lorenza MONDADA \& Danièle DUBOIS, 2003, pp. 26-27).

O processo definidor que predica o atributo (fruta) ao definiendum "cenoura" (ou seja, considera que o conceito fruta constitui um conceito primitivo do conceito derivado cenoura) representa uma nova síntese conceitual paralela à síntese principal, que estabelece uma relação entre os conceitos de cenoura e raiz. Se, de acordo com a ciência — ou seja, com o conceito de verdade científica —, o atributo 〈raiz〉 é pertinente e o atributo sfruta) é impertinente ao objeto cenoura, para uma compreensão fenomênica alternativa este atributo torna-se pertinente, uma vez que o próprio conceito de fruta é recategorizado e uma nova composição conceitual é estipulada, alterando a própria substancialidade do objeto de definição cenoura. Temos, assim, duas versões públicas de uma mesma realidade, permitida, aliás, pela possível transitividade entre os conceitos primitivos que recategorizam o conceito derivado: observemos que as definições de raiz e fruta possuem intensões que se sobrepõem em certos aspectos.

Reunindo nossas observações sobre os objetos-de-discurso, vemos que cabem duas interpretações a eles aplicáveis: podem ser entendidos como produto de uma definição intensional objetiva estipuladora ou como produto de uma definição intensional subjetivo-convencional estipuladora, uma vez que a intensão resultante é formada por traços subjetivo-convencionais e, ao mesmo tempo, por traços objetivos (pois são: 1. traços selecionados por uma (re)categorização de constructos culturais, geradores de um tipo de versão pública de um objeto-de-realidade, construído por meio de práticas discursivas, social e culturalmente situadas; 2 . traços essenciais 
para a caracterização da qüididade desse objeto ${ }^{124}$. Convém, portanto, considerálos como objetos de intensão híbrida - digamos, uma intensão objetivoconvencional.

Como exemplo de definições nominais estipuladoras, temos:

1. "gambito" $\leftarrow \pi$ (jogo de xadrez) oferta de material em troca de compensações posicionais dinâmicas ou estáticas»;

2. "agressiva" $\leftarrow \pi$ «pessoa amoral que age incondicionalmente visando objetivos estritamente pessoais».

\section{3 definição intensional subjetivo-convencional lexical}

Já para as definições intensionais subjetivo-convencionais lexicais, há duas funções principais: a) eliminar ambigüidades por meio da indicação clara de um determinado significado dentre os muitos significados já conhecidos de um termo; b) consolidar o vocabulário de um determinado campo semântico.

As definições lexicais possuem a função de reduzir a imprecisão intensional (ou ambigüidade); porém, neste caso, não se trata de introduzir um novo símbolo em um sistema simbólico ou criar um neologismo (portanto, não se confundem com as definições estipuladoras). Aqui, o termo a ser (re)definido não é novo: já tem um determinado uso estabelecido - "uma definição lexical não dá a seu definiendum um significado que ele não tinha até então, mas declara um significado que o definiendum já tem". Como caso-limite desse tipo de definição, temos a sinonímia ${ }^{125}$.

\footnotetext{
${ }^{124}$ Como vimos, entendemos o objeto-de-discurso como uma "recategorização de constructos culturais ou um tipo de versão pública de um objeto-de-realidade e/ou de um objeto mental ou conceito, construído pelos interagentes por meio de práticas discursivas e cognitivas, social e culturalmente situadas"; assim, se, por um lado, justifica-se o caráter subjetivo-convencional desse objeto, por outro lado seu caráter sintético, gerador de um conceito ad hoc, autoriza a leitura objetiva de sua intensão.

${ }^{125}$ A definição intensional explícita sinonímica, enquanto caso-limite de definição, implica a apresentação de um outro termo que seja considerado como possuidor do mesmo significado do definiendum: "Como se consegue, de fato, definir uma palavra? Que técnicas são usadas para identificar sua intensão convencional, o acordado conjunto de atributos, comum e peculiar aos objetos denotados pela palavra? Muitos métodos são comuns. O mais simples e mais freqüentemente usado - mas tendo limitado poder — é fornecendo outra palavra cujo significado já é conhecido, que tem o mesmo significado que a palavra sendo definida. Duas palavras com o mesmo significado são chamadas 'sinônimos', assim, uma definição desse tipo é chamada uma 'definição sinonímica'" (COPI
} 
Para estas definições, torna-se possível considerar o valor de verdade a elas inerente: uma definição lexical é verdadeira se corresponder ao uso que se faz costumeiramente da relação particular entre esse definiendum e esse definiens (isto é, o significado indicado por uma definição lexical retoma verdadeiramente um significado convencional pré-existente; caso contrário, a definição será falsa). Tais definições implicam, pois, a correta ou incorreta reprodução de um significado já consagrado pelo uso - que gera expectativas de utilização.

Como se vê, não se trata de um critério de verdade ou falsidade que toma em consideração questões de ordem referencial. Por outro lado, para as definições intensionais estipuladoras, quer porque se trate de um neologismo, quer porque aquele significado particular, proposto atualmente, nunca esteve vinculado àquele definiendum específico, torna-se impossível aplicar o critério de verdade ou falsidade.

Os autores distinguem, sob o ponto de vista das definições intensionais lexicais, aquilo que pode ser considerado um uso incorreto e aquilo que é, de fato, um uso heterodoxo. Isso porque o uso surge, antes de tudo, como um problema de variação estatística, condicionado pelo universo de dados tomados em consideração. Nesse universo, torna-se difícil estabelecer um único significado de um termo como o mais representativo; razoável é entender a presença de muitos significados representativos, de acordo com os usos e os contextos de fala e escrita.

O mesmo comentário vale para o conceito de uso correto que toma por parâmetro autores proeminentes ou autoridades acadêmicas e científicas; isso porque a linguagem falada do quotidiano, visando à comunicação e expressão interpessoal, é muito mais dinâmica e mutável do que as línguas científicas, cujos objetivos determinam uma estabilidade semântica maior.

Portanto, as definições intensionais lexicais devem tomar em consideração não só as evoluções terminológicas de caráter científico, mas igualmente esse movimento evolutivo promovido pela linguagem informal do quotidiano. É em relação

\& COHEN, op. cit., p. 121). Dentre as limitações desse tipo de definição, os autores citam: a inexistência de sinonímia exata para muitas palavras; a ocorrência, em muitos casos de sinônimos tão ou mais misteriosos do que o definiendum. 
a esse conjunto lexical e suas definições que uma determinada definição lexical pode ser considerada verdadeira ou falsa, de acordo com o uso.

Como exemplo de definições nominais lexicais, temos:

1. "gambito" $\leftarrow \pi$ rartimanha ou estratégia para enganar e derrotar adversários»;

2. "agressiva" $\leftarrow \pi$ sinclinada a agredir ou provocar, sempre voltando-se para $o$ ataques.

3.4 definição intensional subjetivo-convencional de precisão

A definição intensional de precisão, por sua vez, tem a função de reduzir a imprecisão intensional do definiendum ${ }^{126}$ porque, de acordo com uma dada formulação do definiens, o termo é vago - isto é, inclui e/ou exclui objetos de sua extensão de modo inadequado. Não é possível praticamente obter definições que eximam de modo completo os termos de algum grau de imprecisão extensional; o problema instaura-se, porém, quando esse grau ultrapassa um limite aceitável, além do qual se tornam duvidosas certas inclusões ou exclusões de termos no campo extensional. Há aqui um sério problema porque não é possível, para esses casos, o recurso ao uso comum, uma vez que, fosse ele suficiente, não existiriam problemas de indefinição extensional. Torna-se necessário, portanto, o apelo a outras esferas de conhecimento para atender a tais casos.

As definições intensionais precisadoras diferem das definições intensionais estipuladoras porque o definiendum não é um novo termo, mas sim um termo de uso já estabelecido, porém de algum modo vago em sua capacidade de selecionar os objetos de sua extensão. A definição, portanto, não possui a liberdade de criar um definiens que implique um novo conceito; é necessário observar os usos e significados estabelecidos, porém, com liberdade para precisá-los adequadamente.

\footnotetext{
${ }^{126}$ Lembrando que "um termo é ambíguo [intensionalmente impreciso] em um dado contexto quando ele tem mais de um significado distinto e tal contexto não permite esclarecer qual deles é visado. Um termo é vago [estensionalmente impreciso] quando existem casos fronteiriços, de modo que não se pode determinar se o termo deve ser aplicado a eles ou não. Obviamente, alguns termos, tais como as frases "direito à vida" ou "direito de escolher", podem ser, ao mesmo tempo, ambíguos e vagos" (COPI \& COHEN, op. cit., pp. 106-107).
} 
Também, as definições intensionais de precisão não podem simplesmente, como o fazem as definições intensionais lexicais, reproduzir com exatidão um significado estabelecido, mas devem aperfeiçoá-lo, de modo a resolver um problema extensional existente. Obviamente, em certa medida, uma definição de precisão dependerá, para concretizar-se, de alguma operação estipuladora para introduzir em uso o conceito redefinido.

Como exemplo de uma definição intensional de precisão, temos que o conceito de metro foi outrora definido (ou seja, estipulado) como ra décima milionésima parte da distância de um dos pólos da Terra ao equadon; hoje, metro define-se como ‘distância que a luz viaja em 1 / 299.792.458 de segundo〉. Como vemos, o conceito aperfeiçoou-se: no texto definidor anterior, por exemplo, mencionava-se "um dos pólos da Terra"; cabe indagar sobre a qual conceito de pólo refere-se o definiens: trata-se do eixo imaginário em torno do qual a Terra executa sua rotação ou trata-se da região glacial (de dimensão indefinida, aliás) que teoricamente circunda a extremidade de tal eixo? Ou tratar-se-ia do eixo magnético da Terra?

Como exemplos de definições nominais precisadoras, temos:

1. "iliçar ${ }_{1} " \leftarrow \pi$ «atrair e seduzir mediante afagosı; "iliçar ${ }_{2} " \leftarrow \pi$ «enganar alguém vendendo, hipotecando, penhorando bens que pertencem a outrem ou sobre os quais pesam encargos de qualquer espécie) [como se vê, aqui se trata de precisar a intensão dos termos para impedir que o ato de seduzir não seja confundido com o ato de lograr, ao denominá-los indiferentemente "iliçar];

2. "agressiva ${ }_{1} " \leftarrow \pi$ <dotada de espírito beligerante〉; "agressiva ${ }_{2} " \leftarrow \pi$ 〈empreendedora, energética, aguerrida e lutadora〉 [aqui se trata de distinguir entre as duas intensões do termo "agressiva", para que se interprete corretamente o enunciado: "nos negócios, Marta é uma pessoa agressiva"].

3.5 definição intensional subjetivo-convencional contextual

SALMON (op. cit., p. 77) afirma que é possível considerar dois grupos de termos: a) termos que possuem intensão e extensão (termos que se referem a objetos, propriedades e acontecimentos); b) termos que não possuem intensão nem 
extensão, os quais apenas podem ter significado quando inseridos em determinado $\operatorname{co}(n)$ texto; fora deles, isoladamente, são destituídos de significado relevante (caso dos termos estritamente gramaticais, tais como preposições, conjunções e pronomes) $)^{127}$. Nesses casos, é preciso que, primeiramente, tais termos assumam uma função, para então dela derivarem seus significados: portanto, esses termos têm seus conceitos estabelecidos a partir dos contextos nos quais são empregados; tal método caracteriza as definições intensionais contextuais - trata-se de definições que são construídas a partir de uma contextualização declarada pelo definiens.

Por sua vez, Hegenberg destaca:

\begin{abstract}
"A expressão definida por uma definição nominal não precisa ser um vocábulo ou um símbolo, isoladamente considerado. Também pode ser uma frase, como ocorre em: 'índice cefálico da pessoa x é igual, por definição, a quociente da largura máxima do crânio pelo comprimento máximo do crânio, multiplicado por 100'. [...] Não se introduz um símbolo 's' oferecendo sinônimos de 's' mas, ao contrário, oferecendo sinônimos de expressões que contêm o símbolo. A expressão definida é utilizada em contextos particulares, de modo que não se torna preciso apresentar e expressão isoladamente, mas em contextos lingüísticos apropriados. [...] esse método de fixar significados é o que se chama 'definição contextual' [...] Definição contextual - regra que tem por objetivo traduzir sentenças em que comparece o definiendum, transformando-as em sentenças (sinônimas) que não contêm o definiendum" (op. cit., pp. 29; 72; 128-129).
\end{abstract}

Este tipo de definição apresenta, portanto, não a definição de um conceito, mas sim uma expressão sinônima da expressão que contém esse conceito, uma vez que ele é utilizado em contextos lingüísticos específicos. Assim sendo, torna-se conveniente precisar, na definição, tal contexto, para que haja uma interpretação adequada do conceito em questão. A definição intensional contextual inclui exclusivamente nomes, sendo uma relação puramente semiótica (no sentido de se

\footnotetext{
${ }^{127}$ As palavras lógicas [...] a nada se referem. Palavras como 'se', 'a menos que', 'somente', 'é', 'não', e assim por diante, não admitem extensão nem intensão, não têm significado quando isoladamente consideradas. Têm uma função gramatical, e os seus significados derivam da função que desempenham como elementos que fixam a estrutura das sentenças em que ocorrem. Os significados dessas palavras são fixados mostrando-se de que maneira elas operam em um dado contexto" HEGENBERG, op. cit., p. 72.
} 
considerar apenas a relação entre significante e significado, sem apelo ao referente) $)^{128}$.

Hegenberg comenta a existência de muitos casos nos quais é impossível isolar o termo a ser definido, para que dele se apresente uma definição intensional estipuladora ou lexical; os casos típicos aparecem quando o definiendum constitui uma relação ou função, e não propriamente uma característica específica de um objeto. O exemplo apresentado (op. cit., p. 30) refere-se à definição contextual do conceito de irmão, de caráter relacional: "'x é irmão de y' é igual, por definição, a 'x é do sexo masculino e tem os mesmos pais que $y^{\prime \prime}$.

Comparemos a definição apresentada com esta definição intensional para o mesmo conceito, considerado fora de qualquer contexto: irmão é igual, por definição, a «filho do mesmo pai e da mesma mãe, ou só do mesmo pai (irmão consangüíneo) ou só da mesma mãe (irmão uterino), em relação a outro(s) filho(s)>. Como se vê, a definição contextual, ao especificar naturalmente em que contexto o conceito é empregado, simplifica o enunciado definidor e o torna mais claro sob o ponto de vista referencial.

Como uma observação que serve para distinguir entre ambos os tipos de definição já vistos, temos:

\begin{abstract}
"As definições nominais [intensionais estipuladoras e lexicais] [...] [e as definições] contextuais, apresentadas por meio de predicados observáveis, fornecem não apenas um critério para que o definiendum seja aplicado, como ainda uma regra para a eliminação do definiendum em qualquer sentença em que compareça - sentença que é substituída por sinônima. A diferença está em que, no caso da definição contextual, o termo não deve ser sumariamente substituído por sinônimo sem alterar o restante da sentença. Em outras palavras, a definição contextual é uma regra para traduzir toda a sentença que contém o definiendum, transformando-a em outra sentença sinônima, que não contém o definiendum" (op. cit., p. 30).
\end{abstract}

${ }^{128}$ Como exemplo: "Assim, [...] já se sabe, do estudo da lógica, existir equivalência entre 'Todos os $A$ são B' e 'Apenas os B são A'. Aí está uma definição contextual de 'apenas'. Não há uma só palavra ou frase cujo significado se iguala ao do vocábulo em pauta; em vez disso, o contexto em que ocorre a palavras tem o mesmo significado de outro contexto, em que a palavra não comparece" (HEGENBERG, op. cit., p. 73). 
Ou seja, as definições intensionais contextuais diferem das definições intensionais estipuladoras e lexicais por permitirem estas a permuta entre definiendum e definiens sem modificação semântica entre os enunciados; já as definições intensionais contextuais não explicitam um definiens que possa ser permutado pelo definiendum ${ }^{129}$.

Como exemplo das definições intensionais contextuais, temos:

1. la pessoa ' $P$ ' é dolicocéfalo $\leftarrow \pi$ ra pessoa ' $P$ ' tem índice cefálico menor ou igual a setenta e cincos / [comparar com a seguinte definição: "dolicocéfalo" $\leftarrow \pi$ «tipo humano cujo crânio é oval, sendo o diâmetro transversal menor, em quarto, do que o longitudinals; observar que o termo "dolicocéfalo" do definiendum não aparece no texto do definiens];

2. la pessoa ' $P$ ' é agressiva $\leftarrow \pi$ ra pessoa ' $P$ ' tende a manifestar comportamento violento e belicosos/.

3.6 definição intensional subjetivo-convencional funcional

Em termos práticos, é possível desenvolver uma abordagem funcionalista do processo definidor. Como vimos em capítulo anterior deste trabalho, desenvolve-se o conceito de definição funcional: / definição funcional $\leftarrow \pi$ roperação mental que diz distintamente o que um termo significa em dado contexto de uso /.

Sob o ponto de vista ontológico, tender-se-ia a trabalhar com definições ideais - ou seja, definições que, idealmente, admitem: a) um definiens que declara o gênero e a espécie (traços essenciais ou substanciais) do objeto de definição; b) um definiens que pode ser permutado incondicionalmente pelo definiendum e viceversa. Já, sob um ponto de vista funcionalista, afastamo-nos dessa visão idealista e

\footnotetext{
${ }^{129}$ O exemplo é: “[...] não se dispõe de palavra ou frase que possa substituir 'somente' em, digamos, 'somente os mamíferos são baleias'. Todavia, 'somente os B são A' é equivalente a 'todos os A são B', e aí está uma definição contextual de 'somente'. Essa definição permite substituir toda a sentença em pauta por outra, 'todas as baleias são mamíferos', cujo significado é o mesmo da sentença original - e onde não surge o termo 'somente'. Em certa medida, o significado de 'somente' é especificado pela definição, já que ela nos permite expressar, sem uso do vocábulo, aquilo que era, de início, expresso com seu auxílio" (HEGENBERG, op. cit., p. 77).
} 
operamos apenas em condições concretas, destacando as funções que os termos e os conceitos respectivos — desempenham em situações de uso.

Importa destacar que, em muitos casos, torna-se impossível apresentar definições de um conceito a não ser apresentando as funções discursivas que o termo vinculado ao conceito desempenha: assim, "sabendo, a partir do contexto, qual é a função gramatical do termo, é possível encontrar uma definição para ele. Importa, porém, lembrar que nem sempre a ambigüidade fica eliminada, ainda quando se conheça a função gramatical do termo em definição" (Hegenberg, op. cit., p. 64$)^{130}$.

Nesse quadro, os textos definidores podem lançar mão de certos tipos contextuais de informação, relativas às funções desempenhadas pelo termo informações essas que podem ser as mais relevantes para caracterizar o conceito em questão. Assim, é possível encontrar verbetes que registram observações como "gíria", "antigo", "arcaico", "termo asiático" e "linguagem de criminosos e marginais", "linguagem da droga", "forma histórica" etc. Tais expressões indicam funções do termo em contextos específicos, constituindo-se em informações muitas vezes mais relevantes do que indicações tecnicamente mais rigorosas. Como exemplo, Houaiss registra: "dar um furo": jornalismo brasileiro - publicar uma notícia em primeira mão [em Portugal, obter uma cacha].

Assim resume Hegenberg a necessidade de definições funcionais:

"[...] muitas das proposições que são encaradas como definições não são definições segundo os padrões habituais da lógica. São, em verdade, regras condicionais de tradução (e não puras regras de tradução). Mais do que isso, são regras condicionais de tradução em determinados contextos (e não em todos os possíveis contextos), regras que só podem ser aplicadas quando são mantidas fixas certas condições empíricas" (op. cit., p. 66).

Importa ter em mente que, de acordo com o autor (op. cit., pp. 67-68):

130 "[...] quem encontra, no topo de uma carta, $02 / 11 / 73$, entenderá que se trata de ' 11 de fevereiro de 1973', se inglês, ou que se trata de '2 de novembro de 1973', se brasileiro. O contexto decisivo não é a função, mas a nacionalidade do remetente da carta" (HEGENBERG, op.cit., p. 77). 
a) o ato definidor (mesmo no campo rigoroso da ciência) deve considerar, no processo de investigação, termos primitivos indefiníveis adotados como pontos de partida; assim, é errôneo considerar que "uma investigação não pode principiar sem antes se haver definido seu objeto". Ao contrário, "[...] são muito comuns os casos em que se principia um estudo com termos vagos, que são elucidados com o próprio avança das investigações". Em suma, o objeto de investigação deve sempre ficar estabelecido, mas isso não implica coligir um sistema de definições rigorosamente determinado;

b) a definição de conceitos não ocorre em vazios conceituais: "na ciência, em especial, as definições implicam ou pressupõem leis e se apresentam no seio de sistemas. [...] Definir não é sempre uma atividade simplesmente lingüística, mas, ao contrário, uma atividade que se executa sobre teorias e informações empíricas - ou seja, dentro de determinados contextos teóricos";

c) isso nos leva a considerar que "[...] a definição não deve ser apenas formalmente correta, mas deve, ainda, muitas vezes, ser materialmente adequada" epistemológica e pragmaticamente;

d) enfim, em muitos casos as definições são meros "recursos mnemônicos" conceitualmente aproximativos, adequados para um primeiro grau de exigência teórica, mas insuficientes para graus mais profundos de especificação definidora. $A$ questão se resume, portanto, em se reconhecer até onde operam as funções pragmáticas de uma definição e a partir de que ponto tais funções cedem lugar a necessidades conceituais mais refinadas.

Em suma, devemos entender que o processo definidor pode incorporar em seu campo intensional informações não estritamente atinentes ao objeto de definição, mas também informações suplementares que lhe contextualizam os possíveis significados.

Como exemplos de definições intensionais subjetivo-convencionais funcionais, temos:

1. "labrego" [ê] $\leftarrow \pi$ «(ADJ.); aldeão rústico e grosseiro; (fig.) malcriado, embrutecido; (Bras.) antiga alcunha dos portugueses;; 
2. "agressiva" $\leftarrow \pi$ 〈(ADJ.); PSICOLOGIA $\rightarrow$ aquela que revela predisposição para um comportamento hostil ou destrutivo〉; ‘(ADJ.); JOGO DE XADREZ $\rightarrow$ jogada enérgica que implica resposta obrigatória e forçada do adversário».

3.7 definição intensional subjetivo-convencional implícita (ou postulacional)

As definições intensionais implícitas postulam condições necessárias e suficientes para que o evento implicado pelo definiendum (isto é, a ação declarada pelo definiendum) tenha lugar. O definiendum, no caso destas definições, apresentase não como um único termo, mas como parte de uma estrutura enunciativa ou de um signo complexo (que pode ser um sintagma nominal). O exemplo em Hegenberg é: /igualdade de temperatura $\leftarrow \pi$ 〈dois corpos têm a mesma temperatura se $\underline{e}$ somente se não flui calor através de um terceiro corpo em contato com ambos / (op. cit., p. 73). Observemos que o definiendum é um sintagma nominal e no definiens aparecem postuladas condições para que o evento "ter a mesma temperatura" ocorra ("se e somente se").

Denominam-se "definições intensionais subjetivo-convencionais implícitas" porque os postulados apresentados pelo definiens pressupõem implicitamente conceitos primitivos de uma teoria também implícita no enunciado; assim, de acordo com Hegenberg:

"O status dos postulados é claro: não sendo possível justificar todas as asserções, algumas devem ser tomadas como 'base' para justificar as demais. Entre as básicas, numa teoria, estão os postulados - verdades admitidas de que se pretende extrair conseqüências. Sem embargo, os postulados afirmam fatos relativos aos termos primitivos - cujo significado não foi introduzido no sistema em pauta. De que modo, pois, se pode dizer que os postulados sejam 'verdades', se nem se conhece o significado dos termos que os compõem? [...] o significado dos termos será fixado pelo uso que se dará aos postulados — que enunciam relações lógicas prevalentes entre os termos primitivos. Não se tem [...] um modo de especificar significados, à maneira habitual, mas algo que, de modo indireto, permite [...] fixar significados - o que justificaria a 'definição implícita"' (op. cit., pp. 73-74). 
Como vemos, a relação entre definiendum e definiens estabelece, implicitamente, postulados que, indiretamente, terminam por definir os termos primitivos. Em outras palavras, a definição proposta implica uma situação de uso que permite inferir a definição dos termos utilizados. O autor menciona o exemplo clássico da definição intensional implícita de diagonal por meio dos conceitos primitivos de triângulo e de quadrilátero: ‘as duas diagonais do quadrilátero dividemno em dois triângulos». Portanto, temos a estrutura definidora: /diagonal $\leftarrow \pi$ ras duas diagonais do quadrilátero dividem-no em dois triângulosı /.

Trata-se, na definição implícita, de construir enunciados que incluam o termo cujo conceito deve ser definido, para que se infira, através dos enunciados, uma formulação da definição desse conceito.

Como exemplos de definições nominais implícitas, temos:

1. /ponto $\leftarrow \pi$ ¿duas retas não paralelas interseccionam-se em um ponto〉 /;

2. lagressiva $\leftarrow \pi$ «pessoa agressiva, em uma competição esportiva, é aquela que extrapola em muito os limites naturais do conceito de 'competição' em detrimento do conceito de 'esportiva's/.

3.8 definição intensional subjetivo-convencional autonímica (definições nominais)

Um último tipo de definição intensional subjetivo-convencional é representado pelas "definições autonímicas": trata-se de definições intensionais que tomam como objeto de definição o definiendum enquanto significante. Nesse sentido, declaram as características lingüísticas necessárias e suficientes para que um significante seja aquele significante em particular — temos, pois a explicitação do significado do significante em si mesmo.

Como exemplo, temos: /casa $\leftarrow \pi$ «vocábulo paroxítono formado pelos grafemas 'c', 'a', 's', 'a' e pelos fonemas 'oclusiva velar surda', 'vogal central baixa', 'fricativa alveolar sonora' e 'vogal central baixa's/. Como se vê, o texto definidor declara tudo o que for necessário e suficiente para caracterizar distintamente o objeto de definição — no caso, o nome ou o significante "casa" —, admitindo uma 
permuta incondicional em qualquer contexto lingüístico. Trata-se, contudo, de um significado convencional.

Como exemplos de definições nominais autonímicas, temos:

1. / pi $\leftarrow \pi$ «nome da décima sexta letra do alfabeto grego, equivalente ao "p" português; palavra oxítona; substantivo masculino, nome formado pelos grafemas "p" e "i", e pelos fonemas e , etc.)/;

2. lagressiva" $\leftarrow \pi$ rdo latim "agressus", part. pass. de "agreddi"; palavra paroxítona; adjetivo feminino; nome formado pelos grafemas "a", ... "a" e pelos fonemas , ,..., , etc.) /.

\section{D) GRUPO IV — ESTRUTURAS PSEUDODEFINIDORAS DIVERSAS}

Neste grupo reunimos estruturas que apenas lato sensu podem ser denominadas "definições"; isso porque há algum tipo de subversão ou impropriedade na relação entre definiendum e definiens, de modo que apenas formalmente podemos considerar a presença efetiva da estrutura/definiendum $\leftarrow \pi$ 〈definiens〉 /: de fato, temos, nesses casos, a apresentação de uma simples estrutura predicativa que, discursivamente, é tomada hipoteticamente como uma estrutura definidora.

Consideraremos algumas estruturas pseudodefinidoras formadas por enunciados ou juízos livres sobre: a) temas que guardam alguma relação metafórica com o termo do definiendum; b) a etimologia do definiendum; c) qualquer relação lingüístico-pragmática entre definiendum e definiens, constituindo predicações de caráter subjetivo.

\section{1 pseudodefinição metafórica}

É possível a presença de textos pseudodefinidores que buscam alguma aproximação metafórica entre definiendum e definiens. A aproximação é possível não especificamente no plano intensional ou extensional do conceito, mas sim no plano mental figurativo, ou seja, nas relações entre imagens evocadas pela relação 
definiendum — definiens (estabelece-se uma relação de semelhança subentendida entre as imagens sugeridas pelo significado próprio e as imagens sugeridas pelo significado figurado do termo). Assim, metaforicamente, podemos pseudodefinir o conceito de metrô como "elevador que anda ao contrário, que anda de cá para lá" ou o conceito de telenovela como "laboratório posto no ar".

Como vemos, não existe aqui qualquer conexão direta entre definiendum e definiens, quer sob o ponto de vista lingüístico, quer sob o ponto de vista estritamente lógico, quer sob o ponto de vista práxico. Ocorrem aqui aproximações metafóricas; no primeiro exemplo, a forma ("elevador") e o movimento ("ao contrário" = horizontal), inspiram a aproximação; no segundo caso, a finalidade ("laboratório") justifica a estrutura pseudodefinidora.

Portanto, o objetivo dessas definições não é tornar mais conhecidos os objetos práxicos ou os conceitos metrô e elevador, ao contrário, por uma conveniência discursiva - humor, expressividade etc. - surgem pseudodefinições que se valem do modelo formal das estruturas definidoras para produzir diversas funções na interação em desenvolvimento.

Como exemplo de definições metafóricas, temos:

1. "vassoura" $\approx$ "moça libertina" [pois passa de mão em mão];

2. "agressiva" $\approx$ "nitroglicerina pura" [agressividade imaginada como forte explosão].

\section{2 pseudodefinição etimológica}

Esta é uma forma freqüente de pseudodefinição que, graças à erudição de seu conteúdo, passa por ser uma autêntica definição de um conceito. É, de fato, um recurso retórico que postula a importância da origem dos termos e a concretude da formação primeira desses signos. Como exemplo, podemos afirmar a relação entre o verbo "delirar" em português, significando "devanear", e o verbo latino liro, as, aui, atum, are ("lavrar deixando margens"), formado a partir do substantivo lira, æ ("terra levantada entre dois sulcos formados pelo arado"); portanto, "delirar" significaria originariamente "mover-se para fora da trilha". 
Contudo, cabe indagar sobre qual seria a etimologia concreta de lira, æ, produzindo, assim, um regresso infinito; também, podemos verificar que pouca ajuda tal etimologia prestará na seguinte definição: /delírio [PSIC.] $\leftarrow \pi$ «distúrbio de julgamento devido a alteração global da consciência da realidades /.

IDE (1997, pp. 199-201), tratando da questão das definições puramente etimológicas, afirma:

"[...] a etimologia é sempre interessante. O deslocamento semântico, com efeito, é freqüentemente um resumo da história do pensamento. 'Entusiasmo' significa etimologicamente 'transporte divino', e tal era o sentido na Antigüidade (delírio sagrado que se apodera do intérprete da divindade); hoje, em nossa época secularizada, o termo perdeu sua referência a Deus e significa simplesmente uma 'emoção que impele a admirar' [...]. A etimologia também mostra que, com freqüência, a origem das palavras é muito material e concreta. Assim, o termo grego u3lh, que hoje quer dizer 'matéria', significava primordialmente 'madeira'. Mas a utilização da etimologia está sujeita a uma dupla condição. Por um lado, é preciso certificar-se de sua verdade. [...] Por outro lado, o sentido atual não é obrigatoriamente o sentido primitivo. As palavras têm uma vida, portanto uma evolução: a dos homens e dos pensamentos".

Importa, portanto, enfatizar as diferenças entre o significado original, estabelecido na origem do vocábulo, e a evolução dos significados sucessivos, até o significado contemporâneo ("os escolásticos já distinguiam o 'id a quo imponitur nomen' [a etimologia, a origem da palavra] e 'id ad quod imponitur nomen' [o sentido atual]" [op. cit., p. 201]). Para nós, contemporaneamente, apenas como curiosidade interessa-nos saber que, em "o conceito de 'matéria' no marxismo", a palavra "matéria" derivou-se semanticamente de "u3lh — 'madeira' em grego"; sob o ponto de vista das definições, em nada contribui para a fixação do texto definidor /matéria $\leftarrow \pi$ «fonte única, indestrutível e em perpétuo movimento, que se manifesta em todos os fenômenos da naturezas/.

Conforme destaca o autor, é preciso ter certeza da consistência da evolução diacrônica dos significados; porém, em muitos casos, torna-se simplesmente hipotético postular certas etimologias. Mesmo que tenhamos certeza sobre a origem de um vocábulo, não podemos concluir que haja sempre uma relação válida entre o sentido primitivo e o sentido atual. Assim, em "Chegou ao resultado após um 
rigoroso cálculo" ou "Ele é uma pessoa calculista", pouco importa definir "cálculo" como "palavra derivada do latim 'calculus', que significa 'pedrinha'; Obs.: os antigos utilizavam pequenas pedras para realizar operações aritméticas".

Como exemplo de pseudodefinições etimológicas, temos:

1. "defunto" $\approx$ "substantivo masculino proveniente do latim 'defunctus', particípio de 'defungi', que significa 'desempenhar-se; cumprir uma função'; termo difundido pela Igreja Católica. Portanto, 'defunto' significa 'aquele que desempenhou sua função'";

2. "agressiva" $\approx$ "adjetivo proveniente do latim 'aggressus' e 'aggredior, eris, essus sum, gredi' ('ir em direção a; ir contra'), verbo depoente derivado por 'ad' mais 'gradior' ('caminhar; marchar; adiantar-se'). Portanto, 'agressiva' significa 'aquela que vai contra alguém"'.

\section{3 pseudodefinição predicativa subjetiva}

Por "estrutura predicativa subjetiva" entendemos uma fórmula discursiva "S é $P^{\prime \prime}$ que não se confunde com uma estrutura definidora propriamente dita, pois esta pseudodefinição corresponde à apresentação de um atributo que não contribui, essencial ou contingencialmente, direta ou indiretamente, para a caracterização substancial do objeto, do conceito ou do significado do respectivo termo. Assim, no enunciado "A pedra é bonita", o predicativo "bonita" não particulariza, nem essencialmente, nem contingencialmente, o objeto "pedra" e tampouco é um atributo desse objeto: trata-se, simplesmente, de um juízo formulado por um sujeito definidor e aplicado a tal objeto (não se trata, em suma, de uma característica do objeto ao qual esse juízo se aplica).

Portanto, a estrutura predicativa subjetiva é uma estrutura lingüística simbolizada por "X $\Leftrightarrow Y$ ", composta sintaticamente por um sujeito (o aparente definiendum), cópula e um predicativo (o aparente definiens), sem contribuição essencial ou contingente para a caracterização substancial do objeto de predicação. Como exemplo, temos: "Este leopardo é bonito". A estrutura predicativa não se 
confunde com a estrutura definidora (simbolizada por " $X \approx Y$ " ou " $X \leftarrow \pi\langle Y\rangle$ ", como seria o caso de: "Este leopardo é carnívoro"):

a) esta corresponde à apresentação de um atributo essencial ou contingente do objeto de definição (no caso, carnívoro é atributo essencial do objeto leopardo; sem ele, esse conceito não poderá ser caracterizado enquanto tal, ou seja, deixaria de ser propriamente um leopardo. No caso do enunciado "Este leopardo é da Ásia", teríamos um atributo contingente, pois existem leopardos também na África);

b) já a estrutura predicativa subjetiva corresponde à apresentação de um atributo que não contribui, essencial ou contingencialmente, para a caracterização substancial do objeto (o predicativo "bonito" não define, nem essencial, nem contingencialmente, o objeto leopardo, tampouco constitui um atributo desse objeto — trata-se, de fato, de um juízo presente no sujeito que o formula, e não em seu objeto de julgamento).

Em suma, no caso das estruturas predicativas subjetivas, não há qualquer compromisso com uma declaração visando à substancialidade dos seres, nem sob o ponto de vista conceitual, nem sob o ponto de vista práxico. Eis porque a estrutura predicativa limita-se a declarar um juízo exógeno a tal sujeito.

No exemplo — "boa peça de teatro" ₹ "aquela que atinge diretamente o público" —, a própria formulação do definiendum implica uma perspectiva subjetiva, pela presença do adjetivo "boa" (de fato, uma peça teatral não é, em si mesma, boa ou ruim); igualmente, o definiens, com a expressão "atinge diretamente o público", impõe uma perspectiva externa ao objeto de definição ("que atinge diretamente" não pode ser considerado um atributo definidor do definiendum em questão).

Convém ter sempre em conta a presença de estruturas predicativas aceitas como textos pseudodefinidores. Conforme assinalamos, aqui se verificam juízos que não podem legitimamente ser atribuídos ao definiendum em questão; são, de fato, opiniões manifestadas pelo enunciador que:

a) explicitamente emerge no enunciado proposto através de marcas lingüísticas modalizadoras (tais como 'em minha opinião', 'como costumo dizer', 'sob meu ponto de vista', etc.)"; 
b) implicitamente emerge no enunciado proposto, sendo sua presença inferida pela subjetividade expressa.

Como exemplo de pseudodefinições predicativas subjetivas, temos:

1. "pessoa bem sucedida" ₹ "pessoa que desfruta, como costumo dizer, das 'coisas boas da vida'";

2. "agressiva" "para mim, uma pessoa do mal";

3. "agressiva" $\leftarrow \pi$ «pessoa maldosa e desagradável〉.

Antes de encerrar esta tipologia, cabe finalmente considerar 0 caráter persuasivo ou retórico das definições. SALMON (op. cit., pp. 79-80) menciona que "as definições cuja função principal é a transferência de força emotiva têm o nome de 'definições persuasivas'". A interação verbal pode justificar a presença de pseudodefinições com intuitos puramente psicológicos e argumentativos, visando influenciar atitudes e persuadir o auditório: trata-se de uma pseudodefinição aplicada como ferramenta argumentativa.

Devemos observar que todas as definições possuem, em dada medida, força de persuasão: como exemplos disso, temos em um debate as escolhas ad hoc de definições de conceitos tais como patriota, traidor, liberal e conservador. Portanto, além das funções já mencionadas, as definições operam naturalmente como recursos argumentativos, revelando incontestável força retórica; esta é uma das aplicações mais comuns das definições sob o ponto de vista discursivo.

Assim se manifesta o autor:

"Além das intensões, extensões e funções gramaticais, as palavras têm força emotiva. Um livro que vai aos mínimos detalhes em qualquer matéria poderá ser descrito por uma pessoa como obra erudita e profunda, mas por outra pessoa como pedante e enfadonha. Trata-se menos de que duas pessoas fazem diferentes declarações acerca do livro do que de expressarem diferentes atitudes em relação a ele. Para muitas pessoas, 'profundo' e 'erudito' são termos elogiosos; para quase todas, 'pedante' e 'enfadonho' contêm fortes conotações negativas" (idem).

A partir disso, podemos conceber textos definidores criados com o intuito de explorar exatamente essa força passional dos termos. Dois métodos são apontados: 
a) "em primeiro lugar, podemos escolher uma palavra dotada de considerável força emotiva e defini-la de modo que se aplique a algo que desejamos aplaudir ou condenar". Ou seja: i) escolhe-se um termo que seja dotado de um conteúdo passional, positivo ou negativo (ou, mais precisamente, um termo cujo conceito conote tal carga), vinculado a um objeto específico; ii) vincula-se a tal termo um novo enunciado definidor, apropriadamente criado, que se aplique igualmente, como enunciado definidor, a um outro termo (vinculado a outro objeto específico) ao qual queremos transferir o conteúdo passional em questão. Em suma, trata-se de transferir a força passional de um definiendum para um definiens, igual ou semelhante a outro definiens, e deste definiens para outro definiendum ao qual queremos transferir a mesma força passional ${ }^{131}$;

b) "em segundo lugar, o processo pode ser revertido". Ou seja: i) escolhe-se um determinado objeto, vinculado a um termo específico; ii) redefine-se esse termo por meio de um enunciado que seja dotado de um conteúdo passional, positivo ou negativo; essa nova definição transfere esse conteúdo ao termo e, conseqüentemente, para o próprio objeto (a antiga definição, se possuir um conteúdo passional não conveniente ao propósito, é simplesmente obliterada). Em suma, trata-se de transferir a força passional de um definiens para um definiendum, e deste para o objeto ${ }^{132}$.

O autor destaca a falsa impressão, facilmente formada, de que as definições, quando empregadas persuasivamente, são ilegítimas ou desonestas; ao contrário, tal emprego das definições é importante instrumento que permite a expressão de sentimentos, atitudes e pontos de vista, de modo a aumentar a capacidade interacional da linguagem humana. Deve-se, apenas, mantê-las sob estrito controle,

131 O exemplo é: "[...] podemos definir "socialista" como "que tende a distribuir uniformemente a riqueza por meio de ação governamental". Como o imposto sobre a renda aplicado proporcionalmente tem o efeito de uniformizar a riqueza e a distribuição de bens, a palavra "socialista" é compatível com essa forma de tributação. As pessoas para quem "socialista" tem conotações negativas tendem a transferir as atitudes negativas para o imposto sobre a renda proporcional. Aqueles para quem a palavra "socialista" possui conotações positivas, consideram justamente o oposto" (SALMON, op. cit., p. 80).

132 O exemplo é: "Suponha-se que uma certa obra teatral é reconhecidamente naturalista. Alguém poderia definir "naturalista" como "glorificação da mesquinhez da natureza humana e da indignidade da existência humana". Essa definição transfere a força emotiva negativa do definiens para a palavra "naturalista" — o definiendum — e daí para a própria obra teatral" (SALMON, op. cit., p. 80). 
para que não caracterizem uma distorção inaceitável do conceito sob definição: enquanto persuasivas, as definições devem-se pautar pelos princípios que orientam e legitimam um processo de persuasão, sendo inaceitável que frustrem tais princípios. Há um limite para além do qual já não se trata de persuasão, mas sim, simplesmente, de mendacidade.

Por sua vez, COPI \& COHEN (op. cit., pp. 110-111), ao tratarem das definições persuasivas, observam: "[...] definições podem ser formuladas e usadas persuasivamente para decidir disputas pela influência das atitudes e excitação das emoções, de leitores e ouvintes. Estas nós denominamos 'definições persuasivas'". Ou seja, trata-se de buscar definições de modo premeditado para afetar os sentimentos e modificar comportamentos; a base desse procedimento reside na constatação de que a estrutura das definições pode servir como instrumento para a manipulação das emoções humanas, sem que se caracterize, de fato, qualquer mecanismo definidor cujo intento seja resolver pendências intensionais ou extensionais.

Destacam os autores que as definições persuasivas não se baseiam na função informativa da linguagem, mas se baseiam na criação de textos definidores previamente calculados para afetar emoções e dirigir comportamentos. Tais definições são ferramentas retóricas muito comuns. Assim, políticos de esquerda podem definir socialismo como "democracia aplicada ao campo econômico", enquanto os políticos de direita definem capitalismo como "liberdade aplicada à esfera econômica".

O intento manipulador é patente em tais definições: poucos discordariam que democratizar o campo econômico é positivo, assim como a liberdade na esfera do econômico parece ser uma precondição para a eficiência do mecanismo de oferta e procura. Portanto, a plausibilidade ou razoabilidade de tais argumentos torna difícil a refutação dessas definições e revela o poder manipulador a elas inerente.

Em suma, duas características são enfatizadas nas definições persuasivas: a) seu caráter passional; b) seu caráter valorativo.

Como exemplo de definições persuasivas, temos: 
1. "trator" $\approx$ "termo encomiástico aplicado aos mais eficientes, confiáveis e fiéis funcionários de uma empresa";

2. "agressiva" $\approx$ "pessoa dinâmica, inteligente e com muita iniciativa para gerir os negócios de alto risco em uma companhia".

Tendo apresentado esses diversos tipos de definição, passamos agora a apresentar uma análise sucinta das definições consideradas especificamente sob o ponto de vista da oralidade. Antes, porém, organizamos um quadro de exemplos da tipologia de definições já discutidas, visando facilitar a compreensão do exposto até aqui.

\begin{tabular}{|c|c|}
\hline tipos de definição & exemplos \\
\hline \multicolumn{2}{|r|}{ GRUPO I: pseudodefinições de caráter extensional } \\
\hline $\begin{array}{l}1.1 \text { pseudodefinição } \\
\text { extensional por nomeação }\end{array}$ & "(pessoa) agressiva" $\approx$ "Hitler, Mussolini, ..." \\
\hline $\begin{array}{l}1.2 \text { pseudodefinição } \\
\text { extensional por ostensão }\end{array}$ & $\begin{array}{l}\text { "(pessoa) agressiva" } \approx \text { "'agressiva' é ESTA" (apontando para uma } \\
\text { pessoa) }\end{array}$ \\
\hline $\begin{array}{l}1.3 \text { pseudodefinição } \\
\text { extensional semi-ostensiva } \\
\text { nominal }\end{array}$ & $\begin{array}{l}\text { "(pessoa) agressiva" } \approx \text { "'agressiva' é ESTA assassina serial" } \\
\text { (apontando para uma pessoa) }\end{array}$ \\
\hline $\begin{array}{l}1.4 \text { pseudodefinição } \\
\text { extensional semi-ostensiva } \\
\text { descritiva }\end{array}$ & $\begin{array}{l}\text { "(pessoa) agressiva" } \approx \text { "'agressiva' é ESTA criminosa e ré confessa" } \\
\text { (apontando para uma pessoa) }\end{array}$ \\
\hline \multicolumn{2}{|r|}{ GRUPO II: definições de caráter intensional objetivista } \\
\hline $\begin{array}{l}2.1 \text { definição intensional } \\
\text { objetiva por gênero e } \\
\text { espécie }\end{array}$ & $\begin{array}{l}\text { /(pessoa) agressiva } \leftarrow \pi \text { «homo sapiens contumaz em atacar outrem } \\
\text { com violência» / }\end{array}$ \\
\hline $\begin{array}{l}2.2 \text { definição intensional } \\
\text { objetiva pelas quatro causas }\end{array}$ & $\begin{array}{l}\text { /(pessoa) agressiva } \leftarrow \pi \text { «ser humanóide, gerado por seres } \\
\text { humanóides, cuja finalidade precípua é destruir } /\end{array}$ \\
\hline $\begin{array}{l}2.3 \text { definição intensional } \\
\text { objetiva teorética }\end{array}$ & $\begin{array}{l}\text { /(pessoa) agressiva } \leftarrow \pi \text { ranimal racional que manifesta, segundo a } \\
\text { psicosociologia, ações violentas condicionadas por carências físicas, } \\
\text { emocionais e sociais» / }\end{array}$ \\
\hline $\begin{array}{l}2.4 \text { definição intensional } \\
\text { objetiva operacional }\end{array}$ & $\begin{array}{l}\text { /(pessoa) agressiva } \leftarrow \pi \text { «considerando uma determinada pessoa ' } P \text { ', } \\
\text { colocada em uma sala junto a pessoas encarregadas de realizar uma } \\
\text { tarefa, estando a sala em condições específicas 'C', permite-se que a } \\
\text { pessoa ' } P \text { ' aja livremente, sem qualquer atribuição oficial, sob a } \\
\text { observação de câmaras ocultas. Se a ação de ' } P \text { ' for no sentido de } \\
\text { inibir ou reduzir a ação eficiente das demais pessoas da sala, então ' } P \text { ' } \\
\text { será considerada 'agressiva') / }\end{array}$ \\
\hline $\begin{array}{l}2.5 \text { definição intensional } \\
\text { objetiva condicional }\end{array}$ & $\begin{array}{l}\text { (pessoa) agressiva } \leftarrow \pi \text { <a pessoa ' } P \text { ' será considerada 'agressiva' se, } \\
\text { ao serem oferecidas várias alternativas de comportamento em relação } \\
\text { a pessoas concorrentes, ' } P \text { ' reiteradamente escolher a alternativa que } \\
\text { causa maior dano psicológico e, se possível, físico, a esses } \\
\text { concorrentes) / }\end{array}$ \\
\hline $\begin{array}{l}2.6 \text { definição intensional } \\
\text { objetiva por atributos } \\
\text { secundários }\end{array}$ & $\begin{array}{l}\text { /(pessoa) agressiva } \leftarrow \pi \text { (pessoa competitiva e violenta na utilização } \\
\text { de meios para atingir os fins pretendidos` / }\end{array}$ \\
\hline
\end{tabular}




\begin{tabular}{|c|c|}
\hline $\begin{array}{l}2.7 \text { definição intensional } \\
\text { objetiva estipuladora }\end{array}$ & $\begin{array}{l}\text { /(pessoa) agressiva } \leftarrow \pi \text { ipessoa que persegue inexoravelmente } \\
\text { objetivos pessoais em detrimento de objetivos éticos coletivos) / }\end{array}$ \\
\hline \multicolumn{2}{|c|}{ GRUPO III: definições de caráter intensional subjetivista e/ou convencionalista } \\
\hline $\begin{array}{l}3.1 \text { definição intensional } \\
\text { subjetivo-convencional } \\
\text { sinonímica/parafrástica }\end{array}$ & $\begin{array}{l}\text { /"agressiva" } \approx \text { "hostil" / } \\
\text { /"agressiva" } \approx \text { "que agride, denota ou envolve agressão" / }\end{array}$ \\
\hline $\begin{array}{l}3.2 \text { definição intensional } \\
\text { subjetivo-convencional } \\
\text { estipuladora }\end{array}$ & $\begin{array}{l}\text { /"agressiva" } \approx \text { "que luta enérgica e constantemente pela iniciativa" /; } \\
\text { /"(pessoa) agressiva" } \leftarrow \pi \text { «pessoa dinâmica, inteligente e com muita } \\
\text { iniciativa para gerir os negócios de alto risco em uma companhia / }\end{array}$ \\
\hline $\begin{array}{l}3.3 \text { definição intensional } \\
\text { subjetivo-convencional } \\
\text { lexical }\end{array}$ & $\begin{array}{l}\text { /"agressiva" } \approx \text { "que é inclinada a agredir ou provocar, sempre se } \\
\text { voltando para o ataque" / }\end{array}$ \\
\hline $\begin{array}{l}\text { 3.4 definição intensional } \\
\text { subjetivo-convencional } \\
\text { precisadora }\end{array}$ & $\begin{array}{l}\text { /"agressiva }{ }_{1} \approx \text { dotada de espírito beligerante /; /"agressiva }{ }_{2} \approx \\
\text { "empreendedora, energética, aguerrida e lutadora"/ [aqui se trata de } \\
\text { distinguir entre as duas intensões do termo "agressiva", para que se } \\
\text { interprete corretamente o enunciado: "Nos negócios, Marta é } \\
\text { agressiva"] }\end{array}$ \\
\hline $\begin{array}{l}3.5 d \epsilon \\
\text { subje }\end{array}$ & $\begin{array}{l}\text { "'P' é agressiva" } \approx \text { "'P' tende a manifestar comportamento violento e } \\
\text { belicoso"/ }\end{array}$ \\
\hline $\begin{array}{l}\text { nição intensional } \\
\text { o-convencional } \\
\text { al }\end{array}$ & $\begin{array}{l}\text { /"agressiva" } \approx \text { "(ADJ.); psicologia } \rightarrow \text { aquela que revela predisposição } \\
\text { para um comportamento hostil ou destrutivo" /; "(ADJ.) jogo de xadrez } \\
\rightarrow \text { jogada enérgica que implica resposta obrigatória e forçada do } \\
\text { adversário" / }\end{array}$ \\
\hline $\begin{array}{l}\text { 3.7 defini } \\
\text { subjetivo- } \\
\text { implícita }\end{array}$ & $\begin{array}{l}\text { /"agressiva" } \approx \text { "pessoa agressiva, em uma competição esportiva, } \\
\text { extrapola em muito os limites do conceito de 'competição' em } \\
\text { detrimento do conceito de 'esportiva"' / }\end{array}$ \\
\hline $\begin{array}{l}3.8 \text { definição intensional } \\
\text { subjetivo-convencional } \\
\text { autonímica (definições } \\
\text { nominais) }\end{array}$ & $\begin{array}{l}\text { /"agressiva" } \approx \text { "do latim "agressus", part. pass. de "agreddi"; palavra } \\
\text { paroxítona; adjetivo feminino; nome formado pelos grafemas "a", ... "a" } \\
\text { e pelos fonemas } \quad \text {,..., , etc." / }\end{array}$ \\
\hline \multicolumn{2}{|r|}{ UUPO IV: estruturas pseudodefinidoras diversas } \\
\hline $\begin{array}{l}4.1 \text { pseudodefinição } \\
\text { metafórica }\end{array}$ & "(pessoa) agressiva" $\approx$ "uma autêntica dinami \\
\hline $\begin{array}{l}4.2 \text { pseudodefinição } \\
\text { etimológica }\end{array}$ & $\begin{array}{l}\text { "(pessoa) agressiva" } \approx \text { "adjetivo proveniente do latim "aggressus" e } \\
\text { "aggredior, eris, essus sum, gredi" ("ir em direção a; ir contra"), verbo } \\
\text { depoente derivado por "ad" mais "gradior" ("caminhar; marchar; } \\
\text { adiantar-se". Portanto, "agressiva" significa "aquela que vai contra } \\
\text { alguém")". }\end{array}$ \\
\hline $\begin{array}{l}4.3 \text { pseudodefinição } \\
\text { predicativa subjetiva }\end{array}$ & $\begin{array}{l}\text { "(pessoa) agressiva" } \approx \text { "para mim, uma pessoa do mal" } \\
\text { "(pessoa) agressiva" } \approx \text { "pessoa maldosa e desagradável" }\end{array}$ \\
\hline
\end{tabular}

Como podemos observar através do quadro anterior, as pseudodefinições do grupo um - baseadas na ostensão —, são de fácil caracterização, pois há a presença de elementos dêiticos no definiens ou há uma sinalização de movimentos que apontam para os objetos referidos. 
As definições do grupo dois caracterizam-se pelas peculiaridades do texto definidor, voltado à delimitação precisa da intensão objetiva do conceito vinculado a um termo: assim, o definiens de uma definição por gênero e espécie deve apresentar claramente esses elementos, delimitando com precisão a intensão do conceito. Para as definições desse grupo, não há o objetivo de fornecer alternativas de permuta lingüística incondicional entre o definiendum e o definiens em um contexto determinado: pretende-se, na medida do possível, declarar a qüididade do objeto de definição (especificar sua substância ou sua essência; em outros termos, "dizer o que, de fato, a coisa é").

Temos, como exemplo, a seguinte definição intensional objetiva: /homem $\leftarrow \pi$ ‘mamífero da ordem dos primatas, único representante vivente do gênero 'homo', da espécie 'sapiens', caracterizado por ter cérebro volumoso, posição ereta, mãos preênseis, inteligência dotada da faculdade de abstração e generalização, e capacidade para produzir linguagem articulada) / HOUAISS (2001, p. 1545, verbete "homem").

As definições do grupo três caracterizam-se pelo fato de o texto definidor focalizar os significados dos termos vinculados aos conceitos respectivos: são definições intensionais subjetivas e/ou convencionais cujo foco deixa de ser o objeto mental em si mesmo (isto é, o conceito vinculado a um nome e, eventualmente, a um objeto práxico) - abandonando-se a busca por um texto definidor (idealmente, o melhor texto definidor) que declare a qüididade de uma substância - e passa a ser os significados lingüísticos que correspondem aos conceitos.

As pseudodefinições do grupo quatro, por sua vez, também são de fácil identificação por subverterem as relações lógicas entre definiendum e definiens: no caso das definições metafóricas, a lógica dessa relação se estabelece externamente ao processo definidor; no caso das pseudodefinições etimológicas, considera-se que a palavra, em seu percurso diacrônico, conserva um conteúdo semântico capaz de expressar e delimitar claramente um determinado conceito (e, até mesmo, declarar a essência de um objeto de definição); enfim, no caso das pseudodefinições predicativas subjetivas, o pseudodefiniens declara um atributo aplicado ao pseudodefiniendum por conta de um juízo sob responsabilidade do enunciador. 
Concluindo as considerações sobre este grupo de definições, lembramos que, conforme observa HEGENBERG (op. cit., pp. 55-58; 64-66), convém ter em conta o problema do entendimento do processo definidor como regra de permuta entre definiendum e definiens - abordagem que permeia o conceito de definição intensional subjetivo-convencional, segundo os tipos de definição já apresentados no terceiro grupo - e, igualmente, o conceito de definição intensional objetiva.

Segundo esse ponto de vista, a relação entre definiendum e definiens implica a possibilidade de substituição (in)condicional ou de possível eliminação: aquele pode ser substituído por este, dentro do sistema a que pertencem (em princípio, sem qualquer dano conceitual ou co-textual). De fato, o definiendum, enquanto termo derivado, operaria como uma simples abreviação (passível de eliminação em caso de necessidade) do definiens, formado por termos primitivos.

Porém, segundo o autor, essa regra de substituição incondicional do definiendum pelo definiens raras vezes pode ser aplicada concretamente; em situação de uso, comumente não podemos realizar ou não é aceitável que se proponha uma simples permuta entre eles sem alterações mais ou menos importantes no texto derivado, sob o ponto de vista sintático e semântico. Isso nos levaria a aceitar como excepcional a visão das definições como possibilidade de permuta e eliminação incondicionais entre definiendum e definiens. 


\section{CAPÍTULO IV — DEFINIÇÕES E ORALIDADE}

\subsection{DEFINIÇÕES SEGUNDO O CONTEXTO DA ORALIDADE}

De acordo com o apresentado no capítulo anterior, temos dois grupos de definições que focalizam: a) intensões conceituais objetivas; $b$ ) intensões conceituais subjetivas e intensões conceituais convencionais. Além disso, apresentamos estruturas predicativas que não podem, segundo nossa avaliação, ser consideradas legítimas definições; trata-se, conforme entendemos, de pseudodefinições: dizem respeito a objetos práxicos e a relações entre um pseudodefiniendum e um pseudodefiniens.

Os grupos II e III, majoritários, congregam quinze categorias de definição; dentro desses grupos, encontramos os tipos de definição mais utilizados pelas linguagens artificiais. Assim, as ciências denominadas "exatas" utilizam-se preferencialmente de definições que visam à univocidade dos conceitos definidos, segundo linguagens criadas ad hoc; por sua vez, outros campos científicos - por exemplo, as ciências denominadas "humanas" (tais como a Filosofia, Sociologia etc.) - predominantemente reconstroem uma língua natural, recategorizando termos que, então, passam a expressar significados específicos e, na medida do possível, não ambíguos, para fins particulares.

Quanto às pseudodefinições - assim denominadas por não tomarem como objeto de definição os conceitos implicados nem os significados a estes vinculados - representam o grupo minoritário de sete estruturas predicativas. Sob o ponto de vista das investigações científicas puras, as pseudodefinições não possuem relevância maior; porém, sob o ponto de vista dos objetivos de comunicação quotidiana, podemos atribuir-Ihes papel de destaque — uma vez que desloquemos o foco não para os conceitos, mas para os objetivos da interação discursiva.

Para os propósitos deste trabalho, importa distinguir o saber científico e aquilo que podemos denominar "saber paracientífico": 
"Julgamos conhecer cientificamente ( e) pi/stasqai ) cada coisa, de modo absoluto e não, à maneira sofística, por acidente, quando julgamos conhecer a causa pela qual a coisa é, que ela é sua causa e que não pode essa coisa ser de outra maneira $(\mathrm{mh} \backslash$ e) nde/xesqai alllwj elxein ) [ARISTÓTELES, Segundos Analíticos, I, 2, 71b, 9-12]. Tal é a noção famosa de conhecimento científico que os 'Segundos Analíticos' formulam [...] Por ela entendemos, então, que, em sentido absoluto, só há conhecimento científico de uma coisa quando a conhecemos através do nexo que a une a sua causa, ao mesmo tempo que apreendemos sua impossibilidade de ser de outra maneira, isto é, sua necessidade. [...] Causalidade e necessidade, eis aí, por conseguinte, os dois traços fundamentais que caracterizam a ciência, tal como os 'Segundos Analíticos' a concebem" PEREIRA (2001, pp.35-36).

De acordo com essa observação do autor, o que distingue o conhecimento científico dos demais conhecimentos é sua capacidade de estabelecer claramente a causalidade (respondendo à pergunta "por que é? / por que causa é?") e a necessidade (respondendo à pergunta "por que deve ser assim? / por que não pode ser diferente?") de um objeto ${ }^{133}$. Desse modo, conhecer cientificamente implica conhecer essências e determinar substâncias.

Já para aquilo que denominamos "conhecimento paracientífico" — saber produzido e utilizado nas atividades do quotidiano e, em especial, nas interações verbais espontâneas —, não vigora o propósito de conhecer a qüididade das substâncias; em outras palavras, o conhecimento paracientífico ou conhecimento natural não cogita em fazer ciência enquanto é mobilizado pelas ações interacionais rotineiras. É desse tipo de conhecimento que nos importa tratar doravante; portanto, passamos a considerar um outro fator que se incorpora ao processo definidor: sua função interacional. De fato, tínhamos até aqui a seguinte série de fatores:

substâncias $\leftarrow$ essências $\leftarrow$ conceitos $\leftarrow$ significados $\leftarrow$ nomes referenciais

${ }^{133}$ Há, conforme assinala o autor, quatro investigações básicas promovidas pela ciência, segundo Aristóteles: a) "que o fenômeno é" ( o3ti ); b) "o porquê o fenômeno é" ( dio/ti )"; c) "se o fenômeno é" ( ei) elstin ); d) "o que o fenômeno é" ( ti/ e) stin ). Ver PEREIRA (2001, pp. 279-336) para uma importantíssima explicação sobre as relações entre definições e demonstrações científicas na filosofia aristotélica. 
Como vemos, os indivíduos permanecem como um pressuposto nesse conjunto de elementos: não se trata de desconsiderar o agente definidor e seu contexto interacional; trata-se, apenas, de tomar como óbvia sua presença e entender que suas ações podem ser compreendidas através da articulação dessa série de fatores (ou seja, a ações dos indivíduos no processo definidor implicam as determinações de substâncias, essências, conceitos, significados, nomes e referenciais).

Para nós, o passo decisivo para a compreensão do processo definidor sob o ponto de vista da oralidade está em examinar a complexidade desse elemento pressuposto - os agentes definidores e seus contextos interacionais -; trata-se de:

a) entender a ação dos fatores anteriormente mencionados segundo: i) contextos interacionais concretos; ii) condições de planejamento e produção textuais próprias da oralidade; iii) relações interpessoais gerenciadas durante a atividade discursiva (em suma, focalizar os conceitos de substância, essências, significados, nomes e referenciais segundo o ponto de vista pragmático);

b) distinguir entre os conceitos de língua escrita e língua falada ${ }^{134}$.

Assim, a distribuição conceitual anteriormente apresentada passa a ser mais bem compreendida, sob o ponto de vista de nosso objeto de estudo, como:

CONTEXTO DA ORALIDADE $\leftrightarrow$ OBJETIVOS INTERACIONAIS
\begin{tabular}{|c|} 
substâncias $\leftarrow$ essências $\leftarrow$ conceitos $\leftarrow$ significados $\leftarrow$ nomes \\
referenciais
\end{tabular}

Aqui, importa recordar as definições de substância e essência / qüididade apresentadas anteriormente ${ }^{135}$; para nós, importa destacar que, em nossas

\footnotetext{
${ }^{134}$ Importa aqui considerar os comparativos entre língua falada versus língua escrita, presentes em Ângela C. Souza RODRIGUES (1999, pp. 13-32); Leonor Lopes FÁVERO et alii (1999, pp. 69-113) e Ataliba T. de CASTILHO (1998, pp. 16-21).

${ }^{135}$ Retomando os textos definidores: ‘entenderemos por "substância" aquilo que subsiste dos seres, ou seja, aquilo que há neles de permanente, segundo a percepção subjetiva e/ou convencional, produzida em dado contexto social, ou segundo a percepção objetiva, produzida nesse mesmo contexto); ‘entenderemos por "essência" — ou "qüididade" — o conjunto de atributos necessários e
} 
redefinições desses conceitos, instauramos: a) a percepção fenomênica das intensões (isto é, com destaque para o caráter perceptivo das intensões, mesmo a objetiva); b) a contextualização social que determina essas percepções.

Neste tópico, interessa-nos examinar as definições sob o ponto de vista da oralidade; para isso, tomaremos como referência algumas estruturas definidoras presentes no corpus. Para os objetivos de nossa exposição, analisaremos neste capítulo tais estruturas sem recurso ao co(n)texto original, ou seja, consideraremos exclusivamente as relações estabelecidas entre definiendum e definiens.

Lemos em REY (2000, pp. 9-12) que, na linguagem do quotidiano, a prática da formulação de definições representa um procedimento complexo que não se limita às acepções lexicais registradas em dicionários de uso, mas abrange glossários, enciclopédias, listas de termos técnicos e tratados científicos, além de codificações de significados particulares dos termos em linguagens especiais, como é o caso da linguagem filosófica.

Mesmo que nos limitemos ao campo relativamente estável dos dicionários e enciclopédias, numerosas ambigüidades cercam o termo "definição", conforme o compreendemos ordinariamente (e conforme já tivemos oportunidade de afirmar):

"[...] algumas não são muito problemáticas. É simplesmente uma questão de convenção que 'definição' tem sido chamada de uma equação sêmica (ou, então, o segundo elemento dessa equação). Contudo, por causa de sua forma condensada, o texto de proposições definidoras em dicionários é ambíguo. Por exemplo, a expressão 'a palavra ' $x$ ' significa...' não é diferenciada apropriadamente de uma frase tal como 'aquilo que é chamado de ' $x$ ' $-o$ referente - é..." (op. cit., p. 10).

Como vemos, há, sob o ponto de vista prático, uma grande permeabilidade entre a visão nominalista (terminista) das definições — "a palavra ' $x$ ' significa 'abc'" — e a visão essencialista (substancialista) do processo definidor — "aquilo que é chamado de ' $x$ ' é a essência ' $y$ '": é comum que se transite facilmente entre declarar o

suficientes com os quais uma substância aparece como aquela substância particular e distinta, segundo a percepção subjetiva e/ou convencional, produzida em dado contexto social, ou segundo a percepção objetiva, produzida nesse mesmo contexto, não se confundindo, assim, com nenhuma outra substância /. 
significado lingüístico (a expressão lingüística de um conceito) vinculado convencionalmente a um nome, e declarar o conceito atinente à essência de uma substância (sua qüididade ou o conjunto de suas características necessárias e suficientes) vinculada a um significado e a seu respectivo nome, ou seja, a um termo. A diferença crucial está em que podemos declarar qualquer significado lingüístico, uma vez que consideremos o convencionalismo dos signos; por sua vez, não podemos declarar qualquer conceito que reflita a qüididade de um ser.

O autor destaca uma das principais fontes de ambigüidades para o processo definidor: a transferência de categorias lógico-científicas — produtos da evolução de sistemas conceituais - para atender aos processos de definição no uso quotidiano. Assim, não convém negligenciar a impermeabilidade natural entre os tipos de definições genericamente denominadas "técnicas" (não apenas lógico-filosóficas, mas também científicas) e os tipos de definições voltados para as necessidades da comunicação do quotidiano - em especial no âmbito da oralidade - : nesse sentido, é melhor considerar a existência de duas modalidades de definições, em princípio estanques: podemos denominá-las "definições artificiais" (no sentido de serem definições criadas ad hoc para linguagens não naturais) e "definições naturais" (definições que melhor se adaptam às necessidades das línguas naturais). Aqui, estabelecemos relações entre as definições artificiais e o saber científico, e as definições naturais e o saber paracientífico.

Esse ponto é importante porque assinala a necessidade de discernir entre ambas as modalidades e, igualmente, a conveniência em evitar a idéia de que existe, digamos assim, uma espécie de "norma culta" das definições — definições de caráter técnico-lógico-filosófico para os momentos de formalidade da expressão verbal (visando ao conhecimento científico) e definições pretensamente semicorretas, admitidas em momentos de informalidade nos registros lingüísticos (visando ao conhecimento paracientífico).

Também, assim como já se estabeleceu claramente a distinção entre a escrita e a oralidade, convém igualmente distinguir, dentro do campo das definições, entre o subgrupo das "definições escritas" e o subgrupo de "definições orais", as quais assimilam todas as características, funções e objetivos da língua falada: para tal 
distinção assumimos as mesmas categorias distintivas da língua escrita versus língua falada.

Para aquilo que passamos a denominar "definições orais naturais" definições naturais e orais, visando ao conhecimento paracientífico —, constata-se que o contexto conversacional determina fortemente as características formais do texto definidor (correções e paráfrases, por exemplo, são eventos esperados nessas definições); a impossibilidade de planejamento prévio, ou seja, a contemporaneidade entre planejamento e execução textuais afeta sobremaneira a própria estrutura conceitual das definições orais; enfim, questões de envolvimento e distanciamento interpessoais impõem determinados objetivos pragmáticos perante os quais as definições constituem, antes de tudo, poderosas ferramentas retóricoargumentativas.

É interessante registrar um exemplo de tipologia de definições relativa às "definições orais naturais". Assim, em ALVES (1999, pp. 157-167), há a análise de um trecho do Inquérito no 338 do PROJETO NURC/SP (Elocução Formal), na qual a autora destaca a presença de unidades lexicais típicas da língua comum, ao lado de termos técnicos específicos da Economia (trata-se de uma aula universitária versando sobre "demanda de moeda").

Alves destaca como o contexto discursivo determina o papel das definições em um texto particular: tratando-se de uma aula, os termos técnicos da ciência econômica devem-se tornar acessíveis aos alunos; por isso, o professor emprega os processos de expansão e explicitação de termos primitivos (significados já conhecidos) e dos termos a serem introduzidos (significados a serem determinados).

Segundo a autora, no exemplo analisado, as definições presentes aproximamse do tipo de definição presente em dicionários de uso - dado o caráter pedagógico do discurso em desenvolvimento -; no caso do inquérito em questão,

"[...] os termos explanados pelo professor de Economia, o informante do inquérito analisado, refletem os diferentes tipos de definições, de caráter técnico e científico, características dos textos lexicográficos [...]. As definições mais comumente empregadas pelo informante são as de tipo sinonímico, em que um elemento é substituído por outro(s), considerado(s) contextualmente equivalente(s): 'oferecem...criam moeda' [...]; demandarem moeda a 
procurarem moeda a guardarem moeda' [...]; 'uma demanda de moeda...uma retenção de moeda' [...] (p. 161).

De acordo com essa observação, as definições intensionais subjetivoconvencionais sinonímicas ou parafrásticas predominam no corpus considerado: assim, oferecer um termo considerado equivalente a um termo anterior ou oferecer uma paráfrase que alinhe definiendum e definiens sob o ponto de vista do conteúdo significativo representam procedimentos definidores comuns no campo das definições orais naturais.

A autora também destaca a manutenção do paralelismo sintagmático nas estruturas definidoras, com a reiteração da classe gramatical dos termos que compõem tais estruturas. Por meio de definições sinonímicas de estrutura sintagmática, os termos científicos são permutados por unidades lexicais orais naturais: através desse mecanismo de conversão, termos de uma linguagem não natural encontram equivalência de significado (equivalência lingüística ou parafrástica, porém não equivalência conceitual!) em relação a termos da linguagem do quotidiano.

Ao lado das definições sinonímicas (item "3.1" de nosso quadro tipológico: definições intensionais subjetivo-convencionais sinonímico-parafrásticas) ${ }^{136}$, Alves menciona que as denominadas "definições lógicas" ou "definições analíticas" (definições por gênero e diferença) são evitadas pelo informante ${ }^{137}$. Essa é uma constatação importante para nossos propósitos: as definições intensionais objetivas por gênero próximo e diferença específica (item "2.1" de nosso quadro tipológico) são evitadas pelo falante, em benefício de outras estruturas definidoras "[...] que tendem a tornar sua exposição mais clara e mais facilmente interpretável por seus alunos" (p. 162). De acordo com essa observação, o critério-diretor prioriza os efeitos pragmáticos da definição, projetando para segundo plano o rigor conceitual

\footnotetext{
${ }^{136}$ De acordo com as definições sinonímicas, teríamos: /"demanda de moeda por motivo transação" $\approx$ "procura e retenção de moeda visando ao atendimento de transações"\%.

${ }^{137}$ Segundo as definições lógicas, teríamos: /demanda de moeda por motivo transação $\leftarrow \pi$ «retenção de moeda [gênero próximo] efetuada pelo assalariado que lhe permite o estabelecimento do equilibrio entre receita e despesa [espécie ou diferença específica])/.
} 
que poderia ser alcançado (em suma: a maximização da eficiência interacional precede em importância a maximização da eficiência conceitual).

A autora mostra que, em lugar de optar por definições intensionais objetivas, o informante prefere as "definições por síntese" — nas quais [...] são listados, além dos traços específicos do termo, elementos que com ele estabelecem variadas formas de relações" (Ibidem) ${ }^{138}$ (podemos aqui considerar as definições intensionais objetivas por atributos secundários ou então as definições intensionais subjetivoconvencionais lexicais). Observemos que se utiliza a expressão "traços específicos do termo", fato que demonstra tratar-se de uma referência aos significados em questão: tais definições declaram os traços principais que constituem o significado vinculado ao nome e, também, declaram traços secundários diversos. Melhor considerar aqui, portanto, um tipo de definição intensional subjetivo-convencional.

Há também no inquérito um tipo de "definição por denotação", "[...] que se manifesta mediante exemplos que põem em prática o conceito [...]" implicado pela definição ${ }^{139}$. De acordo com o exemplo selecionado pela autora, trata-se da definição intensional objetiva operacional, em que várias operações são agrupadas em seqüência, de modo a caracterizar inequivocamente o conceito em análise (teríamos aqui as definições intensionais objetivas operacionais).

Em suma, analisando o referido inquérito, assim a autora sintetiza os tipos de definições encontradas: "[...] sinônimos (definição sinonímica); explicações (definição analítica ou lógica); relações diversas (definição por síntese); exemplos práticos (definição por denotação)" (p. 164). Tais processos definidores são equiparados aos procedimentos de reformulação sinonímico-parafrástica ${ }^{140}$.

\footnotetext{
${ }^{138}$ Segundo as definições por síntese, teríamos: /demanda de moeda por motivo transação $\leftarrow \pi$ «principal motivo pelo qual as pessoas retém moeda; deve-se à diferença existente entre as datas de recebimento da renda e as datas de pagamento das despesas efetuado ao longo do mês; demanda de moeda para satisfazer as necessidades de transações e pagamentos; função do nível de renda»/.

${ }^{139}$ Exemplo de definição por denotação: /demanda de moeda por motivo transação $\leftarrow \pi$ ıas pessoas recebem no início do mês, mas não gastam e uma só vez; gastam aos poucos: são obrigadas a deixar uma certa reserva para gastos normais quotidianos, de modo a terem alguma reserva disponívels/.

140 "As definições propostas pelo professor informante a seus alunos correspondem, como já observamos, a tentativas de explicitação de fórmulas - os termos da Economia - antes apresentadas. Tais tentativas definidoras coincidem, portanto, com a reformulação de elementos anteriormente introduzidos e equivalem às atividades de reformulação parafrástica. [...] As
} 
Essa visão de equivalência entre $\circ$ processo definidor e $\circ$ processo parafraseador estabelece um paralelismo entre ambas as tipologias:

\begin{tabular}{|c|c|}
\hline definições sinonímicas & reformulação parafrástica por variação lexical \\
\hline definições por síntese & paráfrases explicativo-definidoras \\
\hline definições por denotação & paráfrases exemplificadoras \\
\hline
\end{tabular}

Em ALVES (2005, pp. 160-164), registra-se um tipo de reformulação metalingüística: os "enunciados definitórios". Verbos metalingüísticos estabelecem relações entre signos e coisas, entre signos e pessoas, e entre signos e signos, exercendo função metalingüística, ao "[...] falarem da linguagem, especificamente do termo que definem por meio de um enunciado metalingüístico que constitui a definição desse termo" (p. 160).

Trata-se da estrutura enunciativa formada pelo verbo "ser", estabelecendo equivalência semântica entre termos e enunciados reformuladores que "[...] reproduzem alguns traços definitórios desses termos". Assim, produzem-se estruturas enunciativas que fazem o papel de definições autênticas; eventualmente, outros verbos metalingüísticos substituem o verbo "ser" ("verbos definitórios" tais como "englobar", "representar", "explicar" e o próprio verbo "definir"). Vejamos os exemplos citados pela autora:

\begin{tabular}{|l|c|l|}
\hline "cartas rogatórias" & $\approx$ & $\begin{array}{l}\text { "são documentos que os ministros do STF precisam assinar quando } \\
\text { uma pessoa que mora no exterior deseja citar alguém no Brasil" }\end{array}$ \\
\hline $\begin{array}{l}\text { "correspondente } \\
\text { bancário" }\end{array}$ & $\approx$ & $\begin{array}{l}\text { "é uma máquina da Caixa operada pelo dono de um } \\
\text { estabelecimento comercial, o que permite às pessoas fazerem } \\
\text { pagamentos de água, luz, telefone, depósito, retirada, transferência" }\end{array}$ \\
\hline "família" & $\approx$ & "é peça central e fundamental da sociedade" \\
\hline "quark" & $\approx$ & "é uma partícula elementar da matéria" \\
\hline "vazio quântico" & $\approx$ & $\begin{array}{l}\text { "é uma complexa combinação de matéria e antimatéria, opostos que } \\
\text { interagem e se anulam; processo que ocorre em milésimos de } \\
\text { segundos e pode ser detectado" }\end{array}$ \\
\hline "biossegurança" & $\approx$ & $\begin{array}{l}\text { "é uma ciência que engloba pesquisas sobre tudo o que diz respeito } \\
\text { à segurança biológica, como o manuseio correto de } \\
\text { microorganismos em laboratório, a prevenção do bioterrorismo e os }\end{array}$ \\
\hline
\end{tabular}

reformulações parafrásticas mais usualmente empregadas pelo professor mostram que, entre os termos e suas respectivas definições, existe uma relação sinonímica. Nesses caso, as reformulações parafrásticas repetem as estruturas sintática manifestada pelos elementos reformulados e apenas revelam variantes de caráter lexical" ALVES (op. cit., p. 164). 


\begin{tabular}{|l|c|l|}
\hline & & riscos de contaminação" \\
\hline "Clonagem terapêutica" & $\approx$ & $\begin{array}{l}\text { "representa um impacto importante para a saúde pública, que pode } \\
\text { salvar milhões de vidas" }\end{array}$ \\
\hline "cosmologia" & $\approx$ & $\begin{array}{l}\text { "tenta explicar de onde vem o que existe, no contexto de que a força } \\
\text { mais importante do Universo é a de gravitação, que atrai um corpo } \\
\text { celeste a outro" }\end{array}$ \\
\hline "pediatra" & $\approx \begin{array}{l}\text { "define-se como o especialista em crianças, mas na verdade é um } \\
\text { médico da familia" }\end{array}$ \\
\hline
\end{tabular}

A autora observa que, em seu corpus, nem todos os enunciados definitórios são introduzidos por verbos metalingüísticos: podem ser iniciados por termo genérico "[...] que integra o termo [definiendum] em seu campo conceitual":

\begin{tabular}{|l|c|l|}
\hline "biossegurança" & $\approx$ & $\begin{array}{l}\text { "a ciência que trata dos aspectos de segurança que envolvem a } \\
\text { pesquisa com seres vivos" }\end{array}$ \\
\hline "xylella fastidiosa" & $\approx$ & "uma praga que causa a doença do amarelinho nos laranjais" \\
\hline "juizite" & $\approx$ & $\begin{array}{l}\text { "doença que acomete principalmente os magistrados mais novos. } \\
\text { Eles chegam cheios de vontade, achando-se super-homens. Muitas } \\
\text { vezes tomam decisões exóticas, que acabam reformadas" }\end{array}$ \\
\hline
\end{tabular}

Também, há casos em que o papel metalingüístico é desempenhado por termos que enfatizam funções ou operações que caracterizam o definiendum (nisso lembrando as definições intensionais objetivas operacionais):

\begin{tabular}{|l|c|l|}
\hline "mosquito transgênico" & $\approx$ & "funciona como uma vacina contra a dengue e a malária" \\
\hline "transgenia" & $\approx$ & $\begin{array}{l}\text { "veio para solucionar esse problema [ou continuamos com os } \\
\text { desmatamentos ou aprimoramos os métodos agrícolas], sem } \\
\text { aumentar a área de plantio e com menos uso de agrotóxicos" }\end{array}$ \\
\hline "buracos negros" & $\approx$ & $\begin{array}{l}\text { "fenômeno em que uma estrela implode e tem um campo } \\
\text { gravitacional tão forte que nada sai dela, nem a luz" }\end{array}$ \\
\hline
\end{tabular}

Em KOCH (2004, pp. 75-77), comenta-se que certas paráfrases baseadas em expressões nominais podem assumir a função definidora, "[...] como se pode verificar em 'argonautas' $\rightarrow$ 'estes tripulantes da nau mitológica Argos ${ }^{\text {1141 }}$. Temos, portanto, "paráfrases anafóricas definicionais" e "paráfrases anafóricas didáticas":

a) nas primeiras, o definiendum é previamente introduzido, frente ao qual o definiens (componente da expressão referencial) realiza movimento anafórico,

${ }^{141}$ O texto fornecido é: "Vocês já ouviram falar dos argonautas? Pois conta-nos a lenda grega que estes tripulantes da nau mitológica Argos saíram à busca do Velocino de Ouro". 
muitas vezes acompanhado de expressões tais como "(um) tipo de" ou "(uma) espécie de": "Entre os conjuntos musicais populares do Nordeste brasileiro encontram-se, ainda, as bandas de pifaros. É bastante curioso ouvir essa espécie de flautim militar, que produz sons agudos e estridentes" ("pifaro" $\approx$ "espécie de flautim militar que produz sons agudos e estridentes");

b) nas segundas, o definiendum aparece na expressão anafórica referencial (freqüentemente entre aspas), enquanto o definiens constitui a expressão introdutora: "Para orientar as manobras dos aviões, os aeródromos são dotados e aparelhos que indicam a direção dos ventos de superfície. As birutas, que têm a forma de sacola cônica, são instalada perpendicularmente à extremidade de um mastro" ("aparelho que indicam a direção dos ventos $d$ superfície" $\approx$ "biruta").

De acordo com esses exemplos, podemos observar, no que diz respeito a essas definições orais naturais, uma aproximação conceitual entre a noção de definição e a noção de paráfrase: assim, se considerássemos esses exemplos, teríamos uma definição de definição oral natural semelhante a: /definir $\leftarrow \pi$ ‘atividade lingüística de reformulação textual, pela qual se estipula uma relação de equivalência de significados entre um enunciado de origem - o definiendum - $e$ um enunciado reformulador - o definiens /.

Procuraremos melhor caracterizar as definições orais naturais a partir da análise dos exemplos colhido no corpus. Nestes exemplos, encontramos recriações das seguintes estruturas: a) /definiendum $\leftarrow \pi$ 〈definiens` / (definições substanciais); b) /"definiendum" $\approx$ "definiens"/ (definições semióticas ou signações); c) "definiendum" $\approx$ "definiens" (pseudodefinições), a partir dos textos originais.

Antes de passarmos ao próximo tópico, uma observação: para o exemplo "1.1", abaixo apresentado, encontramos no texto original: "éh...ehn:.......bom...o que seria então...éh:: uma nota bruta...num teste? seria aquela nota total...de erros...e acertos então cada indivíduo...realiza o seu teste e.: obtém uma nota... que é o total de erros... e acertos...". Podemos verificar que, além da estrutura definidora 
propriamente dita, aparecem outros elementos que fazem parte do processo definidor na oralidade, como é o caso da pergunta - "o que seria então...éh:: uma nota bruta...num teste?" —; tais elementos serão considerados no tópico "5.2" deste trabalho.

\subsection{ANÁLISE DE DEFINIÇÕES PRESENTES NO CORPUS}

Neste tópico apresentaremos algumas análises de definições orais naturais, colhidas no corpus. Interessa-nos aqui apenas a estrutura definidora em si mesma; os trechos de que foram extraídos os exemplos serão apresentados no próximo capítulo, quando focalizaremos as definições enquanto sistemas. Remetemos o leitor ao material do Projeto NURC/SP (CD-Rom - Documentação eletrônica organizada pelo Projeto NURC/SP - Núcleo USP, 2002), caso haja interesse no exame dos trechos em questão.

1. INQUÉRITO $n^{\circ} 377$ - BOBINA No 123 - INFORMANTE $N^{\circ} 416$ -

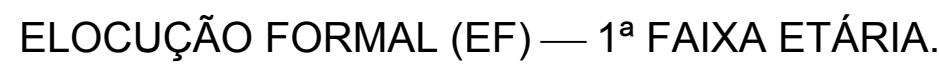

1.1 linhas 180-184: nota bruta (em um teste) $\rightarrow$ total de erros e acertos que cada indivíduo obtém ao realizar um teste.

1.2 linhas 298-299: inteligência $\rightarrow$ algo contínuo; inteligência $\rightarrow$ o uso do intelecto.

Trata-se de uma elocução formal — uma aula universitária cujo tema era "os instrumentos da vida intelectual" — da qual extraímos dois exemplos:

a) o primeiro exemplo apresenta as características de uma definição intensional objetiva operacional (uma ocorrência), uma vez que compreendamos as etapas implícitas no texto definidor. Se completarmos o conjunto de operações sugeridas, teremos: /nota bruta $\leftarrow \pi$ considerando uma determinada pessoa ' $P$ ' que realiza um teste, obteremos sua nota bruta nesse teste se calcularmos a diferença entre $o$ total de acertos e o total de erros obtidos na solução das questões /. Observa-se que se trata de delimitar a intensão do objeto identificado pelo sintagma "nota bruta", 
de modo a distingui-lo de outros objetos concorrentes, tais como "nota líquida" e "nota ponderada";

b) no segundo exemplo, trata-se de definir o conceito de inteligência; i) o primeiro definiens propõe o enunciado "inteligência é algo contínuo"; ii) o segundo definiens propõe "inteligência é o uso do intelecto".

A estrutura definidora "inteligência" $\approx$ "algo contínuo" assim pode ser analisada:

a) não pode pertencer ao primeiro grupo de definições, pois não há qualquer processo extensional desenvolvido (nenhuma ostensão é verificada);

b) também não pode pertencer ao segundo grupo porque não se trata de considerar a realização de qualquer processo intensional que busque definir clara e inequivocamente o conceito vinculado ao nome "inteligência" (observemos que "algo contínuo" é uma expressão ao mesmo tempo ambígua e vaga; o que seria, afinal, "algo contínuo"? Uma substância qualquer? O meio gasoso? O espírito?);

c) igualmente, não pode pertencer ao terceiro grupo de definições (as definições intensionais subjetivo-convencional), pois o definiendum não pode ser considerado como uma aproximação lingüística do definiens (torna-se inaceitável construir "A expressão 'Sua inteligência é assombrosa' é igual, por definição, à expressão 'Seu algo contínuo é assombroso"');

d) não se trata de uma pseudodefinição etimológica nem de uma pseudodefinição predicativa subjetiva, porque: i) não se trata de estabelecer a etimologia da palavra "inteligência"; ii) não existem traços explícitos de subjetividade predicada pelo sujeito definidor (como ocorreria, por exemplo, no texto: "inteligência é, segundo minha percepção, algo contínuo");

e) portanto, convém incluí-la no quarto grupo e no subgrupo das definições metafóricas: a inteligência possui uma relação de semelhança subentendida com qualquer coisa contínua, ou seja, com qualquer objeto que possua como característica a continuidade, seja lá o que isso signifique fenomenicamente para a percepção do sujeito definidor. Decidimos, pois, classificá-la como uma pseudodefinição metafórica (uma ocorrência). 
A estrutura definidora "inteligência" $\approx$ "uso do intelecto" é de mais fácil identificação; se repetirmos a mesma análise anterior, teremos: a) ela não deve ser incluída no grupo das definições extensionais por nomeação ou ostensão; b) não convém, igualmente, incluí-la no grupo das definições intensionais objetivas, pelas mesmas razões apontadas no item "b" da análise anterior; c) as características próprias das definições do grupo quatro também não convêm a este texto definidor. Portanto, trata-se de uma definição do grupo três; podemos entendê-la como uma definição intensional subjetivo-convencional sinonímico-parafrástica (uma ocorrência), pois o definiens reproduz parafrasticamente conteúdo semântico assemelhado ao definiendum (podemos considerar que, de modo geral, o definiens pode ser permutado pelo definiendum sem maiores problemas co(n)textuais: "Pedro revela uma brilhante inteligência" "Pedro revela um brilhante uso do intelecto").

2. INQUÉRITO $n^{\circ} 338$ - BOBINA No 141 - INFORMANTE $N^{\circ} 488-$ ELOCUÇÃO FORMAL (EF) - $1^{\text {a }}$ FAIXA ETÁRIA.

2.1 linhas 39-67: demanda de moeda por transação $\rightarrow$ principal motivo pelo qual a pessoa retém moeda; demanda de moeda por transação $\rightarrow$ demanda de moeda para satisfazer as necessidades de transações e de pagamentos; demanda de moeda por transação $\rightarrow$ demanda de moeda como função do nível de renda nominal.

2.2 linhas 217-234: demanda de moeda por transação $\rightarrow$ demanda de moeda como função do nível de renda; demanda de moeda por transação $\rightarrow$ proporção $k$ desse nível de renda; demanda de moeda por transação $\rightarrow$ proporção $k$ e y da renda nominal; demanda de moeda por transação $\rightarrow$ principal razão pela qual todos nós agora temos um certo montante de dinheiro no bolso.

2.3 linhas 470-483: taxa de juros $\rightarrow$ rendimento que as pessoas obtêm ao comprar um título; taxa de juros $\rightarrow$ rendimento percentual na compra de um título; 
taxa de juros $\rightarrow$ custo de se reter moeda; taxa de juros $\rightarrow$ o que ele [i.e.: a pessoa] ganharia se comprasse o título.

Trata-se de uma elocução formal — aula universitária cujo tema era "a demanda de moeda" —; os exemplos apresentados podem assim ser reagrupados:

/"demanda de moeda por transação" $\leftarrow \pi$

«principal motivo pelo qual a pessoa retém «demanda de moeda como função do nível de moeda); ‘demanda de moeda para satisfazer as renda (nominal)〉; ‘demanda de moeda como necessidades de transações e de pagamentos); função do nível de renda); 〈proporção $k$ desse ‘principal razão pela qual todos nós agora temos nível de renda); ‘proporção $k$ e $y$ da renda um certo montante de dinheiro no bolsos / nominals /

O grupo "II" apresenta textos definidores que caracterizam as definições intensionais objetivas, pois se trata de declarar os traços que identificam de modo não-ambíguo e não-vago um dado objeto, distinguindo-o de todos os outros objetos. Observemos que estão descartadas aqui as definições extensionais e as pseudodefinições (ou seja, tais definições não estão caracterizadas pelos textos definidores em questão).

Dentre as definições intensionais objetivas, cabe especificar a que melhor corresponde a esses textos; de modo unificado, temos um definiens que estabelece que a "demanda de moeda por transação" pode ser compreendida como uma função ou proporção da renda nominal dos agentes econômicos:

a) percebemos que não se trata de uma definição intensional objetiva por gênero e espécie ou pelas quatro causas, pois há outros objetos de definição que poderiam também ser caracterizados como uma função ou proporção do nível de renda nominal (ou seja, a demanda de moeda por transação não detém com exclusividade essa característica). Trata-se, portanto, de uma condição necessária, porém não suficiente para, por si só, constituir uma definição ideal desse definiendum; 
b) não se trata de uma definição intensional objetiva por atributos secundários porque o definiens proposto deve necessariamente integrar a caracterização desse definiendum (ou seja, não são traços contingentes os aqui apresentados: toda demanda de moeda por transação é, necessariamente, função do nível de renda nominal). Novamente, temos uma condição necessária, mas não suficiente;

c) também não podemos propor a presença de uma definição intensional objetiva condicional, como podemos apreender pela formulação do definiens, o qual não estabelece condições para que determinado evento tenha lugar;

d) podemos constatar, além disso, que não existe a caracterização de um definiens típico das definições intensionais objetivas operacionais;

e) portanto, consideramos adequado incluir os textos definidores apresentados no grupo "II" na classe das definições intensionais objetivas teoréticas (quatro ocorrências), lembrando o que já foi afirmado: "uma definição teorética de um termo é uma definição que tenta formular uma descrição teoricamente adequada ou cientificamente útil do objeto ao qual o termo se aplica"142). Isso porque podemos inferir a presença, como um pressuposto, de uma determinada teoria econômica subjacente, que explica a relação entre o tamanho da renda nominal e a quantidade de moeda retida pelo indivíduo para dispêndio ao longo do tempo.

No grupo "I" do quadro anterior, o conceito de demanda de moeda por transação é definido como:

a) «principal motivo pelo qual a pessoa retém moeda). Trata-se de um texto definidor que não pode ser considerado extensional; também não cabe classificá-lo como intensional subjetivo-convencional porque não há uma relação entre expressões lingüísticas (não podemos reconhecer aqui a sentença "seja o termo 'definiendum' sinônimo da expressão 'definiens": o definiens aqui declara uma característica do conceito em questão, e não uma alternativa lingüística para o nome desse conceito); não podemos afirmar, tampouco, a presença de uma pseudodefinição. Portanto, temos aqui uma definição intensional e, dentre elas, uma definição intensional objetiva por atributos secundários (uma ocorrência);

${ }^{142}$ COPI \& COHEN (op. cit., p. 109). 
b) ¿demanda de moeda para satisfazer as necessidades de transações e de pagamentos». Trata-se de um definiens que simplesmente retoma o mesmo conteúdo semântico do definiendum, com ligeiras variações formais; há aqui, portanto, uma definição intensional subjetivo-convencional sinonímico-parafrástica (uma ocorrência). Podemos construir: "a demanda de moeda por transação cresceu muito no país" "demanda de moeda para satisfazer as necessidades de transações e de pagamentos cresceu muito no país", sem maiores problemas co(n)textuais;

c) uprincipal razão pela qual todos nós agora temos um certo montante de dinheiro no bolsos. Trata-se de mais uma definição intensional objetiva por atributos secundários (uma ocorrência). Nesta e na definição deste tipo anterior, informa-se que a transação é o principal motivo de demanda por moeda: isso representa indiscutivelmente um traço intensional do objeto de definição (outros tipos de demanda por moeda distinguem-se deste com o auxílio desta característica); porém, trata-se de um traço secundário que não é nem necessário nem suficiente.

3. INQUÉRITO $n^{\circ} 405$ - BOBINA No 141 - INFORMANTE No 489 ELOCUÇÃO FORMAL (EF) - $2^{\text {a }}$ FAIXA ETÁRIA.

3.1 linhas 3-10: paleolítico $\rightarrow$ período da pedra lascada e que tem uma duração de aproximadamente seiscentos mil anos, quando o homo sapiens, que já deixou de ser macaco, passou a usar a inteligência, a conseguir fazer coisas.

3.2 linhas 14-16: paleolítico superior $\rightarrow$ último período do paleolítico, que vai abranger aproximadamente de vinte mil a doze mil antes de Cristo.

3.3 linhas 134-137: bisonte $\rightarrow$ bisavô do touro.

3.4 linhas 147-148: mamute $\rightarrow$ bisavô do elefante.

Este é um inquérito relativo a uma aula universitária cujo tema é "a arte préhistórica: o paleolítico".

No primeiro exemplo, define-se o significado lingüístico do termo "paleolítico" ou, em outra perspectiva, propõe-se uma equivalência lingüística entre o texto definiens e o termo definiendum. Observa-se que o nome "paleolítico" e o texto 
"período da pedra lascada / pedra antiga" ligam-se etimologicamente; também é perceptível que, em dado momento, o signo "paleolítico" foi criado por uma definição intensional subjetivo-convencional estipuladora. Consideramos esta uma definição intensional subjetivo-convencional lexical (uma ocorrência): podemos propor: "muitos estudos foram feitos sobre o Paleolítico" "muitos estudos foram feitos sobre o período da pedra lascada e que tem uma duração de aproximadamente seiscentos mil anos [...]" satisfatoriamente.

No segundo exemplo, declara-se o que se entende por "paleolítico superior", ou seja, qual a intensão subjetiva e/ou convencional que se vincula a esse nome. Trata-se de uma definição intensional subjetivo-convencional lexical (uma ocorrência) que pressupõe a definição de "paleolítico", caracterizando assim um sistema de definições. Aqui também podemos permutar o definiendum pelo definiens sem problemas co(n)textuais.

No terceiro e no quarto exemplos, temos pseudodefinições metafóricas (duas ocorrências), pois não cabe, objetivamente falando, estabelecer uma relação lógica e concreta entre o definiens e o definiendum por meio do conceito de bisavô. Provavelmente, motivos de ordem interacional justificaram essas definições: por exemplo, a intenção de tornar acessível e figurativa a apreensão do conceito de bisonte e mamute.

4. INQUÉRITO $\mathrm{n}^{\circ} 124$ - BOBINA No 43 - INFORMANTE N N 150 ELOCUÇÃO FORMAL (EF) - 2 $2^{\mathrm{a}}$ FAIXA ETÁRIA.

4.1 linhas 150-152: mito $\rightarrow$ algo que aconteceu segundo um esquema narrativo.

4.2 linhas 240-243: organismo $\rightarrow$ essencialmente atividade.

4.3 linhas 287-290: boldo $\rightarrow$ planta que dá seiva açucarada da qual se faz uma rapadura deliciosa e uma espécie de melado.

4.4 linhas 527-528: poesia $\rightarrow$ exatamente a apreensão de sentidos novos às palavras.

Temos aqui uma elocução formal (aula universitária), cujo tema era: "influência da língua na personalidade do indivíduo". 
O primeiro exemplo refere-se a uma definição do conceito de mito; observando o texto definidor, verificamos que não se trata de uma definição de caráter extensional; tampouco se classifica como uma pseudodefinição. Para ser uma definição intensional objetiva, seu definiens deveria focalizar a qüididade (essencialidade ou substancialidade) do conceito definiendum; ou seja, deve declarar o conjunto total de características compartilhadas por todos os objetos na extensão do termo, de modo que não haja ambigüidade nem vaguidão.

Como podemos verificar, o definiens "algo que aconteceu segundo um esquema narrativo" não caracteriza a qüididade do conceito de mito: outros objetos de definição poderiam acomodar esse definiens e ele é insuficiente para distinguir, clara e inequivocamente, o conceito de mito de outros objetos de definição (por exemplo, uma narrativa é algo que acontece segundo um esquema narrativo; o mesmo pode-se afirmar de uma crônica ou conto). Portanto, trata-se de uma definição de caráter intensional subjetivo ou convencional; parece-nos que, convencionalmente, não haveria unanimidade em relação a esse definiens, fato que nos leva a considerar uma definição intensional subjetivo-convencional lexical (uma ocorrência) que demanda uma definição intensional convencional precisadora para resolver os problemas de vaguidão do texto definidor (não é possível permutar o definiendum pelo definiens sem problemas co(n)textuais).

O segundo exemplo propõem uma relação definidora entre "organismo" e "essencialmente atividade" ou a estrutura sinonímica "organismo é atividade". Tratase, portanto, de uma definição intensional subjetivo-convencional sinonímicoparafrástica (uma ocorrência); o caráter subjetivo pode ser identificado pela presença do advérbio "essencialmente" — termo valorativo introduzido pelo enunciador. Claramente não se pode permutar o definiendum pelo definiens ("O organismo manifestou vida" "A atividade manifestou vida" !!??); alem disso, cabe indagar se objetos que não sejam organismos apresentam atividade (por exemplo, a força gravitacional exerce uma ação sobre os corpos terrestres mas não poderia ser propriamente considerada um organismo). Tais fatos apontam para a necessidade de uma definição intensional convencional precisadora que corrija esses problemas. 
O terceiro exemplo já foi comentado no início deste tópico; o definiens "planta que dá seiva açucarada da qual se faz uma rapadura deliciosa e uma espécie de melado" é vago, pois também poderia ser aplicado, por exemplo, ao objeto "cana de açúcar". Trata-se de uma definição intensional subjetivo-convencional lexical (uma ocorrência) que demanda um definiens mais adequado para o definiendum "boldo", de modo que se torne possível a permuta entre eles.

Propor que "poesia" seja igual por definição a "exatamente a apreensão de sentidos novos às palavras" não constitui uma definição intensional objetiva, pois o definiendum não se caracteriza de modo claro e inequívoco a partir desse definiens (ou seja, por meio desse definiens não podemos caracterizar universalmente o conceito de poesia, pois apreender novos sentidos das palavras poderia caracterizar, por exemplo, a Pragmática ou a Semântica); portanto, trata-se de uma definição que aborda o signo "poesia". Não parece razoável entender que esse texto definidor atende à intensão convencional do termo "poesia", o que nos leva a enxergar aqui uma definição intensional subjetivo-convencional lexical (uma ocorrência), tal qual o exemplo anterior. Igualmente, não é possível a permuta entre definiendum e definiens neste caso.

5. INQUÉRITO $\mathrm{n}^{\circ} 156$ - BOBINA No 54 - INFORMANTE No $182-$ ELOCUÇÃO FORMAL (EF) - $3^{a}$ FAIXA ETÁRIA.

5.1 linhas 216-221: garrafa $\rightarrow$ coisa somente do ponto de vista utilitário; garrafa $\rightarrow$ para a percepção objetiva, uma justaposição de formas, de contornos, de superfícies, de sombra e de luz, de manchas coloridas.

5.2 linhas 223-226: artista $\rightarrow$ aquele que sabe ver não a imagem prática e vulgar que tem a sua representação do mundo, mas o equilíbrio interno dos volumes e das formas.

5.3 linhas 361-367: Impressionismo $\rightarrow$ movimento desesperado, no sentido de que tenta fixar o que não tem possibilidade de ser fixado; Impressionismo $\rightarrow$ tenta 
reter aquilo que está desaparecendo, que é a natureza natural, a natureza exterior ao homem; Impressionismo $\rightarrow$ tenta reter o instante que é impossível de se reter.

Trata-se de uma elocução formal; uma aula universitária cujo tema era "Estética no Brasil na década de trinta".

O primeiro exemplo propõe dois textos definidores para o definiendum "garrafa":

a) aplicar a esse objeto a característica "coisa" sinaliza um fragmento de definição intensional objetiva condicional (uma ocorrência): de fato, faz parte da intensão objetiva do definiendum o traço "coisa" ("objeto inanimado"), mas a condição para isso está expressa por "somente do ponto de vista utilitário", ou seja, poderemos reformular o definiens: "se considerarmos a perspectiva utilitarista, uma garrafa será considerada uma coisa";

b) definir o objeto "garrafa" como "justaposição de formas, de contornos, de superfícies, de sombra e de luz, de manchas coloridas" não caracteriza uma definição intensional objetiva, pois esse definiens poderia vincular-se a inúmeros objetos de definição; portanto, não se declara a qüididade do objeto garrafa.

Tampouco temos aqui uma definição de caráter extensional; também, não parece razoável ver aqui uma definição que considere o signo "garrafa". Portanto, poderíamos pensar em uma pseudodefinição predicativa ou em uma pseudodefinição metafórica; dada a ausência de traços explícitos de subjetividade (como, por exemplo, "em minha opinião", "sob meu ponto de vista" etc), podemos considerar que a expressão "justaposição de formas, contornos, superfícies, sombra e luz" expõe traços que, embora não pertencentes objetiva ou convencionalmente à intensão do objeto garrafa, podem metaforicamente ser acionados para caracterizar tal objeto. Assim, consideramos aqui a existência de uma pseudodefinição metafórica (uma ocorrência).

O segundo exemplo é uma definição do objeto artista. O texto definidor não obedece ao princípio pelo qual a definição deve definir afirmando (não interessa saber o que um artista não é, pois tenderíamos ao infinito se procurássemos declarar seus não-predicados). A afirmação no texto definidor declara que "artista" é "aquele que sabe ver o equilíbrio interno dos volumes e das formas"; dado este 
texto, observamos que o não-predicado foi apresentado como um contraponto a esse predicado: ser capaz de perceber um equilíbrio interno de volumes e formas é o contrário de apreender representações práticas e vulgares da realidade. Porém, essa característica do definiendum aplica-se apenas aos artistas que trabalham com volumes e formas: cabe indagar se um compositor de música orquestral ou um poeta seriam, segundo esse critério, artistas. Portanto, sinaliza-se a presença de uma definição intensional subjetivo-convencional estipuladora (uma ocorrência) que, neste discurso particular, estabelece um significado específico para o signo "artista".

O terceiro exemplo procura definir "Impressionismo". Vejamos uma definição desse conceito em AURÉLIO SÉCULO XXI: "escola de pintura [gênero] surgida na França por volta de 1870, que visava a captar, em princípio, a impressão visual produzidas por cenas e formas derivadas da natureza, e as variações nelas ocasionadas pela incidência da luz, e que se baseava especialmente no emprego das cores e suas relações de contrastes, a fim de obter efeitos plasticamente dinâmicos e objetivos [diferença específica]". Como vemos, define-se não simplesmente o signo "Impressionismo" (apontando o significado vinculado ao nome), mas sim a própria essência desse objeto de definição, declarando-se sua intensão objetiva: trata-se de uma definição intensional objetiva por gênero e diferença específica.

Em nosso exemplo, apresenta-se um traço subjetivo: trata-se de um "movimento desesperado"; em seguida, procura-se explicar o porquê do caráter "desesperado": "fixar o que não pode ser fixado"; "reter o que está desaparecendo"; "reter o instante que é impossível de se reter" — fixar ou reter aquilo que está em constante mutação, a "natureza natural"; "natureza exterior ao homem". Desse modo, podemos entender aqui a presença da estrutura: "Impressionismo" $\approx$ "desespero" (de caráter metafórico), sendo o restante do texto definidor uma justificativa operacional dessa aproximação. Podemos conceder que esta estrutura definidora híbrida caracteriza-se predominantemente como uma definição intensional objetiva operacional (três ocorrências) que procura captar não a essência ou substância do objeto de definição, mas sim uma de suas interpretações psicológicas, sob o ponto de vista do pintor impressionista. 
6. INQUÉRITO $\mathrm{n}^{\circ} 153$ - BOBINA No 52 - INFORMANTE $N^{\circ} 179-$ ELOCUÇÃO FORMAL (EF) - $3^{\text {a } F A I X A ~ E T A ́ R I A . ~}$

6.1 linhas 236-238: cavadores $\rightarrow$ homens que tentam fazer cinema fora dos sistemas estabelecidos.

Trata-se de uma elocução formal, uma aula universitária cujo tema é: "O cinema brasileiro na década de trinta". Aqui temos um exemplo de definição intensional subjetivo-convencional lexical (uma ocorrência): o objetivo da definição é destacar ou selecionar um significado especial que o signo já possui (em certo momento, houve aqui uma definição intensional subjetivo-convencional estipuladora). Um "cavador" denominava aquele produtor cinematográfico independente em relação à indústria do cinema; aqui podemos interpretar também a existência de uma definição intensional subjetivo-convencional precisadora, desde que consideremos sua função de reduzir a vaguidão do termo "cavador".

7. INQUÉRITO $n^{\circ} 18$ - BOBINA No 07 - INFORMANTE N N 23 - DIÁLOGO ENTRE INFORMANTE E DOCUMENTADOR (DID) - $1^{\text {a }}$ FAIXA ETÁRIA.

7.1 linhas 60-61: colono $\rightarrow$ empregado normal que recebe por mês.

7.2 linhas 61-63: camarada $\rightarrow$ [empregado que] recebe por empreitada, por serviço.

7.3 linhas 178-180: terreiro $\rightarrow$ porção de terra calçada com lajota ou cimentada; chão batido.

7.4 linhas 205-207: tulha $\rightarrow$ barracão fechado onde o café fica armazenado.

7.5 linhas 222-230: roda d'água $\rightarrow$ roda muito grande com várias espécies de dentes e vários sulcos colocados em todo o contorno da roda, de maneira que a água cai e vira a roda.

7.6 linhas 507-511: peão $\rightarrow$ pessoa que trata [dos animais]; peão $\rightarrow$ sujeito que leva o sal para o gado no pasto, que põe o sal no cocho e fiscaliza os animais que são tratados em uma cultura extensiva. 
7.7 linhas 734-737: santo antônio $\rightarrow$ cabeça do arreio um pouco mais alta ou bem mais alta, às vezes com uma espécie de aba, que prende pouco as pernas, sendo que atrás também é mais alto.

No exemplo "7.1", temos a definição de "colono" por meio de um texto definidor que declara o gênero ("empregado comum") e uma diferença específica ("que recebe por mês"). Segundo o contexto discursivo em questão, essa definição basta para caracterizar precisa e inequivocamente esse objeto de definição (provavelmente, dentro do tema em desenvolvimento - "A casa, o terreno, vegetais, agricultura, animais, gado" — tal texto definidor seja suficiente para esse propósito).

Porém, trata-se de uma definição vaga porque admite em sua extensão uma série de objetos que não são "colonos" (há, de fato, uma infinidade de empregados comuns que recebem por mês em outros campos de trabalho). Portanto, trata-se de uma definição por gênero e diferença específica contextualizada, mas sem um alcance universal (tal definição não basta para distinguir clara e inequivocamente o conceito de colono de qualquer outro objeto do conhecimento humano). Seria necessária uma definição intensional convencional precisadora para reduzir a vaguidão do conceito. Consideramos melhor incluí-la como uma definição intensional subjetivo-convencional lexical (uma ocorrência).

O exemplo "7.2" define "camarada" também por gênero ("empregado") e por uma diferença específica ("que recebe por empreitada ou por serviço"). Temos aqui também uma definição vaga, pois um assassino de aluguel também seria, de acordo com essa definição, um "camarada". O mesmo comentário aplicado ao exemplo anterior vale aqui: temos uma definição intensional subjetivo-convencional lexical (uma ocorrência) que demanda uma nova definição precisadora para eliminar a vaguidão de sua extensão.

O exemplo "7.3" apresenta uma definição intensional subjetivo-convencional lexical (uma ocorrência) cuja função é dissolver a ambigüidade do signo "terreiro" ("terreiro" como "porção de terra calçada com lajota ou cimentada; chão batido" não se confunde, então, com "terreiro" como "local onde se realizam celebrações de cultos afro-brasileiros" no enunciado "Tenho um terreiro em minha propriedade"). Porém, trata-se de uma definição vaga, pois "uma porção de terra batida, com 
lajotas ou cimentada" poderia incluir em sua extensão um quintal ou uma calçada. Novamente, haveria a necessidade de novas definições intensionais convencionais precisadoras para dissolver a vaguidão do termo. Observemos, contudo, que esse texto definidor está formado por gênero ("porção de terra") e uma diferença específica ("calçada com lajota ou cimentada"), ou seja, apresenta uma estrutura intensional objetiva parcialmente constituída (outras diferenças específicas deverão ser acionadas para declarar a qüididade deste objeto de definição).

O mesmo comentário é válido para o exemplo "7.4": definir "tulha" como "barracão fechado [gênero] onde o café fica armazenado [diferença específica]" não impede que esse nome seja aplicado a "grande arca usada para guardar cereais". Daí a necessidade dessa definição intensional subjetivo-convencional lexical (uma ocorrência); porém, o definiens do exemplo não impede que se proponha uma aproximação com o definiendum "celeiro". Isso indica que a intensão objetiva precisa ser declarada com maior precisão.

Define-se, no exemplo "7.5", "roda d’água" como: a) "roda muito grande com várias espécies de dentes e vários sulcos colocados em todo o contorno da roda"; b) "de maneira que a água cai e vira a roda". A primeira característica pode ser aplicada, por exemplo, a uma engrenagem; a segunda característica, constituindo um esboço de uma definição intensional objetiva operacional, pode ser reformulada para expressar uma característica do objeto de definição: "roda muito grande acionada por força hidráulica —, com várias espécies de dentes [...] em seu contorno". Observemos que AURÉLIO SÉCULO XXI registra: "roda d'água — roda impulsionada à água e destinada a transmitir o movimento a um mecanismo qualquer", definição próxima ao texto definidor apresentado pelo exemplo. Trata-se de uma definição intensional subjetivo-convencional lexical (uma ocorrência).

No exemplo "7.6" temos a definição intensional subjetivo-convencional lexical (duas ocorrências) de "peão": importa especificar, dentre as várias acepções do signo, qual o significado particular que está sendo focalizado; observemos que o definiens possui características de uma definição intensional objetiva operacional.

O exemplo "7.7" define "santo antônio"; trata-se de uma definição intensional subjetivo-convencional lexical (uma ocorrência) que assume como pressuposta a 
definição de "arreio" e "cabeça do arreio": "cabeça do arreio [gênero] um pouco mais alta ou bem mais alta, às vezes com uma espécie de aba, que prende pouco as pernas, sendo que atrás também é mais alto [diferença específica]". Portanto, a matriz definidora é a definição intensional objetiva por gênero e diferença específica.

8. INQUÉRITO $\mathrm{n}^{\circ} 161$ - BOBINA No 56 - INFORMANTE No 186 DIÁLOGO ENTRE INFORMANTE E DOCUMENTADOR (DID) - $1^{\text {a }}$ FAIXA ETÁRIA.

8.1 linhas 227-233: boa peça de teatro $\rightarrow$ aquela que atinge diretamente ao público que a está assistindo; boa peça de teatro $\rightarrow$ aquela que atinge realmente ao público.

Aqui temos um diálogo cujo tema é "Teatro, televisão, rádio, cinema, vestuário"; a definição apresentada procura definir a "boa peça de teatro", propondo, como definiens, o conceito de atingir real e diretamente o público (ou seja, tocá-lo, comovê-lo, sensibilizá-lo). Trata-se de uma pseudodefinição predicativa subjetiva (duas ocorrências), pois a característica mencionada pelo definiens não é inerente ao objeto de definição, mas é inerente ao sujeito definidor (o próprio atributo "boa peça" sinaliza essa subjetividade); torna-se difícil compreender o que significa "atingir diretamente o público" fora do âmbito da psicologia pessoal e coletiva.

9. INQUÉRITO $\mathrm{n}^{\circ} 234$ - BOBINA $\mathrm{N}^{\circ} 88$ - INFORMANTE $\mathrm{N}^{\circ} 281$ DIÁLOGO ENTRE INFORMANTE E DOCUMENTADOR (DID) - $2^{\mathrm{a}}$ FAIXA ETÁRIA.

9.1 linhas 75-80: bom artista $\rightarrow$ o que desempenha o papel na peça de acordo com o que ele está fazendo; bom artista $\rightarrow$ o que a gente percebe que realmente ele está trabalhando bem.

Neste diálogo, cujo tema é "Cinema, televisão, rádio, teatro", temos a definição de "bom artista"; o definiendum já traz a marca da subjetividade no juízo de valor. O definiens apresentado pode ser sintetizado pela expressão "aquele que se percebe estar trabalhando bem". Como podemos observar, trata-se de uma pseudodefinição predicativa subjetiva (duas ocorrências).

10. INQUÉRITO $n^{\circ} 250$ - BOBINA No 90 - INFORMANTE N $N^{\circ} 287$ -

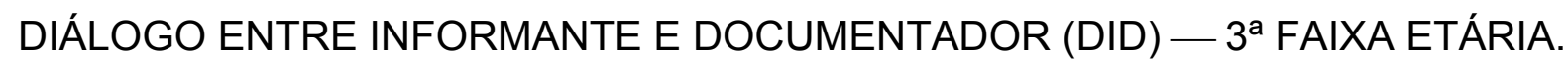


10.1 linhas 112-128: fundo de garantia $\rightarrow$ depósito que se processa por pagamentos mensais, em que o patrão responde por uma parte e o empregado, descontado em seu salário, responde por outra, e que constitui um fundo que, preenchidas as condições legais, assegura ao empregado que se retira um ressarcimento que, por algum tempo, Ihe permitirá a subsistência até que ele obtenha um novo emprego.

10.2 linhas 273-275: procuração ad judicia $\rightarrow$ procuração que permite ao advogado defender os interesses do cliente em juízo.

10.3 linhas 337-340: concordata $\rightarrow$ prazo, com as garantias exigidas por lei, para efetuar o pagamento dos débitos.

10.4 linhas 551-554: cheque visado $\rightarrow$ cheque cuja importância o banco sobre o qual se emite o cheque assegura ser pagável.

Temos aqui um diálogo cujo tema é "Dinheiro, banco, finanças, Bolsa de Valores". O exemplo "10.1" define o objeto "fundo de garantia". Aqui, conforme já comentamos no início deste tópico, temos uma definição de caráter essencialista / substancialista, ou seja, uma definição intensional objetiva por gênero e espécie (uma ocorrência). Três observações aqui são relevantes:

a) o definiens inclui características necessárias e suficientes para especificar precisamente o definiendum. Portanto, para o definiendum vale o critério da "verdade versus falsidade": uma vez estabelecida a definição, o definiendum será verdadeiro se apresentar as características declaradas pelo definiens; caso contrário, será considerado falso. Observamos, com isso, que a falseabilidade de um definiens dá-se pelo critério ontológico (ou seja, o ser declarado existe enquanto ser como um conceito clara e distintamente determinado pelo definiens) e não pelo critério da referência a um objeto-de-realidade (um referencial práxico a ser mencionado pelo discurso);

b) uma vez estabelecida uma definição intensional objetiva, o definiendum equivale rigorosamente ao definiens e pode, semanticamente, permutar-se incondicionalmente por este; 
Em suma: o objeto fundo de garantia não pode prescindir de nenhum dos traços apontados pelo definiens, sob a pena de perder sua caracterização ontológica; também, verifica-se permuta incondicional entre definiendum e definiens em qualquer contexto, ou seja, há equivalência semântica absoluta entre eles.

O segundo exemplo caracteriza uma definição intensional subjetivoconvencional lexical (uma ocorrência) que declara lingüisticamente o significado do signo "procuração ad judicia". Houve, obviamente, uma definição intensional convencional estipuladora que criou e estabeleceu esse signo no sistema de signos que constituem a linguagem jurídica. Cabe indagar se esse definiens também declara a intensão objetiva do objeto, ou seja, proclama sua qüididade de modo claro e inequívoco.

Ao terceiro exemplo aplicam-se os mesmos comentários do exemplo anterior: trata-se de uma definição intensional subjetivo-convencional lexical (uma ocorrência) que seleciona um significado específico aplicável ao termo "concordata": trata-se do prazo estipulado por lei, e não do instituto ou do documento assinado pelas partes envolvidas, ambos também denominados "concordata". A função dessa definição é desfazer a ambigüidade do termo, declarando não a qüididade do conceito de concordata, mas sim qual dos significados do termo está sendo mencionado pelo locutor.

Por fim, o quarto exemplo refere-se a uma definição intensional subjetivoconvencional lexical (uma ocorrência) que especifica o significado do termo "cheque visado". Observamos que o definiens proposto ("cheque cuja importância o banco sobre o qual se emite o cheque assegura ser pagável") não corresponde exatamente à definição intensional objetiva por gênero e diferença específica do objeto cheque visado: "aquele [gênero] em que o banco apôs seu visto, indicando que a quantia respectiva foi debitada na conta do emitente e se encontra à disposição do favorecido [diferença específica]". De fato, cabe perguntar se o definiens do exemplo não poderia ser aplicado também aos cheques administrativos.

11. INQUÉRITO n' 343 - BOBINA No 130 — INFORMANTE N 441 e 442 -

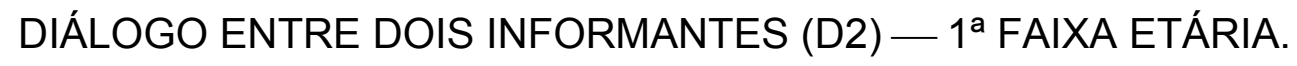

11.1 linhas 217-218: terapia $\rightarrow$ veículo de solução do problema no caso certo. 
11.2 linhas 326-330: metrô $\rightarrow$ elevador que anda ao contrário, que anda de cá para lá.

11.3 linhas 352-353: metrô $\rightarrow$ transporte em linha reta.

11.4 linhas 423-426: metrô $\rightarrow$ forma de comunicação, de levar e trazer pessoas.

11.5 linhas 537-538: indivíduos $\rightarrow$ feixes de emoções condensadas.

Trata-se de um diálogo entre dois informantes cujo tema é "A cidade, o comércio".

O primeiro exemplo procura caracterizar o conceito de terapia; observemos que AURÉLIO SÉCULO XXI registra: "parte da medicina que estuda e põe em prática os meios adequados para aliviar ou curar os doentes", caracterizando com isso uma definição intensional subjetivo-convencional funcional (especifica-se que o definiens "estudo e prática dos meios adequados para a cura ou alívio de enfermidades" aplica-se, segundo essa definição, ao campo da Medicina), fundada em uma definição intensional objetiva por gênero e diferença específica. No definiens do exemplo, declara-se "terapia" como "veículo de solução do problema no caso certo", ou seja, como uma generalização do termo, aplicável a qualquer meio ou recurso para solução ad hoc de problemas (tanto que o locutor considera a possibilidade de uma terapia urbana). Do modo como foi definido pelo locutor, o conceito de terapia é vago, pois acomoda, de acordo com o definiens proposto, o objeto "remédio" ou o objeto "conselho", por exemplo. Essa definição intensional subjetivo-convencional lexical (uma ocorrência) demanda uma definição precisadora que elimine a vaguidão do termo.

Em seguida, temos uma proposta de definição do conceito de metrô. Esse texto definidor caracteriza uma pseudodefinição metafórica (uma ocorrência) que não tem por objetivo definir objetivamente o conceito de metrô, nem tampouco especificar o significado do termo "metrô". O objeto metrô é reconstruído ontologicamente pelo definiens, sem qualquer referência ao objeto concreto denominado "metrô". 
Aqui: a) não conviria reconhecer uma definição nominalista ou terminista (definição intensional subjetiva e/ou convencional), pois o definiens proposto não se vincula significativamente ao nome de modo a constituir um verdadeiro signo; b) não convém reconhecer uma definição intensional objetiva, pois o definiens não declara, obviamente, a qüididade do objeto de definição. Metaforicamente, portanto, podemos aceitar que metrô seja um "elevador que anda ao contrário, que anda de cá para lá".

Os exemplos seguintes definem metrô por meio de outros traços: a) "transporte em linha reta"; b) "forma de comunicação, de levar e trazer pessoas". Inegavelmente, tais características são pertinentes à intensão desse objeto de definição; porém, o são em âmbito secundário (são insuficientes, por si sós, para declarar a qüididade do objeto metrô). Observemos que cabe incluir esses traços na intensão objetiva do objeto, e não simplesmente na intensão subjetiva e/ou convencional (as quais dizem respeito ao significado do signo "metrô"), pois, de fato, o conceito de metrô ou o objeto práxico |metrôlacomodam as características mencionadas pelo definiens. Contudo, trata-se de características insuficientes, por si sós, para delimitar clara e inequivocamente tal objeto de definição; portanto, consideramos aqui a existência de definições intensionais objetivas por atributos secundários (duas ocorrências).

O último exemplo propõe um definiens metafórico para o objeto de definição indivíduo: "feixes de emoções condensadas". AURÉLIO SÉCULO XXI registra para o mesmo verbete: "a pessoa humana (sic), considerada quanto às suas características particulares, físicas e psíquicas"; "o exemplar de uma espécie qualquer, orgânica ou inorgânica, que constitui uma unidade distinta". Como vemos, são duas definições intensionais objetivas que declaram a qüididade do mencionado objeto. Já para a definição do exemplo, não podemos assim considerar: afirmar que um indivíduo é um feixe condensado de emoções não define, em verdade, o conceito de indivíduo, mas sim apresenta um definiens para um novo definiendum a ser proposto, que sintetize em um só termo esse conceito. No caso, consideramos a presença de uma pseudodefinição metafórica (uma ocorrência). 
12. INQUÉRITO n' 255 - BOBINA N 95 - INFORMANTE N ${ }^{\circ} 303$ e $304-$ DIÁLOGO ENTRE DOIS INFORMANTES (D2) - $2^{\text {a }}$ FAIXA ETÁRIA.

12.1 linhas 457-459: televisão $\rightarrow$ móvel no qual a gente apóia alguns objetos.

12.2 linhas 667-670: televisão $\rightarrow$ veículo de promoção de um grupo, de promoção pessoal, enriquecimento pessoal.

12.3 linhas 955-957: imprensa $\rightarrow$ meio de comunicação, juntamente com os meios modernos que existem.

12.4 linhas 1001-1004: imprensa $\rightarrow$ grande instrumento para colocar as pessoas em um nível de participação de tudo o que ocorre e acontece.

Trata-se de um diálogo entre dois informantes cujo tema é "Transportes e viagens, cinema, televisão, rádio e teatro, os meios de comunicação e difusão, a cidade e o comércio".

O primeiro exemplo temos o esboço de uma definição intensional objetiva pelas quatro causas: "televisão" é um "móvel [referindo-se especificamente ao formato da peça de mobiliário: causa formal] no qual a gente apóia alguns objetos [utilidade ou finalidade: causa final]". Comparemos com AURÉLIO: "tecnologia de telecomunicação que permite a transmissão instantânea de imagem e som, gerados ao vivo ou gravados em videoteipe, mediante ondas eletromagnéticas ou transmissão a cabo".

Afirmar que a televisão é um móvel implica declarar uma característica necessária do conceito; porém, trata-se de uma característica insuficiente. Ser um móvel que serve de apoio a objetos não distingue a televisão de uma estante: este atributo nem ao menos pertence à intensão lógica do conceito de televisão. Podemos considerar que esta é uma definição intensional subjetivo-convencional estipuladora (uma ocorrência).

No exemplo "12.2", vemos que o conceito de televisão aparece definido como "veículo de promoção de um grupo / de promoção e enriquecimento pessoal"; tratase de atributos que não pertencem, nem objetiva, nem subjetivo-convencionalmente, 
à intensão do conceito. Convém incluí-la como uma pseudodefinição predicativa subjetiva (uma ocorrência).

Declarar no exemplo "12.3" que o conceito de imprensa é "meio de comunicação, juntamente com os meios modernos que existem" implica propor a definição/imprensa $\leftarrow \pi$ «moderno meio de comunicação»/. Comparemos com HOUAISS (2001, p. 1584, verbete "imprensa") /imprensa $\leftarrow \pi$ rqualquer meio utilizado na difusão de informações jornalísticas; conjunto dos processos de veiculação de informações jornalísticas por veículos impressos ou eletrônicosı/. Como se vê, o exemplo é constituído por uma definição intensional objetiva que declara simplesmente o gênero: temos, pois, um fragmento de uma definição intensional objetiva por gênero e espécie (uma ocorrência).

O exemplo "12.4" propõe que o conceito de imprensa seja definido por rgrande instrumento para colocar as pessoas em um nível de participação de tudo o que ocorre e aconteces. Trata-se da indicação da finalidade ou propósito do objeto de definição (causa final: para quê?); vemos aqui outro exemplo de um fragmento de definição intensional objetiva pelas quatro causas (uma ocorrência).

Resumindo os resultados verificados, temos:

\begin{tabular}{|l|c|c|}
\hline \multicolumn{1}{|c|}{ TIPOS DE DEFINIÇÃO } & $\mathrm{N}$ & $\%$ \\
\hline definição intensional objetiva operacional & 04 & $08,16 \%$ \\
\hline pseudodefinição metafórica & 06 & $12,24 \%$ \\
\hline definição intensional subjetivo-convencional sinonímico-parafrástica & 02 & $04,08 \%$ \\
\hline definição intensional objetiva teorética & 04 & $08,16 \%$ \\
\hline definição intensional objetiva por atributos secundários & 04 & $08,16 \%$ \\
\hline definição intensional subjetivo-convencional lexical & 18 & $36,74 \%$ \\
\hline definição intensional objetiva condicional & 01 & $02,04 \%$ \\
\hline definição intensional subjetivo-convencional estipuladora & 02 & $04,08 \%$ \\
\hline definição intensional objetiva por gênero e espécie & 02 & $04,08 \%$ \\
\hline pseudodefinição predicativa subjetiva & 05 & $10,20 \%$ \\
\hline definição intensional objetiva pelas quatro causas & 01 & $02,04 \%$ \\
\hline
\end{tabular}


Como vemos, no corpus analisado predominam as definições intensionais subjetivo-convencionais lexicais $(36,74 \%)$; em segundo lugar, aparecem as pseudodefinições metafóricas (12,24\%); em terceiro lugar, temos as pseudodefinições predicativas subjetivas $(10,20 \%)$ : esses três tipos perfazem $59,18 \%$ das ocorrências. Ou seja, em quase sessenta por cento das ocorrências, define-se para: a) eliminar ambigüidades dos termos empregados, indicando-se claramente quais dos possíveis significados dos termos devem ser acionados em dado contexto; b) propor um sentido metafórico ou subjetivo aos termos empregados, com intuitos pragmáticos.

Poderíamos dizer, portanto, que os falantes possuem duas preocupações interacionais, no que tange às definições: a) precisar junto aos interlocutores qual dos significados preexistentes deve ser selecionado em uma dada interação verbal; b) introduzir um novo significado ou uma releitura de um termo, sem que haja preocupação com a pertinência conceitual do conteúdo proposto; em outras palavras, trata-se de pseudodefinir com intuitos predominantemente interacionais, visando aumentar a expressividade dos enunciados (ou outro efeito pragmático qualquer).

Definições de caráter objetivo representam em conjunto $32,65 \%$ das ocorrências no corpus; tal resultado é significativo, considerando que o corpus refere-se à norma urbana culta falada: parece, pois, que as definições declarantes da qüididade de uma substância não representam a principal preocupação dos falantes em questão, embora representantes de uma norma urbana culta falada.

Interessa observar, finalmente, a presença de dois únicos casos de definições intensionais subjetivo-convencionais sinonímico-parafrásticas ("inteligência" $\approx$ "uso do intelecto"; "demanda de moeda por transação" ₹ "demanda de moeda para satisfazer as necessidades de transações e de pagamentos"), o que representa $4,08 \%$ das ocorrências; um número pouco representativo, se tomarmos em consideração os dados apresentados em ALVES (1999, pp. 157-167).

Considerando as ocorrências do corpus, constata-se, pelo menos, $26,52 \%$ de casos nos quais o processo de referenciação - a estipulação de objetos-de- 
discurso - ocorre, mesmo nos casos em que o objeto de definição poderia ser constituído por um conceito objetivo ou um referencial práxico passível de ostensão.

Assim, temos exemplos objetos-de-discurso: bisonte $\rightarrow$ bisavô do touro; mamute $\rightarrow$ bisavô do elefante; garrafa $\rightarrow$ justaposição de formas, de contornos, de superfícies, de sombra e de luz, de manchas coloridas; metrô $\rightarrow$ elevador que anda ao contrário; indivíduos $\rightarrow$ feixes de emoções condensadas; televisão $\rightarrow$ móvel no qual a gente apóia alguns objetos. Temos aqui definições que explicitamente estabelecem referenciações e criam objetos-de-discurso cuja validade, sob o ponto de vista da definição, é bastante particularizada, embora se trate de referenciais concretos ou objetos práxicos passíveis de ostensão por parte daquele que define.

Para tais "definições", torna-se evidente uma certa função interacional desempenhada por elas no discurso, ou seja, patenteia-se que não há uma intenção manifesta, por parte dos locutores, de que tais definições sejam consideradas seriamente como os legítimos conceitos que esses falantes vinculam a tais referenciais.

Há definições que incorporam uma maior quantidade de traços essenciais, constituintes da substância mencionada pelo termo respectivo, ou o respectivo conceito: boldo $\rightarrow$ planta que dá seiva açucarada; garrafa $\rightarrow$ coisa somente do ponto de vista utilitário; terreiro $\rightarrow$ porção de terra calçada com lajota ou cimentada; tulha $\rightarrow$ barracão fechado onde o café fica armazenado; roda d'água $\rightarrow$ roda muito grande com várias espécies de dentes e vários sulcos colocados em todo o contorno da roda; metrô $\rightarrow$ transporte em linha reta; metrô $\rightarrow$ forma de levar e trazer pessoas.

Podemos verificar que todas essas definições são vagas, no sentido de poderem ser aplicadas a mais de um referencial: tais definições permitem acomodar, sob o ponto de vista extensional, uma infinidade de objetos outros que não são aqueles cujas definições de maior precisão apontam e especificam (como exemplo, constata-se que há muitos transportes em linha reta que não o metrô). 
Como vimos, há definições cujo caráter é eminentemente metafórico, tais como: indivíduos $\rightarrow$ feixes de emoções. Aqui temos um procedimento freqüente na oralidade: mesmo que exista a possibilidade de uma definição puramente ostensiva (no caso, simplesmente apontar um indivíduo) ou uma definição de caráter mais essencialista, o locutor vale-se da metáfora como um recurso que torna sua exposição verbal mais rica e colorida, e sua argumentação mais apreensível recordando aqui o procedimento de staging discursivo: dizer, para "indivíduo", "feixe de emoções" é muito mais pictórico e eficiente enquanto cena discursiva do que dizer "exemplar orgânico que constitui uma unidade distinta".

Isso aponta para uma função discursiva típica das definições sob o ponto de vista da oralidade: interessa freqüentemente aos locutores não a fidelidade a um conteúdo essencialista dos conceitos definidos, mas sim a apresentação de um novo ângulo semântico, de um recorte conceitual surpreendente, de um aporte informacional exclusivo que denote criatividade argumentativa e possua força retórica. Nessa perspectiva, deparamo-nos também com uma das funções pragmáticas das definições - o trabalho do ethos do orador, a imagem pública que o enunciador elabora por meio de seu discurso —; tal função pragmática não é contemplada pela teoria stricto sensu da definição, voltada para o estabelecimento dos saberes científicos e paracientíficos.

Como se vê, critérios tais com a eficiência na interação e a força retórica da formulação discursiva precedem as considerações de caráter puramente técnico, sob o ponto de vista da precisão e veracidade do conteúdo veiculado. Contudo, no caso das definições de termos próprios às linguagens técnicas, empregados pela oralidade, verificam-se casos nos quais o definiens corresponde melhor ao perfil ideal de definição (as definições objetivas). Assim, temos: nota bruta $\rightarrow$ diferença entre o total de erros e acertos obtidos em um teste; demanda de moeda por transação $\rightarrow$ demanda de moeda como função do nível de renda e proporção $k$ e $y$ da renda nominal; taxa de juros $\rightarrow$ rendimento que as pessoas obtêm ao comprar um título. 
Entretanto, verifica-se que, embora atendendo a uma linguagem técnica específica, sob o ponto de vista extensional muitas dessas definições são precárias, por poderem ser aplicadas a diversos objetos de definição. Em geral, essas definições parecem procurar reproduzir os definiens que se encontram em dicionários técnicos da área, obtendo maior ou menor sucesso na tentativa.

Parece depreender-se, dos exemplos analisados, que os locutores possuem o conhecimento do conceito aplicável a cada termo da lista apresentada, embora não possuam de memória o texto que, tecnicamente, corresponde à formulação oficial dos livros técnicos e dicionários, relativa aos termos especificados. Assim, os locutores produzem um texto híbrido que mescla, em dada proporção, a formulação oficial e a formulação pessoal de cada locutor. Em muitos casos, patenteia-se o esforço do locutor em explicar o conceito que tem em mente, procurando as palavras mais adequadas para tanto; nessas tentativas, mesclam-se características da língua escrita e características da oralidade.

Aqui também nos parece mais apropriado considerar a presença, na maior parte dos casos, de um processo de referenciação e não um processo de pura referência a um objeto-de-realidade previamente categorizado: a própria elasticidade extensional da formulação do conceito assim indica. Assim, a definição "demanda de moeda por transação $\rightarrow$ principal motivo pelo qual a pessoa retém moeda" aparenta ser tecnicamente suficiente mas, de acordo com o contexto, o definiens poderia ser aplicado também à demanda de moeda por precaução. Da mesma forma, muitas coisas podem ser representadas pela expressão "proporção $k$ e $y$ da renda nominal".

Outro grupo de definições patenteia com mais clareza o processo de referenciação; assim ocorre nos exemplos seguintes: inteligência $\rightarrow$ algo contínuo; organismo $\rightarrow$ essencialmente atividade; poesia $\rightarrow$ a apreensão de sentidos novos dados às palavras; artista $\rightarrow$ aquele que sabe ver o equilíbrio interno dos volumes e das formas; Impressionismo $\rightarrow$ movimento desesperado; televisão $\rightarrow$ veículo de 
promoção de um grupo; religião $\rightarrow$ um estado de espírito; vassoura $\rightarrow$ moça escandalosa; telenovela $\rightarrow$ laboratório posto no ar.

Nesses casos, verifica-se um afastamento do perfil de definição ideal e a caracterização de definições marcadas pelo princípio da relevância. Trata-se de objetos-de-discurso, uma vez que o recorte semântico do conceito (e sua pontualidade discursiva) produz definições ad hoc para os discursos fundadores respectivos: assim, a seguinte "definição" — inteligência $\rightarrow$ algo contínuo — só pode ser compreendida dentro do contexto gerado pelo discurso fundador que a propôs; não possui validade para além dele (que é, de fato, "algo contínuo? Um círculo é uma inteligência?).

Enfim, pudemos ver definições intensionais subjetivo-convencionais estipuladoras que criaram obviamente seus objetos-de-discurso: vassoura $\rightarrow$ moça escandalosa no trajar e no portar-se, com atitudes menos recatadas é um caso flagrante. Aqui verificamos a seguinte aporia técnica: o definiendum "vassoura", vinculado ao definiens "moça escandalosa", constitui um objeto-de-discurso particular, mas não denota um referencial ou objeto práxico dado a priori (isto é, previamente categorizado), nem delimita precisamente o conceito respectivo. Por um lado, essa definição possui caráter essencialista, pois precisamente ambos os traços semânticos citados - moça e escandalosa - elaboram esse objeto-de-discurso particular; porém, por outro lado, não há precisão técnica nessa definição (que é, exatamente, uma moça escandalosa?), fato que a afasta do conceito de definição ideal. Temos, portanto, um tipo híbrido de intensão objetivo-convencional. 


\title{
CAPÍTULO V — UMA VISÃO SISTÊMICA DAS DEFINIÇÕES
}

\author{
5.1 PLANO EMPÍRICO E PLANO MENTAL: DISCURSO DEFINIDOR E \\ OBJETO REFERIDO; SÍNTESE DEFINIDORA E CONCEITO REFERENTE
}

Neste capítulo, examinaremos as definições orais naturais sob o ponto de vista sistêmico, ou seja, segundo a perspectiva de um conjunto articulado e coerente de definições explícitas e implícitas. O próprio conceito de definição implica um movimento definidor que parte de conceitos pressupostos (conceitos primitivos) em direção a um conceito posto por aqueles (conceito derivado); nesse sentido, os conceitos incorporados ao definiens são conceitos pressupostos, mencionados enquanto conceitos primitivos (e, portanto, não constituem objetos-de-discurso, no sentido de serem recategorizações conceituais).

Conforme pudemos apreender através da tipologia de definições apresentada no tópico "3.2", agrupamos as definições segundo a seguinte distribuição:

\begin{tabular}{|c|c|c|c|}
\hline \multicolumn{2}{|c|}{ DEFINIÇÕES INTENSIONAIS } & PSEUDODEFINIÇÕES \\
\hline $\begin{array}{c}\text { OBJETIVAS } \\
\text { (GRUPO II) }\end{array}$ & $\begin{array}{c}\text { SUBJETIVO- } \\
\text { CONVENCIONAIS } \\
\text { (GRUPO III) }\end{array}$ & $\begin{array}{c}\text { EXTENSIONAIS } \\
\text { (GRUPO I) }\end{array}$ & $\begin{array}{c}\text { RELAÇÕES LIVRES } \\
\text { ENTRE O } \\
\text { PSEUDODEFINIENDUM } \\
\text { E O } \\
\text { PSEUDODEFINIENS } \\
\text { (GRUPO IV) }\end{array}$ \\
\hline $\begin{array}{c}\text { definições substanciais } \\
\text { ou ideais }\end{array}$ & $\begin{array}{c}\text { definições semióticas } \\
\text { ou signações }\end{array}$ & $\begin{array}{c}\text { pseudodefinições } \\
\text { práxicas }\end{array}$ & $\begin{array}{c}\text { pseudodefinições } \\
\text { diversas }\end{array}$ \\
\hline \multicolumn{2}{|c|}{ foco ou ênfase do texto definidor } \\
\hline $\begin{array}{c}\text { (substâncias>essências) } \\
\text { conceitos }\end{array}$ & $\begin{array}{c}\text { significados } \\
\text { lingüísticos }\end{array}$ & $\begin{array}{c}\text { objetos práxicos ou } \\
\text { fenomênicos }\end{array}$ & interação \\
\hline
\end{tabular}

Como vemos, as definições do grupo I delimitam e determinam conceitos, visando a declarar a qüididade das substâncias (recordando que consideramos o aspecto fenomênico e social das percepções dessas substâncias); as definições do grupo II determinam significados lingüísticos, visando a determinar signos ou termos (estabelecer suas situações de uso); as pseudodefinições do grupo III determinam objetos sensíveis, estabelecendo o vínculo entre eles e seus nomes; por fim as 
pseudodefinições do grupo IV visam a provocar determinados efeitos retóricodiscursivos.

Aqui cabe a seguinte observação: verdadeiramente, os objetivos interacionais estão presentes em todas as fases do processo definidor oral natural, mesmo quando o foco desse processo incide sobre os conceitos, os significados e/ou os objetos práxico-fenomênicos; de fato, devemos recordar que o fim último das definições orais naturais contempla os efeitos sócio-interacionais promovidos pelo discurso. Podemos vislumbrar o caráter interacional do próprio saber científico, uma vez que - se o homem deseja, por natureza, saber — pressupõe-se a capacidade de estabelecer uma interação entre os agentes do conhecimento e seus objetos de conhecimento, uma vez que o que está em jogo são as percepções objetivas dos fenômenos socialmente contextualizados.

Quando se afirma que o foco direto do texto definidor no grupo IV é a interação, queremos dizer que não existe aqui um propósito definidor stricto sensu: as funções das pseudodefinições metafóricas, etimológicas e predicativas subjetivas realizamse de modo a, principalmente, instaurarem a estrutura formal das definições como um recurso retórico-discursivo visando a efeitos pragmáticos.

Contrapondo-se a esse objetivo, as definições substanciais ou ideais focalizam primordialmente os conceitos que expressam a essência de um ser e assim, indiretamente, a constituição desse mesmo ser. As definições semióticas ou signações, por declararem a estrutura da intensão subjetivo-convencional de um conceito, terminam por declarar primordialmente o significado lingüístico (ou expressão lingüística) que se vincula ao nome que menciona esse conceito. Por fim, as pseudodefinições práxicas focalizam, antes de tudo, os objetos sensíveis que fazem parte da extensão de um conceito (sinalizando suas características ou, simplesmente, apontando-os).

O seguinte quadro (próxima página) apresenta os conceitos que se articulam sistemicamente na caracterização do processo definidor; a leitura do quadro deve acompanhar a numeração apresentada (de "1" a "9"). De acordo com o quadro, distinguimos entre as ocorrências do plano sensível "A" e as ocorrências do plano mental "B": aquelas constituem fenômenos empíricos constatados concreta e 
sensivelmente (sensibus subjectum); estas constituem fenômenos cuja existência verifica-se no âmbito estritamente intelectivo, para além das manifestações sensíveis ou práxicas (mentis subjectum). Também distinguimos entre: a) o plano lingüísticodiscursivo "a" (plano das ocorrências lingüístico-discursivas individuais e sociais); b) o plano extralingüístico-discursivo individual "b" (plano dos processos estritamente mentais e individuais); c) o plano extralingüístico-discursivo social "g" (plano dos processos estritamente mentais coletivos ou sociais):

\begin{tabular}{|c|c|c|c|}
\hline \multirow{4}{*}{$\begin{array}{c}\text { (B) } \\
\text { plano mental [mentis } \\
\text { subjectum] }\end{array}$} & \multicolumn{3}{|c|}{$\begin{array}{c}\text { SUBSTÂNCIAS } \\
\text { ESSÊNCIAS }\end{array}$} \\
\hline & $\begin{array}{c}\text { plano expressivo } \\
\text { lingüístico-discursivo } \\
\text { (a) }\end{array}$ & $\begin{array}{l}\text { plano expressivo } \\
\text { extralingüístico- } \\
\text { discursivo individual } \\
\text { ( b ) }\end{array}$ & $\begin{array}{c}\text { plano expressivo } \\
\text { extralingüístico- } \\
\text { discursivo social } \\
\text { (g) }\end{array}$ \\
\hline & $\begin{array}{l}(1+4=5) \text { signo } \\
\text { "homem" = } \\
\mathrm{sig}^{\text {te: }} \text { "homem" + sig }{ }^{\text {do: }} \text { "(para a filosofia } \\
\text { aristotélica) animal } \\
\text { dotado de racionalidade } \\
\text { e discurso ( lo/goj ), e } \\
\text { que se realiza na } \\
\text { organização social } \\
(\text { po/lij)" }\end{array}$ & \multicolumn{2}{|c|}{$\begin{array}{l}\text { síntese/análise definidora } \Rightarrow \text { humanidade }+ \\
\text { animalidade }+ \text { racionalidade + capacitação }+ \text { ação } \\
\text { política }\end{array}$} \\
\hline & $\begin{array}{l}(2>4) \text { significado } \\
\text { lingüístico } \\
\Rightarrow \text { "(para a filosofia } \\
\text { aristotélica) animal } \\
\text { dotado de racionalidade } \\
\text { e discurso ( } 1 \circ / g \circ j) \text { e } \\
\text { que se realiza na } \\
\text { organização social } \\
(\text { po/lij)" }\end{array}$ & $\begin{array}{l}\text { (6) conceito referente } \\
\text { individual (1. objeto } \\
\text { mental para o sujeito; } 2 . \\
\text { objeto-para-o-sujeito; } 3 . \\
\text { objeto-de-discurso } \\
\text { individual) } \Rightarrow \text { 'homem } \\
\text { [conceito individual] }\end{array}$ & $\begin{array}{l}\text { (8) conceito referente } \\
\text { social (1. objeto mental } \\
\text { para o social; } 2 \text {. objeto- } \\
\text { para-o-social; } 3 \text {. objeto- } \\
\text { de-discurso social) } \Rightarrow \\
\text { ‘homem } \\
\text { [conceito social] }\end{array}$ \\
\hline \multirow{3}{*}{$\begin{array}{c}\text { (A) } \\
\text { plano sensível } \\
\text { [sensibus subjectus] }\end{array}$} & $\begin{array}{l}\text { (3) discurso definidor } \Rightarrow \\
\text { "entendo pelo termo } \\
\text { 'homem' o conceito de } \\
\text { ‘animal dotado de } \\
\text { lo/goj e que se } \\
\text { realiza na po/lij)" }\end{array}$ & \multirow{3}{*}{$\begin{array}{l}\text { (7) objeto referido } \\
\text { individual (1. objeto-de- } \\
\text { realidade individual; } 2 \text {. } \\
\text { objeto sensível } \\
\text { individual; } 3 \text {. objeto } \\
\text { fenomênico segundo a } \\
\text { práxis individual; } 4 \text {. } \\
\text { objeto práxico } \\
\text { individual) } \Rightarrow \\
\text { |Sócrates | (para um } \\
\text { indivíduo) }\end{array}$} & \multirow{3}{*}{$\begin{array}{l}\text { (9) objeto referido social } \\
\text { (1. objeto-de-realidade } \\
\text { social; } 2 \text {. objeto } \\
\text { sensível social; } 3 \text {. } \\
\text { objeto fenomênico } \\
\text { segundo a práxis social; } \\
\text { 4. objeto práxico social) } \\
\Rightarrow \mid \text { Sócrates| (para o } \\
\text { social) }\end{array}$} \\
\hline & $\begin{array}{l}\text { (2) texto definidor } \Rightarrow \\
\text { "animal dotado de } \\
\text { lo/goj e que se } \\
\text { realiza na po/lij" }\end{array}$ & & \\
\hline & $\underset{\breve{e}}{(1)} \underset{\text { nome }}{\Rightarrow} \Rightarrow$ "homem"; & & \\
\hline
\end{tabular}


a) o primeiro plano — a — refere-se às ocorrências no âmbito estritamente lingüístico-discursivo, as quais, contudo, são dotadas de caráter social como um pressuposto (uma vez que, conforme já enfatizamos, entendemos as próprias substâncias como permanências determinadas pelas percepções fenomênicas socialmente contextualizadas). Tais ocorrências verificam-se no plano mental e no plano sensível. Três são os elementos presentes no quadrante "Aa" — quadrante lingüístico-discursivo sensível - : i) o "nome" (subquadrante 1); ii) o "texto definidor" (subquadrante 2); iii) o "discurso definidor" (subquadrante 3). Há ainda dois elementos no quadrante "Ba" — quadrante lingüístico-discursivo mental —: i) o "significado lingüístico" (subquadrante 4), derivado do subquadrante 2; ii) o "signo" (subquadrante $5[1+4]$ );

b) o segundo plano — b — diz respeito aos fenômenos atinentes aos âmbitos mental e sensível, ambos individuais e extralingüístico-discursivos. Pela expressão "plano individual" entendemos a existência de um ponto de vista individualizado, manifestado ou apreendido pela perspectiva do indivíduo: isso não significa que o plano social não esteja presente na constituição dessa perspectiva ou ponto de vista; significa, apenas, que há uma expressão particularizadora - uma manifestação individualizada - dos fenômenos em pauta. Trata-se, em suma, de uma expressão individual que se contrapõe à expressão coletiva correspondente.

Há um elemento presente no quadrante "Bb" - quadrante extralingüísticodiscursivo mental -: o "conceito (referente individual)" [subquadrante 6]; esse elemento, um objeto mental ou objeto-para-o-sujeito (idéia cuja existência é puramente mental), pode ou não buscar um referencial transconceitual, ou seja, pode ou não corresponder a um fenômeno ou objeto práxico referido, quer por meio de um processo de abstração, quer por uma identificação sem qualquer base ontológica. No mesmo plano "b", há outro elemento presente no quadrante "Ab" quadrante extralingüístico-discursivo sensível -: o "objeto referido individual (subquadrante 7); esse elemento, um objeto práxico sensível representa o referencial transconceitual que subsiste para além da linguagem e do discurso; 
c) o terceiro plano - g - atende aos fenômenos de âmbito social, nos níveis mental e sensível, ambos extralingüístico-discursivos. Como já frisamos, ocorre a distinção entre o ponto de vista individual e o ponto de vista coletivo, os quais se distinguem necessariamente, uma vez que as apreensões divergem por natureza, mas que interferem entre si (uma vez que adotamos por pressuposto a inserção social do indivíduo, ou seja, que o conceito de indivíduo, compreendido socialmente, apenas faz sentido pelo contraponto em relação ao conceito de social que o constitui).

No quadrante "Bg" — quadrante extralingüístico-discursivo mental —, há o "conceito (referente social)" [subquadrante 8]; trata-se de um objeto-para-o-social que, do mesmo modo, pode ou não corresponder a um objeto práxico referido. No mesmo plano, quadrante "Ag" — quadrante extralingüístico-discursivo sensível —, há o "objeto referido social" (subquadrante 9): trata-se de um objeto práxico coletivamente considerado como o referencial de um determinado conceito referente social.

Importa enfatizar que esses quadrantes aparecem isolados no quadro (ou seja, de modo aparentemente estanque), mas apenas por uma conveniência de exposição: isso não significa que essas categorias sejam impermeáveis na prática, e que suas fronteiras sejam determinadas de modo tão rígido. Assim, a distinção entre um texto definidor (subquadrante 2) e um significado lingüístico (subquadrante 4) é, em termos práticos, puramente processual: é necessário que haja previamente um texto definidor para que possa, conseqüentemente, existir sua conversão lingüísticosemiótica (ou seja, a atribuição do estatuto de significado lingüístico a um texto definidor e, em seguida, a vinculação desse significado a um determinado nome).

Convém examinar mais de perto esses oito elementos sistêmicos, além dos elementos ainda não considerados (síntese / análise definidora; essência e substância). Consideraremos cada qual dos subquadrantes em separado:

a) "Aa1" — temos aqui o "nome", ou seja, uma manifestação lingüística sensível sob a forma de sinais gráficos e/ou sinais sonoros. Como exemplo, temos o nome "estado / e ", expresso em sua materialidade gráfica e/ou sonora. A doutrina nominalista ou terminista das definições considera que as definições têm 
exatamente por função declarar qual o significado lingüístico (subquadrante Ba4), vinculado a um determinado nome, é visado ao pronunciar-se tal nome. Ou seja, trata-se de circunscrever ("definir" como sinônimo de "delimitar") uma determinada acepção de um signo;

b) "Aa2" — aqui temos o "texto definidor": trata-se do objeto lingüísticodiscursivo sensível produzido por um discurso definidor ${ }^{143}$ (o produto material desse ato discursivo). Assim, um texto definidor compatível com o termo "estado" é: "situação ou disposição em que se encontram pessoas ou coisas em dado momento". Aqui, temos a simples formulação lingüística de uma definição (exclusivamente um texto residual do processo de definição), e não propriamente seu discurso definidor, porque este se constitui em um ato enunciativo que aciona uma diversidade de elementos ausentes na noção de texto (o contexto discursivo, por exemplo, não é considerado aqui);

c) "Aa3" — neste subquadrante temos o "discurso definidor". O discurso definidor é passível de duas interpretações polares: i) discurso que declara estritamente a essência (características necessárias e suficientes) de uma dada substância (doutrina substancialista); ii) discurso que declara estritamente o significado e as condições de uso de um signo que designa lingüisticamente a essência de uma substância (doutrina nominalista-terminista). Trata-se, como já afirmamos, da atividade discursiva - a enunciação — cujo produto ou resíduo é um objeto material denominado "texto definidor" ou "enunciado", o qual passará posteriormente à condição de significado lingüístico.

No exemplo, o nome "estado" pode ser vinculado aos seguintes discursos definidores: i) "nessas condições, defino 'estado' como o «modo de ser ou estar〉"; ii) "penso estar certo em definir 'estado' como a «situação ou disposição em que se encontram pessoas ou coisas em dado momento>; iii) "entendo por 'estado' o «modo

\footnotetext{
${ }^{143}$ Lembremos as características do discurso e do texto, conforme MAINGUENEAU (2000, pp, 5157): a) o discurso é uma organização situada para além da frase; o discurso é orientado; o discurso é uma forma de ação; o discurso é interativo;o discurso é contextualizado; o discurso é assumido por um sujeito; o discurso é regido por normas; o discurso é considerado no bojo de um interdiscurso; b) o texto pode ser compreendido como um enunciado que constitui uma totalidade coerente; produção verbal ou oral estruturada de forma a perdurar, a se repetir e a circular longe de seu contexto original; produto de uma atividade discursiva ou enunciativa.
} 
de existir na sociedade>", iv) "nesse contexto, é possível definir 'estado' como «nação politicamente organizadas, etc.

Esses discursos definidores são muitas vezes entendidos, grosso modo, como o próprio ato de definir os significados do termo "estado", significados esses que declaram um conteúdo significativo potencial que necessita ser atualizado discursivamente para adquirir um sentido especificamente contextualizado.

No exemplo, o verdadeiro sentido do termo "estado" (ou seja, seu conteúdo semântico atualizado de acordo com um determinado contexto, de modo a expressar uma particular ordem de idéias) — inserido, digamos, no co-texto "O Estado deverá indenizar as vítimas" - poderá adquirir o sentido de «nação politicamente organizada e socialmente justas, destacado dos outros possíveis significados potenciais $^{144}$. O discurso definidor "hoje em dia, parece-me que entendemos por 'Estado' uma «nação politicamente organizada, ou seja, um organismo político administrativo que, como nação soberana ou divisão territorial, ocupa um território determinado, é dirigido por governo próprio e se constitui em uma pessoa jurídica de direito público, internacionalmente reconhecidas é um discurso que define o conceito de Estado ou o termo "estado", quer adotemos a perspectiva essencialista, quer a perspectiva nominalista das definições.

Importa aqui ter em conta a distinção anteriormente destacada entre "declarar a essência - características necessárias e suficientes — de uma substância" e "declarar o significado e as condições de uso de um signo": a primeira ação implica

${ }^{144}$ LALANDE (op. cit., p. 1003), no verbete "sentido", registra: "o que 'quer dizer', o que comunicam ao espírito uma palavra, uma frase, ou qualquer outro signo que desempenhe um papel semelhante [...]: a) idéia ou intenção daquele que fala; estado de espírito que quer comunicar (representação, sentimento, ação) [...] O sentido da palavra ou frase é, portanto, um conteúdo psíquico muito complexo, uma atitude e um movimento do pensamento que compreendem imagens individuais e concretas, tendências às quais se acrescenta naquele que fala uma volição e naquele que escuta o 'sentimento de compreender', quer dizer, de poder evocar outras imagens ou outros signos ligados àquele por relações definidas, de saber o que é preciso fazer etc. Diz-se que uma expressão e uma fórmula estão 'cheias de sentido' se são capazes de evocar fortemente essa espécie de atividade mental". No mesmo verbete, continua-se a definir o termo "sentido", porém, segundo aquilo que, para nós, passa a constituir o significado de um termo: "valor objetivo de um signo, enquanto estabelecido pelo uso ou por uma convenção científica. O sentido, assim entendido, pode corresponder quer a uma definição (mais ou menos rigorosa), quer a uma intuição simples, para as noções que não podem nem ser decompostas pela análise, nem determinadas por uma definição indireta. Compreende muitas vezes duas partes, das quais uma é o 'sentido literal' da palavra ou da frase e a outra é uma acepção laudativa ou pejorativa, decente ou indecente, conciliadora ou agressiva etc, acepção não só pessoal e momentânea, mas mais ou menos consagradas pelo uso". 
pressupor a possibilidade de conhecimento racional dessas substâncias; a segunda ação implica, menos ambiciosamente, pressupor a possibilidade de distinção discursiva entre os diversos usos de um signo;

d) "Ba4" — neste subquadrante temos o "significado lingüístico". Entendemos por essa expressão um texto definidor particular (um definiens especificamente selecionado) que se presta à vinculação com um determinado significante, com o intuito de constituir um signo lingüístico. Nesse sentido, representa um texto que se constrói a partir de um conjunto prévio de signos lingüísticos (signos primitivos) e que será acionado mentalmente pela enunciação de um nome (uma "etiqueta" lingüística), mobilizando esquemas cognitivos sistemicamente correspondentes.

Conforme afirmamos, esta é uma característica que nos permite distinguir entre a visão essencialista-substancialista e a visão nominalista-terminista das definições:

i) segundo aquela, o definiens refere-se a conceitos que expressam essências que caracterizam as substâncias; os nomes e significados (ou seja, os dados lingüísticos) nisso participam apenas por necessidades e conveniências intelectivas e comunicativas da estrutura mental do homem. Em suma, as definições refletem um mundo de essências e substâncias idealmente atemporais, atópicas e impessoais, frente as quais os objetos sensíveis representam fenômenos particularizados e exemplares cuja essência pode ser passível de abstração. Como conseqüência, um definiens como esse, tomado como significado lingüístico, expressaria o significado (declarar as características necessárias e suficientes) ${ }^{145}$;

ii) segundo esta, o definiens refere-se simplesmente a significados que expressam lingüisticamente múltiplos conceitos; essências e substâncias não entram necessariamente em consideração (ou seja, considera-se que não necessitamos cogitar obrigatoriamente destes elementos durante o processo discursivo definidor). O fenômeno semiótico constitui-se em um sucedâneo da intelecção substancialista: desde que consideremos a impossibilidade da apreensão intelectiva das essências e substâncias em si mesmas, contentamo-nos com a manipulação de um universo semiótico que, para nós, representa a única realidade possível. Como conseqüência,

\footnotetext{
${ }^{145}$ Ver Capítulo II deste trabalho.
} 
um definiens como esse, tomado como significado lingüístico, expressaria simplesmente um dos possíveis significados e usos de um signo instituído.

Em suma, a visão nominalista-terminista implica a elaboração de uma realidade por meio de uma organização de conhecimentos armazenados (frames, schemata, scripts etc.) sob a forma de um sistema coerente de signos; a visão essencialistasubstancialista implica o conhecimento da realidade por meio da aquisição de conhecimentos armazenados sob a forma de um sistema coerente de conceitos atinentes a essências e substâncias. Difere o papel da linguagem: na primeira visão, a linguagem é fator constituinte da própria realidade (a linguagem constitui a realidade); na segunda visão, a linguagem é fator auxiliar para que consigamos expressar a realidade, dada a natureza de nossa constituição intelectiva (a linguagem refere-se à realidade).

e) "Ba5" — este subquadrante integra os subquadrantes 1 e 4: trata-se da vinculação entre o nome e o significado lingüístico, estabelecendo-se com isso o signo. De acordo com a visão essencialista, o signo expressa a essência de uma substância; de acordo com a visão nominalista, o signo expressa simplesmente uma relação intersignos, por equivalência e/ou contraste lingüístico.

f) "Bb6" — na intersecção entre o plano extralingüístico-discursivo individual e o plano mental situa-se o conceito referente individual, conceito que, para o indivíduo, refere-se a algo (que, também, pode ser denominado "objeto mental para o sujeito", "objeto-para-o-sujeito" ou "objeto-de-discurso individual").

Assim podemos entender o conceito de conceito referente ou objeto mental:

i) «fruto do processo de abstração realizado pelo sujeito, frente a uma série de eventos empíricos que podem ser agrupados sob rubricas conceituais, uma vez que determinadas características, consideradas essenciais, tenham sido abstraídas em caráter de traços necessários e suficientes sem os quais o objeto não pode ser considerado como aquele objeto específicos. Trata-se, nesse caso, de um constructo mental, de caráter perceptivo e/ou cognitivo, elaborado pelo discurso de um homo cognitor através de sua práxis mundana;

ii) <resultante de um todo apreensível como uma individualidade dentro de uma multiplicidade de objetos $;$; 
iii) «idéia cuja motivação é puramente mental (não-empírica), isto é, não resultante da experiência sensívelı.

O item "i", pode ser entendido como um conceito a posteriori; o item "iii" como um conceito a priori, e o item "ii" como um conceito a priori ou a posteriori, de acordo com as circunstâncias de apreensão.

Esse objeto mental subsiste como uma totalidade apreendida pelo pensamento, quer sob a forma de imagem, quer como um modo de determinação cognitiva (entendendo-se por "determinação" uma «limitação da extensão de uma noção com o enriquecimento da sua intensão, ou como o resultado dessa limitação> (ABBAGNANO, op. cit., p. 244). Trata-se, em suma, de um objeto intelectivo que se constitui em uma realidade puramente mental, apreendida como um todo conceptivo. Tal objeto mental não depende necessariamente de um discurso definidor, nem depende necessariamente de uma apreensão empírica (presença de um objeto sensível). Isto é, tal objeto intelectivo não é necessariamente um produto mental exclusivo de uma conceituação lingüística fornecida por um discurso racional abstrativo, nem é necessariamente um produto mental exclusivo da percepção de um objeto concreto do mundo sensível: é possível que um objeto mental, enquanto conceito ou idéia, seja produzido e fixado sem que a racionalidade e as afecções sensórias desempenhem qualquer papel nesse processo.

Também denominamos o conceito referente como "objeto-para-o-sujeito", indicando com isso seu caráter eminentemente individual, ou seja, existente para um sujeito específico enquanto processo mental particular. Isso não significa que não haja qualquer condicionamento social nessa concepção; pelo contrário, em grande medida os objetos mentais ou objetos-para-o-sujeito são determinações socioculturais e materiais em caráter de afecções das quais o sujeito é paciente. $O$ que está em destaque pelo conceito de objeto-para-o-sujeito é a internalização e o processamento pessoal de conceitos que o indivíduo, enquanto ser social, produz ou apreende: podemos dizer que uma das características do conceito de razão é a capacidade de racionalizar e reter conceitos cuja produção não depende unicamente da externalidade social. 
Continuando com nosso exemplo, o objeto mental ou conceito referente Estado - considerado como uma unidade cognitiva autônoma que expressa uma determinada realidade mental unitária e distinta das demais realidades mentais - é apreendido integral (e, diríamos, instantaneamente) pela mente de um determinado indivíduo. Em outras palavras, podemos entender que o indivíduo produz seu conceito de Estado (sua interpretação pessoal do conceito), conceito esse que sobrevive ao lado do conceito assim como ele é compreendido socialmente ou como ele é definido oficialmente.

g) "Aa7" — na intersecção entre o plano extralingüístico-discursivo individual e o plano empírico, situa-se o objeto referido individual, objeto a que algo se refere, podendo ser esse "algo" um nome, um texto definidor um conceito referente individual ou um conceito referente social (que, também, pode ser denominado "objeto-de-realidade individual", "objeto sensível individual", "objeto fenomênico segundo a práxis individual" ou "objeto práxico individual"), objeto concreto que se oferece à experiência sensorial do observador, aqui no âmbito práxico individual. No caso de nosso exemplo, trata-se da apreensão pragmática e pessoal de uma entidade jurídica que se denomina "Estado".

Cabe observar que esse elemento não é condição sine qua non para o desenvolvimento do processo definidor, nem para a existência de um conceito referente ou objeto mental: a inexistência de um objeto referido ou objeto sensível (um objeto-de-realidade) não impede a elaboração de um objeto mental ou conceito, ao qual se vinculem um texto definidor e um nome convencional, embora em geral haja um objeto sensível como fundamento de um conceito, objeto ou fenômeno de fundamentação práxica que está à disposição dos instrumentos sensoriais de cognição e apreensão daquilo que, de alguma maneira, pode ser designada como "realidade extramental".

h) "Bg8" — na intersecção entre o plano extralingüístico-discursivo social e o plano mental, encontra-se o conceito referente social ("objeto mental para o social", "objeto-de-discurso social" ou "objeto-para-o-social"). Aqui, valem os mesmos comentários apresentados para o subquadrante "Bb6", considerados agora sob o ponto de vista coletivo ou social: aquilo que foi caracterizado como objeto-de- 
discurso individual passa aqui a ser entendido como objeto-de-discurso social, objeto esse que é produto de "atividades de linguagem realizadas por sujeitos históricos e sociais em interação, sujeitos que constroem mundos textuais cujos objetos não espelham fielmente o 'mundo real', mas são, isto sim, interativamente e discursivamente constituídos em meio a práticas sociais [ou seja, são objetos-dediscurso]" (KOCH et alii, 2005, p. 8). No nosso exemplo, trata-se, portanto, da produção de um objeto-de-discurso a que a convenção social atribui o nome "Estado" — objeto esse que pode concordar ou não concordar com o objeto mental individual de cada um dos interagentes.

i) "Ag9" — na intersecção entre o plano extralingüístico-discursivo social e o plano empírico, localiza-se, por fim, o objeto referido social ("objeto-de-realidade social", "objeto sensível social", "objeto fenomênico segundo a práxis social" ou "objeto práxico social"), para o qual valem as observações apresentadas no item "d". O objeto-de-realidade segundo a práxis social não difere intrinsecamente desse mesmo objeto tomado segundo a práxis individual; o que há são diferentes tipos de observadores ou agentes que apreendem e experimentam essa mesma práxis, segundo pontos de vista diversos: a recepção da experiência em relação a uma entidade denominada "Estado", por parte dos indivíduos que compõem a sociedade, é freqüentemente diversa da apreensão dessa mesma experiência por parte da sociedade enquanto entidade. Essa distinção é importante, pois não podemos excluir nenhuma dessas experiências como determinantes da formação dos conceitos referentes; ao mesmo tempo, não podemos confundi-las, pois esses conceitos são igualmente distintos.

j) "Bbg" — na intersecção entre o plano extralingüístico-discursivo e o plano mental, temos a síntese e/ou a análise definidora, processo que estabelece uma relação entre diversos conceitos referentes (individuais e/ou sociais), de modo a ser possível a organização racional de tais conceitos segundo juízos apropriados. Assim, em nosso exemplo, os conceitos de estado, de situação, de pessoa, de coisa, de disposição e de tempo podem ser racionalmente organizados no plano extralingüístico-discursivo mental, de modo a produzir juízos que sirvam para definir um dos conceitos envolvidos. A razão articula conceitos, sintetizando um juízo que 
expressa lingüisticamente um novo conceito ${ }^{146}$; também, a razão pode decompor os conceitos envolvidos em um juízo, discriminando a estrutura conceitual pressuposta que determina um conceito derivado;

I) o quadro em exame apresenta dois elementos localizados no plano mental "B" e colocados acima dos planos expressivos: trata-se das essências e as substâncias, ambas consideradas em si mesmas, ou seja, entendidas segundo o conceito lato sensu de idéia - a espécie única apenas intuível a partir de uma multiplicidade de manifestações sensíveis que representam a concretização dessa idéia. Não se trata, portanto, da idéia entendida como um objeto qualquer do pensamento humano ou uma representação geral de um objeto qualquer: referimonos, isto sim, às realidades universais que transcendem as experiências particulares (tratadas nos subquadrantes $6,7,8$ e 9), que delas são manifestações individualizadas e, também, socializadas.

Concentrando-se nos nove elementos sistêmicos apresentados (subquadrantes 1-9), podemos distinguir as possibilidades interpretativas que a expressão "definir o conceito $X "$ pode dispor:

a) o conceito $X$ pode ser predicado pelos atributos de um objeto práxico $Y$; a fórmula que representa esse fato é: $\left|X \leftarrow \pi{ }^{P} Y^{P}\right\rangle /$, lida: "o conceito $X$ aceita ser predicado pelas características do objeto práxico $Y^{\prime \prime}$. Trata-se de considerar como referência para a constituição do conceito-definiendum os dados empíricos relativos a objetos referidos individuais e/ou sociais. Como exemplo, as pseudodefinições de caráter extensional operam segundo essa perspectiva;

b1) o conceito $X$ pode ser predicado pelos atributos de um objeto mental $Y$; $a$ fórmula que representa esse fato é: $\mid X \leftarrow \pi\left\langle{ }^{M} Y^{M}\right\rangle /$, lida: "o conceito $X$ aceita ser predicado pelas características do objeto mental $Y^{\prime \prime}$. Trata-se de considerar como referência para a constituição sintética do conceito-definiendum os dados conceituais que, por análise, são estipulados como atributos de um outro conceito $Y$.

${ }^{146}$ Em ABBAGNANO (op. cit., pp. 905-907), lemos: "No segundo significado, o termo ["síntese"] designa a união do sujeito e do predicado na proposição, portanto, o ato ou a atividade intelectual que realiza tal união. [...] foi Kant quem mais utilizou o conceito de síntese, reduzindo a ela todas as espécies de atividade intelectual. Definiu a síntese em geral como 'o ato de unir diferentes representações e de compreender essa unidade num único conhecimento'". 
Como exemplo, as definições de caráter intensional são, em geral, construídas tendo em vista um conjunto pressuposto de conceitos primitivos;

b2) o conceito $X$ pode ser predicado pelos atributos de um objeto-de-discurso $Y$; a fórmula que representa esse fato é: $/ X \leftarrow \pi r^{D} Y^{D}, /$, lida: "o conceito $X$ aceita ser predicado pelas características do objeto-de-discurso $Y^{\prime \prime}$. Aqui, temos como referência para a constituição sintética do conceito-definiendum os dados conceituais atribuídos, individual ou socialmente, a um objeto-de-discurso.

Como vemos, para nossa exposição, é interessante distinguir entre o conceito comum de conceito - os objetos mentais - e o conceito de objeto-de-discurso, que, para nós, constituem um tipo particular de conceito referente. Como exemplo, as definições intensionais subjetivo-convencionais estipuladoras são construídas a partir de um definiens que pode ser compreendido como um objeto-de-discurso. Adiante, estabeleceremos a diferença entre objetos mentais e objetos-de-discurso;

c) o conceito $X$ pode ser predicado pelos atributos de um signo $Y$; a fórmula que representa esse fato é: $/ X \leftarrow \pi\langle " Y "\rangle /$, lida: "o conceito $X$ aceita ser predicado pelas características do signo ' $Y$ '. A referência para a constituição sintética do conceito-definiens, nesse caso, são os signos primitivos. O exemplo claro desse fato são as definições intensionais subjetivo-convencionais sinonímico-parafrásticas.

Para melhor compreender essas possibilidades interpretativas da expressão "definir o conceito $X "$ ", podemos distribuir os elementos de definição segundo a seguinte tipologia:

a) elementos cuja realidade ontológica é necessariamente exterior e/ou anterior a um processo definidor e produtor de seu conceito referente, não dependendo, para existir, de qualquer operação mental ou particular atividade discursiva constitutiva, contextualizada e de caráter interativo; trata-se, portanto, de um elemento ontologicamente independente (ou seja, absolutamente independente). Nessa categoria, situam-se dois extremos ontológicos: os objetos absolutamente empíricos (objetos práxicos ou objetos referidos) e os objetos absolutamente transcendentes (as substâncias absolutas). Como exemplos, no segundo caso, temos o objeto Deus e, no primeiro caso, temos o objeto Sócrates. Ambos os objetos são, por princípio, intrinsecamente indefiníveis (ou seja, não podemos enunciar, verdadeiramente, 
conceitos que os represente); portanto, constituem problemas definidores insolúveis, dado o caráter axiomático envolvido. Porém, há de se ter em conta que tais objetos só podem ser conhecidos pelo homem através de processos mentais e discursivos (individuais e/ou sociais), que estabeleçam, na medida do possível, ou seja, relativamente, a universalidade e a necessidade daquilo que os torna únicos (definindo-os, por exemplo, por gênero e espécie, e/ou pelas quatro causas). Em suma, tais objetos são incognoscíveis em si mesmos; apenas podem ser conhecidos convencionalmente sob a forma de objetos mentais e/ou objetos-de-discurso (não enquanto objetos-em-si, mas sim enquanto objetos-para-o-sujeito ou objetos-para-osocial);

b) elementos cuja realidade ontológica é necessariamente interior e/ou contemporânea a um processo definidor (dependendo, para existir, de uma operação mental, produtora de seu conceito referente), mas não dependendo, para tanto, de qualquer atividade discursiva particular constitutiva, contextualizada e de caráter interativo; trata-se, portanto, de um elemento ontologicamente semidependente (ou seja, relativamente dependente). Nessa categoria, situam-se os conceitos referentes individuais e sociais - com exceção dos objetos-de-discurso. $O$ conceito de homem - enquanto conceito referente que (conforme afirmado) subsiste como uma totalidade apreendida pelo pensamento, quer sob a forma de imagem, quer como um modo de determinação cognitiva, tem sua origem no plano expressivo extralingüístico-discursivo mental e independe de um discurso definidor constitutivo, contextualizado e interativo. Obviamente, a reapresentação desse conceito sob forma de texto definidor ou, então, de signo - como, por exemplo, /homem $\leftarrow \pi$ rqualquer indivíduo pertencente à espécie animal que apresenta o maior grau de complexidade na escala evolutiva; o ser humanos / ou /homem $\leftarrow \pi$ 〈animal político dotado de $10 / g \circ j$ — não implicam um discurso definidor fundador e constitutivo, mas apenas a expressão textual de um objeto mental já estabelecido.

Por outro lado, a produção de uma definição por meio de um discurso constitutivo contextualizado e de caráter interativo — como, por exemplo, a definição irônica produzida por dois interlocutores /homem $\leftarrow \pi$ «ser humano que não se pode afirmar ser humanos - diz respeito a um objeto-de-discurso (como teríamos na 
seguinte enunciação: "Bem...aqui me refiro ao tipo de homem que para chegar a ser humano precisa muito ser humano...");

c) elementos cuja realidade ontológica é necessariamente interior e/ou contemporânea a um processo definidor (dependendo, para existir, de uma operação mental, produtora de seu conceito referente) e dependendo, ao mesmo tempo, de uma particular atividade discursiva constitutiva, contextualizada e de caráter interativo. Ou seja, trata-se de um elemento ontologicamente dependente (ou seja, absolutamente dependente).

Neste caso, temos propriamente os denominados "objeto-de-discurso": enquanto os conceitos referentes são instaurados pelas respostas à pergunta "Que é o conceito $X$ ?", os objetos-de-discurso são instaurados pelas respostas à pergunta "Que é o conceito $X$ para esse discurso específico e para o enunciador ou coenunciadores desse discurso?".

Portanto, assim distinguimos entre conceitos referentes e objetos-de-discurso: a) os primeiros $\left(/ X \leftarrow \pi\left\langle{ }^{M} Y^{M}\right\rangle /\right)$ não dependem de uma particular atividade discursiva, contextualizada e de caráter interativo; b) os segundos $\left(/ X \leftarrow \pi{ }^{D} Y^{D}, /\right)$ dependem de uma tal atividade.

As definições seguintes dizem respeito a objetos-de-discurso: "soberbo canal" $\leftarrow \pi$ «sujo e insignificante filete de água〉; "estradas" $\leftarrow \pi$ «atalhos de um pé de largura, cavados numa profundidade de oito ou dez polegadası e "palácios em mármore branco" $\leftarrow \pi$ «velhas construções enfileiradas umas após as outras, formando treliças, por assim dizer ${ }^{147}$. Patenteia-se nesses exemplos o desenvolvimento de uma particular atividade discursiva constitutiva, contextualizada e de caráter interativo, produzindo um texto definidor marcado pelas características da oralidade, como poderemos verificar nas respectivas contexturas definidoras (discutidas no próximo tópico).

Em suma, para nossos objetivos, interessa sublinhar que:

\footnotetext{
${ }^{147}$ Exemplos presentes em MONDADA, Lorenza \& DUBOIS, Danièle. "Construção dos objetos de discurso e categorização: uma abordagem dos processos de referenciação" In CAVALCANTE (2002, pp. 32-33).
} 
a) os objetos práxicos existem independentemente de qualquer operação mental e discursiva constitutiva particular; b) os conceitos referentes existem dependendo de uma operação mental e independendo de qualquer operação discursiva constitutiva particular; c) os objetos-de-discurso existem dependendo, simultaneamente, de uma operação mental e de uma particular operação discursiva constitutiva, contextualizada e de caráter interativo.

Embora seja possível discernir claramente, sob o ponto de vista teórico, entre esses três tipos de situação, cabe destacar que, sob o ponto de vista prático, a distinção não é tão óbvia: a) o objeto práxico apenas se torna intelectivamente conhecido para o homem enquanto objeto mental e/ou objeto-de-discurso; b) a própria realidade (ou seja, aquilo que nossa convenção social denomina "realidade sensível"), igualmente, apenas se torna conhecida para o homem enquanto objeto mental e objeto-de-discurso, passando a existir propriamente através do 1o/goj o discurso fundador; c) por sua vez, os objetos mentais são, igualmente, formalizados através do discurso definidor.

Portanto, uma vez que a realidade-em-si (isto é, a realidade independentemente de sua relação com o sujeito de conhecimento) e o ser-em-si (isto é, o ser tal qual é em sua essencialidade substancial) apenas fazem sentido para o homem por meio de manifestações discursivas, tornam-se sutis as fronteiras entre esses três objetos e, freqüentemente, de difícil distinção: não surpreende, portanto, que o discurso assuma freqüentemente o estatuto de verdadeira realidade.

Cabe também observar as possíveis inter-relações entre os objetos em questão, ou seja, verificar se é possível que, por exemplo, um conceito referente ou um objeto práxico possam ser predicados por objetos-de-discurso. Como podemos presumir, esse tipo de referência cruzada constitui um evento de alta freqüência nas atividades discursivas da oralidade.

Com essas informações em mãos, podemos examinar possíveis procedimentos definidores, os quais implicam diferentes noções de significado (subquadrante 1) e diferentes noções de entendimento desses significados; para tanto, Hegenberg (op. cit., pp. 59-64) menciona a relação, apresentada por 
Brodbeck $^{148}$, entre vários tipos de significado acionados por um termo e vários tipos de entendimento que tal termo propicia. Tendo por base a exposição do autor, resumiremos uma tipologia de conceitos de entendimento e uma tipologia correspondente de conceitos de significado.

$O$ primeiro tipo de entendimento - entender $_{1}$ ou $E_{1}-$ diz respeito ao entendimento lingüístico de um enunciado: entendemos ${ }_{1}$ quando entendemos referencial ou denotativamente um texto expresso em dado código, isto é, quando: a) entendemos cada um dos termos empregados, e, conseqüentemente, entendemos os enunciados compostos por eles; b) reconhecemos os referenciais vinculados a tais termos: "entender uma linguagem é saber usar certos sons (ou marcas) para expressar pensamentos, atitudes, desejos, dúvidas e, também, para transmitir informações a propósito do mundo" (HEGENBERG, op. cit., p. 62).

Aqui, o que se tem em vista é a definição do conceito a partir de um referencial, ou seja, há entendimento ${ }_{1}$ de certas expressões quando elas possuem significados lingüístico-referenciais. Assim, para os falantes do português, o termo "tese", sob o ponto de vista lingüístico, permite um entendimento $1 \mathrm{e}$, para aqueles que possuem acesso às características do referencial $\mid$ tese $\mid$, tal termo permite um entendimento ainda melhor.

$\mathrm{O}$ segundo tipo de entendimento - entender $\mathrm{r}_{2}$ ou $\mathrm{E}_{2}-$ diz respeito ao entendimento empírico-vivencial dos conceitos vinculados a um determinado termo utilizado. Não se trata, portanto, de um fato lingüístico: assim, em caso de nãoentendimento ${ }_{2}$, "eu não entendo 2 porque não tenho certas emoções, sentimentos especiais, ou atitudes que surgem apenas nos que viveram experiências do tipo ou enfrentaram situações específicas" (Ibidem). Assim, o entendimento empíricovivencial $E_{2}$ do conceito defender tese só é dado a quem vivenciou esse processo, ou seja, a quem dele possui, além do conhecimento lingüístico, um conhecimento empírico (já tenha, de fato, defendido uma tese). Assim, pode-se não ter o entendimento experimental do conceito defender tese, mas havendo entendimento dos termos "defender" e "tese", do enunciado "defender tese", e dos conceitos que se relacionam a esses (defender define-se como roferecer resistência, opor-se ou

\footnotetext{
${ }^{148}$ M. Brodbeck. "Meaning and action" In Philosophy of Science. v. 30, 1963, pp. 309 ss.
} 
proteger-se de um ataque〉, tese define-se como «uma proposição que está em discussão e que, em caso de impugnação, será sustentada> etc.), é possível, projetivamente, entender o que "defender tese" significa.

$O$ terceiro tipo de entendimento - entender ${ }_{3}$ ou $E_{3}-$ diz respeito ao entendimento lingüístico-projetivo vinculado a um determinado termo ou determinadas expressões: é possível que um indivíduo não tenha um entendimento 2 sobre o conceito defender tese; porém, se tiver um entendimento ${ }_{1}$ desse conceito, e tiver um entendimento ${ }_{2}$ dos conceitos parciais defender e tese, poderá projetar o que seria um entendimento 2 do conceito composto.

$\mathrm{O}$ quarto tipo de entendimento - entender 4 ou $\mathrm{E}_{4}-$ diz respeito ao entendimento motivacional vinculado a determinado termo ou expressão: se um indivíduo entende os motivos e propósitos das ações que inspiram determinados comportamentos, expressos por um termo ou expressão, então estará capacitado a entender $_{4}$ a natureza dos conceitos aí envolvidos. Como exemplo, se entendemos 4 por que alguém defende uma tese (suas motivações, seus objetivos, etc.), estaremos aptos a melhor entender 3 o que significa a expressão "defender tese": em outras palavras, se entendermos que defender tese tem por causa obter titulação, participar de concursos, desenvolver carreira acadêmica, etc., teremos um entendimento motivacional do conceito defender tese.

$\mathrm{O}$ quinto tipo de entendimento - entender 5 ou $\mathrm{E}_{5}$ - diz respeito ao entendimento relacional vinculado a um determinado termo: "de modo genérico, entendemos $_{5}$ um tipo de coisa, acontecimento ou comportamento quando sabemos ou acreditamos que há outras coisas, acontecimentos, etc., que se associam, de algum modo, ao que dizemos entender" (HEGENBERG, op. cit., p. 63). Assim, podemos entender que um acréscimo nos impostos acarretará um acréscimo nos custos operacionais que provocarão majoração nos preços finais dos produtos e demais conseqüências.

Portanto, o conceito mencionado por um termo vincula-se aos conceitos mencionados por outros termos, segundo espécies de leis ou princípios (explícitas ou implícitas, sob o ponto de vista do usuário desses termos) de associação mental 


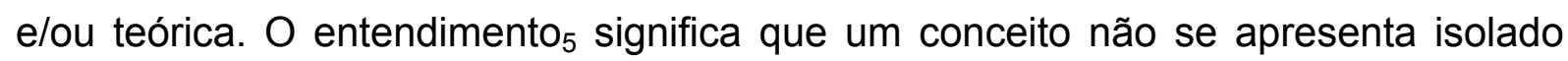
em nossa mente, mas sim enquanto partícipe de uma rede conceitual associada.

Como exemplo, pode-se entender 5 que o conceito de defender (termo "defender") relaciona-se, de algum modo, ao conceito de impugnação (termo "impugnação") e que o conceito de tese (termo "tese") relaciona-se, de algum modo, ao conceito de pesquisa (termo "pesquisa") etc.

$\mathrm{O}$ primeiro tipo de significado - significado $_{1}$ ou $\mathrm{S}_{1}$ - correspondente a entender ${ }_{1}$ ou $E_{1}$ - diz respeito ao significado lingüístico vinculado a um determinado termo: "se, em dado contexto, sabemos que propriedade ou propriedades um termo é chamado a invocar, diz-se que esse termo admite uma referência - ou seja, tem significado-1 (sig-1)" (HEGENBERG, op. cit., p. 59). Portanto, trata-se do entendimento ${ }_{1} \mathrm{do}(\mathrm{s})$ conceito(s) ou propriedades abstraídas de objetos mentais e/ou objetos reais (referenciais), que se vincula $(m)$ a um determinado termo em dado co(n)texto.

Assim, se o termo "tese" vincula-se, no contexto acadêmico, a sproposição apresentada à discussão e possível impugnação, a ser defendida publicamentè (abstração de um conceito genérico de tese), e se essas propriedades, características ou relações forem conhecidas - ou seja, se os objetos proposição, discussão, impugnação e defesa pública forem reconhecidos —, diremos que o termo "tese" tem significado ${ }_{1}$.

$\mathrm{O}$ segundo tipo de significado - significado $_{2}$ ou $\mathrm{S}_{2}$ - correspondente a entender $r_{5}$ ou $E_{5}$ - diz respeito ao significado conceitual-relacional vinculado a um determinado termo: "na ciência, quando se sabe que a referência de um termo está associada (através de leis) a outras coisas, o termo se diz 'significativo': possui significado-2 (sig-2)" (HEGENBERG, op. cit., p. 60).

O significado lingüístico ( significado $_{1}$ ) de um termo empregado vincula-se convencionalmente aos significados lingüísticos de outros termos; já o significado conceitual-relacional $\left(\right.$ significado $\left._{2}\right)$ implica que um significado não se apresenta isolado em nossa mente, mas sim está associado, segundo determinadas leis ou princípios, a uma rede de significados e referenciais associados. Assim, o 
significado $_{2}$ o termo "tese" vincula-se mentalmente, dentre outros, aos significados 2 dos termos "assunção", "princípio" e "afirmação".

Conforme afirma Hegenberg, esses são os únicos tipos de significados de importância para a ciência; contudo, há pelo menos outros dois tipos a serem mencionados (identificados abaixo como $\mathrm{S}_{3}$ e $\mathrm{S}_{4}$ ).

$\mathrm{O}$ terceiro tipo de significado - significado $_{3}$ ou $\mathrm{S}_{3}$ - correspondente a entender ${ }_{2}$ ou $E_{2}$ - diz respeito ao significado compreensivo vinculado a um determinado termo:

"É típico de atos mentais (e apenas de atos mentais), que 'signifiquem' algo mais. O que o pensamento significa, para empregar uma metáfora já em desuso, é a compreensão. O que o pensamento visa (ou significa) é, muitas vezes, entendido como 'significado'. O significado, em tais casos, é, via de regra, algo não-mental: ao pensar em cavalos no jardim, são os cavalos que o pensamento 'significa'. É claro que há exceções: posso pensar em pensamentos meus e de outrem. O 'significado compreensivo', ou significado-3, é o que o ato mental significa, abarca, abrange, visa. Pensar ou pensar acerca de algo é uma coisa. O que tal pensamento visa (ou sig-3) é outra coisa, via de regra não-mental." (op. cit., p. 60).

Assim, é possível que dois termos refiram-se a um mesmo objeto e, desse modo, possuam o mesmo significado ${ }_{1}$; porém, é impossível que dois conceitos compreendam um mesmo objeto; desse modo, nunca possuirão o mesmo significado $_{3}$. Como exemplo, o termo "cinco" significa ${ }_{1}$ o mesmo que o termo "raiz quadrada de vinte e cinco"; porém, o conceito cinco não significa 3 o mesmo que o conceito raiz quadrada de vinte e cinco. Mesmo que dois termos diversos refiram-se a um só objeto, os conceitos vinculados a tais termos não possuem o mesmo significado 3 : "dois conceitos diferentes jamais têm o mesmo sig-3: eles são diferentes precisamente porque visam algo diferente" (HEGENBERG, op. cit., p. 61).

Assim, o significado compreensivo do conceito tese, expresso pelo termo "tese", visa a um objeto sensível e concreto, uma tese específica, isto é, um fato ou evento que foi ou é um objeto-de-realidade, do qual se abstraem propriedades que formam o conceito que se tem dessa tese particular. 
$\mathrm{O}$ quarto tipo de significado - significado $_{4}$ ou $\mathrm{S}_{4}$ - correspondente a entender ${ }_{3}$ ou $E_{3}$ — diz respeito ao significado projetivo vinculado a um determinado termo: não existe aqui um entendimento experimental de um dado objeto, mas porque se domina significado ${ }_{1}$ e significado 2 , é possível imaginar - ou projetar - o que seria o significado projetivo $\left(\right.$ significado $_{3}$ ) do conceito vinculado ao enunciado, segundo um movimento de generalização.

Assim, pode-se não ter o significado experimental do conceito defender uma tese, mas: a) dominando-se os significados ${ }_{1}$ dos termos "defender" e "tese", e do enunciado "defender tese"; b) dominando-se os significados ${ }_{2}$ que se relacionam aos significados $_{1}$, é possível, projetivamente, entender o significado da expressão "defender uma tese", por meio de uma composição desses significados.

O quinto tipo de significado - significado ${ }_{5}$ ou $\mathrm{S}_{5}$ - correspondente a entender 4 ou $\mathrm{E}_{4}$ - diz respeito ao significado psicológico vinculado a um determinado termo: os termos e seus conceitos são objeto de interpretação por parte dos usuários, os quais, inevitavelmente, absorvem-nos e internalizam-nos de modo pessoal. Trata-se, então, de entender os significados psicológicos que o conceito de um determinado termo possui para um indivíduo.

Assim, se atribuirmos à expressão "defender tese" o entendimento motivacional 〈estresse〉, ‘grande esforço mentalı ou ‘abandonar o lazer〉, chegaremos ao significado psicológico do conceito defender tese.

Posto isso, voltemo-nos para alguns dos possíveis processos definidores:

a) [PD1] $\rightarrow$ produzir um texto definidor tomando como objeto-fonte um nome (subquadrante 1): este procedimento implica simplesmente a (re)definição de significantes; possui, portanto, caráter estritamente autonímico. Nesse sentido, corresponde às definições intensionais subjetivo-convencionais autonímicas ("3.8").

Como exemplo, temos a produção de dois textos definidores a partir de um mesmo nome: i) estrutura definidora anterior: /"homem" $\approx$ "substantivo masculino; palavra paroxítona"/; ii) estrutura definidora posterior: /"homem" $\approx$ "substantivo masculino; palavra dissílaba paroxítona que provém do latim homo, hominis, formada pelos grafemas [...] e pelos fonemas [...]" /; 
b) [PD2] $\rightarrow$ produzir um novo texto definidor tomando como objeto-fonte esse mesmo texto definidor (subquadrante 2): trata-se de (re)formular um texto definidor a partir dos elementos lingüísticos constitutivos desse mesmo texto definidor (textofonte), nele introduzindo ou retirando elementos lingüísticos modificadores. Aqui, podemos lembrar as noções de significado projetivo e entendimento lingüísticoprojetivo, apresentadas linhas acima; é possível desenvolver definições em nível meramente lingüístico-empírico, a partir dessas mesmas definições. Não entra aqui em discussão a consistência do objeto mental correlato ou do objeto sensível referido pelo conceito referente.

Como exemplo, a partir do texto definidor (serenidade de ânimo) (ao qual se pode aplicar o nome "calma"), poderemos produzir novos textos definidores pela utilização de ferramentas lingüísticas, tais como a adjetivação, a adverbialização, alterações morfológicos, etc. Poderíamos propor ‘ausência de serenidade de ânimos (que pode ser nomeado como "agitação") e ‘excesso de serenidade de ânimo〉 (que pode ser nomeado como "apatia"). Poderíamos, até mesmo, modalizar o texto definidor: /calma $\leftarrow \pi$ «comportamento por muitos entendido como certa serenidade de ânimo〉/. É possível ter, simplesmente, a transformação de/homem $\leftarrow \pi$ ‘animal racionalı/ para /homem $\leftarrow \pi$ «mais animal que racional`/, pela simples agregação de material lingüístico.

Outro exemplo temos em /cidadão $\leftarrow \pi$ ranimal racional capaz de ação política efetiva em prol da 'ciuitas') /; a partir dessa estrutura definidora, podemos produzir outras estruturas pela simples modificação lingüística dos termos envolvidos; assim, produziríamos /'cidadão' $\leftarrow \pi$ ranimal racional mas incapaz de ação política efetiva em prol da 'ciuitas'), novo texto definidor que flexibiliza o definiendum e reconstrói ontologicamente o objeto de definição, atribuindo-Ihe diferente carga semântica e rearticulando seu sistema de definições correlato (no caso, justificar-se-ia até mesmo a alteração do nome do definiendum). Em suma, esse procedimento nos mostra que é possível construir textos definidores - que poderão, em certos casos, até mesmo passar por autênticas definições conceituais - pela simples manipulação da 
ferramenta lingüística, sem que estejam em jogo quaisquer considerações de ordem conceitual ou referencial;

c) [PD3] $\rightarrow$ produzir um (novo) texto definidor tomando como objetos-fonte outros textos definidores (subquadrante 2): neste caso, trata-se de produzir um texto definidor a partir da recomposição ou recombinação de textos definidores, mediante acréscimo ou subtração de material lingüístico modificador. Aqui, também são úteis as noções de significado projetivo e entendimento lingüístico-projetivo; é possível desenvolver definições em nível meramente lingüístico, por meio da articulação de textos definidores prévios.

Assim, uma vez que conheçamos o teor dos seguintes textos definidores: i) objeto $_{1} \leftarrow \pi$ «medo que foge a um controle racional); ii) objeto ${ }_{2} \leftarrow \pi$ <manifestar doenças orgânicas) (textos vinculados, respectivamente, aos termos "pânico" e "somatizar"), poderemos compor o seguinte enunciado definidor: objeto $\mathrm{o}_{3} \leftarrow \pi$ <medo que foge a um controle racional, capaz de provocar manifestações orgânicas) /, ao qual poderemos convencionalmente aplicar o nome "pânico somatizável" (ou qualquer outro nome, motivado ou imotivado). Nesse caso, igualmente, não entra em discussão a consistência desse objeto mental e/ou a existência desse objeto sensível.

Igualmente, poderíamos retextualizar i) /homem $\leftarrow \pi$ (animal racionals/; ii) /homem $\leftarrow \pi$ (animal político /; iii)/homem $\leftarrow \pi$ (animal dotado de linguagem /, construindo /homem $\leftarrow \pi$ «animal irracional quando dotado de linguagem política /;

d) $[P D 4] \rightarrow$ produzir um texto definidor tomando como objeto-fonte um conjunto articulado de signos, considerados em sua materialidade (subquadrante 5): é possível também produzir um texto definidor a partir de uma pura organização de signos, mesmo que não haja qualquer processo de definição intensional do conceito ao qual determinado nome faz menção ou, então, mesmo que não haja um nome estipulado para a síntese resultante: importa, nesse caso, a própria materialidae dos signos.

Isso é possível pela capacidade humana de estabelecer diversos graus de compreensão racional, considerando os diferentes matizes semânticos dos 
conceitos de entendimento e significado (conforme vimos): de fato, os signos, enquanto sistema, constituem uma linguagem dotada de grande autonomia expressiva, um universo significativo em si mesmo.

Assim, de acordo com as circunstâncias e necessidades expressivas, pode-se ou não aceitar como suficiente a definição /faca $\leftarrow \pi$ icoisa cortante e perigo constantes / (que reúne signos segundo uma estrutura poética especial), frente ao definiens mais objetivo sinstrumento constituído por lâmina cortante presa a um cabo), uma vez que há inúmeras "coisas cortantes e de perigo constante" (dentre elas, o frio polar). Poderíamos propor, até mesmo, /faca $\leftarrow \pi$ «ferramenta perigosa, silenciosa e ardilosa) /: compreendemos que a função poética ${ }^{149}$ pode predominar em uma estrutura definidora (ou pseudodefinidora), assim como a função lúdica pode explicar a estrutura "metrô" $\approx$ "elevador que anda na horizontal" e, enfim as funções poética e lúdica podem justificar uma estrutura de signos tal como: "escoteiros" $\approx$ "um bando de menininhos vestidos de idiota, comandados por um idiota vestido de menininho". Também, de /homem $\leftarrow \pi$ 〈animal políticos / podemos passar para /homem $\leftarrow \pi$ 〈político que não anima /;

e) [PD5] $\rightarrow$ produzir um (novo) texto definidor tomando como objeto-fonte uma síntese/análise definidora, modificando e/ou (re)combinando seus conceitos referentes constitutivos (subquadrantes 6 e 8): trata-se, portanto, de produzir um novo texto definidor a partir da (re)organização de conceitos referentes implicados por uma dada síntese/análise definidora.

Assim, a partir dos conceitos referentes implicados pelo conceito de homem animalidade, humanidade, racionalidade, ação política, dotação —, podemos gerar um novo texto definidor: /homem $\leftarrow \pi$ sser animado e dotado de alma, cuja humanidade determina sua ação política racionalı. Como vemos, esta modalidade difere dos casos "PD2" e "PD3" na medida em que, neste caso, ocorre uma

\footnotetext{
${ }^{149}$ É útil lembrar que, para VANOYE (2003, p.58), "a função poética é aquela que se centra na própria mensagem. Ela coloca em evidência o lado palpável do signo (Jakobson). Tudo o que, numa mensagem, suplementa o sentido da mensagem através do jogo de sua estrutura, de sua tonalidade, de seu ritmo, de sua sonoridade concerne à função poética".
} 
reelaboração conceitual, enquanto naqueles casos ocorre uma reelaboração puramente lingüística do texto definidor (em suma, ali, o foco do processo é o próprio texto definidor e suas transformações lingüísticas, enquanto aqui o foco é o conceito e suas possíveis transformações conceituais);

f) $[$ PD6] $\rightarrow$ produzir um (novo) texto definidor tomando como objetos-fonte pelo menos duas sínteses/análises definidoras, modificando e/ou (re)combinando seus conceitos referentes constitutivos: trata-se, portanto, de produzir um novo texto definidor a partir da (re)organização de conceitos referentes implicados por duas ou mais sínteses/análises definidoras.

Como exemplo, pela reunião aleatória dos conceitos águia, leão e cavalo (sínteses definidoras), podemos produzir o seguinte texto definidor (nova síntese definidora): ‘animal com cabeça de águia, corpo de cavalo e garras de leãos, ao qual podemos atribuir o nome "hipogrifo". Facilmente poderíamos produzir outros textos definidores semelhantes, a partir de novas sínteses definidoras.

Também, a partir de /homem $\leftarrow \pi$ ‘animal dotado de linguagem) /, /auriga $\leftarrow$ $\pi$ «condutor de carros puxados por cavalos` / e /destino $\leftarrow \pi$ ८o que há de vir; futuro; porvir /, podemos propor /homem $\leftarrow \pi$ sanimal que, pela linguagem, é o auriga de seu próprio porvirı/.

Este, juntamente com o anterior, é um dos principais métodos definidores: a partir de um ou mais de um conceito primitivo, promovem-se novas sínteses/análises definidoras, desenvolvendo-se, assim, um processo de pura racionalidade definidora;

g) [PD7] $\rightarrow$ produzir um conceito referente tomando como objeto(s)-fonte objeto(s) referido(s) [subquadrantes 7 e 8]: trata-se aqui de (re)definir um objeto mental a partir de objetos sensíveis, ou seja, temos a elaboração de um conceito referente motivado por objeto(s) referido(s), quer por experiência práxica direta, quer por ação da memória sensorial. Uma vez constituído mentalmente o objeto, em caráter de totalidade, pode-se formular um texto definidor que expresse lingüisticamente o conceito. 
Como exemplo, pela experiência sensível em relação aos objetos-de-realidade objeto $_{1} \rightarrow$ aerossol e objeto $_{2} \rightarrow$ pimenta (ao observá-los, por exemplo), podemos conceber um objeto mental sintetizado a partir das características físicas ou funcionais desses dois objetos práxicos: imagina-se um tipo de "spray" que esparge pimenta, visando à defesa pessoal do usuário. A partir dessa concepção, pode-se produzir um texto definidor que caracterize esse objeto mental (motivado pelos dois objetos sensíveis), para o qual estipula-se um nome qualquer (no caso, "spray de pimenta" é óbvio).

Temos um outro exemplo a partir do objeto mental agasalho, cujo texto definidor é speça de vestuário destinada a conservar o calor do corpo e proteger do frio;; podemos, diante de um impermeável, redefinir o antigo objeto mental agasalho, de modo a incluir essa nova característica como uma de suas funções essenciais. $O$ texto definidor passaria a ser: «peça de vestuário destinada a conservar o calor do corpo, proteger do frio e evitar a penetração de umidades. Cabe, em seguida, a decisão sobre a manutenção ou troca do nome "agasalho".

Este é outro dos principais processos de definição: supondo a ausência de objeto mental já formalizado, temos aqui a observação da realidade sensível e a abstração, mediante indução, das características que formam o respectivo conceito. Assim, a partir de /homem $\leftarrow \pi$ animal racional e político /, pela observação empírica podemos chegar a /homem $\leftarrow \pi$ sser que, para ser político e ser racional, deveria necessariamente ter ânimo e ter alma, ou seja, espírito públicos/. Como vemos, o "deveria" pressupõe a constatação de que os exemplos empíricos não avalizam o conceito;

h) [PD8] $\rightarrow$ produzir um conceito referente tomando como objeto(s)-fonte objeto(s) referido(s) e os objeto(s) referente(s), simultaneamente: trata-se aqui de (re)definir um objeto mental a partir de um outro objeto mental e um objeto sensível. Temos, portanto, a elaboração de um conceito referente, o qual, a partir de um outro conceito referente e perante uma experiência sensível em relação a um dado objeto referido, tem sua constituição, com a conseqüente produção de um texto definidor e a aplicação de um nome convencional. 
Como exemplo, supondo o objeto mental objeto $_{1} \rightarrow$ estrangeiro, podemos, considerando o objeto mental objeto $_{2} \rightarrow$ barbárie, produzir uma determinada orientação definidora para o objeto 1 ; porém, diante da experiência em relação ao objeto sensível objeto $_{3} \rightarrow$ um determinado estrangeiro, poderemos reformular ou, até mesmo anular, a anterior orientação, produzindo um novo texto definidor que incorpora, para o objeto 1 , as conclusões oriundas do objeto 2 e do objeto . $_{\text {. }}$

Também, a partir de /homem $\leftarrow \pi$ sanimal dotado de linguagems / e /homem $\leftarrow \pi$ «ser dotado de racionalidade»/, podemos concluir, a partir desses conceitos e das observações empíricas, que, por exemplo /homem $\leftarrow \pi$ «ser animado cuja linguagem é, em termos práticos, freqüentemente irracionals/. Este é outro procedimento definidor muito produtivo: combinar a observação empírica com os conceitos correlatos, de modo a produzir novos textos definidores.

Os procedimentos definidores apresentados não são exclusivos: freqüentemente, são combinados dois ou mais, segundo o método. Como exemplo, o método indutivo (em especial a indução completa ou formal, de inspiração aristotélica), baseando-se na observação dos fenômenos, no estabelecimento das possíveis relações entre eles e na generalização dessas relações sob a forma de "leis" ou tendências, concentra-se preferencialmente os procedimentos definidores sétimo e oitavo ("PD7" e "PD8") — ou seja, debruça-se sobre os objetos referidos ou fenomênicos. Já o método dedutivo, baseando-se, como ponto de partida, nas generalizações realizadas e expressas sob a forma de "leis" (válidas para um fenômeno particular), concentra-se preferencialmente nos procedimentos definidores quinto e sexto ("PD5" e "PD6") — ou seja, visa aos conceitos referentes ou objetos mentais (os próprios objetos-de-discurso são utilizados como premissas para argumentações). Enfim, o método hipotético-dedutivo popperiano, dadas as suas características, pode estender-se em direção aos procedimentos definidores segundo e terceiro ("PD2" e "PD3").

Resumamos os exemplos de procedimentos definidores já apresentados no quadro seguinte: 


\begin{tabular}{|c|c|c|}
\hline & OBJETO-FONTE & OBJETO-DERIVADO \\
\hline PD1 & $\begin{array}{l}\text { /"homem" } \approx \text { "substantivo masculino; palavra } \\
\text { paroxitona" / }\end{array}$ & $\begin{array}{l}\text { /"homem" ₹ "substantivo masculino; palavra } \\
\text { dissílaba paroxitona que provém do latim } \\
\text { homo, hominis, formada pelos grafemas [...] e } \\
\text { pelos fonemas [...]" / }\end{array}$ \\
\hline PD2 & $\mid$ homem $\leftarrow \pi$ sanimal racional $\rangle$ & |homem $\leftarrow \pi$ «mais animal que racional $>$ \\
\hline PD3 & $\begin{array}{l}\text { /homem } \leftarrow \pi \text { (animal racionals/; ii) /homem } \\
\leftarrow \pi \text { animal políticos /; iii)/homem } \leftarrow \pi \\
\text { sanimal dotado de linguagem / }\end{array}$ & $\begin{array}{l}\text { /homem } \leftarrow \pi \text { ranimal irracional quando } \\
\text { dotado de linguagem políticas / }\end{array}$ \\
\hline PD4 & /homem $\leftarrow \pi$ <animal políticos / & /homem $\leftarrow \pi$ ‘político que não anima〉 / \\
\hline PD5 & $\begin{array}{l}\text { /homem } \rightarrow \text { animalidade, humanidade, } \\
\text { racionalidade, ação política, dotação/ }\end{array}$ & $\begin{array}{l}\text { /homem } \leftarrow \pi \text { user animado e dotado de } \\
\text { alma, cuja humanidade determina sua ação } \\
\text { política racional〉 / }\end{array}$ \\
\hline PD6 & 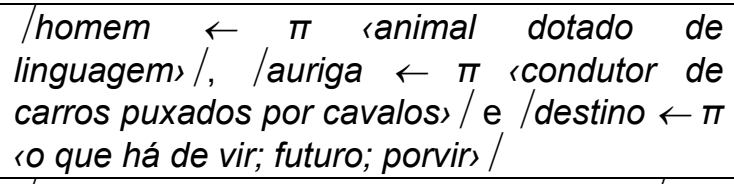 & $\begin{array}{l}\text { /homem } \leftarrow \pi \text { ranimal que, pela linguagem, é } \\
\text { o auriga de seu próprio porvir / }\end{array}$ \\
\hline PD7 & /homem $\leftarrow \pi$ ‘animal racional e político〉 & $\begin{array}{l}\text { /homem } \leftarrow \pi \text { sser que, para ser político e ser } \\
\text { racional, deveria necessariamente ter ânimo } \\
\text { e ter alma, ou seja, espirito público» / }\end{array}$ \\
\hline PD8 & $\begin{array}{l}\text { /homem } \leftarrow \pi \text { ranimal dotado de linguagem } \text { / } \\
\mathrm{e} / \text { /homem } \leftarrow \pi \text { iser dotado de } \\
\text { racionalidade } /\end{array}$ & $\begin{array}{l}\text { /homem } \leftarrow \pi \text { «ser animado cuja linguagem é, } \\
\text { em termos práticos, freqüentemente } \\
\text { irracional / }\end{array}$ \\
\hline
\end{tabular}

Importa observar que há procedimentos que se caracterizam como métodos substancialistas e há procedimentos típicos da abordagem terminista: de fato, é possível distinguir dois grupos de ações definidoras: a) definições universalizantes, que ambicionam produzir textos definidores cuja validade independe de especificidades contextuais; b) definições particularizantes, que buscam produzir textos definidores cuja validade traz, como dados essenciais, considerações de ordem contextual. 
5.2 OS CONCEITOS DE CONTEXTURA (PRÓ-)DEFINIDORA E ESTRUTURA (PRÓ-)DEFINIDORA: O CARÁTER PRAGMÁTICO-FLEXIVO DAS DEFINIÇÕES DEFINIÇÕES PRAGMÁTICO-FLEXIVAS

Conforme pudemos observar no tópico anterior, há uma organização sistêmica de elementos que participam do processo definidor: a) sob o ponto de vista material ou sensível, temos os significantes, os textos definidores enquanto produto, os discursos definidores enquanto processo e os objetos referidos (segundo perspectivas individuais e sociais); b) sob o ponto de vista mental, temos os significados, os signos, os conceitos referentes (segundo perspectivas individuais e sociais) e as sínteses/ análises definidoras (como referências extraprocessuais, temos as essências e substâncias absolutas). Podemos observar que tais elementos relacionam-se sistemicamente, uma vez que todos desempenham funções determinadas e interdependentes, constituindo um conjunto coerente de partes articuladas.

Parece razoável conceber que, sendo sistêmica a organização mental e material dos elementos do processo definidor, a própria manifestação lingüística desse processo deve revelar concretamente características sistêmicas.

Considerando o que foi apresentado até aqui e, em especial, as observações presentes em HEGENBERG (op. cit., pp. 35-68) - particularmente, a constatação de que o processo definidor comporta conceitos primitivos e um conceito derivado, e que há vários modos pelos quais podemos entender os conceitos de significado e compreensão, envolvidos em tal processo - perceberemos, ao examinar os exemplos de definições orais naturais presentes no corpus, a existência de uma "contextura definidora", entendida como um tipo de moldura definidora contextual formada por definições pressupostas e por definições subentendidas - que introduz as "estruturas definidoras", estruturas definidoras postas que desenvolvem lingüística e discursivamente o processo definidor.

Em suma, trata-se da idéia de que nas realizações discursivas do processo definidor, em especial na oralidade, há dois níveis estruturais: 
i) as estruturas lingüísticas vinculadas diretamente ao processo definidor (estruturas definidoras stricto sensu, composta por definições explícitas);

ii) as estruturas lingüísticas vinculadas indiretamente a tal processo e cuja função é contextualizar as estruturas definidoras stricto sensu (temos, então, as contexturas definidoras, compostas por definições implícitas).

Assim, consideremos o seguinte enunciado definidor: /aeronave $\leftarrow \pi$ «para efeito de legislação, é todo e qualquer aparelho que, apto a efetuar transporte, possa ser elevado e dirigido no espaço / (presente em HEGENBERG [op. cit., pp. 36-37]). Trata-se, como vemos, de uma estrutura definidora; se tivermos em conta que esse definiens opera como uma definição posta do definiendum aeronave, compreenderemos que há definições pressupostas e definições subentendidas cuja presença se torna apreensível uma vez tenha sido apresentada essa definição posta: no caso em questão, as conseqüências são surpreendentes. O seguinte quadro ilustra a situação (ver próxima página).

Como o exemplo anterior permite-nos concluir, compreende-se que na prática discursiva as definições não aparecem isoladas; constituem sistemas de definições mais ou menos bem articulados, formados por três categorias de definições: a) definições pressupostas (ou pressuposições definidoras); b) definições postas (ou estruturas definidoras stricto sensu); c) definições subentendidas (ou implicaturas definidoras): como vimos, as primeiras e as últimas pertencem à contextura definidora; as segundas pertencem à estrutura definidora.

Podemos generalizar e afirmar que os conceitos empregados em um discurso põem suas próprias definições, pressupõem definições prévias e subentendem definições conseqüentes. Importa ter em mente que a simples enunciação de um conceito (e mesmo a enunciação de um termo) implica uma proposta de aceitação de suas definições ou, mais precisamente, das definições que, para tal termo, um determinado $\operatorname{co}(\mathrm{n})$ texto permite inferir. Isso configura tipos de "máximas sistêmicas das definições":

a) a qualidade das definições postas depende da qualidade de suas definições pressupostas e de suas definições subentendidas, entendendo-se por "qualidade das definições" a adequação entre: i) o caráter do conceito-definiendum; ii) o 
conteúdo conceitual do definiens proposto; iii) o discurso definidor produzido e as necessidades discursivas da interação. Retomando o exemplo anterior, o texto definidor proposto - além de problemas em relação à própria teoria das definições (tais como ambigüidade e vaguidão) - apresenta problemas qualitativos, uma vez que, por problemas intensionais, admite uma implicatura definidora que distorce a extensão do conceito, comprometendo com isso a validade da definição e sabotando os propósitos interacionais, sob o ponto de vista da cooperação;

\begin{tabular}{|c|c|c|c|}
\hline $\begin{array}{l}\text { pressupostos } \\
\text { acionados }\end{array}$ & $\begin{array}{l}\text { definições pressupostas } \\
\text { correlatas }\end{array}$ & $\begin{array}{l}\text { subentendidos } \\
\text { acionados }\end{array}$ & $\begin{array}{l}\text { definições subentendidas } \\
\text { correlatas }\end{array}$ \\
\hline $\begin{array}{l}\text { 1. uma } \\
\text { aeronave é um } \\
\text { aparelho; } \\
\text { 2. a função de } \\
\text { certos } \\
\text { aparelhos é } \\
\text { transportar } \\
\text { cargas; } \\
\text { 3. as } \\
\text { características } \\
\text { desses } \\
\text { aparelhos são: } \\
\text { a) podem ser } \\
\text { elevados no } \\
\text { espaço; b) } \\
\text { podem ser } \\
\text { dirigidos no } \\
\text { espaço. }\end{array}$ & 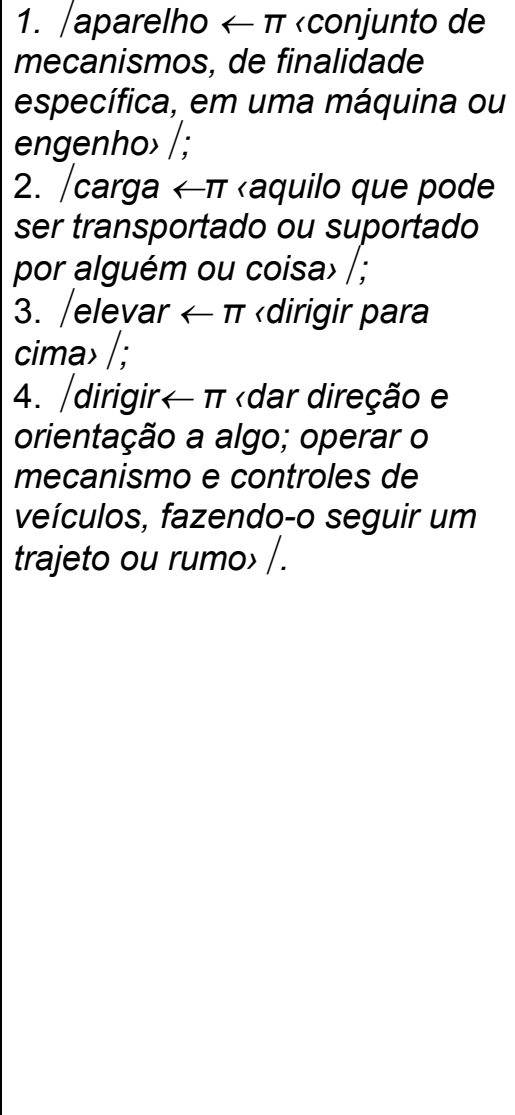 & $\begin{array}{l}\text { 1. essa definição } \\
\text { de aparelho tem } \\
\text { em vista, } \\
\text { especificamente, } \\
\text { as exigências da } \\
\text { legislação em } \\
\text { vigor; } \\
\text { 2. qualquer } \\
\text { artefato ou } \\
\text { engenho que } \\
\text { atenda à } \\
\text { definição } \\
\text { apresentada } \\
\text { pode ser } \\
\text { considerado } \\
\text { uma aeronave; } \\
\text { 3. segundo a } \\
\text { definição } \\
\text { subentendida, } \\
\text { um elevador é } \\
\text { uma aeronave, } \\
\text { pois é apto a } \\
\text { efetuar } \\
\text { transporte, e } \\
\text { pode ser } \\
\text { elevado e } \\
\text { dirigido no } \\
\text { espaço. }\end{array}$ & $\begin{array}{l}\text { 1. lelevador } \leftarrow \pi \text { ‘aeronave } \\
\text { apta a transportar cargas e } \\
\text { capaz de ser elevado e dirigido } \\
\text { no espaço» /. } \\
\text { [em HOUAISS (2001, p.1111, } \\
\text { verbete "elevador"), lemos: } \\
\text { /elevador } \leftarrow \pi \text { «máquina } \\
\text { empregada para transportar, em } \\
\text { deslocamento vertical ou em um } \\
\text { plano inclinado, pessoas ou } \\
\text { cargas` /; na mesma obra } \\
\text { (página 97, verbete "aeronave"), } \\
\text { temos: /aeronave } \leftarrow \pi \\
\text { 'qualquer aparelho capaz de se } \\
\text { sustentar e se conduzir no ar e } \\
\text { que tem como função } \\
\text { transportar pessoas e/ou } \\
\text { objetos /. Como podemos } \\
\text { constatar, continua válida a } \\
\text { definição intensional subjetivo- } \\
\text { convencional sinonímica } \\
\text { /"elevador" } \approx \text { "aeronave"/]. }\end{array}$ \\
\hline
\end{tabular}

b) a proposição de uma definição implica a admissão e a concordância com suas definições pressupostas e suas implicaturas definidoras; em outros termos, propor uma definição significa anuir ao sistema geral de definições no qual se inclui 
tal definição. Assim, se propusermos a definição /homem $\leftarrow \pi$ 〈bípede implume»/, estaremos concordando não só com os conceitos de bípede e implume, mas também com a articulação conceitual entre ambos e o problema extensional derivado que nos autoriza a enunciar: /"homem" $\approx$ "frango depenado"/;

c) as definições postas devem ser interacionalmente mais relevantes do que as respectivas definições pressupostas e definições subentendidas, sendo prioritárias frente a estas.

Outro exemplo: se aceitarmos que a definição do conceito de Naturalismo é rglorificação da mesquinhez da natureza humana e da indignidade da existência humana), perceberemos alguns pressupostos envolvidos nessa definição e, conseqüentemente, definições pressupostas; da mesma forma, há implicaturas possíveis a partir dessa definição e, conseqüentemente, definições subentendidas.

O quadro seguinte ilustra esse aspecto:

\begin{tabular}{|c|c|c|c|}
\hline \multicolumn{4}{|c|}{$\begin{array}{l}\text { /Naturalismo } \leftarrow \pi \text { «glorificação da mesquinhez da natureza humana e da indignidade da existência } \\
\text { humana〉/ }\end{array}$} \\
\hline $\begin{array}{l}\text { pressupostos } \\
\text { acionados }\end{array}$ & $\begin{array}{l}\text { definições pressupostas } \\
\text { correlatas }\end{array}$ & $\begin{array}{l}\text { implicaturas } \\
\text { acionadas }\end{array}$ & $\begin{array}{l}\text { definições subentendidas } \\
\text { correlatas }\end{array}$ \\
\hline $\begin{array}{l}\text { 1. a natureza } \\
\text { humana pode } \\
\text { ser mesquinha; } \\
\text { 2. é possível } \\
\text { glorificar a } \\
\text { mesquinhez } \\
\text { humana; } \\
\text { 3. a existência } \\
\text { humana pode } \\
\text { ser indigna; } \\
\text { 4. é possível } \\
\text { glorificar a } \\
\text { indignidade da } \\
\text { existência } \\
\text { humana. }\end{array}$ & $\begin{array}{l}\text { 1. /mesquinhez } \leftarrow \pi \\
\text { cinsignificância, pequenez, } \\
\text { estreiteza e pobreza de espírito } \\
\text { humanoı /; } \\
\text { 2. /glorificação } \leftarrow \pi \text { «louvação e } \\
\text { exaltação de características e } \\
\text { predicados, como fatores } \\
\text { positivos»/; } \\
\text { 3. /indignidade } \leftarrow \pi \text { ‘falta de } \\
\text { autoridade moral, honestidade, } \\
\text { honra e respeitabilidade»/. }\end{array}$ & $\begin{array}{l}1 . \text { o } \\
\text { naturalismo é } \\
\text { uma orientação } \\
\text { artística que se } \\
\text { presta a exaltar } \\
\text { os aspectos } \\
\text { sórdidos da } \\
\text { natureza } \\
\text { humana; } \\
\text { 2. o } \\
\text { naturalismo é } \\
\text { uma orientação } \\
\text { artística que se } \\
\text { presta a louvar } \\
\text { aspectos } \\
\text { indignos da } \\
\text { existência } \\
\text { humana. } \\
\end{array}$ & $\begin{array}{l}\text { 1. /Naturalismo } \leftarrow \pi \text { rorientação } \\
\text { pseudo-artística que se } \\
\text { caracteriza pela subversão de } \\
\text { valores humanos, dando } \\
\text { destaque positivo a fatores } \\
\text { negativos do comportamento } \\
\text { humano /. }\end{array}$ \\
\hline
\end{tabular}

Tendo em conta que, na atividade discursiva, a arquitetura textual implica sistemas de definições postas, pressupostas e subentendidas, torna-se compreensível a seguinte observação em HEGENBERG (op. cit., p. 19): "compreendemos os termos na medida em que compreendemos as sentenças em 
que eles comparecem. Isso parece paradoxal, pois a compreensão das sentenças depende da compreensão das palavras que a integram". Ou seja, há uma relação constante entre: a) os termos que constituem as sentenças e seu significado global; b) as sentenças constituídas pelos termos e seus significados individuais. Assim, o sentido global de uma sentença é, por um lado, produzido pela conexão entre as partes e, por outro lado, é resultante do todo, mediante superação da simples soma das partes. Simultaneamente, cada parte é, por um lado, uma unidade autônoma de sentido e, por outro lado, uma unidade cujo sentido apenas pode ser apreendido quando estiver inserida em um todo mais amplo. O mesmo vale para as sentenças que formam unidades textuais mais extensas.

Essa observação do autor indica a necessidade de estabelecer um vínculo necessário entre: a) os conceitos empregados em um enunciado; b) as definições postas, as definições pressupostas e as definições subentendidas que constituem o sistema de definições desse enunciado; c) os usos dos termos que são válidos para aquele enunciado particular; d) os contextos apropriados para esses usos.

Assim, o conceito de uso de um termo ${ }^{150}$ relaciona-se ao conceito de contexto $^{151}$, ambos mutuamente interferentes: os usos condicionam contextos específicos, e os contextos condicionam usos específicos. Em suma, os usos e os contextos são fatores que, direta ou indiretamente, intervêm no ato de definição de um conceito, determinando-Ihe características e especificidades; por sua vez os sistemas de definições determinam usos e contextos para a utilização dos termos

\footnotetext{
${ }^{150}$ Lembremos aqui a definição de uso encontrada em DUBOIS et alii (1998, p. 607): "denomina-se 'uso' o conjunto de regras de gramática relativamente estabilizadas e utilizadas pelo maior número possível de falantes em um dado momento e em um contexto social determinado". Já em ABBAGNANO (op. cit., p. 985), registra-se que uso define-se como: "o ato ou o modo de empregar meios, instrumentos ou utensílios. Esse termo é usado em filosofia, sobretudo com referência a instrumentos ou meios intelectuais ou com referência à própria razão. [...] Wittgenstein lançou mão da noção de uso para definir o significado dos termos lingüísticos: 'para uma ampla classe de casos embora não para todos - nos quais empregamos a palavra 'significado', ela pode ser assim definida: o significado de uma palavra é o seu uso na linguagem' (Philosophical Investigations, § 43)".

151 Interessa registrar a definição de contexto em LALANDE (op. cit., p. 203): "encadeamento de idéias que um texto apresenta e, especialmente, conjunto do texto que envolve uma frase citada e de que depende a verdadeira significação desta. Este sentido é o mais usual; é técnico em metodologia. Uma expressão muda de sentido conforme a passagem onde ela se encontra: deve-se, pois, interpretar cada palavra e cada frase não isoladamente, mas levando em conta o sentido geral do excerto (o contexto). É a regra do contexto, regra fundamental da interpretação [...]. Por metáfora, e muito geralmente: conjunto das circunstâncias unidas entre si nas quais se insere um dado fato [...]".
} 
que se referem aos diferentes objetos de definição. Na maior parte dos casos concretos, a compreensão dos enunciados —ou, em outras palavras, o sentido de coerência textual que tais enunciados promovem - depende fortemente dos usos consagrados dos termos empregados e de seus respectivos contextos, entendidos pragmaticamente como o conjunto amplo de circunstâncias nas quais se inserem os termos e seus significados. Torna-se consistente, portanto, conceber uma teoria das definições por meio de uma abordagem sistêmico-pragmática.

A contextura definidora opera como um sistema de signos no qual os termos do definiens representam termos primitivos em relação ao definiendum, que, em relação àqueles, é um termo derivado: isso porque, sob o ponto de vista dos elementos envolvidos, todos os significados dos termos do definiens são, necessariamente, considerados conceitualmente pressupostos - ou seja, não implicam qualquer problema de definição. Dada essa condição, a função definidora dos termos primitivos é a seguinte: recortar, com a maior precisão possível ou desejável, um particular campo conceitual — ou, em outra perspectiva, declarar a essencialidade de um determinado objeto - e atribuir-lhe um nome, que servirá como uma espécie de senha de acesso rápido a esse campo: surge, por esse processo derivacional, um novo signo naquele dado sistema lingüístico ${ }^{152}$.

Assim como se estabelece uma relação entre termos primitivos e termos derivados, pode-se, por analogia, estabelecer uma relação entre conceitos primitivos e conceitos derivados: uma vez que o definiens é formado por termos cujas definições são pressupostas, concluímos que o definiens pode ser visto como uma articulação coerente de conceitos (digamos, os conceitos auxiliares) que, uma vez constituindo um conjunto integrado, passa a compor um novo conceito unitário (digamos, o conceito temático), ao qual será vinculado convencionalmente um sinal sonoro e/ou gráfico (o nome desse conceito temático) que o identificará de imediato perante os usuários.

\footnotetext{
152 “[...] os sistemas admitem um conjunto de vocábulos que têm seus significados estabelecidos (os termos 'primitivos') e um conjunto de vocábulos que são formalmente apresentados (os 'definidos') e que são, relativamente a tal sistema, novos. Numa apresentação sistemática de determinado assunto, é útil deixar explícito o que se toma como 'primitivo', intuitivamente sabido, e aquilo que se define. Isso, via de regra, não é feito, pois o sistema é o dos conhecimentos comuns - para onde, afinal, convergem as discussões" (HEGENBERG, op. cit., p. 38).
} 
Quanto à precisão definidora desses sistemas de signos, deve-se obviamente distinguir entre as especificidades discursivas das línguas naturais e as especificidades das diversas línguas científicas: assim, não se pode projetar as exigências impostas às línguas científicas para o discurso produzido em uma língua natural, particularmente no que diz respeito ao ato de definição. Sob o ponto de vista técnico, as definições produzidas para o uso natural - em especial na oralidade possuem peculiaridades que mereceriam censura, considerando-se os critérios científicos aplicados às definições. Contudo, essas aparentes falhas são determinadas pelas condições de produção do discurso oral: sob esse ponto de vista, não podemos falar em falhas ou inadequações, mas apenas em diversidade de contextos e de condições para a produção textual.

Apresentamos anteriormente as contexturas definidoras, entendidas como um tipo de moldura definidora contextual formada por definições implícitas que introduzem as estruturas definidoras.

Passamos a definir melhor as estruturas definidoras, entendidas como restruturas enunciativas (discursos definidores), constituídas geralmente por três elementos - um objeto a ser definido, um verbo (ou locução verbal) e um objeto que define —, as quais, sob duas possíveis formulações alternativas — a fórmula /" $X "$ "Y" /, que deve ser lida: "o objeto $X$ é igual, por definição, ao objeto $Y$ ", e a fórmula $\mid X \leftarrow \pi\langle Y\rangle /$, que deve ser lida "o objeto $X$ aceita ser predicado pelo objeto $Y "$ realizam o processo definidor de um definiendum por um definiens` Nesse sentido, trata-se de estruturas lingüístico-discursivas que desempenham pelo menos uma das seguintes funções:

a) sinaliza o desenvolvimento de um processo de definição (diretriz: "neste ponto, está em desenvolvimento um processo de (re)definição do objeto ' $X$ '");

b) caracteriza a elaboração de uma solução definidora para um problema específico de definição (diretriz: "neste ponto; por meio deste tipo de definição, o problema de definição do objeto ' $X$ ' está sendo solucionado");

c) contextualiza o processo definidor em desenvolvimento (diretriz: "neste ponto, a definição proposta para o objeto ' $X$ ' deve ser interpretada segundo $O$ contexto ' $\left.C^{\prime \prime \prime}\right)$; 
d) estabelece os efeitos pragmáticos que o processo definidor em desenvolvimento pode produzir e/ou, de fato, produz (diretriz: "neste ponto, a definição proposta para o objeto ' $X$ ' implica os seguintes efeitos pragmáticos: $E_{1}, E_{2}$, $\left.\ldots, E_{n} "\right)$.

Nas estruturas definidoras, o elemento designado pelo termo "definiens" ou pelo símbolo 〈Y〉 é o "texto definidor". Como já indicamos, tais estruturas definidoras, sob o ponto de vista discursivo, apresentam-se normalmente contextualizadas.

Passamos a definir melhor a contextura definidora, entendida como: «moldura contextual, formada por definições pressupostas e por definições subentendidas, além de todos os elementos lingüísticos e supralingüísticos vinculados a essas definições, que, em determinada enunciação, situa contextual e discursivamente a estrutura definidora (a definição posta), atribuindo-Ihe sentidos específicos mediante processos inferenciaisı.

Importa enfatizar, como já afirmamos, que as contexturas definidoras, ao introduzirem pragmaticamente as estruturas definidoras, operam com sistemas de signos nos quais os termos do definiens representam termos primitivos em relação ao definiendum, o qual, em relação àqueles, é um termo derivado: isso porque, sob o ponto de vista dos elementos envolvidos, todos os significados dos termos do definiens são, necessariamente, considerados conceitualmente pressupostos - ou seja, não implicam qualquer problema de definição.

Dada essa condição, a função definidora dos termos primitivos é a seguinte: recortar, com a maior precisão possível, um particular campo conceitual — ou, em outra perspectiva, declarar a substancialidade de um determinado objeto - e atribuir-lhe um nome, que servirá como uma espécie de senha de acesso rápido a esse campo: surge, por esse processo derivacional, um novo signo naquele dado sistema lingüístico.

Assim como se estabelece uma relação entre termos primitivos e termos derivados, pode-se, por analogia, estabelecer uma relação entre conceitos primitivos e conceitos derivados: uma vez que o definiens é formado por termos cujas definições são pressupostas, concluímos que o definiens pode ser visto como uma articulação coerente de conceitos (digamos, os conceitos auxiliares) que, uma vez 
representando um conjunto integrado, compõe um novo conceito unitário (digamos, o conceito temático), ao qual será vinculado convencionalmente um sinal sonoro e/ou gráfico (o nome desse conceito temático) que o identificará de imediato perante os usuários.

Em seguida, definem-se as "estruturas pró-definidoras": são restruturas enunciativas (discursos pró-definidores) cuja função primordial é indicar, em um determinado ponto do discurso, a ocorrência de um problema de intelecção a ser resolvido no âmbito das definiçõesı. Nesse sentido, trata-se de uma estrutura lingüístico-discursiva que desempenha pelo menos uma das seguintes funções:

a) sinaliza a existência de um determinado problema de definição a ser solucionado (diretriz: "neste ponto, é preciso (re)definir o objeto ' $X$ "');

b) sinaliza o tipo de definição que atende ao problema de definição detectado (diretriz: "neste ponto, é preciso elaborar um tipo específico de (re)definição para o objeto ' $X$ '");

c) sinaliza os pressupostos e os subentendidos produzidos por esse processo (diretriz: "neste ponto, (re)definir o objeto ' $X$ ' pressupõe ' $A$ ', 'B', etc. e subentende 'C', 'D', etc.");

d) sinaliza uma proposta de definição a ser confirmada (diretriz: "nesse ponto, coloca-se a seguinte proposta de definição para o objeto ' $X$ '").

Por fim, definem-se as "contexturas pró-definidoras": são «molduras contextuais, formadas por estruturas lingüísticas e supralingüísticas, que, em determinada enunciação, situam discursivamente a estrutura pró-definidora, atribuindo-Ihe sentidos específicos mediante processos inferenciaisı.

Sob o ponto de vista das definições orais naturais, podemos sugerir que esses quatro elementos aparecem sinalizados de alguma forma, explícita ou implicitamente, nos textos orais, uma vez que os problemas de definição emergem por razões predominantemente interativas: trata-se de justificar a necessidade e importância de um processo definidor em determinado ponto da cadeia enunciativa.

O quadro seguinte reúne os quatro conceitos explanados, a partir do seguinte exemplo (PROJETO NURC/SP — INQUÉRITO N² 255 — INFORMANTES Nº 303 E 


\section{4 - DIÁLOGO ENTRE DOIS INFORMANTES [D2] — 2 $2^{\mathrm{a}}$ FAIXA ETÁRIA - LINHAS 945-982).}

945 Doc. então ... então agora nós ... vamos mexer aqui num assunto que parece ser um pouco mais amplo ... o problema da imprensa ... professor ... R. quer falar sobre a imprensa ou dá a primazia aqui ao professor C.?

L1 bom o R. já ... ao se apresentar no início da palestra ...

950 já se definiu como um antigo jornalista pelo menos alguém ... que tinha trabalho nos jornais ... de maneira que a impressão ... do R. acabará sendo muito mais profunda dai se justificar essa prioridade ... eu tenho muito menos a dizer ... digo em primeiro lugar ... ahn ...

955 acredito que:: a imprensa ... é apenas mais um meio de comunicação ... juntamente com os meios modernos que naturalmente existem ... e acredito que tudo quanto foi dito com respeito à televisão ... foi dito com respeito ao correio ... foi dito com respeito ao rádio ... e quem sabe

960 até mesmo ao cinema ... numa dimensão ... diferente ... que que é a dimensão em que a imprensa chega ... o mesmo pode ser dito da própria imprensa ... suponho ... suponho ... que talvez pela sua maior antigüidade no Brasil ... a:: imprensa escrita já chegou a essa sofisticação 965 de oferecer ... ahn veículos diferentes a públicos diferentes ... que a televisão ainda não pôde oferecer ... e que nessas condiçōes ela se torna muito mais seletiva e MUIto MAIS aproveitável ... é óbvio que ... assim como ... falando-se apenas em termos de São Paulo .... Notícias

$970 \quad$ Populares ... com o seu sensacionalismo tem o seu público ... o Jornal da Tarde também tem o seu público dentro de outra linha ... então neste aspecto ... a imprensa escrita já cheGOU a este RAmo de sofisticação ... a este ideAL de sofisticação que pode fazer com que o público

975 venha optar por este ou por aquee órgão ... dos papéis:: que a imprensa ... realmente ... pôde assumir para desempenhar a sua missão ... da do valor da imprensa como veículo de formação na preparação cultural ... ahn acredito ... não ser necessário dizer porque ela nada mais

980 é do que um outro meio de comunicação também importante como os outros citados ... mas o R. como:: quem trabalhou em jornal ... tem muito mais experiência ...

Reproduziremos trechos que correspondem a cada um dos conceitos em questão assim como estão transcritos no exemplo: 
/contextura pró-definidora $\leftarrow \pi$ «moldura contextual, formada por estruturas lingüísticas e supralingüísticas, que, em determinada enunciação, situa discursivamente a estrutura pró-definidora, atribuindo-Ihe sentidos específicos mediante processos inferenciais /

$\rightarrow$ "então...então agora nós...vamos mexer aqui num assunto que parece ser um pouco mais amplo $[\ldots] "$

lestrutura pró-definidora $\leftarrow \pi$ restrutura enunciativa (discurso pró-definidor) cuja função primordial é indicar, em um determinado ponto do discurso, a ocorrência de um problema de intelecção a ser resolvido no âmbito das definições /

$\rightarrow$ "[...] o problema da imprensa....professor...R quer falar sobre a imprensa [...]? [...] digo em primeiro lugar...[...]" (expressão seguida de uma estrutura definidora, o que sinaliza ter "L1" inferido existir um problema de definição a ser solucionado; toda sua exposição se constitui em uma definição do conceito de imprensa)

/contextura definidora $\leftarrow \pi$ rmoldura contextual, formada por definições pressupostas e por definições subentendidas, além de todos os elementos lingüísticos e supralingüísticos vinculados a essas definições, que, em determinada enunciação, situa contextual e discursivamente a estrutura definidora (a definição posta), atribuindo-Ihe sentidos especificos mediante processos inferenciais /

$\rightarrow "[. .$.$] bom o R$ já...ao se apresentar no início da palestra...já se definiu como um antigo jornalista pelo menos alguém...que tinha trabalhado nos jornais...de maneira que a impressão...do $\mathrm{R}$ acabará sendo muito mais profunda [...] eu tenho muito menos a dizer [...] e acredito que tudo quanto foi dito com respeito à televisão...foi dito com respeito ao correio...foi dito com respeito ao rádio...e quem sabe até mesmo ao cinema...numa dimensão...diferente...que que é a dimensão em que a imprensa chega...o mesmo pode ser dito da própria imprensa [...] a:: imprensa escrita já chegou a essa sofisticação de oferecer...ahn veículos diferentes a públicos diferentes...que a televisão ainda não pôde oferecer...e que nessas condições ela se torna muito mais seletiva e MUlto MAIS aproveitável [...] a imprensa escrita já cheGOU a este RAmo de sofisticação...a este ideAL de sofisticação que pode fazer com que o público venha optar por este ou por aquele órgão...dos papéis:: que a imprensa...realmente...pôde assumir para desempenhar sua missão...da do valor da imprensa como veículo de formação na preparação cultural [...] mas o R como:: quem trabalhou em jornal...tem muito mais experiência..."

$\rightarrow$ definições pressupostas: 'media'; comunicação.

$\rightarrow$ definições subentendidas: 'media' que promove a comunicação.

/estrutura definidora $\leftarrow \pi$ (estrutura enunciativa (discurso definidor)), constituída geralmente por três elementos - um objeto a ser definido, um verbo (ou locução verbal) e um objeto que define - $\underline{\text { a }}$ qual, sob duas possíveis formulações alternativas — a fórmula / $X " \approx$ " $Y " /$, que deve ser lida: "o objeto $X$ é igual, por definição, ao objeto $Y$ ", e a fórmula $\mid X \leftarrow \pi\langle Y\rangle /$, que deve ser lida "o objeto $X$ aceita ser predicado pelo objeto $Y^{\prime \prime}$ - realiza o processo definidor de um definiendum por um definiens /

$\rightarrow$ /imprensa $\leftarrow \pi$ rapenas mais um meio de comunicação...juntamente com os meios modernos que naturalmente existem.......] ela nada mais é do que um outro meio de comunicação também importante como os outros citados /

texto definidor stricto sensu $\rightarrow$ /imprensa $\leftarrow \pi$ «um dos modernos e importantes meios de comunicaçãos /

Como se vê, todo o diálogo poderia ser sintetizado em duas enunciações: 
Doc. - "o senhor que falar sobre a imprensa?" (no caso, interpretada, por "L1", como uma estrutura pró-definidora, pois o núcleo de sua intervenção é constituído por uma definição do conceito de imprensa); L1 _ "a imprensa é um dos modernos e importantes meios de comunicação" (estrutura definidora e texto definidor).

A contextura pró-definidora prepara e modaliza a introdução da estrutura pródefinidora, destacando ser o tópico em questão um "assunto que parece ser um pouco mais amplo"; a contextura definidora - constituindo a maior parte da intervenção de "L1" — encarrega-se de: a) direcionar a interpretação da estrutura definidora por parte do documentador; b) produzir leituras e inferências específicas atinentes à definição do conceito de imprensa (os conceitos de televisão, correio, rádio, cinema, dimensão diferente, sofisticação, diversificação de veículos etc.).

Verifiquemos outro exemplo (PROJETO NURC/SP — INQUÉRITO NN 343 INFORMANTES N ${ }^{\circ} 441$ E 442 - DIÁLOGO ENTRE DOIS INFORMANTES [D2] $1^{\text {a }}$ FAIXA ETÁRIA — LINHAS 1-16).

1 Doc. gostaríamos que vocês falassem a respeito da cidade e do comércio...

L1 tem saido ultimamente ... de carro?

L2 ((risos)) tenho mas você diz sair... fora... sair normalmente para a escola essas coisas?

5 L1 pegar a cidade ( )

L2 tenho se bem que eu acho que eu conheço pouco a cidade né? ... por exemplo se eu for comparar com...

L1 -- você viu se está gravando direito aí? -

Doc. está está eu já deixo no automático...

$10 \mathrm{~L} 1$-- ah o automático não indica velô/... --

Doc. não... ((vozes distantes))

L2 tenho saido sim... assim em termos mas eu acho por exemplo::... de sair::... éh::... sabe sair por ai::: descobrir

L1 uhn

15_L2 lugares novos e tal acho que meu conhecimento de São Paulo é muito restrito se comparar com papai por exemplo...

Verifiquemos os mesmos conceitos aplicados ao exemplo anterior:

/contextura pró-definidora $\leftarrow \pi$ «moldura contextual, formada por estruturas lingüísticas e 
supralingüísticas, que, em determinada enunciação, situa discursivamente a estrutura pró-definidora, atribuindo-lhe sentidos especificos mediante processos inferenciais /

$\rightarrow$ "gostaríamos que vocês falassem a respeito da cidade [...] tem saído ultimamente...de carro?"

lestrutura pró-definidora $\leftarrow \pi$ restrutura enunciativa (discurso pró-definidor) cuja função primordial é indicar, em um determinado ponto do discurso, a ocorrência de um problema de intelecção a ser resolvido no âmbito das definições /

$\rightarrow$ "((risos)) tenho mas você diz...[...]"

/contextura definidora $\leftarrow \pi$ imoldura contextual, formada por definições pressupostas e por definições subentendidas, além de todos os elementos lingüísticos e supralingüísticos vinculados a essas definições, que, em determinada enunciação, situa contextual e discursivamente a estrutura definidora (a definição posta), atribuindo-Ihe sentidos específicos mediante processos inferenciaiss /

$\rightarrow$ "[...] sair...fora...sair normalmente para a escola essas coisas? [...] tenho se bem que eu acho que eu conheço pouco a cidade né?[...] tenho saído sim...assim em termos mas eu acho por exemplo::....de sair::...éh::....sabe [...]"

definições pressupostas $\rightarrow$ sair; carro; cidade (como um conjunto de lugares a serem descobertos).

definições subentendidas $\rightarrow$ redescobrir a cidade utilizando um automóvel.

lestrutura definidora $\leftarrow \pi$ (estrutura enunciativa (discurso definidor), constituída geralmente por três elementos - um objeto a ser definido, um verbo (ou locução verbal) e um objeto que define qual, sob duas possíveis formulações alternativas — a fórmula /"X" $\approx$ "Y"/, que deve ser lida: "o objeto $X$ é igual, por definição, ao objeto $Y$ ", e a fórmula $\mid X \leftarrow \pi\langle Y\rangle /$, que deve ser lida "o objeto $X$ aceita ser predicado pelo objeto $Y$ " - realiza o processo definidor de um definiendum por um definiens $/$

$\rightarrow$ "tem saído ultimamente....de carro? [...] pegar a cidade [...] sair por aí::descobrir lugares novos $\underline{\text { e tal }}$ $[\ldots] "$

texto definidor stricto sensu $\rightarrow$ /"sair de carro" $\approx$ "'pegar a cidade'; sair pela cidade e descobrir lugares novos" /

Verificamos que o texto definidor é construído cooperativamente por ambos os interlocutores: "L1" propõe uma pseudodefinição metafórica para sua própria expressão "sair de carro"; "L2" redefine ambas as expressões de "L1", produzindo aquilo que podemos considerar a texto definidor final.

Aqui, temos um problema inicial de definição detectado por L2: frente ao enunciado "tem saído ultimamente...de carro?", L2 apresenta uma contextura pródefinidora: "[...] tenho mas você diz sair...fora...sair normalmente para a escola essas coisas?"; dentre os muitos significados da expressão "sair (de carro)", L2 pergunta pelo significado visado por L1. 
Vemos que, primeiramente, L2 dá uma resposta afirmativa à questão formulada; em seguida, percebendo um problema de definição, sinaliza-o ("[...] mas você diz [...]") e solicita que L1 precise o significado pretendido pelo termo "sair" (a estrutura definidora equivalente poderia ser expressa por: "ao dizer 'sair'", pretendese dizer 'sair para desempenhar atividades normais do quotidiano"').

Como solução ao problema de definição, L1 estabelece a estrutura definidora /"sair de carro" $\approx$ "pegar" a cidade /. Em termos de contextura definidora, assumese, por meio de definições pressupostas, que o conceito designado pela expressão "'pegar' a cidade" não é problemático para L2 e que, também, tal conceito não se confunde com o conceito designado pela expressão "sair normalmente".

Observemos que, nesse exemplo, trata-se de um caso que se insere na doutrina nominalista das definições; sob o ponto de vista da doutrina substancialista, não poderíamos considerar aqui a presença de uma estrutura definidora: não há qualquer relação de substancialidade entre a oração que está em lugar do definiens ("'pegar' a cidade") e a oração que ocupa o lugar do definiendum ("sair de carro"); em outros termos, o ato de "pegar" a cidade não constitui um atributo substancial (essencial e necessário) do ato de sair de carro, de modo a torná-lo único e inconfundível frente a qualquer outro objeto de definição.

Enfim, importa destacar que a própria expressão "'pegar' a cidade" apresentaria problemas de referencialidade; nesse sentido, não poderíamos confortavelmente considerar que o definiens constitui uma definição lexical do definiendum: trata-se, muito mais, de uma proposta de equivalência pragmática entre dois conceitos, expressos pelos termos em questão.

A figura abaixo reúne os componentes do processo definidor, assim como o entendemos neste trabalho:

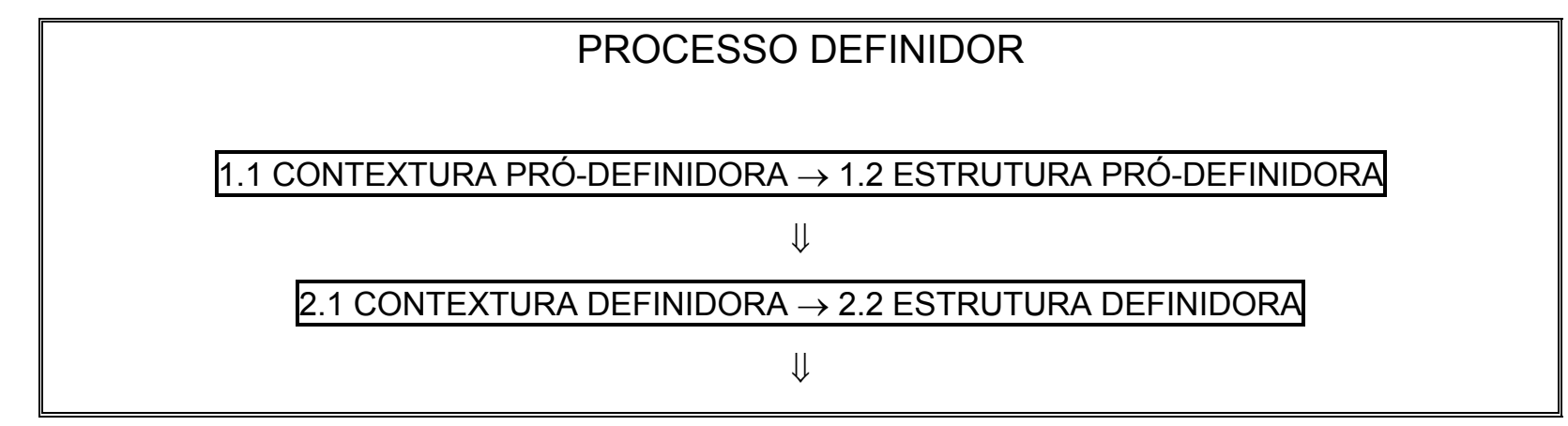


3. PRODUTO: TEXTO DEFINIDOR

Tratemos agora das relações entre o conceito de definição e o conceito de objeto-de-discurso, a partir do conceito de flexividade (referenciais flexíveis e referenciais inflexíveis). Nos capítulos anteriores destacamos a existência de dois possíveis conceitos de intensionalidade: a intensão objetiva (própria das definições substanciais: declaração do conjunto de características necessárias e suficientes para definir a qüididade de um objeto de definição enquanto aquele objeto de definição particular) e a intensão subjetivo-convencional (própria das definições semióticas ou signações: declaração do conjunto de características que se crê serem possuídas por um objeto de definição ou conjunto de características que se convenciona atribuir a um objeto de definição).

Mencionamos, também, a conveniência de distinguir entre "possuir significado" - ser capaz de precisar algum significado, bastando para isso ser um signo constituído - e "possuir o significado" — ser capaz de representar lingüisticamente um conceito formado por características necessárias e suficientes, conceito esse capaz de distinguir essências e substâncias.

Tal distinção corresponde à distinção entre o conceito de objeto definível (robjeto para o qual se pode formular um discurso que declara explicitamente sua substancialidade ou essencialidade)) e o conceito de objeto significante (robjeto para o qual se pode formular um discurso que declara inteligivelmente qual é o significado lingüístico vinculado a seu nomes) — nem todo objeto definível é significante e viceversa.

Também, distinguimos entre conhecimento essencial (implicando afirmar que nosso intelecto, por meio de conceitos, pode expressar certos aspectos essenciais de uma realidade, distinguindo-a de todas as outras; podemos, assim, alcançar um conhecimento essencial de um ser [um ser-para-nós]) e conhecimento da essência (implicando afirmar que nosso intelecto, por meio de conceitos, pode chegar a conhecer integralmente a verdadeira natureza do real; podemos, assim, alcançar o conhecimento absoluto desse mesmo ser [um ser-em-si]). 
Apresentamos a distinção entre definições essenciais e definições descritivas: aquelas ambicionam expressar aquilo que um objeto é em si mesmo; estas ambicionam simplesmente expressar o modo como tal objeto se manifesta enquanto fenômeno.

Citamos a possibilidade teórica de definições que declaram a essência ou a substância dos seres que são objetos de delimitação conceitual, constituindo-os por meio desse ato; ou seja, uma vez que tais seres não preexistem ao discurso definidor enquanto tais (enquanto aqueles seres particulares), passam a existir a partir de um discurso fundador - que nos interessa considerar como um processo definidor contemporâneo a uma particular atividade discursiva constitutiva, contextualizada e de caráter interativo - que os formaliza conceitual e lingüisticamente ${ }^{153}$. Denominamo-las "definições essencialistas constituintes" — um tipo de definição sintética fundada por uma síntese conceitual até então inexistente naquele modo ontológico específico. Nesse sentido, teríamos uma categoria intermediária de definições - uma constituição híbrida em que reuniríamos características ao mesmo tempo substancialistas e ao mesmo tempo terministas.

Recordemos que, pela expressão "objeto-de-discurso" entende-se uma recategorização de constructos culturais ou um tipo de versão pública de um objetode-realidade e/ou de um objeto mental ou conceito, construído pelos interagentes por meio de práticas discursivas e cognitivas, social e culturalmente contextualizadas ( /objeto-de-discurso $\leftarrow \pi$ srecategorização de constructos culturais ou um tipo de versão pública de um objeto-de-realidade e/ou de um objeto mental ou conceito, construído pelos interagentes por meio de práticas discursivas e cognitivas, social e culturalmente situadas)).

Primeiramente, devemos localizar adequadamente os objetos-de-discurso frente aos demais objetos de definição. Pensamos que o conceito de fundação é o mais adequado para estabelecer a distinção ontológica entre os conceitos de objetode-realidade e de objeto-de-discurso.

\footnotetext{
${ }^{153}$ Trata-se, conforme vimos, de elementos cuja realidade ontológica é necessariamente interior e/ou contemporânea a um processo definidor, e que: a) dependem, para existir, de uma operação mental definidora e produtora de seu conceito referente; b) dependem, ao mesmo tempo, de uma particular atividade discursiva constitutiva, contextualizada e de caráter interativo.
} 
Por "objeto-de-realidade" compreende-se neste trabalho um objeto práxicofenomênico, ou seja, como um objeto sensível ou um fenômeno apreensível a partir daquilo que se percebe - social e culturalmente - como uma "realidade" ou, grosso modo, o "mundo". Como destacam muitos autores, os objetos-de-realidade são compreendidos freqüentemente como categorias e/ou objetos de discurso considerados prontos e acabados - digamos, espécie de categorias fechadas disponíveis para simples etiquetagem e referência (menção discursiva). Nesse sentido, não se compreende o caráter fenomênico dos objetos-de-realidade; essa abordagem sobre os objetos-de-realidade não é de interesse para os propósitos deste trabalho.

Para nossos propósitos, não há interesse em entender que operamos discursivamente com "um mundo autônomo já discretizado em objetos ou 'entidades'", mundo esse que "existe independentemente de qualquer sujeito que se refira a ele [... $]^{154 ": ~ a o ~ c o n t r a ́ r i o, ~ s e m p r e ~ e n t e n d e r e m o s ~ q u e ~ o p e r a m o s ~ c o m ~ o b j e t o s-~}$ para-o-discurso, não fazendo sentido — em relação a um discurso específico aceitar a presença de, digamos, objetos pré-discursivos ou mundos autônomos discretizados em objetos previamente dados. Segundo nosso ponto de vista, essa abordagem engessaria demasiadamente o próprio conceito de definição.

Para nós, o processo definidor é um processo sistêmico que se utiliza de definições pressupostas primitivas (tomadas como matéria prima conceitual) e definições postas derivadas (que podem ser consideradas objetos-de-realidade ou objetos-de-discurso, de acordo com a orientação teórica): em dado discurso, as primeiras operam como objetos inflexivos (objetos considerados por determinado discurso como essências ontologicamente definidas, prontas para serem objetos de menção); as segundas, como objetos flexivos (objetos considerados por determinado discurso como essências ontologicamente indefinidas que implicam, além do inevitável processo de menção, um processo simultâneo de (re)elaboração ontológica).

\footnotetext{
${ }^{154}$ Lorenza MONDADA \& Danièle DUBOIS. "Construção dos objetos de discurso e categorização: uma abordagem dos processos de referenciação" In CAVALCANTE, Mônica Magalhães et alii. Referenciação. São Paulo: Contexto, 2003, p. 19.
} 
Como exemplo, a enunciação — "Fiel a um hábito, eu me dirigi para o porto. $\underline{0}$ porto!...nossa É um muro alto de trinta pés, [...] o faz de conta do cais, [...] apartamento, quer dizer, na sala de teto arredondado, obscura e tão ampla que não reconheceríamos o próprio pai se ele estivesse na outra extremidade [...]" $]^{155}$ atende ao seguinte princípio declarado pelas autoras:

"[...] de acordo com esta segunda visão ["os sujeitos constroem, através de práticas discursivas e cognitivas social e culturalmente situadas, versões públicas do mundo"], as categorias e os objetos de discurso pelos quais os sujeitos compreendem o mundo não são nem preexistentes, nem dados, mas se elaboram no curso de suas atividades, transformando-se a partir dos contextos".

Partindo dessa contribuição teórica, entendemos que as estruturas definidoras — /porto" $\approx$ "muro alto de trinta pés"/ e /"apartamento" $\approx$ "sala de teto arredondado, obscura e muito ampla"/ — não seriam operacionais se os coenunciadores não contassem com os objetos inflexivos muro, alto, trinta, pé, sala, teto, arredondado, obscura e ampla, prontos para pura menção -; a partir de tais objetos, os co-enunciadores podem (re)elaborar ontologicamente seus objetos-dediscurso. De fato, apenas conceitos assentados previamente como inflexivos permitem compreender que o enunciado - "muro de trinta pés" - não trata, obviamente, de questões podológicas, mas refere-se à unidade de medida que corresponde aproximadamente a $30,48 \mathrm{~cm}$ (o que dá a esse muro uma altura aproximada de $9,14 \mathrm{~m}$ ). Não nos parece razoável entender que não haja nenhuma categoria inflexiva para a elaboração de objetos-de-discurso; ao contrário, a constituição de um objeto-de-discurso implica, ao mesmo tempo, a elaboração ontológica de uma substância e a menção (ou "referência", como é comum afirmar) a substâncias ontologicamente estabilizadas - sempre de acordo com a perspectiva de um discurso particular.

Para nós, importa ter em mente que a síntese geral das possíveis acepções do termo "objeto" nos leva a entender que os objetos podem ser, ao mesmo tempo,

${ }^{155}$ MONDADA \& DUBOIS (op. cit., p. 31). 
objetos-em-si e objetos-para-nós, ou seja, dependem e, ao mesmo tempo, independem de nossa subjetividade: até ser descoberto, Plutão não existia para nós, embora existisse em si antes de ser descoberto; por outro lado, após sua recente recategorização, Plutão deixou de ser um planeta propriamente dito, mas apenas para nós: Plutão-em-si em nada mudou; Plutão-para-nós só existe, enquanto fenômeno, em nossa percepção e em nossos processos mentais que, como vimos, podem operar com intensões subjetivo-convencionais.

Neste trabalho, interessa-nos considerar os objetos-de-realidade como objetos práxico-fenomênicos, enquanto os objetos-de-discurso são objetos fundados por um discurso particular, que os manifesta pela primeira vez de um modo específico - ou seja, antes de tudo, os objetos-de-discurso constituem uma questão de modo e de ineditismo desse modo de apresentação discursiva de um certo objeto.

Poderíamos argumentar que um objeto-de-discurso não deve ser considerado o produto de um ato discursivo fundador, pois é uma reconstrução ou uma nova versão de algum objeto já conhecido enquanto tal. Porém, interessa enfatizar que o caráter fundador se dá pelo ineditismo ontológico do objeto assim concebido: esse conceito e esse objeto-de-discurso não existiam previamente nessa versão ontológica particular, pois, se assim fosse, seriam para nós um conceito e um objeto aos quais caberia simplesmente mencionar (na condição de conceito primitivo) ou, em último caso, (re)definir ou (re)estipular, uma vez que, conforme afirmamos, não nos parece razoável entender a relação entre objeto-de-realidade (objetos práxicofenomênicos) e objeto-de-discurso segundo uma polarização dicotômica excludente, uma vez que interagem sistemicamente.

Segundo nossa concepção, o objeto-de-discurso possui um determinado caráter substancialista, advindo de seu movimento fundador (expresso pelo definiens); ao mesmo tempo, possui um determinado caráter terminista ou nominalista, advindo de seu movimento de signação (expresso pela escolha do definiendum). Em suma, entendemos que, ao constituir discursivamente esse objeto, fundamos ontologicamente uma nova manifestação fenomênica de uma substância e, ao mesmo tempo, constituímos lingüisticamente enquanto signo (cujo nome é tomado conotativamente). 
Assim, se estabelecermos a estrutura definidora /"'palácios"' $\approx$ "velhas construções enfileiradas umas após outras, formando treliças, por assim, dizer" /156, poderemos entender que: a) esse definiens passa a constituir discursivamente um determinado modo de manifestação práxico-fenomênica de uma substância particular, em si mesma incognoscível; b) esse definiendum estabelece conotativamente essa signação (o nome "palácios", aqui vinculado a "velhas construções enfileiradas umas após outras", passa doravante a conotar esse significado).

Observemos que, se para esse definiens, aplicássemos um nome inédito por exemplo, /"caveações" ₹ "velhas construções enfileiradas umas após outras, formando treliças" / _ , estaríamos também constituindo um novo signo mediante uma definição semiótica estipuladora, ou seja, elaborando um novo objeto-dediscurso, fato que nos leva a considerar que esse é o caminho para a expansão lexical.

Para atender ao conceito de objeto-de-discurso sob o ponto de vista definidor, apresentamos em capítulo anterior deste trabalho as definições intensionais subjetivo-convencionais estipuladoras ("3.2"); interessa-nos agora aplicar esse conceito. Postulamos neste trabalho a conveniência de estabelecer uma categoria intermediária de definições, cujo caráter seja essencialista constituinte ${ }^{157}$ - as definições pragmático-flexivas —, baseadas na flexibilização discursiva de um referencial (conforme já mencionado, entendido como: a) um objeto-de-realidade fenomênico; b) um objeto mental ou conceito; c) um objeto-de-discurso) por parte de um definiens vinculado a determinado definiendum.

Entendemos por "flexibilização discursiva de um referencial" a fundação discursiva de uma nova manifestação fenomênica desse referencial (manifestação desse referencial tal qual surge para o homem, segundo suas particulares condições

\footnotetext{
${ }_{156}^{156}$ MONDADA \& DUBOIS (op. cit., p. 33).

157 Conforme mencionado, trata-se de definições que declaram a essência ou a substância dos seres, constituindo-os precisamente por meio desse ato discursivo definidor; nesse caso, os seres não preexistiam a esse discurso definidor enquanto tais, mas passam a existir através desse discurso fundador que representa a formalização conceitual (de cunho substancialista) e lingüística (de cunho terminista) dessa essencialidade.
} 
cognoscitivas ${ }^{158}$ ), importando o ineditismo ontológico do objeto produzido pelo respectivo discurso definidor, ou seja, importa seu modo de manifestação e o ineditismo desse modo.

Tais definições são capazes de reunir traços essencialistas e traços terministas; isso implica, conseqüentemente, a harmonização entre o conceito de referência a um objeto-de-realidade e o conceito de referenciação a um objeto-dediscurso: isso porque, de acordo com a visão sistêmica do processo definidor (em especial na oralidade):

a) operamos sistemicamente com definições explícitas e implícitas, e com definições primitivas e definições derivadas;

b) entendemos o conceito de objeto-de-realidade como relativo a um objeto práxico-fenomênico, ou seja, a um objeto sensível ou a um fenômeno apreensível a partir daquilo que se percebe, social e culturalmente, como uma "realidade", e ao qual se faz referência;

c) entendemos o conceito de objeto-de-discurso como relativo a um objeto fundado por um discurso particular que o manifesta pela primeira vez segundo aquele modo específico, e ao qual se faz referenciação.

O quadro seguinte permite-nos melhor visualizar o que até aqui discutimos sobre a relação entre as definições e os objetos-de-discurso:

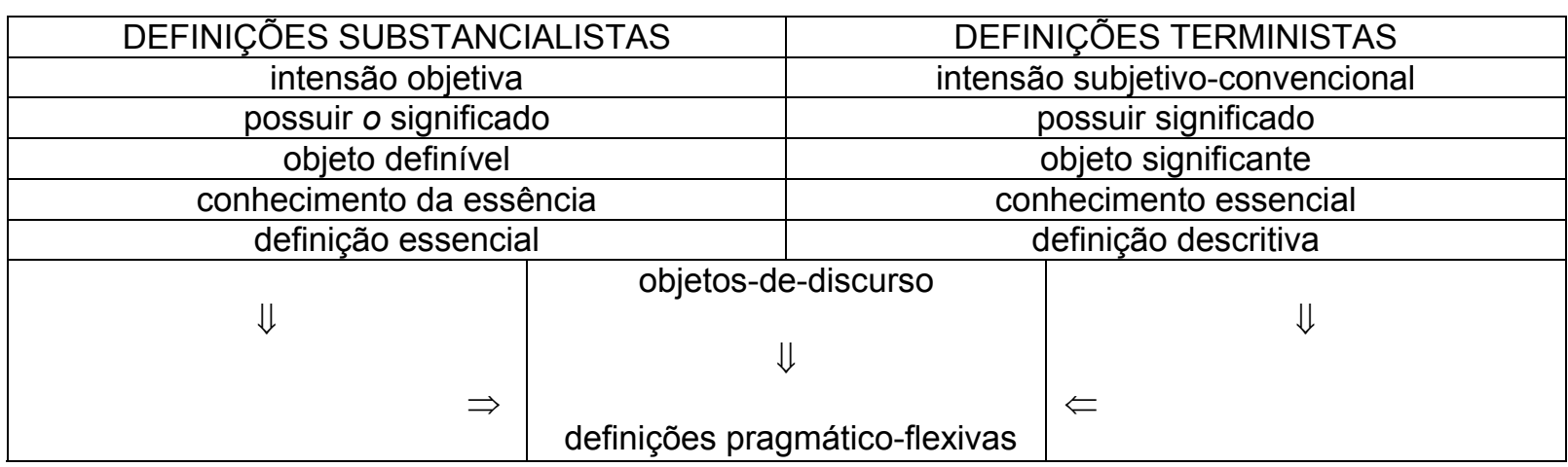

\footnotetext{
${ }^{158}$ Para nossos propósitos, não interessa discutir se o fenômeno é ou não é o em si da coisa em sua manifestação segundo as particulares condições cognoscitivas do homem (ou seja, se é uma aparência da coisa ou se é a própria substância da coisa manifestada). Parece-nos, contudo, conveniente distinguir entre essas duas possibilidades e parece-nos também prudente discernir entre a substância-em-si (que transcende a capacidade cognoscitiva do homem) e o conceito de substância metodologicamente abstraído dos particulares mediante indução-dedução.
} 
Como vimos, o processo definidor implica o problema da interpretação da natureza do objeto de definição; enquanto operação conceitual, importa determinar a natureza do conceito produzido: em suma, ao se colocar uma questão de definibilidade, coloca-se, ao mesmo tempo, uma questão sobre o caráter do objeto focalizado pelo processo definidor. Quanto à natureza dos objetos de definição, podemos considerá-los de acordo com a seguinte tipologia, que distingue entre "objetos inflexivos" e "objetos flexivos" (isto é, referenciais que não podem ser flexionados e referenciais que podem ser flexionados):

a) objetos inflexivos são objetos - considerados pelo discurso definidor como essências ontologicamente acabadas ou definidas, prontas para serem puros objetos de menção. Nesse caso, o discurso definidor apenas se refere ao objeto mencionando-o, mas não interfere na elaboração ontológica enquanto tal. Este seria o caso típico dos denominados "objetos-de-realidade" em sua versão tradicional, fenômenos que implicam exclusivamente um processo de "etiquetagem" e menção da realidade extradiscursiva por parte do discurso. Importa destacar que, para nós, o processo de menção discursiva a um referencial, na qualidade de conceito primitivo, não deve ser descartado porque seria um simples "referente" — como certas leituras do conceito de "referenciação" parecem levar a concluir, sugerindo que tais "referentes" simplesmente não preexistem "naturalmente" à atividade cognitiva e interativa dos sujeitos;

b) objetos flexivos são objetos - considerados pelo discurso definidor - como essências ontologicamente inacabadas ou indefinidas, que implicam, além do processo de menção, um processo de (re)elaboração ontológica do objeto enquanto tal. Este seria o caso típico dos denominados "objetos-de-discurso", objetos que implicam uma (re)elaboração ontológica da essência do objeto por parte do discurso definidor.

Sustentamos a tese de que, no processo definidor - em especial nas definições naturais orais —, inexiste uma oposição excludente entre objetos de definição flexivos e objetos de definição inflexivos: para nós, verificam-se graus diversos de flexividade dos referenciais por parte do definiens - de modo que, por 
detrás de um mesmo nome ou termo, reside a possibilidade de diversos graus de elaboração ontológica do objeto de definição (graus esses que, convencionalmente, são identificados por esse nome): em suma, existe uma flexividade ontológica dos objetos de definição no discurso definidor, em especial na oralidade, fato que implica uma correspondente flexividade intensional subjetivo-convencional, a qual permite a produção de diversos textos definidores que constituem uma autêntica "família" de definições - conjunto esse que, por convenção, continuará a ser identificado ou etiquetado pelo dado nome convencional —, sem que a discrepância entre tais textos definidores seja suficientemente significativa para justificar uma nova nominação.

Tendo em vista essa tese, podemos propor uma definição do ato de definir pragmático-flexivamente:

/definir pragmático-flexivamente $\leftarrow \pi$ «delimitar ou circunscrever conceitualmente um objeto de definição intensionalmente flexivo, distinguindo-o e individualizando-o enquanto substância e manifestação ontológica ajustada a um determinado contexto sócio-discursivo e a um universo conceptual constituído pela intersecção dos universos conceptuais individuais de cada um dos agentes definidoresı /.

Tendo em vista essa definição de definição, parece consistente assim definir as "definições pragmático-flexivas":

/definição pragmático-flexiva $\leftarrow \pi$ «processo definidor e produto desse processo que, ao definir seus objetos, (re)cria-os flexivamente enquanto objetos mentais e/ou objetos-de-discurso ad hoc, para funcionarem vicariamente, em um discurso particular, em lugar dos objetos substanciais correspondentes, enquanto não se produza a definição ideal ou próxima do ideal desse objeto, ou quando não haja conveniência em produzi-la e/ou utilizá-la discursivamentes /.

Pragmaticamente, tais definições possuiriam diferentes graus de essencialidade e de temporalidade, adequados às necessidades do discurso criador que atualiza, sob o ponto de vista da relevância, um conjunto de atributos capaz de caracterizar um eficiente objeto-de-discurso, vicário em relação a seu respectivo objeto substancial. 


\subsection{ANÁLISE DE SISTEMAS DE DEFINIÇÕES PRESENTES NO CORPUS}

Neste trabalho, afirmamos que convém considerar as definições segundo uma abordagem sistêmica, que destaca no processo definidor a relação entre as contexturas (pró-)definidoras e estruturas (pró-)definidoras.

Para ilustrar a discussão até aqui desenvolvida, vamos examinar alguns excertos registrados pelo Projeto NURC/SP, enfatizando os aspectos sistêmicos das definições orais naturais.

[EXCERTO NÚMERO UM]:

105 Doc. certo... quando um empregado professor ele sai por contra... por conta própria... quais os direitos que competem a ele?

Inf. bem... eu eu devo dizer que... ahn... o que vou declarar... é muito aleatório porque... como nós

110 acabamos de ver... eu não sou um advogado militante... e não sou consultor de firmas... mas::... hoje... ah... existe o que se chama o Fundo de Garantia... quer dizer um depósito... que se processa por pagamentos mensais... eu creio que o patrão responde

115 por uma parte... e o empregado descontado em seu salário responde por outra... mas esses depósitos vão constituído vão constituindo um fundo... que:: mediante condições -- não posso precisar exatamente quais porque isso seria... ah... uma questão de::...

120 conhecer muito bem a Legislação Trabalhista e eu estou afastado disso...--

Doc. uhn uhn

Inf. mas::... preenchidas as condições legais... o fundo de garantia justamente assegura... ao empregado que se retira... um:: certo::... ressarcimento... não é? que pelo menos durante algum tempo lhe permitirá a::... a subsistência... até que ele naturalmente obtenha um um novo emprego... eu tenho impressão que hoje (ele) se processa dessa maneira... ANtes do Fundo

[PROJETO NURC/SP; INQUÉRITO N 250; BOBINA N 90; INFORMANTE N 287; DIÁLOGO ENTRE INFORMANTE E DOCUMENTADOR (DID), LINHAS 112129] 
Neste primeiro exemplo, temos uma proposta de definição do conceito referente (individual e/ou social) ou objeto mental (individual e/ou social) fundo de garantia: interessa observar que não se trata de uma definição semiótica ou signação, pois o que se observa aqui é um esforço de se estabelecer a intensão objetiva da substância designada pela expressão "fundo de garantia" e não qualquer processo vinculado ao estabelecimento ou confirmação da intensão subjetiva e/ou convencional compreendida por tal expressão; em seu discurso definidor, o informante procura caracterizar com a máxima precisão possível a natureza desse fundo, realizando uma especificação por gênero e espécie.

O texto definidor - síntese da estrutura definidora - pode ser assim formulado: /Fundo de Garantia $\leftarrow \pi$ rdepósito mensal [gênero], a cargo do empregador e do empregado, que assegura a subsistência do demitido enquanto demanda novo emprego [espécie]) /. Como vemos, a qüididade da substância Fundo de Garantia fica estabelecida por esse texto definidor, embora o informante declare a relatividade de seu conhecimento a respeito do tema.

A estrutura definidora assim pode ser entendida: /Fundo de Garantia [definiendum: trata-se de definir o conceito de fundo de garantia, declarando suas características necessárias e suficientes, ou seja, a essência dessa substância] $\leftarrow \pi$ «Fundo de Garantia.......] um depósito...que se processa por pagamentos mensais.......] o patrão reponde por uma parte...e o empregado descontado em seu salário responde por outra...[...] esses depósitos vão constituindo um fundo...que.: mediante condições [...] preenchidas as condições legais...o fundo de garantia justamente assegura...ao empregado que se retira...um:: certo:.....ressarcimento...[...] que pelo menos durante algum tempo lhe permitirá a:....a subsistência...até que ele obtenha naturalmente um novo empregos [definiens: discurso definidor] /.

A estrutura pró-definidora pode ser identificada pelos fragmentos: "[...] existe o que se chama [...] quer dizer". Como afirmamos, a função da estrutura pró-definidora é indicar, em determinado ponto do discurso, a ocorrência de um problema intelectivo a ser resolvido no âmbito das definições; no excerto em análise, o informante afirma que "existe o que se chama o Fundo de Garantia...quer dizer [...]": como vemos, distingue-se entre aquilo que existe e o nome que lhe é aplicado; a 
estrutura pró-definidora "quer dizer" é seguida de um definiens de base essencialista, fato que implica a detecção de um problema de definição que se resolve no plano conceitual objetivista. Observemos que uma definições semelhante a: /"fundo de garantia" $\approx$ "remuneração à disposição do demitido para que sobreviva até a próxima admissão"/ teria características subjetivista-convencionais, constituindo uma definição semiótica ou signação (de fato, outras remunerações cumprem esse papel sem serem fundos de garantia).

Quanto à contextura definidora - moldura contextual constituída por elementos lingüísticos, supralingüísticos, definições pressupostas e definições subentendidas - no excerto, o informante declara como deve ser interpretada a definição que proporá sobre o conceito em questão: "eu devo dizer que...ahn...o que vou declarar...é muito aleatório porque.......] eu não sou um advogado militante...e não sou um consultor de firmas...mas.:........] eu creio que [...] mediante condições -não posso precisar exatamente quais porque isso seria...ah...uma questão de:.....conhecer muito bem a Legislação Trabalhista e eu estou afastado disso...--[...] não é? [...] eu tenho impressão que hoje (ele) se processa dessa maneira [...]". Portanto, se considerarmos essa contextualização, concluiremos que o discurso definidor produzido pelo informante não deve ser interpretado como a reprodução precisa de um conceito cientificamente estabelecido.

Observa-se que o discurso definidor apresenta marcas de subjetividade: "[...] eu creio que o patrão responde por uma parte...e o empregado descontado em seu salário responde por outra...[...]"; "[...] não posso precisar exatamente quais porque isso seria...ah...uma questão de:....conhecer muito bem a Legislação Trabalhista e eu estou afastado disso...[...]"; "[...] um:.: certo:....ressarcimento...não é?"; "eu tenho a impressão que hoje (ele) se processa dessa maneira"; os alongamentos e as pausas operam como elementos que reforçam esse caráter.

Como é possível observar, há um conjunto de definições pressupostas acionadas por esse texto definidor: por exemplo, o conceito de fundo pressupõe o conceito de depósito mensal; as partes envolvidas são designadas pelos conceitos de patrão e empregado; a composição do fundo pressupõe os conceitos de contribuição patronal e contribuição empregatícia. 
Como desdobramentos para possíveis definições subentendidas, temos que esse fundo é objeto de legislação; ele é uma obrigação das empresas regularmente instituídas e um direito dos trabalhadores regularmente registrados; além disso, ele possui um caráter de compensação ou reparação pela demissão realizada (foi utilizado o conceito de ressarcimento; portanto, a demissão do empregado é subentendida como um prejuízo profissional e pessoal); também, esse fundo deixa implícito que é suficiente apenas para a "subsistência" do trabalhador demitido (como outra implicatura, infere-se a provável redução de seu padrão de vida anterior); também, o período de subsistência previsto pelo fundo não se estende indefinidamente: isso não apenas está textualmente declarado ("pelo menos durante algum tempo"), mas também enfatizado pelo advérbio "naturalmente obtenha um novo emprego".

Quanto à contextura pró-definidora - moldura contextual que situa discursivamente a estrutura pró-definidora - poderíamos destacar a intervenção do documentador: "[...] quando um empregado professor ele sai por contra...por conta própria...quais os direitos que competem a ele?". A pergunta propõe um tema discursivo e, ao mesmo tempo, integra a própria estrutura pró-definidora: "[...] quando um empregado [...] sai por conta própria [...] quais os direitos que competem a ele? [...] hoje [...] existe o que se chama o fundo de garantia...quer dizer [...]". Portanto, essa contextura pró-definidora subentende uma definição: /fundo de garantia $\leftarrow \pi$ 〈um dos diretos do empregado demissionário /〉.

No seguinte exemplo, podemos observar um caso típico de definição de um conceito referente que se vale do objeto referido para a construção do texto definidor.

[EXCERTO NÚMERO DOIS]: 
Doc. o què que caracteriza o Manga-larga?

Inf. o Manga-larga é um tipo de cavalo... não muito grande... que tem um tipo de andar chamado marcha... e tem outras caracteristicas mas eu não sei... eu saberia distinguir 660 se eu visse um Manga-larga e outro cavalo mas a assim::... dar as características como::... estudioso de animal eu não saberia... eu acho que o peito um pouco largo... esse tipo de andar que é a marcha... o formato da cabeça...

[PROJETO NURC/SP; INQUÉRITO No 18; BOBINA Nº7; INFORMANTE Nº 23; DIÁLOGO ENTRE INFORMANTE E DOCUMENTADOR (DID), LINHAS 656-664]

O documentador, por meio de uma contextura/estrutura pró-definidora - "O quê que caracteriza o manga-larga?" - sinaliza claramente um problema de intelecção a ser resolvido no âmbito das definições: trata-se de caracterizar a substância designada pela expressão "manga-larga". Observemos que a expressão "caracterizar o manga-larga" implica indagar sobre a qüididade desse ser, e não sobre o significado do nome "manga-larga"; assim, a definição problematizada não possui caráter nominalista (ou seja, não é o caso de definir o termo "manga-larga"), pois não se trata de buscar uma expressão sinônima ou parafrástica para a expressão em questão (fato que ficaria caracterizado caso a pergunta tivesse sido, por exemplo, "qual o sinônimo de 'manga-larga'?" ou "qual o significado de 'mangalarga'?", casos em que fica implícita a expressão "do termo/nome 'manga-larga'").

Em suma, o caráter substancialista dessa contextura/estrutura pró-definidora fica patenteado pelo emprego do substantivo "quê" e do verbo "caracterizar", ambos solicitando elementos que dão o caráter essencial do ser denominado "mangalarga", de modo a diferenciá-lo de qualquer outro animal real ou fictício.

A estrutura definidora proposta é: /manga-larga $\leftarrow \pi$ «tipo de cavalo não muito grande, com um andar denominado 'marcha' e com peito um tanto largo /. Como podemos verificar, trata-se de um texto definidor que não atende às características básicas de uma definição considerada modelar, embora esteja em jogo a definição de uma intensão objetiva: com exceção da informação de maior validade (sabemos que se trata de um "tipo de cavalo"), as demais características mencionadas não são 
de fato caracterizadoras, pois não recortam com precisão os conceitos apresentados como pressupostos ("não muito grande" e "peito um tanto largo" são expressões vagas; "um andar denominado 'marcha'" nada informa para quem desconhece o conceito de marcha). Em suma, trata-se de uma estrutura definidora tecnicamente precária, sob o ponto de vista da teoria das definições, embora freqüente na oralidade.

Verifica-se que a contextura definidora fornece elementos que subentendem a imprecisão do texto definidor: "[...] e tem outras características mas eu não sei....eu saberia distinguir se eu visse um manga-larga e outro cavalo mas a assim:....dar as características como:....estudioso de animal eu não saberia [...] eu acho que [...]". Infere-se que o texto definidor possui predominantemente um teor descritivo, mas não é formado de modo a apresentar precisamente as características essenciais e necessárias à substancialização desse objeto de definição.

Vemos que a expressão "[...] eu saberia distinguir se eu visse um manga-larga e outro cavalo [...]" é interessante por indicar algo além do óbvio: de imediato entendemos que, sem dúvida, o informante distinguiria visualmente um manga-larga de outro qualquer cavalo; porém, importa destacar que, ao ser capaz de distinguir praxicamente tal manifestação sensível, o informante seria então capaz de distinguila verbalmente, ou seja, estaria em condições de criar um texto definidor que patenteasse, discursivamente, a unicidade desse objeto de definição (manga-larga), diante dos demais objetos com os quais guarda relação ou dos quais se distingue.

Isso indica que o objeto referido é freqüentemente solicitado pelo processo definidor como recurso práxico para a caracterização conceitual de um objeto de definição. Concluímos, então, que os objetos-de-realidade ou objetos fenomênicos (aquilo que comumente é designado pelo termo "referente") não apenas não são descartados pelo processo definidor, como também são freqüentemente exigidos pelo discurso definidor para uma melhor caracterização de seu objeto — operando, muitas vezes, como os únicos recursos para a construção de um texto definidor.

Isso nos leva a considerar que não se pode prescindir inteiramente dos objetos-de-realidade e dos fenômenos práxicos em geral, pelo menos no âmbito das definições, como uma interpretação extremada do conceito de objeto-de-discurso 
poderia sugerir; de fato, não só os objetos sensíveis (ou referenciais práxicos) não podem ser de todo descartados do processo definidor, como também os conceitos pressupostos - as categorias dadas ao discurso - , como já assinalamos.

No seguinte exemplo, temos basicamente uma discussão no âmbito das contexturas pró-definidoras.

[EXCERTO NÚMERO TRÊS]:

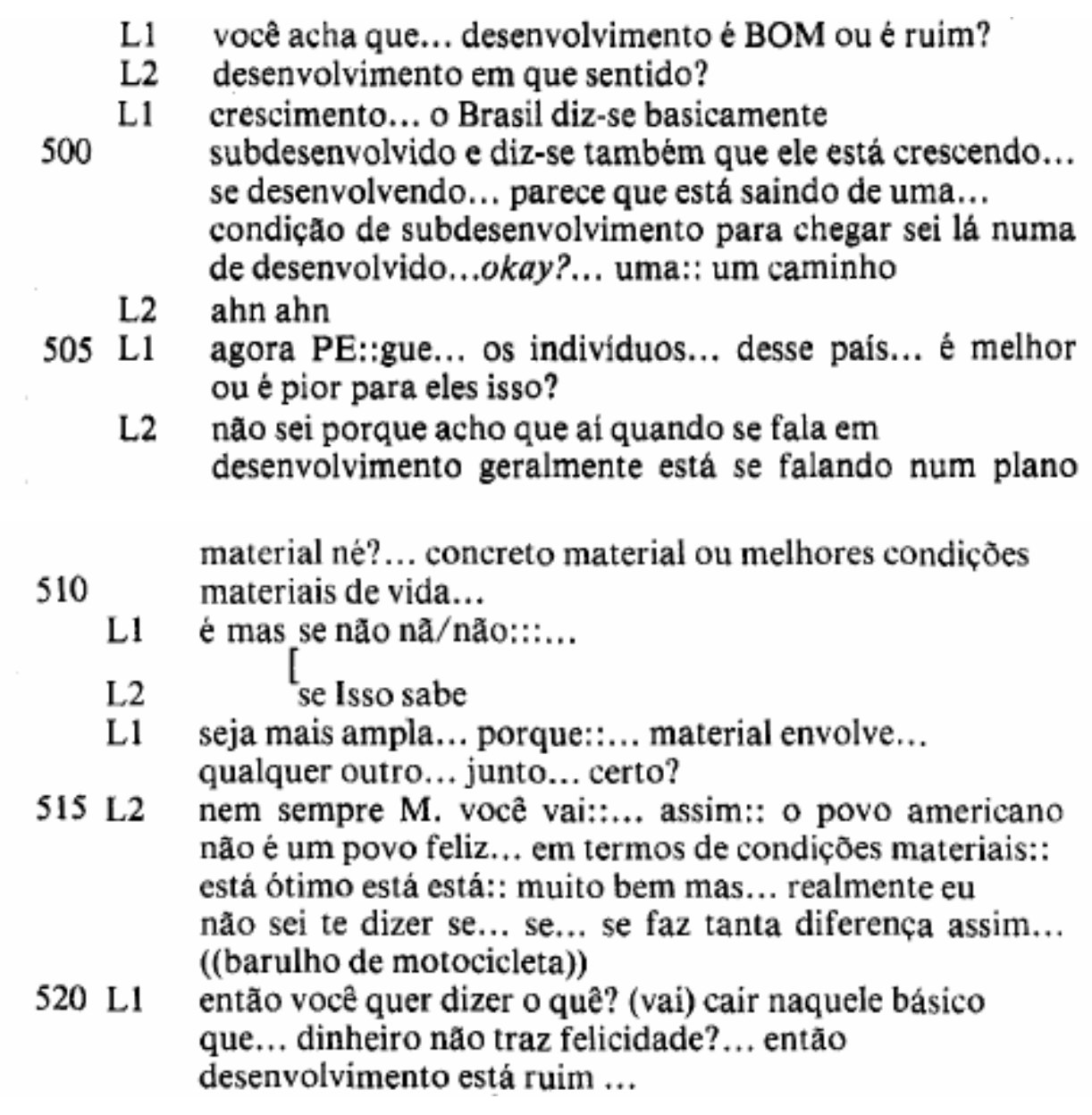


[PROJETO NURC/SP; INQUÉRITO NN 343; BOBINA No 130; INFORMANTES Nº 441 E 442; DIÁLOGO ENTRE DOIS INFORMANTES (D2), LINHAS 497-522]

Nesse excerto, L1 propõe uma questão que parece caracterizar uma pseudodefinição predicativa subjetiva: "você acha que...desenvolvimento é BOM ou ruim?".

L2 responde com uma estrutura pró-definidora - "desenvolvimento em que sentido?" - , sinalizando um problema de definição a ser solucionado por um texto definidor. Infere-se que, para ser possível uma predicação, mesmo que seja subjetiva, é necessário primeiramente definir com clareza o conceito de desenvolvimento.

L1 propõe uma estrutura definidora, cujo caráter de signação parece-nos manifesto e que pode ser sintetizada por: /"desenvolvimento" $\approx$ "crescimento; saída da condição de subdesenvolvido para chegar à condição de desenvolvido"/. De fato, a pergunta "desenvolvimento em que sentido" aponta para um problema de especificação de significados pretendidos pelo interlocutor, caracterizando com isso uma definição intensional subjetivo-convencional sinonímica/parafrástica.

Essa estrutura definidora está inserida em uma contextura definidora, formada por elementos da própria estrutura definidora mais outros elementos lingüísticodiscursivos cuja função é, mediante contextualização, estabelecer a possibilidade de inferências que contribuem para o sentido global desse enunciado: "[...] o Brasil dizse basicamente subdesenvolvido e diz-se também que ele está crescendo...parece que [...] sei lá [...] okay?". Verificamos que a expressão "[...] diz-se basicamente subdesenvolvido e diz-se também que ele está crescendo" pode ser interpretada como modalizadora, subentendendo uma certa neutralidade de L1 em relação ao valor de verdade da proposição, ou mesmo um certo grau de incerteza quanto à aplicabilidade do atributo crescimento ao objeto referido Brasil (observemos que "[...] parece que [...] sei lá [...] okay?" são expressões relativizadoras): assim, L2 procura caracterizar a existência de uma tendência evolutiva para o Brasil, indicada pelo termo "um caminho": há um percurso claro para realizar o crescimento do país. Por outro lado, isso não é uma certeza, mas sim um ponto de vista, uma opinião do 
locutor, baseada em opiniões de terceiros; a confirmação do interlocutor é solicitada ("[...] okay?").

Uma vez que L2 manifesta entendimento ou anuência em relação ao texto definidor proposto (ahn ahn) — ou seja, uma vez que a signação "desenvolvimento" $\approx$ "crescimento" foi aceita —, L1 formula uma pseudodefinição predicativa subjetiva similar à anterior, recolocando a pergunta inicial em outros termos: "agora PE::gue...os indivíduos...desse país...é melhor ou é pior para eles isso?". Em outros termos, trata-se de estabelecer a seguinte relação: desenvolvimento do país $\approx$ crescimento do país $\rightarrow$ benefício para os cidadãos do país.

L2 responde com uma contextura/estrutura pró-definidora: "não sei porque acho que aí quando se fala em desenvolvimento geralmente está se falando num plano material né?...concreto material ou melhores condições materiais de vida...". Ou seja, aponta-se para outro problema de definição; enquanto for mantida a definição semiótica /"desenvolvimento" $\approx$ "crescimento; saída da condição de subdesenvolvido para chegar à condição de desenvolvido"/, L2 considera problemático emitir um claro juízo de valor sobre esse conceito de desenvolvimento. Isso porque, para L2, essa estrutura definidora subentende um atributo: trata-se de desenvolvimento material; ou seja, infere-se "desenvolvimento" $\approx$ "crescimento material; aquisição de melhores condições materiais de vida".

Os elementos mais relevantes da contextura/estrutura pró-definidora são os termos modalizadores: "acho que aí [...] geralmente está se falando [...] né?", que indicam um relativo grau de certeza sobre a identidade entre "desenvolvimento" e "desenvolvimento/crescimento material" (segundo L2, usualmente pressupõe-se que o conceito de desenvolvimento é sinônimo de crescimento material).

Para L1, esse é um pressuposto válido: "seja mais ampla...porque.:...material envolve...qualquer outro...junto...certo?"; assim, temos um curioso redirecionamento argumentativo: a observação anterior de L2 subentendeu uma avaliação redutora da expressão "desenvolvimento material" (o desenvolvimento material seria, então, apenas uma parte — e talvez a menos importante — do desenvolvimento individual); 
para L1, essa expressão pressupõe todos os demais desenvolvimentos individuais; portanto, o conceito de material estaria implícito no conceito de desenvolvimento.

Nas linhas 515-518, L2 questiona a validade dessa pressuposição de L1; assim fazendo, recoloca a objeção representada pela contextura/estrutura pró-definidora das linhas 507-510. Segundo L1, a idéia de que o desenvolvimento material não inclui todos os outros desenvolvimentos implica pressupor que não existe correlação entre felicidade e melhores condições materiais de vida (portanto, o que está em questão é a validade da definição pressuposta, presente já na signação inicial de L1 [linha 497]: /"felicidade" $\approx$ "boas condições materiais de vida, propiciadas, dentre outras coisas, pelo dinheiro"/). Se essa correlação for vetada (por exemplo, por uma signação semelhante a: /felicidade" $\approx$ "estado psicológico que independe das condições materiais de vida, propiciadas, dentre outras coisas, pelo dinheiro"/), então, segundo L1, torna-se necessário aceitar a seguinte estrutura predicativa subjetiva: "desenvolvimento é ruim".

Nos três exemplos seguintes, temos casos de definições aplicadas a objetos lingüísticos; trata-se de definir o significado dos termos empregados por meio de definições de caráter puramente terministas - ou seja, definições semióticas ou signações.

\section{[EXCERTO NÚMERO QUATRO]:}

270

Inf. ah... e ele exige de quem do... do seu... do seu

Doc. isso...

Inf. bem o... todo advogado começa... prudentemente... por::... pedir... além de uma procuração... ad judicia

275 interesses do cliente em juizo... firmar com ele... também... um:: contrato de honorários... haBItualmente... mas isso não é uma::.... uma obrigação legal... os:: advogados cobram vinte por cento

[PROJETO NURC/SP; INQUÉRITO N² 250; BOBINA No 90; INFORMANTE N 287; DIÁLOGO ENTRE INFORMANTE E DOCUMENTADOR (DID), LINHAS 272277] 
Nesse caso, poderemos verificar a seguinte estrutura definidora: /"procuração ad judicia" $\approx$ "procuração que permite ao advogado defender os interesses do cliente em juízo"/. Trata-se de fornecer lingüisticamente uma equivalência parafrástica da expressão latina, sob a forma de uma oração adjetiva restritiva; não se trata de uma definição intensional objetivista, pois não se manifesta um esforço para declarar a qüididade de uma substância designada por esse nome (cabe, por exemplo, indagar se há outros tipos de procuração com a mesma característica aqui declarada).

Percebemos, no corpo do texto definidor, ausência de hesitações e traços típicos de oralidade ("uma procuração que Ihe permite defender os interesses do cliente em juízo"), fato que pode indicar uma reprodução oral do correspondente texto definidor escrito, cujo conteúdo é adiantado pelo informante antes que um problema de definição ficasse caracterizado explicitamente; a expressão "[...] quer dizer [...] parece-nos ser adequadamente entendida como uma antecipação de uma estrutura pró-definidora apontando para uma necessária signação: nesse sentido, equivale à seguinte estrutura parafrástica: "quando digo ' $X$ ', pretendo dizer ' $Y$ '". Trata-se, em suma, de estabelecer acordo sobre o significado dos termos empregados, e não de melhor definir um determinado conceito referente, tendo em vista a qüididade de uma substância.

\section{[EXCERTO NÚMERO CINCO]:}

Doc. professor... o senhor está falando em cheque... eu gostaria que o senhor dissesse... quais os tipos de cheque que o senhor conhece?

515 Inf. tipos de cheque? eu... ((longo silêncio))... $\mathrm{n} /$ não sei se vou responder bem a sua pergunta mas::... o... se você assina por exemplo um cheque... e retira o dinheiro... você mesmo... ou dá a uma pessoa que vai ao banco e retira diretamente... esse cheque é o cheque digamos comum... há um emitente... e há... uma pessoa que recebe... o cheque pode ser ao portador... se:: o nome da pessoa que vai receber está indicado e pode ser... pode ser nominal perdão se está indicado o nome da pessoa que vai receber... pode ser ao portador se o lugar reservado ao nome está em branco...

Doc. uhn uhn 
Inf. se o cheque é nominal... e a pessoa que vai receber não é conhecida no banco em geral o banco exige uma prova de identidade pra saber quem ele é... se ele é conhecido no banco ou tem firma no banco não tem problema...

Doc. uhn uhn

Inf. bem esse digamos é o cheque comum... agora... eu posso pagar a uma pessoa em cheque e essa pessoa... ou simplesmente um cheque ao portador... não precisa ser nominal... ahn... em vez de receber diretamente no meu banco deposita na conta dele num outro. banco... ai aparece o que eles chamam de cheque cruzado...

Doc. uhn uhn

540 Inf. não sei se vocês já repararam que num caso desses o funcionário do banco dá uma carimbadinha assim com duas linhas em diagonal... ele cruza o cheque... por quê? porque ele tem que mandar o cheque ao meu banco... que então vai pagar... ou simplesmente dizer que meu

545 cheque é bom porque:: o cheque é uma espécie de... é é é um substitutivo da... moeda corrente... desde que a pessoa não paga e a outra não recebe em dinheiro... então esse cheque é cruzado o banco de lá diz "pode creditar" os o banco do recebedor então credita na conta

550 dele a importância que eu paguei por cheque cruzado... existe também o cheque que se chama o cheque viSAdo... o cheque visado é simplesmente o cheque... cuja::... importância... o banco... não é? sobre o qual eu emiti

555 o cheque... ahn assegura que é o cheque pagável... é:... o cheque... visado... no caso de importâncias muito

grandes não é?... entendeu? a pessoa vai fazer um pagamento digamos na na compra de um imóvel... vai pagar alguns... algumas centenas de milhares milhöes de

$560 \quad$ cruzeiros... pergunta ... o se/... o com... o... o...o comprador do imóvel nesse caso diz "o senhor quer que eu dê um cheque... ah... o senhor exige um cheque::.... visado?"' o outro que vai receber o vendedor dirá sim ou não... o meu banco visa o cheque... quer dizer ele

565 asseGUra... que eu tenho fundos no banco para... o pagamento daquela importância... esse é o cheque visado... mas só no cas ‘ de operações muito vultosas e... ou noutras talvez...

Doc. uhn uhn

570 Inf. bom são as modalidades que eu conheço... pode ser que haja outras... não sei...

[PROJETO NURC/SP; INQUÉRITO N 250; BOBINA Nº 90; INFORMANTE Nº 287; DIÁLOGO ENTRE INFORMANTE E DOCUMENTADOR (DID), LINHAS 512571] 
Nesse excerto, o documentador assinala um problema de definibilidade, por meio de uma contextura/estrutura pró-definidora: [...] o senhor está falando em cheque...eu gostaria que o senhor dissesse...quais os tipos de cheque que o senhor conhece?. Trata-se, portanto, de delimitar e especificar melhor o conceito genérico de cheque - que, aliás, é conceitualmente definido, embora parcialmente, pelo informante ao longo de sua explanação: "[...] o cheque é uma espécie de...é é é um substitutivo da...moeda corrente...desde que a pessoa não paga e a outra não recebe em dinheiro [...]" —, entendendo que há mais de uma espécie do gênero dessa substância; em outras palavras, sinaliza-se não só um problema de definibilidade, mas também indica-se qual o tipo de definição visada - definições objetivistas substancialistas.

Se observarmos as estruturas definidoras apresentadas pelo informante, teremos as seguintes espécies (transcreveremos integralmente entre aspas angulares simples os discursos definidores):

\begin{tabular}{|c|c|c|}
\hline /cheque 'comum' & $\leftarrow \pi$ & $\begin{array}{l}\text { «...] se você assina [...] um cheque...e retira o } \\
\text { dinheiro...você mesmo ou dá a uma pessoa que vai ao } \\
\text { banco e retira diretamente...esse cheque é o cheque } \\
\text { digamos comum...há um emitente...e há...uma pessoa que } \\
\text { recebes / }\end{array}$ \\
\hline /cheque ao portador & $\leftarrow \pi$ & $\begin{array}{l}\text { [...] o cheque pode ser ao portador [...] pode ser ao portador } \\
\text { se o lugar reservado ao nome está em branco / / }\end{array}$ \\
\hline $\begin{array}{l}\text { lcheque nominal } \\
\text { (cheque comum!?) }\end{array}$ & $\leftarrow \pi$ & $\begin{array}{l}\text { ¿...] o nome da pessoa que vai receber está indicado [...] se } \\
\text { está indicado o nome da pessoa que vai receber [...] se o } \\
\text { cheque é nominal...e a pessoa que vai receber não é } \\
\text { conhecida no banco em geral o banco exige uma prova de } \\
\text { identidade pra saber quem ele é...se ele é conhecido no } \\
\text { banco ou tem firma no banco não tem problema»/ }\end{array}$ \\
\hline /cheque cruzado & $\leftarrow \pi$ & $\begin{array}{l}\text { «[...] eu posso pagar a uma pessoa em cheque e essa } \\
\text { pessoa [...] em vez de receber diretamente no meu banco } \\
\text { deposita na conta dele num outro banco... [...] cheque } \\
\text { cruzado [...] não sei se vocês já repararam que num caso } \\
\text { desses o funcionário do banco dá uma carimbadinha assim } \\
\text { com duas linhas em diagonal...ele cruza o cheque...por quê? } \\
\text { porque ele tem que mandar o cheque ao meu banco...que } \\
\text { então vai pagar...ou simplesmente dizer que meu cheque é } \\
\text { bom [...] então esse cheque é cruzado o banco de lá diz: } \\
\text { 'pode creditar' os o banco do recebedor então credita na } \\
\text { conta dele a importância que eu paguei por cheque } \\
\text { cruzado» / }\end{array}$ \\
\hline /cheque visado & $\leftarrow$ & $\begin{array}{l}\text { ¿...] o cheque visado é } \quad \text { simplesmente } 0 \\
\text { cheque...cuja:....importância o banco [...] sobre o qual eu } \\
\text { emiti o cheque...ahn assegura que é o cheque }\end{array}$ \\
\hline
\end{tabular}




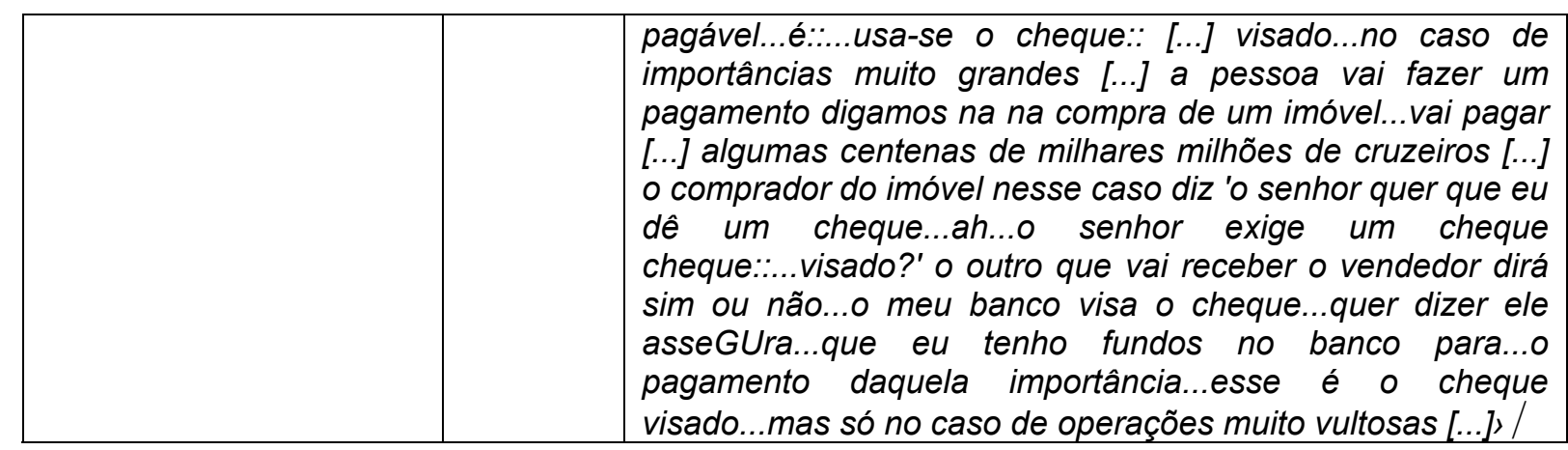

Podemos considerar tais definições como exemplos de definições intensionais objetivas condicionais/operacionais, sob os moldes da oralidade : o informante estabelece em seu discurso definidor as condições e/ou as operações técnicas pelas quais se configura a qüididade da cada uma das espécies de cheques apresentadas.

A contextura definidora permite inferir que as definições a serem apresentadas não constituem textos definidores tecnicamente irrepreensíveis: "tipos de cheque? eu...((longo silêncio))...n/ não sei se vou responder bem a sua pergunta mas:: [...] digamos [...] digamos [...] aí aparece o que eles chamam [...] não é? [...] não é? [...] digamos [...] bom são as modalidades que eu conheço...pode ser que haja outras...não sei...". Como vemos, o informante preocupa-se em assinalar o relativo grau de informalidade de sua conceituação; isso justifica a opção por definições intensionais objetivas condicionais e/ou operacionais: em lugar de apresentar discursivamente os textos definidores em suas versões eminentemente técnicas (o que demandaria uma profundidade teórica maior), o informante procura apresentar as condições e as operações que, uma vez cumpridas, garantem a identificação, de maneira satisfatória, dos respectivos objetos de definição.

No seguinte excerto, podemos examinar um caso em que existe um texto definidor, mas o termo que designa o conceito definido por esse definiens não está claramente determinado.

[EXCERTO NÚMERO SEIS]: 
Doc. e como è que se colhe... o cafe por exemplo o senhor se lembra?

Inf. bom... o: : era colhido tudo manualmente... mas nessa época então:: de:: colheita... até as mulheres passavam a:: a ajudar... porque a colheita teria que ser feita dentro de uma certa época... então é preciso mais gente pra colher... e::... é... costumava-se colocar embaixo do pé de café uma espécie de:: lona... uma esteira... e Doc. e caindo os grãos... depois colhe-se tudo

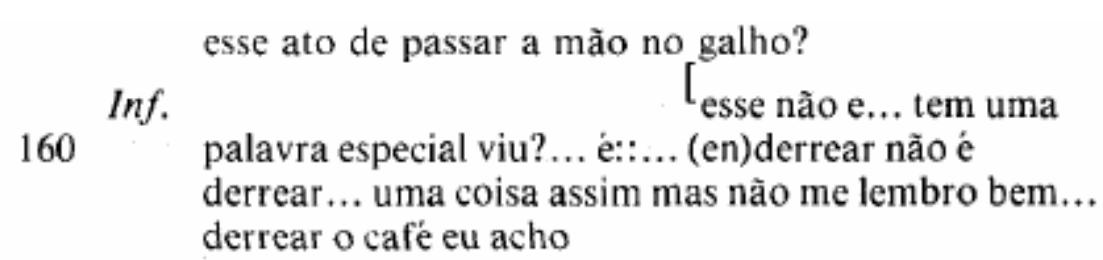

[PROJETO NURC/SP; INQUÉRITO N 18; BOBINA Nº7; INFORMANTE Nº 23; DIÁLOGO ENTRE INFORMANTE E DOCUMENTADOR (DID), LINHAS 147-162]

Na primeira parte desse excerto (linhas 147-156), indaga-se sobre o processo de colheita do café; implicitamente, podemos ver aqui uma estrutura definidora intensional objetiva operacional: /colher café $\leftarrow \pi$ «colocar uma espécie de lona ou esteira embaixo do pé de café; passar a mão no galho; recolher os grãos caídos»/. ou seja, declaram-se as operações que constituem o ato de colher café.

Por meio de uma contextura/estrutura pró-definidora, aponta-se, nas linhas 157-158, um problema inverso de definição, ou seja, há um definiens para o qual falta estipular precisamente um definiendum: "sabe como é que se chama esse ato de passar a mão no galho?". Aqui, temos o conceito delimitado por um texto definidor, mas não conhecemos seguramente o termo específico para designar tal conceito. Estruturalmente, teríamos: $/ ? \leftarrow \pi$ rato de passar as mãos nos galhos do pé de café para extrair-lhe os grãos /. Observa-se que se indaga pelo termo que designa um ato; com isso, configura-se uma definição de caráter essencialista (ou seja, busca-se estabelecer qual o termo que melhor representa lingüisticamente a intensão objetiva de um conceito referente que, por sua vez, constitui um objeto mental equivalente àquela substância particular). 
O informante responde com uma contextura/estrutura definidora - "esse não e...tem uma palavra especial viu?...é......(em)derrear não é derrear...uma coisa assim não me lembro bem...derrear o café eu acho" - , que mantém o problema de definição, pela incerteza sobre a pertinência da estrutura definidora/derrear café (!?) $\leftarrow \pi$ rato de passar as mãos nos galhos do pé de café para extrair-lhe os grãos) /. O informante manifesta, através de sua contextura definidora, a incerteza sobre a pertinência técnica do definiendum proposto: "esse não e...tem uma palavra especial viu?...é.:........] não é [...] uma coisa assim mas não me lembro bem [...] eu acho". Uma das principais acepções do verbo "derrear (-se)", segundo diversos dicionários de uso, é "curvar (-se); vergar (-se)"; daí que tal termo se aplique verdadeiramente ao ato de curvar os pés de café para que, então, realize-se o ato de extração dos grãos. Isso poderia explicar a relativa incerteza no emprego do termo proposto pelo informante, pois a definição pressuposta, mobilizada pelo ato definidor, (/"derrear(-se)" $\approx$ "curvar(-se); vergar(-se)"/) não parece corresponder referencialmente à coerência exigida pelo definiens.

No exemplo seguinte, vemos claramente como uma contextura definidora presta-se para situar contextualmente uma estrutura definidora por meio de informações complementares.

\section{[EXCERTO NÚMERO SETE]:}

225 os nossos cinegrafistas os nossos cineastas... eram uma gente ... muito pobre... éh que vivia nas maiores dificuldades... era os cavadores... esse nome cavadores que foi... que era lançado assim como um insulto não é? pela... pelo comércio cinematográfico

230 estabilizado... né? e vinculado ao estrangeiro contra... os cinegrafistas ah brasileiros... esse nome cavadores acabou sendo realmente um nome aceito... ah por eles próprios não teve uhn mais nada éh de insultuoso e essa... expressão cavadores ah

235 que eu vou usar... aqui o tempo todo... tem uma significação... éh técnica... cavadores eram os homens que tentavam fazer cinema....ah fora dos sistemas ... ahn estabelecidos... o::... Ademar 
[PROJETO NURC/SP; INQUÉRITO No 153 BOBINA N 52; INFORMANTE Nº 179; ELOCUÇÃO FORMAL (EF), LINHAS 227-238]

A estrutura definidora propriamente dita, proposta pelo informante, é /"cavador" ₹ "homem que tenta fazer cinema fora dos sistemas estabelecidos"/. Trata-se de uma signação - uma definição intensional subjetivo-convencional lexical (outrora estipuladora), pois não se trata de estabelecer a qüididade dessa substância (nem qualquer cavador - aquele que cava — está sendo mencionado; nem é inequívoco o texto do definiens: que é "tentar fazer cinema fora dos padrões estabelecidos"? Porventura seria tentar construir um edifício dotado de arquitetura não-convencional para abrigar um cinema?).

A contextura definidora - "os nossos cinegrafistas os nossos cineastas...eram uma gente...muito pobre...éh que vivia nas maiores dificuldades...era os cavadores...esse nome cavadores que foi...que era lançado assim como um insulto não é? pela...pelo comércio cinematográfico especializado...né? e vinculado ao estrangeiro contra...os cinegrafistas ah brasileiros...esse nome cavadores acabou sendo realmente um nome aceito...ah por eles próprios não teve ahn mais nada éh de insultuoso e essa...expressão cavadores ah que eu vou usar...aqui o tempo todo...tem uma significação técnica" - indica a interpretação que esse conceito deve receber por parte do interlocutor.

Assim, os trechos sublinhados apontam para uma leitura estritamente lingüística da estrutura definidora em questão. Além disso, por meio das informações fornecidas pela contextura definidora, podemos identificar uma séria de definições pressupostas e subentendidas que, inferencialmente, justificam a metáfora implícita no termo "cavador": a) "[...] gente [...] muito pobre [...] que vivia nas maiores dificuldades"; b) "nome [...] lançado assim como um insulto [...] pelo comércio cinematográfico especializado [...] vinculado ao estrangeiro contra [...] os cinegrafistas [...] brasileiros"; c) "[...] nome aceito [...] por eles próprios [...] não teve [...] mais nada [...] de insultuoso [...] tem uma significação técnica. Dentre outras coisas, esse sistema de definições permite-nos inferir uma luta desigual entre a grande indústria cinematográfica internacional já estabelecida e os esforços de 
criação de um cinema nacional independente; nesse quadro, a metáfora do "cavador" cabe adequadamente: "cavar" uma oportunidade de produzir mediante muitos esforços um cinema que sobreviva como alternativa à grande indústria cinematográfica norte-americana.

No próximo excerto, temos um caso em que duas estruturas definidoras são empregadas como argumentos para corroborar uma tese formulada pelo informante na contextura definidora.

\section{[EXCERTO NÚMERO OITO]:}

$\begin{array}{ll} & \text { ahn:: a preocupação de Lévi-Strauss é mostrar... } \\ 215 & \text { que não há na... ARte e sobretudo na pintura } \\ & - \text { - que nos está interessando -- ... imagens vulgares... } \\ & \text { se o artista as transfigura... uma garrafa é uma coisa } \\ & \text { somente do ponto de vista utilitário... mas a percepção } \\ & \text { objetiva... mas para A percepção objetiva... uma } \\ & \text { garrafa é uma justaposição de formas de contornos } \\ & \text { de superfícies... de sombra e de luz... de manchas } \\ & \text { coloridas... e o artista disporá tudo isso... } \\ & \text { transformando... os elementos... a seu gosto... } \\ & \text { portanto o artista é aquele que... sabe ver... não } \\ & \text { a imagem prática e vulgar... que tem a sua } \\ & \text { representação no mundo... mas o equilibrio interno } \\ & \text { dos volumes e das formas... da qual a coisa mais }\end{array}$

[PROJETO NURC/SP; INQUÉRITO No 156 BOBINA N 54; INFORMANTE Nº 182; ELOCUÇÃO FORMAL (EF), LINHAS 213-226]

A tese lançada poderia assim ser sintetizada: segundo Lévi-Strauss, não existem na arte e na pintura imagens vulgares, se o artista as transfigura; ou seja, a capacidade de transfigurar supera a vulgarização. Duas estruturas definidoras sustentam essa tese: a) /"garrafa" $\approx$ "uma 'coisa' somente sob o ponto de vista utilitário"/; b) /"garrafa" "para a percepção objetiva, uma justaposição de formas, contornos, superfícies, sombra, luz e de manchas coloridas" /. Como vemos, trata-se de definições intensionais subjetivo-convencionais estipuladoras, pois não se trata de estabelecer a qüididade da substância garrafa (ou seja, declarar o que é uma 
garrafa em si mesma), mas sim estabelecer um conjunto de características que os usuários desse signo entendem pertencer ao objeto designado pelo termo "garrafa".

Temos uma contextura definidora: "[...] a preocupação de Lévi-Strauss é mostrar...que não há na ARte e sobretudo na pintura -- o que nos está interessando - imagens vulgares...se o artista as transfigura [...] e o artista disporá tudo isso...transformando...os elementos... a seu gosto...portanto [...]". Ou seja, encarregase a contextura definidora de declarar a tese de Lévi-Strauss, cabendo às estruturas definidoras extrair as conseqüências dessa tese.

A partir dessa contextura, o informante desenvolve uma nova estrutura definidora: /"artista" $\approx$ "aquele que sabe ver o equilibrio interno dos volumes e formas" /. Portanto, configura-se um sistema de definições — definem-se "artista" e "garrafa" - que procuram validar a tese sustentada por Lévi-Strauss.

No exemplo seguinte, o informante desenvolve longamente, entre as linhas 39236, uma exposição do conceito de demanda de moeda por transação, valendo-se de diferentes textos definidores. Algumas estruturas definidoras relativas a esse conceito emergem de extensas contexturas definidoras; considerados como um sistema de definições, cada texto definidor opera acrescentando, paulatinamente, um novo atributo ao objeto de definição comum.

[EXCERTO NÚMERO NOVE]: 
discutir... cada um deles... ((tosse)) a demanda de moeda por transação... é... principal motivo pelos quais as pessoas... retêm moeda... neceSSItam de moeda... demandam moeda... ahn:::... basicamente... ela se deve à diferença que existe entre as datas de... recebimento de renda de salário e os pagamentos

45 que a gente efetua... ao longo do mês... basicamente a diferença entre data de pagamento e data de recebimento faz com que exista uma de/ ... uma demanda de moeda... uma retenção de moeda... as pessoas recebem no início do mês... mas não gastam

50 de uma vez só... elas vão gastando... aos pouquinhos... elas são obrigadas a deixar... uma certa reserva para o:: cafezinho para o lanche... para o almoço... para os gastos normais... ou seja as pessoas recebem... o dinheiro num... no início do mês e vão gastando... de uma forma... gastando aos poucos ao longo do mês... de tal forma que ela sempre tenha alguma reserva algum dinheiro no bolso... enfim... é uma demanda de moeda para satisfazer as necessidades de... transaçðes... e de... pagamentos...

dar essa notação - - demanda de moeda por motivo transação... é uma função... do nível de renda... ( ) 65 nível de renda nominal... vamos tentar mostrar por que que a demanda de moeda é uma função... do nível de renda... vamos supor... que um assalariado receba...

certo?... então a demanda de moeda por esse motivo... é uma função do nível de renda... e é una proporção $\mathrm{k} . .$. desse nível de... renda...

220 graficamente a gente pode colocar então... que a demanda de moeda... por motivo transação... é uma proporção... k...y... da renda nominal... certo?... é igual um $\mathrm{k} . .$. e y... certo?... sem intercepto não é? não tem nenhum intercepto então sai da origem...

225 está okay?... a gente vai ver isso depois... esse k aqui depende basicamente de parâmetros institucionais... de...grau de verticalização da economia de HÁbitos... da coletividade tudo isso a gente vai discutir um pouquinho melhor depois... então a 230 demanda de moeda é uma porporção k... a demanda de moeda por TRANSAÇÕES... é uma proporção $k$ do nível de renda é a principal razão... pelos quais ... todos nós agora temos um certo montante de dinheiro no bolso ... certo? ... basicamente ele está pensando amanhã é uma coisa óbvia não é?... bom... segundo 
[PROJETO NURC/SP; INQUÉRITO N 338 BOBINA N 141; INFORMANTE Nº 488; ELOCUÇÃO FORMAL (EF), LINHAS 39-236]

A seguinte tabela apresenta as estruturas definidoras ao longo do texto:

\begin{tabular}{|c|c|}
\hline \multirow{8}{*}{$\begin{array}{l}\text { "demanda } \\
\text { de moeda } \\
\text { por } \\
\text { transação" }\end{array}$} & s necessitam, retém e demandam moeda) \\
\hline & $\begin{array}{l}\leftarrow \pi \text { (demanda de moeda para satisfazer as necessidades de transações e de } \\
\text { pagamentos〉 }\end{array}$ \\
\hline & $\leftarrow \pi$ «função do nível de renda nominal» \\
\hline & $\approx\langle$ sinônimo de necessidade e retenção de moeda \\
\hline & $\leftarrow \pi$ 〈retenção de renda para satisfazer as transações de uma forma genérica〉 \\
\hline & $\leftarrow \pi$ «função do nível de renda e uma proporção ' $k$ ' desse nível de renda〉 \\
\hline & $\leftarrow \pi$ 〈proporção 'k' e 'y' da renda nominalı \\
\hline & $\begin{array}{l}\leftarrow \pi \text { 〈proporção ' } k \text { ' do nível de renda e a pri } \\
\text { montante de dinheiro〉 }\end{array}$ \\
\hline
\end{tabular}

Como vemos, a maior parte das estruturas definidoras é de caráter intensional objetivista; apenas uma delas possui caráter de signação.

A contextura definidora nesse exemplo encarrega-se de exemplificar e justificar a doutrina sintetizada pelas estruturas definidoras, mediante adequadas contextualizações. Nesse caso, a definição do conceito de demanda de moeda por transação é obtida pela consolidação da série de definições parciais, com o auxílio de informações postas, pressupostas e subentendidas pelas contexturas.

Neste excerto, desenvolveremos uma análise um tanto mais detalhada do trecho compreendido entre as linhas 447-469 do seguinte fragmento do corpus:

[EXCERTO NÚMERO DEZ]: 
na igreja católica... NAO porque eu ache que seja meLHOR do que essas outras... mas porque eu NÃO VI que nenhuma fosse MElhor do que a outra... então eu ficaria na que eu nasci não é? mas eu conheço bem o protestantismo dessas... desses grupos presbiteriano metodista e::... batista... ah... conheço mais ou menos bem a Igreja Ortodoxa porque ela é muito parecida com a nossa... não é? a ortodoxa russa por exemplo que eu... tenho bastante convivência tenho até afilhados na... ortodoxa russa...

Doc. é parecida em que termos?

Inf. na... nas suas ahn... não só nas interpretações... como... nas:: ahn... manifestaçôes que eles fazem... nos trabalhos religiosos... é muito semelhante à igreja ortodoxa russa que é a que eu tenho mais... ahn... convivência não é?... são essas as religiões... tenho também $o . .$. não não... eu não considero o espiritismo propriamente uma religião... mas tenho muitos amigos:: espíritas:: e que têm até procurado... me:: convenCER de certas coisas... e eu também não... não nego... mas... nunca me interessei... em... me aprofundar mais nesse campo...

Doc. certo... a senhora consideraria umbanda religião?

Inf. não... religião não... mas:: não consideraria propriamente religião... mas indiscutiveimente... também depende do

450 QUE nós chamamos de religião porque é indiscutivelmente uma demonstração de fé... não é? mas sempre que se fala em religião a gente... pensa numa coisa mais orGAnizada... mas:: ahn... eu... quer dizer que é uma demonstração de fé e uma demonstração de fé... bastante forte... que está 455. aumentando assustadoramente.... eu tive até a oportunidade de PREsenciar como esTÁ... extraordinário... uma vez que eu estava em Itanhaém... no dia oito de dezembro... e cheGAram os umbandistas... foi uma coisa que me imPREssionou... a QUANTIDADE de pessoas... a PRAia

460 ficou LOtada... aquela praia grande que é eNORme pois já ((riu)) se chama Praia Grande né? foi uma coisa fantástica... o número de... ônibus... eu até senTI... não ter... contado... o número de ônibus que passou pela nossa casa pra se dirigir às praias... foi uma COIsa... aClma do 465 que podia imaginar... e isto... quer dizer que é uma demonstração de fé... e:: eu penso que... não... não sei s/ bem como eu digo precisaria definir BEM religião pra eu poder dizer se... É ou não é não é? o que é... é uma demonstração de fé indiscutivel...

[PROJETO NURC/SP; INQUÉRITO N 242; BOBINA Nº 92; INFORMANTE Nº 295; DIÁLOGO ENTRE INFORMANTE E DOCUMENTADOR (DID), LINHAS 427469] 
A pergunta formulada pela documentadora - "certo...a senhora consideraria umbanda religião?" (linha 447) — pode ser interpretada como a sinalização de um problema de definição ou, em outros termos, como uma estrutura lingüísticodiscursiva que indica, nesse ponto específico do discurso, o surgimento de uma questão de definição — uma contextura/estrutura pró-definidora.

Retomando a pergunta da documentadora, destacamos o tempo verbal empregado ("consideraria"), o tipo interrogativo do enunciado e os objetos mencionados (a inferência mais adequada diz respeito aos atributos essenciais dos objetos de definição citados — umbanda e religião - e não, propriamente, ao caráter dos particulares signos lingüísticos "umbanda" e "religião"). Podemos expressar tecnicamente tal pergunta por meio do seguinte enunciado: "a hipótese formulada pelo indivíduo 'A' é a seguinte: o objeto $X$ [umbanda] pode ser incorporado à classe dos objetos que possuem como atributo os mesmos atributos do objeto $Y$ [religião]" ou, resumidamente, "o objeto $X$ aceita ser predicado pelo objeto $Y$ ": portanto, o enunciado anterior pode ser reescrito: "a hipótese formulada pelo indivíduo 'A' é a seguinte: o objeto umbanda pode ser predicado pelo objeto religião". Como vemos, essa reformulação implica que um objeto é, na verdade, definido a partir dos atributos de outro(s) objeto(s), ou seja, os objetos definem-se mutuamente, quer pela pertinência de traços definidores, quer por sua ausência, podendo tais traços ser essenciais, contingentes ou, até mesmo, subjetivos.

De acordo com a pergunta formulada, a documentadora indaga a respeito da aceitabilidade dessa hipótese por parte da informante; temos aqui, portanto, uma estrutura discursiva que antecipa um problema de definição. Trata-se, portanto, de uma estrutura pró-definidora, pois:

a) sinaliza-se a presença de um determinado problema de definição a ser solucionado, uma vez que responder afirmativa ou negativamente à documentadora implica aceitar ou não que ambos os objetos mencionados possuem suficiente semelhança intensional para que possam compor um mesmo texto definidor (não se sinaliza, porém, que tal processo de definição esteja em desenvolvimento, fato que apenas se tornará patente a partir da resposta da informante); 
b) sinaliza-se a necessidade de um tipo específico de definição; no caso, tratase de propor uma estrutura definidora do objeto $X$ que postula, como seu predicado, as características definidoras do objeto $Y$. Ou seja, a pergunta fornece não só um sinal de que existe um problema de definição nesse ponto do discurso, mas também sugere que a definição necessária deve ser construída a partir da seguinte diretriz: "o objeto $X$ pode ser definido a partir dos atributos já (re)conhecidos do objeto Y";

c) quanto à sinalização de pressupostos e subentendidos, temos possíveis inferências admitidas pela forma verbal "consideraria", operando como um conectivo para o binômio umbanda-religião. Assim, a pergunta da documentadora pressupõe que os objetos umbanda e religião compartilham um determinado conjunto de atributos, sob o ponto de vista ontológico e semântico; caso contrário, seria impossível qualquer aproximação entre eles e nem seria cabível a questão; também, a pergunta pressupõe que a aproximação proposta não é um consenso absoluto nem se apresenta como um fato indiscutível, caso contrário não seria cabível a dúvida; enfim, aceita-se como pressuposto que a aproximação entre esses objetos pode ser racionalmente determinada, condição inferida a partir do verbo "considerar".

Por outro lado, a pergunta da documentadora permite que se infiram alguns subentendidos (implicaturas); assim, a forma verbal "consideraria" pode ser interpretada como uma modalização: a documentadora, ela mesma, tem dúvidas sobre a possibilidade de aproximação entre esses objetos; sob outra perspectiva, o emprego do condicional pode ser interpretado como um recurso de polidez, deixando claro à informante que a documentadora não pretende impor a ela a certeza de que umbanda é obviamente uma religião.

Se ampliarmos nossa análise co-textual, veremos, no trecho que se inicia a partir da linha 353 do inquérito, que o tópico discursivo em desenvolvimento era "religião católica / Igreja Católica Apostólica Romana" (reproduzimos o inquérito $\mathrm{n}^{\circ}$ 242 em suas linhas 353-360 e linhas 391-400): 


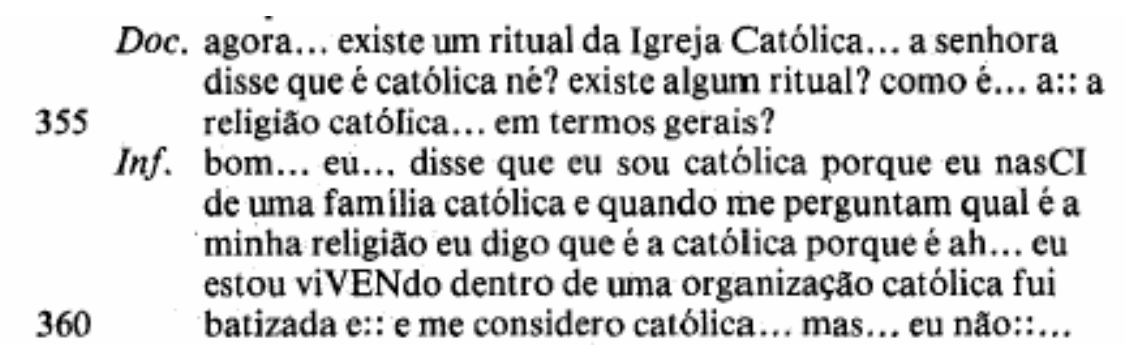

Doc. certo... a senhora disse que acredita em Deus... mas ahn... qual seria o representante de DEUS na Terra... segundo a religião... católica?

inf. bom... segundo a religião católica... é uma coisa que está estabelecido né? nós temos toda uma organização... o Papa e todos:: os:: ahn... ahn... missionários nas suas diferentes categorias e diferentes hierarquias não é? ele seria o representante... e eu... aceito... que possa haVER... uma representação mas é? justamente por isso

Nos trechos reproduzidos, verificamos que o atributo organização já aparece reiterado na fala da informante: esse é um dos atributos reconhecidos por ela como aqueles que caracterizam o objeto catolicismo. Assim, entende-se, por essa referência, porque o objeto umbanda, segundo o ponto de vista da informante, não deve ser incluído na classe de objetos que compartilham o atributo religião: para ela, o traço demonstração de fé é compartilhado pelos objetos catolicismo e umbanda, mas o traço religião não pode ser aplicado ao objeto umbanda; estabelece-se, assim, uma diferença hierárquica entre tais objetos.

Enfim, se retomarmos o trecho do inquérito entre as linhas 430-446, veremos que a informante coloca a Igreja Católica Romana e a Igreja Ortodoxa Russa em nível semelhante: "[...] conheço mais ou menos bem a lgreja Ortodoxa porque ela é muito parecida com a nossa...[...]". Porém, é taxativa em não considerar o Espiritismo como religião: "[...] não não...eu não considero o espiritismo propriamente uma religião.......]".

Aqui encontramos a justificativa para a forma como a pergunta da documentadora foi feita na linha 447: uma vez que a informante não considera Espiritismo uma religião, a pergunta da documentadora subentende que a informante tem em mente uma hierarquia de objetos: distingue entre organizações 
religiosas (Igreja Católica Romana, Igreja Ortodoxa Russa, etc.) e não-religiões (nãoorganizações) que são, contudo, demonstrações de fé (Espiritismo, Umbanda, etc.).

Nesse sentido, a pergunta da documentadora tem por finalidade saber em que grupo deve-se incluir o objeto umbanda, segundo a interpretação da informante; uma vez apresentada a contextura definidora "[...] eu não considero o espiritismo propriamente uma religião [...]", a documentadora emprega a forma verbal "consideraria" para cumprir a função mencionada, caracterizando uma simples hipótese;

d) ao mesmo tempo, a estrutura pró-definidora "[...] a senhora consideraria umbanda religião?" traz em si uma proposta de definição a ser confirmada: trata-se de aceitar ou não que o objeto umbanda possa incluir como um de seus atributos as características do objeto religião. Equivale, portanto, à proposição: "o objeto religião é um dos atributos definidores do objeto umbanda".

Freqüentemente, a pergunta da documentadora é considerada como equivalente à interrogação "umbanda é religião?", em que se verifica a fórmula discursiva definidora "o objeto $X$ é aceito como equivalente ao objeto $Y$ ". Para nossos propósitos, interessa distinguir claramente entre duas fórmulas aparentemente iguais, mas que, de fato, representam situações enunciativas diversas:

a) a fórmula discursiva de definição "o objeto $X$ é aceito como equivalente ao objeto $Y^{\prime \prime}$ implica indagar se o objeto $X$ e o objeto $Y$ referem-se à mesma realidade ontológica. Nesse caso, ambos os objetos poderiam operar praticamente como elementos intercambiáveis, uma vez que se apresentam como duas variáveis em uma igualdade assim considerada;

b) a fórmula que, entendemos, está subentendida pela questão da documentadora é a fórmula discursiva de definição "o objeto $X$ aceita o atributo $Y, o u$ seja, aceita as características do objeto $Y$ como atributos capazes de defini-lo apropriadamente". Aqui, trata-se de indagar se os atributos do objeto $Y$, total ou parcialmente, prestam-se para definir adequadamente o objeto $X$. Como uma generalização, temos a nossa fórmula discursiva de definição: "o objeto $X$ aceita ser predicado pelo objeto $Y^{\prime \prime}$, simbolizada por $/ X \leftarrow \pi\langle Y\rangle /$. 
Examinando as fórmulas apresentadas no item (b) do parágrafo anterior, entendemos que o objeto $Y$ incorpora-se, integral ou parcialmente, como um dos atributos (quer como característica essencial, quer como característica contingente), ao conjunto de atributos ou características (essenciais e/ou contingentes) do objeto $X$. Nesse sentido, compreendemos que:

i) o objeto $X$ deve ser definido por todos os atributos que definem o objeto $Y$, mais algum atributo ausente da definição de $Y$ que, ao ser acrescentado, caracteriza $X$ como um objeto diferente do objeto $Y$. Trata-se da predicação do definiendum pela totalidade do definiens;

ii) o objeto $X$ deve ser definido por alguns dos atributos que definem o objeto $Y$, com exceção de algum atributo presente na definição de $Y$ que, ao ser suprimido, caracteriza $X$ como um objeto diferente do objeto $Y$. Trata-se da predicação do definiendum pela parcialidade do definiens.

Para o excerto em análise, a fórmula apresentada em seguida sintetiza a situação discursiva das estruturas lingüísticas que assinalam algum problema de definição, e deve ser lida: "a hipótese proposta pelo indivíduo 'A', a ser verificada, é esta: o objeto $X$ [umbanda] pode ser predicado pelo objeto $Y$ [religiãol, isto é, o objeto $X$ aceita o objeto $Y$ como um dos atributos capazes de defini-lo apropriadamente". Importa destacar que essa estrutura sinalizadora possui um caráter hipotético, isto é, surge como uma proposição a ser verificada e aceita condicionalmente mediante consenso dos interlocutores.

É possível encontrar na literatura especializada a representação da estrutura definidora por meio da seguinte fórmula discursiva: "X é igual, por definição, a Y". Preferimos não empregar essa representação, pois não é imediatamente evidente o que significa, de fato, a expressão "ser igual por definição": os objetos seriam essencialmente iguais ou seriam iguais por uma mera convenção discursiva? Além disso, como já pudemos verificar anteriormente, há mais de um modo pelo qual podemos compreender os objetos " $X " \mathrm{e}$ " $Y$ " nessa fórmula.

Entendemos que a formulação "o objeto $X$ aceita ser predicado pelo objeto $Y$ " é mais clara em seu significado e implicações: há diferença entre "ser igual por definição" e "aceitar ser predicado por"; dentre elas, evidencia-se que a natureza do 
objeto é levada em conta pela segunda expressão, fato que não fica patenteado pela primeira, a qual pode referir-se a uma aproximação puramente lingüística entre dois termos considerados equiparáveis em dado discurso.

Além disso, essa formulação $(\mid X \leftarrow \pi\langle Y\rangle /)$ é a interpretação que nos parece mais adequada a uma das definições rigorosas de definição: /definir $\leftarrow \pi$ rdelimitar um objeto de tal modo a torná-lo único segundo seu gênero e espécie, declarando sua essência substancialı/. Portanto, trata-se de especificar essa individualidade por meio de especificações as mais precisas possíveis, as quais declaram características essenciais dos objetos de definição (e, quando for o caso, declaram características contingentes). Ao contrário, ser "igual por definição" não implica necessariamente esse processo atributivo: é possível considerar, por convenção, que dois objetos são iguais por definição sem que, de fato, esteja em jogo qualquer consideração de ordem ontológica.

Prosseguindo com nossa análise, vemos que a informante fornece uma resposta direta e inequívoca à indagação da documentadora, mostrando que, segundo seu ponto de vista, é inaceitável a hipótese implicada pela estrutura de sinalização proposta pela documentadora: "não...religião não...mas:: não consideraria propriamente religião". Ou seja, para a informante, o objeto religião não deve ser considerado um atributo do objeto umbanda: haveria uma distorção no processo definidor do conceito de umbanda caso houvesse essa postulação.

Observemos que a conjunção "mas", aqui presente, já antecipa a próxima estrutura pró-definidora elaborada pela informante. Vemos que, nesse caso, começa a desenvolver-se um processo definidor; o tempo verbal ("consideraria"), o advérbio ("propriamente") e a conjunção ("mas") contextualizam a proposta definidora da informante, representada pela fórmula "o objeto $X$ [umbanda] pode ser predicado pelo objeto não-Y [não-religião], isto é, não pode ser predicado por meio do objeto $Y$ [religião]".

Há a seguinte afirmação enfática: "[...] mas indiscutivelmente...também depende do QUE nós chamamos de religião porque é indiscutivelmente uma demonstração de fé...não é? [...]". Este trecho apresenta muitos pontos de interesse; há ênfase manifestada pela reiteração da conjunção "mas" e pela presença do 
advérbio "indiscutivelmente", igualmente reiterado: esses elementos têm por função estabelecer um equilíbrio proposicional entre as sentenças "não...religião não..." e "mas indiscutivelmente...[...] uma demonstração de fé", constituindo-se assim uma contextura definidora.

Essa contextura definidora pode ser simbolicamente expressa por: "a definição proposta pelo indivíduo 'A' é esta: o objeto $X$ [no caso, umbanda] deve ser predicado pelo objeto não-Y lou seja, deve ser predicado por outros objetos, mas não deve ser predicado pelo objeto $Y$, no caso, religiãol e passa a ser predicado pelo objeto $Z$ [no caso, demonstração de fél". Em outras palavras, o objeto $Z$ constitui um dos atributos do objeto $X$, mas o indivíduo "A" não aceita que o objeto $Y$ possa ser considerado como um dos atributos de $X$.

Temos aqui uma contextura definidora porque ocorre uma predicação cuja formulação é: "a definição proposta pelo indivíduo 'A' é esta: o objeto $X$ passa a ser predicado por meio do objeto $Z$, ou seja, o objeto $X$ aceita como um de seus predicados os predicados do objeto Z, incorporando-os em grupo, total ou parcialmente". Caracteriza-se claramente um processo que atende ao problema de definição apontado; segundo essa contextura, a definição "umbanda é indiscutivelmente uma demonstração de fé" destitui o objeto umbanda do atributo religião e lhe atribui, como traço intensional, a característica demonstração de fé.

Observemos que se trata de uma sentença dada por um enunciado afirmativo cuja estrutura genérica é " $X$ é $Y$ ", porém, na qual o verbo "ser", dentre suas múltiplas acepções, deve ser interpretado como equivalente a "tem por atributo", e não ser interpretado como um cotejador do tipo "é igual a", "equivale a" ou "é igual por definição a". Para nós, importa sempre ter presente essa polissemia do verbo "ser" enquanto nexo sentencial nas definições; em particular, sempre distinguiremos entre duas funções específicas desse verbo na sentença " $X$ é $Y$ ": a) quando empregado como sinônimo de "X é igual por definição a $Y$ "; b) quando empregado como sinônimo de " $X$ tem por atributo $Y$ ".

Além da contextura definidora apontada, o trecho em questão introduz uma estrutura pró-definidora que assinala um problema de definição: "[...] também depende do QUE nós chamamos de religião [...]". Claramente, aqui se aponta um 
problema de interpretação condicionada a uma necessidade de estabelecer a definição de um determinado objeto (observemos que a ênfase marcada pelas maiúsculas incide sobre o pronome que). No caso, entendemos o segmento "não...religião não...mas:: não consideraria propriamente religião...mas indiscutivelmente...também depende do QUE nós chamamos de religião porque é indiscutivelmente uma demonstração de fé...não é? [...]" como implicando as seguintes sentenças, verificadas inferencialmente:

a) o objeto umbanda não pode propriamente ser predicado pelo objeto religião $\rightarrow$ "a definição proposta pelo indivíduo 'A' é esta: o objeto $X$ deve ser predicado pelo objeto não-Y";

b) o objeto umbanda pode indiscutivelmente ser predicado pelo objeto demonstração de fé $\rightarrow$ "a definição proposta pelo indivíduo 'A' é esta: o objeto $X$ passa a ser predicado pelo objeto Z";

c) sentença condicionante número um $\rightarrow$ é necessário (re)definir precisamente o objeto religião $\rightarrow$ "o indivíduo 'A' sinaliza a necessidade de se (re)definir o objeto $\underline{Y}^{\prime \prime}$

d) sentença condicionante número dois $\rightarrow$ é necessário estabelecer qual classe de objetos aceita ser predicada pelo objeto recém-(re)definido religião $\rightarrow$ "o indivíduo 'A' sinaliza a necessidade de se estabelecer que classe de objetos pode ser predicada pelo objeto $Y^{\prime \prime}$.

Em suma, dependendo do objeto (ou da classe de objetos) que aceita ser predicado pelo objeto recém-(re)definido religião, o objeto umbanda pode ser predicado por uma escala ou um continuum de atributos que tem, em um extremo, o objeto demonstração de fé e, em outro, o objeto religião, situando-se o objeto umbanda mais ou menos próximo de um desses extremos.

Outro ponto de interesse a ser observado nesse trecho diz respeito à inferência em relação à natureza do objeto focalizado pelas interlocutoras: a inferência de maior probabilidade corresponde a uma clara menção não aos signos "umbanda" e "religião", mas sim aos objetos mentais ou objetos-de-realidade umbanda e religião: parece-nos que em nenhum momento as interlocutoras declarariam estar tratando 
de um problema de definição dos signos lingüísticos "umbanda" e "religião", casos que constituiriam problemas definidores estritamente lingüísticos (definições semióticas ou signações).

A informante prossegue, declarando que o objeto religião aceita ser predicado pelo objeto organização, característica esta ausente no processo definidor do objeto umbanda, como fica claro no trecho seguinte: "[...] mas sempre que se fala em religião a gente...pensa numa coisa mais orGAnizada...mas.: ahn...eu...quer dizer que é uma demonstração de fé e uma demonstração de fé...bastante forte...que está aumentado assustadoramente...[...]" (como se exemplifica pelo episódio narrado em seguida pela informante). Observemos que a informante destaca a importância e a constância do objeto organização para a definição do objeto religião: "[...] mas sempre que se fala em religião a gente...pensa numa coisa mais orGAnizada...[...]".

Em termos estruturais, temos: "a definição proposta pelo indivíduo 'A' é esta: 0 objeto $Y$ [religiãol passa a ser predicado pelo objeto $W$ [(ter) organização; (ser) organizadol".

Interessa observar a estratégia argumentativa da informante: tendo criado uma determinada hierarquia de objetos e seus atributos, nega a um objeto um atributo de nível superior, mas, como movimento compensatório, procura supervalorizar um atributo de nível inferior concedido ao objeto. Assim, segundo a informante, o objeto umbanda não é religião, mas é uma demonstração de fé bastante forte e que cresce assustadoramente (e o episódio narrado [linhas 455-465] tem por função confirmar e reforçar essa avaliação positiva).

No segmento final do trecho em análise (linhas 465-469), retoma-se, por meio de outra contextura estrutura pró-definidora, o problema de definição inicialmente identificado: "[...] e.:eu penso que...não...não sei s/ bem como eu digo precisaria definir BEM religião pra eu poder dizer se...É ou não é não é? [...]". Interessa observar a ênfase aplicada sobre o advérbio "bem", destacando-se que uma definição precisa e rigorosa do objeto religião é condição imprescindível para que se possa definir o objeto umbanda. Formalizando o processo implicado pelas observações da informante, temos os seguintes passos: 
a) passo número um: "a definição apresentada pelo indivíduo 'A' para o objeto $X$ é esta: o objeto $X$ [umbanda] deve ser predicado pelo objeto não-Y [não-religião], ou seja, não deve ser predicado pelo objeto Y";

b) passo número dois "a definição apresentada pelo indivíduo 'A' para o objeto $X$ é esta: o objeto $X$ [umbanda] pode ser predicado pelo objeto $Z$ [demonstração de fé]";

c) passo número três: ressalva $\rightarrow$ "segundo o indivíduo ' $A$ ', é necessário (re)definir o objeto $Y$ [religião]";

d) passo número quatro: "com base na (re)definição feita para o objeto $Y$, a hipótese definidora proposta pelo indivíduo ' $A$ ' para o objeto $X$ é uma destas, a serem verificadas: 1) o objeto $X$ [umbanda] pode ser predicado pelo objeto $Y$ [religião]"; 2) o objeto $X$ [umbanda] deve ser predicado por um objeto não-Y [nãoreligião], ou seja, o objeto $X$ não pode ser predicado pelo objeto $Y^{\prime \prime}$;

e) passo número cinco: "com base na (re)definição feita para o objeto $Y$ e com base em uma das hipóteses definidoras, proposta pelo indivíduo 'A' para o objeto $X$, a definição do objeto $X$ passa a ser uma destas ou ambas: 1) se o objeto $X$ pode ser predicado pelo objeto $Y$, então o objeto $X$ passa a ser predicado pelo objeto $Y^{\prime \prime}$; 2) se o objeto $X$ deve ser predicado pelo objeto não-Y, então o objeto $X$ passa ser predicado pelo objeto não-Y (ou, em outros termos, se o objeto $X$ não pode ser predicado pelo objeto $Y$, então o objeto $X$ não passa a ser predicado pelo objeto $\left.Y^{\prime \prime}\right)$.

Nos passos número um e número dois, temos as atuais estruturas definidoras para o objeto $X$; no passo número três, temos a sinalização de um problema de definição; no passo número quatro, teríamos o início do processo de (re)definição e, no passo número cinco, sua conclusão.

De acordo com a análise realizada, podemos identificar os dois objetos interrelacionados que caracterizam o processo definidor: as "contexturas/estruturas pródefinidoras" e as "contexturas/estruturas definidoras". Devemos observar que as já mencionadas funções desses objetos podem ou não ser verificadas simultaneamente, tanto nas pró-definições quanto nas definições; assim, é possível que uma contextura/estrutura pró-definidora sinalize um problema de definição, apresentando simultaneamente o tipo adequado de definição e uma proposta de 
definição; em outros casos, é possível que a contextura/estrutura pró-definidora apenas sinalize o problema de definição, sem indicar qualquer proposta definicional.

Como vemos, a informante fundamentou no trecho analisado sua definição do objeto umbanda por meio dos traços não-religião e intensa demonstração de fé, em grande expansão; ambos os traços foram apresentados como pressupostos indiscutíveis, embora tenha condicionado uma conclusão taxativa à necessidade de se (re)definir com mais rigor o objeto em questão.

Segundo nosso ponto de vista, o trecho analisado é um exemplo adequado para que se perceba a distinção entre as definições intensionais objetivistas e as definições intensionais subjetivistas-convencionalistas: como vimos no trecho analisado, os objetos umbanda, religião, organização e demonstração de fé são tratados como se fossem autênticos objetos substanciais e não objetos puramente lingüísticos: não se trata de um problema de definição dos termos correspondentes, mas sim de definição dos conceitos referentes e/ou objetos referidos, identificados por tais termos.

Observamos que a informante deixa claro que um melhor conhecimento em relação a esses objetos depende de melhores definições, ou seja, depende da elaboração de discursos definidores que sejam capazes de dar a conhecer, com mais rigor, a verdadeira essência substancial desses objetos. Isso pode ser constatado pela forma como foram apresentadas as contexturas/estruturas pródefinidoras da informante: as estruturas "[...] depende do QUE nós chamamos de religião [...]" e "[...] precisaria definir BEM religião pra eu poder dizer se...É ou não é [...]" sinalizam operações discursivas visando ao melhor conhecimento dos objetos focalizados.

Podemos imaginar, a partir disso, uma sucessão cada vez mais precisa de definições intensionais subjetivo-convencionais estipuladoras - ou, então, definições do objeto-de-discurso religião —, em direção à definição ideal e última do objeto substancial religião (a definição intensional objetiva por gênero e espécie).

Segundo essa visão de um continuum de definições, digamos, provisórias, verificamos a possibilidade de existência simultânea de mais de um texto definidor em relação a um mesmo objeto de definição. Assim, é possível a convivência de 
uma infinidade de textos definidores parcialmente perfeitos (diversos graus de perfeição definidora), que têm por horizonte a definição ideal de seu objeto de definição (definição perfeita que expressa, com absoluta precisão, a substancialidade de seu objeto, de modo a torná-lo absolutamente único sob o ponto de sua caracterização ontológica).

Frente a essa progressão de textos definidores "pré-ideais" — aos quais poderíamos denominar "definições imperfeitamente substanciais" —, entendemos que os atributos apresentados pela informante no trecho analisado estão incluídos no que seria um conjunto de atributos ontológicos imperfeitos e temporários, cuja fronteira inclui os traços definidores imperfeitos, temporários e suficientes para definir um objeto em determinado momento discursivo, excluindo os traços definidores imperfeitos e temporários considerados insuficientes para tanto (ou seja, traços cuja inclusão não caracteriza razoavelmente esse objeto, segundo o ponto de vista dos agentes definidores, em determinado contexto).

Assim, os atributos mencionados (religião, organização e demonstração de fé) foram considerados traços definidores imperfeitos, temporários e suficientes para definir o objeto umbanda, mas, como fica patenteado ao longo do trecho observado, não atingiram o nível dos atributos ontologicamente substanciais, uma vez que uma definição cabal do objeto umbanda não foi produzida ou mencionada: outros discursos definidores mais rigorosos serão necessários para reunir esses atributos (tendo por horizonte a definição perfeita e ideal desse objeto).

Com isso, chegamos às possivelmente denominadas "definições perfeitamente substanciais", baseadas no conceito de conjunto de atributos ontológicos perfeitos e permanentes, cuja fronteira inclui os traços definidores perfeitos, permanentes e suficientes para definir terminantemente um determinado objeto.

As definições imperfeitamente substanciais expressam os diversos graus de perfeição do texto definidor de um determinado objeto, os quais: a) têm por horizonte a definição perfeitamente substancial desse objeto; b) convivem simultaneamente, operando segundo contextos, funções e propósitos específicos (nesse sentido, são textos definidores úteis, pois se adaptam às diversas necessidades discursivas). Com isso, podemos propor que, em termos práticos, o conceito de definição 
perfeitamente substancial de um objeto corresponde à noção de objeto-em-si, enquanto o conceito de definição imperfeitamente substancial corresponde às noções de objeto-de-discurso.

Tal teoria parece confirmada pela análise efetuada: observemos que os atributos mencionados pela informante - organização e demonstração de fé - para estabelecer a distinção entre os objetos umbanda e religião são estritamente imperfeitos e temporários (tais objetos ainda poderão ser caracterizados como objetos substanciais mesmo sem a presença desses atributos); portanto, trata-se de objetos que foram postulados e aceitos como suficientes para caracterizar, de fato, os objetos-de-discurso umbanda e religião, e não os objetos substanciais umbanda e religião, embora o tratamento discursivo dado a esses objetos por parte das interlocutoras aparentemente indique que elas tinham em mente objetos substanciais.

Como já verificamos, a informante deixa clara a necessidade de estabelecer definições mais precisas do objeto religião para que se possa definir com mais rigor o objeto umbanda: nesse sentido, a mencionada progressão definidora parece evoluir da suficiência na caracterização ontológica dos objetos-de-discurso para a suficiência na caracterização ontológica dos objetos substanciais. Também, é possível que, pelo menos sob o ponto de vista da oralidade, talvez se possa sugerir que os objetos-de-discurso - ou, pelo menos, alguns objetos-de-discurso — sejam construídos pela mobilização de certos atributos imperfeitos e temporários que, contudo, cristalizam-se pragmaticamente de modo a adquirirem estatuto de atributos permanentes, embora não rigorosamente essenciais.

Por fim, examinaremos dois excertos nos quais podemos constatar a fundação de objetos-de-discurso e a presença de definições pragmático-flexivas.

[EXCERTOS NÚMEROS ONZE E DOZE]: 
Doc. e qual é o prazo L.que eles dão... para os concursados assumirem? existe alguma lei assim

L2 tem...tem con/

585 concurso é é:: é válido por dois anos mas o nosso con/concurso felizmente

L1 no seu...

L2 para o meu caso...

L1 estendeu-se mais

L2 houve uma série de irre/éh:: de irregularidades... nas

590 lis/na apresentação da lista de classificação irregularidade foi engano... no no no fazer... na confecção da lista... de de aprovados hou/houv/ começaram a haver alguns enganos... então o pessoal que mand/ entrava com mandado de segurança... dizendo que foi contado pontos

595 errados... enGAnos simples comuns eh aritmética (às vezes) de somar o número de pontos... então eles entraram com mandado de segurança... anulando aquela lista de classificação... e então havia publicação de outras... e assim foi indo e:: e a::... de acordo com o

600 edital a validade é dois anos DA publicação... dos resultados... da lista de aprovados... então com a:: com esta... com este recurso de mandado de segurança... não foi propriamente o recurso foram coisas que realmente aconteceram...

[PROJETO NURC/SP; INQUÉRITO N 360; BOBINA N 137; INFORMANTES $N^{\circ} 472$ E N 473; DIÁLOGO ENTRE DOIS INFORMANTES (D2), LINHAS 581-604]

Doc. agora mudando um pouquinho de assunto além das

315 atividades profissionais no no no fim de semana ... vocês vão ao assim algum lugar para se distrair?

L1 bom eu tenho impressão que:: o sitio ... que eu possuo .... e é muito mais sítio .... porque morando na cidade a gente costuma designar de sitio todo terreno um pouco maior do que as dimensð̃es habituais daqueles em que se vive mas na realidade é uma chácara ... este meu sítio:: representa

[PROJETO NURC/SP; INQUÉRITO № 255; BOBINA NN 95; INFORMANTES $N^{\circ} 303$ E N 304; DIÁLOGO ENTRE DOIS INFORMANTES (D2), LINHAS 314-321]

Recordemos que assim definimos as definições pragmático-flexivas: /definição pragmático-flexiva $\leftarrow \pi$ iprocesso definidor e produto desse processo que, ao definir seus objetos, (re)cria-os flexivamente enquanto objetos mentais e/ou objetos-dediscurso ad hoc, para funcionarem vicariamente, em um discurso particular, em lugar 
dos objetos substanciais correspondentes, enquanto não se produza a definição ideal ou próxima do ideal desse objeto, ou quando não haja conveniência em produzi-la e/ou utilizá-la discursivamentes /.

No primeiro desses excertos, o documentador interroga sobre o prazo regular para que permaneça válido o resultado de um concurso; L2 informa que esse resultado normalmente vigora por dois anos. Para um concurso particular, porém, houve prorrogação: "tem...tem com/concurso é é:: é válido por dois anos mas o nosso com/concurso felizmente para o meu caso...houve uma série de irre/éh:: de irregularidades...na lis/na apresentação da lista de classificação [...]". A questão diz respeito ao emprego do termo "irregularidades": aparentemente, a locutora entende que é preciso (re)defini-lo precisamente para que se sinalize uma inferência adequada: de fato, falar em "irregularidades" na lista de classificação em um concurso público poderia conotar má fé, protecionismo ou injustiça deliberada, visando privilegiar algum candidato apadrinhado pelos membros da banca; parecenos que a informante preocupa-se em desfazer essa impressão, atribuindo um sentido específico ao termo "irregularidade".

A locutora propõe a seguinte contextura/estrutura definidora: "[...] irregularidades foi engano... no no no fazer... na confecção da lista... de de aprovados hou/houv/ começaram a haver alguns enganos [...] enGAnos simples comuns eh aritmética [...] de somar o número de pontos [...] foram coisas que realmente aconteceram".

Estabelece-se a seguinte signação: /"'irregularidade' (na confecção e apresentação da lista de classificação em um concurso público)" ₹ "engano aritmético simples e comum, provocado por falhas na soma de pontos"/. Assim, poderíamos construir o seguinte enunciado: "Pedro justificou-se atribuindo grande importância às 'irregularidades' no concurso — que são aqueles enganos aritméticos simples e comuns na soma de pontos".

No segundo desses excertos, o informante emprega o termo "sítio": "bom eu tenho impressão que:: o sítio...que eu possuo[...]"; em seguida, preocupa-se em distingui-lo do termo "chácara": "[...] e é muito mais sítio...porque morando na cidade a gente costuma designar de sítio todo terreno um pouco maior do que as 
dimensões habituais daqueles em que se vive mas na realidade é uma chácara [...]". Percebemos que o informante, nas linhas 332-333 desse inquérito, oscila entre os termos "sítio" e "chácara" ([...] reunir o conjunto de prazeres que esta chácara ou que este sítio [...]); a distinção é esta: "[...] porque morando na cidade, a gente costuma designar de sítio todo terreno um pouco maior do que as dimensões habituais daqueles em que se vive mas na realidade é uma chácara [...]". Observemos que, de acordo com os dicionários de uso, não há uma distinção especial entre ambos os termos.

Estabelece-se a seguinte signação: /"sítio"" $\approx$ "sob o ponto de vista dos citadinos, terreno um pouco maior do que as dimensões habituais dos terrenos urbanos"/. Assim, poderíamos construir o seguinte enunciado, utilizando essa signação: "Pedro viajou para seu 'sítio' — que é aquele terreno um pouco maior do que as dimensões de sua casa em São Paulo".

São essas signações dois exemplos de definições intensionais subjetivas estipuladoras, que produzem objetos-de-discurso ad hoc: nesse sentido, atendem ao conceito de definição pragmático-flexiva:

a) trata-se de discursos fundadores de seus objetos de definição particulares, manifestados pela primeira vez nesses modos específicos: de fato, um terreno de $300 \mathrm{~m}^{2}$ não corresponde habitualmente aos objetos designados pelo termo "sítio"; enganos na confecção de uma lista de concursados (como, por exemplo, erros de impressão) dificilmente mereceriam ser designados pelo termo "irregularidade". Com isso, percebemos o caráter híbrido substancialista-terminista dessas definições: há uma flexibilização discursiva dos referenciais e, ao mesmo tempo, a atribuição de nomes previamente existentes a esses referenciais flexionados. Temos, portanto, definições intensionais subjetivas estipuladoras; porém, o uso reiterado desses termos com esses novos significados constituiria definições intensionais convencionais lexicais;

b) há, nessas signações, uma harmonização entre os conceitos de objeto-derealidade e objeto-de-discurso, de acordo com a abordagem sistêmica das definições: há um conjunto identificável de definições pressupostas e definições subentendidas que se vinculam aos objetos de definição em questão; 
c) os objetos criados flexivamente funcionam, em seus discursos fundadores, como objetos vicários em relação aos objetos substanciais correspondentes; cabe investigar, então, se as substâncias sítio e irregularidade acomodariam em suas intensões objetivas os traços declarados pelos textos definidores apresentados pelos informantes.

De acordo com os exemplos analisados, pensamos que se patenteia a conveniência em se adotar os conceitos apresentados de contextura (pró-)definidora e estrutura (pró-)definidora — ou, mais especificamente, a conveniência em se aceitar a visão sistêmica que tais conceitos implicam. Também, consideramos que o corpus examinado nos autoriza a postular a existência das definições pragmáticoflexivas - conceito que responde adequadamente ao conceito de objeto-dediscurso.

\section{CONSIDERAÇÕES FINAIS}

Ao longo deste trabalho procuramos investigar as razões pelas quais se deve definir e os modos normativos para boas definições. Verificamos que, se existem razões imperativas para as definições, as "regras clássicas" para as boas definições não são plenamente aplicáveis, em especial nas condições de produção da oralidade. Vimos também que o processo definidor diz respeito principalmente à definição de conceitos referentes; observamos que a teoria clássica das definições, fortemente influenciada pela visão aristotélica, entende declarar a qüididade dos seres cujos conceitos estão em processo de definição: porém, despido dos fundamentos da metafísica aristotélica, torna-se incompreensível esse esforço teórico. 
De fato, o pensamento filosófico do estagirita constitui um todo harmônico do qual nenhuma parte pode ser isolada e interpretada per se, sem a percepção dessa totalidade. Se assim fizermos, distorceremos seu pensamento e incorreremos no erro de reduzi-lo a um conjunto de fórmulas obscuras. Assim, conforme assinalamos, sua teoria das definições harmoniza-se com sua metafísica e sua teoria da ciência: apenas quando assim apreendida, sua tipologia definidora revelará uma lógica absoluta e rigorosa.

Também, de acordo com essa abordagem clássica, as definições intensionais objetivas por gênero e espécie representam o modelo ideal de definição, pois declaram inequivocamente a unicidade essencial de seus objetos. Frente a elas, apresentam-se as definições intensionais subjetivas e/ou convencionais, que se afastam da idéia de uma intensão objetiva (própria das definições ideais) e limitamse a estabelecer correspondências lingüísticas entre os termos mobilizados pelo discurso. Neste caso, afastamo-nos do modelo ideal de definição e aproximamo-nos dos processos puramente semióticos ou signações.

Neste trabalho, assinalamos nossa compreensão das intensões - em particular, da intensão objetiva —: para nós, convém considerá-la como uma determinação de características condicionada por percepção fenomênicas de cunho social e cultural. Nesse sentido, a definição /homem $\leftarrow \pi$ ıanimal racional que se realiza plenamente na pólis`/ deve ser considerada, segundo nossa visão, como uma determinação conceitual dada por uma certa percepção subjetiva e/ou convencional, com perenidade suficiente para constituir uma percepção objetiva que subsiste em dado contexto cultural. A questão sobre a possibilidade de atribuir um caráter universal, científico e atemporal a tal determinação parece-nos transcender as necessidades de nosso objeto de estudo: isso porque, conforme já assinalamos, se tal definição for válida universalmente, muitos objetos denunciarão a vaguidão do conceito.

Se, por outro lado, examinarmos a seguinte definição: /homem $\leftarrow \pi$ rqualquer indivíduo pertencente à espécie animal que apresenta o maior grau de complexidade na escala evolutiva; o ser humanos / (AURÉLIO SÉCULO XXI), verificaremos, de acordo com esse texto (desconsiderando a sinonímia "homem" $\approx$ "ser humano"), que 
o definiens pode ser reduzido a sanimal com o maior grau de complexidade na escala evolutiva). Ora, a validade dessa determinação conceitual depende do conceito pressuposto de complexidade (o que se entende precisamente por um "ser complexo"?); também, a importa ter em conta os critérios para a construção dessa escala evolutiva (o que se entende precisamente por "evolução"?): testes para a aferição do quociente de inteligência seriam os parâmetros principais? Valores morais devem ser determinantes? Os valores espirituais devem ser considerados como índice de evolução? A linguagem bem articulada deve pesar enquanto critério? Assassinos seriais e políticos irremediavelmente corruptos deveriam ou não deveriam ser considerados seres humanos?

Segundo nosso ponto de vista, todas essas determinações - mesmo as de caráter objetivo e universal - serão consideradas, com mais prudência, como produtos perceptivos e socioculturais, passíveis, portanto, de impugnação e revisão, de acordo com as possíveis alterações desses contextos, uma vez que estes são, por princípio, heraclitianos.

A partir desses dois paradigmas teóricos - a abordagem essencialistasubstancialista e a abordagem nominalista-terminista —, avançamos o exame de propostas alternativas que procuram conciliar a teoria das definições com as necessidades ou limitações práticas que o processo definidor impõe, em especial para o contexto da oralidade.

Em seguida, procuramos estabelecer os critérios para a construção de uma tipologia de definições; propusemos uma tipologia que distingue entre pseudodefinições extensionais, definições intensionais objetivas, definições intensionais subjetivo-convencionais e pseudodefinições diversas. a partir dessa organização de tipos, passamos a considerar com mais detalhes as definições orais naturais - ou seja, as definições desenvolvidas segundo as condições de produção da oralidade. Exemplificamos a teoria mediante análise de estruturas definidoras extraídas do corpus.

Passamos em seguida a considerar sistemicamente as definições, distinguindo entre plano sensível e plano mental, e plano expressivo lingüístico e plano expressivo extralingüístico. Verificamos, então, que existem diversas possibilidades 
de desenvolvimento do processo definidor, pela combinação dos elementos desse sistema de conceitos. Conforme pudemos observar, objetos lingüísticos, objetos mentais e objetos práxicos podem (isolada ou conjuntamente) produzir textos definidores. Essa constatação estende os processos definidores para além dos modelos substancialista e terminista.

Com base nesse sistema de conceitos, desenvolvemos as noções de contextura (pró-)definidora e estrutura (pró-)definidora, mostrando que o processo definidor implica necessariamente processos inferenciais acionados por definições pressupostas (pressupostos) e definições subentendidas (implicaturas). Assim, ocorrem e/ou podem ocorrer, em um processo definidor, referências a objetos-derealidade - entendidos neste trabalho como fenômenos - e referenciações a objetos-de-discurso - entendidos como objetos produzidos pelo ineditismo de um discurso fundador. Sob esse ponto de vista, não se opõem de modo excludente a menção a categorias prévias e dadas a um discurso (consideradas por muitos como objetos-de-realidade) e a criação de objetos-de-discurso ad hoc.

Fixamos nosso ponto de vista sobre esses objetos: para nós, trata-se da distinção entre objetos práxico-fenomênicos e objetos produzidos ad hoc, inaugurados por um discurso fundador. Tais objetos-de-discurso, assim compreendidos, congregam simultaneamente um caráter substancialista e um caráter terminista, sendo uma especialização das definições intensionais subjetivoconvencionais estipuladoras - ou, dependendo do caráter dos traços componentes do conceito, das definições intensionais objetivas estipuladoras. Uma vez inaugurados, seu uso constante faz dessas definições exemplos de definições intensionais lexicais.

Verificamos, finalmente, que convém criar o conceito de definições pragmáticoflexivas para atender à natureza especial desses objetos-de-discurso - e para atender, de modo geral, à natureza das definições orais naturais —: tal conceito baseia-se na distinção entre objetos flexivos e objetos inflexivos (sendo estes considerados por um discurso particular como essências ontologicamente acabadas e definidas, e sendo aqueles considerados por um discurso particular como essências ontologicamente inacabadas ou indefinidas). A partir disso, podemos 
conceber a flexibilização discursiva de um referencial - a idéia de que são possíveis sucessivas fundações discursivas de novas manifestações fenomênicas desse referencial, atendendo a conveniências pragmáticas.

Sobre essa idéia baseamos nossa tese, que aqui reiteramos e com a qual concluímos a exposição de nosso trabalho: no processo definidor, em especial nas condições de produção da oralidade, inexiste oposição excludente entre objetos flexivos e objetos inflexivos; ao contrário, sustentamos a conveniência de considerar a existência de diversos graus de flexividade dos referenciais, promovidos pelo texto definidor, de modo que, por detrás de um mesmo nome ou termo, habitam inúmeras elaborações ontológicas do objeto de definição, constituindo inúmeras intensões subjetivas e/ou convencionais, ou seja, inúmeras definições ou textos definidores de um conceito (que, em verdade, é em si mesmo flexivo), todos designados, pelo prazo que a conveniência do uso lingüístico deliberar, por um determinado nome ou "rótulo" discursivo. Como exemplo, basta considerar as diversas possibilidades definidoras que, histórica e filosoficamente, flexibilizam-se por detrás da compreensão e aplicação concreta de palavras tais como "Liberdade, Igualdade e Fraternidade".

\section{REFERÊNCIA BIBLIOGRÁFICA}

ABBAGNANO, Nicola. Dicionário de filosofia. $4^{a}$ ed. São Paulo: Martins Fontes, 2003.

ACHINSTEIN, Paul. Concepts of science. Baltimore (USA): Johns Hopkins Press, 1968.

ACKOFF, Russell. Scientific method: optimizing applied research decisions. New York: John Wiley, 1962.

ALVES, leda Maria. "O léxico na língua falada" In PRETI, Dino (Org.). Análise de textos orais. $4^{a}$ ed. São Paulo: Humanitas FFLCH/USP, 1999. 
"O emprego da metalinguagem em diálogos jornalísticos". In PRETI, Dino (Org.). Diálogos na fala e na escrita. São Paulo: Humanitas, 2005.

ARISTÓTELES. The works of Aristotle, vol. I: Logic: Posterior analytics; Topics. Encyclopaedia Britannica, Inc., 1952.

The works of Aristotle, vol. I: Metaphysics. Encyclopaedia Britannica, Inc., 1952.

AURÉLIO SÉCULO XXI. Dicionário eletrônico. Versão 3.0. Rio de Janeiro: Editora Nova Fronteira.

AUROUX, Sylvain. A filosofia da linguagem. Campinas: Editora da UNICAMP, 1998.

BAILLY, Anatole. Le Grand Bailly. Dictionnaire Grec-Français. Paris: Hachette, 2000

CASTILHO, Ataliba T. de. A língua falada no ensino do português. São Paulo: Contexto, 1998.

CAVAlCANTE, Mônica Magalhães et alii. (Org.). Referenciação. São Paulo: Contexto, 2003.

CAYGILL, Howard. Dicionário Kant. Rio de Janeiro; Zahar, 1995.

CHAUÍ, Marilena. Introdução à filosofia: dos pré-socráticos a Aristóteles, volume um. $2^{\mathrm{a}}$ ed. São Paulo: Companhia das Letras, 2002.

CHIERCHIA, Gennaro. Semântica. Campinas: Editora da UNICAMP, 2003. 
COPI, Irving M. \& COHEN, Carl. Introduction to logic. $11^{\text {a }}$ ed. Upper Saddle River, New Jersey (USA): Prentice-Hall, 2001.

COSSUTA, Frédéric. Elementos para a leitura de textos filosóficos. São Paulo: Martins Fontes, 1994.

DUBOIS, Jean et alii. Dicionário de lingüística. $7^{a}$ ed. São Paulo: Cultrix, 1998.

FÁVERO, Leonor Lopes et alii. Oralidade e escrita: perspectiva para o ensino de língua materna. São Paulo: Cortez, 1999.

FOLSCHEID, Dominique \& WUNENBURGER, Jean-Jacques. Metodologia filosófica. $1^{\mathrm{a}}$ ed. São Paulo: Martins Fontes, 1997.

FRAWLEY, Willian. Linguistic semantics. Hissdale, N. J. : Lawrence Erlbaum Associates, Inc., 1992.

GARCIA, Othon Moacyr. Comunicação em prosa moderna: aprenda a escrever, aprendendo a pensar. 19a ed. Rio de Janeiro: Editora FGV, 2000.

GREIMAS, Algiras Julien \& COURTÉS, Joseph. Sémiotique. Dictionnaire raisonné de la théorie du langage. Paris: Hachette, 1979.

GUTHRIE, W. K. C. Os sofistas. São Paulo: Paulus, 1995.

HAACK, Susan. Filosofia das lógicas. São Paulo: Editora UNESP, 2002.

HEGENBERG, Leonidas. Definições. Termos teóricos e significado. São Paulo: Cultrix / Editora da Universidade de São Paulo, 1974. 
Saber de e saber que: alicerces da racionalidade.

Petrópolis (RJ): Vozes, 2001.

(Org.). Métodos. São Paulo: EPU, 2005.

HOBBES, Thomas. Leviatã. São Paulo: Martins Fontes, 2003.

HOUAISS, Antônio \& VILLAR, Mauro de Salles. Dicionário Houaiss da língua portuguesa. $1^{\text {a }}$ ed. Rio de Janeiro: Objetiva, 2001.

IDE, Pascal. A arte de pensar. $1^{a}$ ed. São Paulo: Martins Fontes, 1997.

KANT, Immanuel. Crítica da razão pura. $5^{a}$ ed. Lisboa: Fundação Calouste Gulbenkian, 2001.

KIRKHAM, Richard L. Teorias da verdade: uma introdução crítica. São Leopoldo (RS): Editora da Universidade do Vale dos Sinos, 2003.

$\mathrm{KOCH}$, Ingedore Grunfeld Villaça. Introdução à lingüística textual. São Paulo: Martins Fontes, 2004.

et alii (Org.). Referenciação e discurso. São

Paulo: Contexto, 2005.

LALANDE, André. Vocabulário técnico e crítico da filosofia. $3^{a}$ ed. São Paulo: Martins Fontes, 1999.

LEIBNIZ, Gottfried Wilhelm. Escritos filosóficos. Edición de Ezequiel de Olaso. Madrid: Mínimo Tránsito / A. Machado Libros, 2003. 
LOCKE, John. An essay concerning human understanding. Encyclopaedia Britannica, Inc., 1952.

LYONS, John. Semántica. Barcelona: Editorial Teide S.A, 1980.

MAINGUENEAU, Dominique. Análise de textos de comunicação. São Paulo: Cortez, 2000.

MARCONI, Marina de Andrade \& LAKATOS, Eva Maria. Fundamentos de Metodologia Científica. $6^{a}$ ed. São Paulo: Atlas, 2005.

MONDADA, Lorenza \& DUBOIS, Danièle. "Construção dos objetos de discurso e categorização: uma abordagem dos processos de referenciação" In CAVALCANTE, Mônica Magalhães et alii. (Org.). Referenciação. São Paulo: Contexto, 2003.

MARCUSCHI, Luíz Antônio. Da fala para a escrita: atividades de retextualização. São Paulo: Cortez, 2001.

NEF, Fréderic. A linguagem: uma abordagem filosófica. Rio de Janeiro: Zahar, 1995.

NEVES, Maria Helena de Moura. A vertente grega da gramática tradicional: uma visão do pensamento grego sobre a linguagem. $2^{\mathrm{a}}$ ed. São Paulo: Editora UNESP, 2005.

Texto e gramática. São Paulo: Contexto, 2006.

NOVO AURÉLIO SÉCULO XXI: dicionário eletrônico. Versão 3.0. Rio de Janeiro: Lexicon Informática / Nova Fronteira, s/d.

PALACIOS, Alfredo Raúl \& PALÁCIOS, Alberto Gustavo. La definición. Así en la matemática como en la filosofía. Buenos Aires: Lumen, 2002. 
PERELMAN, Chäim \& OLBRECHTS-TYTECA, Lucie. Tratado da argumentação. A Nova Retórica São Paulo: Martins Fontes, 1996.

PEREIRA, Oswaldo Porchat. Ciência e dialética em Aristóteles. São Paulo: UNESP, 2001.

PERINI, Mário, Gramática descritiva do português. 4ª ed. São Paulo: Ática, 2006.

QUINE, Willard van Orman. From a logical point of view. $2^{\mathrm{a}}$ ed. Cambridge, Mass.: Harvard University Press, 1980.

REBOUL, Olivier. Introdução à Retórica. São Paulo: Martins Fontes, 1998.

REY, Alan. "Defining definition". In SAGER, J. C. (Ed.). Essays on definition. Amsterdam/Philadelphia: John Benjamins Publishing Co., 2000.

RICKERT, Heinrich. Teoria de la definición. México: Universidad Nacional Autónoma de México, 1960.

RODRIGUES, Ângela Cecília Souza. "Língua falada e língua escrita". In PRETI, Dino (Org.). Análise de textos orais. 4 ed. São Paulo: Humanitas FFLCH/USP, 1999.

SAGER, Juan. C. (Ed.). Essays on definition. Amsterdam/Philadelphia: John Benjamins Publishing Co., 2000.

SALMON, Wesley C. Lógica. $3^{a}$ ed. Rio de Janeiro: LTC Livros técnicos e científicos S.A., 1993 .

SANT'ANNA, Adonai S. O que é uma definição. Barueri, SP: Manole, 2005. 
SANTOS, Fausto dos. Filosofia aristotélica da linguagem. Chapecó: Argos, 2002.

SEVERINO, Antônio Joaquim. Metodologia do trabalho científico. $22^{a}$ ed. São Paulo: Cortez, 2002.

SILVA, Marilúze Ferreira de Andrade e. Pensamento e linguagem: Platão, Aristóteles e a visão contemporânea da teoria tradicional da proposição. Rio de Janeiro: PósModerno, 2002.

VANOYE, Francis. Usos da linguagem: problemas e técnicas na produção oral e escrita. 12 ${ }^{\mathrm{a}}$ ed. São Paulo: Martins Fontes, 2003.

WITTGENSTEIN, Ludwig. Tratactus Logico-Philosophicus. $2^{\mathrm{a}}$ ed. São Paulo: Editora da Universidade de São Paulo, 1994.

Gramática Filosófica. São Paulo: Edições Loyola, 2003.

Investigaciones filosóficas. $3^{\text {a }}$ ed. Barcelona: Editorial

Crítica, 2004.

WOLFF, Francis. Dizer o mundo. São Paulo: Discurso Editorial, 1999.

ZIFF, Paul. Semantic analysis. New York: Cornell Univ. Press, 1960. 